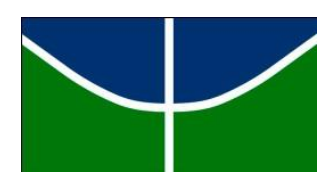

UNIVERSIDADE DE BRASÍLIA

INSTITUTO DE CIÊNCIAS SOCIAIS

DEPARTAMENTO DE ANTROPOLOGIA

Programa de Pós-Graduação em Antropologia Social

MATRONAS AFROPACÍFICAS: FLUXOS, TERRITÓRIOS E VIOLÊNCIAS.

GÊNERO, ETNIA E RAÇA NA COLÔMBIA E NO EQUADOR

Paula Balduino de Melo

Brasília

Agosto de 2015 
Paula Balduino de Melo

\section{MATRONAS AFROPACÍFICAS: FLUXOS, TERRITÓRIOS E VIOLÊNCIAS. GÊNERO, ETNIA E RAÇA NA COLÔMBIA E NO EQUADOR}

Tese apresentada ao Programa de Pós-Graduação em Antropologia Social do Instituto de Ciências Sociais, Departamento de Antropologia, Universidade de Brasília, como requisito parcial à obtenção do título de Doutora em Antropologia.

ORIENTADORA

Lia Zanotta Machado (UnB)

COORIENTADORA

Mara Viveros Vigoya

(Universidad Nacional de Colombia)

\section{BANCA EXAMINADORA}

Lia Zanotta Machado (DAN/UnB) (Presidente)

Antonádia Borges (DAN/UnB)

Jurema Werneck (Criola)

Alecsandro José Prudêncio Ratts (UFG)

Silvia Monroy Alvarez (Centro Nacional de Memoria Histórica de Colombia)

Andréa de Souza Lobo - Suplente (DAN/UnB)

\section{Brasília}

Agosto de 2015 
À dona de minha cabeça, que me conduz por suas águas. E a todos os orixás por me acompanharem.

Às Rosas. As que me antecederam e a que está por vir.

À luta de meu pai pela vida. 


\section{AgradeCimentos}

Comecei a escrever esta sessão do texto em junho de 2013, em Bogotá. Nos intervalos de leituras, emergiam palavras de gratidão que mereciam registro. Voltei a ela ao fim da escrita, relembrando que a trajetória de um doutorado é longa e diversa. Para além de uma experiência intelectual, foi, para mim, uma autoimersão analítica e um percurso afetivo. Espero que as palavras ora manifestas possam retribuir um pedacinho da generosidade regalada.

À minha família. Mãe, Maria Mônica, e irmã, Mariana, por terem me formado como mulher e pelo apoio incondicional. Aos amados sobrinhos, Otto, Igor e Eric, pela compreensão de que a titia é uma pessoa que faz muitas coisas ao mesmo tempo. Gratidão pela amizade que me brindam. À prima doutora Jordana de Castro Balduino, pela inspiração e exemplo. Ao companheiro José Henrique Sampaio Pereira, que entendeu meu fluxo. Com sua serenidade e sapiência, acompanhou meus passos ao longo desse percurso, emprestou-me ouvidos, ajudando a fazer com que os caminhos fossem menos arriscados e mais deleitosos. À Ana Rosa, agradeço porque uma parte do que produzi é fruto de nossa interação. Gestar uma pessoa é uma experiência que pode ser produtiva para o fazer intelectual!

Agradeço muito às minhas orientadoras. Tive a sorte de ter duas. Lia Zanotta Machado bem compreendeu meus anseios. Sua acurada leitura da tese e seus comentários foram centrais para que eles ganhassem concretude em palavras acertadas. Foi um rico processo de composição em diálogo. Agradeço especialmente o cuidado ao final do processo, quando me centrava ansiosamente no fim. Mara Viveros acompanhou de perto o trabalho de campo, que foi um momento borbulhante e delicado. Suas orientações para a etnografia foram valiosas. As palavras, afetuosas e reconfortantes. No fim do processo, quando bateu a insegurança, a leitura de Mara também foi chave, indicando referências bibliográficas que permitiram fazer ajustes e definir com melhor precisão minhas interpretações.

Agradeço à Antonádia Borges, Silvia Monroy, Jurema Werneck e Alex Ratts pelas leituras generosas e pelas reflexões trazidas na defesa da tese.

Agradeço às Pretas Candangas, com quem aprendi o sentido da irmandade. Agradeço à Juliana Cezár Nunes, cuja confiança me impulsionou; à Daniela Luciana por emprestar-me palavras; a Raíssa Gomes, pela partilha da percepção da negritude além da cor da pele e pela insistência na categoria 'mulher negra'; Cecília Bezerra, cujas sábias palavras ajudaram a conectar intelecto e emoção. A nossa convivência fez esse exercício menos solitário. 
À Yalorixá Railda d'Oxum, à Iji Funké e à comunidade do Axé Opô Afonjá - Ilê Oxum, agradeço pelos cuidados espirituais sem os quais não seria possível essa empreitada.

Agradeço a Maria d'Abadia Pereira Guimaraes (Dona Mariinha), Givânia Maria da Silva, Maria Rosalina dos Santos, Sandra Maria dos Santos, Maria Aparecida Mendes e Isabela Cruz. E assim estendo um salve a todas as mulheres quilombolas que, para mim, são ícones de resistência, sabedoria e luta.

Agradeço à Jaqueline Fernandes pela parceria. Junto com Chaia Dechen, à frente da Griô Produções, essas mulheres realizam um festival de suma importância, o Festival da Mulher Afro-Latino-Americana e Caribenha. O Latinidades para mim é como os manguezais para algumas de minhas interlocutoras afro-pacíficas; um berço no qual ideias e conexões são semeadas, germinam e crescem, para depois seguir oceano afora.

À Uila Gabriela de Oliveira Cardoso, agradeço a oportunidade de refletir e compreender conjuntamente maneiras pelas quais o racismo e o sexismo conduzem vidas.

Agradeço à Ana Flávia Magalhães Pinto, “consultora para assuntos acadêmicos”, que me acompanhou e apoiou desde a proposição da Bolsa Sanduíche à revisão da tese, compartilhando os frutos de sua trajetória acadêmica.

Agradeço à Bárbara Oliveira Souza, companheira em muitas trincheiras. Ainda que à distância, seguimos trilhando caminhos que se acercam, compartilhados ainda com Daniel Brasil, a quem também sou grata. Parceria que fortalece.

À Gleides Simone Figueiredo Formiga, agradeço pela ousadia de ocupar espaços que tradicionalmente não estão destinados a nós. E de fazer diferente.

Aos meus colegas de turma Rafael Antunes e Fabíola Gomes, agradeço pela oportunidade de juntos construirmos caminhos de partilha da antropologia.

A Júlia Otero, por me ajudar a pensar sobre a comida como elemento de constituição de pessoas e povos.

À Anita Campos, amiga-irmã que tão bem me conhece, pela leitura da tese e pelos comentários no processo inicial da escrita.

Ao Danilo Clímaco, também pela leitura e reflexões suscitadas, as quais abrem caminho a futuras produções conjuntas. É sempre bom reencontrar parceiros.

À Silvia Monroy novamente agradeço. Em nossos vários encontros no Brasil e na Colômbia, as conexões intelectuais, espirituais e afetivas foram tantas e tão importantes.

À Lara Nigro agradeço por ser uma entusiasta da antropologia que faço.

À Aline Menke, pelos mapas. 
Agradeço à Luciana Pontes, por me ajudar a ouvir meu corpo e compreender meus percursos em seus cruzamentos com percursos de outras mulheres.

Com Eudes Rosaldo, hermanito, foi um encontro especial; por sua ligação com o Brasil, por nosso partilhar da negritude e do feminino. Gracias por apresentar-me a Guajira e mais um pouco do Atlântico colombiano. Os dias em Bogotá ao seu lado foram os melhores.

À Sofí Garzón, pelos ricos momentos em Bogotá, pelas conversas que despertaram grandes questões para a tese.

Agradeço ao Juan Pablo por compartilhar materiais etnográficos valiosos e pela interlocução frutífera. A partir da leitura de sua dissertação e de nossas conversas comecei a refletir sobre o binômio raça/etnia.

Ao Leonardo Rúa, pela amizade e pelos patacones.

Ao Pascal Blum, pelos diálogos em que trocamos percepções estrangeiras sobre a colombianidade e pelas indicações de leituras sobre a violência sociopolítica.

À Marcela Vallejo, pelas frutíferas conversas, excelentes referências bibliográficas, agradáveis momentos na Colômbia e no Brasil, leitura cuidadosa e revisão dos textos em espanhol da tese.

À Camila Rivera, pelo carinho, cuidado e acolhimento em Bogotá.

Agradeço à Alicia Vega, pequena grande mulher quitenha, com quem tive conversas que descortinaram aspectos do meu ser que se colocavam no curso dessa empreitada.

A Barbarita e Isabelita Lara, por me receberam em La Concepción e pela partilha.

A Don Salomón e José Chalá Cruz, que conheci em Brasília, pela hospitalidade em Quito e no Vale do Chota, La Concepción e Salinas.

A Priscila Padro Beltrán, quem encontrei pelos “Quilombos das Américas”, agradeço a acolhida em Ibarra, o apoio em momentos difíceis do trabalho de campo e a interlocução que perdura.

Se transitar pelos terrenos incertos do Pacífico demandava a construção de uma rede de cuidado e orientação, posso dizer que a empreitada teve sucesso graças às pessoas que me acolheram desde o primeiro instante.

Ao indicar-me a travessia entre Equador e Colômbia, Jhon Henry Arboleda direcionou meu percurso. Reconhecendo-me como família, trouxe sentidos de pertencimento e solidariedade a cada momento em que chegavam mensagens: "hola prima, como estás?". Foi também um interlocutor importante para a escrita da tese. 
Carlos Rúa foi companheiro em infindáveis momentos dessa trajetória. Yolanda Murgueitio e Carlos abriram as portas de sua casa e ofertaram-me toda uma rede de aliança. Carlito cumpre perfeitamente o obrigatório requisito de um líder em sua capacidade de ser produtor permanente de alegria e felicidade. Ademais, é um grande intelectual. Nossa interlocução permeia a reflexão e a escrita desta tese, que agora se apresenta em sua memória.

A Hilda Nayibe Hurtado, Nelly, María del Mar, Daniela e todas as mulheres do Bairro Arboleda, agradeço a companhia, os cuidados e mimos que foram fundamentais para superar os problemas de saúde.

Agradeço a confiança de compartilharem suas vidas comigo a todas as mulheres com quem dialoguei: Martha García, María Cecilia, Melania Ester Quiñones, Edith Rivas Klinger Palma, Mérice Benguera, Ruth Ainda Cabezas Ortiz, Lucrecia Borges, Sixta Tulia Londoña Ponce, Emilia Eneyda Valencia Murraín.

Para Inés Morales, teria inúmeras palavras de agradecimento. Gostaria de registrar seu atributo de sempre encontrar maneiras de evitar dizer não quando a coisa vale a pena. Agradeço a toda família de Inés, a de sangue e a de coração: todos do Bairro Novo Horizonte, pelo carinho que sempre tiveram comigo.

À Mailen Aurora Quiñones Mosquera, agradeço a disponibilidade para o convívio e os cuidados com minha enfermidade.

A Eva Lucia Grueso, agradeço por haver me recebido no escritório de PCN e pela densidade de nosso diálogo.

A Rosalba Quiñones e a sua filha Cira Martínez, agradeço o interesse pelo Brasil, a possibilidade de falar sobre meu país e sobre nossas formas de construção e compreensão da diferença.

À Maria Olinda Orobio, agradeço pelas manhãs na praia e pelas cervecitas.

À Marlene Tello, agradeço por poder compartilhar a fé nos orixás.

À Ana Granja Castillo, agradeço a oportunidade de vivenciar a mariscagem. A ela e suas filhas, Ana Karina e Yulisa, agradeço por haverem me recebido em Salahonda. A Martina Granja Castillo e Nidia Quiñones Granja, agradeço as tardes de conversas. Os dias em Salahonda foram um belo presente de aniversário.

A Yonny Nazareno e Amada Cortéz, assim como a todas as mulheres de MOMUNE, agradeço pelo nosso intercâmbio e rendo um tributo especial pela festa de despedida de San Lorenzo, momento em que me senti reconhecida e amada. 
Vilma Estacio Abá recebeu-me em sua casa, em Ricauter, com suas botellas curadas e outros instrumentos usados na parturição. Cantou e tocou para que eu filmasse. Grata por tudo.

À Ana Germania Loma Abá, agradeço por, mesmo doente, haver partilhado questões de sua intimidade, antes não partilhadas.

A família Micolta, Targelia, Leo, Elvia e Eneida, agradeço pela hospitalidade em Palma Real. Os diálogos com Targelia foram incríveis. As tardes com Elvia, muito agradáveis.

A generosidade da partilha de todas essas mulheres tornou possível a construção deste texto.

Quanto aos contatos institucionais, registro aqui a alegria de encontrar nas universidades colombianas e equatorianas intelectuais muito abertos ao diálogo. Agradeço às professoras/es e pesquisadoras/es: Ochy Curiel, Jaime Arocha, Miriam Jimeno e Javier Saenz (Universidad Nacional de Colombia); Eduardo Restrepo (Universidad Javeriana); Catherine Walsh (Universidad Andina Símon Bolívar); Kattya Hernandez, Lisset Coba e Mercedes Pietro (FLACSO-Equador); Francia Jenny Moreno, Yasmin Guilchins, Nathalie Trejol e Olivia Cortez, todas pesquisadoras do Programa de Estudos de Gênero da FLACSO/Equador e Jhon Antón, pesquisador associado à FLACSO.

Um agradecimento especial à Claudia Mosquera, da Universidad Nacional de Colombia, que me recebeu com carinho em Bogotá, compartilhou generosamente sua leitura sobre temas concernentes à pesquisa, além de me regalar valiosas publicações do grupo de pesquisa que ela encabeça (IDCARÁN/CES/UNAL). E à Betty Ruth Lozano Lerma, da Universidad del Valle - Colombia, com quem o diálogo, apesar de breve, foi bastante produtivo.

Aos funcionários do departamento, Jorge Máximo e Rosa Cordeiro, agradeço a prontidão no atendimento de dúvidas e outras questões.

Por fim, agradeço à CAPES e ao CNPQ pelo financiamento. 


\section{RESUMO}

Esta tese resulta de etnografia realizada com mulheres negras/afrodescendentes na região fronteiriça entre Equador e Colômbia, às margens do Oceano Pacífico. Categorias interseccionais como raça/etnia e gênero conduziram-me pelo universo afro-pacífico, o qual conheci por intermédio da escuta atenta às matronas: mulheres que constroem redes de irmandade política e afetiva, conectando doméstico e público. A partir de suas posições de parteiras, curandeiras, rezadeiras ou cantadoras, tornaram-se lideranças políticas em organizações afro/negras, em organizações de mulheres e de mulheres negras. Partindo de suas narrativas, propus uma análise da classificação étnico-racial, buscando compreender os matizes, as tensões e articulações da concepção colombo-equatoriana em torno do antirracismo e da luta pelos direitos territoriais das comunidades negras. A territorialidade afro-pacífica, por sua vez, consiste em uma construção política baseada na vivência do território-água, articulada a uma ideia de permeabilidade entre rural e urbano. A ação feminina dá-se em um contexto de violência nas relações interpessoais de gênero e, contemporaneamente, de violências sociopolíticas decorrentes da ação bélica organizada. Bandas criminais, grupos guerrilheiros e paramilitares, bem como os exércitos nacionais intervêm cotidianamente nos territórios coletivos ancestrais, atravessando as vivências da territorialidade. As matronas são peça-chave na resistência do povo afro-pacífico às violências.

Palavras-Chave: Matronas, Afro-Pacífico, Territorialidade, Etnicidade, Gênero, Violências. 


\begin{abstract}
This thesis is the result of ethnography with black / afrodescendent women, in the border region between Ecuador and Colombia, along the Pacific Ocean. Intersectional categories such as race / ethnicity and gender led me by Afropacific universe, which I met through the attentive listening to the matrons: women that build networks of political and emotional sisterhood, connecting domestic and public. From their positions of midwives, healers, mourners or traditional singers have become political leaders in afrodescendent / black organizations, in women's organization and black women's organizations. Starting from their narratives, I proposed an analysis of ethno-racial classification, trying to understand the nuances, tensions and articulations of the Colombian-Ecuadorian conception around antiracism and the struggle for land rights of black communities. The Afropacific territoriality, in turn, consists of a political construction, articulated with an idea of permeability between rural and urban. The women's action takes place in a context of violence in interpersonal relationships of gender and, simultaneously, of socio-political violence arising from organized warlike action. Criminal bands, guerrillas and paramilitary groups, as well as national armies, intervene daily in the ancestral collective territories, transforming the experiences of territoriality. The matrons are key pieces in Afropacific people's resistance to violence.
\end{abstract}

KEY-WORDS: Matrons, Afro-Pacific, Territoriality, Ethnicity, Gender, Violence. 


\section{SUMÁRIO}

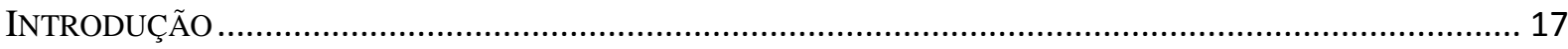

PARTE I

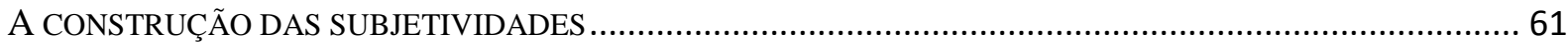

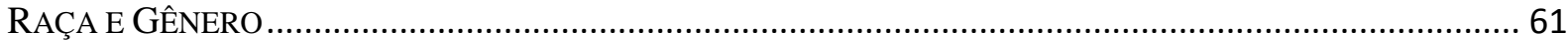

CAPÍTULO 1 - RAÇA E ETNIA NA FRONTEIRA ENTRE COLÔMBIA E EQUADOR....................................... 62

UMA LEITURA HISTÓRICA SOBRE AS CATEGORIAS DE CLASSIFICAÇÃO ÉTNICO-RACIAIS NA

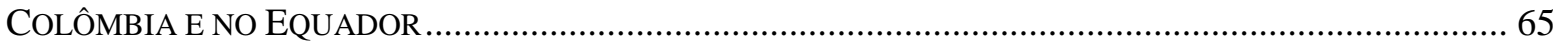

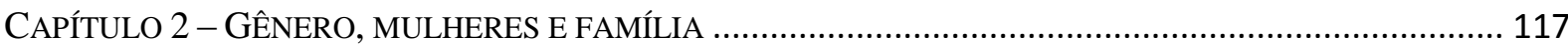

A CONSTRUÇÃO DO FEMININO E DO MASCULINO A PARTIR DA FAMÍLIA .......................................... 128

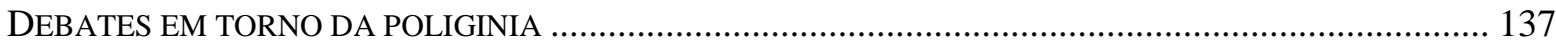

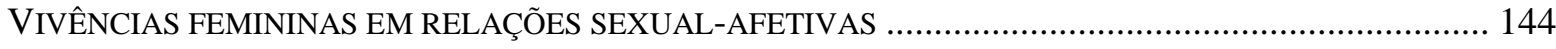

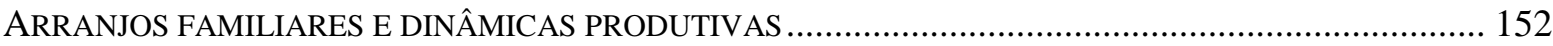

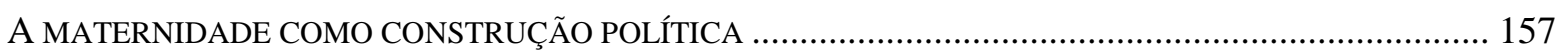

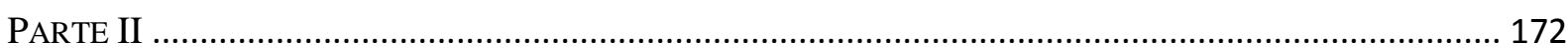

AS MULHERES SÃO COMO AS ÁGUAS, CRESCEM QUANDO SE ENCONTRAM........................................ 172

ORGANIZAÇÃO TERRITORIAL E POLÍTICA NO PACÍFICO NEGRO COLOMBO-EQUATORIANO ................ 172

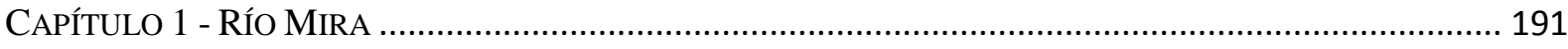

COMO NASCEU O PROCESSO ORGANIZATIVO AFRO-COLOMBIANO? ............................................... 193

COMISIÓN DE MUJERES DEL CONSEJO COMUNITARIO BAJO MIRA Y FRONTERA ............................. 214

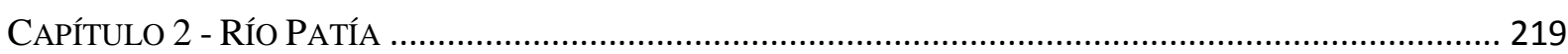

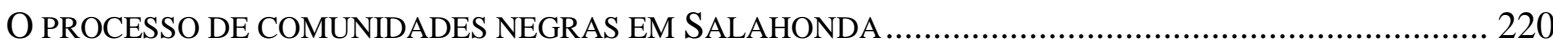

A INCLUSÃO DOS MANGUEZAIS NO TÍTULO COLETIVO .................................................................. 223

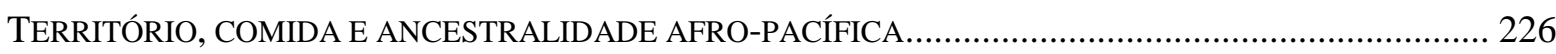

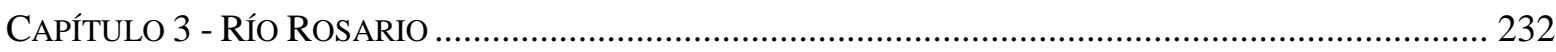

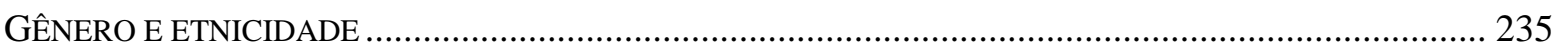

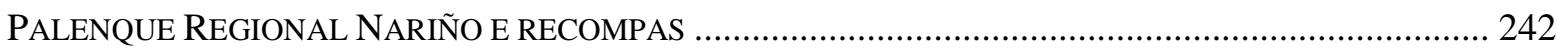

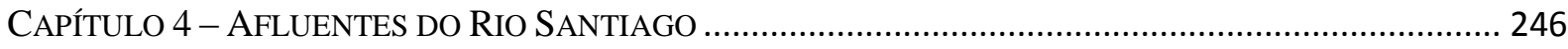

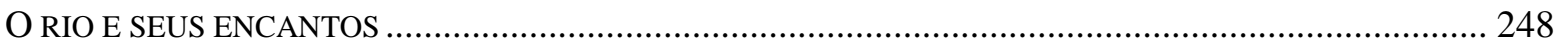

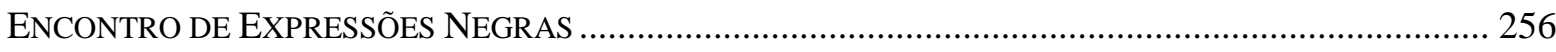

COMARCA AFroECUATORIANA DEL NoRTE DE ESMERALDAS (CANE) ........................................ 258

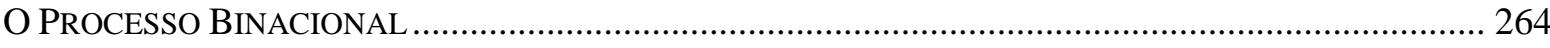

Movimento de MulHeRES NegRAS Do NoRTE DE ESMERALDAS (MOMUNE) …....................... 271

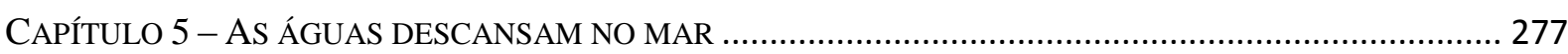




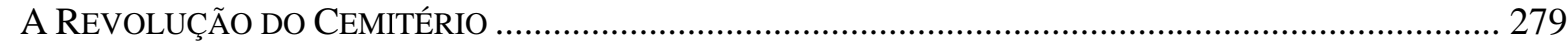

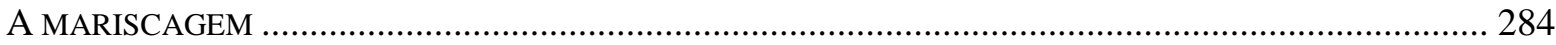

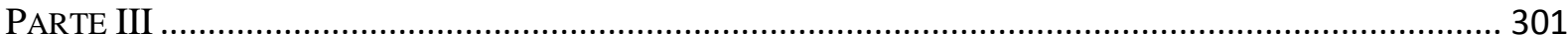

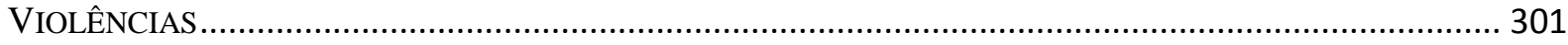

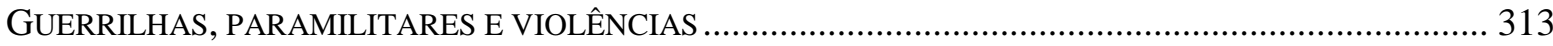

NARRATIVAS FEMININAS E OS IMPACTOS CONTEMPORÂNEOS DA VIOLÊNCIA SOCIOPOLÍTICA......... 322

SOFRIMENTOS, PERDAS, CONSTRANGIMENTOS E RESISTÊNCIAS DAS MULHERES AFRO-PACÍFICAS NO

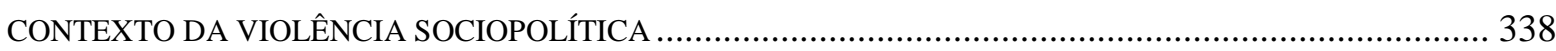

ARTICULAÇÕES E CONTRA-ARTICULAÇÃO NA DISPUTA PELO TERRITÓRIO: TEMPORALIDADES E

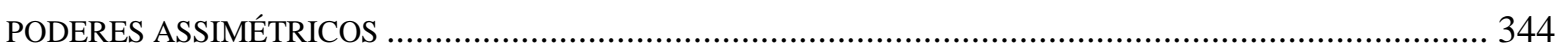

CONFLITOS NA REGIÃO FRONTEIRIÇA: EQUADOR E COLÔMBIA ......................................................... 355

A VIOLÊNCIA SOCIOPOLÍTICA E ALÉM DELA: VIOLÊNCIAS INTERPESSOAIS DE GÊNERO.................... 362 MATRONAS AFRO-PACÍFICAS: RESISTÊNCIA À VIOLÊNCIA E DEFESA POLÍTICA DA TERRITORIALIDADE 380

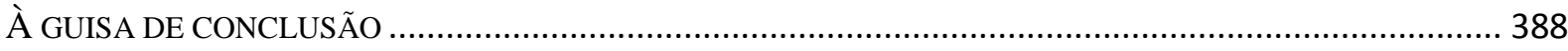

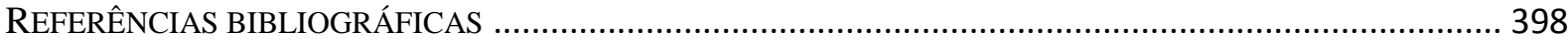

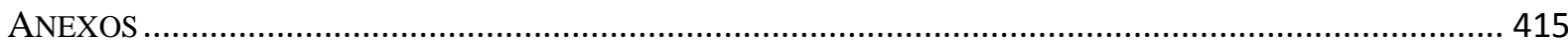




\section{LISTA DE FIGURAS}

Figura 1 - Mapa de localização $\quad 34$

Figura 2 - Isabela Lara com seu filho, Aron Isaías 94

Figura 3 - Mãe e filho em La Concepción 96

Figura 4 - Jairo, Veronica e Axel 99

Figura 5 - María Magdalena $\quad 100$

Figura 6 - Casas sobre pilotis $\quad 181$

Figura 7 - Ana Granja com remo 188

Figura 8 - Martha García com facão 188

Figura 9 - Mapa do Rio Mira 193

Figura 10 - Mapa do Rio Patía

Figuras 11 - Ervas da casa de Targelia, Chillangua, Chirarrán 230

Figura 12 - Mapa do Rio Rosario $\quad 234$

Figura 13 - Mapa dos afluentes do Rio Santiago 248

Figura 14 - Yonny Nazareno playando $\quad 254$

Figura 15 - Mapa do Rio Mataje 279

Figuras 16 - Sangara e piangua $\quad 290$

Figuras 17 - Sangariando: quando chegamos; quando a maré secou 296

Figura 18 - Botes do exército equatoriano 360 


\section{LISTA DE SIGLAS}

ACAPA - Asociación Campesina del Patía, Colômbia.

ACCU - Autodefensas Campesinas de Córdoba y Urabá, Colômbia.

ADCT - Ato das Disposições Constitucionais Transitórias, Brasil.

AFRODES - Asociación Nacional de Afrocolombianos Desplazados, Colômbia.

AGROCREM - Asociación de Grupos Organizados Comunitarias Recolectores del Manglar,

Equador.

ASCONAR - Asociación de Concheros y Concheras de Nariño, Colômbia.

ASCONCHAJAL - Asociación de Concheras de Chajal, Colômbia.

ASOCOETNAR - Asociación de Consejos Comunitarios de la Zona Norte y Centro de la Costa Pacífica de Nariño, Colômbia.

ASOLINAR - Asociación de Lideresas del Pacifico Nariñense, Colômbia.

AUC - Autodefensas de Colombia, Colômbia.

BACRIN - Bandas Criminais, Colômbia.

BID - Banco Interamericano de Desenvolvimento.

CANE - Comarca Afro-Equatoriana do Norte de Esmeraldas, Equador.

CAPES - Coordenação de Aperfeiçoamento de Pessoal de Nível Superior. Brasil.

CDHM - Comissão de Direitos Humanos e Minorias, Câmara dos Deputados, Brasil.

CECOMET - Centro de Epidemiología Comunitaria y Medicina Tropical, Equador.

CES - Centro de Estudos Sociais, Colômbia.

CEUNA - Colectivo de Estudiantes Universitari@s Afrocolombian@s, Colômbia.

COAGROPACÍFICO - Cooperativa Agrícola do Pacífico, Colômbia.

CODAE - Corporación de Desarrollo Afroecuatoriano, Equador.

CONAMUNE - Coordinadora Nacional de Mujeres Negras del Ecuador, Equador.

CONAQ - Coordenação Nacional de Articulação das Comunidades Negras Rurais Quilombolas, Brasil.

CONDICOC - Consejo Comunitario de la Cordillera Occidental de Nariño, Colômbia.

CONEPIA - Comisión Nacional de Estadísticas para Pueblos Indígenas y Afroecuatorianos, Equador.

CTs - Circunscripciones Territoriales, Equador.

CVC - Corporación Autónoma Regional del Valle del Río Cauca, Colômbia.

DANE - Departamento Administrativo Nacional de Estadística, Colômbia. 
DNP - Departamento Nacional de Planeación, Colômbia.

EH - Encuesta de Hogares, Colômbia.

ELC - Ecuador Land Company, Equador.

ELN - Ejército de Liberación Nacional, Colômbia.

ENEM - Exame Nacional do Ensino Médio, Brasil.

EPL - Ejército Popular de Liberación, Colômbia.

ERG - Ejército Revolucionario Guevarista, Colômbia.

ETA's - Entidades Territoriais, Colômbia.

FAO - Organização de Alimentação e Agricultura das Nações Unidas.

FARC - Forças Armadas Revolucionárias da Colômbia, Colômbia.

FECONA - Federación de Comunidades Negras del Alto San Lorenzo, Equador.

FEDARPOM - Federación de Artesanos Afroecuatorianos Recolectores de Productos Bioacuáticos del Manglar, Equador.

FEDARPROBIM - Federación de Asociaciones de Recolectores de Productos Bioacuáticos y Naturales, Equador.

FEDOCA - Federación de Organizaciones Culturales Afro, Equador.

FEPALHUM - Federación Afro Palenque Los del Bajo Humedales Borbón, Equador

FIG-ACDI - Fundo de Igualdade de Gênero da Agência Canadense de Desenvolvimento Internacional.

FLACSO - Faculdade Latino-Americana de Ciências Sociais, Equador.

FUNDEMUJER - Fundación para el Desarrollo de la Mujer de Buenaventura, Colômbia.

IBGE - Instituto Brasileiro de Geografia e Estatística. Brasil.

ICAN - Instituto Colombiano de Antropologia, Colômbia.

ICV - Índice de Calidad de Vida. Equador.

IDCARÁN - Grupo de pesquisa sobre igualdade racial, diversidade cultural, conflitos ambientais e racismos nas Américas Negras, Colômbia.

IESS - Instituto Ecuatoriano de Seguridad Social, Equador.

INCODER - Instituto Colombiano de Desarrollo Rural, Colômbia.

INCORA - Instituto Colombiano para la Reforma Agraria, Colômbia.

INCRA - Instituto Nacional de Colonização e Reforma Agrária, Brasil.

INEC - Instituto Nacional de Estadísticas y Censo, Equador.

INEP - Instituto Nacional de Estudos e Pesquisas Educacionais Anísio Teixeira, Brasil.

JEGA - Jorge Eliécer Gaitán, Colômbia. 
LOOT - Ley Orgánica de Ordenamiento Territorial, Colômbia.

M-19 - Movimiento 19 de abril, Colômbia.

MEC - Ministério da Educação, Brasil.

MERGE - Manejo de Ecosistemas y Recursos con Enfasis en Género, Equador.

MOMUNE - Movimiento de Mujeres Negras del Norte de Ecuador, Equador.

MPD - Partido Movimiento Popular Democrático, Equador.

OIT - Organização Internacional do Trabalho.

ORCONE - Organización de Comunidades Negras, Colômbia.

ORNEP - Organización Negra de Francisco Pizarro, Colômbia.

PLADEICOP - Plan de Desarrollo Integral para la Costa Pacífica, Colômbia.

PCN - Proceso de Comunidades Negras, Colômbia.

PMRC - Programa de Manejo de Recursos Costeiros, Equador.

PNUD - Programa das Nações Unidas para o Desenvolvimento.

PROUNI - Programa Universidade para Todos, Brasil.

PRONATEC - Programa Nacional de Acesso ao Ensino Técnico e Emprego, Brasil.

RECOMPAS - Red de Consejos Comunitarios del Pacifico Sur, Colômbia.

REMACAM - Reserva Ecologica Manglares Cayapas Mataje, Equador.

RESEX - Reservas Extrativistas, Brasil.

SEPPIR - Secretaria de Políticas de Promoção da Igualdade Racial, Brasil.

TLC - Tratado de Livre Comércio, Colômbia.

UC-ELN - Unión Camilista - Ejército de Liberación Nacional, Colômbia.

UONNE - Unión de Organizaciones Negras del Norte de Esmeraldas, Equador.

USAID - Agência dos Estados Unidos para o Desenvolvimento Internacional.

WOLA - Escritório de Washington para América Latina. 


\section{INTRODUÇÃo}

Em agosto de 2010, quando participava do VI Congresso Brasileiro de Pesquisadores Negros, no Rio de Janeiro, comecei a delinear a proposta desta tese. Ouvia, então, Jurema Werneck ${ }^{1}$ falar sobre identidades e práticas teóricas em torno da questão de gênero, no momento em que finalizava a dissertação de mestrado em antropologia. No mestrado, trabalhei com práticas produtivas e políticas públicas, refletindo sobre a experiência do Quilombo de Ivaporunduva, Vale do Ribeira, São Paulo. Jurema dizia que o recorte de gênero começa quando escutamos mulheres em nossas pesquisas. Quando a voz de mulheres se projeta nos escritos acadêmicos a partir de uma escuta atenta e qualificada. Na curta etnografia que fiz no contexto do mestrado, conversei com mulheres e homens de Ivaporunduva. Porém, naquele momento, percebi que não fui capaz de realmente ouvir as mulheres dessa comunidade. Percebi que meu texto trazia em primeiro plano a voz masculina, preponderante nas práticas relacionadas à bananicultura orgânica. Não dava destaque à participação das mulheres na organização produtiva, a qual ganha corpo principalmente no artesanato com a palha da banana e também no turismo étnico-cultural. A insatisfação com a pesquisa do mestrado despertou o desejo de olhar e interatuar com mulheres negras, investigando a condição de ser mulher negra, no contexto do doutorado.

Algum tempo depois, comecei a atuar como consultora do Projeto Quilombos das Américas: articulação de comunidades afrorrurais ${ }^{2}$. Trata-se de iniciativa interinstitucional que, em sua primeira etapa, envolveu Equador, Brasil e Panamá. Consistiu na realização de pesquisa em um território afro-rural de cada um desses países, com vistas a contribuir na promoção da soberania alimentar e na ampliação do acesso a direitos, especialmente direitos territoriais, de comunidades afro-rurais nos três países ${ }^{3}$. Teve o envolvimento de organizações da sociedade civil representativas da população afro-rural, órgãos governamentais e organismos internacionais, sob a coordenação da Secretaria de Políticas para a Promoção da Igualdade Racial (SEPPIR). Teve como objetivo ainda estimular a constituição de uma rede de articulação de comunidades afro-rurais na América Latina e no Caribe. Essa foi a entrada

\footnotetext{
${ }^{1}$ Intelectual e ativista negra brasileira, coordenadora de Criola, organização não governamental carioca fundada em 1992, doutora em Comunicação e Cultura pela Escola de Comunicação da Universidade Federal do Rio de Janeiro (2007).

${ }^{2}$ Nessa consultoria, estive ligada à ONU Mulheres, entre maio de 2011 e março de 2012.

${ }^{3}$ No caso do Equador, o projeto atuou no Território Ancestral Valle del Chota, la Concepción y Salinas. Não participei deste trabalho de campo; fiquei responsável pela sistematização dos relatórios de pesquisa na área de ciências sociais e ciências da terra dos três estudos de caso, que resultaram no livro Quilombos das Américas: articulação de comunidades afrorrurais.
} 
para o universo afro-latino, dando vazão a um desejo de conhecer a diáspora africana em outros lugares da América e do Caribe.

Por esses dois caminhos, esbocei uma etnografia com mulheres afro-colombianas e afro-equatorianas. Importante para a definição do lócus de pesquisa na fronteira entre Colômbia e Equador foi o meu contato com Inés Morales. Conheci Inés em Brasília, em dezembro de 2011, por ocasião da I Oficina de Intercâmbio de Experiências e Pacto de Ações, atividade integrante do Projeto Quilombos das Américas. Depois nos reencontramos na capital equatoriana, Quito, e juntas seguimos para San Lorenzo, ao Norte do Equador. Foi essa líder do movimento de mulheres negras do Equador quem me introduziu no cenário organizativo equatoriano e colombiano de mulheres e comunidades negras.

Essa foi uma viagem de um mês - de maio a junho de 2012 -, a primeira incursão no campo, na qual visitei dois territórios negros ancestrais no Equador: o norte de Esmeraldas e o Valle del Chota, la Concepción y Salinas ${ }^{4}$. Quando estava em San Lorenzo, atravessei a fronteira entre Equador e Colômbia, pelo Oceano Pacífico, e conheci também Tumaco. Fiz esse trajeto motivada por Jhon Henry Arboleda, pesquisador afrocolombiano, nascido em Tumaco, que estava realizando o mestrado na Universidad Andina Símon Bolívar, em Quito, sob a orientação de Catherine Walsh. Quando estive em Quito, nessa primeira incursão, tive a oportunidade de encontrá-lo, mediada por um contato eletrônico com a professora Catherine Walsh ${ }^{5}$. Com Jhon Henry conversei longamente sobre a existência de uma rede de comunicação conectando o Equador, desde San Lorenzo, província de Esmeraldas, a Tumaco, Buenaventura, Quibdó, Cali e Bogotá, a qual configura um cenário de articulação política do povo afrodescendente.

Regressei a campo em outubro de 2012 e permaneci até dezembro do mesmo ano. Nessa ocasião, permaneci no litoral Pacífico, entre San Lorenzo e Tumaco. Inés novamente me recebeu em sua casa, na Rua Armada Nacional, Bairro Novo Horizonte, San Lorenzo, Esmeraldas. Al otro lado de la raya, já em território colombiano, a relação com Carlos Rua, ativista afro-colombiano, foi chave para o desenvolvimento do trabalho de campo em Tumaco. Eu e Carlito nos conhecemos virtualmente por intermédio de Vera Rodrigues. Ela realizou na tese de doutorado um estudo antropológico sobre políticas públicas de reconhecimento de comunidades negras na Colômbia e no Brasil. Carlos e Yolanda, sua

\footnotetext{
${ }^{4}$ Desde a primeira viagem, sempre passei por Bogotá, até por uma questão pragmática, já que tem uma empresa aérea brasileira a qual oferta passagens com milhas para o trecho São Paulo - Bogotá.

${ }^{5}$ Além do contato com Catherine Walsh, tive oportunidade de dialogar com professores/as e pesquisadoras/es no Equador e na Colômbia, que me ajudaram na pesquisa bibliográfica e etnográfica, aos quais agradeço na sessão inaugural da tese.
} 
companheira, me abrigaram na casa de Tumaco e, quando já não moravam mais lá, ajudaram a situar-me na cidade. Ademais, Carlos também me introduziu no cenário políticoorganizativo afro-colombiano.

As primeiras pesquisas foram fundamentais para a elaboração de um projeto de pesquisa com alguma densidade etnográfica. Também ajudaram a definir os caminhos e as relações com mulheres e organizações afro-pacíficas ${ }^{6}$. Nesse sentido, fazem-se presentes no texto, ainda que indiretamente. A etnografia teve continuidade entre abril de 2013 e fevereiro de 2014, quando retornei à Colômbia e ao Equador ${ }^{7}$, dessa vez com apoio da CAPES por meio de Bolsa Sanduíche ${ }^{8}$. Estive, portanto, na região da Costa Pacífica, ao sul da Colômbia e ao norte do Equador, entre maio de 2012 e fevereiro de 2014, em três viagens: a primeira de um mês, a segunda de três meses e a última de dez meses. Permaneci nos países um ano e dois meses, realizando pesquisa de campo e bibliográfica 9 .

O trabalho de campo iniciou-se com a observação participante de fluxo livre. Aprofundando a interlocução com algumas mulheres e expandindo as conexões para novos diálogos com mulheres negras em Tumaco e San Lorenzo, senti a necessidade de precisar minhas questões. Assim, foi concretado um longo roteiro com perguntas orientadoras, agrupadas segundo as seguintes temáticas: atuação política, territorialidade, concheria ou mariscagem, violência, maternidade, conjugalidade, raça/etnia e gênero. O principal objetivo desse roteiro era acessar reflexões que fazem minhas interlocutoras de pesquisa sobre suas vidas. Inicialmente, imaginei que as perguntas poderiam ser propostas em módulos, em diferentes momentos e contextos. O roteiro corresponde ao Anexo 1 da tese.

Com as primeiras interlocutoras, o roteiro foi desenvolvido em várias sessões. Depois de certo tempo, algumas questões ficaram na mente e já não era mais habitual o uso do roteiro. Também percebi que parte das questões era pertinente para o diálogo com algumas mulheres e outras não. Em casos de organizações de mulheres, como a Comisión de Mujeres

\footnotetext{
${ }^{6}$ A definição do escopo de interlocução da pesquisa foi um percurso. Em Tumaco, iniciei o diálogo com a Asociación de Concheros y Concheras de Nariño(ASCONAR) e a Asociación de Concheras de Chajal (ASCONCHAJAL), porém, não tive condições de dar continuidade a ele. Agradeço a disponibilidade e o interesse de Carmen Julia Palacio e Ines Cortes Preciado.

${ }^{7}$ Nessaviagem, permaneci em Bogotá em torno de três meses, onde realizei pesquisa bibliográfica e estabeleci diálogos com a orientadora do Doutorado Sanduíche, Mara Viveros Vigoya, que se tornou co-orientadora da tese, a quem agradeço pelo acompanhamento e pela possibilidade de continuidade do diálogo. Houve ainda um período de residência em Cali, cerca de 20 dias, por questões de saúde.

${ }^{8}$ Processo 3605-13-2(modalidade Doutorado Sanduíche no Exterior). Anterior e posteriormente à bolsa Sanduíche concedida pela CAPES, fui bolsista do CNPq.

${ }^{9}$ Ao longo da pesquisa, nas diversas etapas, vivi alguns percalços relativos à entrada no campo, que estão relacionados à mobilidade em uma área de violência sociopolítica. Questões a eles vinculadas serão abordadas na terceira parte da tese, na qual o tema é a violência.
} 
Negras del Consejo Comunitario Bajo Mira y Frontera, houve conversas feitas com duas mulheres simultaneamente. No caso das mulheres de Palma Real/San Lorenzo/Equador, muitas delas concheras, as conversas contaram com o estímulo de materiais externos, em especial um conjunto de imagens ampliadas em quadros sobre os manguezais do Brasil: o povo do mangue, os produtos, as Reservas Extrativistas (RESEX) Marinhas. No caso das mulheres de Salahonda/Colômbia, que também são marisqueiras, a conversa, especialmente em torno da territorialidade, foi estimulada por uma história em quadrinhos sobre os Quilombos do Brasil ${ }^{10}$.

Ao todo, conversei com trinta mulheres e uma família mista (com a presença de mulheres e homens), nas seguintes localidades: as colombianas Bogotá, Cali ${ }^{11}$,Tumaco e Salahonda (especialmente mulheres dos Rios Rosario, Patía e Baixo Mira); no Equador, San Lorenzo (especialmente mulheres do Rio Santiago e do Rio Mataje) e La Concepción ${ }^{12}$. Os diálogos foram muito diversos e refletem o tipo de relação que construí com essas mulheres ${ }^{13}$. Com algumas, como Emilia Murrain, a interlocução resume-se a um encontro breve em Cali. Com outras, como Marlene Tello, foram cerca de seis horas de conversação gravadas, além das conversas registradas no caderno de campo e aquelas decorrentes da convivência cotidiana, guardadas na memória. Com quase todas as interlocutoras, usei o recurso do gravador; com outras, apenas o caderno de campo. Com essas mulheres, acordamos que os diálogos seriam fonte de pesquisa para a escrita do um texto antropológico ${ }^{14}$. Ao todo, os áudios resultaram em 670 páginas de histórias ${ }^{15}$.

\footnotetext{
${ }^{10}$ A história em quadrinhos é parte da Cartilha O Brasil também é Quilombola, que elaborei em parceria com o Coletivo Muruá, em consultoria para a Coordenação Estadual de Comunidades Quilombolas do Pará, Malungu, em projeto financiado pela SEPPIR.

${ }^{11}$ Em Bogotá e Cali, as conversas se deram de forma menos sistematizada, porém fazem parte das experiências que me permitem compreender a realidade de mulheres negras neste país e, de forma pontual, aparecem no texto.

${ }^{12}$ Essa é uma paróquia, para usar o termo oficial da divisão político-administrativa equatoriana, que pertence ao Território Ancestral Valle del Chota, La Concepción y Salinas, o qual configura outro contexto histórico de ocupação negra no Equador. Dada as amplas diferenças entre essa região e o território do norte de Esmeraldas, não consegui incorporar substancialmente as narrativas das mulheres de La Concepción. Porém, algumas questões serão abordadas em especial na Parte I da tese.

${ }^{13}$ Para Alfredo Molano, "ese es el punto de partida, insisto, de las historias de vida: la relación que uno establece con el entrevistado. Ahi hay algo emocional, hay algo amoroso, si ustedes quieren, que permite comprender mucho más allá de las palabras lo que la gente quiere decir". A relação estabelecida entre quem escuta e quem conta a história é central. Desse momento, provém a luz para elaborar a história, o que permite reescrevê-la. No momento da escuta, se a pessoa se permite, está entrando nela algo novo e que depois deve sair na elaboração da história de vida (Molano, 1998: 103-104).

${ }^{14}$ Houve diálogos desenvolvidos em situações da cotidianidade, com vizinhas e amigas, por exemplo. Quando alguma questão desses diálogos elucida temas de tese, trouxe a conversação usando nomes fictícios, já que não estava acordado que as falas poderiam ser trazidas ao texto.

${ }^{15}$ Nos textos em castelhano e, mais especificamente nas transcrições de diálogos como mulheres Afropacíficas, respeitou-se o dialeto dessas mulheres. Assim, o apóstrofe foi utilizada para marcar palavras cortadas ou letras não pronunciadas nos vocábulos.
} 
Interpreto esse material como narrativas das mulheres com quem dialoguei, histórias de vida. Para algumas das interlocutoras, a partir do nosso diálogo, elaborei uma linha do tempo, uma cronologia de suas andanças, o que me ajudou a situar cada experiência vivida no contexto de suas trajetórias e assim dar continuidade às conversações sistematicamente. Inicialmente, o plano era estruturar a tese com base em algumas dessas histórias de vida, especialmente nas que resultam de interações mais profundas. Entretanto, dada a extensão do material etnográfico ${ }^{16}$, o plano inviabilizou-se.

Alternativamente, busquei então selecionar trechos que falam das questões recortadas nessa tese: raça, etnia, gênero, família, territorialidade e violência. Tais trechos são a base da escrita do texto, com as quais pus a dialogar reflexões da antropologia e do feminismo, mas também de outras áreas, como a geografia, por exemplo. Para não perder de vista o lugar de fala das mulheres com quem dialoguei, elaborei uma síntese da história de vida de cada uma, que corresponde ao Anexo II da tese, o qual merece ser lido anteriormente ao texto principal. Como veremos ao longo do texto, as falas estão inscritas em certos contextos e trajetórias, adquirindo sentido dentro desse cenário, de modo que se faz necessário conhecer os percursos percorridos por essas mulheres.

Com a ajuda de Antonádia Borges, concebo que a experiência etnográfica proporciona um encontro de três matrizes teóricas: teorias antropológicas acadêmicas, teorias antropológicas de minhas anfitriãs e minhas próprias teorias, associadas inextrincavelmente com as duas primeiras (Borges, 2011: 982). Na construção de teorias próprias, conforme coloca Borges, a etnografia passa a ser o locus de invenção de um método de investigação e de diálogo com minhas anfitriãs, no trabalho de campo e na academia. Vale ressaltar que minhas interlocutoras também são investigadoras, na medida em que estão constantemente buscando alternativas para seus problemas cotidianos e/ou envolvidas com a luta política em torno do reconhecimento de territórios ancestrais. Como lideranças de processos socioorganizativos, elas também estão interessadas nos sentidos coletivamente atribuídos aos fatos sociais. Nesse sentido, investigam e elaboram as experiências coletivas nas quais estão envolvidas. Ademais, tais mulheres são tramas de relações. Em cada uma delas, expressa-se uma coletividade.

Sueli Kofes propõe uma distinção entre "histórias de vida", "relatos de vida", "biografia" e "autobiografia". Em sua pesquisa com trabalhadoras domésticas, ela construiu "relatos de vida" que são assim circunscritos, porque foram motivados pela investigadora,

\footnotetext{
${ }^{16}$ Somente o diálogo com Marlene Tello resultou em um documento de 111 páginas.
} 
implicando sua presença como ouvinte e interlocutora; restringem-se à situação de entrevista, sem complementação de outras fontes; referem-se a uma parte da vida da pessoa, que diz respeito ao tema da pesquisa, sem esgotar as várias facetas de uma biografia (Kofes, 1998: 83).

A etnografia que realizei se adequa ao primeiro ponto apontado por Kofes, que de certo modo é inerente ao trabalho etnográfico. Relativamente à interação com as interlocutoras, conforme colocado, foram situações diversas que vivenciei com cada interlocutora, contudo, com a maioria delas, compartilhamos outros momentos para além da entrevista. No caso de Inés Morales, por exemplo, minha anfitriã em San Lorenzo, estivemos juntas em seu aniversário por três anos consecutivos e compartilhamos as festas de fim de ano em 2013. Também pela convivência mais duradoura com muitas das interlocutoras, dialogamos sobre várias dimensões de suas vidas. Conforme ressalta Cardoso, "o entrevistado assume papel de protagonismo quando se lhe concede a oportunidade - é seu direito - de referir-se a temas que considera importante em um momento determinado" (Cardoso, 1998: 143). Penso que, para isso, as pausas e o processo contínuo de diálogo contribuíram. O fato de ter estado com minhas interlocutoras em momentos espaçados também ajudou a arejar a relação e permitir a emergência de espaços que proporcionaram essa dinâmica.

Muito provavelmente, não esgotamos as trajetórias de cada uma delas, mas abordamos um punhado de momentos que elas consideraram marcantes em suas experiências como lideranças, trabalhadoras, mães e companheiras. Isso posto, fiquei com a denominação de "histórias de vida", que é amplamente usada nas ciências sociais para pesquisas que se assemelham a esta ${ }^{17}$. A narrativa da tese, ao mesmo tempo em que visita algumas histórias de vida, não localiza precisamente cada uma delas. Como matronas, entendo que as mulheres são feixes de relações. Ou seja, de certo modo, encarnam a coletividade Afropacífica. Nesse sentido, para além da terceira parte da tese, em que recorri diretamente ao anonimato dado o contexto das violências sociopolíticas, a escrita preserva a condição plural da existência de minhas interlocutoras.

Identifico-me com a epistemologia feminista negra, que requer uma rendição de contas pessoal da autora (Velasco, 2012: 36). Nesse sentido, entendo que subjaz às narrativas de mulheres afro-pacíficas aqui presentes uma narrativa pessoal, que é norteadora das demais e, por isso, algumas vezes explicitada ao longo do texto. A narrativa pessoal inscreve-se, por sua vez, em um "eu que foi considerado outro", "que estava à margem" e caminha entre a "linha

\footnotetext{
${ }^{17}$ Para uma revisão sobre a metodologia das histórias de vida nas ciências sociais, indico Lulle, 1998.
} 
tênue e tensa entre o indivíduo e a coletividade", recorrendo às palavras de Ratts (2014: 1213). A tese não esgota a riqueza das narrativas todas, tampouco a riqueza das narrativas esgota a tese, a qual possui uma dimensão conceitual e analítica. Espero que, em oportunidades futuras, nossas vozes ecoem em outros trabalhos.

Em relação à tese, a perspectiva de gênero apresenta-se - de início - como um desejo de estar consciente dela na vivência e na análise das relações, no contexto dessa incursão na Colômbia e no Equador. Nesse sentido, foi definidor estar posicionada como mulher, especialmente como mulher estrangeira. Ainda que se constituíssem em eventos desestabilizadores, a tentativa de estupro em Tumaco, as fragilidades que senti ao atravessar sozinha a fronteira entre os países (o abuso policial, as aproximações masculinas, a solidariedade de outras mulheres) e a vivência do conflito político armado foram experiências que inscreveram em meu corpo e registraram em minha percepção a dimensão de poder presente nas relações interpessoais que envolvem mulheres e homens nesse contexto. Reflexões sobre essas questões estão na terceira parte da tese, que enfoca questões ligadas à violência.

Poder-se-ia pensar que a posição como mulher me acercava de minhas interlocutoras de pesquisa. Por outro lado, a proposta de intercambiar trajetórias femininas nem sempre foi bem sucedida. Houve desencontros nesse caminho, alguns provocados por minha inabilidade em encontrar a justa distância entre vida cotidiana e trabalho, entre minha vida e a de minhas interlocutoras de pesquisa. Os percursos metodológicos da tese são complexos. Algumas das interlocutoras foram também minhas anfitriãs. Compartimos a cotidianidade, o trabalho, trajetórias de vida, relações de modo geral. Nossas interações prolongadas foram sujeitas à temporalidade, que transforma qualquer relação, seja positiva e/ou negativamente.

Ademais, a própria ideia de que há uma relação privilegiada entre etnógrafa e informantes mulheres, segundo Moore (1991), supõe a existência de uma categoria universal “mulher". Ao contrário, ela defende que a categoria empírica denominada "mulher" tem sempre uma especificidade cultural e histórica. Reconhecê-la implica, portanto, "reformular a parcialidade das etnógrafas para com as mulheres que estudam e reconhecer que as relações de força na confrontação etnográfica não têm porque desaparecer pelo simples fato de que as duas partes sejam do mesmo sexo"18. Ademais, ela pondera que o paralelismo entre mulheres de sociedades díspares deve ser cotejado com as diferentes condições de vida da mulher no mundo inteiro, especialmente no tocante à raça, ao colonialismo, ao auge do capitalismo

\footnotetext{
${ }^{18}$ Texto em espanhol, tradução livre.
} 
industrial e à intervenção dos organismos internacionais para o desenvolvimento (Moore, 1991: 21-22).

Relações entre pares não devem ser idealizadas; entre mulheres, e entre mulheres negras, também há relações de poder. Labrecque ressalta que "as conversações entre representantes de duas culturas diferentes são conversações de poder. Uma história de vida faz parte de uma conversação mais ampla, não somente entre dois indivíduos, mas também entre duas categorias de indivíduos" (Labrecque, 1998: 34). Desde minha perspectiva, busquei essas mulheres por vislumbrar suas singulares trajetórias de vida. Desde o ponto de vista delas, pressuponho, deve haver também uma singularidade em minha história. Encarno certos capitais materiais e simbólicos: provinda de outro país, um país irmanado, porém empoderado financeira e socialmente perante seus irmãos colombianos e equatorianos ${ }^{19}$; $c$ com nível de escolaridade superior ao da maioria de minhas interlocutoras; com nível de renda também superior; e, para algumas delas, de outra etnia. Sobrepuseram-se ainda diferenças geracionais: quase todas minhas interlocutoras são mais velhas do que eu. Outra diferença marcada na nossa relação foi o fato de eu não ser mãe durante a etnografia. A maioria das mulheres de minha idade, nessa região, já experienciou a maternidade.

Enfim, a relação entre pesquisadora e interlocutoras de pesquisa foi matizada por uma série de fatores com potencial de gerar tensionamentos, bem como interações produtivas. Esse constituiu um dos grandes desafios dessa empreitada. Nas palavras da antropóloga Natália Maria Alves Machado ${ }^{20}$, há de se estar permanentemente consciente das opressões que sofremos, mas também das que exercemos, ainda que de maneira não intencional. A forma de manejar as relações interpessoais, especialmente de minha parte, ganhou centralidade. A inteligência relacional e emocional pareou-se com a inteligência intelectual para a consecução da tese.

Por outro lado, penso que o relacionamento estabelecido com as mulheres com quem dialoguei extrapolou de certa forma o contexto de uma pesquisa de campo. Ao final da etnografia, dei-me conta de que raras vezes fui apresentada por minhas interlocutoras a outras pessoas de seu contexto como uma pesquisadora ou antropóloga. No mais das vezes, era referenciada como uma amiga, uma companheira, vinda do Brasil, que estava apoiando o processo de mulheres naquele contexto. Creio, então, que o fato de ter ingressado nesse

\footnotetext{
${ }^{19}$ Seguindo a proposta de Moore (1991), observo que o nível de desenvolvimento do capitalismo industrial no Brasil é mais avançado do que nos outros dois países. Já a intervenção dos organismos internacionais de modo geral é maior na Colômbia e no Equador. Ao longo da tese, discutirei algumas implicações dessa intervenção na fronteira Pacífica dos países foco da pesquisa.

${ }^{20}$ Comunicação pessoal.
} 
universo por um vínculo profissional, conforme explicitado no início dessa introdução, talvez tenha influenciado na construção dessa imagem. Ademais, o fato de fazer parte do movimento de mulheres negras no meu país também me colocava em um lugar que não é apenas de pesquisadora. Por fim, efetivamente o acordo com as lideranças que me introduziram no cenário organizativo de mulheres afro-pacíficas sempre foi o de trabalhar em prol de suas organizações, como um tipo de contrapartida à disposição para interlocução que elas ofereciam.

A sobreposição de gênero e raça complexifica a experiência subjetiva. Há lugares muito sensíveis na história de vida de minhas interlocutoras (assim como na minha), os quais, quando tocados, geram incômodos. Há momentos delicados nos quais as pessoas não estão dispostas a falar, escutar ou refletir sobre essas dores. Nesse sentido, a parcimônia foi grande aliada. Ela ajudou a dar o ritmo, num baile em que busquei me deixar conduzir pela parceira; escutar mais, aprender com o entorno e com elas. Isso foi difícil; dificuldade bem descrita por Molano:

Escuchar a otra persona es una disciplina difícil en la medida en que uno no está escuchando sino que está objetando lo que la otra persona dice. En una historia con la gente, en una entrevista, es necesario abrirse realmente sin consideraciones, sin consideraciones sobre uno, abrirse a lo que la otra persona está diciendo sin objetarla, aceptar sin prejuicios, sin críticas, sin distancias lo que la otra persona va diciendo y ese es un ejercicio difícil, porque nosotros queremos poner sobre lo que oímos, lo que decimos y eso implica sacrificios, implica también formación, capacitación y ejercitación en ese arte de escuchar (Molano, 1992: 106).

A dimensão racial trazida na tese resulta de um diálogo entre concepções que experienciei em campo e outras que formulo desde minha vivência racializada no Brasil, bem como a partir de leituras e reflexões que desenvolvo acadêmica e politicamente há mais de uma década. Em minha compreensão, fenotipicamente, negritude é cor da pele; mas é também cabelo, desenhos do rosto, silhueta. Ideologicamente, reconhecer a negritude implica um exercício permanente de questionar a leitura embranquecedora que sociedades latinoamericanas têm forjado ao longo da história.

Refletindo sobre experiências pessoais, desde criança, percebo-me como não branca, porque não me parecia com as apresentadoras de programas infantis, não encontrava nas lojas de brinquedo bonecas semelhantes a mim, por nunca ter sido considerada a mais bonita da sala e não ser a escolha dos meninos mais cobiçados (que pareciam ser os mais interessantes), por me esforçar duplamente para dar conta dos conteúdos e tarefas e assim ganhar o afeto das professoras e colegas. Quando jovem e adulta, também por ser monitorada em lojas de centros 
comerciais, por exemplo, ou por ser abordada em certos contextos e ser tratada como prostituta. Já a construção da negritude, essa eu vivencio como um processo, materializado na medida em que ressignifico episódios vividos a partir da mirada da violência racial e de gênero; na medida em que sinto meu corpo e minha espiritualidade negros. Também quando olho a história da minha família e aprendo a valorizar o legado de minha mãe, de minha avó e das que nos antecederam.

Minha autoimagem como mulher negra foi se constituindo ao passo em que a sociedade brasileira elaborava e se apropriava de uma concepção ampla de negritude. Desde os anos 1970, os movimentos negros brasileiros trabalham em busca do desenvolvimento da consciência e da identidade negra. E, como veremos, também desde fins da década de 1970, estudos sociológicos, com bases em pesquisas censitárias, compreendem como negras as pessoas pretas e pardas. Mas foi especialmente na primeira década dos anos 2000 que o rosto/corpo negro brasileiro passou a figurar amplamente com diferentes tonalidades de pele, texturas de cabelo, variados traços: olhos, narizes e bocas ${ }^{21}$.

Trata-se de um movimento endógeno, que parte de dentro do grupo social negro para a sociedade brasileira como um todo. Ou seja, o gatilho da mudança é o autorreconhecimento, que é o primeiro passo para o empoderamento, segundo o feminismo negro estadunidense. " $\mathrm{Si}$ un grupo no se define a sí mismo, entonces será definido por y en beneficio de otros" (Velasco, 2012: 37). A implementação de ações afirmativas no Brasil, como as cotas para pessoas negras nas universidades, pode ser apontada como um fator impulsionador desse processo. Percebo que a atuação de jovens organizações negras, seja nas redes sociais, seja em encontros presenciais, tais quais o Festival da Mulher Afro-Latino-Americana e Caribenha, também tem um papel de protagonismo no redesenho da negritude ${ }^{22}$. E a democratização do acesso à internet caminha pari passu com o fenômeno.

A amplitude do conceito não significa, porém, um esvaziamento da categoria negra/o. Ou seja, não cabe nela qualquer pessoa, mas, sim, aquelas que são marcadas pelo preconceito por não se encaixarem no padrão fenotípico socialmente valorizado; aquelas que ocupam lugares de poder assimétricos na estrutura da sociedade brasileira, tendo oportunidades e tratamento diferenciado nos âmbitos social, econômico, político, afetivo. Isso ocorre em

\footnotetext{
${ }^{21}$ Uma expressão disso é o post “As 25 negras mais influentes da internet \#25webnegras”, publicado em 2013, pelas Blogueiras Negras, grupo de mulheres negras reunidas em torno das questões da negritude, do feminismo e da produção de conteúdo. Disponível em: http://blogueirasnegras.org/2013/12/31/25-negras-mais-influentes-dainternet/. Acessado em: 13 de agosto de 2014.

${ }^{22}$ Organizações como as Blogueiras Negras, Meninas Black Power, Pretas Candangas, irmandade de mulheres negras do Distrito Federal que integro, entre outras.
} 
diversas instâncias, como coloca Petruccelli (2007), tais quais educação, emprego, distribuição de renda, moradia, constituição de uniões maritais.

Assim, entendo que o processo de autorreconhecimento implica um duplo movimento: o encontro com a dor da discriminação, passando pelo exercício de nomeá-la como racismo; e a valorização de um legado ancestral. Do ponto de vista externo, a sociedade brasileira deixou-se permear por essa mudança, transformando-se ela também. Nesse sentido, a população negra abriu espaços para a desconstrução de um país que se queria branco, dando passo ao processo de construção de uma nação multirracial.

Obviamente, como qualquer processo de transformação social, o fenômeno ora comentado não ocorre de maneira unívoca. As imagens da negritude constroem-se em um jogo de espelhos no qual representações podem divergir. Porém, esse ponto não configura uma novidade da primeira década do milênio. O Brasil sempre se deparou com uma suposta dificuldade de classificação das pessoas segundo sua raça/cor. Contudo, concordo com Petruccelli na interpretação de que essa argumentação parece se basear mais em ideias preconcebidas do que em fundamentos empíricos, já que "tanto histórica, como contemporaneamente, tem se sabido de forma acurada a quem discriminar racialmente no país" (Petruccelli, 2007: 9). Às vezes, divergências ocorrem dentro do grupo social negro e assim o espelho vai desenhando os contornos do processo de (re)construção da negritude e do imaginário nacional.

$\mathrm{Na}$ incursão desta pesquisa, a mudança de países colocou-me perante diferentes lentes sobre o pertencimento étnico-racial. Inicialmente, não podia precisar até que ponto meu olhar de aproximação em relação às interlocutoras de pesquisa era devolvido com um olhar de semelhanças e/ou de diferenças. Ao longo da pesquisa, explicitou-se uma leitura ausente de qualquer dubiedade, como expressou, por exemplo, Marlene Tello, ao dizer: "yo soy negra, tu eres mestiza". Em outros momentos, fui classificada como afro, como trigueña, colorada, zamba, morena e até mesmo como blanca ${ }^{23}$. A devolução do olhar por vezes gerou sensações perturbadoras. Ao mesmo tempo, aguçou minha atenção para a taxonomia étnico-racial no Pacífico Colombo-equatoriano. Nesse ponto, penso que o cruzamento de subjetividades, inerente à metodologia das histórias de vida, teve um balanço produtivo ${ }^{24}$. Analisando ao

\footnotetext{
${ }^{23}$ A discussão em torno de categorias de classificação étnico-raciais é tema do Capítulo 1 da primeira parte da tese.

24 "La historia de vida como fuente oral de información y conocimiento de la realidad, tiene un carácter indefectiblemente subjetivo. Son los puntos de vista de la persona que habla, en su individual versión e interpretación de los hechos, que a la vez plantea la subjetividad del investigador en su relación de entender a quien habla. En una relación que es ante todo no mecánica, afloran los conflictos personales del investigador,
} 
longo do texto as diferentes lentes de percepção em jogo, também sobre minha pessoa, busquei um caminho para compreender as maneiras pelas quais se concebe a negritude na Colômbia e no Equador.

O processo de diálogo prolongado com algumas das interlocutoras deu passo a um interessante desenrolar das relações interpessoais e do campo de análise antropológica. Se no início do processo priorizei a escuta, em momentos posteriores houve o meu turno de fala. Ao final da etnografia, quando estava em San Lorenzo com as mulheres de MOMUNE, foi oportuno explicitar minha condição étnico-racial, conversando sobre o que chamo da ampla brasileira concepção de negritude, fundamentada principalmente na discriminação social segundo critérios fenotípicos. Então, fui reconhecida como negra ou afrodescendente, como uma mulher "orgulhosa de sua etnia", como uma irmã. Já no processo de escrita da tese, tivemos a oportunidade de vivenciar juntas, eu, Inés Morales e Marlene Tello, o VII Festival da Mulher Afro-Latino-Americana e Caribenha, em Brasília, em 2014. E aí pude conversar, especialmente com Marlene, sobre a construção da negritude no Brasil contemporâneo e sobre meu processo identitário. Penso que também foi uma oportunidade, ainda que curta, para elas vivenciarem essa construção no Brasil.

\section{OS CONCEITOS DE RAÇA, ETNIA, GÊNERO E TERRITORIALIDADE COMO EIXOS DA TESE}

Os conceitos de raça e gênero, que conduzem a análise, são problematizados na Parte I. Ao longo do primeiro capítulo, proponho uma apreciação crítica das categorias de classificação étnico-raciais. Para tanto, realizo uma leitura histórica, passando pelos períodos colonial e republicano, e chegando à era da multiculturalidade colombiana e da interculturalidade equatoriana. No último período, as reflexões antropológicas e narrativas de minhas interlocutoras sobre o tema permitem uma aproximação acadêmica e etnográfica/política do tema. O sentido de negritude/afrodescendência na Colômbia e no Equador é pensado a partir dos sentidos de branquitude e mestiçagem. Exploro também a dicotomia entre raça como fenótipo e etnia como dimensão cultural da identidade.

quien previo reconocimiento de los mismos, para cuidarse de no ser reducido por ellos, puede llegar a operar de dos formas: através de la distancia personal con el entrevistado para tratar de evitar dicha seducción, o asumiendo el concepto del Deveraux 'del investigador como elemento constitutivo de la investigación"' (Selma, 1998: 80). 
No caso do gênero, entendo que a escuta atenta às mulheres sobre a condição de ser mulher configura um primeiro passo, mas não significa fazer um recorte analítico das relações de gênero. No segundo capítulo da primeira parte, a partir da narrativa das mulheres com quem dialoguei e dos escritos antropológicos sobre o tema, busco compreender qual o significado social de ser mulher e de ser homem no Pacífico colombo-equatoriano. Privilegio a construção do masculino e do feminino a partir da família, os debates em torno da poliginia, as vivências femininas em relações sexual-afetivas, os arranjos familiares e as dinâmicas produtivas e a maternidade como construção política. Proponho reconhecer mulheres afropacíficas como "matronas", autoridades familiares e comunitárias, em uma coletividade que é matrifocal.

A territorialidade é mais um eixo que conduz a análise, que domina a segunda parte da tese. A partir da raça e do gênero, procuro pensar sobre como a identidade se faz. Em seguida, a questão é refletir sobre como a vida se faz territorialmente e como se faz política em torno disso. O percurso analítico consiste, pois, em seguir os rios, elementos centrais na gênese das dinâmicas de apropriação cultural do território. A ideia é compreender o rio com tudo o que há nele: peixes, mariscos, ouro, pedras, água, personagens, alimentos na ribeira (especialmente o plátano) e indivíduos, já que se trata de um lugar onde as pessoas pertencem aos rios. É comum escutar as mulheres comentando: “y esa gente, ¿son de qué río?”. Esse fato foi notado também pelo geógrafo norte-americano, Robert West, que pesquisou nas terras baixas do Pacífico colombiano na década de $1950^{25}$.

La gente que vive en un cierto río se considera una comunidad aparte de los habitantes de otros ríos, de quienes los separan despoblados difíciles de atravesar. Negros y mestizos hablan de 'nuestro rio', o dicen por ejemplo que "somos del río Guapi" o "somos guapireños", indicando su vínculo social a un río determinado (West, 2000: 47).

Ainda seguindo o curso dos rios, acompanho os fluxos de mulheres afro-pacíficas do Mira, Rio Patía, Rio Rosário, dos afluentes do Santiago e dos manguezais na desembocadura do Rio Mataje. São mulheres que se movimentam ao longo dos rios, das cidades, do país e do mundo, em alguns casos. Contarei um pouco da mobilização das "comunidades negras" na Colômbia e no Equador, por intermédio de seus relatos, mulheres que foram protagonistas nesse processo. Nesse ponto, explicito o intuito de romper o silenciamento das vozes femininas afro-pacíficas dentro de organizações e coletividade negra, em ambos os países.

\footnotetext{
${ }^{25}$ A área estudada por West compreende desde o Panamá (Darién), passando por toda a costa Pacífica colombiana (Antioquia, Chocó, Valle Del Cauca, Cauca, Nariño) e chegando até o Equador (Esmeraldas).
} 
Busco também compreender como é a construção da subjetividade feminina negra na liderança. A ideia do caminhar constante, ou do fluxo, é parte central dessa subjetividade.

Entendo que a experiência política negra e feminina do Pacífico colombo-equatoriano oferece boas questões para se pensar sobre interseções entre etnia, raça, gênero e ruralidade/urbanidade. As tensões e alianças entre mulheres e homens no "proceso de comunidades negras", bem como a mesma questão entre mulheres negras e mulheres "mestizas" dentro do movimento de mulheres podem elucidar reflexões sobre pontos de identificações e diferenças.

Por fim, a situação do conflito político armado na região pesquisada - que envolve guerrilhas, paramilitares, exército, bandas criminais e outros atores - não permite deixar de falar sobre as violências, suas imbricações com a política, na vida cotidiana e nas relações de gênero e raça/etnia. Procuro discutir interfaces entre a violência interpessoal e a ação bélica organizada. O que acontece com mulheres afro-pacíficas no meio do conflito político armado? Nessa seção, as narrativas serão dissociadas de qualquer indício que permita identificar a interlocutora. O cenário é de risco e isso passa a ser um cuidado vital, além de uma demanda explicitada pelas mulheres com quem dialoguei.

\section{O CONTEXTO ESPACIAL}

O Pacífico colombo-equatoriano é uma região de bosque tropical, com clima úmido e cálido, de temperaturas que oscilam entre $20^{\circ}$ e $32^{\circ}$ e umidade entre 80 e $95 \%$. Segundo West (2000), as terras baixas do Pacífico colombiano são a parte mais chuvosa das Américas, com média anual entre 3 mil a 10 mil milímetros, ainda que na região foco da pesquisa diminua a precipitação total no ano e haja um período seco.

As terras baixas do Pacífico são entrecortadas por centenas de rios que nascem nas montanhas da Cordilheira Ocidental ${ }^{26}$ e caminham em direção ao mar. Segundo West, "os rios são os corredores para o transporte humano e suas ribeiras os principais lugares de habitação humana" (2000: 8) ${ }^{27}$. De acordo com a descrição geográfica do autor, percebemos que os rios Patía, Mira, Mataje e Santiago formam as principais bacias hidrográficas entre o extremo sul da Colômbia e o extremo norte do Equador. Conforme explica González (1995), no

\footnotetext{
${ }^{26}$ Um dos três ramos dos Andes colombianos. Chega a ter 3mil metros acima do nível do mar (West, 2000: 15).

${ }^{27}$ Tradução livre.
} 
departamento de Nariño, as bacias que se destacam são as do Rio Patía e do Rio Mira. Segundo Novoa (2010), na Província de Esmeraldas, os três sistemas hidrográficos principais são: Mira, Santiago e Esmeraldas, sendo que o último recorre às águas das cadeias montanhosas dos Andes até chegar ao Pacífico ${ }^{28}$. Entre eles, ressalta West (2000), o binacional rio Mira é o que possui o maior delta, ou planície deltaica, como diz o autor, cuja deposição aluvial cobre uma área de 25 a $50 \mathrm{~km}$. Os deltas e planícies baixas dos rios se unem e desenham a faixa costeira aluvial do Pacífico.

Às margens do mar, predominam manguezais, que são respaldados por pântanos de água doce. $\mathrm{O}$ autor explica que são quatro faixas geográficas situadas uma atrás da outra partindo do mar em direção à terra: 1) uma faixa de águas pouco profundas e terrenos de lodo antes da costa; 2) uma série de praias de areia descontínuas interrompidas por boqueirões, estuários e amplos terrenos de lodo ${ }^{29}$; 3) uma zona de manguezais que em geral tem a largura de 0,8 a $5 \mathrm{~km}$; 4) uma faixa pantanosa de água doce, situada imediatamente detrás da água salobra dos manguezais (West, 2000: 30-31). É característica dessa região do Pacífico a grande variação das marés, cuja média oscila entre 2,5 a 3 metros e 3,4 a 4 metros em época de lua cheia ou nova. Ao longo da costa aluvial a maré pode entrar no curso dos maiores rios por muitos quilômetros.

Os esteiros fazem a conexão entre rios e mar; percorrem áreas posteriores a praias e manguezais e seguem paralelamente à costa, conectando-se com as partes baixas dos rios. Eles formam um complexo sistema de canais curtos e sinuosos, uma via aquática quase contínua no interior dos bosques de mangue. Ademais, separam grandes áreas de humedal (chamadas ilhas) da terra firme. Os esteiros, às vezes, estreitam-se até formar pequenos riachos, os quais, durante a maré alta, se enchem e regam os manguezais de água salobra. $\mathrm{Na}$ maré alta, os esteiros são fluxo de transporte costeiro para canoas e lanchas de pequeno porte, em alternativa à turbulência do mar aberto. Já na maré baixa, os menores esteiros se secam enquanto os mais fundos se transformam em pequenas quebradas. De todo modo, a navegação por eles não é viável (West, 2000: 36-37).

Nessa pesquisa, trabalhei principalmente em três municípios da costa pacífica: Tumaco e Francisco Pizarro (Salahonda), na Colômbia; San Lorenzo, no Equador.

\footnotetext{
${ }^{28}$ A bacia do Rio Esmeraldas está mais ao sul da província homônima, não sendo tão importante para a região de San Lorenzo, foco da pesquisa.

${ }^{29}$ Vale ressaltar que as praias cobrem de $40 \%$ a $45 \%$ da costa. O resto é lodo e manguezais em baías protegidas e estuários (West, 2000: 31).West ressalta que, como a maioria das costas aluviais baixas, o litoral colombiano coberto por manguezais é instável (Idem, ibidem: 39).
} 

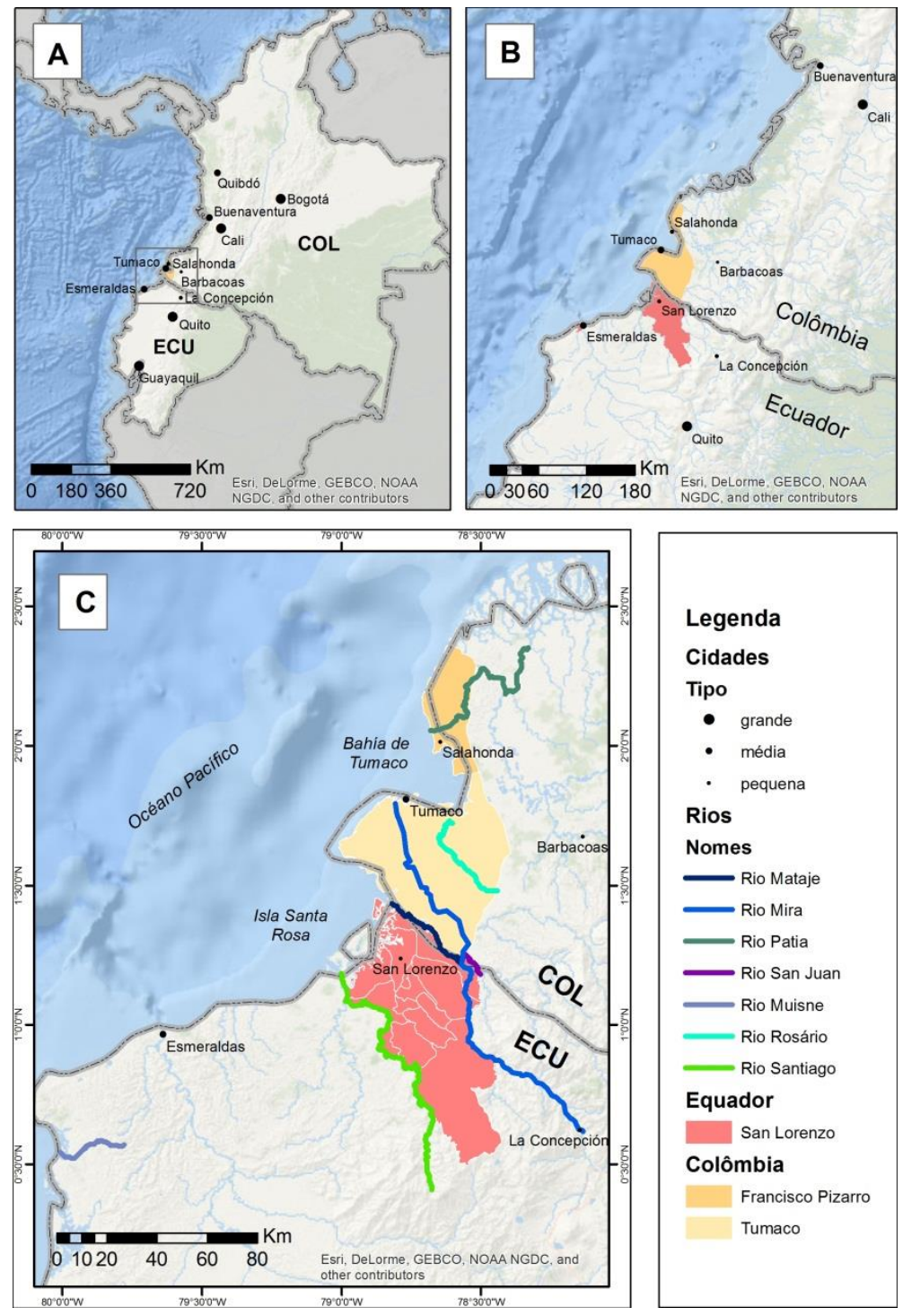

Figura 1 - Mapa de localização

Na Colômbia, a divisão político-administrativa seccionou o país em 32 departamentos e um distrito capital (Bogotá, que é também a capital do departamento de Cundinamarca). Os departamentos são divididos em municípios, por sua vez subdivididos em corregimentos. Esses são compostos por uma cabeceira e veredas, unidades comunitárias da zona rural. Os municípios vizinhos de Tumaco e Salahonda situam-se no departamento de Nariño, que tem uma caracterização peculiar. Pasto, a capital desse departamento, é uma cidade andina, com concentração de populações indígenas e "mestiças", assim como os demais municípios de Nariño, à parte da região amazônica do departamento. Nesse sentido, Tumaco e Salahonda destacam-se no contexto departamental por serem municípios costeiros, tropicais, úmidos e cálidos, e especialmente pela majoritária população negra. Francisco Pizarro, ou Salahonda, como é mais conhecido, já foi um corregimiento de Tumaco e depois se autonomizou. Trata- 
se de um município de pequeníssimo porte, ou um pueblo, como se diz localmente. Sua população é de 11.029 habitantes $^{30}$, segundo dados do Censo Geral de 2005 (DANE) e a infraestrutura é precária, estando a população muito vinculada a Tumaco. Já esta última cidade é de médio porte. Segundo dados do Censo 2005, a projeção da população tumaquenha para o ano de 2010 era de 179.005 habitantes, entre os quais, 97.547 estariam na cabeceira municipal e 81.458 nas chamadas veredas, unidades comunitárias da zona rural, em sua maioria ribeirinhas ${ }^{31}$. Também há debilidade de infraestrutura em Tumaco. O mesmo Censo Geral de 2005 indica que 77,4\% das residências de Tumaco têm energia elétrica; apenas 5,7\% têm rede de esgoto; $29,2 \%$ têm aqueduto; $12,9 \%$ têm telefone. No total, metade da população de Tumaco $(50,7 \%)$ acessa a educação formal em um estabelecimento de ensino.

No Equador, as unidades da divisão político-administrativa são as províncias, que somam 24, agregadas em 4 regiões: Serra, Costeira, Amazônica e Insular. Cada província se subdivide em cantões. São 219 cantões ao todo, que, por sua vez, se subdividem em paróquias, classificadas como rurais ou urbanas. As paróquias podem ainda conter dentro delas recintos. San Lorenzo é o cantão do extremo norte da província de Esmeraldas, cujo território se encontra com o de Tumaco, no extremo sul da Colômbia. Segundo dados do Censo de 2010, a população total de San Lorenzo é de 42.486 pessoas; entre as quais, 19.221 vivem na zona rural. Na homônima cabeceira do cantão, área urbana, vivem 23.265 pessoas; entre as quais, $37,8 \%$ consomem água sem o devido tratamento, $5 \%$ residem em casas em mal estado, $12 \%$ não contam com destinação pública para o lixo, 9,68\% da população têm menos de 10 anos e 10,85\% da população acima de 15 anos é de analfabetos/as. Nota-se que, assim como em Tumaco, os índices de San Lorenzo indicam uma precariedade de infraestrutura e prestação de serviços sociais básicos.

Trabalhar em dois países representou um desafio na medida em que são dois referenciais político-administrativos, jurídicos, legislativos, entre outras dimensões. Por outro lado, as dinâmicas sociais são fluidas entre San Lorenzo e Tumaco, de modo que a fronteira entre nações por vezes demonstra ser apenas uma linha imaginária. Há uma rede de pessoas, ideias, discursos e empreendimentos que conecta paróquias e veredas entre o Equador e a Colômbia. Essa região é povoada por populações pendulares, famílias que se distribuem entre San Lorenzo, Esmeraldas, Tumaco, Cali, extremando-se em Quito e Bogotá. A organização

\footnotetext{
30 ¿Cuántos habitantes tiene Francisco Pizarro (Nariño)?. Disponível em: http://www.venio.info/pregunta/cuantos-habitantes-tiene-francisco-pizarro-narino-16452.html. Acessado em 9 de outubro de 2014.

${ }^{31}$ Em Tumaco há 336 veredas.
} 
em redes opera mediante uma identificação dos sujeitos com sua origem e procedência. Pelas tramas dessa rede, busca-se o reconhecimento de formas ancestrais de ocupação territorial e respostas a anseios por melhores condições de trabalho e vida. A contemporânea fluidez na região de encontro entre Equador e Colômbia reflete a gênese comum desse território.

Para compreendê-la, iniciaremos com um retorno à formação histórica dessa região, retomando os marcos da escravização de africanos e seus descendentes, bem como, e principalmente, dos processos de resistência negra. Compreendo que as reflexões em torno da agência e da busca por autonomia negra são fundamentais. O processo de escravização configura uma condição imposta à população africana e seus descendentes dada a assimetria de poder entre Europa, de um lado, África e América, de outro. Nesse sentido, uso o termo escravização em lugar de escravidão, já que o primeiro remete a essa assimetria de poder. Nessa seção, o Brasil aparece em breves palavras.

\section{CONTEXTO HISTÓRICO ${ }^{32}$}

Ao longo dos séculos XVI a XIX, quinze milhões de mulheres e homens africanos foram forçosamente trazidos para as Américas, em condições desumanas, para trabalhar como escravos em situação igualmente desumana. Cerca de dois terços dessa população nunca chegou a seu local de destino, conforme indica Azopardo (1994 [1980]) ${ }^{33}$. Antecederam ao tráfico transatlântico, "guerras, morticínios de grupos inteiros, destituições e aniquilamentos - tanto físicos quanto culturais - desde o território africano", como ressalta Jurema Werneck (2005: 3).

\footnotetext{
${ }^{32}$ Nesta seção, e em outros momentos da tese, dedico esforços em construir uma revisão bibliográfica histórica, tendo em vista que a tese está direcionada também a leitoras e leitores brasileiros. Dada as lacunas que temos no Brasil sobre a realidade latino-americana, considerei necessário revisitar a história da diáspora negra nos países em que pesquisei. Nesse sentido, não almejo referendar a historiografia hegemônica, sabidamente branca e masculina. As vozes das matronas Afropacíficas trazidas ao longo da tese contrastam com essa perspectiva histórica. Por outro lado, não poderia deixar de trazer, em certa medida, a linearidade de tal narrativa, sobre a qual proponho uma perspectiva crítica.

${ }^{33}$ Segundo Friedemann, "aún no se ha aclarado ni el número de personas que fueron arrancadas de sus territorios, ni el de los que llegaron. Como tampoco su procedencia exacta. Entre los estudios demográficos de la trata, la controversia sobre la magnitud numérica se desenvuelve en cifras que van de los 9 millones hasta los 100 millones, pasando por apreciaciones intermedias de 25 millones y cifras menores de 3 millones (Friedemann y Arocha 1986: 33). Germán Colmenares (1979) anota más de 9 millones, en tanto que Edward Dunbar (véase Curtin 1969) señala unos 14 millones en la trata en América, cifra que se compara con las de Herbert S. Klein (1986: 93) que oscilan entre 10 y 15 millones. Este a su vez anota el hecho de que cuatro quintos del total de esclavos africanos llegado al nuevo mundo fueron transportados en 150 años, desde el siglo XVIII hasta mediados del XIX" (Friedemann, 1993 - Los africanos: cifras y origen, La diáspora africana y el péndulo de las cifras).
} 
Segundo Décio Freitas, o Brasil importou aproximadamente $40 \%$ da população africana sobrevivente traficada para as Américas, que ao total contabilizou em torno de 9,5 milhões de pessoas. Ou seja, chegaram ao Brasil cerca de 3,8 milhões de negras e negros escravizados, o que significa "nove vezes mais do que os Estados Unidos (6\%) e bem mais que o dobro da América Hispânica (18\%), do Caribe Inglês (17\%) e do Caribe Francês (17\%)" (Freitas, 1983: 9). Essa população viveu em toda a extensão territorial brasileira. Como indica Clóvis Moura, “em 1819, conforme estimativa oficial, nenhuma região do Brasil tinha menos de $27 \%$ de escravos em sua população. [...] Em 1872, quando os escravos constituíam 15,2\% da população do País, nenhuma região tinha menos de 7,8\% de habitantes escravos e a taxa mais alta era de apenas 19,5\%" (Moura, 1993: 8). A escravidão, implantada desde a primeira metade do século XVI, foi suprimida formalmente em fins do século XIX, de modo que teve vigência por quase quatrocentos anos da história do Brasil.

Para a América Hispânica, foram traficadas 1,5 milhões de pessoas africanas, segundo dados compilados por Azopardo (1994 [1980]). Na Colômbia, a população africana escravizada quantificou aproximadamente 150.000 pessoas, que adentraram o país entre os séculos XVI e XIX pelo porto de Cartagena, localizado no Caribe colombiano, na costa atlântica, de onde irradiavam chegando até Lima, Peru. Entre essas pessoas, cerca de 80.000 ficaram no que hoje corresponde ao território colombiano, à época, Nueva Granada ${ }^{34}$. Segundo Noboa, "en general parece que la Nueva Granada absorbió 200.000 esclavos en todo el coloniaje y como las tasas de mortalidad fueron muy elevadas, quizá sobrevivieron unos 120.000" (Noboa, 1990: 106).

No tocante ao gênero da população traficada, Zapata indica que: "El porcentaje de mujeres negras esclavas en los cargamentos era de una tercera parte frente a dos partes de varones". A autora explica que mulheres eram trazidas em menor número pela alta taxa de mortalidade na viagem (decorrente de condições insalubres, abusos físicos e doenças) e porque eram consideradas de baixa produtividade, sendo úteis e rentáveis desde a perspectiva reprodutiva: procriação de novos escravos (Zapata, 1985: 30). Zapata informa que a mesma função procriadora estava comprometida pelas condições de vida dentro da escravidão: alta taxa de mortalidade antes e depois do parto, já que mães e bebês não tinham os cuidados necessários; baixa fecundidade por problemas de excesso de trabalho e aniquilação da vida

\footnotetext{
${ }^{34}$ Durante parte do período colonial, a região norte dos Andes era designada como Nueva Granada, correspondente aos atuais países de Equador, Colômbia, Panamá e Venezuela, conforme indica Whitten Jr (1992). O Virreinato de Nueva Granada foi criado em 1739 e se converteu na unidade administrativa para o comércio de escravos (Friedemann e Whitten, 1974).
} 
sexual e familiar; enfermidades contagiosas, maus tratos e abusos sexuais; uso de diferentes práticas abortivas e infanticídios (Idem, ibidem: 31). Ela acrescenta que a vida sexual e reprodutiva das mulheres escravizadas foi marcada pelo abuso sexual por parte dos senhores, que, em alguns casos, as prostituiam para gerar-lhes ainda mais renda.

Às terras baixas do Pacífico sul colombiano, os espanhóis chegaram à primeira metade do século XVII dominando nações indígenas ${ }^{35}$. Cerca de cinquenta anos depois, chegou a população africana por eles traficada, segundo Almario e Castillo (1996). Nessa região, predominou a atividade de mineração. E assim surgiram as cidades de Barbacoas, Iscuandé e Tumaco $^{36}$, povoamentos históricos que se triangulavam na dinâmica sociodemográfica e produtiva $^{37}$.

Na região do Pacífico colombiano, a maioria da população escravizada provinha da África Ocidental, segundo Friedemann e Whitten (1974). Conforme pesquisa de Noboa:

Los grupos básicos de poblamiento correspondieron a Mandingas [Senegambia, a orillas del río Senegal en la costa atlántica de Africa], Congos [Africa Central, río Congo, cerca al sur de Africa, tronco Bantú] y Angolas [sur-oeste de Africa, región de mismo nombre, al sur de los Congos] (Noboa, 1990:110).

Em Tumaco, extremo sul da Colômbia, fronteira com Equador, chegaram africanos escravizados que foram levados à, então, província de Popayán, ao atual município de Barbacoas e a outros lugares da costa pacífica, para trabalhar em minas de ouro. Entre as referências originárias dessa população na África, consta com grande ênfase o grupo étnico iorubá.

No Equador, o tráfico negreiro também se iniciou no século XVI. Segundo Zuluaga e Romero, a primeira expedição à costa pacífica equatoriana e do sul da Colômbia ocorreu no período de 1525-1529 e foi liderada por Francisco Pizarro (Zuluaga e Romero, 2007: 33) ${ }^{38}$.

\footnotetext{
${ }^{35}$ A primeira expedição espanhola ao Mar del Sur foi em 1513, liderada por Vasco Núñez Balboa.

${ }^{36}$ Tumaco era uma etnia indígena pré-colombiana que habitava na Planície do Pacífico (Almario e Castillo, 1996: 88). Segundo Noboa (1990), na região de Barbacoas, compreendida como a área do Oceano Pacífico, frente à Baía de Tumaco e entre os Rios Patía (ao norte) e Mira (ao sul), eram povos originários os Tumas, Iscuandes e Gapios. Um pouco mais ao interior havia os Barbacoas e Temlembís. Já segundo Romero (1995), a costa nariñense era habitada por grupos indígenas Sindagua que migraram desde a zona andina do Valle del Patía, enquanto que ao sul, no Rio Mira, existiam grupos Quaiquer.

${ }^{37}$ Segundo Almario e Castillo (1996), ao longo da colonização, até a abolição da escravatura (1600-1852), Barbacoas e Iscuandé eram cidades importantes, nas quais a seleta população branca (espanhola ou crioula) comandava as relações sociais e de poder, enquanto o porto de Tumaco era secundário. Ao longo da segunda metade do século XIX, a hierarquização se inverteu. Na primeira metade do século XX, Tumaco se converteu no porto de Nariño e, atualmente, na principal população do Pacífico colombiano depois de Buenaventura.

${ }^{38}$ Savoia (2002 [1992]) afirma que a expedição foi liderada por Vasco Núñez de Balboa, entre 1525 e 1526 . Já Tardieu fala em duas expedições, realizadas em 1524-1528, comandadas por Francisco Pizarro e Diego de
} 
Segundo Savoia (2002 [1992]), a primeira viagem espanhola ao Equador aportou no litoral da província de Esmeraldas ${ }^{39}$.

Segundo Fernández-Rasines (2001), a costa norte, atual região de Esmeraldas, teve sua colonização consolidada ao longo do século XIX por colonos inicialmente de origem britânica. A conformação étnico-racial de Esmeraldas, partindo das matrizes populacionais de sua constituição histórica, concentrou-se nos grupos "negro-mulato-zambo"40 (Noboa, 2002 [1992]: 36).

Tardieu estima que, em finais do século XVIII, 1,12\% da população da Audiência de Quito era de escravos, sem contar os "zambos, mulatos e negros livres" (Tardieu, 2006: 11$12)^{41}$. Segundo o mesmo autor, no âmbito da compra e venda de "escravos boçais" em Guayaquil, entre 1628 e 1678, registram-se etnias de "Rios de Guinea": Guinea, Banãl, Mandinga e Nalú; de "Castas de São Tome": Bran, Arará, Popo, Terranovo, Caravalí; e da Zona Bantu: Congo e Angola (Idem, ibidem: 229). Já em Cuenca, registram-se as mesmas procedências, com acréscimos de alguns grupos. Entre os "Rios de Guinea": Cabo Verde, Fulo, Biafara e Zapé; e da Zona Bantu: Anchico e Cazanga; além de negros/as boçais de Moçambique (Idem, ibidem: 271).

O projeto colonialista representou a violação das vidas de mulheres e homens negros. Porém, a colonização tem em sua fisiologia uma intrínseca marca de gênero. Como coloca Sueli Carneiro:

no Brasil e na América Latina, a violação colonial perpetrada pelos senhores brancos contra as mulheres negras e indígenas e a miscigenação daí resultante está na origem de todas as construções de nossa identidade nacional, estruturando o decantado mito da democracia racial latinoamericana [...]. Essa violência sexual colonial é, também, o "cimento" de todas as hierarquias de gênero e raça presentes em nossas sociedades (Carneiro, 2001).

A violência sexual configura, pois, uma modalidade estruturante da dinâmica colonialista, que destinou às mulheres negras um lugar social perverso. Os processos de

Almagro. O autor afirma que, na segunda expedição, em 21 de setembro de 1527, Bartolomé Ruiz aportou na Baía de San Mateo, na desembocadura do Rio Esmeraldas, onde se formou o núcleo da República Zamba (Tardieu, 2006: 15-16).

39 A província ganhou esse nome em função da abundância de pedras preciosas de mesmo nome e/ou da grandiosidade de sua natureza verde (Bass, 2002 [1992]; Tardieu, 2006). O nome pode se derivar também da presença nessa região de indígenas Esmeraldas, entre meados do século XVI até princípios do século XIX (Whitten, 1997 [1965]). Outra possível gênese do termo está relacionada à presença de uma mina mítica jamais descoberta (Charvet: 2010).

${ }^{40}$ A problematização das categorias étnico-raciais será apresentada na Parte I.

${ }^{41}$ A população total chegava a 438.724 pessoas, entre as quais, 4.936 eram escravas (Tardieu, 2006: 11). 
escravização de povos africanos expressaram a coincidência entre classe social, raça e gênero, na medida em que esses três elementos se tornaram meios de exploração das pessoas, transformando a mulher negra em sujeito de tripla discriminação - negra, mulher e escrava, como indica Castañeda (1995).

A historiografia oficial latino-americana apresenta uma narrativa parcial desse longo período, a qual pouco considera as diversas formas de resistência da população africana e de seus descendentes. Da tradição oral de grupos negros situados em diversos pontos da diáspora africana, ecoam outras vozes, que apontam para um continuum de resistência à escravização. Nesse contexto, destaca-se a formação de grupos negros insurgentes que receberam vários nomes nas diversas regiões das Américas: Quilombos, Mocambeiros ou Mocambos no Brasil; Palenques, na Colômbia, Equador, Cuba, México, Panamá e Peru; Cumbes na Venezuela; Maroons no Haiti, Jamaica e demais ilhas do Caribe francês; Batey, na República Dominicana. São núcleos do patrimônio afro-diaspórico latino-americano e caribenho. Constituem também parte relevante do patrimônio cultural de nações profundamente marcadas pela colonização, fundadas em intercursos genéticos e culturais entre povos ameríndios, africanos e europeus, em maior ou menor grau.

Concebo a afro-diáspora como um processo que se iniciou com o tráfico de africanos/as escravizados/as para as Américas. Essa migração forçada gerou subsequentes movimentações espaciais de africanos e afrodescendentes que se insurgiram à condição de escravos, conformando assim territórios autônomos. Entende-se território como uma plataforma de intersecção de diversos planos da vida de grupos negros rurais constituídos no contexto da resistência à escravização. A autonomia é a capacidade desenvolvida por tais grupos de se autonormatizar, ou se autogerir. Tal capacidade contemplaria uma série de domínios no tocante à organização política, social, econômica, entre outras ${ }^{42}$. Tais movimentações ocorreram no interior das nações, caso da formação de quilombos no Brasil, como também entre nações, caso da região fronteiriça Equador-Colômbia.

No Brasil, quilombos, ou comunidades quilombolas, tiveram gêneses muito diversas. Formaram-se quilombos em locais de refúgio ${ }^{43}$, em terras abandonadas por senhores ${ }^{44}$, em

\footnotetext{
${ }^{42}$ Não se trata ainda aqui da autonomia jurídica. O tratamento legal que os Estados nacionais reservam a esses territórios será tratado em momento posterior do texto.

${ }^{43}$ É o célebre caso do Quilombo dos Palmares, grande foco de resistência negra constituído no século XVII, entre os atuais estados nordestinos de Pernambuco e Alagoas. Para citar um exemplo que perdura até os dias de hoje, têm-se os Kalunga, maior território quilombola do Brasil, com perímetro em torno de 230 mil hectares distribuídos nos municípios goianos de Cavalcante, Monte Alegre e Teresina de Goiás (Baiocchi, 2006[1999]).

${ }^{44}$ É o caso das 158 comunidades que conformam o território quilombola de Alcântara, localizado no estado do Maranhão (Almeida, 2006).
} 
terras doadas aos/às negros/as e também em terras doadas aos/às santos/as que os/as negros/as cultuavam $^{45}$. Houve ainda casos em que negros/as (escravos/as ou ex-escravos/as) conseguiram arrecadar capital para comprar terras, onde se constituíram quilombos ${ }^{46}$.

Segundo Clóvis Moura (1993), os quilombos foram formas de negação ao escravismo, embora sem um projeto capaz de substituí-lo. No entanto, foi um processo de protesto radical e permanente, que subvertia o princípio da violência como forma de interação humana fundamental. Assim, contribuíram para o agravamento da crise do modo de produção escravista e apontou a necessidade de uma nova ordenação social.

Em todos os pontos geográficos onde houve escravização, houve resistência, a qual assumiu contornos diversos, como argumentam Reis e Gomes:

Mesmo sob a égide do chicote, o escravo negociava espaços de autonomia com os senhores ou fazia corpo mole no trabalho, quebrava ferramentas, incendiava plantações, agredia senhores e feitores, rebelava-se individual e coletivamente (Reis e Gomes, 2000[1996]: 9).

A "brecha camponesa", cujo curso se deu entre os séculos XVII e XIX em alguns pontos da América negra, é um exemplo da negociação de espaços de autonomia (Cardoso, 1987: 54). Trata-se da concessão de lotes de terras aos negros escravizados, dentro das propriedades rurais, fazendas ou plantations, para a implementação de culturas agrícolas, as quais geravam excedentes que costumavam ser comercializados.

Outros movimentos de resistência, especialmente feminina, consistiam em tirar proveitos de relações com senhores (por vezes, relações sexuais), o que garantia o suprimento de fundos para os quilombos e palenques, o acesso a informações relevantes para a formação e a manutenção de tais grupos, ou ainda a liberdade para si e/ou sua família. Vale lembrar que a escravização das mulheres, especialmente no âmbito doméstico, se estendia à possessão corporal. Ou seja, o padrão das relações entre senhores brancos e mulheres negras escravizadas era a violação sexual. A subversão desse padrão relacional pode ser interpretada

\footnotetext{
${ }^{45}$ O quilombo de Casca, localizado no município de Mostardas, no Rio Grande do Sul, cujo território foi titulado em 2010, é um exemplo de terras doadas a negros e negras recém-libertos (Leite, 2002).

${ }^{46}$ A Família dos Amaros de Paracatu, Minas Gerais, comunidade na qual realizei pesquisa de campo no início de 2000, configura esse tipo de conformação de quilombos (Melo, 2005).
} 
como insurgência ${ }^{47}$. Resistências extremas, como o suicídio e o infanticídio, são ainda manifestações de negação da população negra à condição escrava ${ }^{48}$.

A constituição de agrupamentos negros que não viviam sob a égide de um senhor branco - seja no seio da sociedade escravocrata, seja na sociedade pós-colonial, ainda estruturada em hierarquias sociais calcadas em discriminações de raça e gênero - representa movimentos de defesa da dignidade e da liberdade humanas, em contextos de sua negação a determinados grupos.

A história desses grupos contrapõe-se à falsa imagem que se cultiva no Brasil, e em outras nações latino-americanas e caribenhas, de que houve nessas regiões uma escravidão "humanizada" e "atenuada". No Brasil, a média de vida útil de um escravo era de sete anos e a substituição de um escravo morto era automática, sem que houvesse déficit na produção econômica (Moura, 1993). O tráfico ocorria em proporções imensas e a distribuição de escravos abrangeu todo o território nacional, daí a escravidão ter sido tão constitutiva da formação do Brasil.

Na Colômbia, as lutas e os movimentos por autonomia, tais como fugas, revoltas, demandas judiciais pela troca de amo $^{49}$, automanumissão ${ }^{50}$, iniciaram-se no século XVI e seguiram até o século XIX:

A lo largo y ancho de Colombia, en cada lugar donde se importaron esclavos, se encuentran descripciones de rebeliones, de fugas, y en muchos casos del establecimiento de villorrios bien fortificados que se conocieron como palenques [...] Segundo Jaramillo Uribe (1963:43), la rebelión, el cimarronismo y la proliferación de palenques constituyeron la mayor amenaza a sociedad no-negra de la segunda mitad del siglo XVIII. Se describe a los palenques como democráticos, con líderes elegidos y una vida religiosa y social bien organizada basada en la amalgama de tradiciones afro-hispánicas (Friedemann e Whitten, 1974: 99).

Os palenques ${ }^{51}$ surgiram em todo o território neo-granadino e ao longo de todo o período escravista, em especial entre 1529 e 1799, conforme destaca Azopardo (1994 [1980]).

\footnotetext{
${ }^{47}$ Para o caso do Equador, Fernández-Rasines assinala que "a menudo la resistencia de las esclavas a las propuestas y acosos por parte de los propietarios, llevaban a que éstos tuvieran que negociar el pago de la libertad a cambio de ciertos usos carnales" (Fernández-Rasines, 2001: 64).

${ }^{48}$ Segundo Romero, "eran acciones contra el propietario ya que al morir un esclavo perdía la inversión el propietario" (Romero, 1995: 108).

${ }^{49}$ Recurso legal permitido pela legislação escravista, que era acionado combinadamente com a ação de fuga (Romero, 1991).

${ }^{50}$ A partir de 1821, quando foi sancionada a Ley de Libertad de Vientres, a geração de crianças a partir de relações interraciais também poderia ser uma estratégia de libertação, já que o fruto de uma relação entre um homem branco e uma mulher negra escravizada era legalmente livre.
} 
Segundo o autor, palenques são assentamentos ${ }^{52}$ para onde se deslocaram cimarrones, negros escravizados que fugiam das fazendas, organizando-se em projetos coletivos de enfrentamento declarado ao sistema escravista, constituindo "verdadeiras células de subversão e zonas de resistência" (Azopardo, 1994 [1980]: 24). Para Friedemann e Whitten, são "poblados fortificados construidos por negros libres - desde los cuales salían grupos de guerrilleros que atacaban a las canoas que cargadas de esclavos subían por los ríos principales" (Friedemann e Whitten, 1974: 97).

Narrando a formação dos palenques, Targelia Micolta fala que o processo de aquilombolar-se parte de uma atitude de fuga, territorializa-se e coletiviza-se:

En aquella época de la esclavitud, donde cogían a los negros y los trataban como esclavos. Entonces ahí cogió un negro y se escapó. Y ese negro que se escapó, logró hacer una trinchera. Entonces ahí de noche él se iba gateando como podía y se robaba un negro de los que estaban allá entrincherados, los tenían esclavizados los españoles. Entonces se robaba un negro y se lo traía acá, a su aldea de él. Y ahí ya iban dos negros. Después esos dos negros hacían forma y sacaban otros dos negros de allá. Y así hasta que ellos poquito a poco venían trayendo los negros, los traían acá a sus trincheras de ellos, a su territorio de ellos. Ellos cercaban todo su territorio y ahí metían a sus hermanos negros. Entonces, ya que este hombre rescató a todos sus negros, ¿qué hicieron ellos para poderse vengar de los españoles? Ellos, como no tenían armas, no tenían cómo pelear contra ellos. Porque los españoles todos tenían armas. Entonces, los negros buscaron una hierba llamada barbasco. Y ese barbasco lo molían con piedras y lo echaba en el río al lado de arriba, porque los españoles tenían que tomar esa agua en el lado de abajo. El agua de arriba bajaba por una quebrada y los españoles tenían que tomar esa agua. Porque si no tomaban el agua ellos no podían vivir, pero ellos no sabían el agua qué tenía. Entonces ellos echaron el barbasco arriba y los españoles tomaban el agua. Entonces, de esa forma los españoles que tenían atrincherados a todos esos negros. Ellos se iban muriendo. Por eso creemos que los negros somos inteligentes. No hay negro que sea bruto. Entonces ahí ya los negros fuimos liberándonos. Entonces nos fuimos liberando, liberando. Hasta que ya fuimos libres los negros, pero fue por uno, que fue un líder - Targelia Micolta.

Savoia (2002 [1992]) comenta a existência de palenques ao longo da costa pacífica equatoriana, formados também no curso do sistema escravista no país. Charvet concebe palenques como sociedades de escravos fugidos de plantações escravistas ou minas, de difícil acesso, isoladas, quase inacessíveis, em zonas inóspitas, com organização político-militar

\footnotetext{
${ }^{51} \mathrm{O}$ termo palenque, segundo definição do dicionário eletrônico WordReference, designa cerca ou estaca. Segundo Azopardo (1994 [1980]), o nome faz alusão à conformação geográfica desses territórios em locais de difícil acesso, caracterizados por uma topografia de fossos, em que se utilizaram obstáculos (armadilhas) como estratégia para impedir a chegada de representantes do poder colonial.

${ }^{52} \mathrm{Na}$ bibliografia que aborda o povoamento negro na Colômbia e no Equador, utiliza-se o termo "assentamento" em referência à territorialização negra. Utilizo o termo com o mesmo sentido.
} 
interna (Charvet, 2010: 89). Segundo Savoia (2002 [1992]), Esmeraldas configurou um refúgio de liberdade para africanos fugidos e seus descendentes ${ }^{53}$.

O mesmo autor informa que data de 1540 a constituição do primeiro assentamento negro na província de Esmeraldas, formado por uma população que escapou do naufrágio de um barco procedente da Nicarágua. Porém, a data célebre é o ano de 1553, quando uma embarcação provinda do Panamá soçobrou nas costas esmeraldenhas, mais precisamente na enseada do Rio Portete, ao sul da Baía de San Mateo. Os negros que aí estavam - seis mulheres e dezessete homens provindos da Costa da Guiné - fugiram com armas de fogo recolhidas no barco e aportaram nas praias que hoje correspondem a Muisne, instalando-se na floresta da província de Esmeraldas. E assim se constituiu o agrupamento negro que se consolidaria como a República Zamba ${ }^{54}$. Inicialmente o grupo foi liderado por Antón sucedido por Alonso de Illescas ${ }^{55}$.

Inés Morales chama atenção para a centralidade de Alonso de Illescas na formação do palenque do norte de Esmeraldas, ao qual ela pertence. "Illescas dijo que quería formar su palenque. Se sabe que palenque es un término usado en África para referirse a un territorio. Pues sería un territorio donde la gente negra viviría desde sus propias concepciones de desarrollo. Un territorio despojado de injusticia y inequidad".

Segundo Charvet (2010), houve mais duas ondas migratórias que aportaram pelo mar em Esmeraldas: a primeira em 1570, quando chegaram à Baía de San Mateo navios procedentes da Nicarágua; e a segunda, em 1600, que arribou em frente a "punta de Manglares", na boca do Rio Mira (Charvet, 2010: 33). Novoa (2010) também se refere a esse último naufrágio, na mesma Baía de San Mateo, dos barcos San Felipe y Santiago, nos quais estavam 180 passageiros entre negros e espanhóis.

Ao final do século XVI, segundo Whitten (1992[1974]), a província de Esmeraldas era "República de Zambos". Nas palavras de Charvet, "República Zamba”, fruto da mistura entre negros e indígenas, primeiro grande palenque ou "estado africano" na costa pacífica sul-

\footnotetext{
${ }^{53} \mathrm{O}$ autor baseia-se em escritos de 1744 , especialmente no documento "Memorial impresso", de Don Pedro Vicente Maldonado, que foi governador de Atacames e San Mateo durante os anos de 1735 a 1739 (Savoia, 2002 [1992]: 23).

${ }^{54}$ Whitten (1992[1974]), Friedemann e Whitten (1974), Charvet (2010), Zuluaga e Romero (2007), Tardieu (2006). Dados fundamentados na obra do viageiro e pároco Miguel Cabello Balboa, destinado pelas autoridades espanholas clericais e políticas a dialogar com Alonso de Illescas. Sua obra foi escrita em 1583 e reimpressa em 1945.

${ }^{55}$ Tardieu (2006), com base nos relatos de Miguel Cabello Balboa, traz a informação de que Alonso de Illescas era oriundo de Cabo Verde, o que corrobora Novoa (2010). Mas o mesmo autor coloca em dúvida esse dado, aventando a hipótese de que Illescas fosse nascido na costa ocidental da África. Foi traficado para Sevilla quando tinha em torno de oito anos e aí viveu até os 25 anos, tornando-se ladino.
} 
americana (Charvet, 2010: 50). A conformação territorial dessa República não se limitava ao que hoje corresponde ao Equador; englobava a região do extremo sul da Colômbia, território de Tumaco. O território da República Zamba crescia por fora do controle espanhol, o que gerou subsequentes incursões militares coloniais, as quais objetivavam submeter a população zamba ao julgo colonizador e incorporar o território palenquero à soberania real ${ }^{56}$. Tais incursões, desde 1526, dirigiam-se aos territórios indígenas, posteriormente ao território zambo, e foram intensas até o ano de 1585, segundo Novoa (2010).

Friedemann e Whitten, ao narrar a formação da República de Esmeraldas, remetem-se ao brasileiro Quilombo de Palmares:

La Providencia de Esmeraldas en el Ecuador, estaba dominada por "zambos", gente de descendencia afro-indígena, quienes aparentemente establecieron hegemonía sobre los indígenas de la región, y empezaron a negociar con emisarios de la Corona española antes de finalizar el siglo XVI (Phelan 1967). Este estado quizás se pareció al estado negro de Palmares en el extremo opuesto del continente suramericano. Allá en lo que se conoce como es Estado de Alagoas, Brasil, los africanos resistieron el embate de los ejércitos coloniales durante casi más de un siglo (Chapman 1918, Ramos 1939: 25-26, 42-53) (Friedemann e Whitten, 1974: 92).

Como ressalta Charvet, Esmeraldas constituiu-se, portanto, como "terra de liberdade" (Charvet, 2010: 50). Segundo a autora, intelecutais negros afirmam que nunca houve escravização nesse território ${ }^{57}$. Ela defende que não foi um fenômeno generalizado, mas, sim, focado na zona de Entre Rios (atual cantão de Eloy Alfaro) e em algumas fazendas localizadas no leito do Rio Esmeraldas (atuais cantões de Esmeraldas e Quinindé), que deve ter se iniciado na primeira metade do século XVIII e se estendeu ao século XIX ${ }^{58}$.

Dada a desproporção entre homens e mulheres africanos escravizados no norte do Equador (três homens para cada mulher), a autora deduz que as mulheres da primeira onda migratória negra ao Equador devem ter tido relações com mais de um homem, em razão de seu papel estratégico na reprodução do grupo. Além disso, devem ter desempenhado um forte trabalho em âmbito doméstico, agrícola e extrativista. O desequilíbrio entre homens e mulheres inverteu-se ao longo do século XVII, conforme aponta Charvet (2010), em virtude

\footnotetext{
${ }^{56}$ Segundo Novoa (2010), com isso a Coroa espanhola visava estabelecer para essa população tributos e demais cobranças. Principalmente, visava aproveitar os benefícios econômicos do comércio pela rota de Esmeraldas, que era estratégica.

${ }^{57}$ Tardieu analisa a distribuição da população escrava na Audiência de Quito em fins do século XVIII. Observase que não consta Esmeraldas. Os locais apontados pelo autor são: Ibarra, Guayaquil, Loja, Chimbo, Quito, Otavalo, Ambato, Cuenca, Riobamba, Latacunga e Jaen de Bracamoros (Tardieu, 2006: 14).

${ }^{58}$ Novoa corrobora argumento de Charvet. Em estudo sobre a construção histórico-social da etnicidade negra e processos identitários na bacia do Rio Santiago-Rio Cayapas, ela analisa o caso de comunidades escravizadas do norte de Esmeraldas (Novoa, 2010: 18).
} 
dos contínuos enfrentamentos interétnicos, que acarretavam a diminuição da população masculina. Segundo a autora, tal quadro provocou a difusão da poliginia, ou seja, uma mudança de padrão das uniões sexual-afetivas. Zuluaga e Romero falam sobre o exercício de ampla poliginia desde a chegada dos náufragos em Esmeraldas em 1553, envolvendo majoritariamente homens negros e mulheres indígenas, que resultou em elevadas taxas de natalidade. Essa seria uma das razões para a multiplicação da população negra, zamba e mulata (Zuluaga e Romero, 2007: 48).

Charvet (2010) entende que a República Zamba constituiu uma trama de relações que consistia em redes de comunicações, comércio e alianças políticas com outras comunidades cimarronas e assentamentos indígenas. Segundo Charvet, eram povos originários dessa região Niguas, Yumbos, Campaces, Capayas, Lachas, Málabas, com os quais a população de ascendência africana estabeleceu relações de guerra, mas também de aliança ${ }^{59}$.

O parentesco foi terreno fértil para as alianças expressas em uniões sexual-afetivas, por vezes poligínicas. Zuluaga e Romero (2007) contam que a aliança entre negros e indígenas Niguas se consolidou por meio da união entre Illescas e a filha do cacique desse grupo. Tais aproximações se calcavam em interesses comuns de negros e indígenas perante colonizadores brancos. A expansão territorial iniciada por Illescas, na visão de Charvet, constituiu uma hegemonia zamba sobre o conjunto de territorialidades e chefias indígenas cruzadas e descontínuas. Zuluaga e Romero corroboram essa visão, acrescendo o dado de que, estabelecida a liderança de Alonso de Illescas sobre as comunidades indígenas da província, fortaleceu-se a resistência à penetração espanhola ${ }^{60}$.

Percebe-se que as mulheres não são nomeadas na narração da história da República Zamba. Sendo as alianças matrimoniais uma estratégia importante na consolidação desse povo, o papel da mulher de Illescas é relevante, tal como do próprio Illescas. Porém, não sabemos o nome dela, apenas que era a filha do cacique. Analisando as crônicas coloniais e estudos históricos contemporâneos, Charvet (2010) observa que a memória da República Zamba está contada em perspectiva masculina. Mulheres não figuram nessa história, a

\footnotetext{
${ }^{59}$ Zuluaga e Romero coincidem parcialmente com Charvet no apontamento dos povos originários que viviam na região costeira localizada entre o Rio Esmeraldas e o Rio Mira no século XVI, quando chegaram à região os espanhóis. Segundo eles, eram indígenas Atacames, Campaces, Niguas, Cayapas e Malabas (2007: 22). Desses grupos, sobreviveram os Cayapas, que atualmente vivem às margens do Rio Cayapa.

${ }^{60}$ Interessante o que coloca Tardieu sobre a relação entre negros e indígenas. O autor aponta que narrativas coloniais da época e, ainda hoje, certos trabalhos historiográficos reduzem essa relação à noção de escravização dos indígenas pelos "mulatos" (2006: 117). Ao analisar o fenômeno da mineração, o autor volta a ressaltar narrativas do século XVI, nas quais os colonizadores exigiam que negros e indígenas trabalhassem em quadrilhas separadas, dizendo que são povos inimigos e destacando o temor dos indígenas aos negros (Idem, ibidem: 150).
} 
despeito do importante papel que nela desempenharam. No texto de Miguel Cabello de Balboa, é mencionado o nome de duas filhas de Illesca, Justa, "que Andrés Contero la pudo haber a las manos y la sacó a Guayaquil y la casó con un esclavo suyo, la otra llamada María, ayuntada suciamente con el Gonzalo de Ávila" (Balboa apud Fernández-Rasines, 2001: 47). Fernández-Rasines cita esse trecho do texto de Balboa para denunciar que, sua condição de filha de Illescas, que era livre e tinha certo reconhecimento da Coroa, não a livrou da escravização.

Friedemann e Whitten ressaltam que as relações tecidas pela República Zamba se estenderam até a Coroa espanhola. Dado a ameaça espanhola ao território Zambo, Alonso soube mudar de estratégia em relação aos espanhóis, de uma postura bélica para as negociações, conforme coloca Tardieu (2006). Novoa (2010) também ressalta a aproximação de Illescas com as autoridades reais como uma mudança de estratégia perante as frequentes incursões militares coloniais ao palenque. Segundo Zuluaga e Romero (2007), as conversações entre Alonso de Illescas e Cabello Balboa, que ocorreram no período de 15771600, motivadas possivelmente pelas expedições coloniais sobre o território de Esmeraldas, representavam também uma busca pelo reconhecimento da autonomia e da territorialidade da República Zamba por parte das autoridades coloniais.

Em 1577, houve um primeiro processo de negociação, nos termos de indulto total a Illescas e sua família, bem como sua nomeação como governador da província. Segundo Tardieu (2006), a proposta dos zambos visava ampliar o poder de Illescas sobre o território. Da perspectiva das autoridades coloniais, a contraparte era a redução do território negro a um povoado na Baía de San Mateo. A negociação não se concretizou. Illescas não aceitou reduzir a República Zamba. Em 1585, houve um ataque fracassado, ao qual os negros responderam com a Carta de Libertad, um documento de solicitações direcionado à Real Audiencia de Quito que demandava perdão geral a todos os negros, zambos e indígenas de Esmeraldas, isenção de tributos e nomeação de Alonso de Illescas como governador.

No final do século XVI, as autoridades coloniais empenhavam-se em criar condições para traçar caminhos que conectariam a Baía de San Mateo, Quito e Popayán, uma alternativa à rota que passava pelo Rio San Juan de Buenaventura, ao sul do atual departamento colombiano de Chocó. No século XVII, começava a se concretizar o projeto colonial de construção de caminhos e portos alternativos à rota que subia por Guayaquil ${ }^{61}$. Segundo

\footnotetext{
${ }^{61}$ Tardieu (2006) faz referência a vários caminhos afora o de Guayaquil: caminho do Rio Santiago (ou caminho de Pedro Vicente Maldonado), caminho de Caráquez, caminho do Rio Mira. Novoa cita o Caminho de Malbucho, que pode ser o mesmo caminho do Rio Mira, pois ele partia de Ibarra e avançava paralelamente ao
} 
Novoa, tratava-se de uma velha intenção da elite serrana de construir um caminho que articulasse os centros de produção andinos com portos ao Pacífico e, assim, dinamizar um comércio inter-regional, bem como transoceânico com a Espanha (Novoa, 2010: 12 e 52). Ademais, segundo Tardieu (2006), nessa época, a Audiência de Quito intencionava instalar um assentamento de minas de ouro na região ${ }^{62}$. Para todas as empresas, a presença dos negros, zambos e indígenas figurava como empecilho. Desse modo, as autoridades espanholas deram sequência a um "agressivo processo de pacificação, redução e colonização da região", conforme ressalta Novoa (2010: 85).

Nesse contexto, as autoridades inicialmente aproximaram-se dos grupos indígenas, entendendo que eles superavam em grande número a presença dos zambos ou mulatos que dominavam o território ${ }^{63}$. Começaram a acercar-se de grupos indígenas que tinham conflitos com os negros, como os Cayapa, que, segundo Novoa (2010: 62), foram violentados em seu antigo território em Campi, em 1587. Assim, foram separando os zambos dos indígenas, reduzindo os povos indígenas e submetendo-os ao rei e a Igreja, conforme explica Tardieu (2006).

Já no início do século XVII, percebendo que seria muito difícil transitar pelo território sem a ajuda dos zambos, os representantes coloniais envolveram-nos no projeto de abertura de caminhos ${ }^{64}$. Tardieu (2006) faz uma leitura de que a República Zamba, nesse processo, passou da marginalização à instrumentalização e acabou perdendo sua autonomia. Por fim, os espanhóis lograram quebrar o controle que os descendentes de Illescas tinham sobre a região.

Charvet ressalta que, a partir da morte de Alonso de Illescas em 1607, os espanhóis conseguiram reduzir a República Zamba a dois assentamentos: San Mateo de la Bahía e San

referido rio, atravessando Salinas, Cuajara, Lachas, Malbucho, Licta, em direção ao Rio Santiago (2010: 101102). Tardieu (2006) fala do desvio de um dos caminhos em direção ao norte, à província de Barbacoas (atualmente território colombiano). E comenta ainda de um caminho entre o porto de Buenaventura e Cali, que também pertencem hoje à Colômbia. Nota-se a fluidez do trânsito entre o que hoje são Colômbia e Equador.

${ }^{62}$ Segundo Novoa (2010), Maldonado convocou mineiros de Nova Granada e Quito para explorar veias auríferas nos Rios Santiago e Mira, com intuito de consolidar a rota que reduzia as distâncias do interior andino da Audiência de Quito até os distritos auríferos do Pacífico sul da Nova Granada, tendo como objetivo final o comércio de produtos provindos de Quito para o Pacífico.

${ }^{63}$ Segundo Tardieu (2006: 90), em 1620, a população da República Zamba poderia ser estimada em 600 pessoas.

${ }^{64}$ Novoa entende que a participação da população negra no projeto econômico das elites teve duas etapas: a primeira em que negros e negras não antagonizavam, buscando preservar os benefícios adquiridos com o acordo estabelecido; e a segunda, quando há uma progressiva falta de colaboração em repúdio ao violento exercício de poder por parte dos empresários e ao descumprimento do acordo com as autoridades coloniais (Novoa, 2010: 70). 
Martín de Campaces (2010: 40) ${ }^{65}$. O declínio da República Zamba, na visão de Friedemann e Whitten, aconteceu no século XVIII:

Situaciones tales como la dominación de una provincia, como la de Esmeraldas, por parte de la cultura negra, y la libertad de negociar con nuevos sistemas de gobierno centrales en franca expansión, desaparecieron durante el siglo XVIII, cuando la sucesiva dominación de las Audiencias, y posteriormente de los gobiernos republicanos, trajeron el Estado negro de Esmeraldas bajo la dominación nacional (Friedemann e Whitten, 1974: 96).

Mas o refúgio de liberdade não foi aniquilado. Ao longo dos séculos XVII a XIX, para lá migraram negros e negras, cimarrones, provindos de minas colombianas. A partir de 1640, chegaram à província de Esmeraldas africanos e seus descendentes que fugiram das minas de Barbacoas, como indica Noboa (2002 [1992]). Almario e Castillo (1996) também sublinham que houve migrações negras provenientes de Barbacoas, seguindo o curso do Rio Patía e se estendendo da Isla del Gallo (hoje circunscrição de Salahonda) até a província de Esmeraldas, Equador. O mesmo apontam Zuluaga e Romero (2007). Esmeraldas abrigou negros fugidos de Guapi e Barbacoas que constituíram uma população dispersa desde Tumaco até Esmeraldas ${ }^{66}$.

Novoa ressalta que a migração também levou negros e negras escravizadas de Nova Granada a trabalhar nas minas de Esmeraldas. Ela precisa que, em 1738, houve a primeira fase dessa etapa de migração, quando mineiros de Tumaco, Cali, Popayán e Barbacoas solicitaram ao governador de Esmeraldas a concessão de terras para minerar e criar gado com vistas à manutenção das quadrilhas de escravizados (2010: 85$)^{67}$. A segunda etapa, segundo a autora, ocorreu a partir de 1771, explorando ouro no Rio Santiago e em seus afluentes, como Bogotá, Guembi, Tululbí, Cachavi e Palavi (Novoa, 2010: 96-104) ${ }^{68}$.

A organização social negra em torno da mineração configurou outro importante vetor de subversão ao sistema escravagista. Começou a se desenhar nas minas de Nova Granada e

\footnotetext{
${ }^{65}$ Tardieu assinala que, antes mesmo do falecimento de Illescas, o arrefecimento de lideranças negras da República Zamba, em especial Francisco de Arobe e Alonso Sebastían de Illescas, contribuiu para a derrocada da República Zamba (2006: 78).

${ }^{66}$ Zuluaga e Romero (2007) argumentam que o povoamento nucleado em torno de Illescas não foi muito numeroso. Corroboram a especulação de que a sociedade negra foi abastada pela chegada de negros fugidos de Quito no século XVII e de negros livres e fugidos provindos de Guapi e Barbacoas nos séculos XVIII e XIX.

${ }^{67}$ Nesse contexto, Novoa ressalta que se evidenciaram as permanentes tensões e conflitos jurisdicionais entre Iscuandé (Nova Granada) e Esmeraldas (Equador) pela competência administrativa de Tumaco. E de fato, por proposta de Pedro Vicente Maldonado, Tumaco chegou a pertencer à governação de Esmeraldas entre 1739 e 1764 (Novoa, 2010:89, 90-95).

${ }^{68}$ Ao final do século XIX e início do século XX, registra-se uma última onda migratória a Esmeraldas, correspondente a um contingente de quatro mil trabalhadores jamaicanos contratados para construção da ferrovia do sul (Charvet, 2010).
} 
depois no norte do Equador, conforme relatado pelos autores citados. Quadrilhas eram as unidades produtivas conformadas para a extração de ouro em jazidas. Deveriam ser grupos dedicados exclusivamente a essa atividade, porém, não foi o que aconteceu. $\mathrm{O}$ abastecimento alimentício das quadrilhas era precário. Em Nova Granada, depois que acabava a alimentação provinda das fazendas do Vale do Cauca, o grupo da quadrilha tinha de procurar recursos na selva para complementar sua alimentação. Simultaneamente à fixação de um grupo em um rio ou riacho para a mineração, outro grupo se dedicava à caça, à pesca, ao cultivo de milho e banana-da-terra, próximo às chocas, à coleta de frutos e legumes.

Grupos negros subverteram a concepção escravagista das quadrilhas; imprimiram a elas dimensões social, familiar e cultural que deram origem a comunidades domésticas, nas quais a mulher exercia um papel central para a coesão interna dos grupos, enquanto os homens protagonizavam a relação entre a sociedade negra e a branca envolvente. Assim, relações de parentesco constituíram um dos principais eixos na consolidação das comunidades negras. A família extendida foi um mecanismo de resistência à escravidão, por um lado, e construção da liberdade, por outro. Em geral, nas quadrilhas, estabeleciam-se relações sexuais flexíveis, das quais podiam participar a maior parte dos homens desse grupo social alternadamente com o mínimo de mulheres existentes. A família extensa, engendrada pela sucessão de matrimônios de um mesmo ego genitor, fez com que os filhos se identificassem com a cabeça da família, denominada gran madre. Assim constituiu-se uma tendência à matrilinearidade e matrilocalidade em uma sociedade com patrilinearidade legal ${ }^{69}$.

Como explica Romero, dentro da comunidade, "el ego de poder y autoridad era ejercido por la gran madre con mayor número de parentesco con el mayor número de unidades familiares" (Romero, 1995: 65). Zapata (1985) também ressalta o protagonismo das mulheres na estrutura da família. Na diáspora africana, constituiram-se arranjos familiares nos quais a mulher figura como cabeça ${ }^{70}$.

\footnotetext{
${ }^{69}$ Segundo Novoa, o capítulo VI da Instrução de 1789 determinava que os mineiros deveriam promover o matrimônio entre os escravizados. Segundo o padrão espanhol de organização, impulsionado pelo trabalho missionário, a união conjugal era monogâmica e patrilinear (2010: 119). Fernández-Rasines (2001) argumenta que a família patriarcal entre a população escravizada foi propiciada nas minas de Barbacoas desde princípios do século XVII. Já Novoa reconhece que, paralelamente a esse padrão, outros arranjos familiares se constituíram. Cita, pois, um caso de 1717, em minas de San Lorenzo, no rio Iscuandé, onde existiam mães solteiras que haviam conformado uma família extensa matrilinear e matrilocal (Novoa, 2010: 120). A autora converge com a análise de Romero no tocante ao papel da mulher na coesão social dos grupos negros, também no território de Esmeraldas.

${ }^{70}$ A autora fala sobre mulheres negras na condição de escravizadas e destaca a atribuição de cuidado da prole: "desde el nacimiento estos eran avaluados junto al precio de la madre y era ella la que en el mayor de los casos tenía la obligación de su sostenimiento y educación, sí tenía la fortuna de que su hijo no fuera vendido a otro amo" (Zapata, 1985: 61).
} 
Assim, a autoridade feminina extrapolava o círculo de suas uniões sexual-afetivas, irradiando-se à comunidade. Contribuiu para isso, segundo Romero (1995), o fato de que muitas quadrilhas mantiveram sua constituição ao longo de gerações, de maneira que o grupo reconhecia uma ancestral comum, alicerce fundador, uma mulher: mãe, avó ou tataravó, em torno da qual se desenvolvia a parentela por linha materna. Mesmo migrando, por vezes, a linhagem de parentesco se mantinha. Conforme ressalta Novoa (2010), as quadrilhas mineiras que passaram de Nova Granada a Esmeraldas já haviam vivenciado o processo de conformação de famílias. A autora informa que, no decorrer do século XVIII, no mercado de Popayán, se generalizava a prática de venda de quadrilhas com famílias inteiras.

Essa forma organizativa constituiu uma territorialidade específica, engendrada no contexto da relação entre negros/as escravizados/as e livres. Isso porque, segundo Noboa (1990), em princípios do século XVIII, 80\% da população negra na Colômbia era livre, muitos haviam comprado sua liberdade. Segundo Romero (1993), a forma mais recorrente de obtenção da liberdade por parte de escravos do Pacífico passava pela renda obtida com a mineração:

accedían al metálico vinculándose a la producción minera durante el tiempo "para si"," o se auto alquilaban a otros mineros en temporadas de pocas lluvias, en labores de agricultura. Así, el ahorro que hicieron durante varios años les permitía comprar la libertad, inclusive una mina en donde podían seguir laborando independientemente, como mazamorreros (Romero, 1993: 28).

Na Bacia do Rio Santiago, em Esmeraldas, confome conta Novoa:

las familias esclavizadas fundadoras del distrito minero, movidas por un sentimiento de pertenencia e identificación con los reales de minas, convirtieron estos sitios en lugares de reproducción social, económica y cultural. Así como en espacios de resistencia de los esclavizados y no únicamente en lugares de dominio de los señores de minas, dinámica que supuso una paulatina ocupación del territorio (Novoa, 2010: 129).

Por vezes, logrou-se o reconhecimento das formas de territorialidade experienciadas nesse contexto. Romero conta casos de grupos afro-pacíficos que obtiveram títulos que reconheciam suas formas comunais de posse da terra, bem como a soberania que exerciam sobre determinado território. Além da compra, houve casos de reconhecimento de direitos consuetudinários sobre a terra. O processo reconhecia a ocupação pacífica e a formação de uma comunidade, a qual não raras vezes alugava parte de sua força de trabalho aos

\footnotetext{
${ }^{71}$ Segundo Romero (1993), a legislação escravista permitia para a conversão ao cristianismo (sábado) e um dia para si (domingo, para descanso).
} 
escravistas. Ademais, por sua atividade mineira tradicional, pagavam ao Estado impostos pelo direito de "Mazamorrería" (Romero, 1993: 29).

$\mathrm{O}$ autor explica que grupos de mineradores/as artesanais foram se formando nos interstícios das minas onde funcionavam as quadrilhas. Assim, grupos negros do Pacífico ascederam à liberdade, produzindo a negação da estrutura escravista a partir de sua mesma funcionalidade. Novoa (2010) também assinala a concomitante convivência e a recusa das formas escravistas pela população negra, de modo que se constituiu uma identidade de resistência negra. Trata-se de processo semelhante ao narrado por Reis e Gomes (2010) no tocante às contravenções do povo negro ao sistema escravista brasileiro.

Novoa (2010) argumenta que foram quatro momentos cruciais na busca por liberdade e na construção do território coletivo afro-esmeraldenho: 1) Resistência à escravização nas minas, ação das quadrilhas e relações estabelecidas com diversos grupos étnicos na construção de caminhos; 2) Luta pela concessão de liberdade como estratégia na obtenção de reconhecimento enquanto povo; 3) Insurreições nas minas auríferas que levaram à liberação jurídica por parte do Estado republicano; 4) Compra de terras como forma de se legalizar perante o Estado (Novoa, 2010: 118-119).

Também houve práticas de libertação associadas ao cultivo da terra. A partir da década de 1830, conforme dizem Almario e Castillo (1996), no litoral da província de Barbacoas, apresentam-se modalidades de uso e ocupação da terra pela população negra por meio de arrendamento e parceria (terrazgo e aparcería), o que se assemelha ao processo da "brecha camponesa", anteriormente comentado. Quando foi abolida a escravidão na Colômbia, grande parte da população de ascendência africana que trabalhava nas minas do Pacífico migrou para a costa, formando pequenas comunidades de pescadores, marisqueiras e agricultores, muitas das quais ainda hoje existem, conforme contam Friedemann e Whitten (1974).

Tais comunidades de pequeno porte são fruto do que Almario e Castillo (1996) chamam de ocupação molecular que se deu no período pós-escravista na região. A população negra liberta se dispersou em direção às zonas baixas: esteiros, praias, diques, várzeas, braços e boqueirões dos rios. Romero (1991) também ressalta que o eixo de povoamento foram os rios. A hipótese de Almario e Castillo é de que o avanço se deu por meio de explorações parciais, consolidando uma espacialidade marginal e autônoma com relação ao eixo andino. As modalidades de obtenção de terras eram diversas, desde a ocupação espontânea e a doação testamentária de antigos amos até a compra de porções de terra. 
Tardieu (2006) comenta a dimensão jurídica que a insurgência assumiu, em certos casos. O autor comenta casos de querelantes negros - trabalhadores de minas, agrícolas, domésticos - que demandavam judicialmente contra amos que lhes impunham tarefas excessivas $^{72}$. Denunciavam regimes de trabalho que lhes negavam alimentação adequada e os dias de descanso assegurados pela legislação colonial. Denunciavam agressões físicas, que por vezes eram torturas, acompanhadas de ofensas morais. Questionavam os valores manejados pelos senhores em suas vendas, fossem essas abusivas ou inferiores ao preço de mercado. Assim, buscavam garantir a permanência em seu local de vivência e a proximidade entre mãe e filho, bem como com outros entes. Muitas vezes combinavam a demanda judicial com uma fuga, ausentando-se do ambiente em que eram escravizados enquanto o caso era analisado e julgado. $\mathrm{O}$ autor cita casos em que a decisão judicial advertia o senhor de escravos, determinando que tratasse melhor sua escravizada (Tardieu, 2006: 343). Também pondera que as relações entre a pessoa escravizada e o senhor de escravos se tensionavam bastante em tais situações, já que o ato mesmo de demandar judicialmente ao amo era por ele interpretado como ofensa.

Caso extremo que exemplifica o ponto abordado é trazido por Zapata (1985). O fato ocorreu em Cartagena, ano 1789. A “escrava doméstica” Gertrudis Súbira demandou contra sua ama Juana María Saenz de Meza. Gertrudis declarou:

que su ama le hacía pasar diferentes noches en vela, con los brazos atados por detrás tan fuertemente que le era imposible dormir un instante, otras había en esa dolorosa situación, la hacía untar el rostro con estiércol de gato, cuya fetidez les causaba extraordinaria fatiga en el útero... en otros les daba de comer el mismo excremento del gato, deshechos en orines corruptos también a beber de éstos y huevos crudos podridos cuando los habia ... y también el pescado podrido (Zapata, 1985:82).

Pouco tempo depois da demanda jurídica, Gertrudis morreu em decorrência de múltiplos golpes que lhe proferiu Juana María Sáenz de Meza. O caso visibiliza a tese defendida pela autora, de que a violência perpetrada contra mulheres negras escravizadas resultava não apenas do antagonismo homem-mulher, mas também das contradições de classe e exploração econômica. Caberia, então, acrescentar a desigualdade racial como ponto central nessas relações marcadas pela violência extrema.

\footnotetext{
${ }^{72} \mathrm{O}$ autor comenta que muitos expedientes trazem o argumento dos danos causados pelo trabalho em zonas de ásperas condições climáticas, mas o pior era o trabalho nas minas (Tardieu, 2006: 355). Segundo FernándezRasines (2001), amos e amas ameaçavam de enviar seus escravos e escravas às minas de Barbacoas como medida disciplinar.
} 
Tardieu recorda que a Coroa espanhola havia delegado magistrados para vigiar e assegurar o trato adequado às pessoas escravizadas e sancionado leis que determinavam parâmetros para a escravização, limitando castigos físicos, por exemplo. O que estava por trás de tais determinações era a moralidade cristã. Ao mesmo tempo, porém, a justificativa religiosa encobria a finalidade econômica do sistema colonial-escravagista. $\mathrm{Na}$ opinião do autor, o sistema escravagista "conseguiu provar que a escravidão ao fim e ao cabo era um mal de onde provinha um grande bem: a evangelização dos africanos" (Tardieu, 2006: 319).

Os querelantes eram defendidos judicialmente por procuradores. Os juízes decidiam o caso mediante a ponderação entre a acusação entoada pelos procuradores e a defesa apresentada pelos donos, ou senhores de escravos. O autor ressalta que os próprios magistrados, os quais deveriam velar pelo bom trato das pessoas escravizadas, se deixavam dominar por seus preconceitos (Tardieu, 2006: 323). Afinal, a justiça era parte do sistema escravista hegemônico. Porém, por suas margens, o sistema deixava brechas, das quais se valiam negros e negras no exercício de sua agência em busca da autonomia.

Muitas das querelas jurídicas são protagonizadas por mulheres, o que indica ser esta uma estratégia negra de insurgência à escravização marcadamente feminina ${ }^{73}$. É interessante o caso de María Manuela Navarro, sessenta anos, “criolla de Quito”. Com a idade avançada, ela demandava comprar sua liberdade. Narra uma trajetória de trabalho árduo com serviços domésticos (cuidar de crianças, cozinhar, lavar roupa), envolvendo deslocamentos a fazendas dos senhores que a escravizavam, expondo-se a doenças e colocando em risco sua vida. Isso se passou no ano de 1750, segundo decisão judicial de 5 de outubro, María Manuela logrou comprar sua liberdade. Em outros casos, como o da "mulata" María Gómez, a demanda era pela compra da liberdade de seus filhos (Tardieu, 2006: 321). O autor ressalva que, ainda que se falasse na "concessão"da liberdade, tratava-se de uma conquista cujo custo para a pessoa escravizada representava total alienação, material e/ou espiritual (Idem, ibidem: 324).

Outros estudos também trazem à luz a agência de mulheres negras escravizadas no contexto jurídico. Analisando arquivos historiográficos, Zapata (1987) pesquisou a situação

\footnotetext{
${ }^{73}$ Rasines-Fernández (2001), analisando material do Arquivo Nacional de História do Equador, observa que mulheres foram sujeito e objeto da maior parte das demandas jurídicas. Nesse sentido, a autora também sublinha a agência feminina negra. Analisando dados de 1783 sobre a província de Quito, área que não incorporava a costa esmeraldenha, ela conclui que mulheres dessa época estavam sub-representadas entre a população livre nomeada como "pardos ou de várias cores" e duplamente sub-representadas nessa categoria estavam as mulheres negras (Rasines-Fernández, 2001: 59).
} 
da mulher negra escravizada na Nova Granada do século XVIII ${ }^{74}$. Segundo a autora, essa mulher estava presente mais que tudo nos trabalhos domésticos, atuando como ama de leite, lavadeira, cozinheira, ama de companhia, entre outros. Era símbolo de prestígio, ostentação e poder dos senhores e senhoras escravagistas ${ }^{75}$. Porém, mulheres negras também estavam presentes nas fazendas, às vezes casadas com negros escravizados; nas cidades, vendendo frutas nas ruas e comestíveis nas praças (doces, bollo de maíz, cazabe, guisos); e na atividade mineraria,especialmente de aluvião.

A condição marginal das mulheres escravizadas iniciava-se no próprio sistema jurídico colonial, como indica Zapata: "La ley ignora a la Mujer Negra Esclava cuando esta se ve involucrada en pleitos que atentan contra la Iglesia y las autoridades; los expedientes se archivan, se cierran o no se les da la respectiva importancia" (1985: XII). A autora observa que a maioria dos expedientes corresponde à segunda metade do século XVIII, quando passou a atuar em Nova Granada, como representante jurídico dos demandantes negros, o Procurador Geral dos Povos. Outro fato notório foi que, no mesmo momento, foi expedida uma espécie de "Código Negreiro", que amenizaria a situação da população negra em Nova Granada, determinando bons tratos, garantia de moradia saudável e confortável, subministração de alimentação e respeito à pessoa. Tal lei era chamada de "Instrucción" (Zapata, 1985: 68-69).

Os expedientes analisados por Zapata explicitam que mulheres atuaram em outras modalidades de resistência à escravização. A autora conta o caso de uma escrava crioula de 15 anos de idade, vendida "libre de empeño, hipoteca, com las tachas y defectos de ladrona, borracha y cimarrona, por la suma de 300 patacones de 8 rales castellanos en el año de 1745" (Zapata, 1985: 48). Também comenta episódio ocorrido em 1723 em Villa de Santa Cruz y San Gil de fuga de cinco mulatas escravas (Idem, ibidem: 74). Assim, a busca da liberdade dava-se por meio do cimarronismo, assim como por outros meios: carta de liberdade por serviços prestados, compra direta do escravo a seu amo, amizade ou paternalismo e/ou relações diretas amo-filho, amo-esposa, ou abolição total, conforme indica Zapata $^{76}$.

\footnotetext{
${ }^{74}$ A pesquisa baseia-se no material do "fondo Negros y Esclavos do Archivo Nacional de Colombia sección Colonia", com documentos referentes aos atuais departamentos de Antioquia, Bolivar, Boyacá, Cauca, Cundinamarca, Magdalena, Santander e Tolima (Zapata, 1985: XII).

${ }^{75}$ Rasines-Fernández (2001) argumenta que, na maioria dos casos, a escravização sexual estava implícita na escravização doméstica. Ademais, às vezes, mulheres escravizadas eram exploradas sexualmente para terceiros.

${ }^{76}$ Interessante observar a distinção que a autora faz sobre os casos de insurgência pela fuga. Segundo Zapata, "cimarrón" seria "aquel que huía definitivamente del dominio de su amo hacia el monte, en actitud de enfrentamiento declarado, ubicándose generalmente en Palenques". Enquanto "zapaco" seria "aquel que huye de su amo, pero continúa viviendo en los contornos de la hacienda, mina o núcleo urbano, sin mezclarse con ningún grupo" (1985: 109).
} 
Zapata conta ainda muitos casos de mulheres escravizadas que reclamavam seus direitos, especialmente à liberdade ${ }^{77}$, depois da morte de seus amos, alguns dos quais eram também seus maridos ou homens que com elas viviam relações de concubinato. Narra ainda várias demandas por situação de enfermidade de mulheres negras escravizadas, em geral ocasionadas por maus tratos: tumores, cicatrizes, inchaços e infecções. Esse caso é particularmente interessante por mostrar o trabalho feminino na mineração e na agricultura:

En visita Real de minas, al Capitán General Gobernador de la Provincia del Chocó en el año 1739 llegó hasta Santa Rosa de las Animas donde recibió la queja de una mulata esclava que exigía su libertad. La mulata trabajaba en la cuadrilla de la de Jacinto Palomino en el río de San Agustín de la Provincia de Chocó y según ella: “(...) con mí industria y a costa de unos pesos de oro que tenía adquiridos con mi trabajo en los días festivos como es costumbre en las cuadrillas de labora de minas, hice hacer una roza de maíz en dicho río Agustín a vista y ciencia y paciencia de Nicolás de la Cerna (minero de la mina) y estando dicha Roza en postura de poderse coger, pretendió comprarme el maí (...)" a un precio por debajo pero que, según la mulata, le adeudaba $\$ 400$ pesos de oro con los cuales pretendía comprar su libertad (Zapata, 1985: 50).

Pesquisas de Tardieu (2006) e Zapata (1985) indicam que, em Nova Granada e na Real Audiência de Quito, os caminhos insurgentes trilhados por negras e negros em busca da liberdade se assemelhavam. Em todo o período colonial, ações de âmbito individual projetaram-se em estratégias coletivas de organização contrárias ao sistema escravagista. Em nosso caso, interessa pensar como tais estratégias se orientavam à construção de uma territorialidade negra na região que hoje delimita a fronteira entre a Colômbia e o Equador, percorrendo trajetos que se estendem até o vale interandino Chota-Mira ${ }^{78}$. Em toda a sua complexidade, a insurgência negra como projeto de construção de uma vida livre e autônoma conduzia à territorialidade, como coloca Novoa:

Mediante renovadas acciones como la fuga, la sublevación, la negociación, la desesclavización o la apelación al sistema jurídico colonial, surgieron sentimientos de solidaridad y de identificación, lo que les permitió definirse

\footnotetext{
${ }^{77}$ Mesmo ponto observado por Tardieu (2006) na história da Real Audiência de Quito.

${ }^{78}$ No Equador, houve a conformação de assentamentos negros também no interior do país, no território Valle del Chota-Salinas-La Concepción, região serrana. Nesse caso, a presença negra deveu-se à necessidade de mão de obra por parte dos jesuítas que haviam se apoderado de grandes extensões de terra para o cultivo da cana-deaçúcar. Desde o século XVII, segundo Charvet (2010), os jesuítas compravam "famílias negras” para trabalhar em suas fazendas e para vendê-las no mercado interior. Assim, consolidaram-se no Equador dois territórios ancestrais, o Valle del Chota, la Concepción y Salinas, nas províncias de Carchi, e Imbabura, que contemporaneamente é composto por sessenta comunidades negras dispostas na ribeira do Rio Chota-Mira; e o território ancestral do Norte de Esmeraldas, na província de Esmeraldas (ambos no norte do país). Segundo Fernández-Rasines, no Equador os contrastes entre os contextos de serra e costa são a origem de uma conceitualização regional marcadamente bipolar (2001: 67).
} 
como grupo étnico a partir de un objetivo común: el acceso gradual y colectivo al territorio con fines de reproducción social y económica (Novoa 2010: 12).

No período pós-abolicionista, houve uma onda migratória de ex-escravizados da serra (das fazendas da província de Imbabura e Carchi) para a costa equatoriana, como se pode inferir do estudo de Fernández-Rasines. Charvet (2010) também indica que, provavelmente desde fins do século XVIII, chegaram a Esmeraldas cimarrones do Chota, buscando uma liberdade que estaria garantida graças à inacessibilidade da região (Charvet, 2010: 50) ${ }^{79}$. Desse modo, parece haver um trânsito envolvendo ambos os territórios afro-equatorianos e a Colômbia, ao longo da história.

Vale ressaltar que há, no Pacífico Negro colombo-equatoriano, uma história e uma territorialidade compartilhadas:

(...) independientemente de las definiciones republicanas en materia de límites territoriales, la amplia zona fronteriza del sur entre Colombia y el Ecuador se define como un continuo espacial para uno y otro país a lo largo de la historia, permitiendo un intercambio permanente de efectivos demográficos y bienes, tanto en la sierra y la costa, como en la selva. De tal manera que (...) negros (...) de la costa y varios grupos étnicos de la zona selvática, trasvasarán y compartirán un espacio que les ha pertenecido históricamente, aunque los límites formales pretendan reducir el margen de acción de estos complejos movimientos (Almario e Castillo, 1996: 90) ${ }^{80}$.

O Equador aboliu a escravatura em 1851. A Colômbia decretou a liberdade dos escravizados em 21 de maio de 1851, que passou a valer no dia $1^{\circ}$ de janeiro de 1852 . O Brasil, 35 anos depois, em 1888, foi último a abolir esse sistema nas Américas. Porém, o processo abolicionista em nenhum desses países foi acompanhado por medidas voltadas para a transformação das condições de vida dos grupos populacionais até então escravizados. A situação da população afrodescendente em toda a América não se transformou em seu cerne. No Brasil, no Equador, na Colômbia e outros países latino-americanos e caribenhos, contemporaneamente, afrodescendentes ocupam estratos sociais em que se verificam maiores

\footnotetext{
${ }^{79}$ Whitten Jr (1997), referindo-se a trabalho de campo por ele desenvolvido nos anos 1960, no norte de Esmeraldas, Equador, é mais um autor que comenta sobre migração negra da serra à costa, com a ressalva da ausência de documentos que comprovem esse deslocamento.

${ }^{80}$ Zuluaga e Romero corroboram essa visão, argumentando que, à parte os organismos e instituições políticoadministrativas, as diferenças entre os dois países tendem a diluir-se pelas similitudes étnicas, sociais e culturais de seus habitantes (2007: 21$)$.
} 
índices de desemprego, estão em situação de pobreza e extrema pobreza, com baixa escolaridade e acesso comprometido à educação, à saúde e a outros serviços básicos.

Em fins do século XX, marca a história dos países em foco a promulgação de legislações nacionais que foram acompanhadas por intensas mobilizações sociais, em especial dos povos afrodescendentes. Isso se enquadra em um movimento mais amplo na América Latina, como destaca Restrepo:

la década del noventa puede considerarse como la de las reformas constitucionales y la emergencia de las políticas de la etnicidad en diferentes países de América Latina (Van Cott 2000). Cerca de una decena de países redactaron nuevas constituciones políticas que, con diversos matices y alcances, comparten un giro hacia la incorporación del multiculturalismo como política de Estado. A diferencia de otros países de la región (pero al igual que Brasil y Ecuador), Colombia ha incluido a las poblaciones afrodescendientes en este "giro hacia multiculturalismo" (Restrepo, 2013: 290).

Em 1988, o Brasil promulgou sua Constituição Federal vigente. A Colômbia o fez em 1991. O Equador instituiu em 1998 sua Constituição Nacional, a qual foi revogada em 2008 e substituída por nova norma constitucional ${ }^{81}$. No caso do Brasil e da Colômbia, as Cartas Magnas datam aproximadamente da mesma geração e abordam a temática afrodescendente de forma similar. O Equador acercou-se aos demais e foi mais além na constituição atualmente vigente, a Constituição Política de 2008.

Na Constituição Política da Colômbia, no Capítulo 8, o artigo transitório 55 determina ao Congresso a atribuição de expedir:

una ley que les reconozca a las comunidades negras que han venido ocupando tierras baldías en las zonas rurales ribereñas de los ríos de la Cuenca del Pacífico, de acuerdo con sus prácticas tradicionales de producción, el derecho a la propiedad colectiva sobre las áreas que habrá de demarcar la misma ley ${ }^{82}$

A Constituição estende o direito à propriedade coletiva a territórios negros rurais situados em outras regiões do país, com realidades similares. Estabelece também a proteção da identidade cultural para comunidades negras.

No caso do Brasil, é também um artigo do Ato das Disposições Constitucionais Transitórias (ADCT) que estabelece o direito à propriedade de territórios quilombolas. Como

\footnotetext{
${ }^{81}$ Além dos três países em foco, também promulgaram novas constituições o México (1992), o Paraguai (1992), o Peru (1993), a Argentina (1994), a Bolívia (1994), o Panamá (1995), a Nicarágua (1995) e a Venezuela (1999) (Restrepo, 2013: 290).

${ }^{82}$ Constitución Política de Colombia, Capitulo 8, Articulo Transitorio 55, página 106.
} 
diz o texto integral do Artigo 68 do ADCT: "Aos remanescentes das comunidades dos quilombos que estejam ocupando suas terras é reconhecida a propriedade definitiva, devendo o Estado emitir-lhes os títulos respectivos" $" 83$.

Dois anos após a promulgação da Constituição Política da Colômbia, instituiu-se a Lei n. 70/1993, a qual institui Consejos Comunitarios Territoriales, forma de reconhecimento jurídico de territórios étnicos. Trata-se da "persona jurídica [que] ejerce la máxima autoridad de administración interna dentro de las Tierras de Comunidades Negras". São, portanto, as instâncias encarregadas de realizar o manejo e a administração dos territórios negros ancestrais. A conformação dessa organização jurídica é prerrequisito para a titulação coletiva dos territórios negros ancestrais (artigos $8^{\circ}$ e $9^{\circ}$ ). Em seguida, foi promulgado o Decreto $n$. 1745/1995, que regulamenta o processo para aceder à titulação desses territórios (capítulo 3 da Lei n. 70/1993). Conforme determinam as legislações, o Instituto Colombiano de Desarrollo Rural (INCODER) responsabiliza-se pela implementação dessa política ${ }^{84}$.

No caso do Brasil, a primeira regulamentação do artigo constitucional ocorreu em 2001, por meio do Decreto n. 3.912/2001, que foi revogado e substituído pelo Decreto n. 4.887/2003, o qual estabelece procedimentos para a identificação, o reconhecimento, a delimitação, a demarcação e a titulação das terras ocupadas por remanescentes das comunidades dos quilombos de que trata o art. 68 do Ato das Disposições Constitucionais Transitórias. O Decreto estabelece que, previamente à titulação, há de se constituir uma associação comunitária quilombola, pessoa jurídica, em nome da qual o título é emitido. No Brasil, é o Instituto Nacional de Colonização e Reforma Agrária (INCRA) a instância responsável pela regularização de territórios quilombolas ${ }^{85}$.

Há muitas conexões entre os parâmetros estabelecidos pelas legislações dos dois países. Os territórios negros são de destinação coletiva, geridos por uma organização que representa a comunidade, seja uma associação quilombola, seja um conselho comunitário. São inalienáveis, imprescritíveis e impenhoráveis. Nota-se, assim, que o reconhecimento e a

\footnotetext{
${ }^{83}$ Brasil. Constituição da República Federativa do Brasil de 1988, Ato das Disposições Constitucionais Transitórias, Artigo $\quad 68^{\circ}$. Disponível em: http://www.planalto.gov.br/ccivil_03/constituicao/constitui\%C3\%A7ao.htm\#adct. Acessado em: 7 de setembro de 2012.

${ }^{84}$ Os primeiros títulos saíram em 1996. Até o ano de 2002, segundo informações obtidas em trabalho de campo, foram reconhecidos 180 conselhos comunitários, 162 títulos, compreendendo 6 milhões de hectares aproximadamente. Segundo Almario (2004), a titulação coletiva compreende 5 milhões de hectares em todo o Pacífico colombiano, agrupando cerca de 300 mil pessoas, em 160 Conselhos Comunitários (Almario, 2004: 99).

${ }^{85}$ Entre 1995 e 2012, foram emitidos 123 títulos contemplando 192 comunidades quilombolas e abrangendo 988.371,7824 hectares. Ver: 108 titulos expedidos às comunidades quilombolas. Disponível em: http://www.incra.gov.br/index.php/estrutura-fundiaria/quilombolas/file/108-titulos-expedidos-as-comunidadesquilombolas. Acessado em: 7 de setembro de 2012.
} 
garantia do território visam à perpetuação do espaço e da relação do grupo com ele, ao longo de gerações.

No Equador, desde a Constituição de 1998, os/as afrodescendentes são reconhecidos como "povo", parte do Estado equatoriano. Porém, a Constituição de 1998 não especificava a aplicabilidade de direitos coletivos ao povo afro-equatoriano, da forma como, por exemplo, se especificou para povos indígenas. Tal situação parece ter estimulado o povo afrodescendente a se organizar e reivindicar direitos perante o Estado.

Na Constituição Política de 2008, afro-equatorianos/as seguem tendo o estatuto de povo; parte do Estado equatoriano, intercultural e plurinacional ${ }^{86}$. Segundo Sanchéz (2010), esse estatuto está relacionado à percepção das peculiaridades da população afro-equatoriana em relação à sociedade majoritária e ao fato de que os seus territórios constituíram-se anteriormente à instalação do atual modelo de Estado e da proclamação da República. A referida Constituição reconhece 21 direitos coletivos às comunidades, povos e nacionalidades indígenas, ao povo afro-equatoriano e ao povo montubio ${ }^{87}$. Conserva as propriedades de inalienabilidade, imprescritibilidade, indivisibilidade e impenhorabilidade das terras comunais e reconhece as "comunas", que têm propriedade coletiva da terra como forma ancestral de organização territorial. Ademais, a Constituição Política de 2008 instaura a possibilidade de conformação de Circunscripciones Territoriales (CTs), que exercerão as competências do governo territorial autônomo correspondente, e serão regidas por princípios de interculturalidade, plurinacionalidade, de acordo com os direitos coletivos ${ }^{88}$.

No Brasil e na Colômbia, ficamos com o multiculturalismo e a plurietnicidade. $\mathrm{O}$ Equador avançou no reconhecimento e na celebração de um país intercultural e plurinacional. As interações entre grupos indígenas e grupos negros/afrodescendentes com os Estados nacionais revelam matizes importantes para a compreensão desse quadro. Os Estados nacionais em questão, bem como em outros países latino-americanos, reconhecem aos indígenas o lugar de outros "etnoculturais" e aos negros/afrodescendentes o lugar de outros “raciais" (Juliet Hooker apud Rahier e Dougé-Prosper, 2014). Esse caminho guarda relação direta com a luta dos movimentos negros/afrodescendentes e indígenas. A reverberação das reivindicações indígenas no âmbito dos Estados nacionais coloca em pauta o debate da autonomia e daí provém a ideia de povo, ambas implicando uma noção de territorialidade. A gênese da trajetória da luta negra ou afrodescendente na Colômbia, no Equador e no Brasil

\footnotetext{
${ }^{86}$ Artigo 1 e 56, Constituición Política de Equador, 2008.

${ }^{87}$ Capítulo quarto, artigos 56 e 57, Constituición Política de Equador, 2008.

${ }^{88}$ Capítulo terceiro, artigo 257, Constituición Política de Equador, 2008.
} 
ressalta o combate à discriminação. É em grande medida influenciada pelo movimento estadunidense dos direitos civis. Porém, como veremos ao longo do texto, também se inscreve pela chave da autonomia e da territorialidade. Nesse sentido, está na agenda afrodescendente, nas três nações.

Desde as perspectivas da luta antirracista e dos direitos territoriais, percebo um avanço no projeto de nação intercultural e plurinacional ${ }^{89}$. A Constituição equatoriana,entre os três países em foco, é a única que fala em reparação para o povo afro-equatoriano, abrindo a brecha para as ações afirmativas. Do ponto de vista da territorialidade, as Circunscrições Territoriais são entes territoriais autônomos a serem governados pelo povo afro-equatoriano. O multiculturalismo pode indicar a percepção de uma multiplicidade de povos e comunidades, porém não enuncia o mesmo lugar de sujeito de direitos. Esse cenário está perpassado por lutas de movimentos sociais local e globalmente, do contexto da vivência comunitária ao espaço intelectual e político do contexto internacional, e coloca um novo desafio para o entendimento da questão das etnias e raças.

Em pleno século XXI, a população de ascendência africana latino-americana e caribenha constitui representativo quantitativo populacional, especialmente no Brasil. Atualmente, ultrapassa-se o número de 140 milhões pessoas afro-americanas, constituindo um terço do total de habitantes do continente, que é de 450 milhões, segundo Souza (2008). O Brasil é o país com o maior número de descendentes de africanos na América Latina; a Colômbia ocupa o segundo lugar nesse ranking (Barbary e Urrea, 2004) ${ }^{90}$, e o primeiro na América Hispânica.

No Brasil, 97 milhões de pessoas declaram-se negras (pretas e pardas), no universo de 190.732.694, o que representa 50,74\% da população total brasileira. Tendo em vista a divisão campo-cidade, nota-se que $61 \%$ do total da população do campo é negra ${ }^{91}$. O Estado brasileiro considera oficialmente a existência de 2.007 comunidades quilombolas ${ }^{92}$. Porém, a

\footnotetext{
${ }^{89}$ Conforme ressaltam (Rahier e Dougé-Prosper, 2014), trata-se de um avanço parcial. Em análise comparativa entre as Constituições Políticas Equatorianas de 1998 e 2008, os autores apontam que ambas incorrem em uma mesma problemática. Apresentam os direitos de povos afro-equatorianos como residuais aos direitos dos povos indígenas, reforçando as diferenças históricas no reconhecimento do Estado-nação a ambas as coletividades.

${ }^{90}$ Segundo Restrepo (2013), Colômbia ocuparia o terceiro lugar.

${ }^{91}$ Dados do Instituto Brasileiro de Geografia e Estatística (IBGE), apresentados no Censo Demográfico de 2010, resultantes de cruzamento entre Tabela 1378 (População residente, por situação do domicílio, sexo e idade, segundo a condição no domić́lio e compartilhamento da responsabilidade pelo domicílio) e Tabela 3175 (População residente, por cor ou raça, segundo a situação do domicílio, o sexo e a idade).

${ }^{92}$ A referência aqui utilizada é o número de comunidades certificadas pela Fundação Cultural Palmares, órgão vinculado ao Ministério da Cultura, encarregado de inscrever em Cadastro Geral e expedir certidão respectiva a cada comunidade quilombola autoidentificada. Ver: http://www.palmares.gov.br/?page id=88, acessado em: 15 de junho de 2015.
} 
Coordenação Nacional de Articulação das Comunidades Negras Rurais Quilombolas (CONAQ) calcula que há cerca de cinco mil comunidades presentes em 25 unidades federativas ${ }^{93}$. No caso dos povos indígenas, são 241 etnias, que somam, segundo o Censo IBGE 2010, 896.917 pessoas, o que equivale a $0,47 \%$ da população brasileira.

O Equador tem 14.483.499 habitantes, entre os quais 1.042.811 se autoidentificaram como afro-equatorianos/as, o que corresponde a $7,2 \%{ }^{94}$. Essa população povoa todo o território nacional, com maior incidência no norte do país, nas províncias de Esmeraldas, Carchi e Imbabura e na cidade de Gayaquil. Povos indígenas, no mesmo Censo equatoriano de 2010, somavam 7\% da população. É interessante observar que, em 2010, afroequatorianos/as superaram indígenas, enquanto no censo anterior, de 2001, foi o contrário: indígenas eram $6,8 \%$ e afro-equatorianos/as, $5 \%$.

Segundo dados do Censo General de Población de 2005, realizado pelo Departamento Administrativo Nacional de Estadísticas (DANE), a Colômbia tem população total de 42.888.592 pessoas, em que 4,5 milhões de pessoas, ou 10,6\% da população colombiana, se autodeclaram afro-colombianas, categoria que inclui pessoas autoidentificadas sob as categorias de negras/os, mulatas/os, afro-colombianas/os, afrodescendentes, raizales e palenqueros $^{95}$. No caso dos indígenas, somam 87 povos e 1.378 .884 pessoas, ou seja, 2,9\% da população nacional, segundo dados do Censo de $2005^{96}$.

\footnotetext{
${ }^{93}$ O Brasil possui 27 unidades federativas. Assim, apenas os estados do Acre e de Roraima não possuem comunidades quilombolas identificadas pela CONAQ.

${ }^{94}$ Dados do Censo de población y vivienda, 2010, Instituto Nacional de Estadísticas y Censo (INEC), Equador.

95 Dados compilados por Urrea-Giraldo (2011). O autor ressalta que dados baseados em cálculos de organizações afro-colombianas, sistematizados no Plan de Desarrollo de la Población Afrocolombiana, de 1998, contabilizam a população afro-colombiana (termo que engloba as demais categorias) em $26 \%$ da população nacional. Por sua vez, Urrea-Giraldo, analisando tendências de outros instrumentos estatísticos, estima que a população afrodescendente na Colômbia pudesse flutuar entre $15 \%$ e $20 \%$ da população, entre 6,5 e 8,5 milhões de pessoas (Urrea-Giraldo, 2011: 790).

${ }^{96}$ Paschel (2010), baseando-se em dados de 2007 do DANE, Colômbia, atualiza para 3,4\% a população indígena colombiana.
} 


\section{PARTE I}

\section{A CONSTRUÇÃO DAS SUBJETIVIDADES \\ RAÇA E GÊNERO}




\section{CAPÍTULO 1 - RAÇA E ETNIA NA FRONTEIRA ENTRE COLÔMBIA E EQUADOR}

$\mathrm{Na}$ abordagem sobre raça/etnia, conforme dito na introdução, parto de um diálogo entre concepções que formulo desde minha vivência racializada no Brasil, as pesquisas e estudos que realizei, passando por elaborações conceituais do tema no meu país, encontrando com concepções que percebi em campo e nos escritos antropológicos sobre o tema na Colômbia e no Equador ${ }^{97}$. Proponho uma análise das categorias de classificação étnico-raciais partindo da forma como aparecem na história da Colômbia e do Equador, com especial atenção aos Censos. A leitura histórica permite fazer uma análise diacrônica de um movimento contemporâneo, em que há setores argumentando a inexistência da branquitude. Proponho, então, reflexões sobre negritude, branquitude e mestiçagem. Explorarei ainda a dicotomia entre raça como fenótipo e etnia como dimensão cultural da identidade.

A categoria científica "raça" consagrou-se no século XIX, em correntes do pensamento evolucionista que propunham interpretações biologicistas dos comportamentos humanos. Na história moderna da ciência, pesquisas biológicas invalidaram tal concepção, ao afirmar a igualdade humana constitutiva; demonstrando que seres humanos são pertencentes a uma mesma espécie biológica ${ }^{98}$. Porém, no campo da sociedade, a raça persiste como ferramenta de distinção e opressão, ou seja, opera como categoria social e política. Nas palavras de Petruccelli: “o descrédito da noção biológica de raça não diminui seu poder organizador da percepção comum e estruturante da hierarquia social” (Petruccelli, 2007: 11). Autores latino-americanos e caribenhos ajudam a compreender o sentido contemporâneo da raça.

O sociólogo peruano Aníbal Quijano (2005[2000]) historiciza a construção da categoria social de "raça". Trata-se, segundo o autor, de uma construção mental que expressa a experiência básica da dominação colonial. É, portanto, uma invenção; uma ideia constituída com base em supostas estruturas biológicas diferenciais entre grupos sociais. Porém, não guarda correspondência alguma com a biologia humana. Para Quijano, raça é o primeiro critério fundamental de distribuição da população mundial nas estruturas de poder da sociedade formada a partir do processo de colonização. Aplicou-se aos diversos povos originários que viviam na América quando da colonização, bem como aos também diversos

\footnotetext{
${ }^{97}$ As teorizações sobre raça e etnicidade na Colômbia são, em grande medida, referência para o debate concernente a tais questões no Equador.

${ }^{98}$ Segundo Guimarães (1995), "uma história da formulação e do posterior abandono do conceito de "raça" pelas ciências naturais pode ser consultada em Rex (1986); Banton (1977, 1987); e Barkan (1992)" (Guimarães, 1995: 3).
} 
povos africanos, traficados para as Américas como escravos, no mesmo contexto da colonização. E assim serviu como "modo básico de classificação social universal da população mundial" (Quijano, 2005[2000]: 3).

Stuart Hall (2003) define raça como construção política e social. Nas palavras do autor, trata-se de uma "categoria discursiva em torno da qual se organiza um sistema de poder socioeconômico, de exploração e exclusão - ou seja, o racismo" (Hall, 2003: 66). Raça tem seu sentido estabelecido a partir das cadeias de significado próprias de cada sociedade, de cada contexto e momento. Assim, o significado advém da posição ocupada dentro dos distintos sistemas de diferenças e equivalências. Não há correspondência fixa, literal, entre um termo isolado e uma posição qualquer. O sentido é contextual.

Rita Segato aproxima-se de Hall ao argumentar que "raça é signo", ou seja:

significante produzido no seio de uma estrutura onde o estado e os grupos que com ele se identificam produzem e reproduzem seus processos de instalação em detrimento de e a expensas dos outros que este mesmo processo de emergência justamente secreta e simultaneamente segrega (Segato, 2005: 10).

Nas estruturas sociais, ou nos sistemas de poder, as posições têm rostos, como coloca Segato. Nesse sentido, a noção de raça fundamenta a diferença principalmente com base no fenótipo e, em torno dela, "se cristaliza um vocabulário cromático" (Guimarães, 1995: 28). Assim, o racismo segue um espectro de cor gradativo, no qual, quanto menos pigmentação epidérmica, menor é a discriminação; e, quanto mais pigmentação, maiores são as mazelas do racismo sofridas por quem traz a marca em seu corpo ${ }^{99}$. Entendo que os signos da diferença estão para além da cor da pele, estendendo-se a outros traços anatômicos, cuja presença, em maior ou menor grau, também orienta a classificação social baseada em tais critérios. A categoria raça/cor constitui, nesse sentido, um "indicador baseado na visibilidade do traço de origem africana" (Segato, 2005: 4).

Às características fenotípicas, somam-se características cosmológicas, aqui compreendidas como modos de conceber o mundo e de se portar perante ele. Essa dimensão é relevante especialmente ao se considerar o universo de grupos dotados de uma existência territorialmente marcada. Tais grupos nutrem tradições que os particularizam no seio das sociedades nacionais. Em seus casos, a diferença inferiorizada traduz-se, portanto, em um mix que agrega traços fenotípicos e práticas socioculturais territorialmente inscritas. E, assim,

\footnotetext{
${ }^{99}$ Sistema que, no artigo de Guimarães, é nomeado como pigmentocracia (Guimarães, 1995).
} 
sempre está presente a possibilidade política da emergência da categoria de etnicidade vinculada a uma territorialidade, a uma cosmologia ou a tradições.

Já a questão da etnicidade, segundo Petruccelli, remete a "uma multiplicidade de significados além de cor ou raça, entre os quais pode ser citado, local de nascimento, nacionalidade, etnia, religião, língua, traços culturais, ancestralidade, origem ${ }^{100}$ e, num nível mais subjetivo, o sentimento de pertencer a um determinado grupo, seja qual for a maneira de defini-lo" (Petruccelli, 2007: 8).

Wade também distingue raça e etnia: enquanto a primeira marca a diferença no fenótipo, a segunda o faz em características culturais. O autor defende o uso do termo raça, uma vez que ele evoca significados construídos durante séculos de exploração na história da expansão colonial ocidental: "substituir el término 'etnicidad' (o 'nación', o 'pueblo') por raza corre el riesgo de enmascarar estos significados" (Wade, 1997: 17). O uso do termo "raça" presta-se, portanto, para um esforço intelectual comprometido com o combate ao racismo, com o qual me identifico. Todavia, as disputas políticas pelo reconhecimento dos direitos a terra, religiosidade ou tradições podem, em muitos casos, acionar com mais força a categoria da etnicidade, deixando menos ou mais evidente sua articulação com o combate ao racismo. Importante no trabalho em curso será analisar as formas de articulação discursiva nos movimentos e processos políticos na região afro-pacífica, assim como, na medida do possível, compará-las com as modalidades de entender raça e etnicidade no Brasil.

Negritude e afrodescendência remetem hoje a questões tanto de etnicidade quanto de raça. Assim como Barbary e Urrea (2004), compreendo que raça e etnia aludem a dimensões da vida diretamente relacionadas, porém não idênticas. Ao longo da história, Colômbia, Equador e Brasil têm similaridades, especialmente no período colonial e pós-colonial. Já contemporaneamente, encontraram caminhos diferentes para falar sobre o tema.

Neste capítulo, as reflexões em torno da raça percorrem caminhos da categorização étnico-racial. Lembremos que "o ato de classificar está na base da operação do pensar"; "categorizar é um ato de conhecimento e de reconhecimento" (Petrucelli, 2007: 9-10). Essa operação acontece em um contexto de assimetria entre quem classifica e quem é classificado; a classificação é atravessada por relações de dominação simbólica. Trata-se de um contexto relacional, pois como coloca Petruccelli, a atribuição de uma cor ou raça a determinada pessoa não constitui uma característica natural tampouco inerente a ela. "Ademais, a

\footnotetext{
${ }^{100}$ Acrescento sobrenome, pensando em países como a Costa Rica e a República Dominicana, pela presença de haitianos/as e seus descendentes.
} 
percepção de determinados traços físicos só se constituem como uma cor [raça] e se revestem de significado, no interior de um contexto histórico-cultural específico" (Idem, ibidem: 14).

No processo de nomeação da raça, as pesquisas censitárias, em especial, têm o poder de cristalizar categorias oficiais. A categorização racial veiculada em tais pesquisas reflete ideologias de cada momento histórico ${ }^{101}$. Ao mesmo tempo, nota-se que há disputas em torno da classificação, as quais refletem disputas por reconhecimento e acesso a recursos, ambas as dimensões que pesquisas censitárias oficiais mobilizam. Este trabalho tem especial interesse nas disputas, pois elas permitem perceber os processos endógenos, de autorreconhecimento e autonomeação em torno das categorias étnico-raciais. Discutiremos a seguir disputas na Colômbia e no Equador, especialmente em torno da categoria "mestizo".

\section{UMA LEITURA HISTÓRICA SOBRE AS CATEGORIAS DE CLASSIFICAÇÃO ÉTNICO-RACIAIS NA}

\section{COLÔMBIA E NO EQUADOR}

\section{Período Colonial}

Tardieu (2006) fez um estudo sobre o negro na Real Audiência de Quito, ao longo dos séculos XVI a XVIII. Falando sobre a situação no ano de 1560, ele traz algumas categorias étnico-raciais: "negro/a", "indio/a", "mulato/a", "zambo/a" e "zambahiago", sendo o último, vocábulo que começou a ser usado neste mesmo ano, segundo o autor. "Zambo" ou "zambahiago", conforme coloca Tardieu, é uma categoria étnico-racial que resulta da mescla negro-indígena ${ }^{102}$. Ele explica que o intercurso genético e cultural se dava principalmente entre homens negros e mulheres indígenas. Destaca ainda que os espanhóis costumavam chamar de "mulatos" os descendentes desse tipo de intercurso. Segundo Novoa:

El uso generalizado del término mulato en los documentos coloniales tempranos sobre Esmeraldas, en su mayoría, hacen referencia al mestizaje indoafricano, a los zambos o zambaigos. Pero se debe tener presente que en la época colonial el uso de uno u otro término, mulatos/mestizos, depende del contexto y de la finalidad y que en general corresponde a la población de origen mixto, y que lo más común era recurrir a calificativos como

\footnotetext{
${ }^{101}$ Conforme assinala Paschel (2013), Brasil e Cuba foram os países latino-americanos que sistematizaram o quesito étnico-racial nas enquetes recenseadoras ao longo do século XX. Já nas rodadas censitárias de 2010, a República Dominicana era o único país latino-americano que não incluía perguntas étnico-raciais. Ou seja, entre a década de 1980 e a primeira década do milênio, o tema ganhou espaço regionalmente.

102 Fernandéz-Rasines, ao transcrever trecho do relato de Guamán Poma, redige a categoria como "sanbaigo" e "zanbahigo" (2001: 43).
} 
mestizo, mulatos y demás castas, presentes en el discurso oficial (Novoa, 2010: 40).

Whitten (1992 [1967]) refere-se à categoria "mulato" como fruto da mescla branconegra. E "mestizo", segundo o autor, resulta da união entre pessoas brancas e indígenas. A categoria "moreno" também aparece em relatos datados do início do século XVII, do cronista Guamán Poma, conforme indica Fernandéz-Rasines (2001: 42).

Entre 1582 e 1660, dentro do grupo de "escravos", as pessoas eram classificadas como "bozales", "criollos" e "mulatos" (Tardieu, 2006: 191). Os chamados "escravos boçais" fazem referência à população provinda diretamente da África. Também foram traficados para o Pacífico colombo-equatoriano negros e negras provindos da Península Ibérica, ou "hispanizados", chamados escravos ladinos ou crioulos (Friedemann e Whitten, 1974: 100). Segundo Charvet (2010), ladinos eram aqueles nascidos na Espanha ou que dominavam o idioma castelhano e adotavam costumes da sociedade colonial. Friedmann e Arocha (1986) chamam atenção para o fato de que os/as ladinos/as eram batizados/as. Já Novoa (2010) entende os ladinos como conhecedores do mundo hispânico e africano ao mesmo tempo. Como "mulato/a" aparece ao lado dessas outras duas categorias, parece que era importante marcar a miscigenação, fosse com a etnia branca, fosse com indígenas.

No caso da história de Nova Granada, segundo Friedemann:

el censo de 1964 (Atlas de economía colombiana) trae el dato de que en Colombia un $30 \%$ de la población es negra y mulata. De acuerdo con proyecciones actuales, un $10 \%$ de esa cifra podría considerarse actualmente como población negra y el $20 \%$ restante como impregnada en términos genéticos y de cultura negra (Friedemann, 1993 - Los africanos: cifras y origen, La diáspora africana y el péndulo de las cifras).

Vejamos a periodização proposta por Germán Granda (apud Almario e Castillo, 1996). O primeiro período histórico da Nova Granada corresponde a 1600-1640/50, quando uma minoria espanhola ou crioula dominava os indígenas que trabalhavam nas minas; período em que se estabeleceram Barbacoas, Iscuandé e Tumaco. O período entre 1650-1852 é marcado pela substituição da mão de obra indígena pela negra, dado que o tráfico de pessoas africanas chegou à região, precisamente em 1640. Por fim, a dissolução da sociedade local colonial e o início do período republicano se deram entre 1852-1996. Nesse período, os "brancos" proprietários de minas, administradores e funcionários de fazendas, migraram para Pasto, Cali e Popayán; e a população negra avançou com o processo de "ocupação molecular" do território, dispersando-se em direção às zonas baixas: esteiros, praias, diques, várzeas, 
braços e boqueirões dos rios (Almario e Castillo, 1996: 67-68). Observa-se que a categoria "branco" aludia a uma conexão direta com a ascendência europeia, fosse na Real Audiência de Quito, fosse em Nova Granada/Colômbia.

Trecho da obra de Novoa explicita a referida conexão. Analisando a conformação étnico-racial da população da província de Esmeraldas, em meados do século XVIII, quando Tumaco fazia parte dessa jurisdição, a autora coloca que:

Esta provincia, para 1739, contó con una población aproximada de dos mil habitantes, distribuida en veinte pueblos, cinco ubicados a la Costa, y quince al interior. Los pueblos de la Costa albergaban a españoles, mestizos, zambos, mulatos e indios, a diferencia de los asentamientos del interior donde predominó la población indígena originaria (Novoa, 2010: 90).

Outra menção à classificação étnico-racial da população colombiana é feita por Noboa (1990). Analisando petições referentes a Barbacoas, Tumaco e Iscuandé registradas no Arquivo da Curia de Quito, entre 1800 e 1851, constam as seguintes categorias de classificação étnico-raciais: "pardos libres", "moreno libre", "negra libre", "estado llano", "noble", "cuarterones" 103 , "pardo esclavo", "mestizos", "negros esclavos" (Noboa, 1990: 366). Mais uma categoria aparece na Nueva Recopilación de Leyes de Indias (título V del libro VII), apresentada por Novoa. Essa legislação contém disposições estabelecidas desde meados do século XVI até finais do século XVII. Trata-se da categoria "berbericos", que aparece ao lado de duas outras conhecidas "Mulatos, Negros o Berberiscos" (Novoa, 2010: 39). A raiz do termo remete a berberes, conjunto de povos do Norte da África, que falam línguas berberes, da família de línguas afro-asiáticas ${ }^{104}$.

Friedemann também alude à categoria de "cuarterones", ao falar sobre a mescla genética entre brancos e não brancos (negros ou indígenas), que se intensificou ao longo do século XVIII ${ }^{105}$ :

Resultaron entonces mulatos, zambos, tercerones, cuarterones y hasta quinterones, que ya eran otra vez blancos. Aquellos que genéticamente se aproximaban al quinterón, pero volvían a tener hijos con un cuarterón o con un mulato, eran signados como tentenelaire el primero y como saltatrás el segundo. Y para designar a un zambo o a un mulato libres, apareció el término pardo (Friedemann, 1993 - Castas, mestizaje y blanqueamiento).

\footnotetext{
${ }^{103}$ Segundo o autor, seriam mulatos "de moderadas costumbres" (Noboa, 1990: 366).

${ }^{104}$ Berberes. Disponível em: http://pt.wikipedia.org/wiki/Berberes. Acessado em: 31 de agosto de 2014.

${ }^{105}$ Petruccelli faz referência a essa categoria quando comenta o Censo de 1890 dos Estados Unidos: "O Censo de 1890 acrescenta na classificação racial as categorias de 'quarterons' e 'octoroons' à de 'mulato'” (Petruccelli, 2007: 87).
} 
Detenhamo-nos agora à categoria "mestizo". É interessante retomar o sentido da mestiçagem entre negros/as e indígenas, tendo em vista o contexto da República Zamba. Falando sobre o processo de desintegração do palenque, Tardieu diz:

Todos tenían interés en la "pacificación" de los indios sometidos a los negros y luego a los "mulatos" inculturados que, lejos de la barbarie denunciada por diversas relaciones, tenían a pecho la defensa de una identidad mestiza original, dando muestras de un comportamiento sumamente inteligente, que obligó a la Real Audiencia a adaptarse a las circunstancias (Tardieu, 2006: 360).

Na leitura de Tardieu, portanto, a República Zamba instaura uma "identidade mestiça original". Perspectiva parecida é trazida por Novoa, que também associa a nova identidade mestiça com a condição de liberdade:

Luego de la inicial lógica guerrera puesta en marcha por los esclavizados que arribaron a Esmeraldas en 1553, las alianzas y acuerdos que emprendieron, primero con los indios y luego con los europeos, dio lugar a la conformación de una sociedad mestiza libre, resultado de las nuevas formas de interacción sociocultural y encuentro interétnico, lo que contribuyó a la conformación de una nueva identidad social y étnica (Novoa, 2010: 35).

A autora ressalta que a zambaje, sob a ótica das teorias racistas da mestiçagem, não agregava valor, já que consiste na mescla de dois grupos étnicos não europeus: negros/as e indígenas. Assim, inscreve-se em referências distintas a de purificação da raça. Trata-se, então, de uma combinação contra-hegemônica ${ }^{106}$. Como coloca Novoa:

Por lo que, históricamente, el calificativo de zambos representa una poderosa categoría de autodefinición para aquella población que se enfrentó desde un inicio al dominio colonial mediante variadas formas de resistencia, como ocurrió con los zambos de Esmeraldas en la colonia temprana. (Idem, ibidem: 40).

O intelectual negro colombiano Manuel Zapata Olivella traz perspectiva convergente para interpretar a miscigenação. Ressalto a importância de valorar e resgatar pensadores como ele, especialmente na Colômbia onde não há uma memória consolidada sobre a trajetória de intelectuais negros, como destaca Viveros (2013). Como assinala a autora, para Zapata Olivella, a mestiçagem nas Américas começou muito antes da vinda de europeus, tendo tido consecução com sua chegada, bem como com a de africanas e africanos escravizados. A

\footnotetext{
${ }^{106}$ Assumo a concepção gramsciniana de hegemonia como a integração da oposição à ordem dominante.
} 
mestiçagem básica nas Américas dá-se entre negros e indígenas, o elemento branco-europeu entra em segunda instância.

La idea del mestizaje que crea y utiliza Zapata Olivella en su novela [Changó, el gran Putas] es una idea de liberación, de denuncia histórica y lucha constante contra la opresión, una idea que pretende poner término a la discriminación racial al mismo tiempo que recupera la memoria de las acciones históricas de los antepasados afrodescendientes e indígenas, borradas deliberadamente de la historia (Viveros, 2013: 95).

Ou seja, ele ressalta o sentido subserviso da mestiçagem forjado pela República Zamba. Compreende que as categorias "branco", "negro" e "índio" ocultam a heterogeneidade interna desses grupos sociais, que é grande. Zapata Olivella elaborou o conceito de trietnicidade para referir-se aos intrínsecos intercâmbios culturais que se deram entre espanhóis, africanos e indígenas na Colômbia, em um processo de dominação dos primeiros sobre os demais (Viveros, 2013).

Segundo Arocha, os sistemas de classificação sociorracial desenvolvidos pelos espanhóis e portugueses durante a colonização originaram um intrincado conjunto de denominações que dava conta de tonalidades de pele, formas de nariz, cabelo, olhos e estatura. Tratava-se de um sistema de cálculo analógico e probabilístico capaz de discernir como os tipos físicos se distanciavam ou se aproximavam do branco europeu. Na concepção deste autor, a adoção de terminologias que permitiam distinguir tonalidades oferecia vantagens.

Taxones basados en operaciones más complejas que las de suma y resta numérica que facultaban manejar cantidades de diversidad física, correlacionarlos con grados de diversidad cultural y, por lo tanto, otorgarle peso y funciones a la identidad dentro de los transcursos cotidianos y políticos (Arocha, 1992: 41-42).

Contraponho a visão de Arocha com a da historiadora equatoriana María Eugenia Cháves (2007), que também reflete sobre a taxonomia colonial, partindo da noção de "casta", sistema classificatório no qual as diferenças baseadas em origem/cor expressavam uma hierarquia social. A historiadora ressalta que a diversidade de categorias empregadas no sistema de castas não retratava a complexidade da mestiçagem colonial. Mais bem eram construções intelectuais hegemônicas, que pretendiam dar alguma coerência à mistura ampla e diversificada, associando-a com origem, cor e atributos sociais. Para Arocha, o sistema de classificação sociorracial colonial permitia "reconhecer e salvaguardar o diverso" (Arocha, 1992: 42), o que o leva a lamentar seu desuso com a transição do período colonial para o 
republicano. Já para Cháves (2007) seu efeito foi a dominação e a subalternização das populações autóctones e de africanas/os escravizadas/os, desde os tempos da colônia ao estabelecimento de Estados modernos. A autora adota uma postura crítica perante esse sistema, propondo um exercício de descolonização.

Friedemann (1993) explica o sentido primeiro das "castas":

Al comienzo de la colonia el término casta se había usado para señalar la tribu o el lugar de origen de los esclavos negros. Así eran negros de casta congo o bien biafra o lucumí y a la vez podían especificarse como bozales si eran recién llegados del África con su lengua o lenguas nativas. También se les llama negros de nación, africanos de nacimiento, y si estaban bautizados y tenían algunas experiencias europeas se volvían ladinos (Friedemann, 1993 - Castas, mestizaje y blanqueamiento).

Segundo Friedmann e Arocha (1986), o termo assumiu em seguida um sentido depreciativo ao referir-se à mescla genética, já que a população passava a apresentar matizes fenotípicos variados a partir de intercursos entre indígenas e negros, entre esses e brancos, entre os descendentes de ambos os grupos. Era, então, uma marca daqueles que não eram brancos, conforme ressalta Friedemann (1993). A "casta" foi utilizada posteriormente, no século XVIII, para demarcar a posição socioeconômica que correspondia ao indivíduo. Novoa ressalta o sentido das castas no período derradeiro do sistema colonial:

En la época colonial tardía la sociedad continuó con su tradicional estructuración jerárquica en torno a las castas y estamentos, y con un fuerte discurso racista. En teoría, las castas conformaban individuos de origen racial mixto (mestizos, mulatos, zambos y demás), pero en la práctica se extendió a indios y negros. Este sistema socio-racial de poder, cimentado en la dominación de las castas, debe ser entendido como un "dispositivo de racialización" que calificaba a los negros, moral y genéticamente, como inferiores, justificando las acciones de dominación y explotación (Novoa, 2010: 117).

Restrepo também explica o sistema de castas:

Desde finales del siglo XVII y durante el XVIII, la emergencia y sedimentación de una 'sociedad de castas', con sus múltiples fuentes derivadas de la legislación, disputas judiciales y sanciones sociales, se evidenciaría una articulación de la negridad que fija la diferencia apelando a una detallada gramática de la sangre. La identificación y nominación de la gradiente de posibles mezclas, con tecnologías de marcación de las disimiles 'calidades' y 'tipos', hacen de este un momento muy relevante para la consolidación de la biopolítica colonial (Restrepo, 2013: 32) ${ }^{107}$.

\footnotetext{
${ }^{107}$ Tendo como fontes de consulta os escritos de Alonso de Sandoval, as Cartas Annuas, dos jesuítas, e as primeiras biografias de San Pedro Claver, Restrepo afirma que, durante o século XVII, ou seja, anteriormente ao sistema de castas, a distinção e a hierarquização pela cor da pele não necessariamente se traduziam em uma
} 
Portanto, na visão desses autores, o sistema de castas atrelava a classificação étnicoracial a posicionamentos na estrutura socioeconômica da colônia, os quais se refletiam em diferentes possibilidades de trabalho e se explicitavam, por exemplo, em vestimentas exclusivas de cada casta.

Analisando o período colonial na Real Audiência de Quito, Fernández-Rasines defende que critérios fenotípicos não foram definitivos na taxonomização social, no contexto da ordem colonial racista e sexista. Em sua avaliação, "las categorías raciales han podido ser subvertidas por la posición adquirida, con lo que la política racial del orden colonial sobre la realidad del mestizaje resulta sumamente compleja en la taxonomización social" (Fernández-Rasines, 2001: 49-50). Essa reflexão é contextualizada pela autora em uma análise da República Zamba, centralizada na condição de liderança de Alonso de Illescas. A possibilidade de subversão das categorias raciais, pelo que Fernández-Rasines dá a entender, seria uma prerrogativa masculina, já que:

En los textos que se han analizado las mujeres han sido definidas como relativas a los hombres. No han aparecido aún como agentes protagonistas y no se ha visto que su condición racial haya podido ser subvertida por su condición social adquirida. He visto que las mujeres de origen africano no aparecen sino en condición subalterna como esclavas o como mujeres del linaje de los libertos o cimarrones (Fernández-Rasines, 2001: 49).

Ela argumenta que a servidão estava integrada por homens e mulheres de distintas procedências e não sempre em estado de escravização. Não creio que seja o caso de analisar em profundidade o tema, pois o recorte desta tese é a escravização da população traficada da África e seus descendentes, que teve uma proporção sem tamanhos na história mundial, conforme colocado na introdução. Por um lado, sua argumentação tem a positividade de ressaltar que, desde o início do processo de invasão espanhola ao atual território equatoriano, ter ascendência africana não era sinônimo de estar em condição de escravização, o que também argumentei na introdução, abordando as várias manifestações de resistência negra à escravização. Por outro lado, entendo que, ainda que a mestiçagem pudesse atenuar a condição de mulatos e zambos perante os negros, não garantia um lugar social de privilégio, pois esse era exclusividade dos brancos, como coloca Friedemann:

En la Colonia, en ciudades y pueblos donde el mestizaje fue activo, el goce de ventajas y privilegios basados más en la supuesta cualidad de ser blanco

racialização, ainda que se pudessem identificar nítidas tecnologias de dominação no sistema colonial (Restrepo, 2013: 32). 
se reclamó y se ejerció con vigor. Ser mulato solamente tenía ventajas frente al negro, porque el primero ostentaba mezcla de blanco. Pero ser llamado mulato o zambo era denigrante y ofensivo (Friedemann, 1993 - Castas, mestizaje y blanqueamiento).

Negros, mestiços, zambos, mulatos faziam parte de um conjunto que ameaçava a ordem social construída sobre o sistema de castas raciais em Nova Granada e na Audiência de Quito, como mostram os relatos de repressão aos cimarrones:

Los cimarrones con frecuencia colaboraron en actividades de contrabando, esto les permitió subsistir en los poblados que fundaron en zonas inhóspitas y de difícil acceso. Una práctica que motivó al Rey a emitir la cédula real de 1575, en donde recomienda castigar y hacer la guerra a los negros y corsarios y prohibir que los negros, zambaigos y mestizos porten armas (Novoa, 2010: 77).

Creio, então, que experiências de subversão à dominação colonial, como a liderada por Alonso de Illescas na constituição da República Zamba, não indicam que as categorias raciais fossem subvertidas. Illescas seguia sendo negro, ainda que fosse ladino. Seguia sendo negro, ainda que reivindicasse o posto de governador da província de Esmeraldas. Em sendo negros, mulatos, zambos, Illescas e seu povo eram combatidos pelo sistema colonial. Se as autoridades coloniais negociaram com as lideranças da República Zamba, após uma séria de expedições bélicas ao palenque, foi porque concluíram que era a maneira de ingressar nesse território onde prevaleciam cimarrones e cimarronas.

\section{Período Republicano}

Na passagem do período colonial para o republicano, há um deslizamento da noção de casta para a de raça, como indica León (2011). Segue-se operando uma hierarquização racial, porém, a nova classificação dá-se em um continuum, de maneira um pouco mais fluida em relação à pretensão da sociedade colonial em separar estritamente os grupos populacionais em castas. A noção de raça passa a designar aspectos físicos e morais da população. León ressalta que o conceito na Colômbia surge com a República, consolidando-se em meados do século XIX. Raça e geografia, desde esse momento, formaram um binômio. Como ressalta a autora, as diferentes raças são associadas a diferentes espaços geográficos.

Vale ressaltar a mudança nas classificações que se reflete nos Censos colombianos. Segundo Bejarano:

Os censos e registros coloniais incluíram categorias para classificar a população segundo sua cor [...]. A partir do censo de 1825 [primeiro censo republicano], depois reforçado com a lei de censos de 1834, as classificações 
de cor desaparecem, subsistindo a condição (escravo e livre) (Bejarano, 2010: 18).

O mesmo vale para o Equador, mesmo em momento anterior à instauração da República. No sul da Audiência de Quito, dados do Censo de 1778, sistematizavam a classificação étnico-racial nas seguintes categorias: "libres", "esclavos", "indios" e "blancos" (Tardieu, 2006: 152). Nota-se que as categorias "negro/a", "mulato/a" e "zambo/a" já não aparecem. A forma de classificar pessoas negras era pela condição (ou não) de escravizado.

Foi durante a República que se consolidou o mito da nação mestiça na Colômbia, assim como no Equador ${ }^{108}$. Segundo Mosquera Rosero-Labbé (2011), trata-se de uma ideologia da mestiçagem triétnica, que operou com várias estratégias. Distanciou-se discursivamente das rígidas hierarquias da colonial sociedade de castas; estabeleceu dispositivos públicos de poder - a Igreja, escolas e universidades, partidos políticos - que obliteravam a raça; e estimulou a mescla biológica, cultural e moral com o elemento brancoeuropeu, na medida em que ela possibilitava ascensão social para pessoas de ascendência negra e indígena.

Como explica Arocha:

Se le dio vida argumentando que, pese a la rigidez de las castas españolas, la falta de mujeres, las relaciones paternalistas con los de inferior rango y la búsqueda del ascenso social mediante el blanqueamiento de los hijos, fundieron a indios, negros y blancos en una nueva raza de "iguales", la mestiza (Arocha, 1992: 42).

Essa nova raça seria resultado de uma fusão perfeita, uma "metarraça", como diz Guimarães (2000: 26). Vemos, então, a transmutação da categoria "mestiça": sua face subversiva, que contradizia e negava a matriz genética e cultural hegemônica, foi neutralizada pela ordem social dominante, na medida em que se somou a essa fusão (negra e indígena) o elemento branco-europeu.

Segundo a interpretação de Wade (1997), o ideário da mestiçagem foi levado a cabo pelas elites colombianas de modo que negros e indígenas, ainda que de diferentes maneiras,

\footnotetext{
${ }^{108}$ Ressalta-se que, anteriormente a esse projeto, à luz de teorias eugênicas, a mistura racial era interpretada como degenerativa, tendo em vista a suposta inferioridade moral e intelectual dos negros e indígenas, bem como de descendentes fruto da miscigenação desses povos com população de ascendência europeia. Restrepo comenta a tendência eugênica na Colômbia: "Los debates de la degeneración de la raza y la medicalización de la sociedad de los años veinte, en los cuales Miguel Jiménez López y Luis López de Mesa tuvieron un lugar destacado, constituyen una de las fuentes sobre la racialización científica de la negridad con sus inflexiones eugenésicas y de profilaxis social" (Restrepo, 2013: 33).
} 
podiam ser excluídos como não mestiços e, ao mesmo tempo, incluídos como potenciais recrutas de mestiços/as.

Do ponto de vista da população negra, o autor conceitua esse movimento a partir da polaridade entre adaptação e resistência. Ele fala que, negros e negras, ao se adaptarem aos valores e normas determinados pelas elites, conseguiam participar ou ascender nas hierarquias nacionais de prestígio e status. No campo da cultura, esse processo representava a incorporação de ícones de uma cultura socialmente vista como não negra. Complementarmente, representava a dispersão espacial da população negra e sua diluição por meio da mestiçagem.

Do ponto de vista das elites, o ideal da mestiçagem era a supressão das populações negra e indígena da nação. "El mestizo fue idealizado como de origen biétnico o triétnico, pero la imagen exhibida estaba siempre en el extremo más claro del espectro mestizo" (Wade, 1997: 42). A despeito da suposta democracia desse projeto de sociedade latinoamericana, a "nova" raça "mestiça" em realidade era branqueada e seu legado cultural era europeu.

Nesse sentido, o projeto da nação mestiça tinha duas caras, como interpreta Wade: uma democrática que encobre a diferença, fazendo parecer que ela não existe; e outra hierárquica, que realça a diferença para privilegiar o componente branco (Idem, ibidem: 50). É na articulação entre a mestiçagem e a discriminação que o autor situa o lugar da população negra na Colômbia: "la discriminación es una fuerza principal, como también lo es el mestizaje físico y cultural, y es en la interacción de estos procesos donde se define la posición de la gente negra en Colombia y la naturaleza de la identidad nacional colombiana" (Idem, ibidem: 15-16).

Articulando o ponto de vista da população negra e o das elites, a coexistência e interdependência entre discriminação e mestiçagem permitem à sociedade incluir e excluir a população negra; e possibilita aos negros incluir-se ou apartar-se. Em outras palavras, há uma influência recíproca entre adaptação e discriminação, entre assimilação e resistência em nível de experiência (Idem, ibidem: 80). Vale ressaltar, porém, que, desde o lugar da população negra, não se tratava de um processo de volição; mais bem era uma conjuntura social que abriu espaço para a adaptação em certos contextos, não o abriu em outros ou ainda pressionou processos de adaptação em determinados cenários.

Wade ressalta que o embranquecimento tem um contraponto óbvio: o escurecimento. A construção da nação mestiça logra obliterar esse contraponto na medida em que hierarquiza 
as categorias, colocando "branco/a" no vértice do triângulo racial, "negro/a" e "indígena" nas bases. Assim, no contexto da mestiçagem, os movimentos valorizados são os que avançam de baixo para cima, distanciando-se dos "negros/as" e "indígenas", aproximando-se dos brancos/as.

Segundo Arocha, a carga de homogeneidade atribuída à mestiçagem no período republicano implicava a negação do direito de dissentir e a exclusão quando se desvia do considerado "normal" (Arocha, 1992: 42-44). O autor observa então que uma simples adição substituiu o anterior cálculo de probabilidades, o delineamento de quantidades e a formulação de analogias que operavam na taxonomia colonial, segundo o autor. Ele critica as taxonomias sociais binárias e simplificadoras, dado seu alto poder de mascarar a diversidade.

O mito da nação mestiça mascara não apenas a diversidade, mas também a desigualdade. Como coloca Bejarano (2010), a sociedade colombiana republicana era racialmente homogênea apenas no discurso. Em termos substantivos, atribuía um lugar específico para cada grupo étnico-racial no relato da nação. Aos negros e negras, reservou-se o não lugar.

Retomemos as dinâmicas em torno das pesquisas censitárias, já na era republicana. Depois de um período de quase cem anos, o Censo de 1912 trouxe outra vez a pergunta sobre raça, assim como o de $1918^{109}$, segundo West (2000). O autor desagregou dados de ambas as pesquisas, enfocando nos municípios das terras baixas do Pacífico colombiano. Reproduzo abaixo as informações por ele sistematizadas:

\begin{tabular}{|c|c|c|c|c|c|}
\hline Ano & $\begin{array}{c}\text { Negros } \\
\mathbf{\%}\end{array}$ & $\begin{array}{c}\text { Mestizos } \\
\mathbf{\%}\end{array}$ & $\begin{array}{c}\text { Indios } \\
\mathbf{\%}\end{array}$ & $\begin{array}{c}\text { Blancos } \\
\mathbf{\%}\end{array}$ & $\begin{array}{c}\text { Sin especificar } \\
\mathbf{\%}\end{array}$ \\
\hline 1912 & 68.0 & 17.5 & 7.2 & 7.0 & - \\
\hline 1918 & 55.6 & 21.7 & 5.4 & 9.7 & 4.7 \\
\hline
\end{tabular}

Fonte: West, 2000: 112 .

Entre os quatro grupos em que se categorizou a população, é interessante a interpretação de West sobre a categoria mestiço: “podría ser clasificada como 'negros', juzgando a partir de observaciones de campo" (West, 2000: 112). Vale lembrar que o geógrafo estadunidense realizou pesquisa de campo entre 1951 e 1954. Ele percebia, então, que negros e negras, "que incluyen mezclas con blancos (mulatos) e indios (zambos)",

\footnotetext{
${ }^{109}$ Segundo Bejarano (2010), nos Censos de 1918 e 1928, a variável raça foi excluída. O autor ressalta ainda que, ao longo dos censos de 1938 até 1985, as publicações oficiais não fazem menção alguma à ausência da quantificação da população negra no país.
} 
representavam $85 \%$ da população das terras baixas do Pacífico em 1912, enquanto que, em 1918, o percentual reduziu para $77 \%$ (Idem, ibidem: 47$)^{110}$.

Encontramos aqui outro sentido para a categoria "mestiço". West compreendia que as mesclas da população negra com brancos e indígenas geravam pessoas negras. Parece que sua concepção se reaproxima da identidade construída pela República Zamba. Chamo atenção às concepções de negritude de West em contraste com as de Friedemann (1993) e Arocha (1992) que nomeiam os/as descendentes de negros/as e outros grupos étnicos como povos “impregnados de cultura afro-americana” (Arocha, 1992: 43), mas não como negros/as.

West fala ainda sobre categorias endógenas: “En las localidades más aisladas de las tierras bajas, los negros todavía se autodenominan libres. En la mayoría de las áreas, sin embargo, se usa el término moreno; la palabra negro se usa muy poco, pues es despectiva”, (West, 2000: 56).

Ao mesmo tempo em que relata a miscigenação na gênese da sociedade das terras baixas do Pacífico ${ }^{111}$, o autor fala que uma grande porcentagem da população negra dessa região "tiene sangre africana sin mezclar" e, por isso, ele ressalta a região como uma das principais áreas negras da América Latina (Idem, ibidem: 9). Referindo-se ao período da escravização, Arocha fala sobre "descendentes de africanos escravizados que não tiveram filhos com brancos tampouco com indígenas". Ele atribui esse fato a razões de isolamento geográfico ou resistência política (Arocha, 1992: 43).

Barbary e Urrea explicam que, paralelamente à massiva ocupação negra ao longo da história, houve reduzida mestiçagem na região pacífica em virtude das particulares condições de isolamento dessa região em relação ao resto do país, principalmente entre meados do século XIX até a entrada da década de 50 do século XX, quando a dinâmica principal era a ruralidade com povoamento negro fluvial (Barbary e Urrea, 2004: 73).

No Brasil, desde o levantamento das informações do primeiro recenseamento nacional $(1872)^{112}$, com exceção dos Censos de 1900, 1920 e 1970, as características de cor da população vêm sendo pesquisadas, utilizando-se praticamente as mesmas categorias de

\footnotetext{
${ }^{110} \mathrm{O}$ autor ressalva que essa diferença parecia dever-se a erros no censo.

111 "Tres razas - india, negra y blanca - y sus mezclas componen la población de las tierras bajas del Pacífico" (West, 2000: 47).

${ }^{112}$ O Censo de 1872, segundo Petruccelli, incorporava uma diferenciação entre cativos/pretos e libertos/pardos. "os cativos foram classsificados majoritariamente como pretos na operação censitária, ou como pardos. Por outro lado, contava-se com um razoável contingente de população negra livre na época, que alcançava a $75 \%$ da mesma, classificada como de cor parda em sua maior parte. Havia, então, uma forte identificação de preto com escravos, pela sua extensa justaposição, e de pardo com liberrto ou descendente de escravo, produtos do longo processo colonial de 'mistura racial' da população eurodescendente com africanos e crioulos" (Petruccelli, 2007: 135).
} 
classificação. "A partir do Censo de 1940, as categorias utilizadas no quesito cor se mantêm inalteradas, incluindo: branco, pardo, preto [...] e amarelo" (Petruccelli, 2007: 23) ${ }^{113}$. Em 1950, o Censo passou a adotar o critério de autodeclaração. Segundo Petruccelli, "o núcleo "duro" da categorização racial, constituído, por um lado, pela dicotomia negro/branco e, por outro, pelas categorias residuais de classificação de grupos miscigenados e dos povos nativos, permaneceu intacto durante esse longo período da história social brasileira" (Idem, ibidem: 134), ou seja, de 1872 a 2010.

Ao final da década de 1970, estudos baseados na Pesquisa Nacional por Amostra de Domicílios (PNAD) de $1976^{114}$, articulavam a classificação racial com variáveis socioeconômicas, demonstrando que,

apesar da gradação de cores branca, parda e preta, o sistema de discriminação social brasileiro comporta-se de uma maneira bipolar, com os brancos localizados em condições muito mais favoráveis que os negros identificados como pretos e pardos, em conjunto - revelando-se poucas diferenças entre estes últimos (Hasenbalg, 1979). Ficou caracterizado assim a dicotomia brancos/não-brancos como paradigma do contraste entre os que têm e os que não têm vantagens raciais (Idem, ibidem: 137).

Petruccelli aponta alguns critérios que demonstram tal polarização, como, por exemplo, a distribuição da população por ocupação segundo a cor. Nota-se uma maior proporção de pessoas mulatas, negras, pardas e pretas na categoria de empregados/as domésticos/as. Já no campo da educação "as pessoas que não se identificam como amarelas ou brancas aparecem com menor acesso aos níveis mais altos de escolarização, ao mesmo tempo que figuram em proporções mais altas que a média entre os que nunca frenquentaram a escola" (Idem, ibidem: 44.).

Nesse sentido, desde a década de 1970, pesquisas e estudos mostram o Brasil como "uma sociedade de dupla clivagem, social e racial, onde tanto 'classe' quanto 'raça' remetem a ordens hierárquicas de relações de dominação" (Idem, ibidem: 7). Tais relações desencadeiam um processo complexo e intermitente de discriminação e preconceito voltado aos grupos raciais identificados como indígenas, pardos e pretos ${ }^{115}$, segundo o autor. Nesse sentido, há uma articulação entre desigualdades raciais e desigualdades socioeconômicas, sem que umas se subsumam às outras.

\footnotetext{
113 A partir de 1980, acrescentou-se a elas a categoria indígena.

${ }^{114}$ Em especial, estudos de Carlos Hasengbalg e Nelson do Valle Silva.

${ }^{115}$ No idioma castelhano não há o vocábulo preto/a. Conforme indicado na pesquisa de campo, há uma palavra castelhana semelhante: pietro, que designa cabelo muito crespo.
} 


\section{Período da multi e interculturalidade}

A Constituição Política de 1991 inaugura um novo momento na nação colombiana, cujo ideal é o respeito à diversidade racial. A Colômbia se reconhece como pluriétnica e multicultural. No Equador, a Constituição Política de 1998 também declara o país pluricultural e multiétnico. Mas a Constituição de 2008 caracteriza o Estado como uma entidade de direitos e justiça social, democrática, soberana, independente, unitária, intercultural, plurinacional e laica. A partir dela afro-equatorianas/os passam a ser considerados um povo ou nacionalidade dentro do país ${ }^{116}$.

Iniciamos a reflexão sobre esse período perguntando: como a literatura antropológica colombiana fala sobre negritude e etnicidade no período da multiculturalidade? Faz-se necessário retomar algumas questões anteriores a esse período para melhor compreendê-lo. O conceito de raça, consolidado na Colômbia em meados do século XIX e operante até meados do século seguinte, perde forças no campo acadêmico frente ao contexto mundial da Segunda Guerra Mundial e as atrocidades nazistas cometidas em nome da "raça". León (2011) explica que, enquanto o conceito de raça submerge, a "etnia" ganha espaço como ferramenta para pensar as diferenças culturais, especialmente na antropologia. A despeito disso, a autora ressalta que um conceito não substitui o outro. A etnia tem um alcance limitado - designa na Colômbia primordialmente grupos indígenas -, enquanto a raça tem uma pretensão de universalidade. Sem embargo, as mudanças que tiveram curso na metade do século XX reservaram para a raça um lugar marginal nas ciências sociais. Na vida cotidiana, porém, as classificações e hierarquizações raciais persistiram, assim como o racismo. Ou seja, "os efeitos derivados de seu caráter estrutural e de sua práxis mantêm-se intactos", nas palavras de Mosquera Rosero-Labbé (2011: 19).

A literatura antropológica inscreve-se em um campo de disputa político-acadêmica, como ressalta Arboleda (2012). O autor criticamente define como "Negrología" o vertiginoso crescimento de discursos teóricos com foco nas diferenças culturais, a partir da década de 1990, que abordam a coletividade negra como algo exótico. Fazendo um contraponto ao recente interesse das ciências sociais pela coletividade negra, Arboleda chama atenção para aportes realizados por uma longa tradição de estudiosos e intelectuais afro-colombianos/as,

\footnotetext{
${ }^{116}$ Os debates sobre multiculturalidade e interculturalidade são complexos e não é minha proposta abordá-los aqui. Ressalto apenas que, enquanto o multiculturalismo parte da pluralidade étnico-cultural da sociedade e do direito à diferença, a interculturalidade funda-se na necessidade de construir relações entre culturas, mas também entre práticas, lógicas e conhecimentos distintos, com o afã de confrontar e transformar as relações de poder (incluindo as estruturas e instituições da sociedade), que naturalizam assimetrias sociais. A interculturalidade alude ao diálogo entre culturas que se reconhecem de igual valor, igual dignidade e merecedoras de respeito (CECOMET, 2011: 110)
} 
que antecederam à consolidação dos estudos das "Colômbias Negras" como campo disciplinar. São autores como Jorge Artel, Manuel Saturio Valencia, Sofonías Yacup, Benildo Castillo, Manuel Zapata Olivella, Margarita Hurtado, Arnaldo Palacios, Alfredo Vanín, Helcías Martán Góngora, Hugo Salazar Valdés e Rogerio Velásquez. Nas obras desses e outros intelectuais, poetas e poetisas, decimeros e decimeras, cantadores e cantadoras, persiste a linguagem racial e a denúncia da discriminação racial, como ressalta León (2011).

Feita tal ressalva, debruçar-me-ei sobre algumas produções antropológicas que se consolidam na era da multiculturalidade, dando sequência ao exercício de debulhamento das categorizações étnico-raciais no contexto de pesquisa em foco. Peter Wade, antropólogo britânico que realizou pesquisa de campo com populações negras na Colômbia ao longo da década de 1980, explica que as identificações étnicas expressam uma "geografia da cultura" (Wade, 1997: 78). Ele pesquisou especialmente no Chocó, no Pacífico norte colombiano. Na obra Gente negra, nación mestiza. Dinámicas de las identidades raciales en Colombia, Wade escreve sobre a coexistência e a interdependência entre processos de discriminação e mestiçagem na Colômbia.

No caso da Colômbia, segundo o autor, a região converteu-se em uma poderosa linguagem de diferenciação cultural e racial. Ou seja, a raça foi regionalizada. A geografia da cultura enquadra a ordem racial do país e suas imagens de nacionalidade emergentes. Nesse sentido, o espaço ou região é uma metáfora para a raça e a cultura, ao mesmo tempo em que constituem um meio por meio do qual as relações sociais se concretizam ${ }^{117}$. Segundo Barbary e Urrea:

Los asentamientos afrocolombianos históricos más importantes se encontraban ubicados en cuatro grandes regiones geográficas (...), por lo menos hasta mediados del siglo XX. Estas regiones son: a) las tierras del Litoral Pacifico, (...), y que se extienden hacia la región de Esmeraldas en el Ecuador, la que conforma históricamente una zona de poblamiento negro con redes familiares extendidas en el Pacífico sur colombiano y norte ecuatoriano; b) la región del valle geográfico del río Cauca y que hoy en día corresponde al norte del Cauca y la zona plana del Valle del Cauca; c) las áreas ribereñas del Bajo y Medio Magdalena y del Bajo Cauca y d) el Litoral Atlántico y las llanuras y sabanas adyacentes al mismo, al igual que las regiones cenagosas de los principales ríos que desembocan en el mar Caribe (Barbary e Urrea, 2004: 71).

Entre essas, a região pacífica é a que apresentava maior percentual de afrocolombianas/os na primeira década do milênio, $83 \%$, sendo uma população majoritariamente rural (55\%). Juntando Tumaco, Buenaventura, Quibdó e outras áreas urbanas da região, o

${ }^{117}$ A teoria de Wade é corroborada por outros autores, como Restrepo (2013). 
Pacífico somava 7,9\% do total da população afro-colombiana urbana do país. Dos centros urbanos, desde o século XVI, Cartagena é a cidade de maior concentração negra. Mompós e Santa Marta, até o começo do século XIX também eram polos importantes. No transcurso do século XIX, Quibdó, Barranquilla, Cali, Buenaventura e, posteriormente, Tumaco despontam como cidades negras (2004: 72, 76, 79). Conforme coloca Wade, na região da costa pacífica, raça e região se sobrepõem. Nesse sentido, no Pacífico colombo-equatoriano, a diferença inferiorizada quase sempre agrega traços fenotípicos e práticas socioculturais territorialmente inscritas.

Na Colômbia, a antropologia culturalista fez escola no pensamento antropológico em torno das populações negras. A posição de Nina de Friedemann e Jaime Arocha, autores com os quais dialogo ao longo deste capítulo, explicita-se no conceito de "huellas de Africanía"" "Huellas de Africanía" corresponde a "el bagaje cultural sumergido en el subconsciente iconográfico de los esclavos y transformado creativamente a lo largo de los siglos" (Espinosa e Friedemann, 1993: 100). Trata-se de memórias, sentimentos, aromas, formas estéticas, texturas, cores, harmonia e outros elementos icônicos que se percebem em obras, adornos, bailes, danças, formas de organização, de manejo territorial, comunicação, entre outras. Constituem matéria-prima para a gênese de novos sistemas culturais afro-americanos. Ou seja, os sistemas culturais, ou a cultura, seriam o somatório de tudo isso. Dito de outra forma, as obras, adornos, bailes, etc. são elementos ou aspectos de um todo, a cultura afrocolombiana. Nessa elaboração, há uma ênfase no processo da gênese de sociedades negras na Colômbia e um esforço em conectar esse processo com a África.

Barbary e Urrea (2004) criticam nessa abordagem a sobrevalorização da dimensão cultural na organização social de populações negras. Wade (1997), por sua vez, destaca um problema político que ela pode gerar. Corre-se o risco de restringir a concepção de cultura negra, ou cultura negra legítima, às expressões que demonstrem o elo de conexão com as raízes africanas. Na minha concepção, abordagens que enxergam a coletividade negra desde uma perspectiva de permanência ou vestígios de elementos de sociedades africanas não são as mais interessantes.

Conforme expliquei na introdução, concebo a afro-diáspora como um processo que se iniciou com o tráfico de africanos/as escravizados/as da África para as Américas. Essa

\footnotetext{
${ }^{118}$ Para além da referida conceituação, Friedemann e Arocha dedicaram suas obras ao projeto de visibilizar os grupos negros na história e na antropologia colombianas. E, a partir da denúncia da invisibilidade, buscaram estimular a reivindicação da cidadania negra no contexto das reivindicações pelos direitos humanos, conforme ressalta Wade (1997: 75).
} 
migração forçada gerou um processo extremamente complexo, dentro do qual destaco as subsequentes movimentações espaciais de africanos e afrodescendentes que se insurgiram à condição de escravos, conformando assim territórios autônomos. Minha intenção é compreender a atualidade desses territórios e de suas populações. Para isso, trilhei o caminho de escutar a mulheres negras sobre a trajetória de seu povo. Considero relevante registrar os elementos que grupos negros diaspóricos conectam com a África, nas identificações em processo e nas mobilizações que desse processo decorrem. Ou seja, esse tipo de referência faz sentido na medida em que minhas interlocutoras a ela atribuem sentido.

Outra perspectiva teórica trilhada para compreender a dinâmica de grupos negros na Colômbia e no Equador se estruturou sobre a noção de adaptação, que de modo geral aparece na literatura antropológica combinada com a abordagem anterior. Segundo Friedemann e Whitten (1974), trata-se de um conceito biológico emprestado da teoria de evolução que se refere à sobrevivência de uma população em um meio ambiente, mantendo uma média de fertilidade igual ou maior à de mortalidade. $\mathrm{O}$ conceito de cultura agregado ao de adaptação sugere a ideia de um enfrentamento constante e criativo com restrições impostas (Friedemann e Whitten, 1974: 90). Remete, portanto, às relações históricas entre formas sociais e culturais negras com contextos ecológicos, econômicos, políticos e sociais, dialogando com a Ecologia Cultural. Segundo Arocha, essa abordagem "introducía la posibilidad de ver los desarrollos de esas costas en términos de "invención independiente" y facilitaba el prestarle atención a la relación de la gente con su entorno físico y socio histórico" (Arocha, 1986: 9). Esse conceito foi a base para pensar a mobilidade espacial como característica dos povos afropacíficos, como indica González (1995).

Na mesma década de 1990, surgem estudos focados na etnicidade e na territorialidade que interpretam tradições das comunidades negras como experiências históricas diaspóricas na construção de práticas culturais territorialmente enraizadas (Rivas, 2000; Pazmiño, 2003). Tais estudos enfocam na relação de comunidades negras com o Estado colombiano, buscando o reconhecimento e a legalização de territórios ancestrais, na esteira dos processos desencadeados pela Lei n. 70, de 1993. Essa literatura busca dar conta da pluralidade de categorias que passam a operar, algumas delas, a partir da década de 1990, tais como Comunidades negras, Consejos comunitários, Organizaciones negras (o de comunidades negras), Organizaciones de río, Organizaciones étnicas, Organizaciones étnico territoriales, Palenque, Territorio-región. 
Eduardo Restrepo (2013) interpreta que houve um processo de etnização da negritude na Colômbia, inaugurado pela Lei n. 70 de 1993, no qual o sujeito político e de direitos recaía na noção de que as comunidades negras constituem um grupo étnico com uma cultura própria e diferençável no marco da sociedade colombiana. A partir desse processo, também se criaram subjetividades (identificações) em nome da existência do grupo étnico. $\mathrm{O}$ que caracterizaria esse grupo étnico seriam as práticas produtivas tradicionais em relação harmônica com a natureza e a apropriação coletiva do território, segundo racionalidade econômica derivada de uma adequada adaptação ao meio ambiente. Nas palavras do autor:

Las imágenes predominantes consideran, en primer lugar, a estas comunidades como portadoras de unas prácticas tradicionales de producción en relación armónica con la 'naturaleza' y garantes de la proverbial 'biodiversidad' de esa región del Pacifico cubierta de bosque húmedo tropical. Igualmente, estas 'comunidades' aparecen con unas modalidades de apropiación territorial colectivas mediadas por formas solidarias de trabajo y por troncos familiares que se extienden a lo largo de los ríos, esteros y playas. Finalmente, estas comunidades se suponen con unas tradiciones culturales propias expresadas en prácticas medicinales, funerarias y musicales particulares así como de sistemas de autoridad y de gobierno generacional donde los 'mayores' y la tradición oral desempeñan un lugar de regulación y normatividad comunitarias. La identidad cultural y los derechos étnicos esgrimidos por sus organizaciones políticas locales y regionales se derivan de estas imágenes de tradicionalidad, comunalidad y alteridad cultural (Restrepo, 2013: 289).

O autor situa sua obra como uma leitura alternativa sobre os limites e as possibilidades da intervenção política em nome da produção da diferença em torno da etnicidade. Assume, pois, que: "Se debe cuestionar este desacertado dilema que se plantea en términos de una irreductible dicotomía entre un radical primordialismo que asigna la etnicidad a una esencia trascendental o un descarnado instrumentalismo que imagina la etnicidad como el simple capricho de sujetos calculadores" (Restrepo, 2013: 18).

Restrepo contrapõem-se a Friedemann e Arocha, os quais, segundo ele, concebem a etnicidade como imanência. Segundo esta última perspectiva, os grupos étnicos negros ou afro-colombianos sempre haviam estado no cenário da sociedade colombiana, porém, anteriormente à Constituição Política de 1991, eram invisibilizados. Para Restrepo, em contravia, a etnização da negritude consiste em um processo no qual populações negras são constituídas e se constituem como grupo étnico, em um momento e contexto específicos.

Restrepo tem razão em destacar que a década de 1990 assiste a uma etnização da negritude. Compreendo que houve uma politização da etnia. Assim, por exemplo, em minha despedida de San Lorenzo, as mulheres com quem trabalhei me definiam como uma mulher 
“orgullosa de su etnia”. Melania Quiñones, da comunidade de La Boca, também em San Lorenzo me explicava sobre "los derechos que nos corresponden a nosotros como afro, a las otras etnias como los pachacutec, los chachis, cada uno pelea por los derechos que le corresponden".

Sem embargo, essas pessoas existiam antes do processo de etnização; eram negras e negros. No caso do Pacífico colombo-equatoriano, eram negras e negros territorializados nas ribeiras dos rios. Como coloca Marlene Tello, remetendo-se à afro-colombianidade, vocabulário relacionado à era da etnicidade na Colômbia: "son las leyes que nos denominan afrocolombianos y es que somos negros". Entendo, portanto, que Restrepo, ao ressaltar a constituição do povo negro/afro-colombiano como grupo étnico, em momento e contexto específicos, deixa de valorizar a existência de uma população que, desde a colonização do atual território colombiano, carrega no corpo uma marca usada por essa mesma sociedade para criar assimetrias de poder. Por outro lado, concordo com o autor no sentido de que a década de 1990 abre caminho para que essa população se conceba como coletividade nacional, em busca de direitos.

Essa argumentação não significa, por outro lado, recair na ideia da imanência da negritude/etnicidade. Entendo que identificações em processo são atualizações de relações. Em A Invenção da Cultura, Roy Wagner (2010 [1995]) argumenta que a própria ideia de cultura, como algo monolítico e objetificável, é uma projeção. Trata-se de um aparato inventado pela antropologia, como empreendimento ocidental, parte do processo de compreensão da alteridade (e do próprio Ocidente). A base dessa invenção é a cultura, ou o modo de simbolização, do próprio antropólogo ou antropóloga, que entra em relação com a cultura estudada. Wagner ressalta que as culturas são construídas e transformadas no interior de relações sociais e culturais, em contexto e processo. Ou seja, as identificações em processo tratam de colocar o passado no futuro. A África não é mais África. É afrodescendência. O vestígio inexiste em si mesmo. O que existe é o que as pessoas atualizam nas relações presentes.

Outra perspectiva nos trabalhos sobre raça e etnia na Colômbia são os estudos compilados em Barbary e Urrea (2004). Os autores, junto com outros pesquisadores das áreas de sociologia, antropologia, estatística e geografia, desenvolveram estudos entre 1996 e 2004, em torno da organização social, das dinâmicas culturais e identidades em contexto de mobilidade e urbanização, envolvendo a população negra no Pacífico sul e na cidade de Cali. As pesquisas estiveram vinculadas ao Centro de Investigaciones y Documentación 
Socioeconómica (CIDSE), da Universidad del Valle; ao Institut de Recherche pour le Développement, da França; e ao colombiano COLCIENCIAS, Departamento Administrativo de Ciencia, Tecnología y Innovación.

Essa parece ser uma das poucas abordagens na literatura especializada colombiana da década de 1990 que agrega raça/etnia e condições socioeconômicas ${ }^{119}$, partindo do eixo espacial Cali-Pacífico Sul e projetando-se para o âmbito nacional ${ }^{120}$. Também se destaca entre outros estudos pelo recorte estatístico, baseado na classificação da população segundo critérios fenotípicos, a partir do qual se estudam processos de desigualdade social relacionados com a dimensão racial. Nesse sentido, aproxima-se da abordagem sobre negritude e etnicidade no Brasil. Efetivamente, a experiência brasileira, sobretudo no tocante à série centenária de estatísticas raciais, foi um referente para essa abordagem, como ressalta Urrea-Giraldo (2011). É sem dúvida a abordagem com a qual tenho maior identificação e que me parece mais produtiva para compreender a realidade pesquisada.

O foco da obra, que reúne trabalhos de vários pesquisadores e pesquisadoras, realizados ao longo de quase uma década, repousa sobre problemática de populações negras na sociedade colombiana contemporânea. Os autores sinalizam a diferença entre suas pesquisas e análises com relação aos modelos culturalistas predominantes nas ciências sociais colombianas. Eles entendem que as práticas sociais estão situadas em contextos históricos e assumem uma visão materialista não reducionista da organização social, que valora dimensões sociodemográficas, socioeconômicas, socioculturais, políticas e institucionais. Assim, raça e etnicidade articulam-se com as questões de classe social, gênero, ciclo de vida, idade, orientação sexual e afetiva, entre outros fatores.

Ainda articulando sentidos de pertencimento, especialmente vinculados à raça/etnia, ao gênero e à sexualidade, vale destacar, por fim, a produção antropológica da Escuela de Estudios de Género da Universidad Nacional de Colombia, especialmente do Grupo Interdisciplinar de Estudios de Género, encabeçado por Mara Viveros Vigoya, co-orientadora desta tese.

A literatura ora comentada inscreve-se nos marcos da plurietnicidade e da multiculturalidade e busca caminhos para compreender a realidade da população negra, ou do

\footnotetext{
${ }^{119}$ A partir de meados da década seguinte, são mais comuns abordagens que relacionam pertencimento étnicoracial, desigualdades socioeconômicas e suas conexões com o fenômeno do racismo. Ver, por exemplo, Mosquera Rosero-Labbé e Barcelos (2007).

${ }^{120}$ As ferramentas utilizadas nas análises foram: Censos nacionais, Encuestas Nacionales de Hogares (que serão referenciadas na presente tese), Encuesta Especializada en Cali 1988, Encuesta Banco Mundial 1999. Além delas, observação e participação, entrevistas e enquetes locais também foram instrumentos da pesquisa.
} 
povo afro-colombiano, a partir da Constituição Política de 1991. Vale lembrar que a Colômbia compartilha com outros países latino-americanos a celebração constitucional da diversidade. Retomando a reflexão do período republicano, a emergência do novo modelo de nação no mundo representou uma concorrência à mestiçagem, no campo democrático e antirracista $^{121}$, como coloca Guimarães (2000).

No caso da Colômbia, conforme argumenta Wade (1997), o ideário da nação mestiça seguiu operando paralela e integradamente ao projeto multicultural da nação. Como ressalta Rivera Cusicanqui (2010), o multiculturalismo latino-americano tem sido o mecanismo encobridor por excelência das novas formas de colonização. $\mathrm{Na}$ minha percepção, na Colômbia e no Equador, em especial na fronteira entre ambos, houve nesse período uma nova ressignificação da mestiçagem, que compreendo como um processo de fusão das categorias "branco/a" e "mestiço/a". Busco apresentar o meu entendimento sobre como foi esse processo primeiramente observando as pesquisas censitárias na Colômbia, entre 1993 e 2005, e no Equador, entre 2000 e 2010. Em seguida, trechos de narrativas das interlocutoras de pesquisa me aproximam etnograficamente dos usos das categorias étnico-raciais em San Lorenzo, Tumaco e Salahonda.

O censo de 1993 foi o primeiro realizado nos marcos da multiculturalidade colombiana e inaugurou o critério de autoclassificação étnico-racial nas pesquisas censitárias colombianas por meio da pergunta: “ ¿Pertenece a alguna etnia, grupo indígena o comunidad negra? I. Sí. ¿A cuál? 2. No" (Dane 1993: 58-61; 2000: 19; Barbary e Urrea, 2004: 58). Nele, a população negra foi sub-registrada contabilizando $1,52 \%$ do total populacional, o que se deve, segundo Bejarano (2010), ao fracasso do recorte étnico na pergunta do Censo ${ }^{122}$. Os estudos compilados em Barbary e Urrea (2004) propõem uma correção ao dado produzido pelo Censo de 1993. De 1,52\%, a população afro-colombiana passaria a 20-22\% do total populacional, sendo um grupo majoritariamente urbano (70\%) e concentrado nas principais áreas metropolitanas do país.

Entre 1998 a 2005, foram feitas várias enquetes com o intuito de testar metodologias para o censo seguinte; entre eles, alguns de âmbito nacional como a "Encuesta de Hogares" do ano 2000 (EH/2000), outros regionais como o "Censo experimental de Yopal", 2001, e o de Soacha, 2003. Na operação estatística de 1998, a pergunta contemplava os seguintes

\footnotetext{
121 “Contrariamente à difundida crença da tendência à homogeneização do início do século XX, atualmente é consenso entre os especialistas que a miscigenação não elimina a diversidade” (Petruccelli, 2007: 78).

${ }^{122}$ SegundoBarbary e Urrea: "Volver operacional una noción tan vaga e inestable, como es la de pertenencia étnica, dentro de un formato censal administrado por encuestadores con capacitación necesariamente rápida a una población sumamente heterogénea, se convirtió en un reto prácticamente imposible" (2004: 250).
} 
grupos populacionais: “1. Población indígena, 2. Población negra, 3. Población blanca o mestiza, 4. Población gitana, 5. Otro". A “Encuesta de Hogares" do ano 2000 (EH/2000) operava a "autoclassificação [...] a partir de quatro fotografias onde apareciam rostos de pessoas representando cada uma um grupo étnico-racial diferente" ${ }^{\text {123 }}$. O Censo experimental de Yopal, 2001 considerava as seguintes categorias: "1. Indígena, 2. Raizal del Archipiélago, 3. Palenquero, 4. Rom(Li) gitano(a), 5. Negro(a), 6. Mulato(a), 7. Afrocolombiano(a) Afrodescendiente, 8. Mestizo(a) o Blanco(a), 9. otro ¿cuál?’. O Censo experimental de Soacha, em 2003, ofertava as seguintes opções: "1. Indígena, 2. Negro(a) afrodescendiente, 3. Raizal del Archipiélago, 4. Palenquero, 5. Gitano(a) Rom (li), 6. Mestizo u otro diferente”. E a Encuesta de Hogares, de 2004, fez uma pergunta orientada por critérios "étnicos", cujas respostas eram: “1. Afrocolombiano(a), 2. Indígena, 3. Rom (Gitano), 4. Raizal de San Andrés y Providencia, 5. Palenquero, 6. Ninguna de las anteriores", e outra dirigida a "características físicas": "1. Negro(a), 2. Blanco(a), 3. Mestizo(a), 4. Mulato, 5. Ninguna de las anteriores" 124 (Bejarano, 2010: 53-55).

No caso do Equador, a abordagem censitária do tema é mais recente ${ }^{125}$. O primeiro censo em que se investigou a identificação étnico-racial da população equatoriana foi o de 2001. O critério adotado foi a autoidentificação. Nessa ocasião, perguntou-se: “Como se considera: ¿Indígena, Negro (Afro-ecuatoriano), Mestizo, Mulato, Blanco o Otro?’. Para a resposta “Indígena”, seguia-se outra pergunta: “ “A qué nacionalidad Indígena o pueblo Indígena pertenece?”. No Censo de 2010, perguntou-se: “¿Cómo se identifica [...] según su cultura y costumbres: 1. Indígena, 2. Afroecuatoriano/a Afrodescendiente, 3. Negro/a, 4. Mulato/a, 5. Montubio/a, 6. Mestizo/a, 7. Blanco/a, 8. Otro/a”. Segundo o Censo de 2001, a

\footnotetext{
${ }^{123}$ Segundo Barbary e Urrea: "Las cuatro fotografías a color eran la de un hombre negro; la de una mujer negra-mulata; la de una mujer que podría caer en un fenotipo 'mestizo'; y la de una mujer de fenotipo 'blanco'. Los cuatro personajes (el hombre y las tres mujeres), todos en el mismo rango de edad entre 20 y 30 años, bien vestidos y atractivos, podrían identificarse con perfiles de profesionales. Las fotografías estaban señaladas con números de 1 a 4, con la opción 5 para quien decidía que ninguna de las cuatro fotos se acercaba a su apariencia fenotípica. La tasa de respuesta en este módulo en las 13 áreas metropolitanas en su conjunto fue superior al 95\%, lo cual indica la eficacia del procedimiento utilizado" (Barbary e Urrea, 2004: 70).

${ }^{124}$ Houve ainda um Censo experimental de San Andrés, Providencia y Santa Catalina, em 1999, que contemplava população raizal e não raizal. E um Registro de Población y de Vivienda Embera Katio 2000 e 2004, a pessoa se autoclassificava de acordo com seus costumes e tradições como indígena, negra ou outro.

${ }^{125}$ Segundo publicação do Instituto Nacional de Estatísticas e Censo do Equador: "La experiencia del Ecuador en actividades censales es relativamente reciente, porque si bien existen referencias históricas de los censos en la Colonia y primeros decenios de la República, aquellas se han tratado de acciones asistemáticas con metodologías y objetivos diversos y sin que, en la mayoría de los casos, se encuentre con la documentación de resultados". Os censos nacionais realizados de forma sistemática foram em: 1950, 1962, 1974, 1982, 1990, 2001 e 2010. Ver: Evolución de las variables investigadas en los Censos de Población y Vivienda del Ecuador 1950, 1962, 1974, 1982, 1990, 2001 y 2010. Disponível em: http://www.ecuadorencifras.gob.ec/documentos/webinec/Publicaciones/Evolucion_variables 1950_2010_24_04 2014.pdf. Acessado em: 4 de outubro de 2014.
} 
porcentagem de afrodescendentes (negras/os, afro-equatorianas/os e mulatas/os) no Equador era $4,9 \%{ }^{126}$. Pelos dados de 2010 , esse número passou para $7,2 \%$.

Nota-se que, nas pesquisas colombianas de 1998, 2001 e 2003, os instrumentos estatísticos combinavam critérios fenotípicos e critérios étnicos. A EH 2000 concentrava-se na dimensão fenotípica, enquanto que a EH 2004 separou os critérios de classificação operando com duas perguntas diferentes, uma para fenótipo e outra para etnia. Já os censos equatorianos fazem uma diferença entre a pergunta de 2001 e a de 2010. No último censo, a pergunta enfatiza a dimensão étnica, ao atrelar a identificação com "cultura e costumes".

No Equador, segundo a CODAE (2010), a definição de uma pergunta que combinava fatores fenotípicos (negra e mulata) e étnicos (afro-equatoriana e afrodescendente) foi fruto de uma concertação no âmbito da Comisión Nacional de Estadísticas para Pueblos Indígenas y Afroecuatorianos (CONEPIA), uma das ações preparativas para o censo de 2010. A experiência piloto do Censo equatoriano, realizada em novembro de 2009, mostra questões interessantes. A variável "morena" foi agregada às demais: negra, mulata, afro-equatoriana e afrodescendente. $16 \%$ dos/as entrevistados/as responderam positivamente a esse conjunto de variáveis; entre os quais, $55 \%$ se autoidentificaram como negros/as e 15\% como afroequatorianos/as. "Es decir, según esta prueba piloto los afrodescendientes aun se reconocen más desde una percepción racial (negros, mulatos, morenos) que desde la auto adscripción política étnica de afrodescendencia" (CODAE, 2010: 5). Vale destacar que, desde 2001, primeira vez em que se incluiu a identificação étnico-racial, os Censos equatorianos apresentam a categoria "afro-equatoriano/a" ou "afrodescendente".

Foi neste mesmo ano, 2001, em que passa a operar nas enquetes estatísticas colombianas o termo "afro-colombiano/a" e "afrodescendente". O uso do termo "afro" nesses países contextualiza-se no movimento mundial de ressignificação da identidade forjada no empreendimento colonialista, que nominava um amplo e diverso espectro populacional sob o termo "negro/a". Trata-se de um processo que se iniciou na década de 1980 e se consolidou nos anos 2000, nos marcos da Conferência Mundial contra o Racismo, a Discriminação Racial, a Xenofobia e formas correlatas de Intolerência, realizada em setembro de 2001, em Durban, África do Sul. Em processos preparatórios e na própria Conferência de Durban, as

\footnotetext{
${ }^{126}$ As conseguintes encuestas de hogares y de empleo y desempleo calculavam que a população afro-equatoriana não superava 5,7\% no país (CODAE, 2010).
} 
reflexões coletivas convergiram para o uso da categoria "afrodescendente" em lugar de "negro/a""127.

Segundo Restrepo (2013), a afrodescendência contextualiza-se na crescente transnacionalização da agenda de luta contra o racismo. Dentro da Colômbia, as mudanças da primeira década do novo milênio refletem-se na ampliação do sujeito político e teórico que estava centrado em comunidades rurais ribeirinhas do Pacífico colombiano para um sujeito que interpela também afrodescendentes de centros urbanos e outras regiões do país, os quais compartilham com os demais experiências de marginalização e discriminação (Restrepo, 2013). Urrea-Giraldo (2011) ressalta que tais mudanças se expressam no deslizamento da categorização entre "comunidades negras" e "afro-colombianas/os".

A Campanha Las Caras Lindas de mi Gente Negra..., que antecedeu ao Censo de 2005 , constitui um ícone desse deslizamento ${ }^{128}$. Realizada por diversas organizações negras ou afro-colombianas ${ }^{129}$, entre elas o Proceso de Comunidades Negras (PCN), a campanha visava estimular a identificação em torno da ascendência africana, explorando as várias categorias que a nomeiam - política, regional e localmente -, as quais se vinculam a diferentes fenótipos afrodescendentes presentes na Colômbia, com gradações de mestiçagem ${ }^{130}$. Reproduzo a seguir o texto-chamada da referida campanha:

En el caso de los Negros(as), Mulatos(as), Zambos(as), Morenos(as), Afrodescendientes, Afrocolombianos(as) y Raizales. Es decir todos aquellos descendientes de africanos en Colombia, todos y cada uno de los colombianos a quienes nuestros antepasados nos dejaron, aunque sea una gota de sangre africana (negra). Este censo constituye una posibilidad

\footnotetext{
127 O Brasil não convergiu nesse ponto com os demais países latino-americanos. A posição brasileira argumentava que a ascendência africana pode estar presente em pessoas de fenótipos variados, até mesmo de fenótipo branco-europeu. Porém, o racismo e a discriminação racial dirigem-se às pessoas que estampam no corpo essa ascendência, o que não significa atrelar a ascendência africana à pigmentação escura. Nesse sentido, a delegação brasileira insistia em usar a categoria "negro/a". Há uma ampla discussão no campo políticoacadêmico latino-americano e caribenho sobre os usos das categorias "negra/o" ou "afrodescendente". Para uma boa reflexão sobre o tema, ver: Lozano Lerma (2015).

128 Ver vídeo de comercial televisivo: Censo / Census Colombia Afro-colombia. Disponível em: http://www.youtube.com/watch?v=RSq5FuhS1SE. Acessado em: 4 de outubro de 2014. Para uma boa análise da Campanha e de outros temas relacionados ao Censo de 2005, ver: Paschel (2013).

129 “Conferencia Nacional Afrocolombiana, Proceso de Comunidades Negras, Movimiento Nacional Cimarrón, Asociación de Organizaciones de Comunidades Negras, Asociación de Alcaldes de Municipios con Población Afrodescendiente, Red Nacional de Jóvenes Afrocolombianos, Red Nacional de Mujeres Afrocolombianas [Red Kambiri], Federación de Municipios del Pacifico, entre outras organizações" (Bejarano, 2010: 61). Para uma boa análise da Campanha e de outros temas relacionados ao Censo de 2005, ver: Paschel (2013). A autora acrescenta à lista de Bejarano a Association of Black Community Organizations (ORCONE).

${ }^{130}$ Paschel (2013) comenta um diálogo ocorrido em 2006 com um ativista do Movimento Cimarrón em torno da campanha, a partir do qual a autora faz uma reflexão sobre o fenótipo negro trazido nas peças publicitárias, que contempla pessoas de pele mais escura. Compartilho a crítica trazida por meio desse diálogo, ressaltando que uma parte da população que a campanha pretendia atingir - de pele mais clara, porém, com ascendência africana - pode não ter se identificado com a imagem propagada.
} 
histórica. En los casi 200 años de vida republicana hoy no existen datos sobre el número total de descendientes de africanos en Colombia, ni indicadores reales sobre la situación socioeconómica en que viven.

En el censo preguntarán: si de acuerdo con sus rasgos físicos, su pueblo o su cultura, usted es... Negro(a), Mulato(a), Zambo(a), Afrodescendiente, Afrocolombiano(a), Palenquero(a) o Raizal. Conscientes que responder esta pregunta significa enfrentar factores de autonegación que tienen sus causas en la discriminación y el racismo a que este grupo poblacional y sus miembros hemos sido sometidos a lo largo de toda su historia, las organizaciones de afrocolombianos están desarrollando acciones de incidencia, educación y movilización para que los descendientes de africanos que habitamos esta patria, nos autoidentifiquemos al momento de responder el cuestionario del próximo Censo (PCN, 2005) (Bejarano, 2010:61,62) (Bejarano, 2010: 61-62).

Urrea-Giraldo (2011) ressalta que foi a primeira manifestação do movimento social negro colombiano que se esforçava por integrar dimensões da subjetivação relacionadas à raça e à etnia, conectando processos de identificação em torno da pele e do corpo, bem como da ancestralidade e das tradições culturais.

Na implementação do Censo de 2005, como informa Bejarano (2010), a pergunta feita foi: “¿De acuerdo con su CULTURA, PUEBLO O RASGOS FÍSICOS, ... es o se reconoce como: 1. Indígena, 2. Rom, 3. Raizal del Archipiélago de San Andrés y Providencia, 4. Palenquero de San Basílio, 5. Negro(a), Mulato(a), Afrocolombiano(a) o afrodescendiente, 6. Ninguna de las opciones anteriores?". Segundo resultados desse censo, 10,6\% do total nacional se reconhecia como negros/as, mulatos/as, afro-colombianos/as, afrodescendentes, raizales e palenqueros.

O DANE sistematizou o quesito ora comentado como "pertencimento étnico", apresentado na sessão "Perfil”" do Censo Geral 2005. No glossário dessa sessão, define-se o quesito:

Pertenencia étnica: En Colombia las personas se pueden identificar como pertenecientes a uno de los grupos étnicos reconocidos legalmente (indígenas, ROM o gitanos, raizales del Archipiélago de San Andrés, Providencia y Santa Catalina, palenqueros de San Basilio y afrocolombianos). El criterio empleado en el Censo General 2005 para captar la pertenencia étnica de las personas es el auto reconocimiento por sus costumbres o tradiciones o por sus rasgos físicos (DANE, 2005, p. 6).

A definição dá a entender que o Censo de 2005 compreende como "grupo étnico" as "comunidades tradicionais, culturalmente diferenciadas e territorializadas" (Restrepo, 2013: 21). Conforme ressalta Restrepo, seja no discurso jurídico, acadêmico ou político, os indígenas constituem o paradigma do que seria um grupo étnico, com marcadores linguísticos 
e culturais da diferença. A partir da década de 1990, “comunidades negras" também passam a ser interpretadas como grupo étnico. Em seguida, Raizales e o povo "Rom" ou "Gitano".

Tal acepção da etnicidade é a prevalecente nas últimas décadas, como ressalta Restrepo (2013). Porém, não é a única. Segundo o autor, em princípios do século XX, alguns intelectuais usavam o termo "grupo étnico" como sinônimo de "raça". Por exemplo:

\begin{abstract}
Manuel Zapata Olivella (1974) considera como "grupos étnicos" actuales a los siguientes: el "grupo étnico antioqueño", el "grupo étnico cundiboyacense", el "grupo étnico tolimo-huilense", el "grupo étnico santandereano", el "grupo étnico costeño", el "grupo étnico caucano", el "grupo llanero u oriental" y el "subgrupo isleño". Este campo semántico, ya sea como sinónimo o sustitución de "raza" o "población", se caracteriza porque la noción de "grupo étnico" es aplicable a unidades geopoblacionales o a categorías sociales diversas que compondrían en su totalidad la idea de "pueblo", "cultura" o "nación" colombiana. Así, los colombianos todos, cualesquiera sean las unidades de diferenciación y taxonomías apeladas, hacen parte de "grupos étnicos" (Restrepo, 2013: 23).
\end{abstract}

Essa acepção mais antiga de "grupo étnico" remete-nos aos demais grupos sociais que não são negros/as, afro, raizales, palenqueros, tampouco indígenas. Nas enquetes censitárias entre 1998 e 2004, "brancos/as" e "mestiços/as" alternavam-se como categorias distintas e como uma mesma categoria. O censo de 2005 não dispõe da categoria "branco/a", tampouco "mestiço/a". No caso do Equador, tais categorias estiveram presentes no ano de 2001 e no ano de 2010 e não houve coincidência entre "branco/a" e "mestiço/a".

A análise das enquetes censitárias colombianas realizadas de 1998 a 2005 coloca duas questões importantes para a reflexão. A primeira delas refere-se à concepção da categoria "mestiço/a" no período da multiculturalidade. A imagem do/a mestiço/a forjada no contexto histórico republicano na Colômbia, conforme propõe Bejarano, consistia na "mistura em termos fenotípicos e culturais do branco, do indígena e do negro" (Bejarano, 2010: 25). Articulando essa imagem e a histórica hegemonia branca na hierarquização sociorracial na Colômbia, no Equador e no mundo, depreende-se por que processos de categorização podem fazer coincidir as categorias "branco" e "mestiço". Se o/a mestiço/a é a soma das três raças e o componente branco é hegemônico, então ser mestiça é ser branca. Nesse momento, a transmutação da categoria "mestiça" se complexifica. Se seu sentido subversivo construído na experiência da República Zamba antes estava neutralizado, agora ele é invertido pela ordem social hegemônica. Ou seja, o elemento branco-europeu apoderou-se da categoria "mestiça".

Se as enquetes censitárias fazem coincidir "branco/a" e "mestiço/a", não o fazem certas produções teóricas sobre o tema. Nas obras de Barbary e Urrea (2004) e Wade (1997), 
não há equivalência conceitual entre brancos/as e mestiços/as. Wade, pelo contrário, ressalta assimetrias entre esses grupos populacionais. Ao falar sobre tensões e antagonismos nas identificações étnico-raciais em processo, Wade afirma que tais processos ocorrem "en el contexto de los diferenciales de poder y riqueza que pueden separar al 'negro' del 'no negro' así como también al 'mestizo' del 'blanco"' (Wade, 1997: 392).

A segunda questão concerne às implicações do Censo colombiano de 2005, especialmente no tocante à ausência de categorias referentes à população não negra, não mulata, não afro, não raizal, não palenqueira, não indígena e não cigana. É absolutamente relevante que a população negra/afro seja devidamente contemplada pelos instrumentos censitários, depois de 75 anos de sua ausência nos registros estatísticos nacionais ${ }^{131}$. Porém, a ausência de uma ou mais categorias para registrar a população não afro, não indígena e não cigana deixa uma lacuna no instrumento censitário. Afinal, os indicadores socioeconômicos que derivam desses instrumentos são de ordem comparativa. A branquitude entra de modo residual, contabilizada na opção "nenhuma das anteriores", o que reforça a concepção da etnicidade como diferença cultural. Paschel (2013) faz a mesma leitura sobre esse aspecto do Censo.

Ademais, dessa ausência, pode decorrer questões complexas do ponto de vista da subjetividade coletiva. Lembremo-nos que as pesquisas censitárias têm o poder de cristalizar categorias de classificação étnico-raciais. Assim, o Censo de 2005 pode operar como um instrumento de apagamento do componente branco da sociedade colombiana, o que não é acompanhado por uma desconstrução das hierarquias sociorraciais.

Narrativas que escutei na Colômbia e no Equador ilustram as questões ora discutidas. O sentido da afrodescendência é elucidada pela narrativa de Elisa Isabela Folleco Lara, mulher "afro-equatoriana" de Mascarillas, comunidade do território ancestral Valle del Chota, la Concepción y Salinas, situada ao norte do Equador ${ }^{132}$. Isabelita, como é chamada, teve um filho, Aron Isaías, com um homem não negro. "El papá de ese guagua es de la provincia de Bolívar, de Guarando, pero vive en Mascarillas". Aron tem a pele mais clara e traços que indicam uma mistura. Perguntei como ela o definia em termos étnico-raciais: "Yo lo defino como mi hijo. Yo soy uma mujer afrodescendiente, entonces él es afrodescendiente. Así lo voy a educar. Vamos a ver cuándo crezca, como él se va a definir".

\footnotetext{
${ }^{131}$ Urrea-Giraldo (2011) ressalta que entre 1913 e 1993 não houve qualquer registro estatístico da população negra no país.

${ }^{132}$ É interessante notar que neste território há uma ênfase no termo afrodescendente, mais usado do que o termo "negra", o que difere um pouco do Norte de Esmeraldas, território foco desta pesquisa.
} 


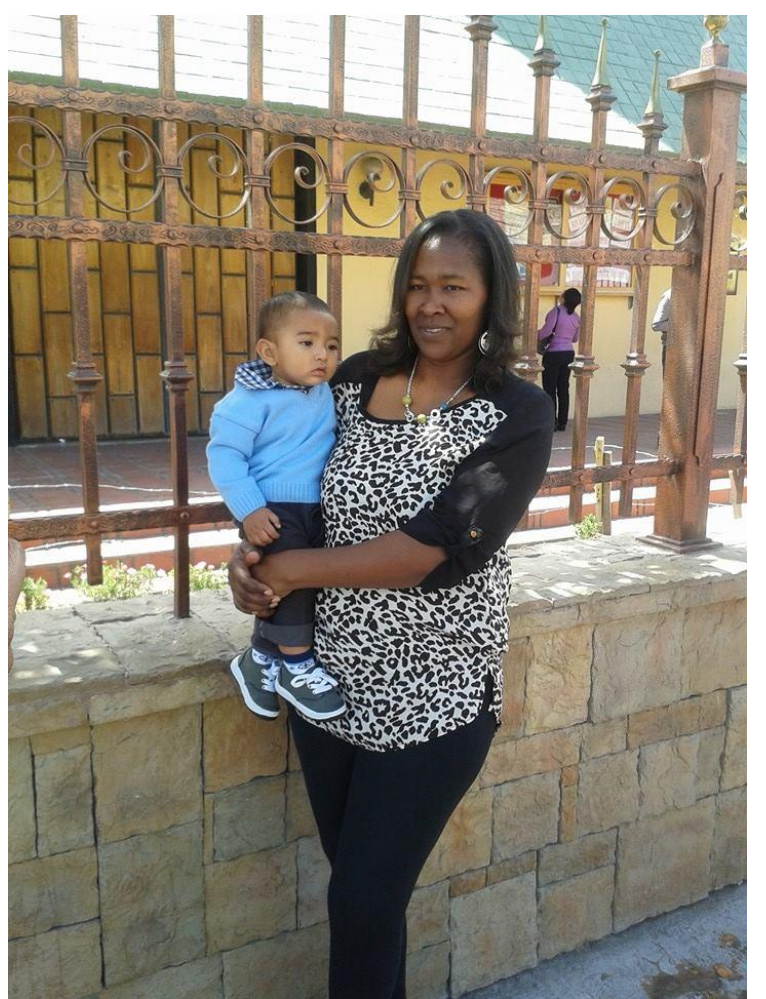

Figura 2 - Isabela Lara com seu filho, Aron Isaías ${ }^{133}$

Conversando com a família Granja Castillo, em Salahonda, a jovem Ana Karina disse: "yo prefiero que me digan afropacífica, es lo mismo que ser negra. No es tanto por el color de la piel pero como uno se siente, lo que lleva adentro". Nas narrativas de Karina e Isabela, o racial e o cultural estão em relação. Ana Karina explicita seu entendimento de que ser negra e ser afrodescendente é o mesmo.

Vejamos a definição de afro-colombiano/a proposta por María Orobio, que tem uma trajetória um pouco diferente das demais mulheres com quem dialoguei, já que possui uma inserção mais pontual no movimento social:

Paula: ¿en la vereda hay gente más oscura y gente más clara?

María: sí. Hay unos más negritos que mí, sino que ya se ha disminuido ese pueblo, ya la gente se ha salido, se han ido a las ciudades.

Paula: María, mi pregunta es ¿si toda esta gente de la vereda, sean los más oscuritos, los más claritos son todos afrocolombianos, o no?

María: si, todos

Paula: ¿y son todos negros?

\footnotetext{
${ }^{133} \mathrm{O}$ uso de fotografias nessa seção da tese não visa definir, tampouco contribuir, para qualquer tipo de resolução das complexidades inerentes à problemática ora discutida. Meu intuito é mostrar como as lógicas de classificação e pertencimento étnico-racial são construções culturais particulares. Ao contrapor minha perspectiva com a de minhas interlocutoras, por exemplo, busco dialogar diferentes lógicas de classificação e pertencimento, visibilizando a flexibilidade de cada contexto cultural.
} 
María: hay negros, hay bien, allá hay personas más de color, sino que como le digo la gente se ha ido, así que a una ciudad, que a Cali, que a Bogotá.

Paula: ¿y cómo se sabe si una persona es afrocolombiana?

María: ¿Cómo será que se sabe? Que sea colombiano y que sea de raza negra ¿diga? Porque hay personas que son blancas, blancas y nacen de familia bien negra, de pronto que la descendencia hay personas que vienen de raza blanca.

Analiticamente, há um matiz importante no uso das categorias. "Negra" alude de forma direta ao marcador identitário da cor da pele, enquanto "afro" remete à ascendência. Estamos em uma região na qual prevalece a dimensão cultural. A fala de Ana Karina agrega o signo (a cor da pele), a origem africana e o pertencimento regional - ser do Pacífico -, que é central na construção da subjetividade dessas mulheres. Percebo que o termo "afropacífica" traduz questões centrais nas identificações étnico-raciais em processo, o que me levou a adotar essa categoria ao longo do texto.

Passemos, então, ao outro extremo da classificação étnico-racial, explorando usos e sentidos das categorias "branca" e "mestiça". Vejamos uma concepção da categoria mestiço/a ilustrada pelo diálogo com Elisa Isabela Folleco Lara, de Mascarillas. María Barbarita Lara Calderón explica a gênese do território de Isabelita, que se difere da região foco desta tese:

En el territorio ancestral Chota, La Concepción, Salinas y Guallupe somos 60 comunidades negras. Valle del Coangue es su nombre ancestral. En general, las comunidades negras están a la orilla del río y las mestizas más alejadas. Hay diferentes orígenes de las comunidades en el Valle del Chota. Los que se escaparan de las haciendas, los cimarrones, los que se quedaran en las haciendas y los migrantes. En ese caso del Valle del Chota son ejemplos de las comunidades formadas por los que se escaparan, Cuncal y Carpuela. Son ejemplos de comunidades libres. Ellos no dependían de las haciendas. Por eso en el Chota, la comunidad del Chota, ahí hay mucha gente de distintas comunidades, de Concepción, de la Loma, de Cuajara. Siempre desde que se les trajeran para vivir y trabajar, se conformaban comunidades, cerca de la casa de la gran hacienda. La hacienda les asignaba el pedazo de tierra en los lugares menos productivos, cerca de los ríos se les daban tierras para producir su propio alimento - Barbarita Lara.

Como indica a explanação de Barbarita, desde a conformação desse território, parece que houve interações mais próximas entre grupos negros e "mestiços" comparativamente ao território Pacífico fronteiriço, daí a maior ocorrência de relações interraciais. Vamos, então, ao diálogo com Isabelita:

Paula: Yo estoy tratando de entender quién es mestizo aquí. ¿Para usted quién es mestizo? 
Isabelita: Mestizo es una mezcla de todo. Acá hay los negros o afroecuatorianos. Hay los indígenas que son los otavaleños, por ejemplo, los Awá. Cuando tienen hijo una mujer negra y un hombre mestizo, hay un mulato, o zambo, como el niño que estaba aquí. Y cuando uno no se identifica así con ninguno de estos es mestizo. Porque en Ecuador no hay blancos, nos hicieron entender eso.

Paula: ¿Quién los hizo entender eso? ¿Fue en la escuela?

Isabelita: No. Eso fue la campaña para el censo. Porque mucha gente no sabía cómo identificarse, entonces hicieron esa campaña. El censo fue en el 2010, eso fue en el 2008, 2009.

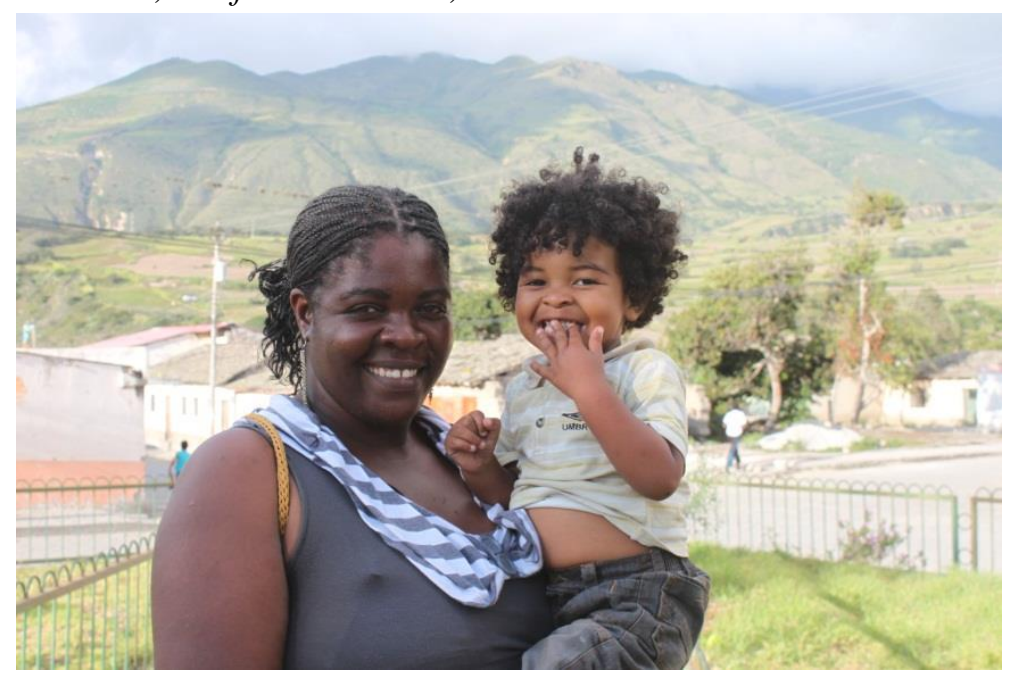

Figura 3 - Mãe e filho em La Concepción

Observa-se que a categoria "mestiço" tem certa amplitude. Como visto anteriormente, há uma acepção da categoria "mestiço" que opera desde o período colonial, segundo a qual uma pessoa mestiça seria descendente de indígena com branco/a. A narrativa de Isabela também designa como mestiça a pessoa que descende da mistura entre negra/o e o próprio mestiço. Ademais, é uma categoria residual. Quem não se enquadra nas demais cabe nela. Porém, o que mais chama atenção na fala de Isabela é o discurso da inexistência da branquitude, a qual ela situa como uma construção recente do Estado equatoriano, no âmbito de uma campanha para o Censo $2010^{134}$.

A inexistência da branquitude é defendida pela tumaquenha Marlene Tello e pela sanlorenzenha Yonny Nazareno. Em entrevista coletiva no VII Festival da Mulher AfroLatino-Americana e Caribenha, em Brasília, Marlene afirmou "nosotros estamos convencidos de que en Colombia y en Latinoamerica no hay blancos". Na oficina no no Movimiento de Mujeres Negras del Norte de Esmeraldas (MOMUNE), em Eloy Alafaro, Yonny explanava:

\footnotetext{
134 A "Campaña de Autoidentificación Afroecuatoriana" foi realizada pela Corporación de Desarrollo Afroecuatoriano (CODAE), instância ligada ao governo, e teve como lema "Familia identifícate: orgullosamente afroecuatorianos".
} 
"recordamos que aquí en nuestro país no tenemos blancos. Tenemos mestizos, indígenas, montubios y afroecuatorianos que somos nosotros" ${ }^{\prime 135}$. Penso que, para se chegar ao discurso da inexistência da branquitude, foi fundamental passar pela fusão das categorias branco/a e mestiço/a, que indicamos na análise das pesquisas censitárias.

O Censo projeta um lugar de enunciação hegemônico, a partir do qual atribui-se certo sentido à fusão das referidas categorias. Sem embargo, o discurso da inexistência da branquitude desde a perspectiva de Marlene e Yonny parece apontar outro sentido. Trata-se de uma leitura política afrocentrada do termo "mestiço", que me foi explicada por Emilia Murrain, e que confere uma interpretação contra hegemônica à inexistência da branquitude ${ }^{136}$. A conotação da categoria de classificação racial "branco" está carregada de superioridade, dada à hierarquização sociorracial. Ser branco é ser vitorioso, na medida em que designa o elemento europeu na tríade colonial África-América-Europa. Porém, como diz Emilia, na empreitada colonial, os espanhóis que chegaram à América Latina não ocupavam o topo da pirâmide social espanhola. Pelo contrário, eram marginais em sua sociedade (presos, criminosos, etc.). Tampouco representavam as mais puras linhagens caucasianas. Em si já eram frutos de mesclas genéticas e culturais. Grueso, Rosero e Escobar (1999) afirmam tratarse de um povo "mestiço", classificado como "branco". Nesse sentido, esquivar-se do uso da categoria "branco" na classificação étnico-racial contemporânea é contrapor-se ao histórico sentido de superioridade autoatribuída a colombianos e colombianas que descendem de famílias europeias.

O tema da mistura ganha contornos e interpretações peculiares no Pacífico colomboequatoriano, onde, ainda que em grau reduzido, houve miscigenação. María Orobio narra o processo de miscigenação em Tumaco:

Entonces, en el tiempo de mis viejos, de mi papá y mamá, cuando vino la draga vinieron gringos, muchos gringos, que eran los que trabajaban y algunos consiguieron novias, sus negritas aquí y acá quedaron. Otros tuvieron hijos, embarazaban las peladas, pues las enamoraban, las negritas me imagino pues no habían visto de pronto blanco, como sería, y se embarazan y tin le salían sus niños blanquito' y asi la generación de aqui se fue formando. Porque aquí hay muchas personas, viejos que usted los ve que son blancos, viejos y son hijos de mujer negrita, porque aqui fue que se mezcló la raza, pero hay gente de todas partes, raza de todas. Así fue la cosa. Aquí hay peladas que se van y son negritas, que se van a trabajar a otras ciudades y de allá vienen con su blanquito, su muchachito, traen su

\footnotetext{
135 A oficina inseria-se no projeto "Buscando voces de mujeres que rompan el silencio", executado por MOMUNE e financiado por Corporación Participación Ciudadana, Equador.

${ }^{136}$ Compreendo branquitude no mesmo sentido em que o faz Viveros (comunicação pessoal), ou seja, como uma referência ao status de privilégio associado ao grupo racial branco.
} 
hijo, ya ese niño ya va regando ¿diga? Ya va regando esa semilla, ya ese niño o esa niña ya tiene su compromiso y ya le va saliendo blanquito y así... así es la cosa - María Orobio.

Pelos elementos que a narrativa traz, a miscigenação com o elemento branco parece relativamente recente e contextualizada no ambiente urbano. Sem embargo, parece que a produção das diferenças étnico-raciais no Pacífico colombo-equatoriano recorre a um ideal de pureza. Em certo sentido, a negritude pressupõe a pureza.

Em estudo sobre afrodescendência no Equador, Fernández-Rasines (2001) cita o relato de Pancho Acosta, um senhor negro nascido na região serrana ao norte do Equador e habitante de um bairro periférico de Quito, que à época de coleta do relato tinha 61 anos. Em certo trecho, ele diz que "el negro-negro existe que vive digamos em San Lorenzo. Esos son los propios negros, de ahí nosotros ya somos mezclados" (Fernández-Rasines, 2001: 86). O ideal da pureza racial trata-se, portanto, de uma construção bem situada no Pacífico.

De certo modo, essa construção encontra respaldo na produção científica antropológica (Arocha, 1992; Friedemann, 1993; West, 2000). Por outro lado, a intelectualidade negra, na pessoa de Manuel Zapata Olivella, diverge dela. Zapata Olivella propõe uma concepção de mestiçagem antirracista radical, segundo a qual a mescla genética, racial e cultural é uma constante e um universal na história da humanidade (Arboleda, 2011). Ressalto, portanto, que se trata de uma construção social, um mito ou ideal, e não uma realidade. Como colocam Barbary e Urrea, não existem grupos socioculturais "puros", muito menos populações fenotípica ou biologicamente "puras" (2004: 56). Fernandéz-Rasines aponta para a mesma questão no tocante ao Equador: "la pureza de la sangre nunca existió sino como constructo sobre el cual fueron sustentadas las jerarquías en base a raza, casta y linaje" (2001: 58).

Quando estávamos com a sanlorenzenha Inés Morales em uma reunião em Quito, Equador, realizada pelos gestores governamentais do Plan Nacional para la Eliminación de la Discriminación Racial y la Exclusión Étnica, vivemos um episódio interessante. Em momento informal, já fora da sala de reuniões, uma das participantes que provinha de outra região foi questionada por Inés. Observando o cabelo da moça, Inés averiguou sua ascendência, dizendo que havia notado nela certa "mestiçagem". Ela dizia então: "sim, minha avó era indígena, mas eu sou afro-equatoriana!” Desde o meu olhar, a moça era negra, de pele escura e cabelo crespo. Vale ressaltar que estávamos entre mulheres militantes engajadas no movimento social negro e no movimentos de mulheres negras. 
Em outros diálogos, percebi que a mistura desautoriza a identificação como negra. Victor Andrés, que viveu conosco na casa de Inés, sendo filho de mãe negra e pai não negro, não se sentia autorizado a se reconhecer como negro, tampouco como afro. Veronica, nora de Inés, diz-se mulata, não negra, porque sua mãe não é negra. Segundo ela, negro é o marido, Jairo, cujos pais são negros. Veronica e Jairo têm um filho, Axel (e agora mais uma filha, Inés Maria). Ao questionar Veronica sobre a identificação étnico-racial de Axel, ela disse que não sabia identificá-lo.

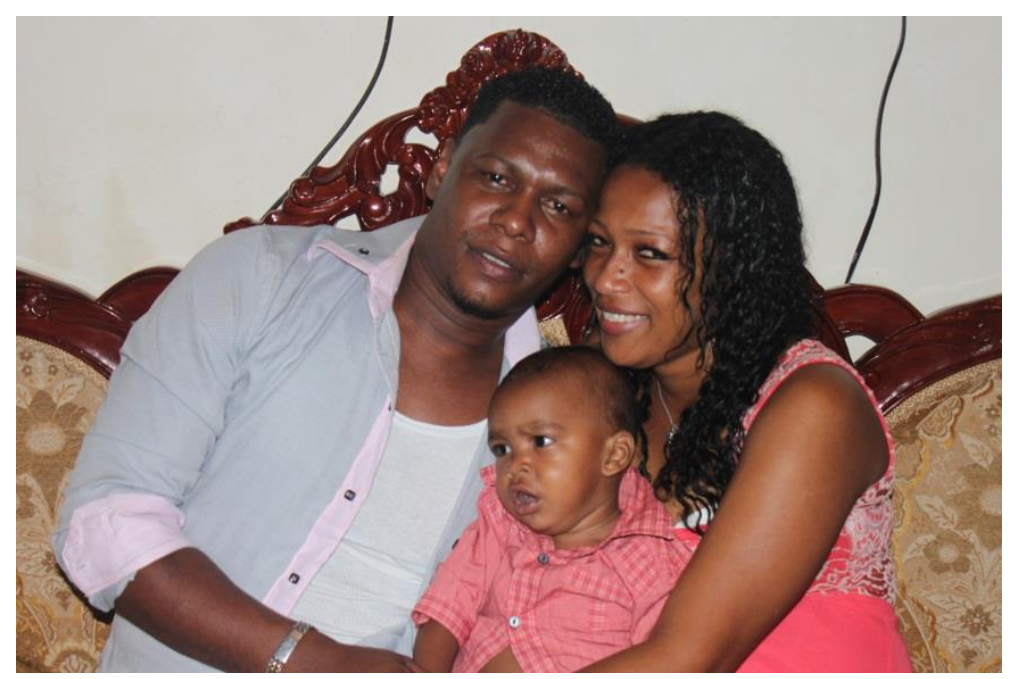

Figura 4 - Jairo, Veronica e Axel

María Magdalena é mãe de Targelia Micolta, que, ao longo de sua vida, tem experienciado a dinâmica pendular entre a Colômbia e o Equador. Atualmente ela reside em Puerto Palma, Bajo Mira, Tumaco e frequentemente visita sua filha Targelia, al otro lado de la raya, em Palma Real, San Lorenzo, Equador. Reproduzo a seguir um diálogo meu com Magdalena:

Paula: ¿Usted no se considera negra?

María Magdalena: Risas.

Paula: ¿! Con ese color?!

María Magdalena: Es que mi papá era blanco, blanco, blanco [italiano]. Pero a él le gustaban las negras. Tuvo tres familias, todas con negras, la primera era del Congal, la segunda del Changal y la tercera de Santo Domingo. Mi mamá fue la que le dio más fuerte, porque mis hermanos son despercudidos ${ }^{137}$, más que usted.

\footnotetext{
${ }^{137}$ Quando usado em referência à pele, o termo tem o sentido de branqueado ou clareardo, segundo dicionário: http://lema.rae.es/drae/?val=despercudido, acessado em 01/07/2015.
} 
As diferenças conceituais em torno da negritude entre o Pacífico colombo-equatoriano e o Brasil se explicitam nesse diálogo. Em minha leitura, o fenótipo indubitavelmente leva à classificação dessa mulher como negra, enquanto ela ressalta sua origem familiar, sendo que a mistura matiza o autorreconhecimento.

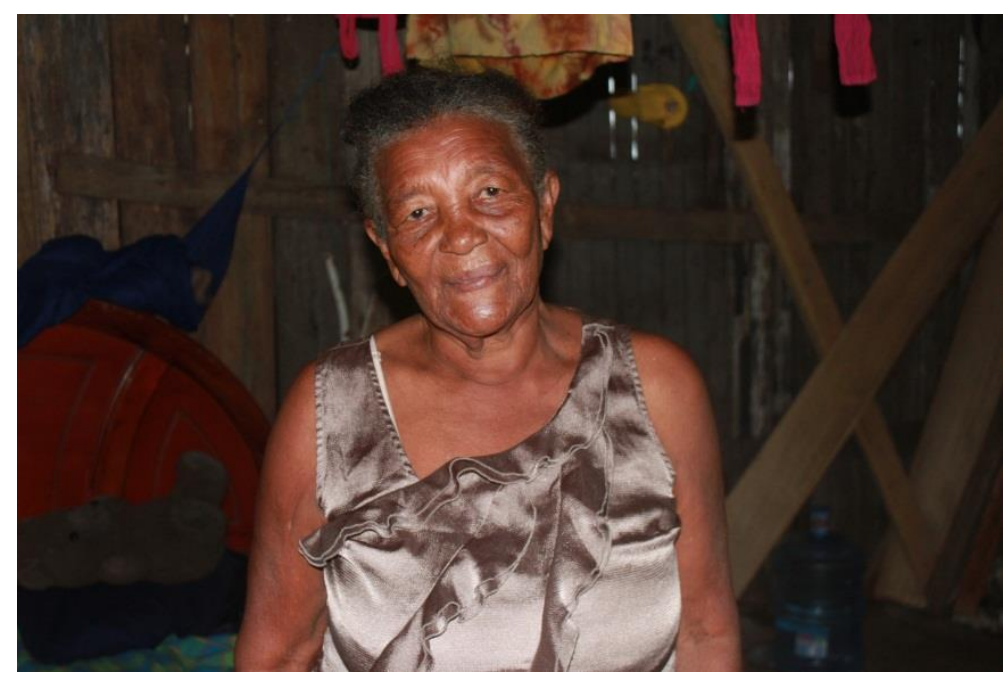

Figura 5 - María Magdalena

Contraponho a essa imagem, um diálogo que tive com uma mulher negra tumaquenha que cresceu em Cali e vive em Bogotá há cerca de trinta anos:

Paula: ¿Arturo [nome fictício] se reconoce como negro?

Yohanda [nome fictício]: ¡Claro! Pues, ¿cómo no? Su papá es chocoano.

Esse exemplo contradiz o anterior. Se María Magdalena não se reconhece como negra porque seu pai é italiano, ainda que ela tenha um fenótipo negro bastante ressaltado, Arturo é negro porque seu pai é chocoano, mesmo tendo a pele pouco pigmentada e traços que indicam a ascendência negra. $\mathrm{O}$ que os dois casos ressaltam é a concepção regionalizada de raça, que leva à construção da etnicidade peculiar ao Pacífico colombo-equatoriano. No primeiro caso, a ascendência referencial é a branco-europeia, enquanto no segundo caso é a negro-pacífica. Como a classificação fenotípica é uma construção social à serviço de uma hierarquia racializada, compreendo que ressaltar a ascendência negro-pacífica constitui um ato contra hegemônico.

Encontrei algumas narrativas que apresentam uma contra imagem sobre a mestiçagem. Em diálogo com Mailen Aurora e María Cecilia, chegamos ao tema a partir de reflexões sobre raízes africanas. E então, María Cecilia ressaltou a mestiçagem de Jesus Cristo: 
Incluso Jesús vino de África. Él era como un mestizo, él no era blanco, blanco. Lo colocan de ojos azules, rubio y todo. Pero él no era así. Era... un mestizaje tenía. La tierra donde estaba Israel estaba cerquita de África. Entonces, las raíces son de África. Entonces a uno le toca ir buscando la historia negra - María Cecilia.

$\mathrm{Na}$ contramão do discurso hegemônico, aqui se ressalta a presença da África na mistura. Outra leitura contra hegemônica aparece na narrativa de Rosalba. Como estava eu acostumada com o uso da categoria "mestiça", em casos em que eu usaria a categoria "branca", assim perguntei a Rosalba:

Paula: ¿Entonces quisiera saber cómo usted percibe este diálogo de mujeres afro con mujeres indígenas, mujeres mestizas?

Rosalba: A ver, ¿cómo le digo? Siempre las mujeres afro con los indígenas, es cuando nos encontramos en algunos eventos. Pero, que para compartir, para dialogar, nos queda a nosotros difícil porque ellos siempre viven más hacia la montaña, entonces uno, la relación más a fondo, para nosotros es más difícil. Nos hemos encontrado en algunos espacios sí y ahí trabajamos por todas y opinamos por todas.

Paula: ¿Y con las mestizas?

Rosalba: ¿Mestizas quién es? ¿Son los blancos?

Nas falas de María Cecilia e de Rosalba não há correspondência entre mestiçagem e branquitude. No caso de Rosalba, a categoria "mestiça” está fora de seu vocabulário.

As narrativas apontam, portanto, para uma multiplicidade de sentidos. Existe um discurso político que defende a inexistência da branquitude, buscando questionar o lugar de superioridade a que se arroga a população de ascendência europeia. Em práticas cotidianas, a população que carrega algum tipo de mistura tende a não se identificar com o pólo negroafricano. Ao mesmo tempo, em certas narrativas, a África é evocada no contexto da mestiçagem. E, em outros relatos, a categoria "mestiça" simplesmente não opera.

Ademais de "afro", "negra”, “indígena”, "mestiça” e "branca”, há outras categorias, muitas das quais conheci por meio da forma como me identificavam as mulheres com quem interlocutei, fosse explicitamente, fosse por meio de comparação com outras pessoas. Marlene Tello me percebe como mestiça. Emilia Eneida Murrain Valencia me reconhece como afro: "aquí usted es afro aunque hay gente como usted en Colombia que no se ve afro"138. Ana Karina me dizia: "es la primera vez que veo una blanca ñata"139. E seguia: "mi abuela es

\footnotetext{
${ }^{138}$ O mesmo ocorre no Brasil, ainda que esteja crescendo o contingente populacional com fenótipo indicativo de mesclas que se identifica como negro.

${ }^{139}$ Quando a questionei sobre o sentido do adjetivo, Karina me explicou que as negras têm nariz ñato, como o dela. A tradução para o português seria nariz chato. Ver: Verbete "Ñato". Disponível em: http://www.wordreference.com/espt/\%C3\%B1ato. Acessado em: 4 de outubro de 2014.
} 
chola $^{140}$. Mi abuelo es colorado ${ }^{141}$, como su color, pero con el pelo duro, duro, duro". Leonela Rocío Valencia me identificou primeiro como branca, depois da referência a minha genealogia, como mestiça. Nesse caso, é importante reproduzir nosso diálogo, quando falávamos sobre o preconceito que Leo viveu com a família de seu ex-companheiro, especialmente com a mãe dele:

Leo: ella [la mamá del compañero] no es blanca, ella no es tan blanca, es mestiza, de raza blanca sí, pero mestiza

Paula: ¿y cómo diferencias quien es mestiza de quien es blanca?

Leo: por ejemplo usted es del color blanco, clara. Ella es más oscura. El papá de ella era indio negro, la mamá si era manaba

Paula: ¿manaba es blanca?

Leo: $s i$

Paula: ¿porque manabo es de Manabi ${ }^{142}$ ?

Leo: sí. De todos modos blancos también es de Guayaquil, pero ella sí era mestiza porque el papá de ella era indio negro

Paula: por ejemplo en mi caso, mi mamá es negra, mi papá es blanco

Leo: isí!! Usted también es mestiza. Yo le dije a mi mami, a varios le dije que usted era mestiza".

Rosalba e Mailen fazem alusão à minha tonalidade de pele como "piel trigueña", ou seja, pele amarela ou pele dourada, que se assemelha à cor do trigo. Agier e Quitín (2004) referem-se à identificação como "trigueño" no contexto de uma tendência à indefinição e neutralização das características raciais. Bejarano informou-me que houve um momento na história da Colômbia em que muitos afro-colombianos/as eram registrados como "trigueños" na cédula de identidade ${ }^{143}$. Segundo Paschel (2013), nas etapas preparatórias do Censo 2005, o PCN defendia que categorias como triguenha, mulata e morena estivessem no questionário censitário, por serem usualmente autorreferenciadas à negritude.

A também tumaquenha Maria Orobio refere-se às pessoas de tez amarela como mulatas:

\footnotetext{
${ }^{140}$ Mescla de indígena com negro/a. O termo "morado" é usado em sentido análogo a "cholo", como por exemplo, na narrativa de Yonny Nazareno: "en Milagro no son blancos, son como moraditos, cholitos". O termo "cholo" também é usado para se referir ao cabelo menos crespo. Por exemplo, Yonny, a moça que trançou meu cabelo, dizia "usted tiene el pelo cholito".

${ }^{141}$ Escutei muito essa categoria em San Lorenzo, Equador. Amada Cortez destacava que é curioso seu uso, uma vez que, em outros lugares, gente de cor é gente de pele escura, enquanto que lá designa pessoas de pele clara com ascendência negra. Uma possível explicação para o peculiar sentido que o termo "colorada" assume nessa região está relacionada à presença indígena. West comenta que: "Otro grupo de indios del bosque, también de la familia chibcha, es el de los colorado o tsátchela, quienes viven en la vertiente occidental de los Andes en el Ecuador, a unos $160 \mathrm{~km}$ al sur del territorio cayapa" (West, 2000: 117).

${ }^{142}$ Segundo Ferández-Rasines (2001: 82), manabas são colonos "blanco-mestizos" expulsos pela pressão demográfica em Manabí, província equatoriana localizada na região centro-noroeste do Equador continental, pegando parte do litoral. Ver: Verbete "Provincia de Manabí". Disponível em: http://es.wikipedia.org/wiki/Provincia_de_Manab\%C3\%AD. Acessado em: 3 de outubro de 2014.

${ }^{143}$ Comunicação pessoal, em 4 de fevereiro de 2014.
} 
mire la familia de mi mamá son todos así amarillitos por parte de padre, toda esa gente son de pelo liso, son así amarillitos, así del color suyo. A ellos le dicen los mulatos, le dicen a la familia de mi mamá, porque toda esa familia de mi mamá de parte de padre ellos vivían en el Bajo San Ignacio y ese Bajo se llama El Bajo de los Mulatos y vivían la gente, pues, así amarillita - María Orobio.

Certo dia, estávamos almoçando com Mailen, um irmão e dois sobrinhos dela, quando conversamos sobre como eu seria classificada naquele contexto. O irmão de Mailen, que vive há cerca de dez anos fora da Colômbia, na Europa, dizia então: "ella no es blanca, ella es morena". Quando perguntei a Mailen se o marido dela era negro, ela me disse que era mais claro que ela, com cabelos lisos. Na visão de Mailen, seu marido, assim como pessoas com o meu fenótipo são afro.

O marido de Rosalba tem o tom de pele claro. Perguntei a ela se ele é negro, ao que ela respondeu: "Sí. El papá era negro, la mamá era clara. Y la familia del papá, dicen que la mamá del papá era india, como parte indígena. Chola, que tiene el pelo liso". Os filhos do casal têm fenótipos que expressam as variações pigmentárias da mescla entre a pele escura e a pele mais clara. A família considera-se uma família negra/afro-pacífica. No caso de Rosalba, o escopo da classificação étnico-racial delineia-se entre negras, indígenas e brancas/paisas, como ela explica ao falar sobre o movimento de mulheres em Tumaco: "Siempre que nos reunimos hay indígenas, hay negras. Como le dije, aún que sea de la tez más clarita, son negras. Pero ya con los blancos, paisa, aquí no". Em seu léxico, não há mestiças ou mestiços. A alteridade, portanto, são os "paisas".

Na narrativa de Marlene, "paisas" também são o outro de afros. Porém, aos "paisas", pareiam-se os "mestizos": "Ah, mira, tú colocas dos canastos de cangrejos. Este canasto de cangrejo son cangrejos afros, y este canasto de cangrejos, son cangrejos paisas o mestizos". Na narrativa de Marlene, a categoria "branca/o" não opera, mas sim a categoria "mestiça/o".

Segundo Restrepo:

con el término "paisas" se conoce en gran parte del país a los individuos provenientes de una región que se corresponde a más o menos con los departamentos de Antioquia, Caldas y Risaralda. Los paisas son fácilmente identificables por particular manera de hablar y sus singularidades culturales, pero sobre todo por un profundo sentido de pertenencia y una actitud de hiper-valoración de lo propio. No obstante, desde este campo semántico, no se suele argumentar esta diferencia en términos de "grupo étnico" sino que se la encuadra en el discurso de la diferencia regional (Restrepo, 2013: 21-22). 
Já Escobar (1996) entende que os "paisas" tendem a formar enclaves étnicos, em parte baseados na construção de um mito de sua "pureza racial". Também entendo que a categorização como "paisa" implica um sentido de etnicidade. Escobar argumenta que antioquenhos/as têm interações contínuas com indígenas e negros/as, as quais foram vividas a partir de uma perspectiva de branqueamento. Para o autor, "sua ideologia se baseia na subordinação do feminino e na negociação do negro e do indígena; ali se mesclam ideias sobre origens étnicas e regionais com ideologias de identidade racial e fatores culturais, legitimando relações econômicas de dominação" (Idem, ibidem:122).

$\mathrm{Na}$ narrativa de Rosalba, assim como na de Leo, a categoria usada é raça. Em outro momento, Rosalba explica os grupos indígenas da região, reafirma a majoritária presença negra na costa pacífica e reafirma também a raça como marcador da diferença.

Acá en la costa tenemos los Awá, los Embéra, los Nastaquá, p'acá, la zona de frontera con Ecuador, en la frontera terrestre, por el centro. Porque en la frontera marítima es puro negro. Negro Ecuador, negro Colombia. También hay otra raza indígena, los Chiripúas. Viven p'ácá pa'l lado del Río Mejicano y para la costa Pacífica, por donde queda el Río Tapaje, el Charco, todo eso. El indígena es regado, ¿no? Se riega por todo el lado ${ }^{144}$ Rosalba Quiñones.

O mesmo nota-se nas narrativas de María: "así es la raza y es mi raza"; e da sanlorenzenha Melania Quiñones: "Sí, pero somos muy pocos los que consumimos eso de granos, porque por ejemplo acá la mayoría de nuestra raza es acostumbrada es a su verde y pescado". Melania morou em Quito e Ibarra, regiões conhecidas como "serra”, e lá aprendeu a consumir feijão, lentinha e outros grãos; sobre isso falava na passagem ora citada.

Nas quatro narrativas, a raça é a linguagem usada para nomear as diferenças entre grupos sociais. Porém, em outros momentos, as mesmas interlocutoras podem usar o termo "etnia" para expressar tais diferenças. Uma das chaves para a compreensão dos matizes na classificação étnico-racial é a questão rural/urbana.

As narrativas de María e Rosalba indicam dinâmicas de classificação semelhantes, ambas em comunidades ribeirinhas, no Baixo Rio San Ignacio e no Rio Rosário. Rosalba relata:

Nosotros allá [no Rio Rosario] somos negros, así tenga la tez amarilla. Porque hemos catalogado que quien está alli dentro de las comunidades come de lo mismo que uno come y hace de lo mismo que uno hace. Entonces, hemos catalogado igual. Nosotros no distinguimos que porque ella tiene la piel, es de otra. Sabemos sí que existen esas diferentes razas, lo sabemos.

\footnotetext{
${ }^{144}$ Nessa acepção, o verbo significa espalhar, indicando que os indígenas se dispersaram por toda parte.
} 
Pero ya en el boom, en el ir y venir, todos somos lo mismo. Eso tenemos nosotros muy presente. Los de la piel más oscuro, somos nosotros, y los de piel más clarita. Y los paisa que han llegado a vivir allá, ya es otra raza. Y ellos viven de otra forma, ahí ya es otra raza - Rosalba Quiñones.

Aqui o foco é nitidamente a dimensão sociocultural, posto que, tendo a pele escura ou clara, quem compartilha o território e compartilha certas práticas, como as alimentares, pertence à raça negra. O lugar de fala de Rosalba e Mailen, ancorado em áreas rurais do Pacífico, reflete-se em uma percepção abrangente de negritude, a qual Barbary e Urrea (2004) referem-se como "modelo de identidade étnico-racial proposto pela Lei 70"145, que, segundo os autores, foi capaz de produzir um sentimento massivo de pertencimento coletivo às “comunidades negras" na região do Pacífico. Trata-se de uma autopercepção como grupo territorializado e culturalmente diferenciado da sociedade em geral.

Barbary e Urrea explicam que, em Cali, o modelo étnico-racial dá lugar a um “jogo mais complexo de determinação da identidade negra em relação às percepções coletivas do fenótipo e aos motores sociais e raciais de discriminação" (2004: 248). As vozes de Marlene e Emilia ecoam desde o contexto urbano. O lugar de fala de Leo também pode ser aí referenciado. Apesar de viver em Palma Real, que configura zona rural no Equador, durante dezessete de seus 32 anos de idade ela esteve em Guayaquil e Santo Domingo. Nas narrativas delas passei por três classificações: para Leo inicialmente fui branca, depois mestiça. Para Marlene, sou mestiça, enquanto que, para Emilia, sou afro.

Segundo teorizam Barbary e Urrea (2004), a classificação no contexto urbano agrega leitura fenotípica com processos de discriminação, o que se assemelha à lógica classificatória brasileira. Compreendo que as relações raciais e as experiências de discriminação são particularizadas conforme o contexto e a época. Desde essa perspectiva, se Marlene e Leo me percebem como branca/mestiça, poder-se-ia pensar que mulheres com o meu fenótipo de modo geral não devem sofrer discriminação direta em cidades como Tumaco e San Lorenzo.

Em Tumaco, segundo Censo de 2005, 88,8\% da população se autorreconhece como negra, mulata, afro-colombiana ou afrodescendente. Em San Lorenzo, 70\% da população se autorreconhece como negra, mulata, afro-equatoriana ou afrodescendente. Considerando a região metropolitana de Cali, segundo estimativa dos autores, entre $30 \%$ e $50 \%$ da população são afro-colombianos/as (Barbary e Urrea, 2004: 76). Pode-se pensar que nos contextos de

\footnotetext{
145 Observando as respostas ao Censo de 1993, os autores explicam que 44,5\% da população do Pacífico respondeu à pergunta de corte "étnico", enquanto em outras áreas do país a reação foi extremamente inferior à presença de afro-colombianos, pelos motivos já explicados. Daí concluem que, nas áreas rurais do Pacífico, a população afro-colombiana se reconhece como "comunidade negra".
} 
Tumaco e San Lorenzo, majoritariamente negros, a construção e a percepção da negritude diferem da que se constrói em Cali.

Com efeito, o tema do preconceito e da discriminação racial está presente nas narrativas de minhas interlocutoras. A tumaquenha Eva Lucia Grueso narra a vivência do preconceito no ambiente escolar:

Cuando yo tenía doce años, nosotras estudiábamos en un colegio de monjas. $Y$ estas monjas obviamente, todas mestizas. Y las profesoras todas negras. Digamos, en esa escuela fue mi encuentro o descubrir el racismo. $90 \%$ de las alumnas éramos negras. Y al 10\% de niñas mestizas, sabíamos que las trataban de forma diferente. No nos permitían ir a la escuela con trenzas. Eso era estar despeinada. Había una monja llamada Irene que nos decía: 'ah, no sé porque esas negras huelen tan feo'. Claro que eres muy niña y no alcanzas a dimensionar, pero yo asistía Raíces y decía: ah, ah. Sí, porque cuando yo tenía doce años de edad, recuerdo que presentaron por primera vez en la televisión esa serie Raíces. Es de Estados Unidos. Y ver esa serie para mi hermana y para mí fue entender lo que mi papá y mi tío nos contaban. Y fue descubrir al fin quienes éramos. $O$, más que descubrir, entendernos. Fue como despertar: miércoles, ;yo soy una mujer negra! Esa es mi historia. Entonces Raíces para mi hermana y para mí significó todo Eva Lucia.

María Barbarita Lara Calderón fala sobre sua vivência no mercado laboral.

Yo entré a trabajar como profesora en el 93. Luché mucho para entrar, un año. No era fácil. Le daban el nombramiento a la persona que tenía quien le apoye. $Y$ en ese momento era bien difícil para los afrodescendientes. La discriminación: ahí ni siquiera prestaba el título. Preferían darle a una persona bachiller que a una persona afrodescendiente. Y yo no era negra bonita; era negra fea. No ve que mientras más negra eres, eres fea Barbarita Lara.

Ela explicita matizes do preconceito contra mulheres negras. Barbarita é a terceira de uma família negra de mulheres líderes: Heremita, Anita (Ana María), Barbarita, Ofelita (Ofelia) e Toíta (María Victoria). Isabelita, filha de Anita, conta que, entre as irmãs, Barbarita é quem tem a pele mais escura. Ela reforça que a negritude é diretamente antagonizada com o padrão estético hegemônico de beleza, o que conduz ou obstrui percursos profissionais.

Marlene Tello também ressalta que o preconceito não interpela mulheres negras de forma equivalente, mas se cruza com outros crivos de discriminação. Na passagem que segue, ela estava refletindo sobre o mesmo tema que Barbarita, a discriminação laboral:

Otra discriminación, que hay es que si la mujer es, es negra y si está gorda tampoco es competente. Tiene que ser una mujer que tenga un cuerpo muy, muy esbelto, una mujer muy bonita, muy agraciada; entonces, esa mujer puede estar más o menos en la línea de trabajar, porque también el amo, 
perdón, el jefe, también está mirando otros intereses allí. Entonces toda esa situación afecta a las mujeres, a las mujeres negras - Marlene Tello.

Aqui Marlene fala sobre o preconceito na dimensão estética e sobre a sexualização de mulheres negras no contexto laboral.

Targelia Micolta, por sua vez, vive em Palma Real, cabeceira da paróquia Ancón de Sardinas, cantão San Lorenzo, província de Esmeraldas, Equador, ponto mais próximo ao território colombiano pelas águas do Pacífico. Em suas andanças esteve em Guayaquil, Cali e outras grandes cidades. Sua vivência de exclusão a partir do recorte racial está diretamente remetida ao ambiente urbano.

Ya, entonces por el trayecto que yo iba y venía, iba y venía me daba de cuenta de que en la ciudad no había casi un espacio para uno trabajar. Porque aún existía el racismo. Ya de que yo llegué que la gente blanca ocupaba los mejores puestos y a los negros no les daban oportunidad de trabajar. Entonces ya me quedé por acá - Targelia Micolta.

O racismo no mercado de trabalho também é objeto de análise de tumaquenha María Orobio, que trabalhou em diversos hotéis de Tumaco:

El rico aquí en Tumaco como que odia al pobre, porque una mujer va a trabajar a esos restaurantes, en esos hoteles abusan de uno. Algunas personas interpretan que abusan es porque la toman el cuerpo a la fuerza, la violan. No, abusar también es en el trabajo, porque uno es pobre o es moreno, piensan que uno no siente, uno se cansa - María Orobio.

Mailen Aurora Quiñones amplia a análise:

Y yo decía, si Tumaco es de los tumaqueños, ¿por qué tenemos que hacer invasión, buscar lo' manglar, la' orillas del mar para vivir? Cuando en el centro de Tumaco llegan otros, hacen grandes edificios, viven sabroso. El mismo tumaqueño tiene que ser empleado de ellos. En el Morro uno no ve un hotel turístico que sea de un negro. Siempre de la otra gente, y el negro cocinando, y el negro de mesero sirviéndolo. Cuando Tumaco es nuestro, las cosas son nuestras y ¿por qué no puede ser un almacén de un negro, un granero de negro, un hotel de un negro? Sin tener racismo, ¿no? - Mailen Quiñones.

Semelhante crítica é apresentada por Yonny Nazareno, referindo-se à realidade equatoriana, mais precisamente sanlorenzenha:

Aquí en el país somos el $10 \%$ de todo, los afroecuatorianos. No cree usted que ese diez por ciento tuviera, por lo mínimo, en cada institución tuviera una negra, un negro trabajando. No solamente con el arma ahí parado de guardia o tampoco de Comcel. Por eso yo escribo. Son mis letras las que me entienden. Siempre digo: son los mejores lugares, los que nos pueden 
brindar, de guardia o recepcionista, si queremos trabajar. Dicen que somos ladrones y nos obligan a cuidar los propios pelucones. Ellos sí pueden robar. Los negros no somos dignos ni de poder manejar. Los saberes de la casa. ¿Qué bonita sociedad! Son tantas cosas que pienso y no las puedo expresar. En los bancos, caras blancas. Y los negros, ¿dónde están? Yo escribo siempre, mis letras me dan la razón. Y siempre digo: no estoy de acuerdo con eso - Yonny Nazareno.

Melania Quiñones analisa a discriminação racial no contexto político:

Paula: y por ejemplo en el caso de los afroecuatorianos ¿cuáles eran los derechos que ese momento ustedes estaban peleando?

Melania: lo que más peleábamos era que nos escuchen, porque nosotros por ser afro no hemos sido atendidos por algunos jefes de Estado, nos tenían aislado', como que nosotros los negros no teníamos preparación para ejercer un cargo público, solo nos daban lo poco, lo grande eso quedaba allá con los blancos, a nosotros nos tenían limitados, por eso ahora usted no ve un negro con cargos públicos, en ese sentido nos tenían como marginal, no nos daban paso a nada.

Os relatos falam sobre discriminação racial no mercado de trabalho, na construção de padrões estéticos, na ocupação de espaços de poder. A perspectiva apresentada na maioria dos relatos é personificada e direta. Compreendo, porém, que a questão da discriminação e do racismo é complexa; também ocorre em nível simbólico, estrutural e coletivo. Nesse sentido, a falta de representação também é discriminação e racismo, assim como o desamor, o desafeto, a negação da história de um povo. Ou ainda, como sugeriu Jhon Antón Sanchez, em um balanço do equatoriano Plan nacional para la eliminación de la discriminación racial y la exclusión étnica, "discriminación racial no es apenas prejucio racial. La negación de derechos a pueblos afro es discriminación. La falta de reglamentación de los territórios afro. Racismo ambiental es discriminación" $" 146$.

À guisa de conclusão, proponho retomar a comparação com o Brasil. Se Colômbia, Equador e Brasil convergem no ideal multi ou intercultural por uma sociedade que respeite a diversidade étnico-racial, o conteúdo dessa diversidade difere em cada país. Os diferentes processos de construção da negritude/etnicidade são informados e ao mesmo tempo informam diferentes sistemas de classificação étnico-raciais. Barbary e Urrea traçam paralelos entre tais

\footnotetext{
${ }^{146}$ Frase proferida em reunião de balanço do referido Plano, realizada em Quito, em 8 de dezembro de 2013.
} 
sistemas no Brasil e na Colômbia. Segundo a interpretação dos autores: "En Brasil por el tipo histórico predominante de mestizaje, con una población indígena reducida y el dominio de la mixtura de 'blanco'y 'negro', el término pardo hace referencia a ambas modalidades mulato y mestizo, distinguidas en otras sociedades como la colombiana" (Barbary e Urrea, 2004: 59). Em outro momento, explicam que a brasileira categoria "pardo/a" se aproxima mais da colombiana "mulato/a"147. Interessa-me pensar também a categoria "moreno/a", que opera em ambos os países, apesar de não se fazer presente nos instrumentos censitários de nenhum deles.

No Brasil, ao fim da década de 1970, Gilberto Freyre "pai” do mito das três raças reivindicava que o IBGE incluísse a categoria "moreno" nas operações censitárias. No contexto de discussões em torno da classificação de cor/raça para o Censo de 1980, Gilberto Freyre escreveu o artigo "Brasileiro-sua cor?", publicado no jornal Folha de S. Paulo, em 5 de dezembro de 1979. Apontava que as categorias de cor historicamente empregadas nos censos estavam equivocadas, recomendando adicionar "morena", categoria que, segundo ele, era coerente com a realidade "meta-racial" do Brasil. Em 1995, o mesmo jornal publicou um suplemento titulado "Racismo Cordial: a mais completa análise sobre preconceito de cor no Brasil", desenvolvendo o mesmo argumento de que "morena" era a categoria de cor da mais ampla aceitação entre a população brasileira (Bejarano, 2010: 58-59).

Em 2004, na Colômbia, o movimento negro defendia a presença da categoria "morena" no censo que se realizaria no ano seguinte. Como avaliação dos resultados da Encuesta de hogares 2004 (EH/2004), o DANE realizou uma oficina com representantes dos movimentos sociais negros, "Taller de socialización para población afrocolombiana del censo 2005". Nessa ocasião, segundo Bejarano (2010), o debate centrou-se na inclusão da categoria "moreno", defendida pelos representantes do movimento social até o ponto de o DANE assinar um ata se comprometendo a estudar a inclusão da categoria, mesmo sem ter sido anteriormente testada.

Em 2009, a organização de mulheres negras da Paraíba Bamidelê encabeçou uma campanha, reeditada em 2012, que tinha como lema: "Morena não, eu sou negra". A campanha visava "contribuir para a valorização da raça negra na Paraíba, por meio da

\footnotetext{
${ }^{147}$ Petruccelli (2007) chama atenção para a categoria "pardo/a". Analisando a série histórica censitária brasileira, o autor percebe que a categoria tem certa amplitude e seu entendimento varia bastante em cada região do país (Norte, Nordeste, Centro-Oeste, Sudeste e Sul). Ainda que o Brasil tenha o mérito de apresentar a mesma estrutura censitária ao longo de quatro décadas, o autor argumenta que uma mudança em relação a essa categoria poderia aproximar as pesquisas da percepção da população brasileira sobre sua raça/cor.
} 
afirmação da identidade de negras/os, como também ampliar o debate na sociedade sobre as relações raciais e a necessidade de políticas públicas de promoção da igualdade racial"148.

Sobre o uso da categoria "morena/o" em Cali, Barbary e Urrea explicam que se trata de um eufemismo que pretende sistematicamente esvaziar todo o conteúdo racial explícito, sobretudo quando utilizada por pessoas que não têm ascendência africana visível, até mesmo em situações objetivas de discriminação racial. Assim, segundo os autores, "aos olhos da maioria da população negra e mulata, moreno/a aparece como uma forma paternalista de matizar ou minimizar o estereótipo racista negro/a" (Barbary e Urrea, 2004: 261). Leitura semelhante por parte de movimentos sociais negros brasileiros motivou a campanha referida. Os autores destacam, por outro lado, que essa leitura predomina em contextos associados a certa invisibilidade do fator racial, em ambientes interraciais, por exemplo, o que não é o caso da região em foco.

Nota-se como a mesma categoria é disputada por forças antagônicas no Brasil e na Colômbia, em diferentes momentos da história. O multiculturalismo tem diferentes impactos e apropriações em cada um dos países, conforme ressalta Restrepo (2013). A formação nacional de alteridades, ou o processo de construção dos "outros" da nação, como diz Segato (2007), assume variados contornos, amoldando-se à história do país.

Já vimos que as pesquisas censitárias brasileiras, articulando classificação racial com variáveis socioeconômicas, apontavam para a polarização da população entre brancos/as e não brancos/as. No polo dos não brancos, houve transformações estatísticas ao longo das últimas décadas. Comparando os Censos de 1991 e 2000, Petruccelli percebeu que "as pessoas que se declararam de cor preta aumentaram em mais de 40\% entre os dois censos" (Petruccelli, 2007: 59). Assim, o autor afirma que "está se assistindo ao alvorecer de uma mudança nos padrões de declaração da cor no país" (Idem, ibidem: 79).

Os escritos de Petruccelli reunidos na obra comentada datam majoritariamente dos anos 2000-2001. Uma década e meia depois, podemos dizer que se intensificaram as mudanças, as quais parecem levar à consolidação de uma nova autoimagem do país na leitura étnico-racial, que se reflete, por exemplo, na campanha organizada por Bamidelê. Nesse sentido, pessoas que antes poderiam se reconhecer como "morenas" ou "pardas", passam a se autoclassificar como "pretas" ou "negras". Ou seja, o gatilho desse processo de mudança é o auto-reconhecimento, conforme colocado na introdução. O exercício de afirmação da

\footnotetext{
148 Organização lança Campanha de Promoção da Identidade Negra na Paraíba nesta quinta-feira. Disponível em: http://www.paraiba.com.br/2012/03/29/92361-organizacao-lanca-campanha-de-promocao-da-identidade-negrana-paraiba-nesta-quinta-feira. Acessado em: 8 de setembro de 2014.
} 
negritude reflete um exercício decolonial, uma re-escritura de categorias hegemônicas. Introduzindo sua tese doutoral, a filósofa Sueli Carneiro escreve, desde um ponto de vista pessoal, dirigindo-se ao "Eu hegemônico". A autora afirma: "Como já te adiantei. Eu hegemônico, sou negra, uma juntada de pretos e pardos. Ora não me peças explicações sobre coisas que tu inventaste como esse 'pardo'. Só sei que a cada dia que passa, ele fica mais negro" (Carneiro, 2005: 22).

O discurso da negritude no Brasil conforma uma teia de interações entre ativistas dos movimentos sociais e pesquisadores/as (em especial por pesquisadores/as negros/as), que, em dado momento, reverberou no Estado. Cabe ressaltar que a primeira década do novo milênio corresponde à gestão de centro-esquerda do Partido dos Trabalhadores no Brasil, que reconheceu caber ao Estado o desenvolvimento de políticas de igualdade racial; que trouxe para esse âmbito uma perspectiva de articulação “(d)a luta por salários mais dignos e direitos sociais com a superação do racismo"; "das políticas públicas universais com ações afirmativas", nas palavras de Luiz Inácio Lula da Silva.

Quando tomei posse, em $1^{\circ}$ de janeiro de 2003 , ressaltei que a prioridade da gestão seria o enfrentamento à fome e à profunda pobreza existentes no Brasil, em função da má distribuição de riqueza. Mas ressaltei também a importância de corrigir rotas históricas que levam às desigualdades - como as étnicas e raciais, e as de gênero, entre outras (Silva, 2012: 9).

Destaco aqui algumas políticas que, de modo especial, reverberaram nesse contexto: o Programa Universidade para Todos (PROUNI), as Cotas em universidades e serviço públicos, o Exame Nacional do Ensino Médio (ENEM), o Programa Nacional de Acesso ao Ensino Técnico e Emprego (PRONATEC), o Programa Ciências sem Fronteiras, o Programa BolsaFamília e as políticas voltadas às comunidades quilombolas. Mesmo quando apresentadas como universalistas, na prática e nos resultados, tais ações têm funcionado como ações afirmativas, instrumentos de reparação e promoção da igualdade num país em que todos os indicadores sociais apontam para a população negra como deficitária de direitos e acesso.

Dados relativos a essas políticas e ações revelam que sua incidência principal dá-se sobre o lugar estruturalmente reservado a mulheres negras no imaginário do país: a base da pirâmide social, as ocupações mais humildes, o espaço subalterno, simbolizado na imagem da empregada doméstica ${ }^{149}$. Assim, as mudanças no imaginário sobre as relações raciais no

\footnotetext{
${ }^{149}$ Entre os participantes do ENEM, as mulheres representam 58,11\% dos/as candidatos/as - mais de 5 milhões. $57,91 \%$ dos/as inscritos/as se declararam negros/as e 37,7\%, brancos/as. De acordo com o presidente do Instituto Nacional de Estudos e Pesquisas Educacionais Anísio Teixeira (INEP), Chico Soares, a Lei de Cotas (Lei n. 12.711, de 29 de agosto de 2012) explica a grande participação dos negros no exame. Em 2014, o PROUNI
} 
Brasil passaram a refletir-se em mudanças na estrutura da sociedade brasileira. Políticas de transferência de renda representam a ascensão socioeconômica de parte da população negra brasileira. E a maioria delas é de mulheres. Políticas no campo da educação representam o aumento dos níveis de escolarização da população negra, em sua maioria mulheres, que por vezes são a primeira representante de uma família a ter curso superior. E ações no campo do trabalho e emprego, combinadas com os programas educativos, desencadeiam transformações no padrão do mercado de trabalho, historicamente marcado pelo racismo.

Vale ressaltar que essas transformações não acontecem em um ambiente pacífico. Mulheres negras somam um quarto da população brasileira. A fratura no status quo gerada pela ascensão desse segmento desencadeia reações racistas e nada cordiais. Se a mulher em questão estivesse dizendo que é morena, provavelmente não causaria tanto incômodo. A afirmação da negritude, combinada com a ascensão social, expressa mudanças simbólicas e materiais que representam um duro golpe na ideologia da democracia racial brasileira.

Petruccelli (2007) comentava sobre artigo do Jornal de Brasil de 26 de agosto de 2001, intitulado "As 300 cores dos brasileiros". Os argumentos deste artigo dialogam com as duas matérias do mesmo periódico ora citadas, o artigo escrito por Freyre, em 1979, e o suplemento de 1995. O artigo de 2001 explorava a questão da variada gama de categorias pelas quais a população se autoidentificava nas pesquisas censitárias, as quais não tinham relevância estatística nas pesquisas, conforme explica o autor ${ }^{150}$.

No ano de 2015, matérias jornalísticas com tais conteúdos ainda são produzidas por setores conservadores da mídia brasileira. No entanto, a cada manifestação hegemônica, há uma rede contra-hegemônica em ação, que devolve o olhar, projetando uma sociedade brasileira que se quer cada dia mais negra. Por meio dessa rede, o país depara-se com as desigualdades de modo visceral, as conexões entre exclusão social e racismo saltam aos olhos e a população autoidentificada como negra, a partir do conceito amplo de negritude, denuncia e cobra mudanças nas práticas discriminatórias das quais são alvo ${ }^{151}$.

registrou 653.992 inscritos, segundo o balanço divulgado pelo Ministério da Educação (MEC). O número representa um aumento de $50 \%$ em relação à edição de 2013 . As mulheres foram $59 \%$ do total de inscritos em 2014. A maior parte dos candidatos é negra: 62,6\%. No caso do Bolsa Família, mulheres são maioria na titularidade do acesso ao benefício, que tirou milhões de pessoas da miséria no Brasil.

${ }^{150}$ Partindo das estatísticas, Petruccelli (2007) demonstra a falácia do argumento de que a amplitude das categorias de autoclassificação impede a categorização da população brasileira em qualquer espectro limitado de variáveis. Comparando os resultados de questões abertas e fechadas, ele mostra que as várias nomenclaturas podem ser agrupadas dentro das cinco categorias usadas pelo IBGE, sem prejuízos, pois muitos nomes citados pela população não têm relevância estatística, já que sua ocorrência é muito pequena.

${ }^{151} \mathrm{O}$ episódio de racismo sofrido por um pai e dois jovens negros, em São José dos Campos, interior de São Paulo, mostra bem isso. No meio da rua, o pai reage à abordagem racista dos policiais, que o acusavam de ter 
Wade (1997) comenta a proposta de Silva e Hasenbalg de interpretar a categorização étnico-racial a partir da distinção entre brancos/as e não brancos/as. Para compreender a realidade da Colômbia, ele sustenta outra distinção: a de negros/as e não negros/as.

Los negros en Colombia son una categoría menor y están mucho más concentrados regionalmente; a la población mezclada corresponde tanto el mestizo como el mulato debido a la gran herencia indígena. Por lo tanto, mientras que una distinción blanco/no blanco puede tener más sentido en el Brasil, sostengo que en Colombia una distinción negro / no negro es más apropiada en algunos contextos: es un aspecto del modo en que están espacialmente estructuradas las relaciones de raza (Wade, 1997: 77).

Mara Viveros (2008), refletindo sobre relações sexual-afetivas a partir do recorte racial em Bogotá, também trabalha com essa distinção. Ela ressalta que prefere "hablar de personas no negras para subrayar que la población blanca o mestiza de la capital autodefine su color de piel en forma más relacional que autónoma respecto a lo negro" (Vivero, 2008: 247).

Penso que isso faz sentido. A minha questão refere-se à concepção das referidas categorias. Compartilho com Barbary e Urrea (2004) a ideia de que, como resultado de um longo processo histórico, as relações sociais na Colômbia contemporânea enquadram-se em uma hierarquia racializada, a qual, apesar de variações temporais e regionais, se concretiza sistematicamente em fenômenos de discriminação racial, articulada a outros fatores, que se refletem em diferentes posições econômicas, sociais, culturais, políticas e afetivas. Na leitura diacrônica das categorias étnico-raciais, vimos que a sociedade colonial sempre taxou as pessoas mescladas a partir da carga de negritude que tinham. Então, mulatos, zambos, mestiços eram monitorados e cerceados no exercício de manutenção da ordem racial da Colônia. Depois, no período republicano, o conceito de mestiça/o foi embranquecido. Ou seja, a negritude continuava sendo indesejada. $\mathrm{Na}$ era da nação multicultural, tendo em vista a fusão das categorias branco/a e mestiço/a, pode-se pensar que o polo não negro esteja se homogeneizando e se embranquecendo.

Barbary e Urrea (2004) sugerem trabalhar com os termos população afro-colombiana e não afro-colombiana, que poderia ser escrita pela chave da afrodescendência, sem prejuízos

roubado um tênis, em um centro comercial. O homem negro explicita o preconceito que norteava a ação institucional e reivindica respeito aos $52 \%$ da população que representam negros e negras no Brasil. Ver: Pai compra tênis à vista para os filhos, é tratado como ladrão e dá uma aula de resistência negra para a PM. Disponível em: http://www.geledes.org.br/pai-compra-tenis-vista-para-os-filhos-e-tratado-como-ladrao-e-dauma-aula-de-resistencia-negra-para-pm/\#axzz3CHMUdNSf. Acessado em: 6 de setembro de 2014. 
de entendimento. Nessa abordagem, a afro-colombianidade engloba negros/as e mulatos/as. Como explicam os autores:

estamos aludiendo, en la sociedad colombiana contemporánea, a las poblaciones que de algún modo son descendientes, a través de múltiples generaciones y dinámicas de mestizaje, de los antiguos esclavos africanos, muchos de ellos inicialmente libertos por sí mismos (compra de su libertad o manumisión), mediante cimarronaje o concesión de la libertad por participar en los ejércitos libertadores, y luego en 1851 por la abolición de la esclavitud. Posteriormente [...] la gente negra ha conformado un importante grupo poblacional de nuestra sociedad, que comprende hoy en día desde zonas rurales en donde históricamente había alcanzado la mayor concentración, hasta asentamientos urbanos en las grandes ciudades del país al igual que en ciudades intermedias [...] su inserción social está afectada por mecanismos de diferenciación y discriminación colectiva, vía la segregación residencial urbana, el origen migratorio y el color de piel (Barbary e Urrea, 2004: 52).

Sendo a raça um dispositivo sócio-histórico de exclusão social tanto na Colômbia quanto no Equador, compreendo que os grupos populacionais historicamente excluídos são: negros, mulatos e zambos, acrescentando um termo êmico. Pessoas negras, mulatas e zambas configuram uma alteridade social à branquitude e à figura mestiça idealizada no período republicano. O fato de agrupá-las como afrodescendentes constitui um exercício analítico e político, o que não significa, contudo, homogeneizá-las. Em uma reflexão que cruza pertencimentos de raça e gênero, Jurema Werneck traz essa questão de modo instigante:

As mulheres negras não existem. Ou, falando de outra forma: as mulheres negras, como sujeitos identitários e políticos, são resultado de uma articulação de heterogeneidades, resultante de demandas históricas, políticas, culturais, de enfrentamento das condições adversas estabelecidas pela dominação ocidental eurocêntrica ao longo dos séculos de escravidão, expropriação colonial e da modernidade racializada e racista em que vivemos (Werneck, 2010:10).

É precisamente sobre essa articulação de heterogeneidades a que me refiro por meio da categoria afro-pacífica. Como identidade política, ela aciona diferentes elementos circulantes, estabelecendo nexos entre distintos momentos e sujeitos, permitindo variadas singularizações, como bem coloca Werneck (2010). Tais singularizações expressam-se também nas experiências do racismo e da discriminação na Colômbia e no Equador ${ }^{152}$ : "un racismo difuso y poroso, como dispositivo discriminador no homogéneo y no necesariamente dicotómico, con matices y variaciones que permiten la representación en gradaciones de

\footnotetext{
${ }^{152}$ Assim como Viveros, o racismo aqui é compreendido como uma experiência: a da vítima da designação racista ou do ato racista (Viveros, 2008: 252).
} 
'colores de piel', dependiendo de contextos específicos, urbanos y regionales" (Barbary e Urrea, 2004: 401).

Assim, a regionalização da raça traduz-se em um mapa de desigualdades sociorraciais, seja na Colômbia, seja no Equador. O quesito classe social soma-se ao racial, como explica Eva Lucia: "Hay un clasismo estructural que actúa junto al racismo, entonces si eres una persona negra y pobre, te jodiste. No puedes acceder a la educación, en todas las partes que vas te cierran las puertas porque eres negra"153. Com feito, dados estatísticos explicitam o tema. Indicadores da equatoriana Encuesta nacional de empleo, desempleo y subempleo, de junho de 2010, mostram que a taxa de desemprego da população afro-equatoriana excede a média nacional $(7,4 \%$ e $6,2 \%$, respectivamente). A participação no mercado de trabalho (taxa de ocupação plena) para a população nacional é de 32,6\%, enquanto para afro-equatorianos/as é de $29,7 \%$. No serviço doméstico, a participação da população nacional é de 3,2\%, enquanto afro-equatorianas/os têm o dobro de incidência, 6,3\%. No acesso à educação (nível superior), a média nacional é de $21,5 \%$, enquanto afro-equatorianos/as têm a porcentagem de 12,2\%, quase metade. O acesso à seguridade social (IESS, seguro geral) também é abaixo da média, 20,4\% é o percentual nacional e 17,6\% o de afro-equatorianas/os (CODAE, 2010: 25-29).

No caso da Colômbia, conforme indica Wade (2012), a partir de dados do Censo de 2005, a expectativa de vida de afrodescendentes está abaixo da média nacional em 5,5 anos para os homens e aproximadamente 11 anos para as mulheres. A mortalidade infantil entre a população afro era de 44/100, enquanto a média nacional era de 19/100. 54\% de afrocolombianos/as vivem em situação de necessidades básicas insatisfeitas, enquanto no cenário nacional esse índice é de $47 \%$. A taxa de desemprego entre afro-colombianos/as era de 6\%, ao passo que a taxa nacional era de 3\%. O Pacífico colombiano agrega os piores índices socioeconômicos do país, segundo dados do estudo Los municipios colombianos hacia los objetivos de desarrollo del milenio (DNP-PNUD, 2006) ${ }^{154}$.

A questão da hierarquia racializada perpassa toda a história colombiana e continua a atuar. Sem embargo, a linguagem da etnicidade, em construções do discurso político, acadêmico e jurídico vinculadas ao Pacífico colombiano, englobou a raça. Entendo que a proeminência da etnicidade tem relação direta com a intensa presença indígena na Colômbia, tanto demográfica quanto simbolicamente. Nesse ponto, em comparação com o Brasil, a

\footnotetext{
${ }^{153}$ Entrevista concedida no dia 07 de fevereiro de 2014, em Bogotá.

${ }^{154} \mathrm{O}$ indicador que mede as condições de vida na região está quinze pontos abaixo da média nacional. Entre 1997 e 2003, o Pacífico teve a mais baixa taxa de melhoria das condições de vida do país, $-4,7 \%$. De 133 municípios da região, 117 estão abaixo do mínimo constitucional de 67 pontos do Índice de Calidad de Vida (ICV) (Mosquera Rosero-Labbé e Barcelos, 2007).
} 
etnicidade na Colômbia encontrou terreno fértil na elaboração das diferenças entre grupos sociais no âmbito do imaginário social.

Sem embargo, se o vocabulário político no Pacífico sul colombiano, é centrado na etnicidade, isso não exclui a raça, que é remetida, ainda que de forma indireta. Embora não explicitada em algumas falas identitárias, ela está presente. Trata-se de uma sociedade racializada, onde as diferenças são expressas predominantemente na linguagem da etnicidade. Não é eminentemente racializada, mas é estruturalmente racializada. A regionalização território e cultura - não deixa a raça escapar. Assim, a lógica social racializada serve de substrato tanto para a categoria "raça" quanto para a "etnia", como bem aponta Mosquera Rosero-Labbé (2011), o que se explicita em uma das narrativas de Rosalba Quiñones neste capítulo $^{155}$.

Barbary e Urrea sinalizam como é problemático o deslizamento da raça para a etnia: "El sustituir la noción de raza por la de etnia, afirmando los factores o atributos culturales en lugar de los fenotípicos, no resuelve el problema en el caso colombiano y latinoamericano porque existe un solapamiento ineludible de lo cultural con lo racial" (Barbary e Urrea, 2004: 56). Mosquera Rosero-Labbé (2011) ressalta que a substituição do conceito de raça pelo de grupo étnico minimiza os efeitos do racismo e reifica o conceito de raça, remetendo-o ao reino da "natureza", em contraste com a etnicidade que então falaria sobre a "cultura". A autora destaca ainda que esse movimento de substituição de conceitos se presta a um enfoque liberal do racismo, pois deixa de compreendê-lo como um sistema de dominação mundialmente estruturado e diretamente articulado ao capitalismo.

Cenário mais recente, contudo, contextualizado na Conferência Mundial contra o Racismo, realizada em Durban, em 2001, retoma o discurso em torno da raça. Na produção acadêmica, a raça, o racismo, as ações afirmativas e a questão da reparação histórica entram em foco ${ }^{156}$. Retomando, então, o debate em torno das escolas de pensamento que comentamos ao longo do capítulo, vale ressaltar o trabalho do Grupo de pesquisa sobre igualdade racial, diversidade cultural, conflitos ambientais e racismos nas américas negras (IDCARÁN), do Centro de Estudos Sociais (CES), ligado ao Departamento de Serviço Social. A partir de meados da década de 2000, Claudia Mosquera Rosero-Labé organiza uma série de

\footnotetext{
${ }^{155}$ Rosalba usa a categoria "raça" em referência à dimensão sociocultural: quem compartilha o território e certas práticas culturais pertence à "raça negra" (Ver pp. 87/88).

${ }^{156}$ León (2011) compreende que a raça volta ao campo acadêmico colombiano na década de 1990 em estudos centrados na população negra. Argumenta que, desde então, pesquisas sobre temas raciais estão emparentadas com estudos sobre etnicidade negra. Na antropologia, com Peter Wade, Jaime Arocha, Eduardo Restrepo e Mara Viveros.
} 
publicações do referido grupo, com diversos artigos que abordam tais temáticas na Colômbia e nas Américas Negras de modo geral ${ }^{157}$.

Já no Equador, a meu ver, a politização da etnia não obliterou a dimensão racial com a mesma intensidade, comparativamente ao Pacífico colombiano. A pergunta censitária na última enquete combinava categorias fenotípicas (negra e mulata) e étnicas (afro-equatoriana e afrodescendente). Segundo Charvet (2010), a adoção do termo "afro-equatoriano/a" não substituiu a autoidentificação como negro/a, focalizada no marcador da cor de pele (Charvet, 2010: 352). Nesse país, o vocabulário da afrodescendência parece mais colado ao Estado, como indica a campanha realizada pela CODAE no contexto do Censo de 2010. Movimentos sociais afirmam a negritude. É o caso do Movimento de Mulheres Negras do Norte de Esmeraldas. Inés Morales, explicando-me sobre o surgimento do MOMUNE, diz que foi uma escolha política a identificação como mulheres negras.

En el año 2000 yo viajé a Perú, para una actividad con el Movimiento de Mujeres Afroperuanas. Ahí fue que yo conocí la expresión de las mujeres negras y percibí la necesidad de tener un espacio en el proceso para nosotras, como mujeres. Como aquí manejábamos mucho lo de negro, negra, pusimos Movimiento de Mujeres Negras - Inés Morales.

Sendo a raça e a etnia construções sociais e políticas, cujo sentido é contextual, é mister considerá-las de modo articulado a outras construções sociais e políticas, entre elas o gênero. Raça e sexo/gênero são atribuições naturalizadas, percebidas como intrínsecas; porém, são construções sociais que estruturam um sistema valorativo, dentro do qual se evocam posições de inferioridade e superioridade. Quijano (2011) compara os binômios raça/cor e sexo/gênero, ambos usados como padrão de classificação e hierarquização racial. Ele argumenta que as diferenças sexuais estão sustentadas em aspectos biológicos, enquanto o gênero é uma construção social em torno de tais diferenças. Já raça e cor, ambas, são construções sociais que não guardam qualquer relação com a biologia.

$\mathrm{Na}$ concepção que assumo ao longo da tese, sexo e gênero são pensados conjuntamente, desde uma perspectiva em que aspectos biológicos e construções socioculturais não estão apartados. Assim, entendo que tanto o racismo como o sexismo se nutrem de diferenciações estabelecidas com base em categorias naturalizadas pela anatomia política. Segato (2005) argumenta que, em países como o Brasil, o que estendo à Colômbia e ao Equador, a leitura binária de gênero e raça são crivos automatizados na classificação social

\footnotetext{
${ }^{157}$ Ver Mosquera Rosero-Labbé e Barcelos (2007), Mosquera Rosero-Labbé e Diáz (2009), Mosquera RoseroLabbé, Láo-Montes e Garavito (2010).
} 
das pessoas. Ademais, operam de forma articulada, de modo que o gênero resulta ser também uma categoria racial e a raça uma categoria de gênero. Nesse sentido, pertencimentos de gênero e de raça configuram dimensões fundamentais da estruturação subjetiva. 


\section{CAPÍTULO 2 - GÊNERO, MULHERES E FAMÍLIA}

Qual o significado social do sexo no Pacífico Negro colombo-equatoriano? De que maneiras opera a identificação como mulher e como homem? Essas perguntas fazem sentido desde a perspectiva de que seres humanos são seres biologicamente culturais, que se desenvolvem como pessoa por meio de relações intersubjetivas, em um ambiente específico (Moore, 2007). Assim sendo, tornamo-nos seres sexuados e racializados em um contexto social e em um ambiente que já são genderizados e racializados. Tornar-se um ser sexuado, por sua vez, significa ser marcado pela diferença sexual, reconhecer os limites dessa diferença, lutar com o fato de não se poder mapear facilmente nos corpos machos e fêmeas a masculinidade e a feminilidade (Idem, ibidem: 13). Tornar-se um ser sexuado é uma condição para a subjetividade e para que a sociedade se faça.

Cada sociedade e cultura percorre caminhos singulares na construção do sexo/gênero ${ }^{158}$, a qual se articula com constituição de outras formas de diferença, como raça, etnicidade, classe e religião. Discursos de gênero e raça em qualquer contexto são hierarquicamente organizados, de maneira articulada a iniquidades de poder e recursos. No caso das nações latino-americanas, o gênero e a raça foram constructos coloniais que articuladamente racializaram e genderizaram as sociedades submetidas (Mendoza, 2010). As posições de gênero e raça são fruto de representação e significação cultural, mas também de práxis e relações vividas. Por conseguinte, compreender o sentido de ser mulher afrodescendente no Pacífico colombo-equatoriano na contemporaneidade implica compreender uma série de construções históricas e culturais, as quais tenho acesso por meio das representações e práticas de mulheres afro-pacíficas.

Neste capítulo, recorro às narrativas das mulheres com quem dialoguei, mas também aos escritos antropológicos sobre o tema, com vistas a entender tais questões. No campo etnográfico, a imagem masculina emerge da voz das mulheres. Praticamente, não dialoguei com homens. Conforme colocado na introdução, essa foi uma escolha consciente, inicialmente tomada por uma necessidade minha de escutar as mulheres e reforçada em seguida pela percepção de que há um silenciamento das vozes femininas nas organizações negras na Colômbia e no Equador, o que não difere muito do Brasil. Segundo relatado pelas

\footnotetext{
${ }^{158}$ Sexo designa o corpo sexuado, enquanto gênero alude à identidade a ele associada. Ambos são cultural e socialmente construídos, já que o corpo não precede representações subjetivas e sociais: "there are no lived biological attributes without representations of biological attributes" (Moore, 2007: 189). É o gênero que cria o problema da diferença sexual, na medida em que ele demanda repetições posteriores. Gênero é o porquê de macho e fêmea nunca serem suficientes (Idem, ibidem: 160).
} 
mulheres com quem dialoguei, trata-se de uma invisibilização feminina no contexto político, ainda que mulheres sejam protagonistas dos processos organizativos negros. Nesse sentido, situo a tese nos marcos de um projeto investigativo cujo propósito consiste em que as mulheres sejam sujeitos ativos, de maneira que a pesquisa seja feita com e para elas (Labrecque, 1998: 32). Assim, o foco de atenção ao longo deste texto são as representações femininas contemporâneas sobre o significado social do sexo/gênero nesse contexto.

Começamos delineando brevemente a história dos estudos concernentes ao tema na Colômbia e no Equador, bem como a contextualizando no mundo. Sobre o contexto colombiano, observando os percursos da antropologia no país e dos movimentos de mulheres (e sua influência sobre as ciências sociais), Bejarano situa a antropologia cultural colombiana em uma trajetória que parte de estudos sobre a família colombiana, passando pela “antropologia da mulher", chegando à "antropologia de gênero" (Bejarano, 1995: 32). Nancy Motta González recorre à mesma periodização e explica o enfoque das escolas:

en los Estudios de la Mujer, el eje de análisis es la mujer por referencia al ombre privilegiando su condición de sujeto social subordinado; en los Estudios de Género, el referente es el ser humano como actor social y entonces el análisis se desplaza al terreno de las relaciones hombre/mujer y a los determinantes históricos y culturales de sus identidades sexuadas (González, 1995: 7-8).

Segundo Moore (1991), a antropologia, de modo geral, seguiu percursos parecidos com o que Bejarano (1995) e González (1995) apontam no campo colombiano. Moore destaca o tradicional interesse antropológico pela família, desde a gênese da construção desse campo do saber. Na década de 1970, em um contexto no qual a antropologia articulava o mundo em idioma masculino, surgiu uma corrente denominada "antropologia da mulher", que, contudo, mantinha um viés androcêntrico (Moore, 1991: 16). A autora assinala a importantíssima diferença entre "antropologia da mulher" e "antropologia feminista"159, a qual "franqueia a fronteira do estudo da mulher e se adentra no estudo do gênero, da relação entre a mulher e o homem, e do papel do gênero na estruturação das sociedades humanas, de sua história, ideologia, sistema econômico e organização política"(Idem, ibidem: 18) ${ }^{160}$.

Conforme exposto por Viveros e Zambrano (2011), na antropologia, a gênese das reflexões sobre sexo/gênero remonta aos anos 1930 e refere-se à ideia de que diferenças entre homens e mulheres são construções socioculturais e não fatos biológicos. Na antropologia, a

\footnotetext{
${ }^{159}$ Sobre a passagem dos estudos da mulher para os estudos de gênero, ver: Machado, 1992.

${ }^{160}$ Texto em espanhol, tradução livre.
} 
clássica obra de Margaret Mead sobre "sexo e temperamento" em Samoa, datada de 1935, em discussão em torno dos papéis sexuais, evidenciou a partir de dados etnográficos a dimensão cultural na definição dos comportamentos sexuais, apontando a relatividade e a variabilidade das categorias "mulher" e "homem", desconstruindo, assim, as premissas de um essencialismo biológico e de um determinismo natural. Na filosofia, Simone de Beauvoir (1949) inaugurou reflexões que questionam a naturalização do sexo/gênero a partir de sua afirmação: "não se nasce mulher, torna-se mulher".

A menção à "antropologia feminista" leva-nos a uma breve reflexão sobre interfaces entre antropologia e feminismo. Machado (2010) percebe que o pensamento antropológico é tributário do direito à diversidade cultural, enquanto os direitos à igualdade de gênero podem ser atribuídos ao pensamento feminista. De modo geral, ambos os campos são refratários ao tema primordial de cada um deles. Ou seja, os saberes antropológicos minimizam ou fazem desaparecer a percepção das formas desiguais de poder nas relações de gênero, ao passo em que os saberes feministas transversalizam as desigualdades de gênero na análise das diversas culturas ou minimizam o efeito da diversidade cultural relativa às formas de desigualdade e de violência nas relações de gênero.

Viveros (2007) e Viveros e Zambrano (2011) fazem essa reflexão especialmente a partir do lugar da "diferença", inquietude constante, seja na história do feminismo ou na história da antropologia. Viveros (2007) trabalha com a periodização proposta por Nancy Fraser para compreender a discussão sobre a diferença no feminismo do século XX. A primeira fase corresponderia ao fim dos anos 1970 até meados dos 1980, durante a qual o foco era a diferença de sexo. Da segunda metade dos anos 1980 ao início da década de 1990, a atenção volta-se às diferenças entre mulheres. Na fase em curso, as análises estruturam-se em torno das múltiplas diferenças e suas intersecções.

Segundo Moore (1991), a redefinição do projeto de "estudo da mulher" para "estudo do gênero" partiu de uma reestruturação crítica da categoria unitária "mulher". Assim como Viveros (2007) e Viveros e Zambrano (2011), Moore ressalta que, desde o fim da década de 1980, tem curso um processo de reconciliação da antropologia feminista com as diferenças reais entre as mulheres. Nesse sentido, em certa medida, cruza-se a condição feminina com questões de raça/etnia, classe, geração, orientação sexual-afetiva, entre outras. Segundo Moore, trata-se de um resurgir da diferença em detrimento da semelhança (Moore, 1991: 24).

No feminismo estadunidense, durante a década de 1970, antropólogas como Sherry Ortner (1972) e Michelle Rosaldo (1974), e ainda a psicóloga e escritora Betty Friedan 
(1977), entre outras, escreviam artigos e organizavam livros que se transformaram em clássicos da literatura feminista mundial. Essa produção intelectual, a qual se estruturava sobre um conceito de mulher situado a partir da experiência de mulheres brancas de classe média-alta, consolidou-se como hegemônica. A partir da década de 1980, foram publicados os primeiros textos da teoria feminista negra: muitos deles da escritora bell hooks (1981, 1984, 1989), mas também da filósofa Angela Davis (1982), das educadoras e escritoras Gloria T. Hull, Patricia Bell Scott e Barbara Smith (1982), e da socióloga Patricia Hill Collins (1990), já no início da década seguinte ${ }^{161}$. Nas décadas ulteriores, quando paulatinamente se visibilizou a produção intelectual de mulheres negras, em um processo que ficou conhecido como a segundo onda do feminismo, o projeto hegemônico passou a reconhecer a diversidade das mulheres e, assim, a diversidade de modos de pensamento feministas.

Como plataforma de articulação entre teoria e ação, o feminismo afro-estadunidense, ainda que tenha ganhado visibilidade nos anos 1980, remonta ao século XIX. Conforme ressalta Jabardo (2012), investigar sua base genealógica leva-nos ao discurso de Sojourner Truth, intitulado “Ain't I a Woman?" e proferido na Convenção dos Direitos da Mulher em Akron, Ohio, EUA, em 1852. Nesse sentido, a gênese do feminismo negro, segundo Jabardo, é a resistência ao contexto escravista e algumas de suas marcas são: a forma coletiva de produzir conhecimento e a oralidade como uma de suas plataformas de existência. Segundo Jabardo:

Sojourner Truth deconstruye la categoría (hegemónica) de mujer - una categoría desde la que se la niega - reivindicando su propia identidad en tanto que mujer. La intersección de la "raza" con el género, que desde el sistema hegemónico construye a las mujeres negras como no-mujeres, reaparece en el discurso de Sojourner en términos inclusivos. Detrás de su “¿Acaso no soy una mujer?”, detrás de las luchas de otras ex esclavas como Harriet Jacobs, aparece un anhelo que pugna por resignificar el término mujer. Su aspiración era ser libres, no sólo de la opresión racista, sino también de la dominación sexista (Jabardo, 2012: 29).

Ou seja, desde sua base fundacional, o feminismo negro estadunidense reposiciona o sentido de ser mulher, contrapondo-se a um conceito do feminino forjado em um contexto dentro do qual nunca coube a experiência de mulheres negras. Segundo Henrietta Moore, uma definição minimalista do feminismo o identificaria como a tomada de consciência da opressão e da exploração da mulher no trabalho, no lar e na sociedade, assim como a iniciativa política

${ }^{161}$ Outros tipos de produção, como a literária, datam de período anterior. Por exemplo, já na década de 1960, Audre Lorde, que também tem proeminência na teoria feminista afro-estadunidense, publicava suas poesias. Em 1980, Lorde junto com Barbara Smith e Cherríe Moraga fundaram a primeira editora estadunidense para mulheres de cor, a Kitchen Table: Women of Color Press. 
deliberada tomada pelas mulheres para retificar essa situação (Moore, 1991: 23). Esse conceito parte da premissa de que há uma real ou potencial identidade comum a todas as mulheres, cujos interesses formam um corpo unitário. No cenário estadunidense, o que o feminismo negro denunciou é que essa pretensa unidade correspondia a um tipo de experiência feminina, que era a das mulheres brancas de classe média-alta.

Segundo Viveros (2007), que é vinculada ao Centro de Estudos de Gênero da Universidad Nacional, Colômbia, ao contrário do que ocorreu nos EUA, o feminismo em seu país não construiu a categoria "mulher" ancorada na experiência feminina urbana e de classe média. As diferenças de classe desde o início foram problematizadas em estudos feministas, em consequência do legado marxista na formação de várias pesquisadoras feministas colombianas. Porém, consideraram-se apenas as diferenças de classe. Pertencimento étnicoracial, orientação sexual-afetiva, grupos etários, entre outros temas não foram tocados. As diferenças culturais e os processos identitários coletivos não são cabalmente tratados nos estudos feministas colombianos, como ressalta Viveros, tampouco a compreensão das conexões entre diferenças e desigualdades sociais. Segundo Viveros e Zambrano (2011), isso se deve à matriz eurocêntrica de muitas das teorias feministas, mas também ao temor de ver debilitado o sujeito do feminismo, ao se considerar as múltiplas diferenças existentes entre as mulheres, o que extrapola o âmbito acadêmico.

Viveros reflete sobre as implicações do cenário descrito no campo político:

En el ámbito político, la separación de los intereses de clase, étnico-raciales y de género y sexualidad ha producido una serie de cegueras mutuas y ha puesto en evidencia los límites de estas separaciones hacia la dificultad de incluir los temas del género y la sexualidad en la agenda de los movimientos étnico-raciales; los temas de raza y discriminación racial en la agenda de los movimientos feministas y antiheterosexistas; y el tema de la homofobia y la misoginia en la agenda de los movimientos sindicales (Viveros, 2007: 181).

Importante dizer, conforme contextualiza a autora, que mobilizações em torno de identidades étnico-raciais ganham corpo na Colômbia a partir da década de 1990, impulsionadas pelo reconhecimento constitucional do caráter multiétnico e pluricultural da nação colombiana, rompendo com a tradição republicana fundada no princípio da igualdade.

Avançando na reflexão, Viveros (Ibidem) ressalta a falta de diálogo entre a produção acadêmica colombiana no campo dos estudos de gênero e as mobilizações políticoorganizativas de mulheres que reivindicam um pertencimento étnico-racial diferenciado, sobretudo afro-colombianas e indígenas. Conclui que: “los programas de género requieren 
desarrollar actitudes de autorreflexión acerca de las convergencias entre el tipo de herramientas analíticas que emplean y la composición social y étnico-racial de quienes, de hecho, teorizan el género en el ámbito académico colombiano" (Viveros, 2007: 185).

Segundo Gioconda Herrera, em uma antologia sobre gênero que data de 2001, no Equador, os estudos de gênero são um campo do saber em construção nas ciências sociais do país. À luz de Joan Scott, que também subsidia a conceituação de gênero na Colômbia, a autora define o objeto de estudo desse campo como a "indagación sobre el sentido atribuido a lo masculino y lo femenino en determinado contexto cultural e histórico, su expresión en las estructuras sociales, las instituciones, las normas y los símbolos, y sobre la forma en que estas construcciones culturales otorgan significado a determinadas relaciones de poder" (Herrera, 2001: 9). Informa que se trata de uma produção mais localizada em estudos extraacadêmicos, vinculadas a ONGs, fundações e organismos internacionais, em práticas relacionadas às políticas públicas e na perspectiva do gênero e desenvolvimento ${ }^{162}$. Aponta, pois, para uma ausência da discussão teórica em torno da categoria analítica "gênero" dentro das ciências sociais equatorianas.

Herrera historiciza, então, os estudos de gênero equatorianos, cujo caminho encontra semelhanças com a Colômbia. A autora ressalta que, de modo geral, há um desequilíbrio regional. Pouca atenção é dada às relações de gênero na Costa, sendo que a maioria dos trabalhos se concentra na Serra. Na década de 1980, alguns centros e organizações não governamentais vinculadas à defesa dos direitos das mulheres passaram a abordar as questões das mulheres com certa especificidade. Até a entrada dos anos 1990, segundo a autora, fala-se mais de "investigaciones sobre la mujer" do que de gênero. A partir de então, aparece um conjunto de pesquisas sobre variadas dimensões das relações de gênero, realizadas por pesquisadoras europeias e norte-americanas, por acadêmicas equatorianas e por centros nacionais de pesquisa aplicada. Cada um desses campos privilegia determinados temas, atores e perspectivas de análise, de modo que o significado do gênero assume diferentes acepções dependendo do campo de onde se produz o saber. A autora avalia que há pouca comunicação entre esses campos e que isso restringe a legitimidade da área de estudos de gênero dentro das ciências sociais equatorianas.

No tocante aos temas privilegiados nos estudos de gênero equatorianos, Herrera fala sobre um campo que ressaltava a importância do espaço doméstico, das relações interpessoais e da intimidade como lugares relevantes da análise das desigualdades sociais e de gênero.

\footnotetext{
${ }^{162}$ Há uma linha de políticas públicas implementadas nos anos 1990 no Equador que se chamou Mujer en el Desarrollo (MED ), que gerou análises no campo dos estudos de gênero.
} 
Nesses estudos, a maternidade é abordada como um contexto em que se constitui a identidade feminina, ao mesmo tempo como lugar de construção da subordinação da mulher. Nessa primeira fase dos estudos de gênero, segundo a autora, pouco se articula gênero com outras dimensões da desigualdade social, como a sexualidade, etnicidade, raça e classe social, ainda que haja algumas exceções, como o trabalho de Paloma Fernández-Rasines (2001) com mulheres afro-equatorianas. Na primeira década do milênio, as pesquisa em gênero tratavam da presença e da intervenção das mulheres em espaços públicos. Algumas buscavam entender o sentido da participação de mulheres em processos organizativos diversos, em nível comunitário e em movimentos sociais. Ainda assim, a autora sublinha a ausência de reflexões sobre movimentos feministas, suas práticas e discursos, e sobre lideranças locais e nacionais.

No caso das mulheres e relações de gênero no meio rural, as pesquisas situam-se a partir da década de 1980, antecedendo aos estudos urbanos, políticos e econômicos. Inicialmente, concentraram-se nos temas da participação das mulheres na economia camponesa e das relações de gênero no mundo indígena. Nesses estudos, segundo Herrera (2001), a posição das mulheres é estudada a partir da família, que aparece como espaço de realização das estratégias de reprodução e como unidade de referência, além de ser âmbito de formação das identidades de gênero. A crítica da autora refere-se ao fato de que, nesses estudos, mulheres camponesas e indígenas ainda não aparecem como sujeitos culturais que se modificam em processos de transição dos sistemas camponeses e indígenas em relação com o capitalismo ou com a cultura ocidental. Na década de 1990, os estudos privilegiam a dimensão cultural da análise, em detrimento da perspectiva socioeconômica que predominava na etapa anterior. Passam a enfocar a situação e a condição das mulheres frente ao desenvolvimento rural, bem como abordam o sentido das relações de gênero em um contexto não ocidental. Já na década seguinte, pesquisas apontavam para uma tendência analítica homogeneizadora das mulheres rurais e começavam a discutir a instrumentalização da perspectiva de gênero no discurso do desenvolvimento e sua progressiva despolitização. No caso de gênero e ambiente, aborda-se o tema do manejo dos recursos naturais e da conservação da biodiversidade, sendo alguns trabalhos realizados no marco conceitual do Manejo de ecosistemas y recursos con énfasis en género (MERGE).

Nas abordagens da historiografia equatoriana sobre trajetórias de mulheres e construções culturais de gênero, a história oral e os relatos de vida são ferramentas metodológicas fundamentais. Um exemplo são as pesquisas sobre líderes indígenas, empreendidas por Raquel Rodas. Penso que a presente proposta investigativa dialoga também 
com essa abordagem, pela ênfase nas histórias de vida, especialmente de mulheres afropacíficas que protagonizam processos político-organizativos.

Por fim, interessa-me mencionar uma linha contemporânea, a de gênero e nação. Gioconda Herrera junto com Mercedez Pietro (2007), ambas professoras do Programa de Estudos de Gênero da FLACSO, Equador, situam essa linha de pesquisa em uma análise que ao mesmo tempo considera as representações hegemônicas de projetos nacionalistas e as diversas manifestações de resistência a seu programa normalizador. Sendo a nação um conceito construído com múltiplas vozes, as relações de gênero, as mulheres, seus corpos e suas representações disputam narrativas sobre a nação. Essa perspectiva parece buscar preencher a lacuna apontada por Herrera (2001) no tocante às relações entre gênero, poder, Estado e cidadania no Equador.

Conforme ressalta Herrera (Ibidem), estudos de gênero enfocando mulheres afroequatorianas são poucos. Além do citado trabalho de Paloma Rasines (2001), Erika Charvet (2010) sistematizou trabalhos de pesquisa em torno da feminilidade e da masculinidade na cultura afro-equatoriana. Já no campo da produção intelectual e técnica colombiana, há vários artigos e algumas teses e livros baseados em estudos etnográficos com mulheres negras na Colômbia. Meu foco de atenção voltou-se especialmente aos trabalhos sobre mulheres afropacíficas $^{163}$.

A categoria gênero articula a narrativa de muitas mulheres com quem dialoguei. Mailen Aurora Quiñones é liderança do Baixo Rio Mira, Tumaco, Colômbia. Em sua explicação sobre a atuação das mulheres do Baixo Rio Mira no âmbito do Conselho Comunitário, a categoria é central:

Yo decía a mi compañera Cecilia. Mira: eso lo vamos a manejar como mujeres. Reconocer que somos parte de la Junta y somos un género, porque también hay cinco hombres. Pero a través los cinco hombres, siempre ella pedía la palabra: deme un espacio que yo quiero hablar lo de las mujeres y siempre a ella la dejaban con la palabra en la boca. Ahora queremos demostrar a ellos que inosotras también podemos! Y lo que más le queremos enseñar es que lo' vamos incluir a ellos. Nosotras como mujeres no vamos a desconocer el género. O sea, enseñándoles como deben ser las cosas. No con peleas ni con golpes pero sino con acciones, actuando - Mailen Quiñones.

${ }^{163}$ Entre eles, destacaria: Asher (2009); Camacho (2004); Camacho e Tapia (1997); Cuesta (1997 e 2004); Espinosa e Friedemann (1993); Friedemann e Espinosa (1995); Lopéz (1997); Mena García (1993); Mujeres Afrocolombianas (2011); Rincón (2004); Red de Mujeres Negras del Pacífico (1997); Rodriguez (1997); Zapata (1985, 1987 e 1993). 
Parece que o "gênero" ganha sentido pela dimensão relacional que evoca. "Gênero é uma capacidade relacional em vez de ser uma série de atributos" (Moore, 2007: 185). Nota-se isso também na fala de Eva Lucia Grueso, mais uma líder do Baixo Rio Mira e uma das figuras centrais do Processo de Comunidades Negras no Pacífico sul colombiano: "el trabajo es conjunto. Entendemos que no podemos andar solas, el hombre tampoco. No se trata de hablar de mujeres pero de género, mujeres y hombres"164.

Já o termo "feminismo" é desconhecido pela maioria de minhas interlocutoras e recusado por outras. Eva Lucia Grueso, em diálogo ocorrido em junho de 2012, na minha primeira incursão a campo, afirma que, há cerca de seis ou sete anos, as mulheres do colombiano Proceso de Comunidades Negras assumiram o desafio de investigar o que significa ser mulher afro-colombiana:

¿Qué es ser mujer afrodescendiente o mujer negra en Colombia? Desde lo
urbano, desde lo rural, desde los orígenes que estamos pegadas. Nosotras
mujeres negras estamos conversando sobre eso y llegamos a la conclusión
que no tenemos mucho que ver con el devenir político de las mujeres afro-
yanquis. Porque cualquier cosa nosotras planteamos desde la familia y
desde el territorio. Traer para acá la historia de mujeres negras de los
Estados Unidos, desconociendo que acá hay una historia, no funciona.
Tenemos el reto de construir un discurso propio. Entonces, tengo dificultad
en aceptar la palabra feminismo. Es eurocéntrico ${ }^{165}$ - Eva Lucia.

A apreciação sobre o feminismo que Eva propõe me parece ao encontro da crítica que tece a intelectualidade feminina negra dos EUA ao feminismo hegemônico, especialmente no tocante à pretensa homogeneidade da categoria "mulher". Por outro lado, percebo na fala de Eva Lucia um questionamento ao uso do "feminismo" como um guarda-chuva que abarcaria as variadas e diversas formas de resistência de mulheres negras ao racismo e ao sexismo. Esse questionamento ecoa em reflexões de mulheres afro-brasileiras, que preferem dispor de outras categorias para nomear tais experiências de luta e subversão, categorias que encontram lastro na trajetória local de mulheres negras.

Jurema Werneck, por exemplo, enfatiza que o conceito "feminismo" foi forjado na luta de mulheres brancas burguesas europeias a partir da década de 1970, desde uma perspectiva ocidental, fundada na ignorância sobre outras mulheres do mundo e fundamentada no individualismo crescente, inerente à lógica do capital. Ela questiona a capacidade desse conceito em abarcar todas as mulheres, todo o ativismo, toda luta. Explica que as conquistas individuais na luta pela emancipação de mulheres negras são como veículos para gerar

\footnotetext{
${ }^{164}$ Entrevista concedida em 26 de junho de 2012.

${ }^{165}$ Entrevista concedida em 26 de junho de 2012.
} 
transformações na vida da população negra. Werneck explicita "a impossibilidade prática de dissociação entre patriarcado, racismo, colonialismo e capitalismo - tudo parte do mesmo 'pacote' de dominação do ocidente sobre as demais regiões do mundo" (Werneck, 2005: 2).

Para conceituar a representação política das mulheres negras contemporâneas, ela retoma o conceito de ialodê ${ }^{166}$, que faz referência a lideranças políticas femininas de ação fundamentalmente urbana, figuras emblemáticas, representantes das mulheres. Contemporaneamente, ialodês são mulheres que assumem papéis de liderança ou responsabilidade coletiva; afirmam sua presença a partir de narrativas corporais e orais, nos diferentes espaços onde as tradições são herdadas e atualizadas. São mulheres que se colocam como agentes políticos de mudança, detentoras principais das riquezas conquistadas. $\mathrm{O}$ conceito de ialodê diz respeito a "dimensões de luta, de instabilidade de posições, de poderes de agenciamento e transformação capazes de serem vividos pelas mulheres" (Idem, ibidem: 8). Com isso, Werneck explicita que as lutas de mulheres negras contra o racismo e o sexismo, ou contra "o patriarcado e a dominação política e econômica associadas a ele" são muito anteriores ao feminismo como teoria (Idem, ibidem).

As ialodês chegaram ao Brasil junto com africanos e africanas escravizados. Trata-se de um título dado a Oxum, divindade cuja gênese está ligada à Nigéria, África, em Ijexá e Ijebu, e a Nanã, "assinalando seu poder de ligar passado e futuro, unindo fecundidade e morte desde uma perspectiva de tempo cíclico, suas continuidades e transformações" (Idem, ibidem: 13). A autora compreende que as modalidades de organização, assim como as formas de representação e ação política das mulheres africanas e suas descendentes no Brasil "vêm de uma África mítica, imaginada; de uma África que é real, porém traduzida" (Idem, ibidem: 5). Isso porque a escravização representou para essas mulheres uma ruptura profunda com formas antigas de exercício do poder, fosse em âmbito individual, corporal, fosse no coletivo, em aspectos políticos e de relação com o sagrado.

O texto de Werneck explicita as intersecções entre raça, gênero e colonialidade. Ela ressalta a dimensão de contestação ao sistema capitalista-burguês que as formas organizativas das mulheres negras contemporâneas carregam. Mara Viveros (2007) ressalta a crítica à colonialidade como dimensão ausente do pensamento feminista pós-modernista estadunidense e europeu. Nesse sentido, a autora recorre aos debates do feminismo de color ou feminismo terceiro-mundista ${ }^{167}$. Trata-se de reflexões acadêmicas e plataformas políticas que articulam

\footnotetext{
${ }^{166}$ Forma brasileira para a palavra iorubana Íyálóòde (Werneck, 2005: 6).

${ }^{167}$ Viveros (2007) destaca que correntes feministas ligadas às críticas pós-coloniais e à teoria queer também consideram a multiplicidade de relações de poder que atravessam o grupo das mulheres (2007: 163).
} 
racismo e heterossexismo com os efeitos da colonização, descolonização e migrações transnacionais. Buscam compreender o local em sua relação com processos transnacionais mais amplos, práticas do capitalismo global. Tudo isso atravessado pelos pertencimentos e as opressões de raça/etnia e de gênero.

Do ponto de vista da produção intelectual, o feminismo situado nos EUA e na Europa, pelo seu próprio lugar de fala, pode incorrer em eurocentrismo e deixar de fazer a crítica à colonialidade. Do ponto de vista do devir político, há distanciamentos entre a perspectiva de mulheres afro-pacíficas e de mulheres negras estadunidenses, como aponta a narrativa de Eva Lucia. Para além das diferentes condições históricas que envolvem mulheres afrocolombianas e afro-estadunidenses no cenário da geopolítica mundial, há embates contemporâneos entre Colômbia e Estados Unidos, os quais afetam diretamente mulheres negras colombianas. Refiro-me principalmente a temas relacionados ao narcotráfico e ao conflito político armado.

Feitas tais considerações, ressalvo que, desde meu ponto de vista, a epistemologia do feminismo negro estadunidense oferece ferramentas interessantes para a nossa produção textual. Há um pioneiro acúmulo de reflexões escritas sobre a construção do conhecimento protagonizada por mulheres negras. Ademais, como sublinha Jabardo, “al colocar en el racismo el epicentro de la desigualdad de las mujeres negras, el feminismo negro estadounidense abrió la puerta a otros feminismos" (Jabardo, 2012: 45). Nesse sentido, países latino-americanos também têm se destacado no campo do saber que cruza pertencimentos e opressões de raça, gênero, classe social e outros fatores. Sueli Carneiro e Jurema Werneck são dois exemplos incontestes no Brasil. Na Colômbia, Mara Viveros, Betty Ruth Lozano Lerma, Ochy Curiel, Claudia Mosquera Rosero-Labbé têm escritos importantes no tema.

Ademais, se nossa maneira de produzir conhecimento é coletiva e por vezes tem a oralidade como plataforma de existência, penso que é pertinente tomar as narrativas que construí junto com as interlocutoras dessa pesquisa como fonte epistemológica. Nesse sentido, a territorialidade constituiu-se como um eixo de análise e a família um lugar privilegiado para se pensar sobre o significado social do sexo. A fala de Eva Lucia Grueso, portanto, reforçou minha prévia sensibilidade de que "território" e "família" são caminhos importantes para compreender o sentido da existência dessas mulheres. Trilhando esses caminhos, busco me situar a partir de um ponto de vista que procura desvendar as relações de desigualdade e poder, levando em conta, ao mesmo tempo, o ponto de vista situado das 
mulheres ao ocuparem certos lugares dentro do território e da família ${ }^{168}$. A subjetividade dessas mulheres se constrói a partir das posições que elas ocupam na família e no território. A maneira pela qual elas concebem a família e a territorialidade é chave para sua agencialidade.

\section{A CONSTRUÇÃo dO FEMININO E dO MASCULINO A PARTIR DA FAMÍLIA}

$\mathrm{Na}$ literatura antropológica colombiana, as imagens sobre feminino e masculino afropacíficos emergem da família. A masculina parece estar colada à poligamia, enquanto a feminina está diretamente associada à maternidade. Em ambos os casos, mulheres e homens são centralizados no contexto da família, que tem sido um espaço ímpar para se pensar a construção social do sexo no Pacífico Negro. Estudos feministas de distintas disciplinas e correntes situam a família como o centro da opressão da mulher na sociedade.

$\mathrm{Na}$ busca pela compreensão do sentido de família para as mulheres com quem dialoguei, ao atentar-me às variadas estratégias de resistência dessas mulheres, faço um exercício de compreender especialmente a posição feminina nesse contexto, a qual percebo como ambivalente. As mulheres com quem dialoguei narram experiências de opressão e violência em relações sexual-afetivas, mas também situam vivências ligadas à família como fonte de empoderamento.

Conforme explica Camacho (1999 e 2004), estudos clássicos sobre família negra na Colômbia caracterizavam-na como instável, disfuncional, ilegítima, desordenada, poligínica, com um pai ausente em razão da sazonalidade das atividades produtivas masculinas dispersas pelo território e uma mãe ancorada no território, eixo central da família extensa (Camacho, 1999: 109). A autora refere-se especialmente aos escritos da antropóloga Virginia Gutiérrez de Pineda, pioneira em estudos sobre a família na Colômbia, publicados ao longo da década de $1960^{169}$. Gutiérrez de Pineda, numa análise que zonificou o país em complexos culturais, classificou a população negra do litoral no complexo cultural "Negroide" ou "Litoral FluvioMinero".

Contrapondo-se a essa abordagem, Nina de Friedemann e Monica Espinosa, ao longo da década de 1990, realizaram estudos sobre o desempenho da mulher afro-colombiana na

\footnotetext{
${ }^{168}$ A referência é a teoria metodológica do standpoint, que considera que o conhecimento é socialmente situado e que as posições dos sujeitos em uma sociedade e cultura são relacionais, não são idênticas ou uniformatadas (Sandra Harding, 1991 e 2004).

${ }^{169} \mathrm{Na}$ periodização acima comentada, Gutierréz de Pineda enquadrar-se-ia no primeiro momento, dos estudos sobre a família.
} 
família. Nessa tese, atento-me especialmente aos estudos das autoras que abordam a família do litoral pacífico no contexto da mineração ${ }^{170}$. Segundo Friedemann e Espinosa (1993a), as famílias negras nesse contexto se organizavam em sistemas de troncos ou ramagem, cuja gênese pode ter sido a estrutura das quadrilhas, narrada por Romero (1991). Elas explicam que os grupos de descendência se assemelham a troncos de uma árvore que se enraíza nos terrenos auríferos. São grupos de parentes consanguíneos que remontam sua linhagem por via materna ou paterna, até um antepassado homem ou mulher fundador da descendência. São regidos por princípios de solidariedade, cooperação e respeito, marcados pela presença constante da consanguinidade e de regras exogâmicas de conjugalidade. O pertencimento a um tronco confere direitos de residência, de trabalho e herança sobre as terras de mineração e de cultivos agrícolas.

De acordo com as autoras, a exogamia permite que sempre se mesclem diferentes troncos, o que propicia a constituição de uma rede de reciprocidade entre eles, bem como a mobilidade ao longo dos rios. González (1995) também ressalta que a família afro-pacífica se caracteriza por um esquema fortemente exogâmico de circulação masculina, entre troncos distintos, com residência feminina da prole e com a construção de redes de apoio na criação, na socialização e na identificação da mesma prole por meio da parentela materna.

Friedemann e Espinosa propõem uma análise da família extensa negra fora do paradigma da família nuclear. Situam a ideia de família nuclear como uma construção datada, europeia, referenciada no desenvolvimento do capitalismo e no crescimento urbanístico, ao longo dos séculos XVIII e XIX. Denunciam preconceitos racistas que subjazem a teorias e obras antropológicas, particularmente em conceitualizações de arranjos familiares não ocidentais. Buscam distanciar-se, portanto, da concepção antropológica clássica de família, desenvolvida por Malinowski (1913), que argumentava ser a família uma instituição universal. Segundo as autoras, desde a perspectiva que toma por referência a família nuclear, famílias afro-pacíficas foram alvo de uma conceituação estereotipada pela antropologia, na qual as mulheres são o centro do lar, enquanto o homem hipersexualizado mantém relações com várias mulheres ao mesmo tempo e permanece longe da educação e do sustento dos filhos. Recorrendo a Henrietta Moore (1991), as autoras desconstroem as categorias

\footnotetext{
${ }^{170}$ Em Friedemann e Espinosa (1993b), há uma análise sobre o Palenque de San Basílio, em que Friedemann realizou pesquisas que foram registradas no livro Ma N'gombe: guerreros y ganaderos en Palenque (1979). As autoras apresentam ainda uma reflexão sobre o sistema cultural afro-colombiano nas fazendas.
} 
universais "homem" e "mulher" e dissolvem a noção de "subordinação universal da mulher", para dar passo a um estudo da diferença (1993b: 98$)^{171}$.

Buscando compreender as peculiaridades da construção do gênero entre grupos negros e suas formas de organização familiar, Espinosa e Friedemann recorrem ao conceito das "huellas de africanía". Assim, as formas familiares dos grupos negros do Pacífico seriam reelaborações diaspóricas de linhagens, famílias extensas ou padrões poligâmicos africanos. Baseando-se em Sudarkasa (1980), elas argumentam que o mais importante legado africano à diáspora é o que provém da família extensa; constelação de indivíduos que descendem de um/a ancestral fundador/a do grupo, na qual os vínculos consanguíneos têm mais importância que os conjugais, em que o ciclo conjugal possui uma fase monogâmica seguida de outra poligâmica. Ou seja, não se trata de famílias múltiplas com um esposo-pai em comum. Tratase de uma família, seja quando o homem tem uma mulher e filhos, duas mulheres e filhos ou várias mulheres e filhos.

A estabilidade desse arranjo familiar provém do exercício de direitos de consanguinidade no grupo familiar (em geral de base poligênica) e não da união conjugal, segundo as autoras. Assim como Espinosa e Friedemann, González (2002) também está atenta à estabilidade dos arranjos familiares na estruturação da organização social afro-pacífica ${ }^{172}$. Segundo a autora, as mulheres estabilizam a esfera das unidades domésticas produtivas e residenciais, desenvolvendo uma economia doméstica, enquanto os homens estabilizam a esfera do parentesco e mantêm em funcionamento as redes relacionais. "Los hombres llegan a ellas en cumplimiento de las redes de la exogamia y de ampliación del parentesco, se articulan al espacio doméstico femenino, trabajan en las diferentes actividades y circulan a través de los ríos, de los esteros y el mangle, visitan otros montes en el tiempo y en el espacio en su situación de poliginia" (González, 2002: 15). Na concepção de González, a circulação pelos rios, esteiros e manguezais é uma prerrogativa masculina, enquanto as mulheres estariam fixadas no espaço doméstico.

\footnotetext{
${ }^{171}$ No tocante à "subordinação universal da mulher", as autoras parecem dialogar criticamente com Sherry Ortner, em especial com o ensaio "Is Female to Male as Nature is to Culture?", originalmente publicado em 1972, no qual a autora busca compreender e explicitar a lógica subjacente ao pensamento cultural que assume a inferioridade das mulheres. Ortner defende que o status secundário da mulher na sociedade é um verdadeiro "universal cultural", fato "pan-cultural", porém culturalmente atribuído em toda e qualquer sociedade, com contornos imensamente variados (Ortner, 1996 [1972]: 21-22).

${ }^{172}$ A antropóloga colombiana e professora da Universidad del Valle Nancy Motta González realizou trabalho de campo que resultou em monografia de graduação em Salahonda, Colômbia, em meados da década de 1970. Depois seguiu atuando na área. Realizou pesquisa sobre gênero no Pacífico, entre 1993 e 1994, para o Plan Pacifico - Departamento Nacional de Planeación (DNP), em convênio com a Universidad del Valle e Banco Interamericano de Desarrollo (BID) - entidade financiadora.
} 
Espinosa e Friedemann concluem que os mundos do homem e da mulher afropacíficos são, de alguma forma, independentes entre si e geram poderes distintos, de modo que as diferenças não implicam necessariamente inferioridade e superioridade. Essa perspectiva não descarta situações em que possa existir subordinação das mulheres negras dentro da coletividade.

Jaime Arocha também recorre às "huellas de africanía" para compreender arranjos familiares afro-colombianos, porém, parece que identifica uma estrutura diferente da descrita pelas autoras ora comentadas. Em estudos sobre mulheres concheiras do bairro Panamá, em Tumaco, Colômbia, Arocha (1986) identifica como eixo central da família o núcleo avó-mãefilha, com esposos rotativos. As famílias estão nucleadas em torno da mãe, suas filhas e a prole delas; há uma permutabilidade dos vínculos entre homens e mulheres. Segundo Arocha, isso tem de ser observado à luz dos efeitos da escravização ${ }^{173}$, bem como de um possível legado africano. Neste caso, o autor interpreta a situação a partir do recorte de grupos de idade, encontrado em muitas culturas da África ocidental. O desenho de arranjos familiares, argumenta Arocha, está diretamente ligado à produtividade e a raiz é o legado africano. “ $E l$ concheo persiste gracias a la herencia africana" (Idem, ibidem: 9).

Convergindo ao destacar o legado africano em arranjos familiares afro-pacíficos, Espinosa e Friedemann e Arocha percebem que os vínculos consanguíneos, e não os conjugais, seriam o principal eixo para o exercício de direitos no grupo familiar. Por outro lado, enquanto as autoras argumentam que o arranjo constitui uma só família centrada no homem, Arocha centraliza a família no núcleo avó-mãe-filha e considera que há uma rotatividade de esposos. González (2002), por seu turno, reconhece que os arranjos familiares se constituem em torno de uma figura feminina permanente ao redor da qual há uma descendência de distintos pais, contudo aponta o protagonismo masculino na constituição da rede de parentesco, assim como Espinosa e Friedemann. Na visão de González, a reprodução do laço social por intermédio do parentesco é prerrogativa masculina.

La iniciativa de establecer una unión le es negada [a las mujeres] institucionalmente: sólo el varón posee la capacidad de reproducir el lazo social. La filiación se realiza por su intermedio. La mujer entonces es controlada, sometida, orientada hacia las alianzas definidas por las obligaciones de su comunidad matrifocal, de manera que la procreación se realiza en el marco de las relaciones de afinidad pero con filiación en el grupo doméstico femenino (González, 2002: 62).

\footnotetext{
173 Segundo Arocha (1986), a empresa colonial implementou estratégias para reduzir ao máximo as possibilidades de aglutinamento étnico. E a frequente rotatividade entre trabalhos mineiros e agrícolas deve ter contribuído para enfraquecer os vínculos conjugais entre pessoas escravizadas.
} 
Enquanto Arocha fala sobre rotatividade das uniões entre homens e mulheres, Espinosa e Friedemann, assim como González, estão em busca da estabilidade desse arranjo, contrapondo-se à vertente consagrada por Pineda de Gutiérrez nos estudos sobre família colombiana, que caracterizava as famílias negras como desajustadas.

Conversando com mulheres afro-pacíficas em San Lorenzo, Tumaco e Salahonda, percebo que a categoria "estabilidade", ressaltada por Espinoza e Friedemann, bem como por González, não é a melhor para vislumbrar arranjos familiares afro-pacíficos. Com isso, porém, não me acerco a interpretações baseadas no modelo ocidental e branco da família, que identificam famílias negras como desajustadas. O modelo da família nuclear não é minha referência de análise. Considero relevante buscar uma aproximação com as formas como as mulheres vivenciam e interpretam as relações conjugais e familiares.

Partindo da etnografia, percebo, então, que elas constroem em torno de si uma rede que envolve parentela feminina, mas também relações de afinidade, ao redor da qual pode haver uma rotatividade de parceiros conjugais, ou uma ausência desse masculino. Ademais, há sempre a possibilidade de permanência, de casais cuja união perdura ${ }^{174}$. Em San Lorenzo, conheci uma canção de ninar ou canción de cuna, que fala jocosamente sobre a rotatividade de parceiros:

Mamita, mamita, ¿quién es mi papá?

Mi hijito del alma ${ }^{175}$ no sé quién será

Ándate a la calle e empiece a llorar

El que te acaricie, ese es tu papá

As mulheres parecem sempre partir do pressuposto de que podem ficar sem um pai para esse/a filho/a. Ou seja, a ausência do masculino está no horizonte de previsibilidade das mulheres. A expectativa social é de que são as mulheres que permanecem com os filhos. Nesses casos, conforme pude observar etnograficamente, tampouco se mantêm vínculos com a família do pai, de modo geral. Sem embargo, uma regra de normalidade não significa que não exista ressentimento, tristeza, brabeza e outros sentimentos relacionados ao comportamento considerado normal. A salahondenha Ana Granja fala sobre o tema: "acá los hombres medio responden por los hijos cuando están con la mujer. Se separan de la mujer, se separan de los hijos, se olvidan de los hijos". A regra é questionada também por homens,

\footnotetext{
${ }^{174}$ Etnograficamente, casos assim serão tratados logo a seguir, no item "Vivências das mulheres de relações sexual-afetivas".

${ }^{175}$ Esses cantos têm variações. Em uma delas, o trecho assinalado é substituído por: De tantos que pasan.
} 
como Marcelino Hurtado, representante legal do Conselho Comunitário Unión de Río Chaguí: "hay un desamor en el padre de familia. Él se olvida del niño".

A expectativa social tampouco significa que não existam diferentes estratégias das mulheres para lidar com essa caracterização da paternidade. A canção aponta que uma das estratégias possíveis reside na paternidade social. Quando existe um parceiro conjugal, ele assume a paternidade das crianças, tendo gerado as criaturas ou não. Vejamos, por exemplo, o caso de Targelia Micolta. Quando tinha 32 anos, encontrou-se com Juan David Valencia Perlaza, um pescador da região de Barbacoas, que pescava em Palma Real, onde ela vive. Com ele, Targelia teve a sétima criatura, Elvia Micolta. Quando ela tinha cerca de nove meses de nascida, o casal se separou e Elvia nunca mais teve contato com o pai biológico. Em seguida, Targelia uniu-se a Wellinton Castillo, conhecido como Tico, colombiano da vereda El Congal, que pertence ao Conselho Comunitário Bajo Mira y Frontera. Tico foi quem criou Elvia, dos sete aos quinze anos, aproximadamente. Ele foi o pai social da filha caçula de Targelia, a jovem Elvia.

Por outro lado, as regras de normalidade não dão conta da diversidade da realidade social. Também acontece caso reverso, em que a mulher se separa e segue seu rumo, sem os/as filhos/as. Quando a mulher deixa o filho, de modo geral, quem assume é a avó paterna, que costuma manter vínculos com a mãe da criança, ou com a família materna. A mãe biológica de um dos netos de Inés Morales, por exemplo, nunca se responsabilizou por essa maternidade. Até quando a criança tinha sete anos, vivia com Inés. Em seguida, a avó paterna mandou-a viver com o pai. Explicava-me que sempre previu esse momento, mas estava aguardando a configuração de cenário favorável. No caso, o pai vivia uma união estável com outra mulher, com quem tinha um filho de dois anos. $\mathrm{O}$ sentido de ambos, paternidade e maternidade, longe de expressar uma realidade biológica, é culturalmente construído.

Outra estratégia das mulheres consiste na construção de redes relacionais em torno das quais criam filhos/as. Tais redes são nutridas por elas. "La mujer negra trama una red de acciones solidarias que sirve de fundamento a nuestra identidad personal y grupal, y que refuerza nuestro sentido de pertenencia a la gran familia étnica negra" (Mena, 1993: 92).

A experiência de Eva Lucia Grueso bem ilustra essa perspectiva:

En Tumaco, vivíamos en una casa típica del Pacífico, casa grande porque somos muchos. En la calle Nueva Creación. Es la casa donde está el ombligo de todos. La placenta y el ombligo de ellos están enterrados en el patio de la casa. Deivy, Nela y yo nacimos en el río. Pero Pablo, todos mis sobrinos nacieron en esa casa, con partera. 
Entonces vivíamos mi papá y mi mamá, mis cuatro hermanos, o sea, yo y tres más. Mi hermana dos hijos, yo dos hijos. Eso'éramos lo que vivíamos de planta. Pero igual la casa era el lugar de llegada de la familia cuando venían del río. Entonces cuando venían a Tumaco se quedaban ahí, entonces la casa siempre estuvo llena. Hasta ahora sigue llena - Eva Lucia.

As relações de parentesco são vistas como relações em construção, elas não são dadas. E quem nutre tais relações são as mulheres. A casa abriga uma extensão de relações. Na casa da família Grueso, além das moradoras e moradores fixos, outros parentes que vêm do rio encontram abrigo. A parentela de Eva é responsável, junto com ela, pela criação dos filhos. É bastante comum no Pacífico Negro, que as crianças cresçam chamando a avó materna de mamá. A mãe biológica também pode ser assim denominada ou, às vezes, é chamada por seu nome. Quando o pai biológico é ausente - em casos como o dos filhos de Eva Lucia, Kissy Liliana, cujo progenitor nunca foi pai social, e Deiby, cujo pai biológico durante quatro anos foi pai social -, a figura masculina é representada pelo avô materno e complementarmente pelos tios maternos.

Nos recorridos das mulheres, quando distantes da casa, em geral são seus pais quem realizam o cuidado e a criação dos/as filhos/as. Isso aconteceu na família de Eva e Nela, as irmãs Grueso. "Nuestros hijos tuvieron mamá, que era mi mamá. De hecho la relación de mi mamá con sus nietos fue fuerte, muy fuerte. A nosotras nos llaman por nuestro nombre a quién llaman mamá es a la abuela (risas). Y a mi papá y a mis hermanos, la figura paterna fueron ellos. Sin el apoyo de ellos, a nosotras no hubiera sido posible asumir de la forma como asumimos el proceso". Ela teve mais um filho, Jean Carlos. "Él y Deivy son hermanos de padre. Él llegó a mi vida cuando tenía cuatro años. Él nació en Cartagena y el papá hizo un acuerdo con la mamá, cosa que el hijo lo cogió él. Entonces, el niño llegó a mis manos. Cuando nos separamos el niño no quiso ir con el papá, entonces se quedó conmigo toda la vida". Jean Carlos viveu na casa da família Grueso em Tumaco, com os pais de Eva, até seu falecimento.

Percebo ainda uma diferenciação entre narrativas sobre família e relatos sobre relações sexual-afetivas. Ao conceituar "família", noto nos depoimentos de mulheres com quem dialoguei uma perspectiva que se assemelha à destacada por Friedemann e Espinosa. Em uma oficina promovida pelo Movimiento de Mujeres Negras del Norte de Esmeraldas (MOMUNE), Equador ${ }^{176}$, Sulia Maribel Caicedo dizia que "familia no es apenas papá mamá - hijos. Hay un tronco familiar, un árbol genealógico que viene desde antes de los

\footnotetext{
${ }^{176}$ Acompanhei duas das oficinas realizadas no âmbito do projeto "Buscando voces de mujeres que rompan el silencio", sobre o qual comentarei na seguinte seção da tese.
} 
abuelos. Hasta el quinto grado debemos respetar los lazos de parentesco. Eso es familia. Es la misma sangre". Então, uma das mulheres que participava da oficina complementava: " $m i$ abuelo hacia del consejero de un tronco familiar, Porozo".

Segundo essa concepção, a família extensa é predominantemente matrilinear. Atende a uma proeminência de matrilinearidade e consanguinidade. Mas também pode atender a um englobamento do parentesco que provém de uma lógica de pertencimento ao território e à política, como é o caso de Eva Lucia Grueso, cuja ancestralidade provém do pai, Abel Grueso, e de Marlene Tello, tumaquenha, descendente de Juan Bauptista Tello Cortez. Eva Lucia explica que a família paterna representa sua origem ribeirinha, que provém do Rio Mira, enquanto a materna é urbana. A origem camponesa de Marlene, por sua vez, também deriva da família paterna, que pertence à vereda Chilví las Mareas, hoje parte do Conselho Comunitário Rescate las Varas. Daí que provêm seus saberes ancestrais, também no campo espiritual. É o mesmo caso da família Granja, de Ana, Martina, Karina e Nidia.

Na concepção política de família extensa, ela estende-se ainda mais e extrapola os vínculos de consanguinidade, passando a compreender a coletividade negra. Para Marlene Tello, a família corresponde ao povo afro-tumaquenho: “ $Y$ cuando yo digo, nuestros hijos, no es mi hijo, no es tu hijo. Digo nuestros hijos, porque yo considero que Tumaco es una sola familia". Eva Lucia Grueso também define família a partir do legado ancestral afrotumaquenho:

Para mí, la familia va mucho más allá. Y digo para mí desde mis prácticas culturales. Para nosotros comunidad negra, la familia es todo aquél con el que no necesariamente comparto sangre, pero con quién yo construyo lazos. La persona que yo sé que siempre va estar allí para mí y que yo siempre voy estar alli para ella. Entonces, por eso es que para nosotros PCN no es cualquier organización. Para nosotros es la familia. Entonces por eso entre nosotros nos llamamos hermanos y nuestros hijos nos llaman tío, tía. Por eso mis hijos a Yosu, a Carlos los llaman tío. Porque para ellos son sus tíos, los hermanos de su mamá. Por eso cuando yo veo los hijos de mis hermanos haciendo algo malo yo sé que los puedo regañar, hasta darles unas palmadas, que el papá y la mamá no van a reclamar porque saben que ese es mi deber de tía - Eva Lucia.

Enquanto Espinosa e Friedemann e Arocha percebem que as relações consanguíneas seriam o principal eixo na constituição da família, a narrativa de Eva Lucia indica que o aspecto primordial é a construção de vínculos, necessária para que se constituam tanto a família extensa quanto a família política. Na concepção política de família, os vínculos extraconsanguíneo construídos por relações de afinidade não se dão por meio de laços conjugais. Trata-se de uma irmandade organizativa, política e afetiva. Nas narrativas de Eva 
Lucia e de Marlene, encontramos então uma concepção de família vivenciada no processo organizativo negro e ancorada na territorialidade.

No Equador, a campanha desenvolvida para estimular a autoidentificação de afroequatorianas/os no Censo 2010 baseou-se em semelhante conceituação da família, apostando em sua força e sua capacidade de mobilização:

es precisamente el concepto de "Familia" que une a la gran diáspora africana en el país. El concepto se aplica a la familia ampliada, que se extiende por territorios rurales y urbanos. Una familia unida no solo por apellidos, sino por solidariedades, por parentescos políticos y territoriales, que responde a marcadores identitarios socio raciales y étnicos. Es decir la "familia es una sola, es afroecuatoriana" (CODAE, 2010: 6).

Então tudo começa no rio. A família Grueso, por exemplo, é constituída pelo povo da vereda Bajo Jagua, que fica às margens do Baixo Rio Mira. É uma família extensa delineada por vínculos consanguíneos e de afinidade, um tronco familiar. Desde o ponto de vista de Eva, que aos oito anos foi viver na área urbana de Tumaco para frequentar a escola, a família passou a materializar-se na casa da calle Nueva Creación, que abriga moradores fixos mais o povo que sazonalmente vem do Baixo Rio Mira. Na medida em que Eva e Nela, "las Hermanas Grueso", engajaram-se no Proceso de Comunidades Negras (PCN), a família estendeu-se ainda mais, configurando uma irmandade organizativa, política e afetiva. Então, o trânsito de Tumaco para Bogotá significou que a rede de Eva Lucia se estendeu da calle Nueva Creación, Tumaco, para o escritório do Proceso de Comunidades Negras, no centro bogotano.

$\mathrm{O}$ que permite fazer a passagem de um parentesco matrilinear e extenso para um parentesco político é o estabelecimento de vínculos, que é o núcleo do entendimento da noção de família. Seja na relação consanguínea, seja na relação política, as mulheres estabelecem laços de ordem organizativa e de ordem afetiva. As mulheres estão dizendo que as relações de parentesco estão em construção. Não basta dar à luz uma pessoa, a mulher se constrói como mãe e o homem como pai na medida em que nutrem laços, constroem relações, estruturam afetos entre si.

Partindo desse conceito de família, percebemos que a distinção entre privado/público, chave de leitura dos estudos feministas para compreender a opressão das mulheres, não seria a melhor maneira de compreender a realidade das mulheres do Pacífico Negro. Moore (1991), a partir de vários estudos, revela diferenças da distinção privado/público e demonstra que o doméstico e o político não constituem necessariamente dois mundos irreconciliáveis. O que noto no contexto pesquisado é que não há uma cisão entre o âmbito doméstico e o público. 
Strathern (2006) compreende que é o conceito ocidental de indivíduo autônomo que precisa da divisão entre as esferas "doméstica" e "pública" da vida social. E associa as mulheres ao primeiro e os homens ao segundo termo do par. Entre os Hagen, Strathern argumenta que uma pessoa, independentemente de seu sexo, pode atuar de forma masculina ou feminina. A distinção privado/público está na base da definição padrão de política. Em contraposição, a antropologia cunhou uma concepção na qual a esfera "política" não se pode separar da esfera "doméstica", já que ambas interagem entre si. Em consequência, as atividades e os interesses das mulheres não são exclusivamente pessoais, tampouco se limitam ao lar; são realmente políticos (Moore, 1991: 209).

\section{DEBATES EM TORNO DA POLIGINIA}

Segundo González (1995), a estrutura familiar poligínica é um dos mais fidedignos terrenos de supervalorização das capacidades sexuais masculinas, que desemboca em uma ideologia e em práticas machistas. A autora define dois tipos de poliginia, a do solteiro e a do casado, "llamada por la sociedad occidental de concubinato" (González, 2002: 55), que origina uma família composta ou plural. Quando se fala sobre a poliginia del soltero, considera-se como solteiro homens que estão em união livre, o que me parece equivocado ${ }^{177}$. Conforme pude perceber, as pessoas consideram a união livre como vínculo afetivo-sexual. Ou seja, o homem que possui uma união livre não é solteiro. Desde a perspectiva do ego feminino, segundo a autora, constituem-se monogamias seriadas.

A autora afirma que:

A medida que se desplaza por sus actividades económicas a todo lo largo de las Tierras Bajas del Pacífico, va el hombre constituyendo unidades conyugales, por lo cual las distintas co-esposas viven en diferentes unidades habitacionales, siguiendo como norma cultural de residencia la matrilocalidad, uxorilocalidad y neolocalidad (...) En el ámbito poligínico existe una co-esposa principal que asume preponderancia sobre las demás, que no son secundarias sino complementarias. La co-esposa principal goza de la más alta estima del varón, administra su tiempo sexual y reviste más autoridad y disponibilidad económica (González, 2002: 55-56).

\footnotetext{
177 Assumo a definição de união livre proposta por Fernández-Rasines: "união consensual entre homem e mulher para a convivência, o intercâmbio heterossexual e a procriação, na qual não intervém sanção civil tampouco eclesiástica"(2001: 193). Segundo a autora, esse é o principal modo de conjugalidade na costa pacífica equatoriana, observação referendada pela etnografia que realizei e que estendo ao Pacífico sul colombiano (Tumaco e Salahonda). Já na região serrana, segundo ela, as uniões conjugais em sua maioria são celebradas na religião católica. Os depoimentos de Barbarita e Isabelita Lara confirmam a percepção.
} 
$\mathrm{Na}$ visão da antropóloga, a coesposa principal exerce funções administrativas e autoritárias sobre as demais. A ela é reconhecida a representatividade perante a sociedade de seu núcleo doméstico, que figura como a casa verdadeira, enquanto as outras figuram como satélites. Os critérios para definir a coesposa, segundo a autora, são ambíguos e contraditórios. Pode ser a primeira mulher na cronologia afetiva do homem, a mulher que mais filhos deu a ele, a mais velha do grupo, a última mulher na cronologia afetiva do homem ou a mais nova (quase adolescente) (Idem, ibidem: 63). Segundo González, quando os papéis estão bem definidos, pode haver cooperação entre as coesposas; caso contrário, há competição. O que mais chama atenção é o argumento de que se trata de uma questão aberta e sob o amplo consenso da comunidade. "Estas mujeres aceptan su papel de co-esposa, como complementaria" (Idem, ibidem: 61).

Whitten (1974), tal qual colocado por González (2002), compreende que os homens circulam configurando redes de parentesco, enquanto as mulheres permanecem imóveis e passivas no circuito das unidades domésticas. $\mathrm{O}$ autor fala sobre sistemas de poliginia seriada como adaptação às flutuações econômicas do contexto e como consequência da eficiência econômica de certos homens.

Este proceso se llama poliginia seriada. Entiendo la poliginia seriada como un ajuste social efectivo dentro de la sociedad de consumo. Este ajuste permite ordenar los asuntos domésticos de un modo fluido, con el fin de acomodar las fluctuaciones de los recursos económicos en el entorno (Whitten, 1974: 118).

Ele argumenta que homens passam por uniões múltiplas ao longo de suas vidas, ao passo que as mulheres fazem o possível para assegurar-lhes um homem pela mais longa duração. Em sua descrição, a agência é masculina. Como bem observa Fernández-Rasines (2001), o autor não problematiza a geração de renda na família, tampouco o direito sobre a moradia, que são centralizados nas mulheres. Trata-se de uma interpretação que situa os homens no centro do sistema a partir de uma visão funcionalista, na qual não aparecem as percepções dos atores envolvidos, fossem eles os homens-maridos, mulheres-esposas ou mulheres-amantes. O androcentrismo também está presente em González (2002) e em Friedemann e Espinosa (1993a e 1993b).

Arocha (1986), em fins da década de 1980, notava o decrescimento de famílias poligínicas, que estavam sendo substituídas por famílias dentro das quais os vínculos conjugais são perduráveis. Já Fernández-Rasines, no tocante à costa esmeraldenha, argumenta que a ordem monogâmica foi implantada pela política colonial e que ela não foi superada pela 
prática da poligamia, a qual aparece nos últimos quarenta anos. Ela define as relações poligâmicas como "un tipo de sistema de afinidad de hecho, donde hombres y mujeres se ubican en redes parentales vinculadas por lazos de consanguineidad y afinidad que escapan del ámbito del ideal de familia nuclear" (Fernández-Rasines, 2001: 116). Camacho (2008: 183) ressalta a ausência de trabalhos que indaguem sobre a poliginia desde a perspectiva das mulheres, suas experiências e suas expectativas perante as relações conjugais, que é justamente minha proposta investigativa.

Os arranjos chamados poligínicos são duramente criticados pelas mulheres com quem dialoguei. Nenhuma delas se diz confortável nesse tipo de arranjo. Martha Estela García, que é concheira e liderança de Bajito/Vaquería, Baixo Mira, Tumaco, conta que se juntou a um homem que estava oficialmente casado, porém efetivamente separado da mulher. Tendo ele voltado a encontrá-la, Martha se separou

\begin{abstract}
Paula: ¿a usted no le parecía bien compartir el marido con otra mujer? Martha: no tanto eso. Sí, no me parecía bien, sino que a mí que otra mujer venga a voltearme mal la cara por otro hombre, o venir cuando le daba la gana, sin saber nosotros en dos, tres días que él no venía que comíamos con los hijos y después venia y vuelta. ¡No! Entonces no, usted verá a quien escoge, y como la otra era su mujer que estaba casado entonces siga con ella. Yo no tengo problema. Yo estaba joven para mantener mis hijos.

Paula: acá se dice que es muy común que el hombre tenga más de una familia.

Martha: no es común sino que es un vicio, aquí el hombre que tenga dos mujeres no es, como se dice, cosa de otro mundo. Pero hay unas que se aguantan, otras no nos aguantamos, todas no somos iguales, yo no comparto con ella. Los hombres cuando tienen dos mujeres se vuelven muy orgullosos, quieren humillar a las mujeres, o hacer lo que se da la gana con ellas y si no se deja entonces ahora sí, como tienen otra no les importa y no debe ser así, porque lo primero es primero.
\end{abstract}

Martha sabia que seu companheiro tinha um vínculo conjugal com outra mulher. A ele uniu-se por compreender que se tratava de uma relação finalizada, já que viviam separadamente havia cinco anos, em cidades diferentes. Quando a senhora retornou para Tumaco e os dois voltaram a se encontrar, ela separou-se dele. Martha ressalta o incômodo gerado pela tensão entre as mulheres em função da disputa por um homem. Também demonstra que se frustraram as expectativas voltadas ao companheiro, no desempenho de seu papel no âmbito da manutenção do lar e dos filhos. É muito interessante a nomeação da diferença entre as mulheres e o questionamento que traz essa narrativa ao padrão masculino referendado pela literatura comentada. 
Vamos conhecer também um pouco da história da salahondenha Nidia ${ }^{178}$. Ela engravidou pela primeira vez de Gerson, que foi seu namorado por dois anos. Ambos estavam estudando e decidiram primeiro terminar o bacharelado para em seguida organizar uma vida conjugal. A criança ficou com a família de Gerson, na comunidade de San Pedro, que pertence ao Conselho Comunitário ACAPA. Tempo passou depois que se graduaram; ela aguardando-o em Salahonda e ele argumentando que precisava levantar recursos para buscá-la e, então, estabelecerem um lar. Certo dia um cunhado de Gerson disse a Nidia que ele havia arrecadado o dinheiro, mas comprara uma moto para a outra namorada que tinha em Tumaco. Ela partiu em busca do namorado em Tumaco. Gerson disse a Nidia que já não viveriam juntos, mas seguiu buscando-a. "Y me molestaba por aquí me molestaba por allá pero yo no quise más. Porque él no tenía buenas intenciones conmigo". Regresando a Salahonda, ela viveu uma nova relação.

Ahí encontré al papá de Estiven, la experiencia con él fue bonita, yo venía de un desamor, de un despecho, de una tusa, y pues me encontré con él y en el encontré como un refugio, fuimos novios, a él no le importó que yo tenía un hijo, me decía que me quería, que íbamos a llegar lejos y todo. De ahí otra vez salí embarazada, de Estiven, en todo el embarazo fue pelea. Tuve el niño, él no estuvo en el parto, me sentía sola, me sentía mal, pero estaba mi mamá, mi mami siempre me ha apoyado y luego vine para acá con mi mami. Él después vino conoció el niño y la familia de él que al niño mejor dicho, que cuando venían mis amigas a visitarme y el niño siempre lo tenían allá, solo lo traían a comer y a dormir. De ahí volvimos con él, estuvimos, pero nunca me llegó a decir nosotros vamos a ser marido y mujer, vamos a vivir juntos, no. Luego después cuando lo miré con una muchacha, andaba de brazos con ella, yo no le dije nada. Ya no fue a mi casa, luego la muchacha se fue y él vino a mi casa otra vez y yo como tonta. Se fue pa' Cali pa'donde la muchacha, luego volvió y yo vuelta lo acepté. Después ya la gente me decía, y vos no le haces reclamos, qué le voy a hacer reclamos si él está conmigo. Luego un día le dije que si los dos no nos organizábamos como marido y mujer que mejor dejáramos las cosas así, me dijo que sí, que dejáramos las cosas así y que él no iba a sacrificar su felicidad por mí. Yo le dije bueno listo y de ahí me quedé sola. Salían pretendientes así, amigos, pero yo no quería aceptar. En mayo apareció una persona, esa persona desde antes de yo tener a mi hijo, a Gerson, él había estado, como decimos acá, tirándome los perros. Yo le aceptaba invitaciones, de ir a bailar o ir a comer, él a veces dormía aquí en la casa pero sin ningún compromiso, ni dormir los dos juntos ni nada. Entonces en mayo volvió a hablarme y decirme que estaba interesado todavía en mí, yo le dije pues yo tengo dos hijos, él me dijo que también tenía dos hijos. Entonces yo le dije que sí, listo, entonces en junio me fui para allá porque él es de la vereda el Bajo San Ignacio. Y luego yo fui para allá, con mi mamá porque a ella le gusta tanto los velorios de los santos. Luego él vino y se estuvo una semana, en junio. $Y$ fuimos al monte allá donde mi mami, sembramos cedro, plátano, banano, también fuimos a un cocal y todo bien. Como había un campeonato de futbol

\footnotetext{
${ }^{178}$ Recordo ao/à leitor/a que Salahonda foi onde González realizou pesquisa de campo.
} 
aquí en Salahonda ellos venían todos los días, ellos vinieron el 3 de agosto y ellos quedaron de segundo puesto, de subcampeón. Llegó y me dijo que se iba a hacer un viaje a Barbacoas, cuando volviera de allá recogía a los hijos de él y se venía acá a Salahonda acá a la casa, todavía lo estoy esperando. Eso fue el 4 de agosto. Estuvo aquí en Salahonda, pero no vino para acá. Con mi hijo me mandó diez mil pesos y que en estos días venía. Ya pasó un mes y no ha llamado, aunque allá la comunicación no es como acá, toca colocarle antena al teléfono, pero si hay puestos donde toca colocarle minutos, pero no ha venido, no me ha llamado, no sé nada de él. Escucho por otras personas que tiene alguien allá en el Bajo.

Paula: eso es lo que te iba a comentar acá es muy común que los hombres tengan más de una mujer ¿no?

Nidia: por lo general si

Paula: ¿y a usted eso no le parece bien?

Nidia: Eso le duele a uno, ¿cierto? Lo que más me dolió es que yo me quedé como la segunda. Cuando llegó ese ahora, todos se quedaron contentos, pensando que había llegado un hombre que me iba valorar, que me iba cuidar.

Narrativas de mulheres de Tumaco e Salahonda demonstram um ponto de vista que não corrobora a configuração de um arranjo consensuado, como pressupõem os autores e autoras que definem as relações afro-pacíficas como poligínicas. Para refletir sobre esse ponto, recorro à análise de Machado (2010) sobre tese de Daniel Simião acerca do conceito de violência contra a mulher no contexto cultural do Timor Leste. A autora afirma que "se a agressão física conjugal não é insulto moral coletivo aos olhos da comunidade, nada indica que não seja aos olhos das mulheres agredidas, percebida como desconsideração, provocando ressentimentos" (Machado, 2010: 101). Complementa dizendo que, em geral, a totalidade é expressa em voz masculina.

No caso do Pacífico Negro, o fato de existir uma convenção social que permite aos homens ter mais de uma relação sexual-afetiva ao mesmo tempo, nada indica que as mulheres estejam confortáveis nesses arranjos. Essa parece ser uma prática amplamente questionada por mulheres, como Martha, que a caracteriza como "vício". A experiência de dor narrada por Nidia é um indicativo de que as relações são vivenciadas de diferentes formas por homens e mulheres. A diferença aqui se traduz em desigualdade, ou seja, esse é um arranjo no qual as mulheres se percebem em desvantagem. A dinâmica dos lares satélites que González (2002) comentava não ecoa na narrativa de Nidia. Ainda que no caso dela não se tenha configurado um lar a partir das relações estabelecidas, a narrativa demonstra que havia essa expectativa. E nesse caso, é explícita a frustração em ser preterida por outra mulher.

A diversidade de percepções conforme o posicionamento do sujeito é algo para o qual Henrietta Moore (1991 e 2007) chama atenção reiteradamente. Machado (2010) também ressalta que os sujeitos estão posicionados na estrutura social. Há posições hierárquicas das 
categorias de gênero e, assim, há deslizamentos de sentido e tendências polifônicas divergentes entre os gêneros. "No espaço interacional, as posições de sujeitos não se equivalem. Não são as mesmas. Estão sempre abertas tanto para a concordância como para a disputa" (Machado, 2010: 86). Moore (2007) ressalta que há uma instabilidade ou ambiguidade da diferença sexual, tendo em vista que as representações sociais não podem ser mapeadas no mundo de uma forma estável e fixa. Nesse contexto, há uma múltipla constituição da subjetividade e da agência do sujeito.

O depoimento de Martha García indica diferenças nas concepções e vivências das relações sexual-afetivas entre mulheres. Como ela diz, há mulheres que aguentam compartilhar o marido com outra mulher e há mulheres que não aguentam. Comungo com Machado (2010) o entendimento de que "compartilhar valores culturais" não significa que a diversidade cultural expressa uma totalidade unitária. Pelo contrário, diversidade cultural refere-se a "modos culturais do estabelecimento de relações de sociabilidade, onde as agencialidades sociais se distinguem por suas percepções e ações simbólicas recíprocas e distintamente orientadas, segundo suas posições e investimentos subjetivos" (Machado, 2010: 83-84). Os valores culturais, mesmo que compartilhados, são vividos e apreciados por distintas perspectivas entre homens e mulheres, entre mulheres e mulheres, entre homens e homens.

O caso de Nely (nome fictício), vizinha de uma amiga com quem vivi na área urbana de San Lorenzo, Equador, traz questões interessantes. Ela partilhou sua primeira experiência sexual com o atual marido. Logo passaram a habitar juntos e tiveram muitos filhos. Nely afirma saber que ele possui "amigas" ou "namoradas". Sua posição perante isso é complexa e ambivalente. Podemos interpretá-la a partir da afirmação de Matthieu (apud Machado, 2010): “ceder não é consentir”. Nely vivencia essa dinâmica ao longo da relação, de alguma forma compreende e faz concessões, mas nunca consentiu. Em certa época da história conjugal, a partir do momento em que notou que o companheiro estava mais presente na casa de uma das namoradas (presença física e econômica), explicitou contrariedade à dinâmica. Fez isso indo até a casa da outra e a atacando fisicamente. Depois de deflagrado o conflito, ele a deixou para viver com a outra mulher. Passaram cerca de um ano separados. Nesse ínterim, faleceu o filho mais novo do casal, que, assim como os demais filhos, vivia com ela. Depois disso, voltaram a morar juntos. O homem desculpou-se e assumiu responsabilidades pela morte da criança, dada sua ausência no lar. 
A atitude dessa mulher reflete que há uma valoração negativa feminina sobre relações de convivência extramarital vivenciadas pelos homens. As mulheres afetadas tendem a se contrapor quando a vivência de tais relações implica que o homem-marido esteja desatendendo seu lar, o que também é observado por Fernández-Rasines (2001) no contexto do bairro de Silanes, Quito. O depoimento de Martha sobre os motivos de uma separação conjugal coincidem com o argumento ora exposto.

Ao ser questionada sobre como se sentia no contexto da relação, Nely relatou-me experiências de dor e frustração, bem como ressentimentos com relação ao marido. Quando lhe perguntei sobre as motivações para permanecer nessa relação, disse-me que "un hogar necesita un hombre, Paula". Fernández-Rasines (Ibidem), em estudo sobre arranjos matrifocais em coletividades afro-equatorianas, percebe que a necessidade de um homemmarido configura um imperativo da norma social. Junto com ele, aparece a norma da família nuclear monogâmica, na qual o homem é o provedor e a mulher, mãe-esposa, confinada ao espaço do lar. Tais normas se inscrevem na ley del derecho paterno equatoriana, pela qual o marido-pai tem a função representativa do grupo familiar a efeitos fiscais (Idem, ibidem: 200). Nesse sentido, entendo que o depoimento ora citado manifesta as expectativas sociais sobre os arranjos familiares e sobre os papéis feminino e masculino.

Mailen Aurora, ao falar sobre sua infância, narra relações extramaritais que seu pai e seu padrasto vivenciaram e as reações contrárias de sua mãe:

Mi madre me decía que mi padre era bueno, que ellos trabajaban juntos. Lo único es que cuando él agarraba la plata, mujereaba y no compraba nada. Una vez mi madre lo encontró a él, en la misma casa de mi mamá, haciendo el amor con otra mujer. Ella quisiera apuñalarlo, pero pensó en nosotros (los hijos). Entonces apuñaló a la mujer. Con mi padrastro pasó lo mismo. Ella lo agarró del pene y tuvieran que morderle el dedo, porque ella iba arrancarle el pene - Mailen Quiñones.

Nos casos das mães de Mailen e de Nely, nota-se a competição entre mulheres, no contexto da disputa por um homem. Tais relatos contrastam com o de Martha García, que parece ter preferido abdicar do companheiro para não entrar em choque direto com outra mulher. Nos dois primeiros casos, as mulheres reivindicaram a manutenção da exclusiva relação conjugal por meio da disputa física com outras mulheres. Já no caso de Martha, quando se uniu ao homem em questão, estava ciente de que ele tinha um vínculo conjugal anterior com outra mulher, porém dela estava separado. Não disputa, tampouco aceita a conjugalidade compartilhada. 
Sobre as possibilidades de mulheres terem mais de um parceiro conjugal ao mesmo tempo, há um trecho do relato de Martina, de Salahonda, que faz alusão a isso. Segundo ela, “la mujer que tiene más de un marido le llamamos puta. El hombre mujeriego, perro". Essa fala aponta que, se a prática masculina nesse tocante é criticada, eventualmente pode ser tolerada; mas, no caso das mulheres, parece ser uma atitude socialmente reprovada. Contudo, quando se trata de rotatividade de parceiros, tanto na área rural quanto na urbana, é expectativa comum para mulheres e homens. Marlene Tello, revelando contundência à "modernidade" e à urbanidade da ideia de casamento monogâmico, explicitou outro ponto de vista. Ela diz que, mesmo depois de separadas, há reprovação social no caso de mulheres terem novos parceiros conjugais. Novas relações sexuais parecem ser feitas às escondidas. "Vea el caso de mujeres que se separaron de los maridos porque les daban malos tratos o el marido la' dejó. Pero esa mujer no podía tener má' marido. Se quedaron ahí, solas con sus hijos, criando a sus hijos. Comiendo calladito, eso es, teniendo sus mozos, sus amigos, comiendo calladito, haciéndose Señora ante la sociedad".

\section{VIVÊNCIAS FEMININAS EM RELAÇÕES SEXUAL-AFETIVAS}

As relações sexual-afetivas na região analisada operam em um cenário diversificado, em que há constantes alianças e rupturas entre mulheres e homens, onde a rotatividade de parceiros é constante, ao lado de relações conjugais de longo tempo. As vivências das relações sexuais afetivas na sua atualização ou em momentos de ruptura não são experimentadas ou sentidas da mesma forma por homens e mulheres, assim como há percepções diferenciadas entre mulheres sobre suas relações. Trata-se de relações afetivas que potencialmente tendem a disputas, conflitos e acertos. Tem-se sempre presente a tensão entre, de um lado, valores tradicionais hegemônicos da valorização do poder masculino e, de outro, valores de relações que se querem afetivas e solidárias.

Vilma Estacio de Sá de Ricauter, San Lorenzo, Equador, conta histórias de homens que "pasaran volando", ou deram banda voou, como dizemos no Brasil. É o caso de seu avô, que teve uma relação sexual com sua avó e foi-se embora.

Paula: ¿Y la mamá suya, Carlota Abá Mina era de acá mismo, de Ricaute?

Vilma: Sí, de Ricaute.

Paula: ¿Y quién eran los papás de ella?

Vilma: La mamá era Rosalina Abá. 
Paula: ¿Y él papá?

Vilma: El papá no puedo decir porque el papá es bochincha'o. [...] Un José Meterio. Pero uno no lo identificó a él, pues.

Paula: ¿Y él era de aquí, pero no la registró?

Vilma: Sí, él era de aquí. No. Como mujer no. Sino que pasó volando pues.

Conta também histórias de homens como seu primeiro marido, que lhe disse: "yo te amo para mi mujer". Juntos viveram, até o falecimento dele, uma relação que não envolvia outras pessoas.

El primer marido que tuve, él que me sacó de la casa, hasta que murió. Yo tenía dieciocho años. Yo era virgen. Nos enamoramos, pues. Él vino a la casa, cuando mi mamá no estaba. Él venía a la casa, a conversar. Ya cuando mi mamá iba llegando, se iba. Era el tiempo. Él me hacía así, me sobaba y todo. Ahí me pidió un beso. Yo se lo di. "¿A usted le hace feliz conmigo?" Yo decía sí. "Yo la amo para mi mujer". Asi me dijo. "Yo la amo para mi mujer". Él también estaba joven. Tenía como 22. Yo le dije: "bueno pues, si es de todo corazón, lo acepto. Pero si no es de todo corazón, sea sincero", le dije. "Sea sincero. Si no es de todo corazón, ahi no nos quedamos". Dijo: "no, sí es de todo corazón". Y yo lo vía pendiente de mi mamá. Y él me pidió, pero mi mamá no quiso. Ahí nosotros tuvimos más de dos años enamorados. Y ya conversábamos y ya consultamos a irnos. $Y$ ahí yo, después ya decidi, me voy. "Si me vas hacer feliz, sáqueme". Y ahi nos huimos. Nos fuimos escondidos -Vilma Estacio.

Nas narrativas que construímos em diálogo com mulheres afro-colombianas e afroequatorianas, a dominação masculina é uma tônica das relações sexuais afetivas entre mulheres e homens. A assimetria entre mulheres e homens nominada como "machismo" se expressa, por exemplo, no comportamento masculino considerado "poligínico", para a literatura antropológica predominante, ou mulherengo, como dizem as mulheres. Expressa-se na desigual divisão do trabalho, em que são atribuídas exclusivamente às mulheres as tarefas relativas ao ambiente doméstico, ademais da expectativa de seus trabalhos na mariscagem, na agricultura, na mineração artesanal. E ainda nas dificuldades de o companheiro respeitar o trabalho profissional e o ativismo político das mulheres.

Yo siempre me gustaba ser libre. No me gustaba tener pareja oficial. Acá el machismo es тиy fuerte. Una de las principales razones de deserción escolar en la secundaria para las mujeres es el matrimonio. Si yo fuera madre, no hubiera estudiado - María Barbarita Lara Calderón ${ }^{179}$.

El hombre de acá ha sido muy machista, ¿no? El hombre de acá es que la mujer tiene que estar en la casa, y la mujer tiene que ser pa' los hijos y la

\footnotetext{
${ }^{179} \mathrm{O}$ ciclo educacional no Equador começa com pré-kinder, guardería (creche), primária ( $1^{\circ}$ a $6^{\circ}$ ano ou curso) e secundária $\left(7^{\circ}\right.$ ao $9^{\circ}$ curso $/ 10^{\circ}$ ao $12^{\circ}$ curso: bacharelado). Até a primária, a unidade educacional é a escola. $\mathrm{Na}$ secundária, o colégio.
} 
mujer tiene que ser pa' los niños, eso. Pero, ya pa' andar, ellos mismos le prohibían - Rosalba Quiñones.

Yo con Tico una parte nos dejamos por el machismo de él. Yo salía y él no aceptaba. Dudaba de uno. Me decía que o mi pueblo o él. Si mi pueblo me eligió no puedo dejarlo. Yo pensaba en el futuro de mis hijos y nietos - Targelia Micolta.

Porque acá nos criaron a las mujeres con un machismo. Hay que dar pleitesía a todo, rendir homenaje a los hombres - Ana Karina Granja.

Los hombres han sido machistas en estos territorios nuestros. Él quería ser más porque era del pueblo y era hombre, quería humillar a la campesina mujer. ;Para hacerte los hijos no era campesina! - Martina Granja.

Hombres son conchudos. Son machistas. Ven a las mujeres en oficio y no son capaces de ayudar. Un detalle tan bonito que un hombre ayude a una mujer. Los hombres son detallistas cuando no han conocido a las mujeres. Hablo de la época mía hasta ahora- Ana Granja.

Os depoimentos trazem uma série de imagens sobre o masculino e o feminino. Com a fala de Barbarita, que vive no Valle del Chota, la Concepción y Salinas, a conjugalidade aparece como um aprisionamento da mulher. A experiência da maternidade, na visão de Barbarita, é uma das dimensões desse aprisionamento. Rosalba, liderança do Rio Rosário (Tumaco), indica uma questão que pode lançar luz sobre a situação de privação à qual Barbarita se refere: a expectativa masculina que deseja restringir as mulheres ao ambiente doméstico no contexto da relação conjugal. Mulheres ativistas geralmente colecionam estórias de relacionamentos desfeitos pela falta de aceitação dos parceiros com relação a suas trajetórias de liderança. A tumaquenha Marlene Tello expõe essa ideia: "Andar en las organizaciones, en las luchas, nos deja sin marido. Hay que ser un hombre muy comprensivo. El hombre que nos mira a nosotras como lideresas no nos para bola”. A salahondenha Martina aponta que as opressões se articulam. Ela saiu de Salahonda para trabalhar em Tumaco e lá conheceu o homem que se tornou seu primeiro marido, um tumaquenho. Ela define a relação de doze anos que os dois tiveram como "una vida de maltrato". Entende que ele, homem citadino, a oprimia por ser ela mulher e camponesa.

A opressão por vezes se expressa no uso da violência física. Foi o caso dessa relação que Martina viveu. "Yo protegía a mis ojos pa' que él no los golpeara. Él me daba en la espalda, me mordía. Me daba golpe'. Yo lo cogía y salía corriendo. A los muchachos les daba con látigo. Él tomaba y fumaba cigarrillo. Siempre fue así. Yo creo que, si yo viviera con él, aún hoy sería asî’.

Os relatos de violência doméstica são numerosos. 
Entonces este señor, yo le tenía era miedo. Yo con él no dormía. Yo de la cama me volaba y me metía a la cama de una hermana de él. Eso hacía que él más se enfureciera y a veces se bajaba. Y a mí no podía nadie saludarme, quedarme mirando porque él ya era celoso. Y como a la semana me estuvo pegando. Y eso aumentaba más mi odio contra él, por lo que había hecho y aun así como se comportaba - Mailen Aurora Quiñones.

Nesse momento, Mailen falava sobre o primeiro homem com quem viveu, que a estuprou. As agressões físicas agravaram-se ao ponto das ameaças de morte, quando então Mailen conseguiu escapar, indo viver provisoriamente em Tumaco.

Ao mesmo tempo em que os relatos trazem uma realidade dura, a dominação e a violência não são linguagem única na vida delas. Recorrendo novamente às dinâmicas vivenciadas na oficina promovida pelo Movimiento de Mujeres Negras del Norte de Esmeraldas (MOMUNE), Equador, encontrei um leque de representações sobre o masculino. Instigadas por Sulia Maribel Caicedo, as líderes comunitárias sanlorenzenhas caracterizavam os homens como machistas, mentirosos, abusivos, mulherengos, irresponsáveis, abusadores, déspotas, "pegón", traidores, covardes, ciumentos. Contudo, na visão delas, os homens também podem ser amorosos, sensíveis, compreensivos, respeitosos, carinhosos, detalhistas, fortes, necessários, valiosos e amantes.

Inés Morales contou que seu casamento desconstruía imagens opressoras sobre o masculino e o feminino. Ela disse que o finado Don Armengol, desde que os dois começaram a viver juntos, se encarregou das tarefas de ordenamento doméstico:

En mi casa siempre fue Don Armengol que cuidó de eso. Empezó él comprando las cosas de la casa: las tinas de lavar ropa, por ejemplo. Y yo entendí que eso era algo que le cabía a él hacerlo. Nunca yo supe donde era que se arreglaban los cuchillos o machetes. Él lo hacía todo. Nuestro patio siempre fue pequeño, entonces él me decía, hay que aprovechar el espacio. Aún hoy hay clavos en la pared, donde se clavan las tinas de lavar ropa Inés Morales.

Inés contou que levava as companheiras e companheiros do Proceso de Comunidades Negras para se hospedar em casa. Enquanto se organizavam, discutiam e se mobilizavam, Don Armengol fazia as refeições para todos. No cuidado com os filhos, também o aporte de Don Armengol e da parentela feminina de Inés foi fundamental. Inés conta que, enquanto participava das mobilizações e estudava, sua participação na criação da prole era mínima.

No caso de Mailen, depois de abusos e tentativas de estupro na adolescência e de um estupro efetivado na iniciação sexual, ela se engajou em uma história diferente: 
Mi esposo que tengo ahora me decía, 'deje ese hombre, que ese hombre no es para usted. Usted no se merece esa vida'. Él decía: 'esas manos que yo tengo no son para pegar a ninguna mujer'. Él me seguía enamorando. Pero yo, a todos los hombres los vía igual. Yo todo lo que me decían, me enamoraban, yo los miraba a todos igual. Que todos eran iguales. Yo le decía eso y él me decía: "no, no todos somos iguales. Uno no puede pensar uno por los demás" - Mailen Quiñones.

Nesse trecho novamente evoca-se a diferença, dessa vez entre os homens, mostrando a multiplicidade das posições de gênero. Mailen conta que, ao longo de três décadas e meia nessa relação, ela conquistou seu espaço e liberdade:

En el caso mío fue muy duro porque además de tener esas ganas de ayudar a los demás, uno siente también que está abandonando a sus hijos, que el esposo también se siente sólo y que necesita el hogar. Pero que al mismo tiempo eso le permite a uno construir su hogar. Eso me ayudó mucho, a yo poder charlar con mi esposo y con mis hijos. Mira, las cosas son así. Entonces para mí fue duro, a veces encontraba el marido así con la carita arrugada, muchas veces me quería como que insinuar, pero yo también le daba a entender: a mí me gusta eso, no me gusta estar aquí parada, yo puedo hacer por el bien de nosotros y de otras personas. O sea, que uno sea útil también para aportar en algo constructivo. Y hoy en día él ya está, yo le digo: de pronto vuelvo mañana, pero resulta mañana todas las demandas, llegan un montón de cosas y que uno obligatoriamente tiene que estar. Pues en la casa ya tengo esa apropiación, esa libertad de decir: no sé cuándo vengo, solamente sé cuándo me voy. Ya tengo un derecho ganado, que ya me lo entienden - Mailen Quiñones.

A transformação na vida de Mailen tem relação com o papel assumido como liderança de seu povo. A partir daí, a divisão do trabalho na conjugalidade foi-se transformando, ao ponto de ela conquistar a autonomia sobre a qual comentou.

Lo mismo que hemos dicho antes que la mujer siempre ha sido discriminada y que sólo tiene que ser la del hogar, eso permite que cuando una mujer ya conoce sus derechos se meta a eso de lideresa. Eso mismo le ayuda a uno a hacerse sentir que nosotras también no somos de la casa. Yo puedo hacer otras cosas, fuera de la casa. Y de eso también se va caminando no sólo a su hogar, pero también de ayudar otros hogares, otras mujeres. Y hacer que los hombres también entiendan los otros roles que nosotras podemos desempeñar. $Y$ también en ayudar al hombre en el hogar. Ya económicamente, ya ya con cualquier cosa que se necesita en el hogar. Eso también ha ayudado al hombre, que me voy a hacer tal cosa y ya mismo ya traigo la comida. Traigo una libra de arroz. Entonces eso también hace que el hombre tenga en cuenta: sí, sí, la mujer también asume los roles de sostener la casa y que él también puede desempeñar lo mismo que uno hace en casa, colaborando. Entonces es ahí cuando el hombre viene a entender que entre ambos, debámonos apoyar mutuamente, que tenemos los mismos derechos - Mailen Quiñones. 
Nessa relação, Mailen transformou a expectativa do marido sustentada na norma social, segundo a qual o homem-marido é o provedor e a mulher-esposa fica confinada ao espaço do lar, não deve mover-se de maneira autônoma em ausência do marido (FernándezRasines, 2001: 161). No seu relato, ela diz ter conseguido construir com o marido uma nova forma de relacionamento na qual obteve autonomia e apoio nas suas atividades políticas. Em grande medida, as mulheres com quem dialoguei subverteram tais expectativas, já que elas são mulheres que caminham, seja para a política, seja para o trabalho.

Outro exemplo de mulher que vivenciou a opressão e encontrou meios de enfrentá-la, mantendo-se na mesma relação, vem do caso de Rosalba:

Paula: Cómo fue con Luis Antonio [el marido], ¿usted ha podido hacer ese trabajo?

Rosalba: Él era también jodido. Pero, yo me salí de los rieles y ino! Eché pa'delante. Yo ya no tenía más hijos pequeñitos. Cuando teníamos una serie de problemas con él, pero, pues yo la soportaba. Lo único es que en esa época no le remuneraba nada a uno, para la ayuda a su hogar, para que fortalezca. ¡Nada! Pero yo no me dejé apabullar, fuera lo que fuera que él hiciera o dijera. Yo tenía mi compromiso, me tocaba una reunión, yo me iba. Así fue y rompí el hielo. A veces él hacía unos laberintos, adelante de la gente. A veces me daba vergüenza, adelante de la gente. Pero yo, a nada de eso retrocedía. Siempre encontré una salida a los laberintos de él. ¿Y pregunte quién ha hablado de separación? Hasta hoy estamos los dos juntos.

É o que também aconteceu com Martina em sua segunda união conjugal. “En 1998 me junté con Nicolas Estacio, afrocolombiano. Él se quedaba bravísimo. Era celoso. Los hombres son machistas, no dejan que las mujeres participen en las reuniones. Pero yo nunca dejé de ir, por él no". Depois de viver uma relação de violência extrema e de vivenciar também o ativismo político, Martina construiu uma relação conjugal na qual não abria mão de sua atuação nos processos organizativos.

As expectativas sociais atribuídas a mulheres e homens na conjugalidade são atravessadas pelo tema da divisão do trabalho dentro do lar, que tem interface direta com a questão econômica. As narrativas indicam uma expectativa de que o parceiro sustente a mulher economicamente, que lhe dê roupa, comida, ao passo em que a mulher deve trabalhar dentro do lar e prover serviços ao companheiro:

Es mejorable salir de su casa con un marido pero, pues, ahorita los hombres ya no es así. Los hombres no son responsables de las mujeres - Martina Granja. 
Entonces yo le dije que yo no iba a ninguna parte a bailar porque, cuál era la ropa que él me había comprado, ¿para que yo saliera con él a bailar? - Mailen Aurora Quiñones.

Paula: ¿un hombre espera que la mujer este en el hogar, que le cocine, que le lave?

Martha: que le sirva, claro, porque si un hombre busca una mujer es para sus servicios también. Porque el hombre puede llevar digamos, le puede dar la plata a uno pa'comprar remesa pa'comer, pero si no hay quién lo prepare, él se va a trabajar y si uno también sale ¿quién prepara la comida? $Y$ él viene con la esperanza de que la comida esté cocida porque él dio la plata pa' cocinar, pero uno por andar por allá no prepara los alimentos, no le da de comer a los hijos, cualquiera se enoja. Dice, bueno no quiere cocinar, no doy plata y me busco otro lado, busca otra mujer que le sirva, que lo atienda. Porque dirá que el hombre solo para acostarse con las mujeres y ¿sus servicios personales? Sus servicios materiales mejor dicho, porque para el lavado de la ropa, plancharles... como va a ser que se busque una mujer y no más va a ser para la cama y tiene que pagar quien le consigue y le lave la ropa. Para mí no está bien. Es como de mujeres, uno busca un hombre para que le dé. Y si uno de mujer está haciendo su oficio, le cocina, le lava y ese hombre lo que coge se lo da a otra mujer o se va a beber, se gasta la plata, una mujer también se siente mal. Entonces toda cosa es compartida.

No território ancestral Valle del Chota, la Concepción y Salinas, as atividades produtivas são diferentes, mas as expectativas sociais direcionadas a mulheres e homens assemelham-se.

\begin{abstract}
Aquí lo primero que se hace es enseñar a cocinar [a la mujer]. Después se enseña a lavar los platos, a lavar la ropa. Hacer las cosas de la mujer. Cuando se va a casar hay que saber lavar, cocinar, planchar. Si no el marido le va hinchar el ojo. Las mamás son las encargadas de enseñar a las hijas. Por eso ellas están detrás de las mamás. Se nos enseña que, por el afecto, se pone el niño a dormir con la mamá, para que se ponga cariñoso, para sentir el calor de la mamá, para sentirse protegido. Y los hombres del papá, porque él les enseña a trabajar, a coger la pala. Para ser hombres hay que saber coger la pala y el machete - Elisa Isabela Folleco Lara.
\end{abstract}

Por meio de vários depoimentos, busco mostrar que esse arranjo do masculino/feminino não é inexorável. Por exemplo, algumas mulheres com quem dialoguei não correspondem a tais expectativas, em razão da incidência política externa, do trabalho fora de casa e das trajetórias estudantis e acadêmicas. Suas relações conjugais tomam caminhos muito diversos: algumas se separam, outras logram construir um espaço de negociação dentro da relação, outras já vivenciavam uma relação que não se amoldava a tal arranjo.

A maioria das relações sexual-afetivas ora relatadas envolve homens afrodescendentes. As exceções são os casos de Martha García e Leo Micolta, que tiveram 
companheiros não afros. Fernández-Rasines interpreta a tendência à endogamia no contexto da norma de direito paterno para a transmissão da herança patrimonial e da linhagem. Segundo ela, "as primeiras núpcias ajustam-se ao deber hacer porque delas surgirão descendentes de direito". Ressalvo que se trata de uma análise das dinâmicas conjugais na serra norte do Equador, onde a endogamia é padrão recorrente nos últimos cinquenta anos, o que não cabe para a costa de Esmeraldas (Fernández-Rasines, 2001: 113). Em Esmeraldas, a autora destaca que não são raras as uniões entre gente negra e indígenas Chachis ou Cayapas, tanto nas primeiras como em uniões posteriores. Eu pouco encontrei esse tipo de união.

Relatos que Fernández-Rasines construiu em diálogo com mulheres migrantes afrodescendentes do bairro Silanes, em Quito, indicam que muitas delas são "madres solas", que se orgulham de criar sua descendência autonomamente e que, em alguns casos, não manifestavam desejo algum de compartilhar a vida com um homem. Por outro lado, alguns relatos informam à autora que tanto homens como mulheres se movem nas relações múltiplas com relativa fluidez. Mulheres com quem dialoguei, em sua maioria, são responsáveis financeira e afetivamente pela criação da prole. À parte disso, parecem ter uma grande disposição para as relações sexual-afetivas, que é consciente do que isso significa subjetivamente. Assim, enxergo uma agência feminina nas relações conjugais. Ao falar sobre agência feminina, refiro-me a uma ação consciente e autônoma, que leva ao empoderamento das mulheres e a uma capacidade de intervir e transformar os sistemas de desigualdade social.

Mulheres como Targelia vivem em um lugar onde o trabalho é extremamente duro e a violência, especialmente em torno do conflito armado, cotidianamente cerca e cerceia as pessoas. Nesse universo, a vida a dois é valorizada. "Esta soledad es dura", como expressa Targelia. Ao mesmo tempo em que a conjugalidade é desejável, como as relações conjugais são eivadas de desencontros e por vezes desrespeitos, o que envolve dor e sofrimento, uniões e desuniões são bastante frequentes. Trata-se, pois, de uma aposta que envolve colocar-se em risco. Nesse sentido, a abertura ao outro revela uma capacidade meio inesgotável de reconstruir vínculos afetivos, de se reinventar nas relações, o que é valorado positivamente.

Em uma conversa sobre experiências afetivas com Targelia, perguntava-lhe como era a relação com o último companheiro que teve, de quem havia se separado pouco antes, o colombiano Tico, cuja história contei anteriormente. Nessa relação, a opção de Targelia foi pela negação do arranjo familiar "poligínico". Explicou-me que a separação foi motivada não apenas pela existência de outra mulher, mas também porque "los hombres no aceptan que las mujeres digan: tal cosa no la voy hacer. Ellos no saben decir: vamos hacer juntos". Ela 
nomeia esse comportamento masculino como "machismo de los hombres", que pode descambar para a violência física, como vimos. Nesse tocante, ela dá um depoimento de um vigor inspirador: "el cuerpo mío no es para ser maltratado, porque no soy un animal. No permito que um hombre maltrate mi cuerpo". Targelia perguntou-me, então, por que eu e meu ex-companheiro havíamos nos deixado. Eu contei a ela que nessa relação sofri demasiadamente e falamos um pouco sobre os maus-tratos que vivi. Targelia então me perguntou: "si te encuentras un hombre bueno y que a ti te guste, te vas a vivir con él, ¿no?" Eu respondi: "creo que sî".

Quando saí de Palma Real, em fevereiro de 2014, Targelia me contava que estava começando uma nova relação conjugal, com um rapaz com quem ela já tinha tido uma história anteriormente e que a buscava agora para uma união livre. Dizia que entre eles havia uma grande diferença de idade, em torno de trinta anos, mas que "para el amor no hay edad".

\section{ARRANJOS FAMILIARES E DINÂMICAS PRODUTIVAS}

Observando principalmente o cotidiano das mulheres marisqueiras, percebem-se dinâmicas particulares, as quais precisam ser compreendidas por meio das interfaces entre arranjos familiares e dimensões da produção. Conforme explicado na introdução, a pesquisa se concentrou em comunidades ribeirinhas, localizadas às margens de rios. No caso do Rio Mataje, situado na exata fronteira entre o Equador e a Colômbia, a equatoriana localidade de Palma Real, onde trabalhei, encontra-se em áreas de manguezais e praia. No caso do Río Patía (Salahonda/Tumaco), realidade similar se apresenta. Nesse contexto, as principais atividades produtivas são a mariscagem e a pesca.

Em Palma Real, Salahonda e Tumaco uma combinação de fatores permitiu a mulheres trabalhar coletando conchas nos manguezais e concomitantemente construir estratégias de cuidado e atenção aos filhos. Segundo Arocha (1986), são fatores ecossistêmicos, que facilitaram a redução da jornada extrativa e a utilização de tecnologias manuais, e fatores sócio-históricos, que entendo serem especialmente a matrifocalidade e as redes relacionais que as mulheres nutrem em torno de si. Elas saem para conchar em locais próximos à residência. Em geral o fazem no horário em que filhos/as estão na escola ou, quando necessário, podem levar as crianças para os manguezais. Uma possibilidade extra é a criação de arranjos solidários com outras mulheres, enquanto umas saem para trabalhar, outras ficam 
em casa com as crianças. Trata-se de uma rede basicamente feminina que engloba vários lares ligados por relações de parentesco, mas também de amizade e laços matrimoniais, realidade similar com a descrita por Carol Stack sobre uma comunidade negra urbana dos Estados Unidos (1974). A existência dessa rede permite às mulheres desenvolver a mariscagem, ou concheo.

Nesse contexto, lar e local de trabalho se imiscuem. Não há uma rígida separação entre ambos, como se percebe na economia capitalista. Assim, as mulheres não são donas de casa, tampouco assalariadas. Como coloca Lozano, "a tradicional divisão sexual do trabalho no Pacífico não permitia traçar uma linha definitiva entre trabalho doméstico e o agrícola ou produtivo" (Lozano, 1996: 185). Moore (1991) chama atenção para o fato de que, em situações como essa, há uma combinação especial de relações produtivas e reprodutivas, que pôs ao alcance das mulheres uma fonte de renda, sem implicar ausência da casa. Ela ressalta que tal configuração não significa necessariamente a ruptura da divisão sexual do trabalho e a transformação das relações de gênero.

A família de Targelia Micolta, por exemplo, é composta por mulheres concheiras, que vivem direta ou indiretamente da extração da piangua nos manguezais de Palma Real. No derradeiro momento em que estive convivendo com a família, entre o fim de 2013 e o início de 2014, vivia cada uma em sua residência: a mãe, Targelia, e duas de suas filhas, Eneida e Leo. Leo estava casada com um rapaz de Palma Real que também vive da mariscagem. Ela diariamente sai para a jornada de trabalho com seu marido. O filho mais velho vai à escola, enquanto o mais novo fica com Eneida, que também se encarrega de cuidar de seus oito filhos. Targelia trabalha produzindo mechones, instrumentos feitos de fibra vegetal da Rhizophora mangle, árvore dos manguezais, usados para espantar mosquitos durante a jornada de extração da piangua. Então, antes de sair para conchar, as mulheres crianças e homens se dirigem à casa de Targelia para comprar seus mechones. Ao retornar da labuta, por vezes, Eneida compra de Leo as conchas para revendê-las. Nesse sentido, entre elas, constituise um circuito produtivo-econômico e doméstico, que envolve os encargos de cuidado com a descendência e geração de renda.

O concheo é uma atividade extenuante e que expõe as mulheres a enfermidades decorrentes da picada do peixe-sapo e eventualmente víboras; quedas acidentais, problemas ósseos, ginecológicos e dermatológicos a médio/longo prazo, em função da umidade do ambiente. Ademais, o contexto socioeconômico de Palma Real é bastante precário. Manoela Salazar descreve as mulheres concheiras como "las mujeres de la pesca, que son las que 
capturan la concha, que son mujeres viudas, mujeres que son cabeza de familia, mujeres que han perdido sus hijos y sus esposos, esas mujeres son de la pesca, ¿no? También no tienen ayuda, nada. Mujeres que quedan en la frontera con Ecuador, ¿no?”. Assim, parece existir uma associação entre o concheo e as mulheres sem cônjuge. Quando encontram parceiros conjugais, as mulheres podem contar com a complementariedade do trabalho masculino e, assim, tem a possibilidade de "descansar".

O depoimento de Martha acena para o fato de que há uma cooperação, mulheres mariscam e os homens pescam. Não necessariamente ambos o fazem ao mesmo tempo, mas complementarmente:

O sea por ejemplo yo cuando ya me junté con él ya no concheé más. Me quedé descansando en mi casa porque era mucho lo que había conchado, yo conchaba cuando estaba sola, pero cuando se trabaja en el Bajito por lo menos, las mujeres conchan y los hombres pescan, ahí están compartiendo el hogar, están ayudando al hogar todos dos. Por que cuando el hombre deja de pescar, la mujer concha y con esa plata están comiendo esos días mientras llega la plata del marido o ayudando a los hijos pa'colegio p’alguna cosa - Martha García.

Ao longo da convivência com a marisqueira família de Targelia, a pauperização é explicitada a todo o momento. São constantes os diálogos entre ela e suas filhas sobre como conseguir recursos para pagar as despesas cotidianas da casa ou como aumentar a renda da família. Targelia Micolta também fala sobre a possibilidade de descansar quando se tem um marido:

Paula: Cuando una mujer busca marido, ¿para qué es? ... ¿marido sirve para qué?

Targelia: ¡Para uno descansar! Uno no... por lo menos yo aquí. ¡Mire, la casa se me quiere caer! Mire, aquí tengo que hacer este trabajo de ahí. Tengo que tener plata para que me lo hagan. Porque si no tengo la plata, pues ninguno me lo hace. Usted con un marido...

Pensando no caso de mulheres como Martha e Targelia, compreendo sua posição nos arranjos familiares como estratégias por elas aplicadas para sobreviver e otimizar seus recursos e oportunidades nas circunstâncias em que vivem, que envolvem, além da dimensão produtivo-econômica, dimensões sociais, políticas e ideológicas.

Quando acompanhamos mulheres mais jovens, a dinâmica pode ser um pouco diferente. Leo saiu de casa, de Palma Real, San Lorenzo, Equador, aos sete anos de idade. A avó materna, María Magdalena, levou-a para Guayaquil. "Ella me llevó por allá y me dejó como compañera de la señora, pero no sabía que me iba a poner de empleada". Desde que 
saiu da casa dessa senhora, Leo trabalha ${ }^{180}$. Aos dezesseis anos ela ganhou a primeira filha, fruto da união com seu primeiro "compromisso", de quem posteriormente se separou.

Paula: ahí te separaste ¿y qué hiciste con esa niña?

Leo: ¿con mi niña? Andaba conmigo. Yo trabajé en una camaronera, una empresa de camarones

Paula: ¿allá en Guayaquil?

Leo: sí. Ahí trabajé en esa camaronera un buen tiempo

Paula: ¿en eso tenías cuantos años?

Leo: ya tenía mis veinte años. Entonces él [el papá de la niña] ya se fue, estaba yo trabajando ahí mantenía a mi hija, cuando necesitaba la niña algo yo mandaba la niña donde él, él la tenía. Cuando me tocaba trabajar de noche, él iba a dormir con ella, porque él después se hizo de otra mujer, entonces ahí yo trabajaba y él la cuidaba.

Vemos, pois, que Leo contou com apoio do pai da criança para cuidá-la, o que parece ser um aspecto relevante para a possibilidade de seguir trabalhando na empresa de cultivo de camarão. Desde que retornou a Palma Real, sua atividade principal é a mariscagem. Ela assumiu uma nova relação conjugal. Seu atual companheiro também é conchero, mas Leo não deixou de mariscar:

Yo tengo que aprender le decía yo a ella [la hermana Eneida], a mí me gustaba ir a conchar y tenía que aprender a mantener a mis hijos. Ahí ya me hice un compromiso. A mi hijo mayor tampoco le gusta que yo vaya a conchar. Pero yo no puedo estar en la casa, no puedo, no me gusta. Me da flojera estar solo encerrada en la casa sin hacer nada, me canso más en la casa que en el conchero - Leo Micolta.

Vários depoimentos indicam que há um corte geracional no tocante às expectativas sociais direcionadas a mulheres e homens. O depoimento de Martina Granja anteriormente apresentado também indica que há mudanças contemporâneas nesse quesito. O mesmo é colocado por sua sobrinha, Ana Karina Granja: “Antes se enseñaba que el marido no puede lavar un plato. Las madres no permitían que un hombre hijo de ella salga a lavar en la casa. Yo discuto eso con la mamá de mi novio. Ella dice que no. El hijo de ella no. Yo tampoco voy a ser empleada de su hijo, yo le digo. ¡Nunca!".

Elvia Micolta fala sobre essa questão, referindo-se à equidade de gênero, tema que estudou no curso dedicado à formação de jovens líderes afro-equatorianos/as, em San Lorenzo $^{181}$ :

\footnotetext{
${ }^{180}$ Para Lozano (1996), a mobilidade feminina no Pacífico é uma das mudanças trazidas pela entrada do grande capital e pela perspectiva do desenvolvimento.

${ }^{181} \mathrm{O}$ curso desenvolvido no Centro Binacional Martin Luther King, que é também sede da Federación de Artesanos Afroecuatorianos Recolectores de Productos Bioacuáticos del Manglar, chamou-se Ciclo de Formación de Líderes y Liderezas. Consistiu em cinco encontros presenciais, de dois dias cada um, entre os meses de outubro e dezembro, encerrado com conferências ("diálogo de saberes") e um ato de formatura. A
} 
Me gustó eso y también sobre la equidad de género, que tanto los hombres como las mujeres, así como ellos tienen derecho uno también lo tiene, así como ahorita ellos trabajan uno también trabaja, yo hago esto tu también lo haces, porque ahorita tiene que haber una equidad de género entre los dos. No es que porque tu trabajas me vas a humillar, no, los dos trabajamos, los dos tenemos ese derecho, los dos nos vamos a compartir todo, tu a mí no me vas a maltratar ni yo a ti, los dos para que allá una equidad, ni tu más arriba ni yo más abajo, los dos estamos ahí en el centro (...) a partir del 2010, del 2012 ya ha habido más la equidad de género, ya no hay más como antes que existía un capricho que los hombres le podían hacer de todo a las mujeres, ahora no. Si es posible una mujer lava la ropa y él va lavando los platos, hay esposos que te ayudan a barrer, ayudan cocinando. Entonces ahorita hay una equidad de género, tanto como allá [Palma Real] tanto como algunas partes de aquí también [San Lorenzo]. Por acá ahorita hay un poco más, para lo de antes que era machismo, capricho, ahora ya no - Elvia Micolta.

Marlene trouxe o tema no contexto de uma reflexão que envolvia várias mulheres negras na "Mesa de Género", do Pre-Congreso Departamental Nariño, Etapa preparatoria al Primer Congreso Nacional de Consejos Comunitarios y Organizaciones Étnicas Afrocolombianas, Palenqueras y Raizales ${ }^{182}$. Marlene argumentava que as mudanças seguem a direção de desconstruir opressões de gênero, começando dentro do lar: "los hijos que nosotras criamos ya no son machistas. En mi casa, todos limpiamos platos. Hay que desaprender determinadas cosas y volver a construir”. Nesse contexto, à fala de Marlene foi contraposta uma perspectiva de que papéis sociais femininos e masculinos estão consolidados e que não cabe às mulheres intervir nessa construção. Edna Padilla, liderança que faz parte da Mesa Departamental de Mujeres de Nariño, foi quem trouxe tal perspectiva.

Nuestro lugar debe ser con los hombres no como ellos. Culturalmente, somos hombres y somos mujeres y hay lugar para cada uno. Yo en mi casa hago todo para mi hijo. Si le soltamos a los hombres a la cocina, ¿yo qué hago? Es compartido el quehacer de la casa. Están trabajando los dos (el hijo y la hija) pero cada uno en su espacio: el lava el patio, ella barre y trapea. El límpido mariquea, el ajo también ${ }^{183}$ - Edna Padilla.

seguir descrevo os temas e facilitadores de cada módulo: Módulo 1: Realidade Nacional e Global - Pablo Vergara (13 e 14 de outubro de 2012); Módulo 2: Democracia e Participação - Liliana Suárez (27 e 28 de outubro de 2012); Módulo 3: Poder Cidadão - Katherine Chalá (10 e 11 de novembro de 2012); Módulo 4: Políticas Públicas e Ações Afirmativas - Jhon Antón (24 e 25 de novembro de 2012); Módulo 5: Identidade Cultural - Juan García y Pablo de la Torre (8 e 9 de dezembro de 2012).

${ }^{182}$ O evento ocorreu entre os dias 9 e 10 de agosto de 2013, no Liceo Max Eidel, Tumaco, Nariño, Colômbia. Foi organizado em nível local por RECOMPAS, ASOCOETNAR e CONDICOC, com apoio da comissão de organização do congresso em nível nacional.

${ }^{183}$ Límpido é um produto de limpeza. Marica em espanhol tem o mesmo sentido que o termo assume no Brasil. 
Fernández-Rasines ajuda-nos a compreendê-la. Em diálogos com mulheres afroequatorianas da costa e da serra, a autora observou uma dinâmica disciplinar por meio da qual as mães dividem tarefas do lar que eram comuns para filhas e filhos em idade mais jovem. Isso ocorre especialmente a partir da puberdade, quando se faz necessário dar "caráter de homem" aos meninos (Fernández-Rasines, 2001: 163). O depoimento, portanto, afirma o entendimento de que, ao realizar tarefas domésticas de limpeza e cozinha, o homem perde sua virilidade, aproximando-se da mulher.

Edna Padilla estava isolada na defesa de seu argumento no contexto da Mesa de Gênero e sua fala destoa das vozes de mulheres com quem dialoguei processualmente. Ana Karina Granja, por exemplo, dizia "mi papá se metió a la cocina, mi papá no es marica”. A maioria das narrativas aponta o machismo como um problema cultural, cuja raiz se encontra também na educação doméstica dentro das famílias afro-pacíficas, que pode sedimentar papéis masculinos e femininos gerando uma condição de desvantagem para as mulheres.

Novamente, retomamos Machado (2010) e sua reflexão sobre as tensões no processo de ressignificação cultural que envolve a defesa simultânea de direitos das mulheres e direitos à diversidade cultural de suas comunidades e povos. A autora ressalta que arranjos familiares ancorados em tradições culturais devem se adequar ao acordado em relação aos direitos humanos das mulheres: "os direitos coletivos devem ser preservados desde quando não forem contrários ao que foi acordado como direitos individuais" (Machado, 2010: 73). Para Asher (2009), os papéis de gênero, moldados por estruturas de passado, estão se reconfigurando e se reformulando, ainda que com tensões e dificuldades, em contextos políticos contemporâneos dos movimentos negros ou afro-colombianos.

Percebo, então, que as mulheres com quem dialoguei priorizam, nesse tocante, os direitos das mulheres, comprometendo-se com a transformação social desde suas próprias famílias, como diziam na Mesa de Gênero: "hay que construir en el proceso pero también en la casa. La primera escuela es el hogar".

\section{A MATERNIDADE COMO CONSTRUÇÃo POLÍTICA}

Los dioses acá se mimetizan en la madre.

Carlos Rua 
Debruçamo-nos então sobre a associação entre feminino e maternidade. González caracteriza o Pacífico Negro a partir de um ethos cultural de feminilidade e virilidade. Assim, "la representación de la feminidad está relacionada con la condición fálica de la cultura del Pacífico, por tanto se es mujer en cuanto se es madre” (González, 1995:42); “una mujer adulta que no tenga compañero, ni tenga hijo es vista como mujer incompleta o no 'es mujer" (Idem, ibidem: 43). Na argumentação da autora, nota-se que a condição de mãe se origina da dimensão fálica afro-pacífica. Ou seja, a construção do feminino provém da construção do masculino. E a maternidade figura como uma prisão, uma condição inexorável ao ser mulher.

Nas elaborações de Ortner (1972), a maternidade é um dos elementos chave para a compreensão da inferiorização das mulheres ${ }^{184}$. Conforme interpreta a autora, culturalmente a mulher parece simbolizar algo que toda cultura deprecia, algo que toda cultura define como sendo de uma ordem inferior de existência, relacionado à natureza (Ortner, 1972/9: 25). As mulheres são vistas como estando mais próximas à natureza do que os homens, o que, segundo a autora, está relacionado ao corpo e à procriação. As funções fisiológicas da mulher universalmente tenderiam a limitar sua movimentação social, motivado principalmente pelo processo de lactação, confinando-a a certos contextos sociais vistos como mais próximos da natureza, tais quais o contexto familiar doméstico (Idem, ibidem: 31).

Conforme coloca Moore, "uma das razões aduzidas por Ortner para explicar porque a mulher se considera 'mais próxima da natureza' é a associação espontânea da mulher com o aspecto 'doméstico', em oposição ao aspecto 'público', da vida social” (Moore, 1991: 36). A autora explica que a "antropologia da mulher" estabeleceu uma correspondência entre a dicotomia natureza/cultura e a divisão "doméstico"/“público”. O último par dessa correspondência é tema do artigo Michelle Rosaldo, segundo o qual, há uma oposição universal e estrutural entre os domínios de atividades domésticas (compreendidas como instituições e modos mínimos de atividades organizadas imediatamente em torno de uma ou mais mães e filhos) e públicas (atividades, instituições e formas de associações que ligam grupos mãe-filho particulares) (Rosaldo, 1974: 23). E há uma identificação muito geral das mulheres com a vida doméstica e dos homens com a pública. Tais domínios são hierarquizados de modo que a esfera feminina e doméstica está englobada pela esfera masculina e pública. Moore ressalta que a oposição doméstico/público se valida no pressuposto da universalidade da unidade mãe-filho/a (Moore, 1991: 37).

\footnotetext{
${ }^{184}$ Interessa-me debater com essa perspectiva de Ortner. Porém, ela reconsiderou tais argumentos no artigo "So, Is Female to Male as Nature Is to Culture?", escrito em 1995 (Ortner, 1996: 173-180).
} 
Segundo Moore, a separação entre doméstico e público, bem como a configuração de direitos políticos com base no sexo, que gerou uma desigualdade entre mulheres e homens, são características da sociedade ocidental de fins do século XIX e começo do século XX.

\begin{abstract}
La identificación de esta desigualdad de 'derechos' se tradujo posteriormente en una concepción cultural específica de lo que la mujer y el hombre debían ser, tanto en el hogar como fuera de él. Esta concepción constituyó la base de una serie de ideas acerca de la maternidad, la paternidad, la familia y el hogar; ideas que han sobrevivido en la sociedad occidental de muy distintas maneras, y han influido en el mantenimiento de la dicotomía 'doméstico'/ 'público' como estructura analítica de la antropología social (Moore, 1991: 37).
\end{abstract}

Ou seja, os pares de oposição natureza/cultura e "doméstico"/“público", assim como a correspondência entre eles não são universais. Tampouco, é universal a unidade mãe-filho/a. Cabe, portanto, questionar a pertinência desse modelo para analisar dada realidade social. Como colocado anteriormente, o conceito mesmo de família que encontro nas narrativas de mulheres afro-pacíficas desbanca esse modelo analítico. Porém, González recorre ao esquema ora criticado para explicar a função das mulheres como estabilizadoras da esfera das unidades domésticas produtivas e residenciais, ao argumentar que a vinculação de mulheres com espaços domésticos tem relação com seu papel de reprodutoras, portadoras e alimentadoras dos filhos/as (González, 2002: 37).

Segundo González (1995 e 2002), a obrigatoriedade da descendência aprisiona não apenas mulheres, mas também homens:

En el Pacífico hay una sola manera de ser hombre y una sola manera de ser mujeres, no existen las diversas formas masculinas y femeninas que se dan en nuestra cultura occidental. Es decir, allí las mujeres sirven y acompañan a su hombre, cocinan, lavan, barren, sacan el viche, ahúman y secan el pescado, van a pianguar, pero primordialmente tienen muchos hijos. Además saben perfectamente en qué posición de estatus se encuentran en la poliginia de su hombre. Por su parte, el hombre circulando en los grupos domésticos femeninos, provee de alguna manera el sustento diario de su mujer y de sus hijos: (tanto biológicos como culturales) cortan troza, pescan, cazan, tejen trasmallos, 'paran' sus viviendas, etc. No obstante, lo que asegura su condición de hombres es tener una numerosa prole, para asegurar la continuidad de su tronco familiar y ampliar las redes del parentesco a través de la exogamia. A parte de estas dos maneras de ser y funcionar en esta sociedad, no existe ninguna otra (González, 1995: 43-44).

Estamos diante de uma visão estereotipada, etnocêntrica e absolutamente reducionista da construção da masculinidade e da feminidade afro-pacífica. O trecho é praticamente idêntico ao artigo de María Cristina Tenorio, citado pela própria Nancy Motta González, que 
substituiu "Matanga" por "Pacífico" e fez pequenas modificações ${ }^{185}$. O texto original baseiase no material etnográfico produzido em pesquisas demonografias de graduação em psicologia de María Teresa Cucalón e Claudia Martínez. As pesquisas foram realizadas em um povoado negro às margens do Rio San Juan, cuja população à época era de 159 pessoas. Nota-se que a antropóloga Nancy Motta González generalizou para todo o Pacífico as conclusões de estudos de psicologia sobre uma comunidade de pequeno porte.

As críticas que Asher (2009) faz aos argumentos de González apontam tratar-se de uma visão biologicamente determinada sobre papéis sexuais; e uma avaliação racista, na medida em que reforça estereótipos sobre a sexualidade negra ao naturalizar as iniquidades de gênero e essencializar homens negros como seres hipersexualizados. Ressalto profunda discordância com o reducionismo pelo qual González conceitua "feminino" e "masculino" no Pacífico Negro. Após viver em Salahonda/Nariño, "día y noche y durante un año sin interrupción en el año de 1975" (González, 1976: 26) e seguir atuando no Pacífico colombiano nas décadas seguintes, parece-me surpreendente que a antropóloga encontre uma única forma de ser mulher e uma única forma de ser homem afro-pacíficos, todas as duas vinculadas à procriação. $\mathrm{O}$ que constitui o maternal e o paternal não é dado, é construído, é diverso e deve ser investigado.

As narrativas de mulheres afro-pacíficas aqui apresentadas mostram outros caminhos de construção do feminino. Junto com Henrietta Moore (2007), compreendo que não se pode conceber a subjetividade de gênero como uma identidade fixa e singular. Não se adquire identidades de gênero a partir de um modelo singular de feminilidade e masculinidade. Múltiplos modelos de gênero existem em qualquer contexto. O sujeito encontra-se, portanto, com múltiplas posições de gênero, algumas das quais podem ser contraditórias e conflitantes. Trata-se de um processo de produzir e sustentar um self por meio da identificação e/ou da resistência a múltiplas posições subjetivas, as quais são apresentadas pelos diferentes discursos que atravessam a construção da subjetividade de gênero. Isso acontece em um palco de intensas lutas em torno de poder, significados, valores e recursos.

Mesmo no contexto das construções de gênero e raça hegemônicas, sempre há uma parte do ser que escapa de determinações pelo social. O processo de subjetivação, de tornar-se

\footnotetext{
185 “En Matanga hay una sola manera de ser hombre y una sola manera de ser mujeres. No existen las diversas formas masculinas y femeninas que se dan en nuestra cultura occidental. Es decir, alli 'las mujeres sirven y acompañan a su hombre', cocinan, lavan, barren, sacan el viche, pero primordialmente tienen muchos hijos. Los hombres de una u otra forma proveen el sustento diario de su mujer y de sus hijos: cortan troza, pescan, cazan, tejen trasmallos, etc. No obstante, lo que asegura su condición de hombres es tener una numerosa prole con el fin de que les ayude a trabajar, pero básicamente para asegurar la continuidad de su linaje. Aparte de estas dos maneras de ser y funcionar en esta sociedad no existe ninguna otra" (Tenorio, 1993: 73).
} 
sujeito, nunca está finalizado ou fechado. Poder e ideologia produzem posições sociais, mas não determinam como indivíduos se identificarão e assumirão diferentes posições subjetivas, em diferentes momentos. Como nos ensina Homi Bhabha (1998), o significado jamais é fixo, controlado permanentemente pelos grupos hegemônicos. O sistema projeta sentidos, interpelando os sujeitos, contudo há maneiras de desestabilizar os sentidos. A questão é perceber o quanto e como efetivamente uma pessoa pode reconhecer e escolher as diferentes posições subjetivas que assume e do quanto a pessoa é efetivamente capaz de resistir aos termos dos discursos hegemônicos, como explica Moore (2007).

As narrativas de mulheres afro-pacíficas contam histórias sobre ser mulher negra nesse contexto que por vezes contrariam as imagens consolidadas na literatura antropológica e feminista. Meu intento é por dialogar com outros lugares que homens e mulheres ocupam e outros significados sociais atribuídos a esses mesmos lugares.

Somos un canto a la vida: Para nosotras el estar preñadas es estar contentas. El tener un hijo, lejos de ser una carga o un problema, es una alegría. Entre más hijos, más garantía de perpetuidad de los troncos familiares. Una familia pequeña pierde el respeto, mientras que una familia grande da respaldo y fortaleza (Mena, 1993: 93).

Conversando com mulheres afro-pacíficas, noto que a maternidade é um lugar de empoderamento, ainda que em determinados contextos represente aprisionamento. As tensões entre lugares de empoderamento e aprisionamento são abordadas por Patricia Hill Collins no contexto do trabalho não remunerado de mulheres negras dentro das redes familiares. A autora ressalta a perspectiva de quem realiza esses trabalhos, ou seja, de mulheres negras, e o valora mais como uma forma de resistência à opressão do que como uma forma de exploração pelo homem (Collins, 2000: 46).

Para María Barbarita Lara, cujo depoimento foi anteriormente citado, a maternidade configura um aspecto limitante de seus anseios. Se tivesse sido mãe, não teria estudado. Vale lembrar que Barbarita vive no território ancestral Valle del Chota, Salinas y la Concepción. Conforme explicado, é uma região no interior do Equador; não se situa na zona do Pacífico Negro colombo-equatoriano, área foco desta pesquisa. Mas, assim como seria no Pacífico, dentro de seu território, o ponto de vista de Barbarita e sua trajetória são peculiares. Aí também a maioria das mulheres são mães. Ela relata que sua inadequação à expectativa social relativa à maternidade resulta em desconforto e certa dor.

Como vimos no depoimento de Eva Lucia, os filhos não representaram um peso em sua vida, porque a coletividade os assumiu, junto com ela. Ou seja, não se trata de uma 
unidade mãe-filho/a, ou avó-mãe-filha/o. Essa relação é plural, envolvendo a parentela e a irmandade política, social e afetiva na qual estão engajadas as mães. Nesse sentido, percebo um sentido de família que contesta também as formulações da antropologia mais moderna, como as de Fortes e Fox (apud Moore, 1991), que alegavam ser a díade mãe-filho a unidade básica da sociedade e que, apesar de eliminar o pai da unidade familiar, conservavam o conceito básico de família proposto por Malinowski (Moore, 1991: 38). No contexto afropacífico, a vida é responsabilidade de toda a coletividade. Como dizem as parteiras afroequatorianas de Borbón, região do norte de Esmeraldas, Equador: "en las comunidades que nosotras alcanzamos a conocer ninguna criatura después que estuviera nacida era guachara $^{186 "}$ (CECOMET, 2011: 37). Nesse sentido, Eva pôde seguir desenvolvendo sua sexualidade, seu trabalho e, mais que tudo, sua militância, paralelamente à vivência da maternidade.

Lembremo-nos da construção da família no processo de organização social negra em torno da mineração no Pacífico, nos séculos de XVII a XIX. Segundo Romero (1995), a família extensa era a chave desse processo organizativo. As quadrilhas, que começaram como unidades produtivas conformadas para a extração de ouro em jazidas e se transformaram em unidades socioculturais, dinamizaram relações sexuais nas quais participava a maior parte dos homens da quadrilha, alternadamente com o mínimo de mulheres existentes. A família extensa engendrada pela sucessão de matrimônios de um mesmo ego genitor fez com que os filhos se identificassem com a cabeça da família, denominada gran madre. Assim, constituiuse uma tendência à matrilinearidade (descendência) e à matrilocalidade (residência) em uma sociedade com patrilinearidade legal. Conforme ressalta Romero (1991), a ancestralidade era feminina. Desde o século XVII, o alicerce fundador do grupo social negro correspondia, de modo geral, a uma mulher: mãe, avó ou tataravó, em torno da qual se desenvolvia a parentela por linha materna.

No curso da história a matrilinearidade observada por Romero pode ter se modificado, conforme comentado anteriormente. O ponto de partida dos troncos familiares é a organização social em torno dos rios, de modo que a ruralidade é a gênese desses arranjos. Assim, as mudanças expressam o englobamento do parentesco por uma lógica de pertencimento ao território e à política. Ainda que sua ascesdência seja paterna, Eva Lucia compreende que o Pacífico colombo-equatoriano é "matriarcal":

${ }^{186}$ Criança órfã. 
La comunidad negra es matriarcal. Cuando la mujer decide que es cuidadora, eso es poder. Porque ella está actuando en el devenir de la comunidad. La mujer entonces como que dice al hombre: "no quiero su interferencia cuando estoy acá, formando los niños y niñas". El poder lo manejamos desde otra lógica. Hombres y mujeres tenemos visiones diferentes del poder y lo manejamos diferentemente. El hombre, macho alfa, tiene una manada. La mujer quiere compartir con las compañeras. La tarea es educar hombres y reeducar las mujeres. Cuando tomamos el poder, actuamos como hombres. El poder es para joder, esa es una visión eurocéntrica - Eva Lucia.

O sentido que o matriarcado parece assumir na fala de Eva Lucia, e que está presente também no discurso de mulheres afro-sanlorenzenhas, é o de um sistema em que a mulher tem um reconhecimento e uma importância, porque ela tem filhos. As mulheres como mães constituem o eixo da organização nos troncos familiares e na sociedade de modo geral. Entendo, portanto, que a autoridade feminina parte do espaço doméstico e irradia-se pela comunidade. O âmbito comunitário é construído em estreita conexão com o familiar, o que também imiscui as dimensões chamadas privada e pública. Portanto, a maternidade é constitutiva do social e tem um potencial político de transformação, no sentido de que, por meio dela, as mulheres intervêm nas relações sociais de poder e assimetrias de gênero, mas também de raça. Ela é o veículo pelo qual as mulheres perpetuam a comunidade, não tanto pela dimensão da geração de pessoas, mas principalmente pela gestão dessas pessoas.

Nesse sentido, não cabe a associação entre maternidade e domínio privado em contraposição a uma atuação "política" no âmbito público. Poder-se-ia pensar que a presença de mulheres afro-colombianas no espaço público, seja no passado ou contemporaneamente, não significa que estejam elas situadas em um espaço político, no sentido de estarem posicionadas estruturalmente em um lugar de fala com capacidade de fazer incidir seus interesses e questões específicas. Nota-se que, ao discorrer sobre o matriarcado afro-pacífico, Eva Lucia faz uma crítica e uma autocrítica, já que as mulheres por vezes introjetam a lógica masculina e eurocêntrica do poder. Na perspectiva da autocrítica, é elucidativo o depoimento de uma mulher negra valluna, do Vale do Cauca, trazido por Viveros (2008: 271). Segundo análise dessa mulher, a "cultura matriarcal" do povo negro cria os homens com a ideia de que podem ter todas as mulheres e todos os filhos que quiserem, já que são as mulheres quem ficam com a obrigação de cuidá-los. Seria, então, um "matriarcado machista", como dito na cartilha de formação de mulheres afro-colombianas em equidade de gênero no desenvolvimento local e regional. Na visão de Eva, o vetor da mudança são as mulheres. Elas têm o potencial de construir uma organização social e política afrocentrada, com equidade de 
gênero. Marlene Tello também acredita nisso. Sua argumentação se articula em torno da desconstrução da violência como modo de agir no Pacífico Negro, como linguagem social.

Em estudo sobre afrodescendência no Equador, Fernández-Rasines também concebe a centralidade das mães para explicar as dinâmicas de poder e autoridade em toda sua extensão política. Ela usa o conceito de matrifocalidade para pensar a maternidade como metáfora da liderança política, fonte de transformação de sistemas perpetuadores de desigualdades sociais. A maternidade, nesse sentido, designa a autoridade para a tomada de decisões coletivas e para atuar como representante e interlocutora frente às instâncias institucionais e administrativas locais (Fernández-Rasines, 2001: 139).

Um caso peculiar analisado por Fernández-Rasines é o de Emiliana, “mamá de Silanes", em cuja vida a maternidade se materializou por meio de uma construção alheia à reprodução biogenética. Ela não é mãe biológica, mas sua autoridade se reveste com o exercício de uma maternidade social, como explica a autora. Como membro fundador do bairro, Emiliana foi socialmente investida de uma autoridade como mãe simbólica e como mulher formada desde a autonomia (Idem, ibidem: 95-138). A autora conclui que a maternidade tem um significado como exercício da faculdade biorreprodutiva e outro associado à tutela, à liderança e à representação política em extensão. Nesse sentido, mulheres podem ascender à liderança por meio de sua posição como mães, mas também ocorre que mulheres adquiram a posição de mães mediante sua condição de líderes e agentes interlocutoras no espaço político, segundo a autora (Idem, ibidem: 199).

Segundo a percepção de Fernández-Rasines, na prática, a reprodução biológica é majoritariamente um interesse masculino, dos homens-maridos; "es como si los hombres mostraran mayor interés en materializar la progenie que las mujeres" (Fernández-Rasines, 2001: 174). No caso das mulheres, o exercício da maternidade como faculdade biorreprodutiva supõe a iniciação de jovens mulheres como sujeitos nodais dentro do grupo de parentesco. Fernández-Rasines percebe que os significantes de mulher e homem são ocupados pelos significantes de mãe e pai, respectivamente: "no se entiende que una mujer ocupe esta posición políticamente estratégica si no es conceptualizada como madre [...] no es inteligible pensar en un hombre como gestor y como líder, si no es desde su posición como padre" (Idem, ibidem: 176).

Camacho (2008) também ressalta que a maternidade e a paternidade são marcadores da condição de adultos/as, expressando a plenitude individual e social. É interessante notar que as autoras chamam atenção para questão similar à levantada por González (1995). 
Percebem, porém, que isso não reduz mulheres e homens aos papéis materno e paterno no sentido da reprodução biogenética. Fernández-Rasines explica que, a partir dessa construção, ambos podem ocupar posições políticas estratégicas, atuam como líderes e gestores.

Penso que a leitura da maternidade para além da faculdade biorreprodutiva é interessante. Não obstante, a partir das narrativas construídas com algumas mulheres afropacíficas, compreendo que ambos os significados da maternidade estão muito imbricados, de modo que é difícil separá-los. Em minha percepção, a reprodução biológica também é interesse feminino. Concordo com a leitura de que a maternidade posiciona mulheres como sujeitos nodais nas relações de parentesco. Porém, acrescento a percepção de que tais relações extrapolam o domínio do núcleo familiar e se estendem à coletividade. Nesse sentido, tornarse mãe biologicamente é também tornar-se mãe socialmente.

Fernández-Rasines ajuda a pensar sobre como o mundo da família e do parentesco estão conectados com o mundo da política. Sem embargo, apesar das referências a lugares políticos que remetem à maternidade e à paternidade, entendo que a entrada no mundo político não está atrelada à imagem de mãe e pai. Conforme me relataram as mulheres com quem dialoguei, a visão que a sociedade elabora sobre elas dentro da política, ou seja, como lideranças comunitárias, nem sempre é da mulher-mãe, por vezes é como mulher-"puta". Vendo a questão de outra perspectiva, o pertencimento a uma organização político-territorial não imuniza de conflitos no campo das relações conjugais, paternais e maternais. Quando do exercício da atividade política, há dificuldades, desencontros e culpas no campo das relações sexual-afetivas e familiares. A posição das mulheres como sujeitos nodais na construção das relações que a maternidade conduz, ao mesmo tempo em que abre caminho para o mundo político, também gera uma série de tensões nas relações conjugais e familiares.

González igualmente recorre ao conceito de matrifocalidade para caracterizar os arranjos familiares afro-pacíficos, porém, em sua obra, o conceito parece ter outro sentido: "En la organización social de las comunidades negras del Litoral del Pacífico, la matrifocalidad es lo relevante queriendo significar que en los grupos domésticos, la mujer además de ser el eje de la familia es también fuente principal de ingreso" (González, 1995: 9).

A autora reconhece o protagonismo feminino na organização do grupo doméstico e na geração de renda da família, mas não consegue perceber que são as mulheres, em seu papel de mães, que centralizam as relações sociais. Tendo em vista o estilo de mobilidade desse sistema de parentesco e partindo da premissa de que a circulação é prerrogativa masculina, ela centraliza o sistema de parentesco nos homens. No caso de Espinosa e Friedemann, bem 
como de Whitten, a centralização da família no homem está diretamente relacionada à concepção dos arranjos conjugais pela poliginia, o que as narrativas de mulheres afropacíficas contestam. Em meu entendimento, não se trata de que os homens fazem parentesco e as mulheres ficam em casa. Ambos fazem parentesco, saindo e ficando em casa.

Entendo, pois, que a coletividade afro-pacífica é matrifocal, no sentido de que a maternidade é fonte de liderança política e tem um potencial transformador das relações sociais de poder e assimetrias de gênero. $\mathrm{O}$ conceito de matrona me parece interessante para pensar a matrifocalidade. Marlene Tello se reconhece como matrona, como uma autoridade familiar e comunitária.

Zulia Mena, que é chocoana, primeira mulher negra eleita para a Câmara de Representantes colombiana, explica que:

La mujer negra dentro de nuestro grupo étnico, en un sentido general, es "matrona", lo que significa ser eje de familia alargada o grande. En torno a ella, se va estructurando en forma dinámica nuestra etnia, nuestra simbología, nuestro ser como pueblo. Ella maneja muy bien las relaciones con los hijos, los familiares y la comunidad. Ella forma, transmite y guía las normas internas y los controles característicos de nuestras comunidades (Mena, 1993: 90).

Trata-se de um lugar da mulher negra que expressa o poder de liderança e de agenciamentos. Ademais, situa as mulheres no centro da gestão produtivo-econômica e simbólica, primeiramente dentro de seu núcleo familiar, o que vai lhe abrindo caminho para ser reconhecida como matrona no âmbito comunitário.

Penso que podemos estender a autointitulação de Marlene como matrona às demais mulheres com quem dialoguei, que compartilham essa construção. Proponho utilizar a matrona como chave de leitura, como metáfora de liderança e autogoverno, assim como o faz Werneck (2005 e 2010) com as ialodês. Desse modo, a matrona se investe de poder no papel daquela que cuida e provê. Define um espectro de ação que limita a intervenção masculina e que se pretende alternativo e subversivo à lógica masculina de exercício do poder. Esse espectro de ação não é individual, mas, sim, é compartilhado entre um coletivo feminino.

A configuração de uma matrona é diversa e polifônica. Ela indica que há um poder de cuidado que é coletivizado; estende-se para além do grupo familiar e da família extensa. Lideranças políticas femininas de maior hierarquia são matronas. Mas as matronas não são apenas as lideranças políticas. As mulheres parteiras também são figuras de poder no contexto do povo afro-equatoriano e afro-colombiano. Elas iconizam o sentido das mulheres como aquelas que guardam a memória coletiva. "La mujer es el núcleo del aspecto ideológico de 
nuestro pueblo: es quien reza, canta, observa, prevé el futuro; es la equilibradora de lo divino y lo humano, lo caliente y lo frío. Es quien posee la "malicia” y el "sexto sentido". Es la mensajera cultural" (Mena, 1993: 91). Segundo Massolo (1998), o sistema sexo/gênero, ao organizar e regular as relações e divisões sociais entre os gêneros, estabeleceu que recordações e esquecimentos são matéria-prima da memória feminina. Essa memória está inscrita no corpo de mulheres negras. Segundo Camacho (2008), ela pode ser comunicada por meio de gestos e movimentos. Na relação entre parteiras e grávidas, explicita-se essa dimensão:

La relación entre partera-embarazada es un compartir cotidiano desde
cuando la partera atiende la mujer y usa sus manos como instrumento de
diálogo en el momento de la toca de la barriga, de acomodo del niño en
busca de la mejor posición. Esta forma de compartir se transforma en una
actitud, en un modo-de-ser que ennoblece a partera y le da reconocimiento
colectivo. En este compartir la partera usa fundamentalmente sus manos: la
mano que toca, la mano que acaricia, la mano que establece relación, la
mano que arrulla, la mano que trae sosiego. Pero la mano es más que una
mano. Es la persona humana que, a través de la mano y en la mano, revela
un modo-de-ser cariñoso y de cuidado esencial con la persona que atiende,
por lo cual recibe un reconocimiento [...] desde su comunidad por sus
saberes (CECOMET, 2001: 111).

As mãos da parteira abrem caminho a uma nova vida. Vilma conta que "cuando la mujer es baja de hueso y cerrada de carne, la partera usa el dedo para abrirla". Nessa interação em torno do nascimento, as mãos são o veículo que materializa as relações de uma coletividade na qual as mulheres são protagonistas. Ou seja, a figura da parteira explicita o poder de cuidado coletivizado que caracteriza as matronas. Nessa relação, novamente, visualizamos que o eu feminino é plural: visibiliza relações com outras pessoas (MASSOLO, 1998: 17).

Pelas mãos de mulheres parteiras todos e todas passam. Elas são matronas por excelência. Eva Lucia explicita isso ao falar sobre a parteira que a acompanhou:

La mamá Celina, tiene casi cien años, 97 años y sigue de partera. Ella era y sigue siendo la partera del barrio. Todo el mundo pasó por mamá Celina, o ella te trajo al mundo, o ayudó a traer tu muchachito. Todos, mis sobrinos, vecinos, mamá Celina la bendición, mamá Celina la bendición. Entonces todo el control, todo es con ella. Tú vas al médico, el control, las medicinas, las vitaminas y todo eso. Pero quién hace el control, que te está tocando, mirando si el niño está bien puesto, es ella. Y al momento de dar a luz, de hecho ella sabe primero que uno porque de hecho ella va llegando. Ella vive a dos cuadras de mi casa. Cuando fue Kissy, el médico me había dicho, usted debe dar la luz entre el 20 diciembre y el 23 de enero. Mi mamá no sabía eso, cuando va llegando una tarde. Era 20 de diciembre. Ella iba saliendo con su maletica y yo pregunté: ¿dónde vas mamá Celina? A tu 
casa, mija, la muchachita ya está que se pare. Y de hecho se acomodó su cama, generalmente al lado de la cama de la parturiente, la mujer embarazada. Desde que llegó esa tarde, toda hora se levantaba a tocar mi barriga. Uhum, ya está que se viene. $Y$ efectivamente. $Y$ entonces, de mi casa, no se iba hasta 10 días después hasta su casa que era a dos cuadras (risos). Hay que hacer los baños de asiento. Hay que curar el ombligo al niño. Todo eso. Enseñarle uno a pajarlo, a darle de comer. Diez días después se iba- Eva Lucia.

Recorrendo às reflexões coletivas das parteiras afro-equatorianas de Borbón, Esmeraldas, compiladas e sistematizadas pelo Centro de Epidemiología Comunitaria y Medicina Tropical (CECOMET, 2011), encontramos o termo "mamá grande" por meio do qual a coletividade afro-esmeraldenha nomeia as alumbradoras ancestrais. Entendo que seria o mesmo que chamá-las matronas.

A mãe de María Barbarita Lara Calderón era parteira de Mascarillas, localidade do território ancestral Chota, La Concepción, Salinas y Guallupe. Barbarita conta que sua mãe levava as filhas para acompanhá-la nos atendimentos. Sua mãe atuava como conselheira; chamava atenção dos maridos que não cumpriam bem seu papel conjugal, das mães que se descuidavam das crias. Como explicam as parteiras afro-equatorianas de Borbón, a mamá grande de uma comunidade ou de um rio tem compromisso com todas as mulheres e com todo o povo dessa coletividade.

A maternidade social está atrelada à faculdade biorreprodutiva. Barbarita explica que, por não ter nunca parido, não se desenvolveu como parteira. O mesmo afirmam as parteiras afro-equatorianas da área de saúde Borbón, Esmeraldas: "la mujer que se quiere hacer partera primero tiene que ser mujer hecha y derecha, porque lo primero que una partera tiene que saber es que un hijo duele, duele parirlo y duele mucho más cuando por alguna razón se lo pierde" (CECOMET, 2011: 25). Segundo as parteiras afro-equatorianas da área de saúde de Borbón, a tradição ensina que uma boa parteira tem de haver ela mesma parido muitos filhos.

Vilma Estácio Sá, de Ricauter, San Lorenzo, também se tornou parteira a partir do legado de sua mãe: “Carlota, mi mamá, era partera titulada. Ella nos llevaba junto a la hijas, cuando iba a partear, pero nos daba asco ver esas cosas. No nos quedamos. Y después que ella se murió, ya nos dirigimos a partear, yo y mi hermana Leona". Vilma pariu duas meninas, ambas faleceram. Ela conta que realizou sozinha o primeiro parto:

Y como ya vía como ella hacía cuando iba a partear. Yo dije: "vea mujer, tráeme una cobija y unas damagua"187. Póngame una damagua y tiéndame.

\footnotetext{
${ }^{187}$ Manto feito de pele de animal sobre o qual as mulheres costumam parir.
} 
A Arturo le decía: "agárreme por detrás, agárreme duro por detrás”. Y ahi yo parí. Después que se salió la niña, y ahora ¿cómo hago aquí pá sacar eso? Y estaba la placenta, las cosas todas adentro. ¿Cómo hago? Me movía, me movía, me movía. Y ahí me metí el dedo a la boca. Hice ansia. Salieran las placentas - Vilma Estácio.

Os depoimentos indicam que a arte de partejar é ancestral. Ou seja, no campo do sagrado, a matronagem também delineia lugares de sucessão pelo vínculo de descendência genealógica. Barbarita e Vilma tinham mães parteiras. Os conhecimentos ancestrais da parturição foram passados de geração a geração na memória coletiva, sendo, portanto, herdados:

la medicina tradicional [...] tiene que ser entendida como el resultado de um largo y permanente proceso de resistencia cultural muy activo frente a lo que es impuesto desde la sociedad dominante y donde el saber de los secretos entendidos como el poder de la fé, ligado al conocimiento del poder sanador de las plantas medicinales, jugaron un papel fundamental en las prácticas curativas que nuestros mayores usan para sanar el cuerpo y el alma $^{188}$ (CECOMET, 2011: 20).

Ao mesmo tempo em que se inscreve na tradição, contemporaneamente, a parturição dialoga com saberes da medicina ocidental. Vilma, por exemplo, é conhecida como "la doctora". Ela conta que gostaria de trabalhar no hospital: "Antes de ver el doctor que yo los mirara [aos pacientes], si tiene espanto, malaire, ojo. Trabajar solito con eso. Con las yerbas". No Equador, há uma discussão em curso sobre o tema. Gestores da área de saúde pública, ao discutir o racismo na saúde, falam sobre a necessidade de se reconhecer o trabalho das parteiras. "Ellas no son profesionales, pero pasan una vida, veinticuatro horas, trabajando. ¿Cómo garantirzarles un sueldo?”"189. Inés Morales coloca que a nova Lei de Saúde do Equador reconhece o trabalho das alumbradoras. Ela exemplifica com o caso do Hospital de San Lorenzo, onde está sendo reconhecido o trabalho das remedeiras e curandeiras no tratamento de enfermidade como ojo e espanto.

\footnotetext{
${ }^{188}$ Depoimentos de algumas mulheres com quem dialoguei mostram que, associados aos saberes do bem-nascer, há conhecimentos de tratamento e cura de enfermidades da alma e do corpo, que podem livrar uma criança com virtude das ações de bruxas, que tratam mal aire, espanto seco, espanto de água, ojo secador, ojo de pasión, ojo de amor, ojo de venganza. Cura-se "con palabras, con yerbas, el sobijo, con yerbas. Y tengo las botellas curadas", como nos conta Dona Vilma. Camacho (2008) referencia uma série de pesquisas sobre práticas religiosas, mágicas, de curanderia e parto, bem como práticas que foram tachadas como bruxaria, feitiçaria e adivinhação. Trata-se de uma das abordagens de estudos históricos e antropológicos sobre mulheres afrocolombianas e afro-equatorianas. Infelizmente, não desenvolverei essa abordagem na tese. Fica para uma próxima oportunidade.

${ }^{189}$ Fala de Irma Bauptista, afro-equatoriana que trabalha no Ministério da Saúde, durante reunião de balanço do Plano Plurinacional contra a Discriminação Racial e a Exclusão Étnico Racial, realizada em Quito, em 8 de dezembro de 2013.
} 
Mailen Quiñones é liderança política e parteira, indicando que pode haver uma sobreposição de sentidos de matrona em uma mesma pessoa. A tradição remonta a três gerações que a antecedem:

Era partera mi bisabuela, abuela, madre y yo. Y mi hermana María Eresma Mosquera. Mi mamá desde que yo tenía seis años me llevaba a ver como era el parto. Y me enseñaba las plantas, cómo cocinar, pa'que sirven. Mi mamá me sacó cinco hijos, sólo el primer hijo mío no salió con mi mami - Mailen Quiñones.

Na visão das parteiras afro-equatorianas de Borbón, há um dever ser para a mulher e para o homem. Nessa perspectiva, se o dever da mulher é o de parir, o dever do homem é o de acomodar o ambiente para o parto e assumir o compromisso do reconhecimento à parteira. Elas explicam que o reconhecimento da coletividade é o ponto de partida para que uma mulher se consagre como parteira, pois é ele quem leva as grávidas e seus familiares a buscar certa parteira para que lhe acompanhe e ajude no processo do bem-nascer. O reconhecimento é coletivo; porém, em cada relação estabelecida em torno da faculdade biorreprodutiva, cabe ao homem-pai expressá-lo. Nesse âmbito, o reconhecimento tem uma dimensão material que nos leva de volta ao corpo, mais precisamente, às mãos: "lo que más se acostumbraba darle a la partera eran las manos del compañero de la parida y uno las recibía cuando necesitaba manos para hacer algún trabajo". Assim se constitui um ciclo de reciprocidade: "manos que dan, manos que reciben" (CECOMET, 2011: 100-101). Essa fala das parteiras interpela toda a comunidade, mas especialmente os homens, para a reciprocidade: o dar e receber.

A matronagem agrega algumas ideias-valores centrais no mundo Afropacífico: a construção da liderança a partir de posições como as da parteira, rezandeira, conselheira, dentre outras; o lugar do sagrado nessa liderança; a fluidez das águas (e o rio como território); a família como coletividade, como rede e organização; a centralidade feminina na gestão econômica.

Seja no âmbito da maternidade, das relações sexual-afetivas, das relações familiares, no âmbito político-organizativo e em outros, matronas afro-pacíficas constroem um repertório de identidades, ou de feminilidades, como coloca Werneck (2010), que se nutre de uma ancestralidade que provém da África e ao mesmo tempo questiona matrizes da tradição cultural entendidas como fonte de assimetrias. Ou seja, trata-se de uma atualização seletiva de elementos da tradição afro-pacífica, recorrendo a palavras que Werneck (Ibidem) usou para pensar o contexto brasileiro. Como sintetizaram as mulheres presentes na Mesa de Gênero, evento anteriormente comentado: 
El contexto de las mujeres negras en Colombia es el de la mujer procedente de África. Es un comportamiento muy ancestral. Nuestra formación se enmarca netamente en los valores de ser mujer. Las mujeres negras en el Pacífico hemos hecho cosas muy buenas, pero hemos estado invisibilizadas. Es como un mantel grueso de lona de los hombres sobre las mujeres. Los que siempre han manejado el poder son los hombres. Nosotras mujeres negras sufrimos la discriminación racial y la discriminación a las mujeres.

Na segunda parte da tese, percorrendo os rios que banham o litoral pacífico, haverá oportunidade de aprofundar as reflexões sobre a construção do feminino em torno da ação política e os processos de invisibilização do protagonismo feminino nesse âmbito. 


\section{PARTe II}

AS MULHERES SÃo COMO AS ÁGUAS, CRESCEM QUANDO SE ENCONTRAM

Organização territorial e POLÍTICA No PaCífico Negro COLOMBO-EQUATORIANO 
Poema 2 - De Mistérios do Rio

Daniela Luciana

como o rio passa e não se perde? e ainda ensina a ser guardiã de mistérios?

sabe do rio, só o momento quem mergulha naquela hora ou passeia no raso só sabe que vem onda ou barranco quem conhece onde tem pedra

e sabe apenas daquela hora e já perde o fio lá adiante rio já transmuta alguém represa

aí, na frente, vem leito liso, ou cascata, é caudal do outro lado, praia, abismo, loca, grota seca

é da natureza ser passante, fluir e mudar

segue adiante molha pirambeira, recôncavo, cabeceira resvala alimenta queda, cascata, corrente

o rio é o rio há o rio está onde deve estar para sobreviver e avança

vai descansar no mar sem morrer

Nesta segunda parte, investigamos como a vida se faz territorialmente e como a política se faz em torno disso. Para tanto, busco compreender o território no contexto afropacífico, um território-água, que assim se caracteriza tanto na dimensão geográfica quanto na simbólica $^{190}$. As águas tecem as dinâmicas de povoamento negro na região. A coletividade afro-pacífica constituiu-se habitando as ribeiras dos rios. Ao longo da história, rios são eixos da organização social negra. Como conceito, o território-água alude à fluidez, o que permite compreender peculiares dinâmicas territoriais a partir das quais se imiscuem fronteiras entre rural e urbano, entre doméstico e político, entre Estados-nação. Nesse sentido, o territórioágua assinala aspectos geográficos e simbólicos.

\footnotetext{
${ }^{190}$ Neste capítulo abordo trajetórias de mulheres agregadas em torno de rios. Os três primeiros capítulos (sobre os Rios Mira, Patía e Rosário) estão focados na Colômbia e os dois últimos (sobre afluentes do Santiago e Mataje), no Equador.
} 
Os sentidos de ser mulher e ser homem no Pacífico Negro são retomados para se entender como o território é genderizado. A abordagem do processo organizativo afropacífico torna necessário definir algumas categorias-chave, como a de "comunidades negras". $\mathrm{Na}$ medida em que navegamos pelos rios do Pacífico colombo-equatoriano, encontramo-nos com categorias por meio das quais se articula o discurso das mulheres que construíram o "processo de comunidades negras" em ambos os países e vamos destrinchando-as. Busco ainda aprofundar a compreensão sobre a construção da subjetividade feminina negra na liderança.

O Pacífico colombo-equatoriano tem sido nomeado a partir de uma variedade de categorias que estendem ou restringem sua abrangência; cada qual tem sua historicidade. Conforme leitura de Zuluaga e Romero (2007), o Pacífico sul colombiano agrega terras baixas e altas, incluindo os vales interandinos, como o Valle del Cauca. A Reserva da Costa Pacífica foi criada pela Lei n. 2 de 1959, colombiana, e compreende toda a Bacia do Pacífico desde a fronteira com Equador até a com o Panamá, delimitada pela divisória de águas da Cordilheira Ocidental ${ }^{191}$. O Pacífico norte equatoriano contempla a vertente pacífica entre os Rios Muisne e Mira, desde a Cordilheira dos Andes até o mar, compreendendo a costa de Esmeraldas (terras baixas) e o Valle de Coangue ou Valle del Chota, la Concepción y Salinas (terras altas).

A categoria "Chocó Biogeográfico" ou "Complejo Ecoregional del Chocó Biogeográfico", ou ainda "Complejo Ecorregional Chocó-Darién" passou a existir nos anos 1990 e designa uma ampla extensão da costa pacífica, desde a província panamenha de Darién e a zona do Golfo de Urabá, ao norte, até a província equatoriana de Manabí, ao sul; desde o Oceano Pacífico, a leste, e as águas da vertente ocidental da Cordilheira dos Andes, a oeste. Segundo Grueso, Rosero e Escobar (1999) são aproximadamente $70.000 \mathrm{~km}^{2}$. Essa região é reconhecida como uma das maiores diversidades biológicas e culturais do mundo, de importância planetária, sendo provavelmente a área com menos intervenção humana da costa pacífica da América do Sul, segundo a $\mathrm{WWF}^{192}$. Sobre a diversidade humana, os autores explicam que:

\footnotetext{
${ }^{191}$ Trata-se de uma Zona de Reserva Florestal e de Bosques Nacionais que cobre uma área aproximada de 10 milhões de hectares, segundo Antón (2005). O autor (ibid.) argumenta que a referida Lei apresenta uma visão do Pacífico como "un monte baldío, sin gentes, reserva forestal y mesa servida para explotadores y colonizadores extranjeros e interioranos" (Antón, 2005:229).

${ }^{192}$ Peces dulceacuícolas del Chocó. Disponível em: http://www.wwf.org.co/?210359/Peces-dulceacuicolas-delChoco. Acessado em: 3 de dezembro de 2014.
} 
Alrededor del 60\% de sus 900.000 habitantes (800.000 afrocolombianos, aproximadamente 50.000 embera, waunana y otros pueblos indígenas, y otros 50.000 colonos mestizos) vive en las pocas ciudades y pueblos; el resto habita en los márgenes de los más de 240 ríos de la región, los cuales fluyen en su mayoría desde los Andes hasta el océano Pacífico (Grueso, Rosero e Escobar, 1999: 237).

A região foco dessa pesquisa situa-se nas terras baixas do Pacífico sul colombiano e do Pacífico norte equatoriano, mais especificamente nos municípios colombianos de Tumaco e Salahonda (Francisco Pizarro), assim como no equatoriano San Lorenzo, localizados na bacia conformada pelas águas tributárias ao Oceano Pacífico em território equatoriano e colombiano, reconhecida como reserva natural mundial pelas Nações Unidas. Nessa área, "la costa al sur del río San Juan, y un poco más al sur de la desembocadura del río Patía, se caracteriza por los esteros que crean un colchón que amortigua el impacto directo del mar sobre la costa. A partir del río Mira y hasta los confines de la costa Esmeraldeña, en Ecuador, la costa vuelve a ser abierta frente al Océano" (Zuluaga e Romero, 2007: 17). Como a região em foco se situa entre a desembocadura do Rio Patía e do Rio Mataje, um pouco abaixo do Mira, a maior parte dela é caracterizada por esteiros, como assinalam Zuluaga e Romero.

Partindo do ponto de encontro entre Equador e Colômbia, é importante conhecer os caminhos e as conexões que as águas desenham. Há uma bacia hidrográfica binacional, que leva o nome de dois rios pelos quais naveguei: Mira-Mataje. O Rio Mira é o nascedouro dos demais rios. Sua cabeceira localiza-se no Equador, nutrida por águas das bacias dos Rios Chota, Ambi, Lita e Baboso, mais precisamente na província de Carchi; Cantón Mira; paróquias de Jacinto, Jijón y Caamaño, Salinas, La Carolina, Lita; localidade de San Juan de Lachas. "El río Ita desagua en el Río Mira, de aquí se desvía para el norte y sigue como Mira”, explica María Barbarita Lara Calderón, que vive na paróquia de La Concepción, próxima ao referido rio, localizada no território ancestral Valle del Chota, la Concepción y Salinas. Ao chegar à Colômbia pelo departamento de Nariño, o Mira atravessa o Rio Mataje e segue até desaguar no Pacífico, na localidade de Cabo Manglares, saída da Baía Ancón de Sardinas.

Do lado do Equador, o rio tem um papel central na vida das comunidades negras do Valle del Chota, la Concepción y Salinas. O mesmo ocorre do lado colombiano. Dispostas ao longo do Rio Mira, 42 veredas colombianas, que secularmente são assentamentos negros ${ }^{193}$,

${ }^{193}$ Conforme dito na introdução, o sentido do termo "assentamento" na Colômbia e Equador não corresponde à acepção corrente no Brasil. No caso em análise, é usado em referência à povoação do espaço pelas populações negras, exemplo: "En un proceso de 'amansamiento' del monte bravo, los primeros pobladores negros 
compõem o Conselho Comunitário Baixo Mira e Fronteira, segundo dados do Instituto Colombiano de Desarrollo Rural (INCODER), Ministério da Agricultura ${ }^{194}$. Como vimos na introdução, Conselhos Comunitários correspondem à figura jurídica em torno da qual se dá o reconhecimento legal da ancestralidade negra ribeirinha. O Rio Mira, dada a sua grande extensão, foi regularizado em dois territórios coletivos. O Conselho Comunitário Alto Mira e Fronteira, por sua vez, é composto por 39 veredas ${ }^{195}$. O Baixo Mira é o eixo do primeiro capítulo, o qual percorremos por meio dos relatos de mulheres como Manoela Salazar, que foi a primeira representante legal desse Conselho Comunitário; María Cecilia, atualmente subsecretária do Conselho; Mailen Quiñones, secretária na junta diretiva do Conselho. Eva Lucia Grueso nasceu na vereda Bajo Jagua, também no Baixo Mira. Ela é uma das fundadoras do Proceso de Comunidades Negras (PCN) e atualmente trabalha no escritório nacional da organização, em Bogotá. Martha García é conchera e lideresa na vereda Bajito Vaquería, a porta de entrada/saída desse território, situada bem próxima à sede de Tumaco e distante das demais veredas do Conselho Comunitário Bajo Mira y Frontera ${ }^{196}$. Ainda que tenha saída para a praia, na beira-mar, as águas marinhas ficam doces quando cresce o Rio Mira, como conta Martha, dada a amplitude do caudal deste rio.

Em seguida navegamos pelo colombiano Rio Patía, que adentra o departamento de Nariño, depois da Baía de Tumaco. Nesse Rio, o Conselho Comunitário ACAPA é o território das irmãs Ana e Martina Granja e de suas respectivas filhas Ana Karina e Nídia. ACAPA possui área de 94.388,4425 hectares, localizada em três municípios: Francisco Pizarro (Salahonda), Tumaco, Olaya Herrera (Mosquera) ${ }^{197}$. No povoado de Salahonda, situado no delta formado pela desembocadura do Rio Patía, encontrei também a família Puertocarrero, com quem dialoguei sobre el concheo.

Para chegar ao palco das andanças de Rosalba Quiñones, geograficamente voltei um pouco em direção ao ponto de partida: a fronteira Colômbia-Equador. O Rio Rosário nasce

transformaron estos territorios en tierras cultivables y en asentamientos humanos que dejaron de ser peligroso y extraños para convertirse en escenarios de sociabilización, intercambio y recreación" (Camacho e Tapia, 1997: 30).

${ }^{194}$ Criado em 2003, pela Resolução n. 46, o Conselho Comunitário Baixo Mira e Fronteira está situado no município de Tumaco, departamento de Nariño. Possui área de 46.481,9407 hectares, população estimada de 1.240 famílias, 6.271 pessoas. No tocante a estimativas demográficas, sempre as informações do INCODER sobre os conselhos comunitários datam do mesmo ano da resolução do título coletivo, ou do ano anterior.

${ }^{195}$ Por sua vez, criado entre 2005 e 2006, por meio das Resoluções n. 397 e 525, está situado no mesmo município, possui área de 24.790,4537 hectares, população estimada de 1.327 famílias, 6.784 pessoas, segundo dados da mesma fonte.

196 Segundo informou Martha García, ao final de novembro de 2012, a vereda possuía 469 habitantes, distribuídos em 100 famílias e 100 residências.

${ }^{197}$ Foi titulado no ano 2000, por meio da Resolução n. 1.119, com 32 veredas, 1.453 famílias e 8.106 pessoas. 
nos Andes, seguindo seu percurso paralelamente ao Mira, porém mais ao interior do departamento de Nariño, até desaguar na Baía de Tumaco, em uma localidade denominada Bocana del Rosario. Aí se inscreve o Conselho Comunitário Unión Río Rosário, com área de 10.647,9204 hectares, conformado por treze veredas, segundo dados do INCODER ${ }^{198}$.

Al otro lado de la raya, em solo equatoriano, voltamos ao Rio Mira. É dele que provêm as águas dos afluentes do Rio Santiago, entre os quais naveguei por: Palaví, Tululbí, Bogotá e Cachaví. Nas ribeiras destes rios nasceram e cresceram Yonny Nazareno, Vilma Estacio de Sa, Edith Rivas Klinger Palma, Melania Ester Quiñones e sua mãe Rosaura Quiñonez Hurtado, Inés Morales e Amada Cortez, mulheres que nos contarão sobre suas vivências nas "comunidades de rio".

Por fim, observamos o Rio Mataje, a outra metade da Bacia por onde começamos a navegar. Esse rio demarca a fronteira terrestre entre os dois países em foco. Colômbia e Equador encontram-se por terra e por mar. A fronteira terrestre, demarcada definitivamente pelo Tratado Muñoz Vernaza-Suárez, de 15 de julho de 1916. É uma linha divisória de 586 km que se estende de leste a oeste, desde o Rio Güepí até a desembocadura do Rio Mataje na Baía Ancón de Sardinas, no Oceano Pacífico. A fronteira marítima parte da mesma desembocadura de rio e adentra o oceano em 200 milhas, segundo expressado no direito do mar. Foi demarcada pelo Tratado Liévano-Lucio, de 23 de agosto de 1975. Encontrei o Mataje no justo ponto de sua entrega ao mar. É aí, na comunidade de Palma Real, em que deslancha a trajetória de Targelia Micolta. Em Palma Real encontrei a mãe de Targelia, María Magdalena, e suas filhas Leonela Rocío Valencia e Elvia Eunice Valencia Micolta. E também dialoguei com Mérice Benguera e Ruth Aida.

Percorrendo esses rios, busco visibilizar trajetórias de mulheres cuja atuação tem destaque, ressaltando as especificidades das dinâmicas vividas em cada rio e, ao mesmo tempo, extrapolando-os para mostrar as similaridades e articulações entre essas trajetórias.

Inés Morales possui uma vasta biblioteca em sua casa, no bairro Nuevo Horizonte, em San Lorenzo, Esmeraldas, Equador. Boa parte de seu acervo concerne ao processo de construção da territorialidade negra na região fronteiriça. Segundo um documento cujo tema se circunscreve como "territorialidade e meio ambiente" 199 , a territorialidade é uma apropriação e uma construção cultural do espaço, sustentada em fluxos ou percursos naturais

\footnotetext{
${ }^{198}$ Foi titulado em 2002, por meio da Resolução n. 2546, com 482 famílias, 2.289 pessoas.

199 Trata-se de um documento fotocopiado, sem referência bibliográfica. Quando perguntei a Inés sobre a origem do texto, fui informada de que ela reuniu muitos documentos fotocopiados em oficinas ditadas pelo "maestro Juan", o antropólogo e ativista afro-equatoriano Juan García Salazar, sobre o qual falarei mais adiante.
} 
- rios e mar - e culturais - práticas produtivas, migrações e retornos. O mar orienta a percepção da espacialidade, composta por faixas: mar, bajamar, manguezais, firme, guandal e loma. Mas é em torno dos rios que as dinâmicas de apropriação cultural do espaço consolidam-se. Barbarita Lara explica bem esse ponto ao falar sobre a dinâmica de povoamento do Valle del Chota, la Concepción e Salinas em torno do Rio Mira:

El río era parte de la vida. Servía prácticamente para todo: para sembrar, para cultivar, para la alimentación, para lavar su ropa, para bañarse, para amarse, para conversar. Eran espacios de conversatorio. Espacios donde se sentaban para elaborar sus estrategias de resistencia. Ahora se le concibe como parte de divisiones, los ríos, en cambio antes era parte de unidad. Sí, era una unidad. Servía para conectarse, servía para todo, servía para sacar la leña. Porque más allá del río hay tantos elementos que le constituyen. La arena, las piedras. De ahi sacaban las piedras para moler sus alimentos. Las piedras para elaborar figuras. Entonces el río es un conjunto de elementos físicos y un conjunto de elementos espirituales que también constituyen la cosmovisión del pueblo afro. Es agua para sanar el espíritu, para sanar el alma, para sanar el cuerpo, para sanar la mente. Porque, un ejemplo: si tú estabas muy triste, nerviosa, deprimida, ellos le aconsejaban irse al río y tirar hierbitas, hojitas o piedritas. Para que con él, se vayan las penas, se vayan las tristezas, se vayan las preocupaciones. Para bañarse, si te duele el cuerpo, en un aspecto físico, hay que bañarse donde golpea el agua, buscar un espacio donde golpea el agua. Inclusive para tomar, eso cuando el río era limpio, cuando todavía no nos estaban dañándolo. Nos aconsejaban que no tenía que tomar de la remansa, pero que tenía que tomar de donde golpea el agua. Hay algunos elementos y algunos saberes que se tejen alrededor del río - Barbarita Lara.

Os rios, de modo geral, são elementos de conexão. São o vetor de comunicação entre a coletividade negra, desde o povoamento da região. Contemporaneamente, no Pacífico colombo-equatoriano, os rios são a espinha dorsal na construção dos Conselhos Comunitários e Comunas. Junto com os rios, consideram-se as outras formas hidrográficas que as águas constituem: riachuelos, esteros, saltos e quebradas. Algumas delas são artificiais, criadas pelo ser humano, como é o caso do canal ou sanja. O acúmulo das águas em canais formam os esteiros que, no Pacífico colombo-equatoriano, são labirínticos. "Si lo hace el hombre se llama canal o sanja. Estero es el que se forma y ese ecosistema se va llenando de manglar", como explica Ana Granja Castillo, liderança do Rio Patía.

Ademais das extensas redes de rios, esteiros e canais, as águas expressam-se em altos níveis pluviométricos e de umidade, bem como nos movimentos das marés - que dão o compasso cotidiano do ritmo laboral nas "comunidades de mangue" e influenciam diretamente "comunidades de rio", já que a maré se sente até vinte quilômetros ao interior do 
território. Águas salgadas e doces conversam intensamente no Pacífico Negro. O curso dos rios tem relação direta com o sobe e desce das marés, pujas e quiebras, llenas e vaciantes.

Frequentemente rios transbordam durante a fase de fortes chuvas. Em composição conjunta, as diversas águas podem chegar a inundar parte das comunidades, levando-as ao deslocamento $^{200}$. O povo de Trojillo, por exemplo, vereda situada na beira-mar do Conselho Comunitário Unión Río Rosário, já se mudou inúmeras vezes e sabe que seguirá se deslocando, pois, de tempos em tempos, o mar avança sobre as casas. A engenharia das casas na região parece muito favorável a essa dinâmica, na medida em que a suspensão sobre pilotis protege até certo nível as casas do avanço das águas.

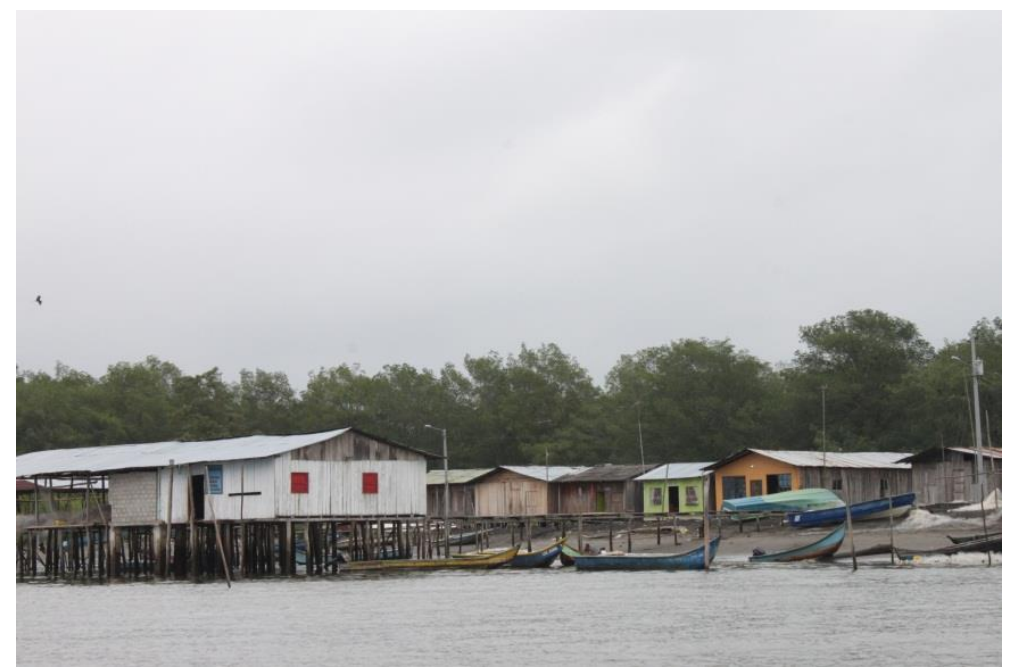

Figura 6 - Casas sobre pilotis

Quando a força aquática se faz soberana, os moradores e moradoras desse povoado dispõem com certa facilidade de madeira, quando não em seu próprio território, em outros próximos, e a mão de obra para a reconstrução de casas são os próprios moradores. Trata-se, pois, de um território sujeito à instabilidade ambiental, mas também política, dada a complexidade das relações entre atores armados que atuam ali, tema da Parte III.

Enquanto refiro-me à territorialidade a partir da ideia de território-água, Ulrich Oslender fala sobre "espaço aquático": "un espacio en el cual se manifiesta una variedad de factores acuáticos, como por ejemplo climáticos, geográficos, marítimos, etc., de tal manera, que tiene un impacto considerable sobre la constitución de la vida cotidiana" (Oslender,

\footnotetext{
${ }^{200}$ Além das inundações, outros fatores como terremotos e tsunamis também contribuem para a característica mobilidade do povo afro-pacífico. O mais recente foi o terremoto de 1979, que, segundo Pazmiño (2003), ocorreu cinco anos depois da construção do chamado canal Naranjo, por um aserrador particular que pretendia encurtar as distâncias e tempos de extração da madeira proveniente dos Rios Patía e Patía Viejo até o rio Sanquianga. O pesquisador caracteriza a construção desse canal como uma tragédia socioambiental, que causou a inundação de terras de cultivo e deslocamento de habitantes do Rio Sanquianga, o qual aumentou muito de volume.
} 
1999: 37). O autor ressalta que o conceito não expressa um determinismo ambiental, mas, sim, destaca o fato de que nessa região "as condições geográficas explicitam sua participação nas atividades humanas", usando palavras de Zuluaga e Romero (2007). Trata-se de uma convivência entre o povo afro-pacífico e o espaço aquático, a qual se expressa de distintas maneiras. Essa convivência peculiar levou, segundo Oslender (2001), à construção de uma “estrutura local aquática de sentimento". Nesse sentido, a força das águas se faz sentir não apenas nas condições materiais da vida desse povo, mas também na construção de seus afetos. No plano cosmológico e espiritual, permitem articular mundo, inframundo e supramundo.

Compreendo que as águas são também terreno do simbólico. Em minha concepção, o território-água expressa a imagem que o povo afro-pacífico constrói sobre si mesmo. Nele, encontramos a fonte de elementos que constituem a pessoa afro-pacífica, como indica a sabedoria das parteiras afro-equatorianas de Borbón ${ }^{201}$. Os rios desempenham um papel nas práticas ancestrais do bem nascer. O movimento das águas do rio acomoda a posição do bebê. "llevaban a la embarazada al rio y en un lugar donde no fuera muy hondo, pero donde hubiera una corriente más o menos fuerte, metían a la embarazada en el agua, con la fuerza de la corriente y con la ayuda de la partera se le acomodaba la posición de la criatura". Tais práticas estão baseadas em uma analogia entre o rio e o ventre da mulher grávida: "la criatura siente que la mamá está nadando en un mundo igual al que la criatura tiene en la barriga" (CECOMET, 2011: 38).

A analogia entre útero e rio expressa a ideia de que, enquanto a gestação de um ser ocorre no útero, o rio gesta a coletividade afro-pacífica. Rios são também o melhor destino para o leite materno, quando se está desmamando a um/a filho/a. "Esto de echar la leche en el río también es um secreto para que a la mujer no le falte nunca la leche materna" (CECOMET, 2011: 88). Ou seja, o rio é abundância. É a seiva dessa coletividade, assim como o leite é o alimento da criatura recém-nascida.

No território-água, a territorialidade é a inscrição espacial da ancestralidade. A concepção de ancestralidade, que circula no Equador e na Colômbia desde a década de 1980, remete diretamente ao território, sublinhando a secular presença da população afrodescendente em ambos os países. A partir das reflexões de Ratts (2014), entendo que se trata de uma ancestralidade política, uma pertença que remete a um "retorno cíclico, mítico, estético e político" à África diaspórica (Ratts, 2014: 14). Para Martina Granja Castillo, "el territorio es la tierra y lo que está adentro: aire, bosque, laguna, montaña, quebrada y todos

\footnotetext{
${ }^{201}$ Recorro à acepção de pessoa presente em Strathern (2006). A pessoa é construída desde a perspectiva das relações que a constituem.
} 
los animales". Ao território estão relacionadas também ideias como autonomia e soberania. Para Mailen Quiñones, "la territorialidad es concepto de autonomía y gobierno. Que define nuestro pueblo, en su reglamiento interno. El territorio es sentido de identidad cultural. Símbolo de soberanía y del sistema ambiental”. Assim, o território compreende as águas, o solo, o subsolo, as práticas produtivas e identitárias, bem como elementos associados a tais práticas.

Grueso, Rosero e Escobar (1999) explicam que a apropriação do território negro cruza movimentos longitudinais, horizontais e verticais:

Los asentamientos ribereños, por ejemplo, muestran un patrón longitudinal y discontinuo a lo largo de los ríos, en los cuales se combinan y articulan múltiples actividades económicas (pesca, agricultura, minería y silvicultura de pequeña escala, caza y recolección y actividades de subsistencia y mercado), según la ubicación del asentamiento en el segmento alto, medio o bajo del río. Esta dimensión longitudinal se articula con un eje horizontal regulado por el conocimiento y uso de múltiples recursos, desde los cercanos al margen del río que han sido domesticados -incluidas hierbas medicinales y alimenticias - hasta las especies no domesticadas que se encuentran en las varias capas de bosque alejadas del río. Un eje vertical desde el inframundo hasta el supramundo, poblados por espíritus tanto benevolentes como peligrosos - también contribuye a articular los patrones de significado/uso de los recursos. Estos diferentes ejes también dependen del mantenimiento de las relaciones sociales entre las comunidades, las cuales en algunas partes del Pacífico incluyen relaciones entre comunidades negras e indígenas (Grueso, Rosero e Escobar, 1999: 256).

No tocante ao padrão longitudinal, conforme pude compreender etnograficamente, a zona baixa dos rios, onde se configuram praias e manguezais, é o cenário de preponderância da mariscagem. São os casos, por exemplo, das comunidades Palma Real (Rio Mataje), Bajito Vaquería (Rio Mira), Salahonda (Rio Patia), Trojillo (Rio Rosario). Na seção média/alta dos rios, dá-se principalmente a agricultura. No caso do Rio Rosário, os principais cultivos são coco, cacau e banana-da-terra, além de algumas árvores frutíferas. Aí estão instaladas as fincas: pequenas unidades de exploração agrícola voltadas principalmente para o consumo próprio. Diferentemente das fincas, el monte corresponde a uma sequência de lotes em distintos lugares, de exploração agrícola e/ou extrativista, como, por exemplo, a extração de madeira. Está localizado ao longo dos rios e no interior do bosque (González, 2002: 130). Já a mineração artesanal ou playada desenvolve-se no curso alto dos rios, como é o caso da comunidade de Ricaute e La Boca, localizadas nos respectivos afluentes dos Rios Santiago, Palaví e Tululbí. Isso não significa que as atividades sejam exclusivas de cada uma dessas regiões, mas, sim, prevalecentes. Há uma polivalência de atividades produtivas associadas a 
peculiares práticas culturais, as quais são também constitutivas do território. Ou seja, a apropriação afro-pacífica dos rios, praias e montes constrói a territorialidade.

Sobre definições dos espaços familiares e coletivos, o direito à utilização de um terreno, especialmente para a agricultura, está assentado sobre as relações de parentesco, ou, como coloca González (2002), sobre o pertencimento a uma família extensa cujo antepassado foi a primeira pessoa a utilizar tal terreno. Nesse caso, a tradição pode ser herdada por patri ou matrilinearidade:

el padre le da a sus hijo sin importar que sean de distintas mujeres y, la madre les llega a los suyos pero no a los engendrados por su cónyuge con otras mujeres. Estos últimos reciben de sus respectivas madres y padres; por consiguiente, los hilos invisibles del parentesco, trazados tanto por la linealidad materna como paterna, regulan el uso del territorio de manera colectiva (González, 2002: 127-128).

Já o manejo de manguezais é coletivo. Manguezais, praias, rios e bosques são apropriados coletivamente. Essa lógica de apropriação do território reflete-se nos procedimentos de titulação. Segundo determina a colombiana Lei n. 70, de 1993, a titulação coletiva contempla áreas produtivas (manguezais, ribeiras de rios e praias, bem como bosque de respaldo), áreas em que constam edificações e outras referências ao patrimônio cultural. São essas parcelas da terra, destinadas ao uso coletivo, que possuem caráter de inalienáveis, imprescritíveis e impenhoráveis. As áreas residenciais e agrícolas, as chamadas fincas, são tituladas por família. Não estão incluídas no título coletivo, portanto, áreas assinaladas a cada grupo familiar ${ }^{202}$. Porém, essas áreas apenas podem ser alienadas conforme regulamento interno, sendo que o direito preferencial de ocupação ou aquisição recai a outros membros da "comunidade" e, em segundo plano, do "grupo étnico", segundo informa a mesma lei.

De maneira articulada às relações de parentesco, o gênero orienta o manejo dos recursos naturais e, nesse sentido, também constitui territorialidade. Partindo da premissa de que a circulação no Pacífico Negro é prerrogativa masculina, González analisa o estilo de mobilidade do sistema de parentesco e suas projeções sobre o território:

La construcción social del territorio con relación a la organización familiar desde la perspectiva de género, nos remite a un sistema de ordenamiento del espacio. Mientras para el hombre se tiene un territorio móvil, circulando entre los diversos grupos domésticos matrifocales, la mujer es la artífice de la territorialidad permanente, ya que con ella se tienen prácticas

\footnotetext{
${ }^{202}$ Nesse ponto, os procedimentos colombiano e brasileiro diferenciam-se. No Brasil, os títulos de territórios quilombolas englobam áreas de uso coletivo e familiar. A gestão dessas áreas cabe à Associação Quilombola, que mantém a integridade das terras ancestralmente usadas pelos grupos familiares.
} 
residenciales uxorilocales o matrilocales, o sea, en viviendas cerca de la madre de la mujer del varón, o en la unidad habitacional de ella y su madre, constituyéndose por ende, en la generadora de comunidades estables. Ella forma, transmite y guía las normas internas y los controles sociales de las comunidades. Es ella también la que asume roles de rezandera, cantaora, partera, curandera y una gran activista de la economía familiar y comunitaria. En su monogamia serial para el establecimiento diádico de madre/marido y madre/hijo, ejerce por largos períodos el rol de jefe de hogar o jefe de la unidad domésticas, desarrollando sistemas de producción cercanos a la vivienda, por lo cual ha definido a través de la residencia, la propiedad territorial de la familia y el sentido de pertenencia al territorio. Así la mujer es quién ha construido la identidad cultural /étnica y territorial (González, 2002: 127).

Conforme dito na primeira parte da tese, discordo de vários dos argumentos de González. 1. Entendo que mulheres também circulam. 2. As coletividades não são estáveis. Relações sexual-afetivas revelam constantes alianças e rupturas entre mulheres e homens. Trata-se ademais de um território sujeito a instabilidade ambiental e política, o que leva a deslocamentos compulsórios. 3. As díades mãe-marido, mãe-filho/a não são as melhores chaves de compreensão da organização social, desde o ponto de vista das mulheres. Prefiro ressaltar a rede que as mulheres estruturam em torno de si, dentro das quais a atuação e o protagonismo feminino irradiam-se da casa à coletividade, da coletividade ao município, do município à região e daí em diante. Ou seja, ao dizer que as mulheres são as principais construtoras e disseminadoras das identificações étnico-raciais em processo, as quais estão territorialmente inscritas, quero dizer coisas bem diferentes do que argumenta González (2002).

No tocante à circulação, Camacho (1999) fala sobre uma prática comum no Pacífico Negro, a de "salir a caminar": sair de seu lugar de origem e mover-se a outros lugares, para trabalhar, militar, conhecer, visitar parentes, vivenciar experiências (Camacho, 1999: 110). Segundo Camacho, esse movimento se contextualiza na característica mobilidade espacial de povos afro-pacíficos, a qual se expressa em movimentos migratórios de curta e longa duração, em recorridos não lineares, com possíveis trajetos de retorno e frequentes traslados temporais.

Ainda que Camacho (2004) ressalte a migração de mulheres rurais em busca de melhores condições econômicas, de trabalho ou educativas, assim como para ganhar autonomia e mobilidade social, a literatura antropológica de modo geral atribui essa característica mais aos homens do que às mulheres. O que observei na etnografia realizada entre San Lorenzo, Tumaco e Salahonda é que mulheres também vivenciam a mobilidade. Nas coletividades rurais, algumas mulheres que desempenham um papel de liderança circulam em muitos espaços, na sede de seus municípios, em outras cidades, em capitais, em 
outros países. É o caso de Inés Morales, Amada Cortez, Rosalba Quiñones, Mailén Aurora, Ana Granja, Targelia Micolta. Mulheres em busca de trabalho ou estudo, como Leo Micolta, Elvia Micolta e Ana Karina Granja, também "salen a caminar". Com seus trabalhos, elas nutrem suas unidades domésticas e, por vezes, também a de sua parentela. Na construção da subjetividade dessas mulheres, a prática de sair a caminhar é central. Os relatos narram com profundidade suas andanças e a maneira como elas constituem sua visão de mundo e as relações com outros a partir dessas trajetórias.

Como líderes comunitárias, mulheres afro-pacíficas constroem um discurso que possibilita o empoderamento delas e de sua coletividade. Por outro lado, ao mesmo tempo em que despontam como lideranças de base, ocupam em pequena escala a representação formal dos espaços organizativos, dominados por homens. Isso porque esbarram no machismo dessa sociedade, vivenciado nos processos organizativos, mas também no ambiente no lar. $\mathrm{O}$ problema é explicitado no documento produzido coletivamente por mulheres que construíram a Mesa de Gênero do Pre-Congreso Departamental Nariño, Etapa preparatoria al Primer Congreso Nacional de Consejos Comunitarios y Organizaciones Étnicas Afrocolombianas, Palenqueras y Raizales, realizado em Tumaco, em agosto de 2013:

\begin{abstract}
El contexto de las mujeres negras en Colombia es el de la mujer procedente de África. Es un comportamiento muy ancestral. Nuestra formación se enmarca netamente en los valores de ser mujer. Las mujeres negras en el Pacífico hemos hecho cosas muy buenas, pero hemos estado invisibilizadas. Es como un mantel grueso de lona de los hombres sobre las mujeres. Los que siempre han manejado el poder son los hombres. Nosotras mujeres negras sufrimos la discriminación racial y la discriminación a las mujeres. Debemos buscar condiciones para asumir posiciones de igualdad de derechos y empoderamiento dentro del territorio.
\end{abstract}

Esta tese figura, então, como um esforço de registrar e interpretar o papel das mulheres na construção da territorialidade e dos processos organizativos em torno do território, os quais estão conectados com a construção da subjetividade feminina como lideranças de base, que, por sua vez, passa pela prática do salir a caminar $^{203}$. Por meio dos fluxos das mulheres, tecemos uma história na qual mobilidade e territorialidade são facetas de um mesmo processo organizativo.

\footnotetext{
${ }^{203}$ Esse esforço contextualiza-se em um cenário de ausência de estudos sobre movimentos de mulheres no Equador, como ressalta Herrera (2010), o que se agrava quando acrescentamos o recorte racial. No caso da Colômbia, segundo Camacho (2004), é muito pouco o que se conhece das experiências organizativas urbanas e rurais de mulheres negras ou afro-colombianas e de sua participação na esfera pública, cívica e política.
} 
Paralelamente, dedico certa atenção às dinâmicas locais da vivência territorializada, que também é genderizada. Na minha compreensão, investigar a territorialização do gênero expressa-se, por exemplo, na indagação sobre como se estabelecem os direitos de mulheres e homens ao território coletivo e ao manejo dos recursos naturais. Diversas narrativas apontam para uma divisão sexual do trabalho que se reflete em uma divisão sexual do território:

hay espacios de trabajo que exigen mayor fortaleza física y culturalmente están reservados para los hombres como por ejemplo en el monte, la sacada de madera, la cacería; la pesca de altura en el mar afuera, etc. En los cultivos de las fincas trabajan hombres y mujeres, aunque con actividades diferentes al igual que en la mina (Mujeres Afrocolombianas, 2011: 83).

As parteiras de Borbón falam sobre o costume dos mais velhos de apresentar a casa à criatura recém-nascida, que constitui uma interessante fonte de compreensão do feminino e do masculino territorializados. Aos meninos era apresentado "el mundo del varón”, qual seja, "se lo llevaba a la pampa y se le presentaba el rompedero de leña, se le mostraba la orilla del río, se le hacía tocar el machete, el canalete, se le mostraba el camino para ir a los trabajos, se le mostraba los canastos de cargadera ${ }^{204}$ ". No caso das meninas, "se le mostraba el río, se le hacía tocar a las bateas, los canastos de coger los camarones, se le mostraba el fogón, la piedra de moler las balas, el molinillo, las cucharas de mate, se le mostraba la kawinga ${ }^{205}$, la zuzunga ${ }^{206, "(C E C O M E T, ~ 2011: ~ 81) . ~}$

$\mathrm{Na}$ etnografia, não encontrei esse tipo de prática. Porém, entendo que ela traz elementos para se pensar nas associações com o masculino e com o feminino, no contexto da socialidade afro-pacífica contemporaneamente ${ }^{207}$. Ainda que introduzido ao pequeno homem, o facão é bem manejado também pelas mulheres, ao que pude notar na cotidianidade, principalmente para abrir o coco e limpar o pescado. Os remos também fazem parte do repertório feminino, seja nas “comunidades de rio", seja nas "comunidades de mangue".

\footnotetext{
${ }^{204}$ Cestos com correias para carregar nas costas.

${ }^{205}$ Kawinga: paleta para misturar as comidas ou chicórias.

206 Zuzunga: cernedor feito com a metade de uma cabaça.

${ }^{207}$ Ao longo do texto, uso o conceito de socialidade na acepção de Strathern (2006), em alusão à tessitura das relações sociais em certo contexto, preferindo-o ao conceito de sociabilidade, na medida em que ele indica as posições diferenciadas de sujeito no interior das relações sociais.
} 


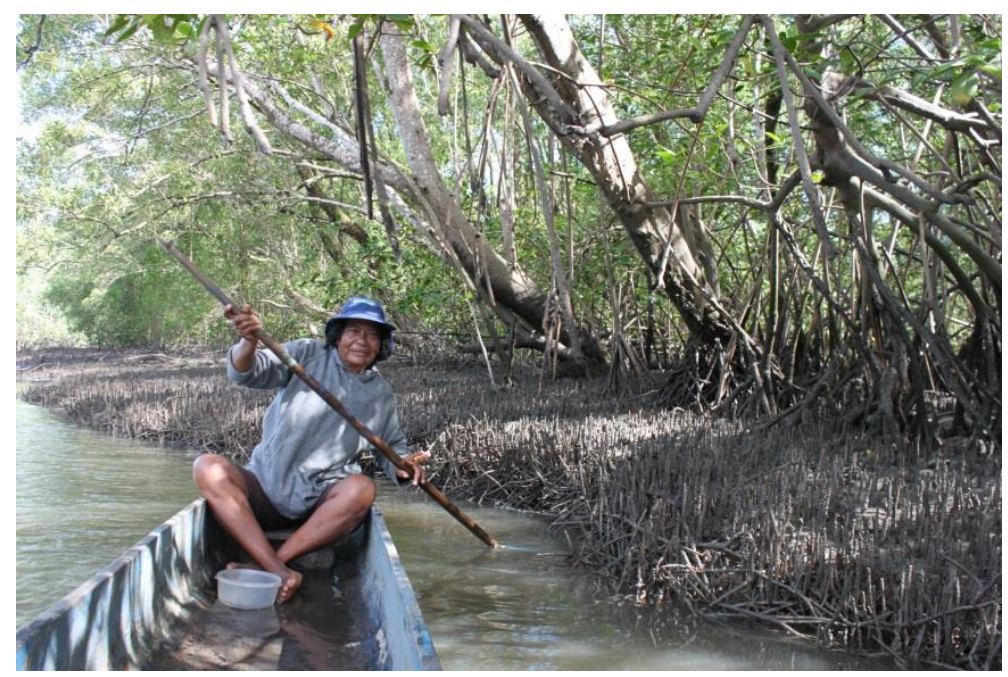

Figura 7 - Ana Granja com remo

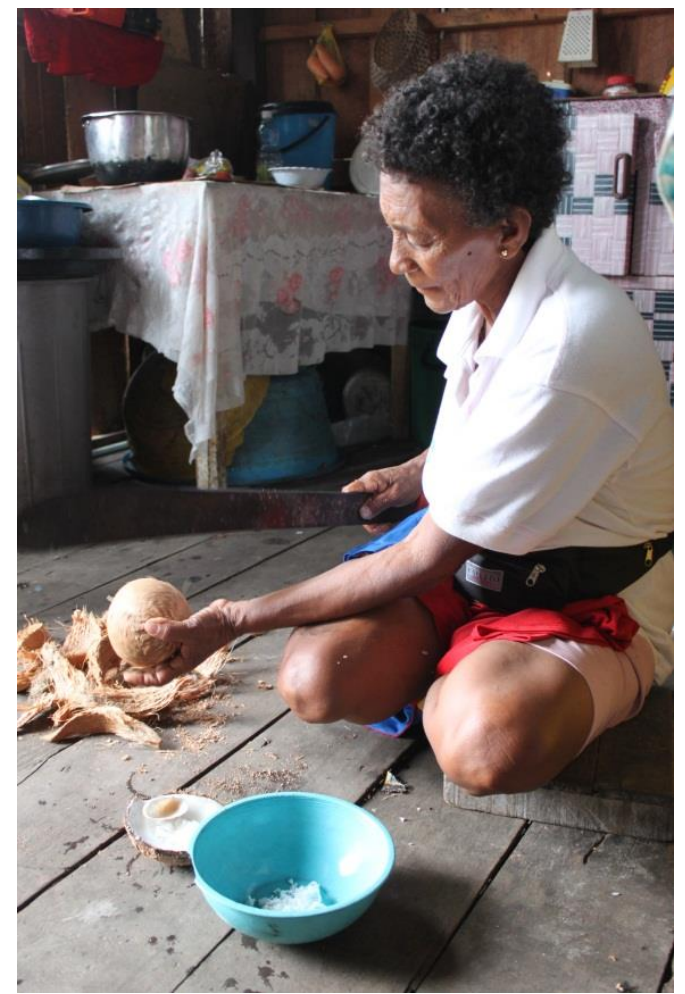

Figuras 8 - Martha García com facão

Nesse sentido, a compreensão das relações entre gênero e território passa pela compreensão do gênero e do trabalho produtivo. Moore (1991) reitera que a incidência de mulheres no trabalho produtivo está relacionada com sua capacidade de controlar, utilizar e dispor de recursos econômicos e do fruto desses recursos. Ressalto, portanto, a centralidade da participação feminina nas formas ancestrais de organização produtiva, como as mingas e cambio de manos; mas também as interfaces entre territorialidade e projetos de desenvolvimento, que intercedem diretamente sobre as formas organizativas ancestrais. Argumenta-se que, ao longo da história, o Pacífico Negro consolidou certa autonomia, 
especialmente no campo da produção de alimentos. No entanto, nas últimas décadas, o território é alvo de intervenções diretas do capital em níveis local, regional, nacional e global, as quais interferem diretamente no controle, na utilização e na disposição dos recursos produtivos, seja pelas mulheres, seja pelos homens.

No contexto de intervenção do grande capital, a coletividade negra retoma o palenque - símbolo de resistência -, como estratégia organizativa para a defesa de sua autonomia frente à presença de inúmeros interesses econômicos sobre a região. Os palenques expressam a possibilidade que dispõe o povo negro de controlar um espaço geográfico e seus recursos, bem como as dinâmicas sociais e culturais de seu povo. Na década de 1990, configurou-se como instância organizativa regional do Proceso de Comunidades Negras (PCN) na Colômbia e no Equador, como veremos a seguir. É necessário, então, compreender quais são os interesses do grande capital no Pacífico Negro colombo-equatoriano, especialmente em Tumaco e San Lorenzo.

Do lado do Equador, conforme assinala Fernández-Rasines (2001), com base nos livros de viagem do geógrafo francês Thoron, de meados do século XIX, a produção agrícola de Esmeraldas era quase inteiramente voltada para o autoconsumo, com poucos excedentes para o mercado exterior. Uma das atividades que o viajante descreve é o concheo: "recogen en la orilla del mar mariscos y tortugas en la desembocadura de los ríos, muy buenas ostras, que se hallan en bancos, y éstas se agarran no solamente a las rocas sino también a las raíces de los manglares que crecen entre los lodos y aguas medio saladas de estos ríos" (Thoron apud Fernández-Rasines, 2001: 73).

No tocante às atividades voltadas para o mercado, a extração madeireira tem lastro na história. Desde o início do século XVIII, Vicente Maldonado, que fora governador da província de Esmeraldas à época, havia concedido licença para a exploração madeireira. Durante o século XIX, a empresa britânica Ecuador Land Company (ELC), que já exportava produtos tropicais, principalmente cacau, passou a explorar madeira na costa do país, como nos informa Fernández-Rasines (2001).

Na Colômbia, Tumaco consolidou-se como centro de maior importância econômica e populacional do Pacífico sul entre as duas últimas décadas do século XIX e os anos 1940 (Restrepo, 1999). Foi a época da crise do modelo mineiro colonial baseado nas quadrilhas e da chegada do capital estrangeiro, primeiramente com a extração da borracha e do marfim vegetal (caucho e tagua), exportados a mercados europeus e norte-americanos pelo porto de Tumaco. Desenvolveu-se ainda o cultivo e a comercialização de produtos agrícolas como o 
arroz e o cacau. Assim, consolidou-se uma elite comercial branca, composta por migrantes estrangeiros e membros da antiga elite barbacoana, a qual se polarizava com a majoritária população negra agricultora, pescadora e extrativista.

Em Tumaco, a partir de meados da década de 1940 até a segunda metade dos anos 1970, cresce a indústria madeireira de exportação, bem como a extração do tanino, ambas atividades movidas por capital externo. É o auge da exploração da árvore dos manguezais, ou melhor, a extração de tanino da casca dessa árvore, enquanto o tronco geralmente era abandonado nos esteiros ou deixado a mercê da maré. A crise da madeira, segundo Reyes (1978), aconteceu entre 1974 e 1975, em virtude da suspensão de atividades de construção civil nos Estados Unidos da América, motivada pela crise energética mundial. O país era, então, o principal comprador da madeira colombiana ${ }^{208}$. Segundo Restrepo (1999), essa fase é marcada pela radical transformação do espaço urbano: crescimento demográfico, zonas de ocupação irregular e configuração de uma periferia habitada conforme estratégias culturais e práticas residenciais trazidas pela população negra da área rural.

No norte do Equador, as atividades de exportação também despontaram durante o século XX. O cacau foi rentável até 1920; a banana teve seu auge em 1948 e sua decadência logo em seguida, nos anos 1950. Outros produtos foram o tabaco, a extração de seringa e demais resinas, extração da jarina ou marfim-vegetal, bem como a continuidade da exploração de madeira. O boom da seringa e da madeira ocorreu no período da Segunda Guerra Mundial, 1939-1945. Um fato que marca esse novo momento na economia regional foi a construção da ferrovia, em 1957, e da estrada que ligou a serra equatoriana com a costa de selva tropical úmida, Pan-Americana Norte, no início da década de 1960 (Whitten, 1997[1965]: 19).

A partir dos anos 1950, o dendezeiro, ou palma africana, e as indústrias camaroeiras assumiram um protagonismo econômico na região de San Lorenzo e na província de Esmeraldas como um todo, conforme assinala Fernández-Rasines (2001). Dinâmica muito similar teve curso em Tumaco, um pouco depois. Capital provindo principalmente do Vale do Cauca e Cundinamarca passou a centrar-se na agroindústria do dendezeiro, iniciada nos anos $1970^{209}$, e nos criatórios de camarão, cujo auge acontece a partir de 1984.

\footnotetext{
${ }^{208}$ Conforme interpretação desse autor, desde a primeira década do século XIX, os EUA apoderaram-se de recursos naturais e plantações agrícolas colombianas, mas foi com o fim da $1^{\text {a }}$ Guerra Mundial que o domínio estadunidense sobre a Colômbia se consolidou (Reyes, 1978: iv).

${ }^{209}$ Escobar retroage até 1958 , quando um especialista da FAO pela primeira vez levou a semente da palma africana à Colômbia, que foi experimentalmente implantada em Tumaco. Em 1996, a Colômbia era o quinto país produtor de óleo de dendê no mundo, depois de Malásia, Indonésia, Nigéria e Costa do Marfim (Escobar, 1996).
} 
As indústria camaroeira e da palma africana passaram, então, a ser as pontas de lança da ação estatal e privada para o desenvolvimento do Pacífico e sua inserção na economia mundial, segundo Escobar (1996). A implantação de ambas as indústrias em territórios étnicos ancestrais significaram a apropriação do trabalho do povo afro-pacífico para a produção de lucro e mais-valia; a apropriação do território, com o consequente deslocamento forçado de um significativo número de coletivos e pessoas negras; e a apropriação do dinheiro local, convertido em mecanismo para a obtenção de mercadorias e o pagamento de impostos.

Em 1991, a produção camaroeira do Equador era de 100 mil toneladas e abarcava mais de 100 mil hectares, como informa Escobar. Na enseada de Tumaco, em 1993, havia cerca de 1.300 hectares produzindo camarões, porém as áreas concedidas às camaroeiras eram bem superiores(Idem, ibidem). Ou seja, a atividade deve ter se expandido bastante nas últimas duas décadas.

Em Tumaco, entre as décadas de 1980 e 1990, processos de associação gremial e cooperativa intensificam-se, conforme ressalta Restrepo (1999). O cenário tumaquenho povoa-se de múltiplas "agências de desenvolvimento e integração", tanto estatais quanto vinculadas a organismos internacionais. Governo colombiano e agências internacionais desenvolveram estratégias voltadas ao "desenvolvimento" do Pacífico, como o Plan de Desarrollo Integral para la Costa Pacífica (PLADEICOP) e o Plan Pacífico, planejamentos imbuídos de uma lógica patriarcal que dá prioridade aos investimentos em setores produtivos, segundo Lozano $(1996)^{210}$.

Esse momento corresponde ao boom da cooperação técnica internacional, que chegou com o discurso de conservação da biodiversidade e do desenvolvimento sustentável. Discurso que responde ao processo de destruição de reservas e perdas de espécies e que mobiliza diversos atores nacionais e internacionais (ONGs, governo, cientistas) em prol da preservação ambiental do Pacífico colombiano. Restrepo assinala que também nessa fase os discursos do processo organizativo negro assumem o tom da etnicidade, como estratégia política.

\footnotetext{
${ }^{210}$ De acordo com Lozano (1996), o PLADEICOP foi apresentado em 1983, como diretriz política para o desenvolvimento do Pacífico no governo de Belisario Betancur. Abrangia 23 municípios dos departamentos de Chocó, Vale do Cauca, Cauca e Nariño e tinha como objetivos principais elevar os níveis de bem-estar da população e propiciar a integração física, econômica e social do litoral com o resto do país. Ele desencadeou o Plan Pacifíco, que, por sua vez, abarcou 38 municípios dos mesmos departamentos, foi encabeçado pelo Departamento Nacional de Planeación (DNP), financiado pelo Banco Interamericano de Desarrollo (BID) e envolveu pesquisas vinculadas à Universidad del Valle.
} 
Do ponto de vista da Red de Mujeres Negras del Pacífico ${ }^{211}$, a partir dos últimos anos da década de 1980, a coletividade negra é continuamente ameaçada e violada pela intromissão e a expropriação do território por parte de colonos e agentes institucionais nacionais e internacionais, com interesses econômicos e políticos, no contexto de relações de dominação próprias do sistema de produção capitalista (Red de Mujeres Negras del Pacífico, 1997: 37). A visão da Rede de Mulheres Negras do Pacífico converge com a de Grueso, Rosero e Escobar (1999), que situam na década de 1990 a abertura da economia colombiana aos mercados mundiais, especialmente no tocante à sua integração com outros países do Pacífico.

Na Colômbia, assim como no Equador, o mercado da agroindústria da palma africana e do cultivo de camarão é dominado por grandes grupos industriais, em sua maioria estrangeiros, com subsídios do Estado. Finalizamos, assim, uma síntese dos impactos das dinâmicas do grande capital sobre a territorialidade afro-pacífica.

\footnotetext{
${ }^{211}$ Iniciativa concretizada em 1992, com apoio do Fundemujer de Buenaventura e outros grupos de mulheres, em um encontro de mulheres do Pacífico colombiano realizado em Guapi, no contexto das mobilizações em torno do Artigo Transitório 55 da Constituição Política de 1991 (Rojas Silva, 1996). Quando estive fazendo trabalho de campo, não pude perceber a rede operando.
} 


\section{Capítulo 1 - Río Mira}

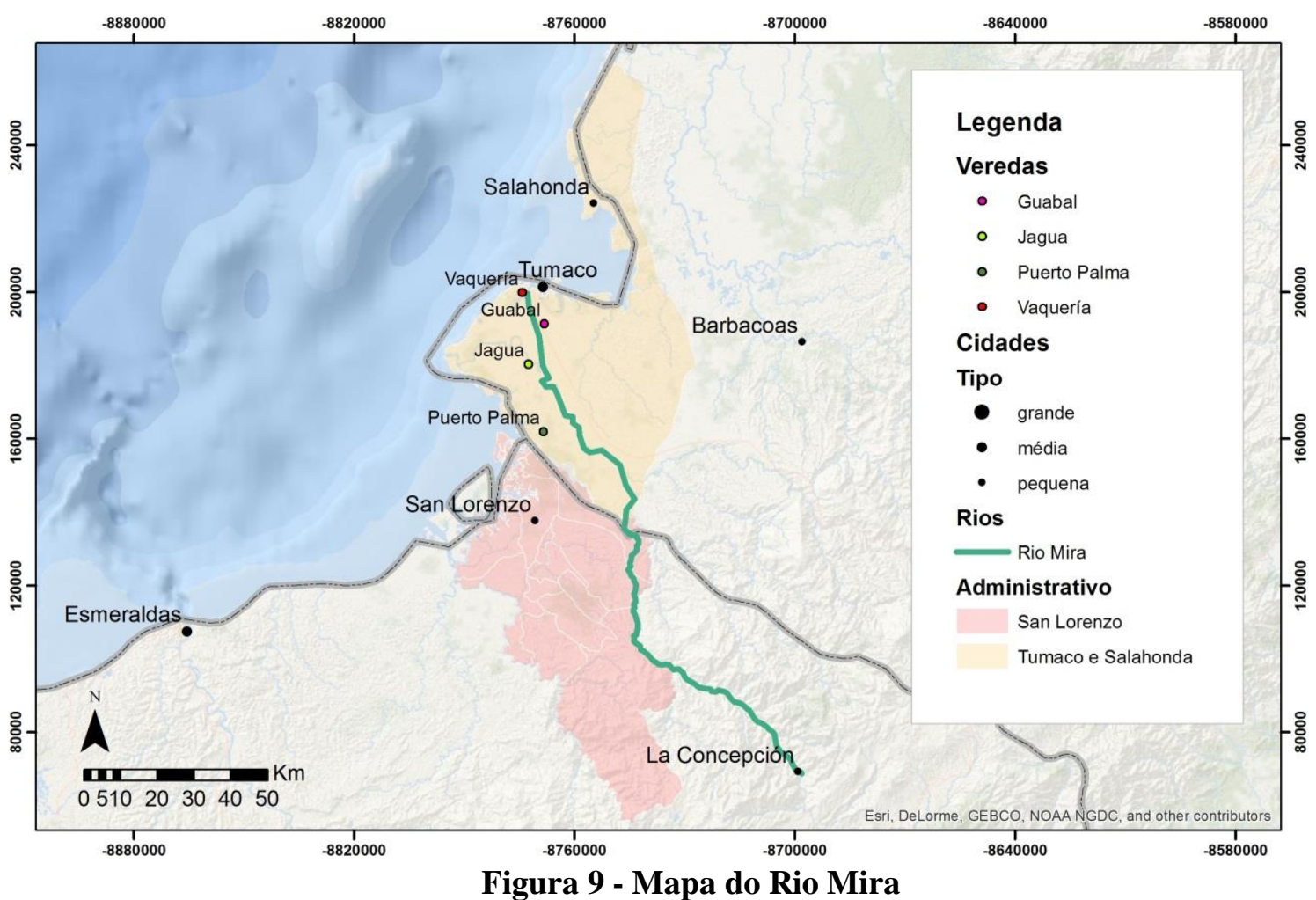

La gente de mi vereda pregunta por el río. - Y el río ¿cómo está? - Ah, no ha crecido por estos días. Está bien. - Pero, ¿está seco o está crecido? - No, está seco. - Ah, bien. Y ¿cómo va mi tío no sé quién? Entonces la gente primero pregunta por el río. Y es fuerte fuerte la relación con el río y el respeto hacia el río. Para mí el río de un lado es mi papá. Representa mi papá. Porque si había un lugar que mi papá quería en el mundo era ese lugar. Dos: mi infancia, la infancia más feliz que un niño puede tener. A mí el río me enseño todo. Todo lo que soy es ese río, si yo nazco en otro lugar del mundo no sería la misma persona. Me recuerdo de mi infancia desde los cinco años. Y entonces de ahí aprendí a nadar, después ya no salía más del río. La rutina era, tipo 4 de la tarde, nos mandaban recoger la fruta que estaba en cosecha o era pepepán, o era chontaduro, o era caimito, o era zapote. Era lo que íbamos a comer en la noche, mientras nos echaban cuento los mayores. Luego veníamos y era el momento de la lucha. Una lucha de todos contra todos. Yo y mi hermana éramos las únicas niñas, mis primos eran todos hombres, y teníamos que luchar. Mi papá no permitía que lloráramos. La lección de eso es que tenía que ser fuerte. La vida te va a dar golpes más duros, eso no es nada. Luego, lo que pasaba en la lucha allí terminaba, pronto, se acabó. No era permitido que uno se quedara molesto con el otro después. Luego de la lucha nos metíamos al río, bañe, bañe, bañe. Hasta que nos poníamos como uvas pasas, mi mamá y mi tía nos llamaban: súbanse. La finca de mi papá y mi tío es al lado del barranco. Allá independiente de estar el río crecido o bajo había agua. Hacia el otro lado del río saca playa. Es una curva. Bañábamos desnudos, andábamos desnudos. En el río los niños y las niñas andaban desnudos hasta que no nos empezara a salir pellos púbicos. Entonces, ya para dormir, nos hacían poner ropa. Entonces los viejos ya se iban acomodando con sus pipas y ya, 
pues no había energía eléctrica, era luz de lámpara que funcionaba con petróleo. Ya nos íbamos sentando. Y los viejos empezaban a contar las historias, dentro de la casa.Los cuentos hablando del cotidiano de ellos, lo que habian hecho en el día, la semana. En ese tiempo y hasta hace poco, cada casa quedaba en su finca. Ese modelo que hay en las veredas, de unir las casas en pueblito, eso es nuevo. Entonces sabíamos la hora que nos estaban diciendo que era la hora de acostar porque empezaban a echar cuentos de terror (risos) - Eva Lucia Grueso ${ }^{212}$.

A narrativa suscita a construção de uma série de imagens sobre o território da família Grueso, às margens do Rio Mira, onde Eva Lucia passou os primeiros anos de sua infância, na segunda metade da década de 1970. Como explica Eva Lucia, na vereda Bajo Jagua quase todas as pessoas são "família", fazem parte de um mesmo tronco familiar, o que nos remete à concepção de família extensa. A construção das relações, lugares e posições de parentesco passa pela vivência da territorialidade. É nas rodas de conversa, quando os mais velhos contam histórias para os mais novos, que essa relação é atualizada, por exemplo. Ao compartilhar narrativas que falam sobre as peripécias de uma caçada, entre outras, constituem-se e transmitem-se as imagens sobre o território, bem como são compartilhadas as condutas para nele atuar. Enquanto escutam as histórias, os mais novos saboreiam pepepán (Artocarpus camansi), espécie da mesma família da fruta-pão; pupunha ou chontaduro (Bactris gasipaes); caimito (Chrysophyllum cainito); sapota-do-solimões, fruta típica do Amazonas brasileiro, ou zapote (Quararibea cordata).

Em seu depoimento, Eva Lucia traz algumas relevantes associações, no tocante à representação do Rio Mira. Ela diz que o rio é o seu pai, em seguida diz que o rio é, ou representa, a sua infância. Em outro momento, o território é chamado de rio: "allá en el río". A narrativa mostra, pois, que a pessoa afro-pacífica é constituída pelo rio. Ao mesmo tempo, segundo a concepção do território-água, em torno do rio, constrói-se uma territorialidade, e também uma sociabilidade. Na ribeira do rio, Eva e Nela, las Hermanas Grueso, como se sabe chamá-las, rompiam estereótipos sobre a mulher. Quando pequenas, foram ensinadas a enfrentar fisicamente outras crianças, sobretudo meninos, como escola para o enfrentamento da vida.

Como o poema da epígrafe nos ensina: "é da natureza ser passante, fluir e mudar". O cenário descrito por Eva Lucia sofreu grandes transformações. Algumas delas em decorrência direta da intervenção do grande capital no Pacífico colombo-equatoriano. Eva Lucia conta que seu pai e seu tio, Abel e Federico Grueso, foram pioneiros na luta em defesa das terras da família contra Palmas de Tumaco, empresa de cultivo de dendezeiro que se instalou no baixo

${ }^{212}$ Entrevista concedida em 7 de fevereiro de 2014. 
Rio Mira em princípios dos anos 1960, o que corresponde à entrada das palmeiras na região $^{213}$. A luta de Abel e Federico nos anos 1960 era a luta de um tronco familiar negro pelas terras herdadas de seus antepassados. Ela inspirou as irmãs Grueso a seguir o caminho na defesa dos territórios negros ancestrais, que passou a ser uma luta da coletividade negra em âmbito nacional, a partir da década de 1990.

\section{COMO NASCEU O PROCESSO ORGANIZATIVO AFRO-COLOMBIANO?}

Entonces yo y mi hermana ya de jóvenes estuvimos involucradas en las luchas sociales de Tumaco, siempre, salíamos a tirar piedra. Hacíamos parte de todo movimiento social que se organizó en Tumaco ${ }^{214}$. Entonces, cuando en el año 91, aparece la nueva Constitución Política, y aparece el Artículo Transitorio 55, y nos llegó la noticia a Tumaco, pues, imagínese: por fin vamos a pelear por lo que realmente es nuestro! - Eva Lucia Grueso $^{215}$

A principio yo miraba como algunos nos miran ahora: ellos andan de arriba abajo, ¿qué hace esa gente? Entonces un día me invitó Lidoro Hurtado a participar de una reunión. Pasé a andar con Manuela. Nos íbamos de vereda en vereda dando a conocer porque los negros tenían que pedir una ley para que reconocieran nuestros derechos, porque la importancia de titular la tierra. Entonces fue antes del 93, porque es así. El Convenio 169 de la OIT $^{216}$, ahí da pie para que se haga el artículo transitorio 55, la ley 70 de 1993 y el decreto 1745 de $1995^{217}$. Y aquél día los del mar traían pescado y los de parte alta, el plátano. Nadie nos apoyaba con refrigerio, no. Todo era de nosotros mismos. Uno llevaba el pescado, otro la panela, hacíamos el tapa'o. Amanecíamos todos en la misma casa, donde habíamos acostado. Andábamos a canalete. $Y$ había hombres y mujeres. Pero siempre quien ha sido la fuerza son las mujeres. Entonces desde ahí empecé a irme metiendo más, apropiarme. En ese tiempo yo era docente en mi vereda. Aprovechaba la charla para ahí mismo enseñarle el derecho que teníamos a mis niños, los negros y todo eso - Mailen Aurora Quiñones.

Yo fue la dinamizadora y promotora de todas las formas organizativas de lo que se llama el Consejo Comunitario Bajo Mira. Primeramente me colocaran como tesorera. Estábamos en punto de prueba. Manuela pasa la

\footnotetext{
${ }^{213}$ Em 1970, o dendezeiro tomava 960 hectares do município de Tumaco, enquanto que em 1996 passou a ocupar 30 mil hectares (Restrepo, 1999).

${ }^{214}$ Segundo Restrepo (1999), entre meados dos anos 1940 e a segunda metade dos anos 1970, houve uma significativa expressão política do movimento camponês e estudantil em Tumaco.

${ }^{215}$ Entrevista concedida em 07 de fevereiro de 2014.

${ }^{216}$ Ratificado pela Colômbia, em 7 de agosto de 1991, pela Lei n. 121, de 1991.

${ }^{217}$ Decreto 1745 de 1995. Disponível em: http://www.alcaldiabogota.gov.co/sisjur/normas/Norma1.jsp?i=7389. Acessado em: 3 de abril de 2014 .
} 
prueba y luego la colocan en la organización madre del consejo comunitario, como representante legal - Manoela Salazar.

Cuando ya llegó Manuela trayéndonos la noticia que fue aprobado. ;Eso fue una locura! Eso llorábamos, gritábamos, porque eso era algo que nunca, o sea, jera mucho pá nosotros! Ahí miramos que la lucha no fue vana, andar a canalete, aguantando sol, aguantando aguacero, porque eso fue muy hermoso. Entonces ya Lidoro y Manuela vinieran a entregarnos ese título colectivo. $O$ este reconocimiento. Entonces ya nos fuimos de vereda en vereda a decir que teníamos que nos reunir en Cacagual para la primera asamblea. Creo que fue en el 27 de septiembre del 93. Y entonces le cuento que llegaran más de quinientas personas. ¡Eso fue lo máximo! ¡Fue lo máximo! Fue tan hermoso que la gente traía sus petates ${ }^{218}$, se acomodaba en la casa del vecino, del amigo, de alguien. Eso fue muy hermoso. Y decían alcen las manos los de la vereda tal. Ya, aquí está su comida. Eso el mismo pueblo. Ya por comisiones. Cada vereda tenía una comisión. Cuando llegaran ya los de Incoder, para ellos fue un asombro total mirar que cantidad de gente. $Y$ este día ellos felicitaban. $Y$ ahí fue Manuela la primera representante legal del consejo.Ya cuando empezó la lucha de proceder al reconocimiento de la Ley 70 , el título colectivo, ya se empezó a hacer mapas veredales, los límites de una vereda a otra, todo eso se hacía a lápiz, a pulso. No contábamos con nada, todo se hacía por iniciativa propia. Y ya se creó, se llamaba la junta central, donde todos los miembros de otras organizaciones, otros consejos comunitarios, había la unidad también. Ahí salió un sentir comunitario. Se hablaba el mismo idioma, sabíamos cuál era la causa por lo que íbamos luchar y todos apoyaban esa causa - Mailen Aurora Quiñones.

O Baixo Rio Mira foi palco de intensas movimentações. As narrativas apresentadas refletem mobilizações em nível local que se articulavam com outras de nível nacional. Neste pioneiro rio, e subsequentemente em outros, desenvolvia-se, então, um processo pedagógico com vistas à compreensão dos direitos assegurados na Constituição em nome da coletividade negra, em especial, o direito ao território.

Como indica a narrativa de Mailen, esse processo se dava de vereda em vereda, protagonizado por um grupo de mulheres e homens que percorriam o Rio Mira com essa missão. Mas também se dava em sala de aula, já que a professora de uma das veredas desse rio fazia parte do referido grupo e estava se constituindo como uma liderança étnica. Esse processo de constituição como lideresa, no caso da matrona Mailen, parte de um lugar de destaque no cenário comunitário - o de professora e parteira - e irradia-se para o "processo de comunidades negras".

Sem embargo, trata-se de trajetórias eivadas de tensões e conflitos, como dá a entender o depoimento de Manoela Salazar. Ainda que houvesse um protagonismo feminino, o desempenho das mulheres no processo organizativo era posto à prova. Manoela passou no

${ }^{218}$ Tecido sobre o qual as pessoas dormem, feito por mulheres, homens e crianças, com matéria-prima da região. 
teste e conseguiu eleger-se como a primeira representante legal do Conselho Comunitário Baixo Mira e Fronteira. No Baixo Mira, esse foi um momento ímpar de exercício e fortalecimento da capacidade organizativa local.

A luta da coletividade negra assumiu um qualificativo a partir da década de 1990. Passou a ser uma luta étnica. Nesse sentido, mulheres como Eva Lucia e Nela, as irmãs Grueso, que já eram mulheres de luta, finalmente assumiram uma bandeira reivindicativa própria. Essa bandeira se sustentava em alguns conceitos fundamentais como: território, práticas tradicionais de produção ${ }^{219}$ e utilização de recursos naturais. No cenário nacional, o processo organizativo enfatizava "o controle social do território e de seus recursos naturais como condição para sobrevivência, recriação e fortalecimento da cultura" (Grueso, Rosero e Escobar, 1999: 241).

Vale retomar um pouco da história política colombiana para compreender o cenário nacional em que se contextualizam os depoimentos ora apresentados. Como informa Arocha (1992), em 27 de maio de 1990, foi realizado um plesbicito na Colômbia. Por decisão dessa consulta pública, o então presidente César Gaviria iniciou seu mandato com o compromisso de convocar uma Assembleia Nacional Constituinte, composta por setenta membros eleitos popularmente, que substituiria a carta de 1886. Os trabalhos da assembleia foram precedidos de "Mesas de concertación y análisis". Também a precedeu a Conferencia Pré-Constituinte das Comunidades Negras, realizada em Cali, em agosto de 1990, com a participação de pessoas e organizações que mantinham vínculos com a população negra, desde setores da Igreja católica, passando pela esquerda, partidos tradicionais (Liberal e Conservador), programas governamentais e ONGs, segundo Grueso, Rosero e Escobar (1999).

Conforme a percepção desses autores, dada a heterogeneidade entre as organizações negras e seus pontos de vista, não houve consenso quanto à eleição de uma representação negra para a Assembleia Constituinte. A coletividade negra e a indígena fizeram, então, uma aliança. Os pleitos negros foram apresentados na Constituinte pelo indígena Emberá Francisco Rojas Birry ${ }^{220}$. Vale lembrar que, ao longo dos períodos colonial e republicano, existiam relações institucionalizadas entre Estado e grupos indígenas, enquanto interações entre Estado e grupos negros foram marcadas pela marginalidade (Wade, 1997; Arocha,

\footnotetext{
${ }^{219}$ Segundo a Lei n. 70, de 1993, artigo $2^{\circ}$, inciso 7: "son las actividades y técnicas agrícolas, mineras, de extracción forestal, pecuarias, de caza, pesca y recolección de productos naturales en general, que han utilizado consuetudinariamente las comunidades negras para garantizar la conservación de la vida y el desarrollo autosostenible".

${ }^{220}$ Para uma análise detalhada da mobilização negra/afro-colombiana na Constituinte e na construção da Lei n. 70 de 1993, ver: Paschel, 2010.
} 
1992). Nesse sentido, o reconhecimento dos grupos negros pelo Estado colombiano passava pela assunção do discurso da etnicidade, que involucrava a relação do Estado com indígenas, ou a indigenização dos/as negros/as ${ }^{221}$, como coloca Wade (1997).

Segundo Arocha (1992), apesar do avanço na pactuação entre grupos indígenas e negros, não foi cumprido o acordado no tocante às reivindicações dos negros, em particular relacionadas à territorialidade no litoral pacífico. Arocha percebia no texto constitucional uma contradição central: ao tempo em que definia o caráter pluriétnico e multicultural da nação colombiana (Artigo $7^{\circ}$ ), condicionava os direitos étnicos das "comunidades negras das zonas rurais ribeirinhas dos rios da Bacia do Pacífico" à promulgação de outra lei. Ademais, o texto sustenta que tais comunidades ao longo da história vinham ocupando "terras baldias", desconhecendo o processo secular de ocupação negra nessa região, sobre o qual falamos na introdução da tese $\mathrm{e}^{222}$. Na visão de Arocha (Ibidem), ainda que o Artigo Transitório 55 tenha representado um avanço, a Constituição Política de 1991 mantinha a população afrodescendente excluída do projeto nacional. $\mathrm{O}$ autor atribui isso à persistência do verticalizado sistema de castas sociorraciais vigente no curso da colônia espanhola.

Em contraponto, para Grueso, Rosero e Escobar (1999), o Transitório 55 representou uma conquista das "comunidades negras". Subsequentemente ao processo constitucional, uma parcela das organizações negras nele envolvidas seguiu atuante na regulamentação do referido artigo. Foram dois anos de intensas mobilizações protagonizadas por lideranças negras do Pacífico colombiano (Nariño, Chocó, Valle e Cauca), até chegar à tão falada Lei n. 70, de 1993, em decorrência da determinação do Artigo Transitório 55 da Constituição Política de $1991^{223}$.

Segundo Grueso, Rosero e Escobar (Ibidem), nesse momento havia uma grande complexidade e heterogeneidade entre as organizações negras. Os autores ressaltam

\footnotetext{
${ }^{221}$ A relevância da questão indígena para o Estado colombiano, comparativamente à questão negra ou afrocolombiana, fica explícita na análise que Paschel (2010) faz sobre a presença demográfica de ambas as populações e a regularização de seus territórios ancestrais, com base em dados do Departamento Administrativo Nacional de Estatística (DANE, 2007). Enquanto a população indígena corresponde a 3,4\% da população nacional e os resguardos indígenas representam $29,8 \%$ do território colombiano, a população afro-colombiana soma $10,6 \%$ do total nacional e os conselhos comunitários constituem 4,1\% da área territorial do país.

${ }^{222}$ A caracterização das terras ocupadas pelas coletividades ribeirinhas do Pacífico sul como "baldias" é bastante questionada na literatura antropológica colombiana. Para o Estado, baldio poderia ser um terreno não habitado ou cuidado e que, portanto, é sua propriedade, conforme indica González (2002). A categoria de "terras baldias" encontra paralelo nas brasileiras "terras devolutas", penso eu. São parcelas do território nacional que não se caracterizam como propriedade privada; são, portanto, propriedades do Estado. Também são aquelas que, havendo saído do patrimônio do Estado, voltaram a seu domínio por incumprimento dos fins a que estavam destinadas.

${ }^{223}$ Paschel (2010) ressalta que outros setores do movimento negro/afro-colombiano, como, por exemplo, Movimento Cimarrón, foram alijados desse processo.
} 
divergências entre uma tendência do movimento personificada em representantes de partidos políticos tradicionais e grupos a eles vinculados, no departamento de Chocó, e outra tendência que se consolidou como o Processo de Comunidades Negras $(\mathrm{PCN})^{224}$. A primeira tendência correspondia a uma elite negra, enquanto a segunda era formada por setores populares e organizações comunitárias, como de camponeses/as, pescadores e marisqueiras de Nariño, Cauca e Vale do Cauca, o que reflete ainda um recorte de classe nas tensões eclodidas naquele momento histórico.

O PCN é uma das organizações sociais negras/afro-colombianas de maior expressividade no país, considerada uma entidade étnico-cultural. Atualmente, a organização tem sede em Bogotá e afiliados em diversas regiões do país, como Buenaventura, Tumaco e outras cidades do Pacífico colombiano. Estrutura-se em cinco princípios básicos, segundo Grueso, Rosero e Escobar (1999). O primeiro deles é a reafirmação da identidade, ou o direito a ser negro/a, concebido a partir de uma lógica cultural e uma visão de mundo próprias, em antagonismo à lógica de dominação, exploração e tentativa de submissão do povo negro. Esse princípio enfatiza a diferença étnico/cultural da população negra em relação aos demais grupos sociais. Trata-se de um exercício que parte da autoconscientização sobre a diferença.

Em seguida, temos o princípio do direito ao território, concebido como espaço de recriação e desenvolvimento da visão cultural própria ao povo negro, espaço para o desenvolvimento da coletividade negra em harmonia com a natureza. O princípio da autonomia, por sua vez, é o direito ao exercício do ser. A concepção de autonomia converge com a que trouxemos no início dessa sessão, por meio das palavras de Mailen. O conceito ganha sentido na relação com a sociedade dominante, com outros grupos étnicos e partidos políticos. A autonomia surge de uma lógica cultural própria, que se concebe internamente autônoma no âmbito político, aspirando a uma autonomia social e econômica.

O caminho da autonomia social e econômica passa pela construção de uma perspectiva de futuro autônoma, quarto princípio. Aqui se afirma uma visão própria de desenvolvimento, baseada na cultura, nas formas de produção e na organização social tradicionais negras. São temas importantes para a concepção de desenvolvimento a compensação, a equidade, a autodeterminação e a sustentabilidade. Por fim, o PCN faz uma declaração de solidariedade à luta por direitos dos povos negros de todo o mundo. Esse é o quinto e último princípio.

\footnotetext{
${ }^{224}$ Em muitas narrativas fala-se sobre o "processo de comunidades negras". No mais das vezes, trata-se de uma referência à luta da coletividade negra por seus direitos, em especial, o direito aos territórios ancestrais. Sem embargo, em vários depoimentos a menção é feita diretamente à organização PCN.
} 
O Processo de Comunidades Negras surgiu em contraposição a um discurso sobre a negritude que enfatizava a pigmentocracia, o qual era veiculado por setores ligados aos partidos tradicionais. A ruptura no enfoque e no discurso do movimento social negro é bem explicada em um artigo escrito conjuntamente por Libia Grueso, Carlos Rosero - ambos fundadores do PCN - e Arturo Escobar:

\begin{abstract}
Durante muchos años, el acercamiento a la realidad de los negros en Colombia se moldeaba a partir de tres conceptos: marginalidad, discriminación e igualdad. La identidad negra se concebía mayormente en términos de igualdad ante la ley. El carácter ambiguo de esta formulación ha sido señalado en muchas ocasiones, hasta el punto de que la afirmación "todos somos iguales ante la ley" - que niega la existencia de discriminación y promulga la ideología de las elites de "democracia racial" predominante en la mayor parte de América Latina - hace que la articulación de un discurso étnico de oposición sea imposible (Wade 1993). Hasta hace muy poco tiempo, la oposición negra hacía énfasis en un pasado común basado en la esclavitud y en las formas de resistencia a ella, especialmente en los palenques. En esta visión, la historia era principalmente conmemorativa e indeleblemente marcada por la representación de un pasado siempre disminuido por la dominación. En contraste, el PCN afirma inflexiblemente que la invocación de un pasado común debe ir acompañada de la identificación paralela de lecciones para el presente y un proyecto para el futuro. Este énfasis constituye una ruptura con los esfuerzos de organización de los negros en el período entre 1970 y 1990, los cuales clamaban por la integración como forma de superar la discriminación y la opresión sociales. Esta teoría inicial de la lucha surgió de la marginalidad económica y política de la región y compartía algunas similitudes con las luchas negras por los derechos civiles en otras partes del mundo, en especial los Estados Unidos (Grueso, Rosero e Escobar, 1999: 248).
\end{abstract}

Os marcos legais da década de 1990 ampliaram o escopo de atuação do processo organizativo negro, que passou a exigir "muito mais além do mero desejo de integração e igualdade racial, como até então havia sustentado outros setores da comunidade negra", como dizem Grueso, Rosero e Escobar (Ibidem: 242). Os autores reforçam que "os ativistas étnico/culturais abraçam uma visão da negritude que vai muito mais além de assuntos de cor de pele e aspectos raciais da identidade" (Ibidem: 249). Percebo que, para além de acréscimos, há uma mudança de ênfase no discurso: da raça para a etnia, da igualdade para a diferença. E uma mudança no que almejava o movimento social negro: da integração para o reconhecimento da diversidade.

A partir dos anos 1990, o referente étnico e a alteridade cultural passam a ser as vertentes principais na construção do discurso político de "comunidades negras" no Pacífico. Com o Artigo Transitório 55, da Constituição Política de 1991, e a Lei n. 70, de 1993, a luta se reveste de um discurso orientado à defesa da identidade e da territorialidade das 
“comunidades negras" como grupo étnico. A singularidade cultural é situada na origem e na ancestralidade comum proveniente da África, mas também nas experiências históricas diaspóricas de construção de práticas culturais territorialmente enraizadas.

Se existem diferenças culturais marcantes entre a população negra e os grupos sociais circundantes, a integração ao meio social hegemônico implicaria desrespeito à lógica cultural negra. Ao contrário, a superação das desigualdades socioeconômicas e políticas às quais a população negra está submetida seria alcançada por meio do reconhecimento e da valorização de suas diferenças culturais, inscritas em âmbito regional e emolduradas em um "território" e em uma "cultura".

Nesse ponto, explicita-se a diferença quanto ao discurso construído no Brasil, onde a articulação proposta - o somatório entre negritude, território e cultura - nos leva aos quilombos. Quilombos contemporâneos são coletividades negras com sentido de pertencimento enraizado em um território, conformadas por laços de parentesco consanguíneos ou afins. Seu contexto é o meio rural, ainda que, em alguns casos, as cidades tenham se aproximado demasiadamente e até englobado tais coletividades, como aconteceu em Paracatu, estado de Minas Gerais ${ }^{225}$. Nesse sentido, ser quilombola é viver em um quilombo. Ivaporunduva, quilombo localizado no Vale do Ribeira, em São Paulo, estabelece regras no estatuto da associação comunitária que limitam as possibilidades de atuação de pessoas que não nasceram e não se criaram no quilombo, bem como daquelas que, nascidas e criadas ali, afastaram-se por muitos anos. A partir daí, podemos entender que ser quilombola, em sua plenitude, é nascer, se criar e permanecer em um quilombo.

O Quilombismo, por sua vez, conceito elaborado pelo intelectual e ativista negro Abdias Nascimento, consiste em um projeto de descolonização das paisagens mentais, ou reinscrição do texto cultural desde o lugar da subalternidade. Nesse sentido, os quilombos do passado e, ainda mais os contemporâneos, representam experiências de sustentação da comunidade africana no Brasil e de seus descendentes, focos de resistência física e cultural, espaços de liberdade e revigoramento dos laços étnicos e ancestrais. Segundo Nascimento, "ter um passado é ter uma consequente responsabilidade nos destinos e no futuro da nação negro-africana, mesmo enquanto preservando a nossa condição de edificadores deste país e de cidadãos genuínos do Brasil” (Nascimento, 2002: 258).

A proposta de Nascimento, datada da década de 1980, configura uma práxis afrobrasileira, fator de mobilização do povo negro no Brasil. Não obstante, o exercício

\footnotetext{
${ }^{225}$ Vale ressaltar a existência dos "quilombos urbanos", como a Pedra do Sal e Sacopã, no Rio de Janeiro, cujo contexto de sua formação histórica originária advém da cidade.
} 
contemporâneo de afirmação da ancestralidade negra no Brasil, ainda que possa se inspirar na referência dos quilombos, não se esgota nela. A população negra brasileira citadina experiencia outros processos de construção e afirmação identitária, desde um lugar próprio e heterogêneo, o que se expressa na pluralidade de organizações protagonizadas pelo povo negro brasileiro urbano: organizações de mulheres negras, de mulheres negras lésbicas, coletivos de universitários/as negros/as, organizações de matriz africana, entre outros.

A digressão ao Brasil visa situar que, enquanto nós alcunhamos o conceito de comunidades quilombolas, que representa uma parcela do universo negro ou afro-brasileiro, o qual extrapola tais comunidades, o discurso político construído no Pacífico colombiano e materializado na Lei n. 70, de 1993, concebe "comunidades negras" partindo da realidade do Pacífico e estendendo-se à coletividade negra como grupo étnico.

Paralelamente, chamo atenção para certa convergência entre Brasil e Colômbia, ressaltando o pensamento do brasileiro Abdias Nascimento e do colombiano Manuel Zapata Olivella, intelectuais e ativistas negros que foram contemporâneos. Ambos estavam envolvidos no cenário regional e nacional de mobilização em torno da negritude, nas décadas de 1970 e 1980. Juntos organizaram o $1^{\circ}$ Congresso de Cultura Negra Américas, ou Congresso de Negritudes, realizado em Cali, em 1977. Voltaram a se encontrar em outros congressos subsequentes $^{226}$. Ambos ressaltaram os aportes de africanas, africanos e seus descendentes na formação das Américas e elaboraram projetos políticos em posições críticas à organização mundial do capitalismo e do colonialismo. Zapata foi um dos primeiros intelectuais colombianos a ressaltar as contribuições culturais de afro-colombianos à nação, como ressalta Viveros (2013). Ele e Nascimento compartilham uma identificação política com ideais socialistas e anticolonialistas.

Observando os fatos que sucederam à promulgação da Constituição Política de 1991, nota-se uma sequência de instrumentos legais, como indica Mailen - ratificação da Convenção 169 da OIT, Lei n. 70, de 1993, e Decreto n. 1745, de $1995^{227}$ - que têm centralidade na organização territorial e política da coletividade afro-pacífica na Colômbia e no Equador, já que, como veremos, o Proceso de Comunidades Negras colombiano inspirou as mobilizações da coletividade negra no Equador.

A Lei n. 70, de 1993, é conhecida como "Lei de Comunidades Negras", ou "Lei de Negritudes", como prefere chamá-la Juan Pablo Estupiñan Bejarano (2010). Em seu artigo

\footnotetext{
${ }^{226}$ Comunicação pessoal, Mara Viveros.

${ }^{227}$ Regulamenta o Capítulo III da Lei n. 70, de 1993, e instrui procedimentos para o reconhecimento do direito à propriedade coletiva da "terra das comunidades negras", bem como adota outras provisões.
} 
terceiro, a lei assim conceitua "comunidade negra": "el conjunto de familias de ascendencia afrocolombiana que poseen una cultura propia, comparten una historia y tienen sus propias tradiciones y costumbres dentro de la relación campo-poblado, que revelan y conservan conciencia e identidad que las distinguen de otros grupos étnicos". Peter Wade (1997) ressalta que a definição do público da Lei 70 qualifica as "comunidades negras"; de modo que não são todas elas, mas as "comunidades negras das zonas rurais ribeirinhas dos rios da Bacia do Pacífico". Ou seja, o recorte seguiu critérios geográficos e étnicos. A raça na Colômbia é regionalizada. Vale ressaltar, portanto, que o conceito de "comunidades negras" foi forjado na década de 1990, em alusão a um contexto rural, do Pacífico, acenando para aspectos étnicoterritoriais.

No discurso das mulheres com quem dialoguei, "comunidades negras", ao mesmo tempo em que têm uma referência territorializada, possuem uma amplitude que designa o universo de afro-colombianas/os e afro-equatorianas/os. Na primeira acepção, "comunidade" está inscrita em uma perspectiva territorial endógena, que não necessariamente corresponde às divisões político-administrativas dos projetos nacionais. Por exemplo, na introdução vimos que o Estado equatoriano classifica como paróquias as subdivisões dos cantões, que podem ser rurais ou urbanas. Ao explicar o conceito de "comunidade", Inés Morales explicita a distância entre a concepção estatal e a concepção do povo afro-equatoriano:

Parroquia es el término que usa el Estado. Dentro de una parroquia, hay recintos, ¿cierto? Yo casi no te hablo de parroquia, porque para nosotros todas son comunidades. ¿Y por qué? Hay puntos en común entre todas: las mismas necesidades básicas insatisfechas, la misma población, mismas costumbres. Entre la parte alta y la baja, a veces hay particularidades, en las costumbres más que todo. Pero son realidades muy parecidas" - Inés Morales.

A perspectiva territorial endógena não apenas deixa de obedecer às divisões políticoadministrativas, como pode concorrer com elas. Em diálogos com lideranças tumaquenhas, conversamos sobre a possibilidade de reconhecimento dos Conselhos Comunitários como entidades territoriais (ETAs), que teriam orçamento próprio, funcionando tal qual uma prefeitura. O artigo 286 da Constituição Política da Colômbia define como entidades territoriais, certos departamentos, distritos, municípios e os territórios indígenas. Regiões e 
províncias que se constituam em termos da Constituição e da Lei também podem ser entidades territoriais ${ }^{228}$.

Trata-se de uma proposta semelhante às equatorianas Circunscrições Territoriais (CT), cuja conformação está prescrita na Constituição Política de $2008^{229}$ e cujas normas de funcionamento, segundo determina a Constituição, deverão ser estabelecidas em lei. Segundo o Decreto n. 60, de 2009, que institui o Plano Plurinacional para Eliminação de todas as formas de Racismo e Discriminação Racial, no item sobre direitos territoriais, eixo Justiça e Legislação, caberia à Lei de Organização Territorial do Estado a criação das circunscrições territoriais de nacionalidades e povos indígenas e afro-equatorianos como regimes especiais, bem como a dotação de recursos econômicos e de uma estrutura legal, administrativa, política e de justiça própria a tais circunscrições ${ }^{230}$.

Em que pesem as propostas de territorialidade negra autônoma tanto na Colômbia quanto no Equador, a autonomia ainda é um projeto. Em ambos os países, há forte resistência dos poderes instituídos em garantir a autonomia dos territórios negros coletivos. No caso colombiano, onde o reconhecimento dos territórios ancestrais avançou mais, é importante observar que a titulação de territórios coletivos não intervém na estrutura fundiária privada ou destinada a outros fins públicos, como preservação ambiental, mineração, entre outras. As áreas tituladas pela Lei n. 70, conforme Resolución de Titulación Colectiva de las Tierras de Comunidades Negras, são aquelas de domínio público, que não coincidem com outros tipos de propriedade, quais sejam:
a. El dominio sobre los bienes de uso público.
b. Las áreas urbanas de los municipios.
c. Los recursos naturales renovables y no renovables.

\footnotetext{
${ }^{228} \mathrm{~S}$ egundo o analista e ativista afro-colombiano Carlos Rua, a Lei n. 47, de 1993, por meio da qual foram criados os municípios étnicos de San Andrés, Providencia e Santa Catalina, oferece outra brecha: a criação de departamentos ou municípios étnicos.

${ }^{229}$ Artigos 60 e 257 da Constituição Política do Equador, 2008.

${ }^{230}$ O Anteprojeto de Lei Orgânica de Direitos Coletivos do Povo Afro-Equatoriano, proposta de lei apresentada pela Corporación de Desarrollo Afroecuatoriano (CODAE) ao presidente da Assembleia Nacional, em 22 de março de 2011, detalha mais as circunscrições territoriais afro-equatorianas, consideradas regimes especiais de governo autônomo descentralizado, estabelecidos por livre determinação. Poderão se constituir no contexto de populações que compartilham "um território, uma história, uma cultura e subsistemas de organização social, econômica e política". Além da Constituição, das leis infraconstitucionais e de tratados internacionais, são parâmetros para tais modos de gestão territorial as formas próprias de convivência, organização social e autoridade, nos territórios comunitários de posse ancestral. Conforme determina o referido Anteprojeto, para se constituir uma circunscrição territorial, a iniciativa deve partir das organizações afro-equatorianas. As paróquias, cantões ou províncias majoritariamente afrodescendentes deverão realizar uma consulta entre seus habitantes, com apoio do Conselho Nacional Eleitoral, à qual deve aderir positivamente pelo menos 2/3 dos eleitores válidos. Nessa consulta também se votará o estatuto de constituição e o funcionamento da CT. Para esse modelo se materializar, depois de aprovado o referido anteprojeto, há de se aprovar outro instrumento legal, regulamentando-a nesse específico quesito.
} 
d. Las tierras de resguardos indígenas legalmente constituidos.

e. El subsuelo y los predios rurales en los cuales se acredite propiedad particular conforme a la ley 200 de 1936.

f. Las áreas reservadas para la seguridad y defensa nacional.

g. Areas del sistema de Parques Nacionales (Lei 70 de 1993, artigo 6º).

Certa leitura do cenário contemporâneo, como a que oferece Wade (2011 e 2012), argumenta que o reconhecimento de direitos específicos às coletividades ribeirinhas do Pacífico permitiu um melhor controle desse território por parte do governo colombiano.

O sentido de "comunidades negras" como referente local e nacional ecoa também no conceito de território, nas mesmas narrativas de mulheres afro-pacíficas. Pazmiño diferencia o território como o espaço que a coletividade utiliza para satisfazer suas necessidades e onde tem curso seu desenvolvimento social e cultural; e o território-região, como construção que articula o projeto de vida dos grupos negros locais com o projeto político do movimento social, defendendo o território e sua sustentabilidade (Pazmiño, 2003: 90-91). Neste segundo nível, o conceito de territorialidade cumpre papel central na construção política da etnicidade a partir da experiência negra. É a territorialidade que confere o sentido de pertencimento da e para a coletividade negra.

Ao narrar a construção do PCN, Grueso, Rosero e Escobar falam sobre isso:

Este proceso avanzó en dos niveles, uno centrado en la vida y prácticas cotidianas de las comunidades negras del Pacífico, y el otro en las reflexiones ideológicas y políticas de los activistas. El primer nivel, llevado a cabo en el espiritu de la "lógica del rio", se basaba en la amplia participación de habitantes locales en la articulación de sus propios derechos, aspiraciones y sueños. El segundo nivel, aunque con el referente de los ríos y los caseríos, buscaba trascender el ámbito rural y promover asuntos de mayor envergadura relacionados con las gentes negras como grupo étnico, incluso más allá de lo que podía garantizar la ley. Este nivel generó un nuevo proceso de articulación de las nociones de territorio y desarrollo, y las relaciones sociales de las comunidades negras con el resto de la sociedad colombiana (Grueso, Rosero e Escobar, 1999: 241).

O PCN propõe uma permeabilidade entre rural e urbano na conceituação e na vivência da etnicidade entre o povo negro/afro-colombiano. Tal concepção foi incorporada no texto da Lei n. 70, que circunscreve a "comunidade negra" dentro da relação campo-cidade. No discurso das mulheres com quem dialoguei, o conceito de território pressupõe essa permeabilidade. Ana Granja, nascida em uma vereda do Rio Patía, que vive atualmente na zona urbana de Salahonda, ressalta que mulheres da cidade também estão dentro do território. "Para nosotros, un proyecto productivo también abarca el casco urbano, porque la mayoría de nosotros estamos en el casco urbano". 
O território é o lugar por onde caminham as mulheres, os homens, os animais e a vida. Em sendo um território-água, um de seus atributos é a fluidez. Ele prolonga-se acompanhando os passos das mulheres; a volubilidade da vida. Nesse sentido, na concepção afro-pacífica, o território negro pode englobar a zona urbana de municípios como Tumaco, onde cerca de 90\% da população é afro-colombiana. Mais ainda a sede de municípios como Salahonda, que, além de majoritariamente negro, em muito se assemelha ao campo, pela predominância das casas palafíticas e estrutura de pequeno porte. Ou seja, territorialidade não se esgota na ruralidade.

Por outro lado, as narrativas apontam que, dentro dos processos organizativos, começam a se desenhar tensões entre a vivência da etnicidade nas veredas e na cidade, no campo e no poblado. Na concepção de Ana Granja, as formas organizativas desencadeiam diferentes focos de autoridade. Como porta-voz da zona rural na construção da Política Pública Departamental, Regional e Municipal de Equidade de Gênero, Ana Granja representa as organizações étnico-territoriais, o que ela traduz como sendo "as mulheres dos Conselhos Comunitários de Tumaco e Francisco Pizarro"231. Tais organizações, nas palavras de Ana Granja, nascem com a mesma Lei n. 70, dentro dos Conselhos Comunitários. Além das organizações étnico-territoriais, participam da construção da referida política entidades de base, que estão situadas na zona urbana. Segundo Ana Granja, a diferença entre organizações étnico-territoriais e de base reside no fato de que, nos Conselhos Comunitários, o pensamento é coletivo, enquanto que, nas organizações urbanas, o pensamento é microempresarial.

No caso de Tumaco, a experiência do Mira sobre os desafios da luta de mulheres afropacíficas dentro dos movimentos de mulheres faz alusão ao tema:

En la organización como mujeres, Luz-Mari, de PCN, nos acercó un poco a la importancia del grupo de mujeres. Lo que sí alcancé yo a percibir en un taller ese sábado es que entre mujeres no debe de haber egoísmo. Claro, queremos hacer un sólo grupo de mujeres, pero en algunas cosas como que no nos cobijaba. Es bogar, pero para la misma dirección. Tener plena conciencia de que hay algunas que tiene que bogar allá y otras tienen que bogar acá, pero sin desconocer ese sentir. Por eso fue que nos nació: somos mujeres del consejo comunitario, somos mujeres rurales, entonces nos unamos con las mujeres de allá. Si alguna de allá por x o y razón le tocó desplazarse acá, ya sabe que acá también hay un grupo de mujeres, sin desconocer que hay también el grupo de allá, del territorio. Y ella hace

\footnotetext{
${ }^{231}$ Trata-se da Política Pública para Equidade de Gênero, para a Equidade das Mulheres Narinhenses desde sua diversidade étnica, social e cultural, em um território em construção de paz (Ordenanza n. 15, de 29 de julio de 2009). Está situada no Plano de Desenvolvimento Departamental Adelante Nariño 2008-2011. A política estrutura-se em seis direitos: participação social e incidência política; autonomia econômica em condições de igualdade; saúde integral, com ênfase na sexual e reprodutiva; educação equitativa não sexista e respeitosa; vida livre de medo e de violência baseada em gênero; e paz.
} 
parte del territorio. Y las que la reciben acá no desconozcan que ella hace parte de un territorio y que sea recibida como tal - Mailen Quiñones.

No discurso de Mailen, as mulheres do território são aquelas que vivem dentro dos Conselhos Comunitários. As que, por alguma razão, tiveram de deslocar-se para a sede do município, continuam a fazer parte do território, porém passam a integrar outra organização de mulheres. Ou seja, as diferenças fazem-se sentir principalmente no atuar políticoorganizativo. A concepção de território engloba rural e urbano, contudo, as práticas organizativas no campo e na cidade não coincidem e podem até mesmo divergir.

Maria Cecília, também do Baixo Mira, comenta sobre um momento no processo organizativo das mulheres de Tumaco em que o grupo ASOLINAR passou a recorrer a uma série de organizações de mulheres, cerca de 250 organizações, algumas delas envolvendo mulheres de origem rural. "Cuando hablamos de las mujeres rurales que son de los consejos comunitarios, pues, no me sentía recogida, porque a veces, hay reuniones aquí como mujeres y nosotras, si no nos invitan, nosotras no venimos. ¿Sí?”. Rosalba Quiñones, liderança do tumaquenho Rio Rosário, mencionou a mesma organização:

Porque aquí en Tumaco hay una organización que se llama Asolinar, que la
manejaba Mireya Olvieda, pero directamente es con la zona urbana. Y ella
dice que representa a todas las mujeres, al cual nosotras sabemos que a las
rurales no están ahí involucradas porque ni siquiera se da cuenta qué ella
está haciendo. Por eso la necesidad que sentimos de organizarnos en lo
rural - Rosalba Quiñones.

No contexto tumaquenho, como indicam as narrativas de Mailen, María Cecilia e Rosalba, os diálogos dentro do movimento de mulheres refletem divergências entre mulheres dos Conselhos Comunitários, que são mulheres rurais, e mulheres da cidade. Tais divergências se explicitam quando Mailen discorre sobre a Mesa Municipal de Mulheres de Tumaco:

Por ejemplo, yo hago parte de la Mesa Municipal de Mujeres, me eligió el mismo alcalde. Asistí como a tres reuniones y la encabezó Doña Mireya. Entonces, cuando me llamó Doña Mireya para asistir a una reunión yo la dije: compañera yo estoy aquí en el campo, no tengo pasaje, no tengo el transporte para movilizarme $y$, si lo presto, ¿allá me lo van a dar para yo venir y le pagar lo que presto? Me dijo que no, que plata no había. Entonces: ¿cómo yo hacía? Yo tengo el interés, tengo la gana, pero: a mí me da hambre, yo necesito el transporte - Mailen Aurora Quiñones.

A mulher que encabeça a Mesa Municipal de Mulheres é a mesma representante de ASOLINAR, que é considerada uma mulher mestiça. As críticas apresentadas acima à ASOLINAR tendem a estender-se à Mesa. O depoimento de Mailen indica que há uma 
questão de cunho logístico, que parece não ser secundária. Envolver as mulheres dos Conselhos Comunitários nas agendas de mulheres do município de Tumaco implica um aporte financeiro direto para viabilizar a participação delas.

Nota-se ainda um questionamento quanto ao tema da representatividade. A Mesa Municipal de Mulheres fala em nome de todas as mulheres de Tumaco. Em que medida essa voz reverbera as perspectivas, os anseios e as demandas de mulheres rurais que pouco ou não participam da dinâmica operativa dessa organização? Se essa voz se pretende ser também a voz das mulheres dos Conselhos Comunitários, como a Mesa pode ser a máxima autoridade se os Conselhos Comunitários se concebem como organizações autônomas?

$\mathrm{Na}$ Mesa de Gênero do Pré-Congresso Departamental Nariño, etapa regional preparatória para o Primer Congreso Nacional de Consejos Comunitarios y Organizaciones Étnicas Afrocolombianas, Palenqueras y Raizales, realizada em Tumaco, em agosto de 2013, onde estavam presentes mulheres das veredas e da cidade, entre elas Rosalba Quiñones e Ana Granja, as diferenças e semelhanças entre a vivência da etnicidade nas veredas e na cidade foram um dos temas mais discutidos. Argumentava-se que, no traslado do rio para a cidade, "es lógico (el cambio). Se cambia el modo de vestir, la comida. Hasta el caminar es distinto". Em outra ocasião, foram apontadas diferenças também no tocante ao modo de falar do povo das veredas e da cidade ${ }^{232}$.

Os depoimentos convergiam quanto ao fato de que as mulheres urbanas têm uma origem rural. Ao tempo em que há concordância sobre a centralidade do rural para as mulheres afro-pacíficas, parece haver divergências quanto às implicações da mobilidade. As mulheres que vivem ou viveram na cidade, como Constanza Cortes do Consejo Comunitario Renacer Campesino, de Barbacoas, argumentam que a mulher se sente afetada pelas coisas que passam no território rural. As mulheres dos conselhos comunitários, por outro lado, argumentam que ser afetada não é o mesmo que estar vivendo ali: "no es lo mismo que estar en mi vereda". A identificação acompanha a vivência, como coloca Edna Padilla, que se apresentou como partícipe da Mesa Departamental de Mujeres de Nariño: "yo tengo una casa en el casco urbano, pero vivo metida en mi consejo comunitario. Yo me identifico es con mi territorio, con lo que yo vivo".

Em contraposição, Marlene defende a possibilidade de deslocar o lugar de fala do sujeito conforme o contexto:

\footnotetext{
${ }^{232}$ Isso foi em uma oficina sobre a Lei n 70, realizada na sede de Tumaco, pela organização Palenque Afro Urbano, no dia 17 de novembro de 2012.
} 
Si estoy en un territorio urbano, estoy en lo urbano: pero si me toca ir a luchar por la mujer que está en un consejo comunitario, pues yo voy a ser una mujer que está en el consejo comunitario. $Y$ si voy a estar en un territorio indígena, tengo que asumir como una mujer indígena; porque es la pelea de ella, y lo que uno va estar es luchando para ella. Yo tengo que identificarme con esta mujer que está allí. Entonce' de allí viene el tema cultural y es: como tú te defines, jeso lo hace la cultura mija! Sí yo nací en Tumaco, yo me defiendo con mi cultura de Tumaco. Pero si de pronto me tengo que ir a Brasil, y tengo que adoptar tu cultura para vivir en tu territorio, Paula. Entonces yo ya no voy a tener una cultura tumaqueña, sino que me voy a tener una cultura brasileña. Pero, sin olvidar mis ancestros, de donde vengo. $Y$ contándole a mis hijos que voy a parir en tu territorio, Brasil. ¿Quién es Marlene Tello en el territorio ancestral que es Tumaco? ¿Qué hizo? ¿Quién era? Entonces eso es lo que tenemos que recuperar. Donde tenemos que desaprender y volver a aprender. Esa es la clave para acabar con tantos problemas - Marlene Tello ${ }^{233}$.

Não obstante o ponto de vista sustentado por Marlene, prevaleceu a perspectiva situada. No documento produzido coletivamente pela Mesa, o tema foi assim problematizado:

Es diferente el pensamiento de la mujer rural y urbana. Ahí juega un papel muy importante el tema cultural. Al mismo tiempo, al trasladar del territorio para la ciudad, la persona es la misma. Lleva consigo sus creencias, su valor. Las dos, mujeres negras en la ciudad como en los territorios colectivos, tienen que enfrentarse al patriarcado (el hombre es el que debe representar y decidir) y al machismo (imposición de poder sobre los demás).

No referido trecho, o território coletivo não compreende a cidade. Trata-se de territorialidades distintas. O foco, neste caso, são as mulheres e dá-se preponderância ao "tema cultural", que pode ser entendido como o sistema de crenças e valores, esses, sim, permeáveis entre campo e cidade. Trata-se ainda de uma reflexão sobre os processos migratórios. A mobilidade espacial e social das populações afro-pacíficas pode ser compreendida a partir dos percursos: rios-rios, rios-cidade de Tumaco, rios-Cali, TumacoCali, rios ou Tumaco-outras áreas (Barbary e Urrea, 2004: 28). Nesses vários percursos, as mulheres fazem movimentos pendulares, com idas e vindas.

A dinâmica pendular feminina campo-poblado encontra sustentação na rede familiar, entendida como a parentela e a irmandade política, social e afetiva na qual estão engajadas as mães. Nesse sentido, mulheres que migram sazonalmente a outra parte mandam seus filhos aos locais de residência do tronco familiar, seja o rio, seja a casa em Tumaco, Salahonda ou San Lorenzo. No mais das vezes, os filhos ficam com a avó e eventualmente com o avô. Esse foi o caso de Eva Lucia, que migrou para Bogotá e depois para o Canadá. Segundo indica Moore (1991), essa relação oferece vantagens à mãe e à filha. As mulheres que permanecem

${ }^{233}$ Entrevista concedida em 21 de agosto de 2013. 
na zona rural ou urbana de municípios de pequeno porte, como San Lorenzo, recebem apoio financeiro, bens e alimentos das filhas que migraram para a cidade. Esses bens apoiam no cuidado da prole e de toda a família. Vale lembrar que a chave organizativa das redes é a identificação dos sujeitos com sua origem e procedência. Trata-se de um exercício da territorialidade que envolve uma noção particular de território, evidenciada no deslocamento ou desplazamiento, quando se trata da migração no contexto das violências sóciopolíticas, sobre a qual falaremos na última parte da tese. Nesse sentido, as trajetórias das mulheres migrantes na cidade remetem diretamente a sua origem e procedência.

Trago duas experiências com intuito de ilustrar as variadas vivências que se pode ter na mobilidade. Marlene Tello nasceu em uma família camponesa, na vereda Chilví las Mareas, que pertence ao Conselho Comunitário Rescate las Varas $^{234}$. Aos três anos, junto com seu núcleo familiar (pai, mãe e irmãos), ela foi viver na sede de Tumaco e criou-se no bairro Nueva Creación, onde também viveu Eva Lucia Grueso. Depois ela migrou para outras cidades e outros países.

Em Tumaco, vivi na casa de uma família provinda do Rio Tablón Salado ${ }^{235}$. A casa localiza-se em um bairro palafítico que se assemelha muito a certos locais pertencentes à zona rural, como Palma Real, na fronteira entre a Colômbia e o Equador. Dentro do bairro Arboleda, o setor dessa residência configura verdadeiro reduto de Tablón, quase como uma extensão do campo para a cidade. Na casa vivem duas irmãs e suas respectivas filhas, de dez e cinco anos de idade. Aí as moradias são construídas com madeira que provêm de Tablón. Os pais delas mandam periodicamente produtos do campo (plátano, coco, limão, etc.). São recorrentes as conversas sobre a gestão do território e o desempenho da junta diretiva do conselho comunitário. Antes de viajar, minha amiga, que é dirigente de uma organização étnico-territorial, liga para os pais e informa quando vai e regressa. Pelo telefone também acompanha a situação de saúde do povo do rio. As férias sempre são disfrutadas em Tablón e especialmente as crianças demonstram ansiedade por viver esse momento a cada ano. Ademais, a casa do Arboleda consiste em pouso para toda a rede de parentela que vive no rio, assim como é a casa de Eva Lucia na Nueva Creación.

Enquanto Marlene migrou quando vivia a primeira infância junto com seu núcleo familiar, minha outra amiga se mudou para Tumaco já adulta e seus pais, bem como tios

\footnotetext{
${ }^{234}$ Criado em 13 de dezembro de 2006, pela Resolução n. 2786, com 14.674,6438 hectares, agregando quinze veredas tumaquenhas, 952 famílias, 4.126 pessoas.

${ }^{235}$ Consejo Comunitario del Rio Tablón Salado, criado em 23 de dezembro de 2002, por meio da Resolução n. 2539, que tem área de 3.114,8997 hectares, agregando quatro veredas, 140 famílias, 725 pessoas.
} 
primos e demais parentes ficaram em Tablón. As conexões de minha amiga com Tablón estão materializadas em muitos sentidos. Marlene morou em Buenaventura, em seguida no Panamá e ainda na Alemanha. Parece-me que os largos passos que essa mulher afro-pacífica trilhou, de certa forma, afastaram-na da vereda Chilví las Mareas e das dinâmicas próprias a essa localidade. Isso não significa, porém, que a tenha afastado da "ancestralidade", da "cultura" de seu povo, tampouco de seu "território". Ao mesmo tempo, a experiência migratória agregou-lhe uma capacidade de aportar novas questões. Nos trabalhos da referida Mesa de Gênero, Marlene pautou temas como a homoafetividade, por exemplo, que ela situa como um tabu no Pacífico Negro, que é também a minha percepção. Foi ainda uma das vozes proeminentes no discurso de desconstrução das opressões de gênero, começando dentro do lar, tema sobre o qual falamos na primeira parte da tese.

No âmbito da Mesa de Gênero do Pré-Congresso Departalmental de Nariño, o contexto eram os processos organizativos da coletividade negra, que se preparava para um momento ímpar: o primeiro encontro nacional que reuniria organizações étnicas, afrocolombianas, palenqueiras e raizales, do campo e da cidade. As discussões refletiam, portanto, tensões entre organizações étnico-territoriais - tais quais os Conselhos Comunitários, que são territorialmente inscritos -, e étnico-culturais - aquelas que têm abrangência mais ampla, até mesmo citadina, como o PCN.

Etnograficamente identifiquei a materialização desses tensionamentos em análises críticas à Lei n. 70. Marlene Tello questiona: “;la Ley 70 nos recoge a todos nosotros como negros?". Ela argumenta que a questão dos conselhos comunitários está dividindo a coletividade negra: "esta familia, que es una sola, ya no se mira con los ojos de sororidad. Estos lazos se rompen y ya no va haber lealtad". O intelectual e ativista negro Manuel Zapatta Olivella também criticou a Lei n. 70, entendendo que ela segrega a população afrocolombiana por meio do espaço geográfico nacional (Arboleda, 2011).

A fala de Marlene encontra ressonância ainda nas reflexões do antropólogo britânico Peter Wade (1997), que já ressaltava o risco de a Lei 70 homogeneizar a variedade de interesses da população negra, bem como contribuir para a fragmentação da identidade negra. $\mathrm{Na}$ interpretação de Wade (2012), a Lei n. 70 indigenizou, regionalizou e ruralizou a negritude na Colômbia. Um dos efeitos desse processo, segundo o autor (2012), foi o emudecimento de questões relacionadas ao racismo no panorama de construção da afrocolombianidade como etnia, no contexto da década de 1990, na Colômbia. Em consonância com Wade, Viveros (2015) ressalta ainda que tal dinâmica de certo modo condicionou a 
população negra a elaborar uma autoimagem como grupo culturalmente diferenciado da sociedade englobante, como um pressuposto para o reconhecimento da negritude. Vale destacar que foi essa a concepção de negritude que informou o Censo de 1993, sobre o qual falamos na primeira parte da tese, cuja pergunta estava orientada pelo critério étnico-cultural.

Rua (2002), interpretando textos do Artigo Transitório n. 55, da Constituição Política de 1991, e da Lei 70, de 1993, defende que tais instrumentos legais não limitaram as dimensões territoriais da população afro-colombiana ao Pacífico, tampouco validam unicamente a titulação coletiva às zonas rurais do Pacífico. Trata-se ao contrário, do reconhecimento de direitos à coletividade afro-colombiana nacional. Nas palavras do autor, é uma "manga ancha en donde está presente la comunidade afrocolombiana de todo el país" (Rua, 2002: 562). Nesse ponto, ele se contrapõe às interpretações anteriormente expostas. Vale ressaltar, como o faz Paschel (2013), que essa interpretação da Lei n. 70 permitiu que ela fosse apropriada por ativistas afro-colombianos/as fora da costa pacífica, até mesmo em áreas urbanas, ainda que seja difícil demandar do Estado colombiano fora da linguagem da etnicidade.

Ou seja, duas interpretações da Lei n. 70 estão em disputa, uma delas restritiva: têm-se mais direitos quanto mais se é da zona rural do Pacífico; e outra que defende a extensão a toda a coletividade negra dos direitos nomeados à população ribeirinha do Pacífico. Essas interpretações estão no discurso acadêmico e dos movimentos sociais. Lembrando que se trata de um campo político-acadêmico, quer dizer, os discursos acadêmicos também são políticos e o ativismo político pode adentrar a academia, ou ao menos permeá-la ${ }^{236}$. Vale ressaltar que os discursos conectam-se, porém não sem tensionamentos. Por vezes, seguem direções opostas. Nesse sentido, tais interpretações, ainda que emanadas das referidas leis, extrapolam a dimensão legal, projetando-se nas dinâmicas organizativas da coletividade negra e na produção intelectual sobre "comunidades negras". Trata-se bem mais de uma retroalimentação. O campo político-acadêmico incidiu no processo de fabricação do Artigo Transitório n. 55 e da Lei n. 70 e, em seguida, se vê atravessado por eles.

\footnotetext{
${ }^{236}$ Exemplo da permeabilidade entre o campo acadêmico e o político é a experiência de trabalho da comissão composta em 1992 para normatizar o Artigo Transitório n. 55, que resultou na Lei n. 70. O grupo era composto por lideranças negras do Pacífico e sua secretaria técnica cabia ao Instituto Colombiano de Antropologia (ICAN). Segundo Paschel (2010), que analisa documentos de trabalho da referida comissão, divergências entre antropólogos/as ligados ao Estado (antropólogos indigenistas) e ativistas negros/as giravam em torno, principalmente, da definição de grupo étnico e da abrangência da coletividade negra dentro dessa definição. Enquanto ativistas negros se reconheciam como grupo étnico, antropólogos indigenistas refutavam conceitualmente tal sentido de pertencimento.
} 
A partir das questões propostas por Arboleda (2012), questiono em que medida a produção intelectual das ciências sociais, como uma das construções que representam a coletividade negra colombiana, corrobora uma ou outra interpretação. Nesse sentido, a ênfase no estudo da diferença cultural, proposta por Arocha e Friedemann, assim como a ênfase na "etnização da negritude", conceituação de Restrepo, engrossariam uma concepção de "comunidade negra" excludente daquilo que escapa ao caráter rural afro-pacífico. Na visão de Arboleda (2012), o texto do artigo primeiro da Lei n. 70 é diretamente informado por essa concepção antropológica de "comunidade negra", que tem um caráter excludente.

O questionamento de Marlene sobre a capacidade da Lei n. 70 em representar a todas/os as/os negras/os ou afro-colombianas/os leva, portanto, à retomada de uma questão que trabalhei na primeira parte da tese, referente ao englobamento da raça pela etnia nos discursos da e sobre a população negra/afro-colombiana, a partir da década de 1990. Vale lembrar que a mudança de ênfase da raça para a etnia traduz-se na mudança discursiva da igualdade para a diferença, acompanhada por um deslocamento das demandas do movimento social - da integração para o reconhecimento da diversidade. Na perspectiva de Lozano e Peñaranda (2007), as tendências do movimento social negro ou afro-colombiano parecem ter se polarizado em duas posições irreconciliáveis: uma de combate ao racismo, desde uma perspectiva integracionista e liberalista, e outra de reivindicação da diferença e da identidade, desde a perspectiva multicultural.

O conceito de etnicidade proposto pelo PCN almeja um sentimento de unidade entre a coletividade negra estruturado em torno de um "território" e uma "cultura". O que ora problematizo, à luz dos processos organizativos em Tumaco, são as lacunas que essa proposta de unidade deixou na vivência da etnicidade, tendo em vista os tensionamentos entre veredas e cidade. Nesse sentido, entendo que, no exercício de transcendência da realidade rural para a concepção do povo negro como grupo étnico proposto pelo PCN, prevaleceu a "lógica do rio", usando as palavras de Grueso, Rosero e Escobar (1999).

Pensando na realidade de coletividades negras territorialmente inscritas, especialmente na região pacífica, a reivindicação principal parece ser a do reconhecimento da diversidade: as diferentes formas de organização social, produtiva, e de ordenamento territorial. Por outro lado, pensando na realidade de mulheres como Marlene, que vive no contexto urbano, mas também pacífico ${ }^{237}$, ganha relevância o tema do combate ao racismo, da igualdade de

${ }^{237}$ Segundo Urrea-Giraldo (2011), em toda a Colômbia, a população afro predomina nas cidades, inclusive na região do Pacífico, onde 65\% dos/as afro-pacíficos/as estão situados/as nas cidades, conforme dados do Censo de 2005. Trata-se de uma mudança significativa entre os dois censos, de 1993 e de 2005, que indica uma intensa 
oportunidades e das ações afirmativas ${ }^{238}$, com vistas a incrementar a representação negra/afrocolombiana no sistema educacional, no mercado de trabalho e no sistema político-partidário, por exemplo $^{239}$. A etnografia leva-me, pois, a propor uma associação entre o reconhecimento da diferença com a realidade ribeirinha e a demanda por igualdade de oportunidades com uma vivência citadina.

Trata-se, portanto, de duas questões: uma relacionada a demandas étnico-territoriais dos povos ribeirinhos do Pacífico e outra relacionada ao contexto urbano. Contemporaneamente, mediante a intensificação da migração afro-colombiana do campo para as cidades, no Pacífico sul colombiano, as tensões entre as duas perspectivas parecem se aprofundar. Como o vocabulário no Pacífico enfatiza a etnia, o foco do discurso político construído nos marcos da Lei n. 70 é o reconhecimento da diferença. Nesse sentido, na articulação entre essa dimensão e a luta contra as opressões raciais, a primeira ganha preponderância sobre a segunda.

Esse é um dos nódulos que o questionamento de Marlene expõe. A Lei n. 70, em seu artigo primeiro, enuncia a "protección de la identidad cultural de los derechos de las comunidades negras colombianas en su condición de grupo étnico, el fomento de su desarrollo económico y social con el fin de garantizar que obtengan condiciones reales de igualdad de oportunidades frente al resto de la sociedad colombiana". Porém, o instrumento legal apresenta uma perspectiva eminentemente rural $^{240}$. Tal perspectiva tem dificuldades em acolher as demandas de aproximadamente $70 \%$ da população afro-colombiana, que habita áreas urbanas, como ressalta Urrea-Giraldo (2011).

Por outro lado, a partir de meados da década de 2000, quando a raça volta a figurar com maior densidade no cenário político colombiano, motivada em grande medida pelo contexto internacional desencadeado pela Conferência de Durban, a luta por igualdade de oportunidades se fortalece, articulada pela linguagem do combate ao racismo e à

migração rural-urbana no Pacífico, que decorre em grande medida da violência sociopolítica instaurada na região, tema da terceira parte da tese.

${ }^{238}$ Compreendo ações afirmativas como um conjunto de estratégias para alcançar a igualdade plena e efetiva das pessoas alvo de racismo, discriminação racial, xenofobia e formas correlatas de intolerência, conceito presente da Declaração de Durban, resultado da Conferência Mundial contra o Racismo, a Discriminação Racial, a Xenofobia e formas correlatas de Intolerência, realizada em 2001.

${ }^{239}$ Vale ressaltar que o reconhecimento dos territórios negros ancestrais das ribeiras de rios do Pacífico é uma política de afro-reparação.

${ }^{240} \mathrm{O}$ tema da discriminação está presente na Constituição Política da Colômbia. O artigo $13^{\circ}$ indica que qualquer tipo de discriminação, inclusive a racial, é ilegal e deve ser evitada. Também é tocado pela Lei n. 70, em seu artigo 33, no tom de evitar racismo e discriminação e promover a igualdade. Porém, em ambos os casos não são estabelecidas de forma explícita sanções para o ato racista, tampouco se estabelece política de combate ao racismo e à discriminação. 
discriminação racial. Nesse novo contexto, o combate ao racismo não se coloca como uma estratégia integracionista, mas, sim, a partir de uma perspectiva de valorização "de lo propio", ou seja, desde uma visão endógena da coletividade negra que se coloca para a sociedade em geral.

Nesse cenário, o discurso político do Proceso de Comunidades Negras incorpora o tema do combate ao racismo como eixo central. Como ressaltam León (2011) e Wade (2012), o PCN engaja-se no Observatório de Discriminação Racial, projeto do Centro de Investigaciones Jurídicas de la Universidad de los Andes, estabelecido em 2007, com vistas a monitorar o racismo no país. Outros movimentos sociais trazem temas correlatos, como, por exemplo, o Colectivo de Estudiantes Universitari@s Afrocolombian@s (CEUNA), que surgiu no início da primeira década do milênio, em defesa do direito da juventude afro-colombiana à Educação Superior $^{241}$.

Em meu entendimento, esse processo tem curso no cenário nacional colombiano. Trago como ícone a Semana da Afro-Colombianidade "BogotAFRO 2013", realizada em Bogotá, entre 18 e 31 de maio de $2013^{242}$. Celebrou-se a abertura da semana na "Gran Movilización por la Afrocolombianidad los Derechos Humanos y la NO discriminación", marcha organizada pelo Movimiento Nacional por los Derechos Humanos de las Comunidades Afrocolombianas - Cimarrón ${ }^{243} \mathrm{e}$ a Asociación Nacional de Afrocolombianos Desplazados (AFRODES). O PCN não estava presente na marcha, o que aponta para o cenário de fragmentação do processo organizativo afro-colombiano, que remonta à década de 1970, como vimos há pouco.

No contexto do Pacífico sul, em especial em Tumaco e Salahonda, na minha percepção, o discurso político ainda está construído em torno das demandas étnico-territoriais dos povos ribeirinhos. Paralelamente, as vivências cotidianas, em especial aquelas ligadas à discriminação racial, são nomeadas pela linguagem da raça, como vimos em diversos depoimentos. Ou seja, nas relações de poder a raça aparece. Nesse sentido, no discurso político, o englobamento do étnico sobre o racial pode inverter-se. Há uma circulação de sentidos dentro dos contextos argumentativos políticos.

No tocante ao Equador, ainda que o vocabulário político também seja a etnia, o instrumento legal - Plan Plurinacional contra la Discriminación Racial y la Exclusión Étnica

\footnotetext{
${ }^{241}$ Vale ressaltar que o tema da educação está presente na Lei n. 70, expresso no direito à etno-educação (artigos 32 a 42 da referida Lei).

${ }^{242}$ A realização da Semana da Afro-Colombianidade tem como mote o Dia Nacional da Afro-Colombianidade, 21 de março, decretado pela Lei n. 725, de 27 de dezembro de 2001.

${ }^{243}$ Para uma abordagem sobre a formação e os princípios do Movimento Cimarrón, ver: Paschel, 2010.
} 
y Racial - articula bem o discurso do reconhecimento étnico com o do combate à discriminação racial. O Plano está vinculado ao Ministerio de Cultura y Patrimonio e envolve outras instituições governamentais, de acordo com as temáticas abordadas. Há quatro eixos: justiça e legislação; direitos; educação; e participação cidadã. No campo da territorialidade, aborda as Circunscripciones Territoriales (CTs), a titulação coletiva e a preservação dos ecossistemas (incluindo manguezais). Também coteja ações afirmativas no serviço público, resgate e valorização da memória do povo afro-equatoriano.

A propósito, acompanhei Inés Morales a uma reunião de monitoramento do referido Plano, promovida por instâncias do governo equatoriano ${ }^{244}$. No discurso de lideranças e pesquisadores afro-equatorianas presentes, pude notar que se estabelecia um paralelo entre a colombiana (Lei n. 70/1993) e o equatoriano Decreto n. 60, de 2009, que institui o referido Plano. Algumas lideranças manifestavam a reivindicação de que o Decreto n. 60 fosse promulgado como lei.

O decreto equatoriano contempla o povo afro-equatoriano em uma perspectiva abrangente, no campo e na cidade, no território esmeraldenho e chotenho, assim como na província de Cuenca, Guayas e outras onde também há ocupação negra ancestral. "El plan está escrito desde una perspectiva afrocéntrica. Recoge todas las inquietudes que el Pueblo Afroecuatoriano viene planteando desde el 2003”, é o que coloca Jhon Antón Sánchez, intelectual e ativista afro-colombiano radicado no Equador. Nesse sentido, a comparação entre os instrumentos legais leva a crer que o Decreto n. 60 estaria isento da crítica que apresentamos à Lei n. $70^{245}$.

\section{COMisión de Mujeres del ConSEjo Comunitario Bajo Mira y Frontera}

Nosotros comenzamos la Comisión de Mujeres del Consejo Comunitario Bajo Mira y Frontera como el 20 de febrero del 2012. Manuela fue la que

\footnotetext{
${ }^{244}$ Realizada em 8 de dezembro de 2013, em Quito, para a qual foram convidados/as em torno de vinte lideranças afro-equatorianas das várias regiões do país onde há presença do povo afro-equatoriano. Algumas dessas lideranças também ocupavam cargos de gestão dentro do governo, a exemplo de Irma Bauptista, ligada ao Ministério da Saúde, e Sonia Viveros, à época gestora do referido Plano.

${ }^{245} \mathrm{Na}$ Colômbia, a questão da igualdade de oportunidades é foco de um projeto elaborado pelo governo colombiano e lançado pelo presidente Juan Manuel Santos, em meados de 2011, chamado "Ley de Igualdad de Oportunidades para la Población Afrocolombiana". Soube da existência do referido projeto durante a Semana de Afro-Colombianidade 2013, em Bogotá. Escutei referências ao projeto apenas em Bogotá, não nas cidades do Pacífico sul em que trabalhei. E as falas de lideranças afro-colombianas ao longo desse evento desaprovavam a criação da referida lei, reivindicando o fortalecimento e amplitude do escopo da Lei n. 70.
} 
tuvo la idea. Miren que están llegando proyectos, pero se está yendo muy general y hacia la mujer está quedando sola - María Cecilia ${ }^{246}$.

Llevé dos años dándole ahí. Ahora empezaran las mujeres a escucharme. Nosotras no tenemos recursos. Nosotras tenemos ya todo el recorrido por las veredas. $Y$ hablamos de un plan, el fortalecimiento organizativo, vienen unos proyectos de cacao nativo, el arroz, la caña. Y pues, educación, ¿no? Y cultura? Son mujeres agricultoras y pesqueras y médicas, con la sabiduría ancestral. El plátano, por ejemplo, viene por la tradición - Manoela Salazar.

Entonces la primera asamblea que vamos hacer con las mujeres en el consejo es algo muy grande, como que las mujeres ganan su espacio. Ya no seamos la cinco que estamos en la junta, pero vamos a ser muchas más. Es la primera vez en la historia del consejo que estamos así. Siempre en la junta directiva son la mayoría hombres y dos mujercitas o tres, pero ahora fue mit-mit - Mailen Quiñones.

Manoela Salazar elegeu-se como representante legal do Conselho Comunitário Baixo Mira e Fronteira em 1993. Naquele momento, era minoria na estrutura de direção da organização. Demorou quase dez anos para que as mulheres ocupassem 50\% dos cargos diretivos do Conselho Comunitário. Mesmo com o protagonismo político de mulheres como ela, como Mailén, Eva Lucia, María Cecilia e outras, os espaços de poder foram dominados por homens. Como maioria na junta diretiva, os homens consolidaram a prática de silenciar as mulheres presentes na gestão, principalmente quando traziam temas relacionados a elas.

$\mathrm{Na}$ década de 2010, com o impulso novamente protagonizado por Manoela e o fortalecimento feminino na junta diretiva, os processos de organização das mulheres do Baixo Rio Mira ganha fôlego. Ciente das dificuldades enfrentadas perante os companheiros homens na gestão política organizativa local, elas se mobilizam em torno da Comissão de Mulheres do Conselho Comunitário Baixo Rio Mira, com a proposta de atuar por dentro da junta diretiva, que é formalizada como pessoa jurídica, pautando os temas "como mulheres". O diálogo entre Mailen e María Cecilia explicita a posição:

Mailen Aurora: Si la junta directiva tiene personería jurídica, o sea, un gobierno dentro de la junta, no se puede sacar otra junta.

María Cecilia: Porque nos vamos a dividir.

Mailen Aurora: Somos un brazo de la junta, o sea, no podemos hacer nada que no tengamos que decirle a la junta. No podemos hacer nada sin socializarlo con los demás: que es lo que vamos hacer porque lo vamos hacer y cómo lo vamos hacer en el territorio. No podemos estar desligados lo uno de lo otro. O sea, somos de la junta y ustedes también van a reconocer los derechos que tenemos dentro de la junta como mujeres.Queremos demostrar a ellos que inosotras también podemos! Y lo

${ }^{246}$ Entrevista concedida em 5 de setembro de 2013. 
que más le queremos enseñar es que lo vamos incluir a ellos. Nosotras como mujeres no vamos a desconocer el género. $O$ sea, enseñándoles como deben ser las cosas. No con peleas ni con golpes pero sino con acciones, actuando ${ }^{247}$.

Trata-se de uma proposta de ação coletiva que empreende uma subversão das assimetrias de gênero e da lógica masculina de exercício do poder. A perspectiva é de horizontalidade e não de inversão das hierarquias. Como matronas, essas mulheres se investem de um poder de cuidado que é coletivizado, direcionado até mesmo aos homens, que historicamente as excluíram dos espaços de poder comunitários.

Nesse sentido, a luta de mulheres negras é uma luta pela coletividade negra. $\mathrm{O}$ eu feminino é plural, o que contrasta com o masculino unitário. Como diz Ana Granja, “los hombres son vacíos. Las propuestas que hacen son como yo con yo, del hombre para el hombre". Nesse sentido, ela ressalta que a presença das mulheres nos processos organizativos possibilita a expressão do sentido coletivo, enquanto a perspectiva masculina sabe representar apenas a si mesma.

Em suas trajetórias como lideranças, mulheres afro-pacíficas rompem padrões e expectativas sobre papéis femininos e masculinos. Com a necessidade de socializar a mobilização da Comissão de Mulheres do Baixo Mira, as lideranças aprenderam, por exemplo, a manejar as embarcações, tarefa tradicionalmente executada por homens. O processo organizativo é uma possibilidade ímpar de empoderamento dessas mulheres.

Yo fue una mujer bastante - !Ay! Lo que faltó fue morirme de stress. Sin embargo, gracias a ese proceso yo estoy colguida. Gracias a este proceso yo puedo decir: yo me siento, yo sé lo que quiero y donde voy. Al igual que yo hay muchas mujeres que ahora por ellas pueden hablar - Yonny Nazareno $^{248}$.

Elas assumem desafios e adotam condutas que abrem caminho para uma reconstrução do feminino e do masculino afro-pacíficos. Ademais, o reconhecimento como ponto de apoio e referência para a coletividade, assim como o compartilhar com outras mulheres são aspectos ressaltados pelas mulheres do Baixo Rio Mira como focos de empoderamento.

$Y$ otra cosa que uno siente que la gente tiene más confianza a uno de decir: mire que me está pasando eso. Mire que la líder de aquí es ella, cuando ella llegue que la diga tal cosa. Ya como que la gente cree en uno. Pues ahí dentro de la misma organización, del consejo, donde uno comparte con la compañera, con las otras mujeres, comparte de sus problemas, sus ideas.

\footnotetext{
${ }^{247}$ Entrevista concedida em 5 de setembro de 2013.

${ }^{248}$ Entrevista concedida em 10 de dezembro de 2013.
} 
Para nosotras es algo muy grande que ya podamos juntas con otras mujeres hacer asamblea y que ellas hagan propuestas, que digan lo que quiere, como lo quiere - Mailen Aurora Quiñones.

Como as mulheres estão também envolvidas na gestão produtiva e simbólica familiar e comunitária- são "agricultoras, marisqueiras e médicas" -, as matronas se empoderam no aspecto produtivo, tendo em vista formas organizativas tradicionais. Elas contam algumas das experiências em curso:

Por ejemplo en mi vereda Bocas de Guabal allá arrancamos en la siembra de arroz. Quiero que sea un centro piloto para que otras veredas dentro de la organización tengan ese sentir, de visualizar la cosa. Es volviendo a las mingas de sembrar el arroz. Entonces, nos reunimos las mujeres todas para sembrar el arroz donde una sola compañera. Después en la otra semana, cuando ella nos llama, vamos todas otra vez. Entonces, el trabajo que me llevaría cuatro o cinco días lo puedo hacer en un día con el apoyo de las compañeras. Entonces, si no hay para hacer la mazamorra, el envuelto y el cazabe, cada cual va comiendo de su casa, pero estamos integrándonos porque durante el trabajo estamos cantando el arrullo, estamos recordando lo de antes. $O$ sea es una vivencia, es una tradición que, ahí, trabajando, recuperamos todas esas cosas. Y al mismo tiempo estamos enseñando como que se debe trabajar y cómo se debe hacer las cosas. Es una iniciativa nuestra. No nos está financiando nadie. O sea, rescatando la época de nuestros abuelos, como antes hicieran sus cosas sin depender de un proyecto. Nuestros antepasados vivían sabroso, comían juntos, acababan la faena y seguía la convivencia. Los cuentos. Y ellos eran ricos, hacían de todo, no les faltaba nada - Mailen Quiñones.

En mi vereda, Sagunbita, las mujeres han comenzado con la siembra de la caña para transformar la panela. La idea es rescatar todas las prácticas tradicionales, como era con las mingas. Allá, donde nosotros, había un árbol de almendro y todos venían a sentarse ahí, por sentir la frescura del árbol y ahí empezaban a decir: ay, con fulana pasó tal cosa, o a ver algo. El bochinchero. Hay otra cosa también de las mujeres que están con nosotras. Es un proyecto de la transformación de chocolate en el Bajo Jagua, grupo con unas quince mujereschocolateras. Ellas cogen el cacao, luego lo secan, luego lo tuestan. Hacen la transformación completa del chocolate. Y llegamos a hablar con una ONG, de los proyectos que se está manejando de lo consejo comunitario con los de USAID. De una vez las van apoyar a ellas con unas maquinarias, unas herramientas que necesitaban, porque las manitos se las pelaban a ellas, por el calor - María Cecilia ${ }^{249}$.

As mingas ou cambio de manos são os mutirões. Nos casos narrados, as mulheres se coletivizam para fortalecer os projetos produtivos de cada uma delas, e ao mesmo tempo de todas. As iniciativas produtivas de mulheres associam-se a práticas produtivas familiares, que envolvem a mulher, seu companheiro, filhos e possivelmente outros parentes, como o ancestral cultivo orgânico de banana-da-terra nas ribeiras dos rios.

${ }^{249}$ Entrevista concedida em 05 de setembro de 2013. 
Nas experiências relatadas, associado ao processo produtivo, as mulheres vivenciam tradições culturais: celebram cânticos, produzem comidas ancestrais. Também fortalecem os espaços de sociabilidade, como o bochinchero ou mentideiros, lugares agradáveis debaixo de uma árvore ou num caramanchão de madeira, onde a coletividade se reúne para atualizar as novidades, contar histórias, fofocar. Mailen, que tem uma posição crítica à injeção de recursos externos, ressalta as formas organizativas tradicionais de produção. Já María Cecilia valoriza os aportes financeiros externos, mas não deixa de ressaltar a importância das formas organizativas tradicionais.

A organização das mulheres do Baixo Rio Mira articula tradições, afetos, trabalho coletivo e incidência política. As mulheres vivenciam a territorialidade e fazem política como sujeitos posicionados nas relações sociais. Assim surgiu a Comissão de Mulheres do Conselho Comunitário Baixo Rio Mira e Fronteira, sobre o qual falarei mais no terceiro capítulo. Para elas os territórios ancestrais são territórios sagrados, a partir dos quais se constitui a subjetividade. Os rios são metáfora da pessoa afro-pacífica. As práticas produtivas tecidas em torno das águas constituem caminhos de atualização das tradições territorialmente enraizadas. Por esses caminhos, as mulheres vinculam-se com o fazer político no âmbito dos movimentos negros mistos. Dentro de organizações étnico-territoriais, como os Conselhos Comunitários, elas propõem uma lógica de exercício do poder que se orienta à coletividade, desde uma perspectiva que parte do âmbito familiar, estendendo-se ao comunitário e irradiando-se pelo "processo de comunidades negras". 


\section{Capítulo 2 - Río Patía}

Entre Salahonda, Tumaco e Mosquera, todos municípios do departamento de Nariño, localiza-se o Conselho Comunitário do Rio Patía Grande sus Brazos y Ensenada ACAPA, que foi titulado em 22 de maio de 2000, pela Resolução n. 1.119, com 94.388,4425 hectares, englobando 32 veredas, 1.453 família e 8.106 pessoas, segundo dados do INCODER. A região na qual trabalhei corresponde à desembocadura do Rio Patía, a qual se localiza na Zona 4 da Asociación Campesina del Patía (ACAPA) limítrofe à sede do município de Salahonda ${ }^{250}$, onde o rio verte suas águas para o Pacífico. Já a Zona 1 do Conselho Comunitário, como informa Ana Granja, colimita com outros Conselhos: Veredas Unidas, Sanquianga, Unión Patía Viejo.

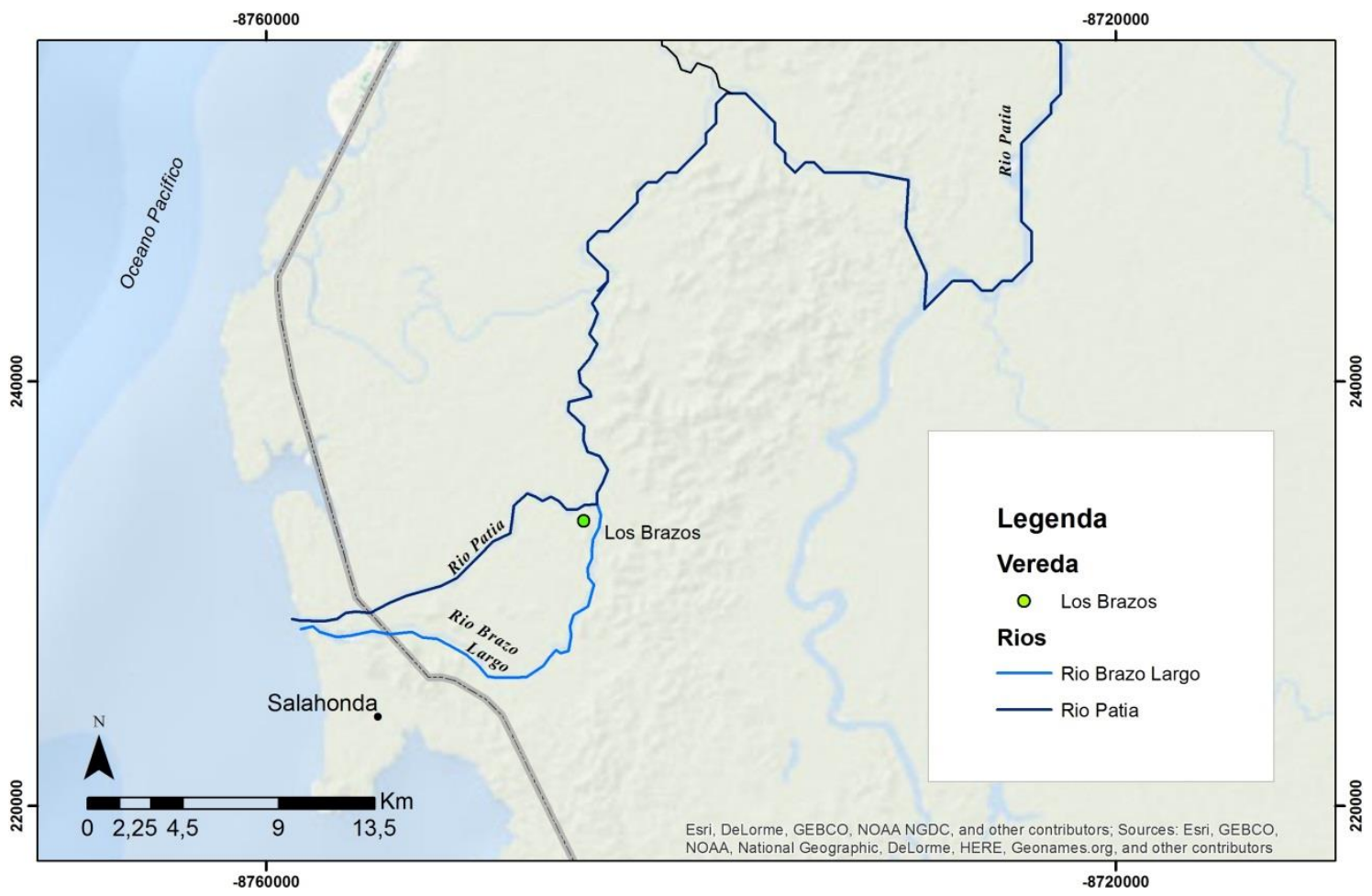

Figura 10 - Mapa do Rio Patía

Salahonda oficialmente é Francisco Pizarro, segunda prefeitura criada na região, após Iscuandé, em 1526. Trata-se de um povoado habitado por pescadores e marisqueiras. Houve um momento em que Tumaco foi oficializado como município e Salahonda, um corregimiento de Tumaco. Em 1975, Salahonda voltou a constituir-se como município. Ainda

\footnotetext{
${ }^{250}$ Como explica Ana Granja, há uma regra de que deve haver no mínimo cem metros entre a zona urbana e a zona rural. No caso da ACAPA, adotou-se o limite mínimo, de modo que Salahonda e La Playa, a primeira vereda deste Conselho Comunitário, são bastante próximas.
} 
que o povoado possua contemporaneamente 11.029 habitantes ${ }^{251}$, na sede do município devem residir em torno de 5 mil pessoas, segundo me informou Ana Granja Castillo. O vínculo com Tumaco, mesmo que legalmente inexistente, na prática é forte. Habitantes de Salahonda recorrem a Tumaco para usar serviços de correio, bancos, entre outros. O prefeito de Salahonda, à época da realização do trabalho de campo, vivia em Tumaco.

A família com quem dialoguei nesse território é a família Granja, em especial as irmãs Ana e Martina e com suas respectivas filhas, Ana Karina e Nidia. Essa família provém da vereda Los Brazos que se localiza entre dois braços do Rio Patía: Brazo Largo e Yari, unidos pela titulação coletiva.

\section{O PROCESSO DE COMUNIDADES NEGRAS EM SALAHONDA}

A história da mobilização nessa região assemelha-se ao ocorrido na ribeira dos Rios Satinga e Sanquianga, município de Olaya Herrera, departamento de Nariño, caso estudado por Pazmiño (2003), que também teve início no fim dos anos 1980, impulsionado por setores da Igreja católica, especialmente das Comissões Pastorais, com mobilizações conformadas em organizações camponesas.

Las primeras reuniones fueron en 1986. En el 91 fue la Constitución Política. Ahí era Asociación Campesina del Patía. Salahonda fue la base principal - María Valeria Mina ${ }^{252}$.

La historia de acá prácticamente la conformó las Hermanas de la Legión María. Llegaron en la década del 70. En 1999-2000, vinieron las últimas. No eran colombianas. Había una italiana, de México, Rusia. Llegaron y conocieron La Playa, la primera vereda del Consejo Comunitario y del Municipio [Salahonda], se aporta en ella. Trajeron sus amistades. Ayudaron en el trabajo educativo. La hermana Yolanda fue la mamá de ACAPA, la gestora. Trabajaron la parte organizativa de mujeres del Pacífico. La Diócesis de Tumaco, la hicimos nosotras. Ellas iban investigando familia por familia. Querían entender qué hacían las mujeres. Sus tradiciones y costumbres. Qué era la mujer del Pacífico. Mandaron un ejemplar del libro a cada una de nosotras. Eso fue en 1993, 1994. En ese tiempo nos apoyaba la Iglesia: Cáritas Suecia, Cáritas Suiza, Cáritas Alemania - Ana Granja.

En los años 90, 91 empezó el Proceso de Comunidades Negras. Los que sabían era en el Patía, con la hermana Yolanda. Había dos organizaciones,

\footnotetext{
${ }^{251}$ Dados do Censo Geral de 2005 (DANE).

${ }^{252}$ As conversas com María Valeria Mina, com Ana Graja, Martina Granja, Yulisa Granja, Ana Karina e Nídia Granja ocorreram entre 20 e 28 de outubro, em Salahonda. Com Nidia, também conversei em Tumaco, entre 28 de outubro e 03 de novembro.
} 
una en lo urbano y otra en lo rural. Yo tenía una prima en el casco urbano y ahí empecé a participar en la Organización Negra de Francisco Pizarro ORNEP. Pero la gente no se organizaba. Yo iba a las reuniones traía los informes y la gente no le ponía atención. Entonces, un día, yo estaba en la vereda Novillal. Era un día lluvioso. Llegaron de la reunión de La Playa con la hermana Yolanda. Traían un arrullo para presentar al Vice-Ministro de Gobierno. Entonces Olivia Estacio me dijo: "Hágame el favor y me ayuda". Me agarró el ritmo y le pongo la música. Y la señora me llevó. Dejó a un señor que andaba. El señor no sabía que iba hacer allí - Martina Granja.

Del 91 al 93, pensábamos: “¿Qué queríamos nosotros como comunidades negras?". La Asamblea Departamental de Nariño fue en el 1992, 1993. Ahi estaba Tumaco, La Tola, Barbacoas, San Jose, Mosquera, Satinga, Iscuandé, Salahonda. Nosotros nos reuníamos en tal municipio, después en el otro. Dialogábamos. De ahí salía un representante que nosotros elegíamos a Pasto o Bogotá. El vocero. Yo iba como representante de Salahonda. Había muchas mujeres en el proceso. Otra de El Charco, La Tola. Daira Elsa Quiñones de La Nupa. Las hermanas que eran: Nela e Eva Grueso de Tumaco, Martina y Ana Granja de Salahonda. Queremos que nuestro territorio no sea invadido por gente de afuera. Forasteros iban llevarse el oro, el recurso, como el mangle. De eso vivimos. Si no tenemos comida, no hay vida - Martina Granja.

A gênese do processo organizativo local gira em torno do campesinato e remonta à década de 1970. Os depoimentos reiteram a centralidade das intervenções católicas nesse momento. Também indicam que as mulheres eram foco de atenção. As irmãs estavam atentas em especial às "tradições e costumes" das mulheres do Pacífico. Investigadoras também eram mulheres, irmãs russas, mexicanas, entre outras. Naquele momento, uma articulação internacional orquestrada por dentro das instituições religiosas foi fundamental para a estruturação da luta.

Logo no início da década de 1990, as mobilizações investem-se do discurso étnico. Inicia-se o Processo de Comunidades Negras. Martina traz referências à mobilização em nível regional. Fala sobre os diálogos entre os vários municípios de Nariño e sobre a construção de uma representação para interlocutar com o governo. A partir de sua narrativa, vemos como o processo de Salahonda encontra-se com o do Rio Mira, cruzando as trajetórias de Martina e Ana Granja, Eva Lucia e Nela Grueso.

No momento inicial das mobilizações, como ressalta Ana Granja, a organização era incipiente, "não se sabia bem como fazer as coisas". Ao mesmo tempo, na perspectiva apontada por Martina, “os que sabiam eram do Patía". Ou seja, o saber está localizado no povo do rio. Era aí onde a organização fluía de forma mais consistente. E foi a partir desse lugar de fala que se construiu o foco da luta negra: a defesa dos territórios ancestrais. Assim como no Rio Mira, os relatos do Patía situam a Constituição Política de 1991 e a Lei n. 70 
como marcos na luta negra do Pacífico sul colombiano, a qual, desde então, foi se estruturando em torno dos Conselhos Comunitários.

En el 1995, fue el Decreto [1745/1995]. En 1996 empezamos el trabajo de caracterización del territorio. En el 1997, fue la conformación del Consejo. Se hizo una asamblea con 5 mil personas en La Playa. ¡Fue la asamblea más grande de toda esa costa! En ese mismo día hicimos la solicitud para la titulación colectiva al INCODER. Ya teníamos todo cuando lo hicimos: El Plan de Vida - Ana Granja.

Yo precisamente nací en una reunión de la Ley 70, el día tres de agosto de 1998 a las siete de la noche. Mi mami por las contracciones salió de la reunión e iba por Ciudadela [bairro de Tumaco] buscando llegar rápido al hospital. Pero ella no alcanzó a llegar al hospital. Y yo nací en la calle. Una cuñada que vivía cerca supo que ella estaba parida en la calle. Por eso mi mami me dice Ley 70 a mí también - Yulisa Granja.

Os relatos do Rio Patía, e também do Mira, valorizam o nascedouro dos processos de reconhecimento da territorialidade ribeirinha, no âmbito das legislações da era multicultural. As menções ao quantitativo de pessoas presentes nas assembleias fundacionais do trabalho de caracterização e reconhecimento do território ancestral ${ }^{253}$ revelam apreço e admiração pelo trabalho cultivado. Entendo que a assembleia materializa os esforços que essas mulheres empreenderam na luta, em nome da coletividade negra. A assembleia constitui a própria coletividade, que foi mobilizada por elas em inúmeras mobilizações de canoa a remo, debaixo de sol e chuva.

Como Yulisa, há outras e outros jovens nomeados "filhos/as do processo". Elas consideram, portanto, que realizaram diferentes gestações; geriram a Lei n. 70 e pessoas comprometidas com o processo de comunidades negras. Yulisa, que é a caçula de Ana Granja, contou-me sobre seu engajamento no grupo de dança local Lllanto negro, bem como em organizações da Igreja católica e em outros processos coletivos nos quais se envolveu a partir dos doze anos de idade. Ana Karina, que antecede Yulisa, faz parte do grupo jovem do PCN e participa de atividades da militância negra desde seus dez anos de idade. Uma das filhas de Martina faz parte da atual junta diretiva da ACAPA. E assim essas mulheres vão fazendo filhos e formando novas lideranças que as sucederão no processo de comunidades negras. Nesse sentido, a matronagem delineia lugares de sucessão, especialmente no campo da atuação política, pelo vínculo de descendência genealógica.

\footnotetext{
253 A solicitação de titulação coletiva ao INCODER, segundo informa a Lei n. 70, de 1993, deve vir acompanhada de uma descrição física do território que se pretende titular, os antecedentes etno-históricos da localidade, a descrição demográfica do território e das práticas tradicionais de produção.
} 


\section{A INCLUS̃̃o DOS MANGUEZAIS NO TítULO COLETIVO}

O tema ambiental é um dos focos de preocupação e, por conseguinte, de atuação de Ana e Martina Granja. A história da ACAPA passa pela garantia da titulação dos manguezais, fonte de vida de parte das 32 veredas abrigadas no Conselho Comunitário. Na luta pela inclusão dos manguezais no título coletivo, essas mulheres foram vanguardistas e, assim, trouxeram o tema para o âmbito nacional.

Ana e Martina Granja contam como foi o processo de negociação com o Estado colombiano para a resolução do título coletivo da ACAPA e a inclusão dos manguezais no documento:

Los del INCORA fueron duros. Pero nosotros hicimos muchas vueltas para hablar de la Constitución, la Ley 70, el título colectivo de ACAPA. Fueron dos años de negociación para el título. Yo casi no tenía ropa para los viajes. Yo lavaba la ropa y salía con ella mojada. Llegando a Satinga, la extendía. El otro día, yo la usaba. Y a veces se me olvidaba la ropa interior. Iba dejando ropa interior por ahí. Yo con Ana éramos las voceras de aquí. Andábamos de Los Brazos hasta Ramos. Íbamos haciendo los puntos por el mapa. Hace falta tal quebrada, o laguna, o loma. En el 2001, hacíamos parte del Consejo Veredal de Los Brazos. Nos ayudaban bastantes abogados de Bogotá. Hubo un conversatorio de Acción Ciudadana, que fueron unos cuatro años.Dan el título, pero no dan los manglares. Me tocó ir a Bogotá - Martina Granja.

Hey, ¿¿no está quedando algo por fuera?! ¿¿El manglar, no cuenta?! Porque yo soy de territorio de río y de manglar. Ahí fue que entraron en el título 45.000 hectáreas que tenemos de manglar. Hay una temporalidad. Los manglares fueron metidos en el título por diez años - Ana Granja.

Os manguezais representam, portanto, cerca de metade da área reconhecida como Conselho Comunitário. Vale ressaltar, como o faz Rivas (2000), que, nesse ínterim, outros títulos haviam sido emitidos deixando de fora as áreas de mangue. Depois que os manguezais entraram no título coletivo da ACAPA, passou-se a incluir o ecossistema nos demais títulos de Conselhos Comunitários colombianos. Constituiu-se um Acordo dos Manguezais, ou seja, um texto que consta em títulos coletivos de Conselhos Comunitários situados em zonas de manguezais, por meio do qual são incorporados nas áreas tituladas ecossistemas arbóreos de mangue. Essa foi uma manobra, pois, pela Lei n. 70, não se poderia titular áreas inundáveis. Ressalto, portanto, o protagonismo da ACAPA e, especificamente de Martina e Ana Granja, na inclusão dos manguezais na regularização de territórios coletivos negros. Após a titulação, a questão ambiental segue sendo um dos focos de atenção da família Granja, que levou o tema para dentro da gestão do Conselho Comunitário. 
Dentro del Consejo Comunitario, en la primera junta directiva, cuando era representante legal Quintiniano Vasquéz, se nombraran comisiones: territorio y medio ambiente, desarrollo, derechos humanos y comisión administradora. Cuando se fue a hacer la titulación, en el 2000, INCODER nos dio 66 millones de pesos. Por el PNUD teníamos 3millones para un taller. La plata la manejaba el Consejo Comunitario. Hicimos una economía. Se quedaron doce millones de pesos. Con eso hicimos la Zonificación ecológica y el Diagnóstico ambiental. Eso lo hice cuando fui representante legal por el Proyecto de Protección de Tierra y Patrimonio de la Población Desplazada. Todos los dibujos lo' hace mi hermana. Todo está en el libro. En el 2003 fue que yo entré como representante legal. He sido la primera y única mujer en el Consejo Comunitario. Y la que más historia dejó a mi pueblo. La mujer siempre es la primera en todo y la última en la participación - Ana Granja.

O depoimento de Ana Granja reitera a denúncia da hegemonia masculina nos espaços de poder comunitários, a despeito do protagonismo feminino no "processo de comunidades negras". Sob a liderança de Ana Granja, única representante legal mulher em quatorze anos de existência da ACAPA, o Conselho Comunitário mais uma vez saiu na frente com a realização da zonificação ecológica e o diagnóstico ambiental do território. O trabalho consolidado no livro Gente de esteros, ríos y mar mapeia a área do Conselho Comunitário conforme os ecossistemas ali presentes, bem como as vocações produtivas e atividades implementadas pelo povo do rio e do mangue. Trata-se de um excelente instrumento para viabilizar a gestão ambiental e produtiva do território titulado.

Segundo interpretações de pesquisadoras e pesquisadores colombianos, a questão ambiental é pano de fundo inconteste da Lei n. 70. Argumentam que a dimensão da preservação ambiental está diretamente ligada à titulação coletiva de territórios negros ancestrais. Segundo Rivas (2000), apesar da Lei n. 70 sustentar-se sobre as premissas do pluriétnico e multicultural, sua matriz é a lógica de conservação da biodiversidade. A autora argumenta que "la Ley 70 más que una ley para los negros es una ley para el Pacífico" (Rivas, 2000: 5) ${ }^{254}$. Como ressaltam Rivas (2000) e Pazmiño (2003), as resoluções estabelecem obrigações de proteção aos recursos naturais para as "comunidades negras".

Do ponto de vista hegemônico - nesse momento encarnado pelo Estado -, a tarefa de conservação do meio ambiente é a maneira pela qual se integra ao país essa parcela da população historicamente alijada do contexto nacional, como coloca Rivas (2000). Já na visão do PCN, o respeito à natureza é uma prática tradicional da coletividade negra, que foi reconhecida ou reforçada no texto da Lei. A Lei n. 70 é fruto do processo organizativo afro-

\footnotetext{
${ }^{254}$ Restrepo, 1997; Arocha, 1992; Wade, 1996; Friedemann, 1992; Agudelo, 1999; e Hoffmann, 1998 convergem nessa interpretação da Lei n. 70, segundo compilado por Rivas (2000).
} 
colombiano. O movimento social negro reivindica seu protagonismo na construção da lei. A partir dessa perspectiva, o enfoque de preservação ambiental que contém a Lei n. 70 reverbera diretamente no discurso e na prática da coletividade negra. É dessa maneira que compreendo o processo conceituado por Pazmiño como a "conversão das organizações étnicas em guardiãs da natureza pelo Estado e suas instituições" (Pazmiño, 2003: 21).

$\mathrm{Na}$ afirmação de uma lógica cultural, formas de produção e de organização social próprias, a coletividade negra se posiciona em resistência ao capitalismo, oferecendo uma alternativa a esse sistema socioeconômico e político. Nesse posicionamento, a ênfase sobre uma existência humana em harmonia com a natureza é central. A particular interação entre humano e cultural está imbuída de uma "lógica da biodiversidade", nas palavras de Grueso e Escobar (1996: 107). Há uma concepção de natureza e sociedade em estreita relação. A definição de biodiversidade como "território mais cultura" explicita isso, como ressaltam Grueso, Rosero e Escobar (1999: 257). A relação entre pessoas e natureza é significada e vivenciada de modo peculiar, o que está encarnado em práticas e relações sociais concretas, como coloca Escobar (1996). A Lei n. 70, por sua vez, expressou isso em seu texto.

Sem embargo, há uma contradição na Lei n. 70, como bem ressalta Rivas (2000). Ao tempo em que legaliza a conservação da natureza como tarefa da coletividade negra, não limita as intervenções desenvolvimentistas dentro de territórios coletivos negros, como a construção de mega projetos. Assim, a Lei dá brechas a uma mercantilização da natureza, que diverge fundamentalmente da concepção vivenciada pela coletividade negra. A ação do Estado colombiano corrobora a visão desenvolvimentista, que também norteia os grandes planos de desenvolvimento postos em marcha na região, desde o Plan para el Desarrollo Integral de la Costa Pacifica (PLADEICOP) (1983-1993), até o Plan Pacifico para el Desarrollo Sostenible (1992), conforme argumentam Grueso, Rosero e Escobar (1999) ${ }^{255}$. Nelly Rivas pesquisou no território da ACAPA, onde houve intervenções desenvolvimentistas, anterior e contemporaneamente aos marcos legais comentados. Ela coloca que, durante a década de 1950, havia extração de mangue para produção de tanino e, em 1991, houve uma tentativa de criar uma camaroeira nesse território.

A gestão territorial de ACAPA ao longo da primeira década de sua criação buscou manter os princípios do processo de comunidades negras, tendo como parâmetro para o desenvolvimento as práticas locais e ancestrais. O nato, por exemplo, é a madeira usada por

\footnotetext{
${ }^{255}$ Segundo Grueso, Rosero e Escobar (1999), nestes planos de desenvolvimento, a intervenção estatal encaminhou-se para a racionalização da extração de recursos naturais e estruturou-se a partir de um discurso que busca homogeneizar o desenvolvimento.
} 
Martina para confeccionar certos instrumentos musicais, como o percussivo bombo. Nesse caso, a madeira é usada verde. Para o corpo do bombo usa-se a chimbuza e a pele pode ser de veado. Mas o nato também é usado para o piso das casas palafíticas do povoado. O plano de manejo no qual a gestão da ACAPA inicialmente trabalhava buscava viabilidade sustentável de extração da madeira pela população residente no território.

En el 2006, me fracturé la columna dentro de la lancha de ACAPA,
comprada con apoyo de ECOFONDO. Yo me enfermé y tuve que dejar la
representación legal a Quintiniano, que siguió la misma línea que nosotros
estábamos llevando. Cuando ya salimos, se nombra otra junta, se cambia la
dinámica. Ahora la visión es diferente. Juan Carlos Angulo se quedó hasta
que se realizó la nueva asamblea, en el 2008. Ahí ingresaron los que están
muy en desacuerdo con la línea anterior. Desde el 2009 no se está
trabajando con la Iglesia. Ya la dirección desarrolla proyectos productivos
de alta tecnología pero beneficia a otros. El problema mío con ellos es que,
cuando me formaron, era para defender el territorio y buscar un desarrollo
conforme la vida de la gente. Ahora el pobre campesino no puede sacar el
nato, pero los grandes pueden venir a explotar lo que quieren - Ana
Granja. A partir de 2009, a gestão territorial da ACAPA muda o rumo, segundo a perspectiva das irmãs Granja. As portas do território foram abertas para os de fora, os forasteiros, como dizia Martina. A tecnologia chega ao território, porém, a serviço de interesses forâneos.

\section{TERRITÓRIO, COMIDA E ANCESTRALIDADE AFRO-PACÍFICA}

El territorio es todo, la tierra de uno es todo. A mí me gustaba mucho ir allá [Los Brazos]. Cuando mi tía Martina vivía allá arriba, yo me iba a pasar una semana, quince días. Más que todo cuando era cosecha de fruta. El agua era muy escasa. Tocaba ir al río a lavar. Me gustaba tirarme al río. Es como tener sentido de pertenencia y saber que no es traer multinacional para plantación de banano. Porque eso lo que hace es acabar con el territorio. Es una ilusión pensar que eso nos volvería rico. Uno es rico cuando come sano, su plátano, su arroz. No digo que sea retroceder en términos de tecnología, pero volver a las costumbres. Mi abuela tiene 101 años pero está bien, no tiene dolor en el cuerpo. No sufre de presión. Ella sufre de su vejez. Eso tiene que ver con la manera como se cocinaba antes, sin maggi, sin color. Se usaba el achiote. El sabor era de la Chiyangua y el Chiraran. O sea, lo bueno es tener su finquita. Si usted vive en Cali, paga alguien para cuidarle. A cada dos meses viene y lleva su plátanito, su arroz para comer en su casa. La finca mía sería en Los Brazos porque es más cerca. Pero yo tengo derecho en el territorio de mi papá como en el de mi mamá -Ana Karina. 
Assim como nos mostra a experiência das mulheres do Baixo Mira, o depoimento de Ana Karina indica que a reflexão sobre o território leva a uma reflexão sobre a comida. Poderse-ia pensar no tripé território - família - produção como chave para compreender a ocupação negra no Pacífico colombo-equatoriano, conforme indica o ativista e analista afro-colombiano Carlos Rúa ${ }^{256}$. Na narrativa, o direito à terra obedece à matri e à patrilinearidade, conforme dito anteriormente.

Da forma como pude apreender o Pacífico colombo-equatoriano, a comida tem uma conexão direta com a ancestralidade e com o território, ambos constitutivos da pessoa afropacífica.

Yo soy afroecuatoriana, soy afroesmeraldeña. Yo soy negra porque tengo mis raices africanas. A mí me gusta mi tapa'o de pesca'o. Donde vaya, ló voy a llevar - Yonny Nazareno ${ }^{257}$.

La comida fue algo muy fuerte, que me permitió estar todavía ligada con el territorio. Entonces, en mi casa en Toronto era mi comida del Pacífico: pescao' con coco, con las yerbitas. Yo en la primavera las cultivaba en el jardín, cuando llegaba el invierno las metía al sótano, con bombillo. Era todo eso para mantenerme, sentirme parte de algo - Eva Lucia Grueso ${ }^{258}$.

Em tese doutoral sobre os Arara, povo indígena de Rondônia, no norte brasileiro, Júlia Otero dos Santos (2015) reflete, entre outras coisas, sobre as formas de coletivização ali presentes. Nesse contexto, "o compartilhamento de comida define corpos, fronteiras e coletivos", segundo a autora (Idem, ibidem: 17). Como a vida cotidiana gira em torno da comida, ela é um dos elementos que permitem fazer a passagem da família, "unidade social" mais relevante nesse contexto, para uma forma "povo", que une as aldeias em um contexto interétnico no qual os coletivos indígenas devem aparecer como povos (Idem, ibidem: 35). Isso porque a comida e a bebida objetificam relações sociais e, assim, constituem parentesco. Santos está atenta à "diferenciação entre uma sociabilidade considerada mais restrita (marcada pelo parentesco e semelhança) e uma mais expandida (marcada pela alteridade e diferença)" (Idem, ibidem).

Nos territórios em que pesquisei, percebo que a comida é constitutiva da pessoa, em especial da mulher afro-pacífica. De certo modo, elas são o que comem. Yonny é afroesmeraldenha porque produz e come seu tapao' de pescao'. Para tal, ela tem de dominar as técnicas; tem de cultivar certas ervas e temperos, como a chiyangua, o chiraran e o achote.

\footnotetext{
${ }^{256}$ Comunicação pessoal.

${ }^{257}$ Entrevista concedida em 13 de dezembro de 2013.

${ }^{258}$ Entrevista concedida em 7 de fevereiro de 2014.
} 
Preferencialmente tem de estar próxima ao rio, ou ao mar, de onde vem o pescado. Nesse sentido, a comida articula ancestralidade e território.

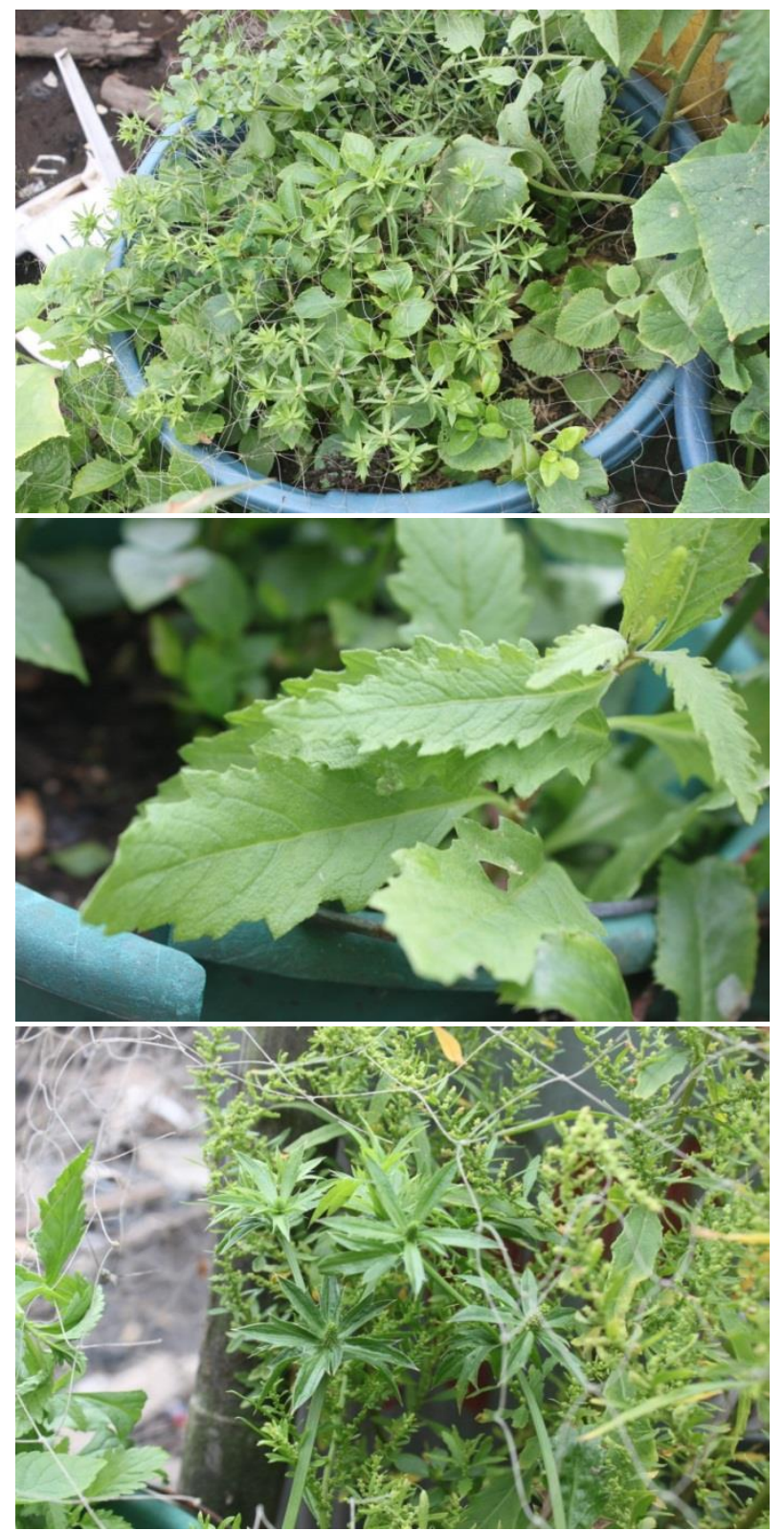

Figuras 11 - Ervas da casa de Targelia, Chiyangua, Chiraran

Mesmo quando estão fora do território, como foi o caso de Eva Lucia quando viveu no Canadá, há um esforço para seguir produzindo e consumindo a comida do Pacífico Negro, o que cria um sentimento de coletividade, ou de família, no sentido político do termo. Trata-se de um exercício da territorialidade no qual a identificação dos sujeitos remete diretamente a sua origem e procedência, como dito anteriormente. Mulheres migrantes constituem-se subjetivamente na relação com a comida, a qual materializa a relação com o Pacífico Negro, enquanto território e enquanto rede de relações. 
O repertório das comidas ancestrais é amplo e saboroso ${ }^{259}$. O pescado com banana-daterra verde, chamado tapao' de pescao'; o ceviche de concha, feito com a piangua, cebola, tomate e ervas; o arroz com coco, servido com pescado frito e patacones, fritura feita com a banana-da-terra verde; encocao' de pescao', de arraia ou de paca; sancocho, uma espécie de sopa, de galinha caipira; o chocolate, que pode ser feito com água e/ou com leite, às vezes acrescentando-lhe amendoim; coladas ou mingaus feitos com frutas, grãos e farinha de banana-da-terra verde.

Tanto os alimentos próprios do Pacífico quanto o modo de prepará-los são ressaltados como sendo peculiares aos povos afro-pacíficos e mais ainda às mulheres. Exemplos disso são as pedras que transformam elementos em comida, moendo a banana-da-terra verde, ou macerando o alho e as ervas como chiyangua e chiraran; o modo de lavar peixes, aves e carnes de caça com bastante limão e sal; o achote ou urucum que é preparado como um óleo e usado para temperar a comida. Registro também a forma de preparo da proteína animal com coco, usada tanto para peixes e mariscos quanto para carnes de caça. Além da paca, é comum comer tatu, raposa, cutia, veado, coelho do mato, javali e capivara.

O tamal de concha é preparado com massa de banana-da-terra verde e piangua. O plátano é moído entre duas pedras e em seguida pré-cozido com temperos como o alho, a cebolla larga ${ }^{260}$, cebolla colorada ${ }^{261}$, chillangua e chirarán. À parte, prepara-se o marisco. $\mathrm{Na}$ folha de bananeira, dispõe-se a massa e recheia-se com a concha, podendo agregar cenoura, ervilha e batata ${ }^{262}$. Há uma técnica para embrulhar o tamal, da mesma forma que há um saber especializado para embrulhar a brasileira pamonha. O tamal é levado ao cozimento por aproximadamente quarenta e cinco minutos. Identifica-se quando está pronto pela cor da folha de bananeira.

De modo geral, mulheres de uma mesma família, que podem residir na mesma casa ou não, costumam trabalhar juntas nesse processo, com funções especializadas para cada uma delas, como, por exemplo, embrulhar os tamales ou dedicar-se à venda. Recorrem ao pátio da casa para buscar alguns dos ingredientes. Inés explica que toda mulher afro-pacífica tem uma pequena horta no pátio de casa onde cultiva chillangua, chirarán, orégano, erva doce, etc. $\mathrm{O}$ plátano vem do rio e a piangua, do mangue, coletada pelas mulheres concheiras. Esse é um

\footnotetext{
${ }^{259}$ Na região do Pacífico sul colombiano, de modo geral, a produção é orgânica. Apenas nas localidades situadas na estrada que leva de Tumaco a Pasto é que se começou a produzir banana-da-terra com adubos e fertilizantes.

${ }^{260}$ Espécie muito parecida com alho-poró, porém bastante popular no Pacífico Negro.

${ }^{261}$ É a brasileira cebola roxa.

${ }^{262}$ Essa é a forma de fazer indicada por Inés Morales. Sixta Tulia afirma que a melhor folha para embalar os tamales é a chamada folha branca. A folha de bananeira não é tão boa para envolver o tamal.
} 
saber das "mulheres de comunidade", como diz Inés Morales. Há mulheres, portanto, que "sabem fazer" um tamal. Por exemplo, quando, no processo de cozimento, a massa escorre, dizem que a mulher não sabe fazer o tamal. Ao migrar para a cidade, elas passam a fazê-lo na zona urbana e vendem nos arredores de casa. Quando alguém saboreia um bom tamal, comenta com a vizinhança e assim um grupo de mulheres vai se constituindo nesse negócio. Com a venda de tamales, pode-se manter uma família.

A relação que a produção dos tamales coloca em relevo é uma relação entre mulheres aparentadas, que se contextualiza na construção da rede de sociabilidade entre elas. Essa mesma rede é a que se responsabiliza, junto com a mãe, pela criação da prole de uma mulher. Nesse sentido, reforça-se a ideia de que o parentesco é um "estado relacional que pode ser criado, reiterado ou interrompido", como ressalta Santos (2015: 158). Não se trata de algo dado, mas, sim, socialmente construído. Nesse sentido, assim como Santos, refuto a abordagem clássica antropológica da "família nuclear como dado biológico e nexo gerativo do parentesco como fenômeno da vida social" (Idem, ibidem: 188). No contexto de pesquisa, compreendo que a construção da família, seja sob a perspectiva das relações consanguíneas, seja das relações políticas, depende do trabalho das mulheres na constituição de laços de ordem produtiva, organizativa e afetiva.

As narrativas de mulheres afro-pacíficas com quem dialoguei ressaltam, portanto, um forte vínculo com a alimentação na representação do feminino. Poder-se-ia pensar que a associação entre mulheres e comida reforçaria a imagem das mulheres aprisionadas ao lar, tema sobre o qual discorremos na primeira parte da tese. Porém, não parece ser esse o sentido que elas conferem à associação. Como detentoras de saberes e práticas produtivas e alimentares ancestrais, as mulheres se colocam em um lugar de ação, na acepção que Strathern confere à agência, no sentido de construção de relações, e em um lugar de poder. Camacho (2008) reforça que a identidade feminina afro-pacífica está evidentemente ligada à alimentação: fabricar, distribuir, alimentar-se e se relacionar, constituindo-se como pessoa feminina em interação familiar e comunitária. Estudos sobre gênero no mundo indígena equatoriano também percebem o contexto da produção de alimentos e outras tarefas domésticas como espaço de poder para mulheres indígenas (Weismantel, 1994), o qual eu chamaria de espaço de agência e de construção de relações sociais.

Nesse sentido, como coloca Ana Karina, falar sobre o território é falar sobre práticas produtivas, sobre comida e sobre relações sociais. Daí se compreende melhor a prioridade eleita por Ana Granja, quando era representante legal da ACAPA, em realizar um 
mapeamento ambiental e produtivo do território. Falar sobre a comida é falar sobre ancestralidade afro-pacífica. A conexão das mulheres com o território passa pela comida e o caminho são as práticas ancestrais de cultivo e preparo dos alimentos, alguns dos quais têm também poder curativo. Entendo que essa é uma das maneiras pelas quais as mulheres entendem e falam sobre o território.

$\mathrm{Na}$ medida em que as mulheres têm papel de protagonismo na atualização de saberes vinculados às práticas produtivas, bem como na fabricação de comidas e pessoas, elas sustentam ao longo de séculos uma concepção territorial e a luta política pelo território. Território este que se vê ameaçado pela parceria entre Estados colombiano e equatoriano com capitais estrangeiros, expressa em grandes projetos desenvolvimentistas. Como vimos, no Pacífico colombo-equatoriano, teve grande apelo uma concepção de desenvolvimento sustentável, acompanhada por um discurso de conservação da biodiversidade. Vale ressaltar, por fim, que os conceitos evocados pelas "comunidades negras" no tocante ao respeito pela natureza divergem daqueles norteadores dos discursos estatais sobre preservação e conservação da natureza. Na concepção da coletividade negra, a existência humana está em correlação com a natureza. Trata-se de uma relação harmoniosa que pressupõe práticas ancestrais de gestão e uma concepção da natureza como dotada de agência, como aprofundarei no quarto capítulo. 


\section{CAPítulo 3 - Río Rosario}

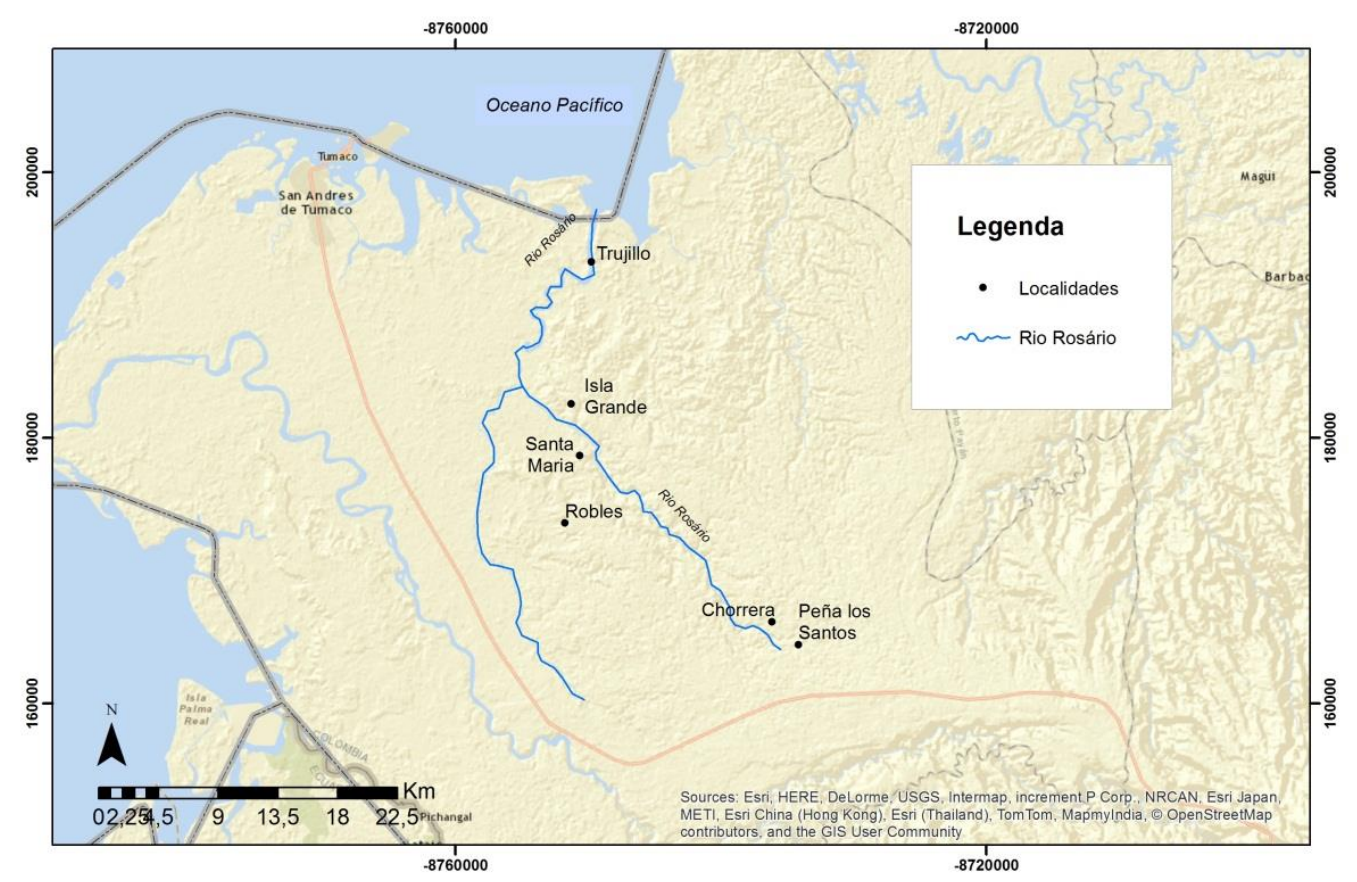

Figura 12 - Mapa do Rio Rosario

O Conselho Comunitário Unión Río Rosario, segundo dados do INCODER, possui 10.647,9204 hectares, treze veredas, 482 famílias, 2.289 pessoas ${ }^{263}$. Rosalba Quiñones, liderança do Rosário, retifica que são quinze veredas. O processo de mobilização no Rio Rosário foi concomitante à mobilização dos demais rios situados dentro da enseada de Tumaco: Gualajo, Mejicano, los Tablones, Imbilpí y Rio Chagüí. É um processo que ocorre posteriormente ao desencadeado nos Rios Mira e Patía. Segundo Rosalba, inicialmente, a organização girava em torno das práticas produtivas:

Resulta que antes de eso de los consejos comunitarios llegó una entidad, CVC Holanda, que trabajó en todos los ríos de la ensenada. Río Rosario, Río Gualajo, Mejicano, Los Tablones, Imbilpí y Río Chagüí. A tratar de organizar la gente. $O$ sea que el proyecto era organizativo y productivo. Empezamos a recorrer y a hacer reuniones por las comunidades y a organizar la gente en la finca, a mejorar su finca. Eso tiene veinte y pico de años. COAGRO Pacífico fue el producto de esa organización que se conformó con CVC Holanda. Nos organizamos tanto que llegamos a conformar una cooperativa, para empezar a comercializar el coco. La gente producía coco a la lata y lo que se vendía era muy barato. La gente andaba

${ }^{263}$ Foi titulado pela Resolução n. 2546, de 23 de dezembro de 2002. 
con su canoita de coco pa'rriba y pa' bajo. Los comerciantes en Tumaco lo compraban regalado cuando se lo querían comprar o se lo rechazaban todo. Mejor dicho, era una odisea el producto del coco. Para conformar la cooperativa nos pusimos en acuerdo 366 socios de todos los ríos. Efectivamente nos dio resultado. CVC nos apoyó con hacer las bodegas en los ríos. CVC apoyó comprar la casa donde iba a ser aquí [sede do municipio de Tumaco] la cooperativa. CVC nos apoyaba todo el ir y venir de esa gestión, la gasolina. Si necesitábamos hacer una reunión en Chagüí, íbamos todos los de Rosario, todos los de Gualajo, todos los de Tablones. En la bocana nos encontrábamos, todas las canoas subíamos hasta donde iba a ser la reunión. ;Eso era divino! Esa situación de estos años fue muy bonito, muy bonito. Ahí fue donde nos conocimos. En ese tiempo yo era la presidente del Comité de Educación. Porque había comité de apelación, había Juntas veredales. Había todos estos componentes - Rosalba Quiñones ${ }^{264}$.

O caso narrado foi fruto de um acordo entre a Corporación Autónoma Regional del Valle del Río Cauca (CVC) e a Cooperação Internacional Holandesa, celebrado em 1987 e que seguiu atuando por cerca de dez anos nos rios dessa região, segundo cálculos feitos a partir da memória de Rosalba ${ }^{265}$. Segundo relatos de outras lideranças, o diferencial dessa experiência foi a densidade do trabalho de campo. Os técnicos permaneciam em campo, realizando oficinais e assessoria aos camponeses diariamente. Na leitura de Grueso e Escobar (1996), o processo de gestão foi central para que a COAGROPACÍFICO fosse qualificada como a "mais interessante e autônoma experiência associativista na história do Pacífico colombiano" (Grueso e Escobar, 1996: 102). Nos primeiros dois anos, inicialmente a gestão cabia aos funcionários, em seguida houve uma cogestão, compartilhada entre agricultores/as e técnicos, e por fim a autogestão.

A experiência contextualiza-se naquele momento em que Tumaco começou a vivenciar intensa intervenção de agências de desenvolvimento e integração, com participação da cooperação internacional. Ao final dos anos 1980, estava em curso o Plan de Desarrollo Integral para la Región Pacífico (PLADEICOP). O Pacífico sul colombiano foi, então, cenário privilegiado para a execução de políticas promovidas pelo Estado, com financiamento de agências internacionais de crédito, por meio das quais se buscava abrir a Bacia do Pacífico aos mercados internacionais, dada sua posição geoestratégica e os abundantes recursos naturais que a caracterizam. Segundo Escobar e Pedrosa, investidores e gestores dos planos de

\footnotetext{
${ }^{264}$ Conforme dito na primeira parte, os diálogos com Rosalba Quiñones ocorreram entre 07 de agosto e 12 de setembro / entre 12 de outubro e 03 de novembro de 2013.

${ }^{265}$ Segundo Grueso e Escobar (1996), a experiência do cooperativismo no Pacífico sul colombiano é persistente e múltipla. Apesar de repetidos fracassos, há um forte e positivo imaginário sobre o tema entre a população, o que se explicita na narrativa de Rosalba.
} 
desenvolvimento da época viam o Pacífico como "um depósito de recursos à espera que a mão branca da economia e a tecnologia liberem seu valor" (Idem, ibidem: 15).

Do ponto de vista de Rosalba e de outras mulheres e homens protagonistas da COAGROPACÍFICO, a experiência associativa e as mobilizações em torno da Constituição Política de 1991 conectavam-se. No Rio Rosário, assim como no Patía, a mobilização que se iniciou com um caráter camponês foi ganhando novos contornos na década de 1990. A mobilização em torno da etnicidade, por sua vez, não significa que se deixou de ser camponês.

Entonces, como yo ya tenía esa trayectoria, en el año 1998 llegó Jairo Ruben Quiñones y me buscó en el río Rosario para que hiciéramos el trabajo allá. Que él había hecho una propuesta al INCODER para empezar a organizar la gente como Consejo Comunitario acá y luego se lo aprobaran. Ya estaba el Proceso de Comunidades Negras, pero uno ni lo conocía, nada sabíamos. Sabíamos que había una lucha de los compañeros negros, que se unieron con todos los negros del Pacífico acá y Chocó a hacer propuestas para que al negro se lo mirara de otra forma porque el negro siempre era medido al igual que lo común, que los demás, al igual que los campesinos de otras zonas. Y que uno de manera, tiene una diferencia. Entonces ellos buscaron eso, y pelearon, eso en el Congreso, hasta que lograron conseguir que se aprobara un pedacito de esa Ley que fue la Ley 70 del 1993. ¡Eso sí! - Rosalba Quiñones.

A narrativa explicita o conceito de etnia com o qual estamos trabalhando, que parte de uma concepção regionalizada e ressalta características culturais no processo de identificação de um povo. Nesse sentido, negras e negros do Pacífico são camponeses, porém "tem uma diferença" em relação aos camponeses de outras zonas do país, como diz Rosalba. O lugar da diferença expressa a valorização de uma "cultura" que se quer outra. É essa diferença que leva à necessidade de um tratamento especial por parte do Estado. Entendo que a diferença está localizada em um "território" e em uma "cultura" afro-pacíficos.

Rosalba continua sua narrativa, explicitando que, afora os aspectos levantados, a etnicidade tem uma raiz histórica na resistência africana à escravização:

Los europeos que vinieron a saquear Colombia y trajeron a los negros esclavizados para hacer todos los trabajos más fuertes históricamente tienen una deuda con nosotros. Y a nosotros no nos han tratado como se debe. Siempre nos han tratado como cualquier campesino, sabiendo que para llegar la gente acá a estos ríos fue una lucha. Ellos tuvieron que volarse de esos maltratos que les daban en esas minas, en esos trabajos. Palenque era lo que conformaban los negros cuando se escapaban de los amos y se volaban de ese yugo que los mantenían trabajando. Entonces hubieran negros muy resistentes, que se escaparan y se metían a lo profundo de los ríos, a las quebradas adentro, esa era una forma de protección para que no los encontraran. Ellos salían a buscar y si lo encontraban lo mataban o le 
daban palo, pero el que se alcanzaba volar, se volaba. Y después buscaba la forma de comunicarse con los otros negros para que se fueran también para allá. Era el churro que se manejaba. Y cuando se oía un chirrido, el otro negro escuchaba que allá había otro negro. E iban formando su grupo. Palenque era porque lo cercaban y ponían trampas para, cuando los fueran a perseguir, los blancos y los amos cayeran en esas trampas. Entonces, históricamente saquearon a este territorio y nuestra gente quedó rezagada en esas montañas cuidando de todas esas riquezas y de la producción de oxígeno que es lo principal en esas montañas. Y resulta que los compañeros mirando toda esa historia, mirando los mal tratos, empezaron a buscar una ley que tratara al negro de una mejor forma. Ley que se hizo con tanta lucha y tanta discusión - Rosalba Quiñones.

Entendo que Rosalba articula dois discursos políticos sobre a afrocolombianidade/negritude. Para compreendê-los, retomamos o momento de construção da Lei n. 70, entre 1991 e 1993. Segundo Grueso, Rosero e Escobar (1999), tratava-se de um momento de divergências entre uma tendência do movimento no departamento de Chocó, representado por uma "elite negra", e outra tendência formada por setores populares e organizações comunitárias (camponeses/as, pescadores e marisqueiras) de Nariño, Cauca e Vale do Cauca. Segundo os autores, o PCN germina da segunda tendência, contrapondo-se a um discurso sobre a negritude que enfatizava a pigmentocracia e representava o passado da escravização de modo festivo.

$\mathrm{Na}$ narrativa de Rosalba, a escravização e as formas de resistência negra, especialmente os palenques, não são cenas de um passado diminuído pela dominação. Pelo contrário, o legado escravista gera uma dívida histórica da sociedade colombiana com a população africana escravizada em terras colombianas e com seus descendentes. Ou seja, o passado é invocado para dar sentido ao presente, com um projeto de futuro. Paralelamente, Rosalba reforça que a afro-colombianidade tem especificidades étnicas, está imbuída de concepções próprias de territorialidade e cultura.

\section{GÊNERO E ETNICIDADE}

Durante o processo organizativo em torno do campesinato que antecedeu à década de 1990, as mulheres lograram mais espaço do que no "processo de comunidades negras".

Había muy pocas mujeres. En otros ríos, se encontraban algunas mujeres. Porque después de conformado el [Consejo Comunitario] de Rosario, se conformó el de Gualajo, de Los Tablones. Eso ya vino el boom de conformación de los Consejos Comunitarios. Con CVC hubo más mujeres 
participando que con el Consejo. En el Consejo, siempre los hombres es que les gusta el puesto. Y las mujeres dicen que no, que no las dejan, que no tienen tiempo. Los maridos a veces dicen no coja cargo - Rosalba Quiñones.

Mulheres da sub-região pacífica envolvidas na construção da Política Pública Narinhense para a Equidade de Gênero assinalaram como uma das problemáticas mais sentidas em matéria econômica o fato de que os processos de titulação dos territórios negros como Conselhos Comunitários não as favorecem. Será, então, que a década de 1990 inaugura um momento político para o povo negro/afro-colombiano no qual são maiores, ou mais complexos, os obstáculos para a participação das mulheres nos espaços de poder dentro do movimento?

González questiona a capacidade da Lei n. 70 em contemplar o lugar de fala de mulheres e homens negros:

La ley 70 habla de territorio colectivo desde una perspectiva de la sociedad patriarcal, porque el hombre circula entre los distintos ecosistemas a nivel vertical y horizontal, a lo largo del Pacífico, de sur a norte y del oeste al este, pero no se ha considerado el territorio desde las unidades habitacionales y de la estructura parental matrifocal y matrilineal (González, 2002: 16).

Ainda que minha perspectiva divirja da de González no tocante à circulação de homens e mulheres afro-pacíficos, o argumento de que a lei não considera os territórios a partir de uma perspectiva matrifocal e matrilinear parece fazer sentido. Outras autoras, como Camacho (2004), ressaltam a ausência de ferramentas normativas que articulem o aspecto étnico-racial com o componente de gênero. Analisando as mobilizações sociais afrocolombianas em torno do Artigo Transitório n. 55, da Constituição Política da Colômbia, e da Lei n 70, de 1993, Asher (2009) faz uma leitura de que esse contexto abriu uma brecha para mulheres negras associarem o tema dos direitos étnicos e territoriais com outros temas de suas vivências. Por outro lado, a participação de mulheres nessas mobilizações permaneceu invisibilizada, segundo a antropóloga indiana radicada nos EUA.

A partir de depoimentos de Ana Granja, percebemos que a questão se conecta diretamente com a estrutura organizativa definida pela Lei, a qual se sobrepõe à organização tradicional de rio e a outras formas organizativas, e principalmente com a ocupação dos espaços de poder gerados a partir dessa estrutura. "Nosotras las mujeres comenzamos con el proceso. En la hora de elegir, los más privilegiados son los hombres. Los hombres siempre quieren tener al otro aplastado". 
Entendo que a Lei n. 70, de 1993, constitui-se numa perspectiva andocêntrica do poder. A estrutura organizativa definida pela lei, especialmente as juntas diretivas dos Conselhos Comunitários, privilegiam certo tipo de liderança. Aquela que representa a comunidade para um público externo, o que exige algum nível de escolaridade, disponibilidade para viagens e agendas de interlocução com o poder público, as agências internacionais e outros atores. Possivelmente, se a lei tivesse uma dimensão explícita de valorização das práticas de saúde ancestrais, por exemplo, as mulheres estariam em primeiro plano. Esse seria por excelência o cenário das matronas. Não obstante, para compreender em profundidade os obstáculos para o reconhecimento da liderança feminina e para sua participação, é necessário destrinchar as práticas dos movimentos sociais.

Observando discursos de mulheres e homens afro-ativistas, Asher (2009) aponta para uma resistência, especialmente no $\mathrm{PCN}$, em trazer a discussão de gênero para o seio do movimento, manifesta no argumento de que isso comprometeria os avanços políticos em ambos os sentidos, com o risco de que as mulheres se organizassem independentemente dos movimentos étnicos.

O depoimento de Eva Lucia Grueso sobre os esforços de trabalhar a questão das mulheres dentro do PCN converge com a perspectiva trazida por Asher.

\begin{abstract}
Aunque PCN tiene ya veinte años de existencia, nosotras mujeres nos estamos pensando dentro de PCN desde hace cinco años para acá. Mujeres siempre estuvimos en el Proceso. Siempre ha sido una construcción conjunta de mujeres y hombres. En ese quehacer diario perdimos nuestra esencia y nuestro espacio. Habia y sigue habiendo desde los hombres: 'no hablemos de mujeres pues eso puede dividirnos, dividir PCN, puede debilitarnos'. Listo: asumamos el riesgo para no seguir invisibilizadas en algo que siempre construimos nosotras. ¿Por qué los hombres no cuestionan si mantener el patriarcado puede debilitarnos? La gran mayoría de los compañeros hombres no quieren asumir la discusión con el discurso de que aqui todo está bien: 'machista, ¿yo?! Pero jadoro las mujeres!'. Pero para nosotras ese tema es inapagable, no es negociable. Si queremos un PCN fuerte, no podemos dejar. Aún no tuvimos espacios para ese trabajo en el PCN a nivel nacional. Pero estamos trabajando mucho en el local. La propuesta es fortalecer las mujeres dentro de los Consejos Comunitarios. $O$ sea, estamos buscando cambios estructurales desde lo local - Eva Lucia Grueso $^{266}$.
\end{abstract}

A experiência da Comisión de Mujeres del Consejo Comunitario Bajo Mira y Frontera bem ilustra a dinâmica que Eva Lucia aponta nesse depoimento, refletindo os esforços por reconstruir o lugar de protagonismo das mulheres dentro dos Conselhos

\footnotetext{
${ }^{266}$ Entrevista concedida em 26 de junho de 2012.
} 
Comunitários. Isso é feito a partir de uma visão de coletividade, que engloba mulheres e homens. Nesse sentido, Eva Lucia e Mailén Quiñones, que protagonizam a referida Comissão, ressaltam a caminhada conjunta de mulheres e homens afro-pacíficos. Por outro lado, expõem a invisibilização das mulheres dentro das organizações mistas e as ações por elas empreendidas para desconstruir e reconstituir o lugar reservado às mulheres dentro do movimento. Essa mesma experiência mostra que as mulheres do Baixo Mira buscam visibilizar a presença feminina dentro dos Conselhos Comunitários e, ao mesmo tempo, ressaltam suas divergências com movimentos de mulheres, como a Mesa Municipal de Mulheres de Tumaco, que não reconhecem o pertencimento racial territorializado.

A reação dos homens de PCN não é isolada. Conforme ressalta Machado (2010), no campo de movimentos feitos em nome dos povos indígenas brasileiros, também há uma tendência à ênfase retórica na totalidade como unicidade para representar a diversidade cultural. Daí, “a defesa dos direitos das mulheres indígenas poderia representar perigo e contaminação para a defesa da diversidade cultural de cada povo indígena" (Machado, 2010: 75). Viveros (2007) fala que as tensões entre a afirmação da experiência histórica, política e cultural coletiva e práticas patriarcais dessa mesma coletividade podem reforçar o lugar de subordinação das mulheres.

A resposta de Eva Lucia a tal postura masculina dentro do Processo de Comunidades Negras é o desafio de assumir o risco, indicando que a falta de reconhecimento do protagonismo feminino na luta das comunidades negras está a ponto de implodir essa mesma luta. Sua posição nos ajuda a entender que não há tradição que se mantenha sem a vontade política de uma coletividade. E essa vontade política pode levar a mudanças na tradição. Em Ilhas da História, Sahlins fala que "uma tradição sempre implica alguma consciência", que a "consciência da tradição implica alguma invenção" e que a "invenção da tradição implica alguma tradição" (Sahlins, 1990: 89). Tradições não são inertes; modificam-se, flexibilizamse, reinventam-se. Laó-Montes também pleiteia que a tradição e a cultura podem ser compreendidas como processos de transformação e espaços atravessados por lutas "casa adentro", o que implica combinar a defesa da ancestralidade com a construção de culturas de libertação (Láo-Montes, 2011: 323). Para Wagner (2010[1975]), todas as simbolizações dotadas de significado produzem inovações. Como metáforas, elas têm o efeito de estender suas significações para outras áreas; assim, simbolizações significativas sempre inovam a cultura. 
A mudança da tradição afro-pacífica no que ela tem de machista é um investimento político-organizativo de mulheres afro-pacíficas; uma proposta que elas estendem a toda a coletividade negra. Creio que esse investimento se consolida e se empodera no movimento de mulheres afro-pacíficas, mas vai além dele. Prolonga-se para o lar, como coloca Marlene Tello, ao afirmar que certas coisas devem ser desaprendidas e reconstruídas, exemplificando com a educação dos filhos e filhas: "en mi casa, todos limpiamos platos"267. Melhor dito, a trajetória de liderança das mulheres com quem dialoguei conecta o lar, a "comunidade" e as organizações sociopolíticas. São mulheres que conseguiram romper barreiras e se inserir em espaços de poder. Vale ressaltar que o ponto de partida das trajetórias de liderança é a base, são os rios.

O reconhecimento de Rosalba como uma importante líder no Rio Rosário se explicitou no exercício da representação legal do Conselho Comunitário, que durou dez anos, desde a criação do Conselho. Ela nasceu na vereda San Luis Robles, hoje pertencente ao Conselho Comunitário Rescate Las Varas. Chegou ao Rio Rosário ao final dos anos 1960, acompanhando seu pai, que estava envolvido em um projeto promovido pelo INCORA, que hoje é INCODER ${ }^{268}$, o qual promovia experiências associativas entre o povo da vereda Isla Grande e da vereda Chapilao. Em Isla Grande conheceu Luis Antonio, com quem se casou, passando a viver nessa vereda. O caso de Rosalba assemelha-se ao de Mailen no sentido de que ambas trilharam trajetórias de liderança em localidades nas quais foram viver em situação marital. Trata-se da migração rios-rios, retomando a tipologia da mobilidade espacial e social das populações afro-pacíficas proposta por Barbary e Urrea (2004). As duas já tinham vivenciado anteriormente outras dinâmicas migratórias. Rosalba fez o percurso rios-cidade de Tumaco. Mailen, no trecho rios ou Tumaco-outras áreas, passou pelo fronteiriço município narinhense de Ipiales e chegou até o vizinho Equador, Cuenca. Após chegarem a Bocas de Guabal e Isla Grande, respectivamente, Mailen e Rosalba construíram uma vida de ativismo nessas localidades.

A construção da liderança feminina segue um caminho peculiar, como nos explica Zulia Mena: "Esta función de liderazgo es natural, sin elección, y se da por la relación especial y constante que establece con todos los miembros de la comunidad en calidad de rezandera, partera, curandera, consejera, etc" (Mena, 1993: 91).

\footnotetext{
${ }^{267}$ Fala proferida entre 9 e 10 de agosto na Mesa de Gênero preparatória para o Primer Congreso Nacional de Consejos Comunitarios y Organizaciones Étnicas Afrocolombianas, Palenqueras y Raizales.

${ }^{268}$ Segundo Grueso e Escobar (1996), o INCORA, recém-criado à época, chegou ao Pacífico sul colombiano com um pacote tecnológico que continha um plano de desenvolvimento econômico baseado em propostas de ação cooperativa.
} 
Ou seja, a mulher ganha o reconhecimento e o respeito da coletividade a partir de sua atuação a nível local. Mailen foi educadora e parteira em Bocas de Guabal, no Baixo Mira. Rosalba também esteve envolvida com educação e outros temas afetos ao povo do Rio Rosário. Do nível local, as lideranças passam a circular em circuitos cada vez mais amplos, como representantes de seu povo. Por exemplo, Rosalba conta que esteve em Santa Marta, no Encontro Nacional Afro, em Bogotá, Bueventura, Cali, em San Gil, que pertence ao departamento de Santander. Percorreu muitas cidades colombianas no bojo desse processo organizativo. A movimentação dessas mulheres, que começa nas ribeiras dos rios e se prolonga em níveis regional, nacional e internacional, reflete-se na formalização de movimentos sociais. Nesse sentido, não há uma cisão entre o âmbito doméstico e o público. A política perpassa a ambos. Matronas como Rosalba e Mailen são mulheres que fazem política em suas casas, em suas “comunidades" e no "processo de comunidades negras".

A filha mais velha de Rosalba, Cira Colorado Martinez, fala sobre a liderança da mãe:

Mi mami es una mujer líder por naturaleza. Ese liderazgo es innato en ella. No se cultivó, nació con ella. Y esas comunidades son comunidades donde se carece de todo, donde las políticas del Estado no ayudan mucho para que la gente esté bien. Entonces esa misma necesidad va creando ese vínculo como que de yo estar metidita. Entonces mi mami ¿qué es lo que hizo? Sino también dedicarse a unas actividades comunitarias, y fue participando y con ella fue moviendo a otros. Porque la gente no participa mucho hasta que usted los traiga, los diga, los mueva, los incentive - Cira Colorado ${ }^{269}$.

Ela ressalta o trabalho das matronas como tecedoras de vínculos entre as pessoas. A condição da liderança como um atributo intrínseco a certas mulheres é mencionada não apenas por Cira. Vejamos o que diz Targelia Micolta sobre o tema:

Por eso yo digo que el líder nace. Sin ser ellos bien estudiados, ellos fueron unos líderes. Lucharon por su gente, lucharon contra el poder y rescataron su gente que debían de rescatarlos. Yo siempre digo, que el líder no se hace. Para mí, el líder nace. Ante mí, me considero como una líder. Porque yo lo que hago, no lo hago por dinero. Yo me sentí, me apropié como lideresa cuando recién llegué aquí, de escuchar el problema de los manglares. Yo a los primeros no hablaba porque me daba como temor. Me iba a sentir como criticada de los demás. Más bien yo escuchaba y escuchaba. Pero ya después, ya fui como perdiendo ese miedo y ya comencé a los debates. Hasta que yo ahora, si me toca discutir, defender mis derechos, como de mi comunidad, de donde toque discutir, yo ya salgo en la televisión, yo ya he discutido muchas cosas - Targelia Micolta ${ }^{270}$.

\footnotetext{
${ }^{269}$ Conversa ocorrida em 20 de agosto de 2013.

${ }^{270}$ Entrevista concedida entre 16 e 18 de dezembro de 2013.
} 
Ao mesmo tempo em que dizem que a liderança é um atributo inato, as narrativas mostram o processo de construção da liderança ao longo da trajetória dessas mulheres. Ambas as narrativas apontam para um despertar que brota dentro nelas, uma atenção e uma dedicação a demandas comunitárias que ultrapassam a circunscrição da família, espaço em que as mulheres emergem como cuidadoras. Os relatos apontam também para um reconhecimento coletivo do trabalho comunitário empreendido. Entendo a busca por reforçar uma "vocação natural" à defesa dos direitos do povo afro-pacífico, que de certa forma reforça sua legitimidade nesse lugar. Sem embargo, também mencionam os obstáculos que enfrentam, as etapas da vida que tiveram de ultrapassar para se consolidarem como lideranças, assim como as benesses de ser liderança; enfim, as dificuldades e os logros desse caminho de vida. Nesse sentido, revelam a dimensão processual da constituição da liderança feminina afro-pacífica.

Rosalba conta sobre a situação familiar que vivenciava e que lhe permitiu começar uma trajetória dedicada ao "trabalho social":

Yo en esa fecha ya tenía treinta y pico de años. Todos los hijos ya los tenía, ya estaban unos grandecitos. Yo tuve mis hijos temprano y ya empecé a cuidar de ellos hasta que ... iAh! Yo era muy activa en la comunidad. Siempre participaba en reuniones. Si llegaba una entidad, ahí estaba, si llegaba la otra. Siempre me ha gustado eso de cobijarme con la gente. Ahí fue donde empezamos a conocernos y a mirarnos. Desde ahí empezó mi gestión: a andar y a recorrer. Y me gustó eso que se llama ¿Cómo se dice? Trabajo social, ¿ ¿í? - Rosalba Quiñones.

Observando o perfil das mulheres que constroem esse movimento, entre aquelas com quem dialoguei, percebo que a maioria tem idade superior a 50 anos. Comentando um estudo realizado com mulheres de Kulima, Kênia, Henrietta Moore (1991) observa que as jovens casadas naquele contexto encontravam dificuldades para se dedicar a atividades coletivas por terem filhos pequenos, assim dispunham de menos autoridade e liberdade de movimento que as mulheres de mais idade.

Noto um paralelo entre o caso comentado por Moore e o caso do Pacífico Negro colombo-equatoriano. $\mathrm{O}$ fato de estar casada não necessariamente impede a construção de uma trajetória de liderança; depende do tipo de arranjo conjugal que mulheres e homens são capazes de constituir. Em uma sociedade machista, como é a afro-pacífica, isso costuma exigir das mulheres uma capacidade de questionamento e uma atitude de contestação dentro do ambiente doméstico, com vistas a subverter os papéis sociais atribuídos a mulheres e homens. Em geral, elas logram construir arranjos conjugais mais libertários na maturidade. 
No caso da maternidade, ao mesmo tempo em que é um investimento político, já que ser mãe é um caminho para se construir como matrona, também há tensões entre a maternidade e a liderança política.

A veces yo decía: "mis hijos, dios mio, los tengo abandonados ¿qué hago?” Porque con la defensa de los manglares nos tocó duro, jayyy! nos tocaba ir a Quito a hacer grandes movilizaciones. El cuidado mío a ellos era mínimo, más lo hacia la sobrina y don Armengol. Yo, lo poquito que podía - Inés Morales.

A fala de Inés explicita como ela ficava dividida entre o cuidado com os/as filhos/as e as agendas do movimento social. Sua opção foi a de sustentar uma presença mínima na criação dos filhos/as e dedicar-se à defesa do território ancestral, que também é um patrimônio de sua prole. Uma fala de Martina Granja explicita essa questão: "En ese tiempo yo vivía allá afuera, los muchachos se quedaban en lo' rancho' sin ni un peso. Me preocupaba por ellos y me preocupaba por el proceso. Prefería ir porque más adelante mis hijos disfrutarían del proceso" ${ }^{271}$. Maternidade e política se tencionam, mas também se imiscuem. Por um lado, o engajamento político restringe a dedicação doméstica, especialmente o cuidado com a prole. Por outro lado, ter filhos faz parte de uma construção política, que é a construção como matrona, e o engajamento político também é um projeto para os filhos, ou seja, para as gerações vindouras.

\section{Palenque Regional Nariño e recompas}

O Palenque Regional Nariño surgiu em 1994 como coordenação regional do PCN no Departamento de Nariño, com sede em Tumaco. O Proceso de Comunidades Negras desenvolveu-se por meio de articulações regionais. Segundo Grueso, Rosero e Escobar:

El PCN está compuesto de palenques regionales, un comité coordinador nacional y equipos técnicos en el nivel nacional, y ocasionalmente en el regional. A pesar de que originalmente designaban territorios autónomos a esclavos liberados o abandonados en la época colonial, los palenques de hoy en día, son espacios de discusión, toma de decisiones y evaluación de políticas, establecidos en regiones con un alto índice de población negra. Operan en conjunto con la Asamblea Nacional de Comunidades Negras, y juntos forman el Consejo Nacional de Palenques (Grueso, Rosero e Escobar, 1999: 240).

${ }^{271}$ Entrevista concedida em 25/10/2013, em Salahonda. 
$\mathrm{Na}$ medida em que foram surgindo, os Conselhos Comunitários em Nariño vinculavam-se a esse Palenque Regional, que se consolidou no começo da década de 1990 como instância regional de representação e interlocução, irradiando-se ao plano nacional (Rivas, 2000).

Em 1999, surge, na zona norte de Nariño, a Asociación de Consejos Comunitarios de la Zona Norte y Centro de la Costa Pacífica de Nariño (ASOCOETNAR), instância organizativa própria, que reivindicava autonomia decisória. Isso provocou fissuras no Palenque Regional Nariño, que acabou se desarticulando na década de $2000^{272}$. Em 2003, surgiu a Red de Consejos Comunitarios del Pacifico Sur (RECOMPAS), considerada uma organização étnico-territorial. Como explicam Mailen e Rosalba, foi uma instância de aglutinação criada pelos quinze Conselhos Comunitários do Pacífico sul colombiano. Ou seja, o agrupamento dos conselhos em torno do Palenque Regional Nariño foi substituído por ASOCOETNAR, RECOMPAS e CONDICOC ${ }^{273}$.

Rosalba fala sobre a falência do Palenque Regional Nariño e a construção da RECOMPAS:

No nos entendíamos. Eso era una discusión ... Nosotros, en esa asamblea general, nos ibamos hasta tres días discutiendo propuesta' y peleando. A veces en la noche llegaba dos, tres de la mañana. ;Uy! Pero que tragedia lidiar con toda esa gente desde Alto Mira hasta la gente de allá de la Cordillera. Eran todos ellos, los líderes de todos ellos. Ochenta o ciento y pico de personas - Rosalba Quiñones.

Na visão de Pazmiño (2003), o Palenque Regional Nariño era dominado, às vezes monopolizado, por dirigentes tumaquenhos. Não era, portanto, compartido com as organizações étnico-territoriais das diferentes localidades do Pacífico. Na perspectiva de Rosalba, as dificuldades encontradas no Palenque Regional Nariño, pelo contrário, residiam na pluralidade de vozes dentro de uma mesma organização. Eram representantes de várias zonas, da Cordilheira à Costa, cada qual com sua peculiaridade. A polifonia gerava desentendimentos.

\footnotetext{
${ }^{272}$ A representação regional de PCN atualmente é o Palenque de Kurrulao, que tem uma incidência mais urbana, pelo que percebi ao longo da etnografia em Tumaco.

273 Trata-se de um grande Conselho Comunitário com área de 136.265,3152 hectares, nos municípios narinhenses de Policarpa e Santa Barbara de Iscuandé, que agrega 35 veredas. Foi criado pela Resolução n. 402, de 28 de abril de 2003. Em sendo a representação dessa zona departamental, COPDICONC faz as vezes de organização de segundo nível. Assim, por exemplo, na realização da etapa departamental de Nariño do Primer Congreso Nacional de Consejos Comunitarios y Organizaciones Étnicas Afrocolombianas, Palenqueras y Raizales, estavam a frente RECOMPAS, ASOCOETNAR e COPDICONC.
} 
A região em que pesquisei é atualmente representada pela Rede de Conselhos do Pacífico Sul. Em dez anos de existência, a RECOMPAS é objeto de amplas críticas, as quais convergem na percepção de que a Rede se desconectou dos princípios de luta constituídos na década de 1990, começou a atuar sem as bases e perdeu autonomia.

A medida que cambiaron todas las juntas de gobierno y la junta directiva, Recompas se perdió el rumbo de todo. Sucedió que el hijo quiso pegarle al papá. Recompas puede desaparecer cuando los Consejos Comunitarios lo requieran, porque fue una instancia que la crearon los consejos. Pero los Consejos Comunitarios siguen siendo Consejos Comunitarios sin Recompas. Son cuatro, cinco, seis los que toman la decisión por 15 o 16 Consejos Comunitarios que existen acá en el Pacífico sur. Entonces se ha perdido pecho - Mailen Aurora Quiñones.

En ACAPA, en la junta directiva del Consejo, no hay presidente. Quién nombró eso fue Recompas. Los primeros Consejos Comunitarios fueron Bajo Mira, ACAPA y Mandela. Todos no tienen presidente. No éramos junta comunal. Éramos junta de gobierno del territorio. Junta de río. La Asamblea es la máxima autoridad. Deciden ahí quien es el representante legal, el tesorero/a, secretario/a, los fiscales y vocales. De ella participan diez personas de cada vereda con voz y voto. Tienen que estar registrados en la mesa de la Secretaría - Ana Granja.

A medida en que la gente fue buscando los proyectos para mejorar calidad de vida, para mejorar nuestros hogares o nuestra comunidad, desde ahí empezó a perderse nuestra autonomía. La palabra autonomía tiene un sentido muy complejo. Autonomía es cuando yo misma decido qué me como, cómo me visto, dónde lo quiero, cómo lo quiero. Pero cuando ya vienen otros a decidir por mí, ahí ya se va perdiendo la autonomía. Ya somos mandados. Entonces desde ahí se empezó a perder parte de ese sentido de pertenencia de nuestras organizaciones porque empezamos a depender y quien pone la plata, pone las condiciones - Mailen Aurora Quiñones.

As narrativas estão centradas em questões organizativas. Ana Granja questiona o modelo diretivo que a RECOMPAS implementou, o qual dispõe de uma estrutura verticalizada, encabeçada por um/a presidente/a. Já as formas organizativas locais eram as juntas de rio, que faziam a gestão do território a partir de uma visão horizontal da coletividade, expressa na figura da assembleia. O depoimento de Mailen ressalta que essa quebra na perspectiva de gestão está relacionada à entrada de novas lideranças no processo. Ela questiona a representatividade da organização de segundo nível, que fala em nome de quinze organizações, porém, expressa a visão de cinco ou seis delas.

PCN e RECOMPAS são as duas principais organizações de segundo nível que atuam em Tumaco. A primeira delas compreende-se como "organização étnico-cultural” e a segunda como "organização étnico-territorial". Ambas nomeiam sentidos de pertencimento da população negra ou afro-pacífica em torno da etnia. Como vimos no primeiro capítulo, o PCN 
surgiu como instância agregadora de organizações ribeirinhas, de grupos e pessoas das cidades de Tumaco, Buenaventura, entre outras. Constituiu-se na década de 1990, ganhando forças no processo da Constituinte e de elaboração da Lei n. 70. Ao longo dos anos 1990, avançou o reconhecimento de territórios coletivos ancestrais nas ribeiras dos rios do Pacífico, com a consolidação de vários Conselhos Comunitários. Quase uma década depois, em 2003, a voz que emanava dos rios da enseada de Tumaco já não ressoava nas práticas do PCN. As especificidades dos Conselhos Comunitários do Pacífico sul colombiano demandavam um lugar de fala próprio, desde uma perspectiva territorialmente inscrita. Assim surge a RECOMPAS. Há, portanto, uma disputa em torno do lugar de fala das ribeiras dos rios do Pacífico Negro. A RECOMPAS reivindica esse lugar de fala que antes era assumido pelo PCN.

As narrativas de mulheres afro-pacíficas com quem dialoguei - algumas delas envolvidas com a RECOMPAS, outras com o PCN e outras com ambas as organizações -, têm uma mirada crítica sobre as dificuldades da organização PCN em reconhecer o protagonismo das mulheres no processo de comunidades negras. A tensão, nesse caso, configura-se entre etnicidade e gênero. No caso da RECOMPAS, as narrativas denunciam um desvio de princípios e uma mercantilização das organizações comunitárias. Existe, portanto, um conflito entre etnicidade e capital externo.

Neste capítulo, explorei a trajetória de mulheres que lograram se constituir como matronas. Suas histórias de vida visibilizam a construção de uma liderança feminina que se prolonga do âmbito familiar ao "processo de comunidades negras". São trajetórias de superação, nas quais o feminino é qualificado como um atributo guerreiro. Elas são designadas como mulheres echadas p'adelante, que se arriscam, que vão além. Para tal, enfrentaram parceiros conjugais e tiveram que significar a maternidade a partir de sua atuação política, ou seja, desde uma perspectiva da coletividade negra. Cotidianamente, dentro dos movimentos mistos, elas disputam o lugar de fala com companheiros negros. 


\section{Capítulo 4 - Afluentes do Rio Santiago}

Na região do norte de Esmeraldas, tem um papel relevante o sistema hidrográfico conformado pelo Rio Santiago e seus afluentes, entre os quais tive contatos com os Palaví, Tululbí, Bogotá e Cachaví. Segundo o estudo feito por Charvet, o Santiago é visto pelos afroesmeraldenhos como um rio brincalhão (2010: 102). O rio inunda e destrói plantações, casas, entre outras coisas. O Rio Palaví deságua no Tululbí, rios que banham a paróquia Tululbí, mais conhecida como Ricaurter, onde nasceram Yonny Nazareno, Vilma Estacio de Sa, Edith Rivas Klinger Palma, Ana Germania. O mesmo Tululbí, acompanhado do Rio Bogotá, banha a localidade La Boca, onde vivem Melania Ester Quiñones e sua mãe Rosaura Quiñonez Hurtado, que tem esse nome em homenagem aos dois rios que se unificam aos pés desse povoado. O Rio Tululbí desagua no Rio Bogotá, que cruza a localidade Carondelet, de minha anfitriã Inés Morales, e segue para o leito do Rio Santiago. Cachaví, rio que passa por Los Ajos, onde nasceu Amada Cortez, engrossa o caudal do Bogotá ${ }^{274}$. Os rios, quando se somam, tomam o nome do caudal. Por fim, o Santiago chega ao mar Pacífico, no cantón Esmeraldas, província homônima.

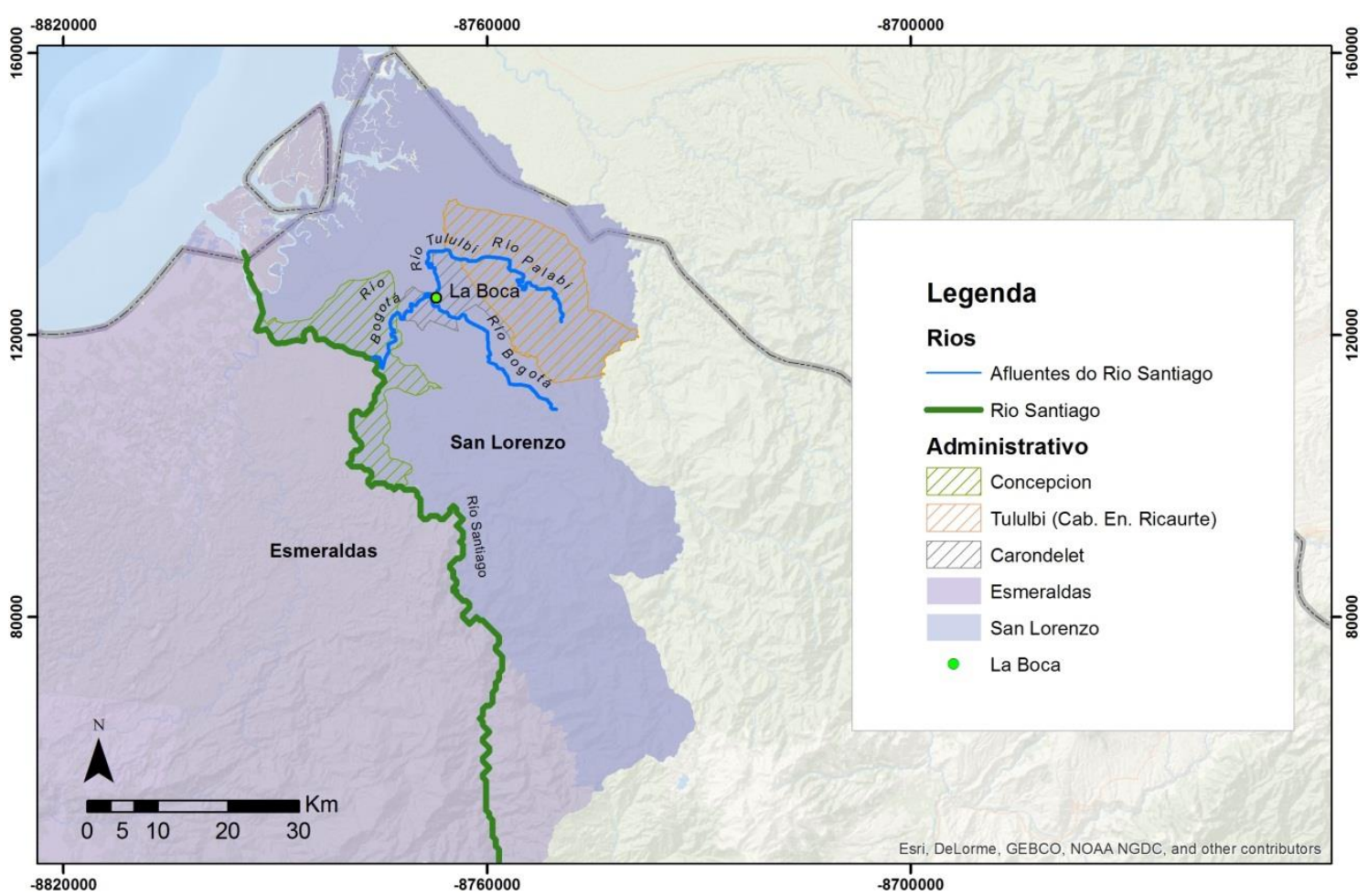

Figura 13 - Mapa dos afluentes do Rio Santiago

\footnotetext{
${ }^{274}$ Não tive a oportunidade de conhecer Los Ajos, tampouco o Cachaví. No mapeamento, não foi possível localizá-los com os dados disponíveis para a região. Por isso, não figuram no mapa.
} 
Trata-se de um território de encontros. Trabalhei em duas localidades equatorianas que representam pontos de conexão direta entre Equador e Colômbia. Uma delas é Ricaute, que faz fronteira com a Colômbia por el monte, en el Rio Mataje. Mesmo nas comunidades de La Boca, Carondelet e Los Ajos, que não se encontram diretamente com território colombiano, as referências à Colômbia são constantes. Em sua maioria, a genealogia das mulheres com quem dialoguei remete à Barbacoas, que, como vimos, é uma das gêneses da ocupação negra no Pacífico colombo-equatoriano. A relação entre Colômbia e Equador é muito dinâmica, com contornos que variam a cada momento da história.

Além das fronteiras nacionais, o território é marcado por fronteiras interétnicas. Os grupos Chachi, Cayapas, Awa, Embera são vizinhos do Povo afro-equatoriano, especialmente na "comunidade de rio" Ricaute. Nessa região, há Reservas Indígenas Chachi e Awá ${ }^{275}$. As fronteiras internacionais e interétnicas podem ainda sobrepor-se. Alguns desses grupos têm origem colombiana, que é o caso dos Awá, como conta Yonny Nazareno:

Hace más de cuarenta años llegaron los indígenas colombianos Awá, en el río Palaví, más arriba. Porque esa parroquia es muy cerca, muy cerquita de Colombia. Ellos son invasores. Vinieron de Colombia y se agarraron tierras que no eran de ellos. Don Jaime Levi, un gringo de EUA con el pelo churoso, les dio respaldo. En esa época no había respaldo al negro. Él se casó con una indígena y naturalizó todos ellos como ecuatorianos, allá en Tobar Donoso. Ellos no sabían manejar potro. Los Chachi, Cayapas son ecuatorianos. Son criollos. Ellos saben andar en potro. Yo tengo muchos recuerdos de la infancia con los indígenas Awá. Ellos hacían parte de mi contexto. Mi papá tenía un bar. Ellos llegaban allá por la música y mi papá los invitaba a entrar. Cuando habían tomado, empezaban a hablar. Uno de ellos me decía: "¿usted quiere a mi??" Yo miraba abajo y decía: "no”. Él estaba enamorado. Ellos casi no hablaban español, hablan awapit - Yonny Nazareno ${ }^{276}$.

Os relatos de Yonny, ao tempo em que indicam a existência de uma convivência interétnica, ressaltam certo tensionamento nas relações entre afro-equatorianos e indígenas, o que se revela, por exemplo, na caracterização dos Awá como invasores. O cerne da questão parece residir nas diferenças de reconhecimento e na relação que o Estado equatoriano brindava aos diferentes povos. A "naturalização" dos indígenas como cidadãos equatorianos

\footnotetext{
${ }^{275}$ No caso dos Awá, em 1994 foi realizada a adjudicação e a escrituração comunitária do território da Reserva Étnica Awá. Em 1998, o Acuerdo Ministerial n. 16, de 13 de setembro de 1998, determinou os lindeiros da área de assentamento tradicional e declarou uma Reserva Étnica y Forestal, com 101 mil hectares, considerada patrimônio florestal do Estado. Contempla a Bacia Hidrográfica Mira-Mataje e a parte alta das subcuenca alta del Río Bogotá e algumas subcuencas tributarias del río San Juan. Está inscrita nas paróquias de Ricaute, Santa Rita e Alto Tambo, que pertencem ao cantão San Lorenzo, província de Esmeraldas; bem como nas paróquias de Tobar Donoso e Maldonado, cantão de Tulcán, província de Carchi.

${ }^{276}$ Entrevista concedida em 7 de dezembro de 2013.
} 
demonstra o "respaldo" que o Estado conferia a esse povo, o que não era o caso do Povo Negro. Segundo Rahier e Dougé-Prosper (2014), desde a colonização do Equador, passando pelo período republicano, as elites nacionais viam os indígenas, e não os negros, como dignos de direitos humanos. O projeto das elites para a construção da identidade nacional durante o período da mestiçagem incorporava os indígenas, enquanto alijava os negros, processo muito semelhante ao ocorrido na Colômbia, como vimos nos capítulos anteriores. Na narrativa de Yonny, há uma gradação na valoração dos povos indígenas. Os Awá, de origem colombiana, não sabiam andar em potro. Já os Chachi e Cayapas, que ela reconhece como equatorianos ou crioulos, esses, sim, sabem andar em potro. De fato, acredita-se que a origem dessa embarcação seja indígena, apropriada pelos povos afro-pacíficos ao seu patrimônio.

\section{O RIO E SEUS ENCANTOS}

Conforme dito na introdução, minha busca é por compreender o rio com tudo o que há nele. Inés Morales ensinou-me que a água é um dos elementos do rio, mas o rio é a fonte de vida.

Nos estan convocando para una discusión sobre los saberes ancestrales del agua en los pueblos afroecuatorianos. Nosotros les décimos que son los saberes ancestrales del río. Él es la fuente de vida, la fuente de resistencia. Él ha resistido, siempre. Dentro de él está el agua pero también está el pescado, la locomoción (en barcos), los minerales, el Riviel que anda en su potrillo - Inés Morales ${ }^{277}$.

O rio é fonte de vida e fonte de resistência. No território que nasceu da República Zamba, viver é resistir. O rio tem resistido ao longo dos séculos, assim como a população afrodescendente. Retomando o conceito de territorialidade proposto por Grueso, Rosero e Escobar (1999), há de se cruzar eixos longitudinais, horizontais e verticais da apropriação territorial. No depoimento de Inés, há referências a todos eles. As águas dos rios são o vetor de mobilidade e comunicação. O pescado é a base da alimentação. Os minerais presentes no rio fazem do plátano de rio outro sustentáculo da dieta afro-pacífica, um alimento diferenciado, com alto poder nutritivo. No domínio vertical da territorialidade, encontramos seres, como el Riviel e las Sirenas, que povoam os rios. Mas não qualquer rio, e sim aquele onde há encanto, onde há ouro.

\footnotetext{
${ }^{277}$ Como dito na primeira parte, a maioria das conversas com Inés Morales ocorreu entre 29 de novembro de 2013 e 31 de janeiro de 2014.
} 
As relações das pessoas com seres encantados também constroem os significados e usos dos recursos. São seres que vivem na natureza, nos rios, nas florestas, manguezais: la Tunda, el Duende, el Diablo, el Bambero, el Cuco, la Gualgura. São personagens das histórias dos/as velhos/as, transmitidas pela tradição oral. "Los ancestros nos dejaron estos personajes para enseñar a cuidar de la naturaleza", explica Amada ${ }^{278}$.

Targelia: La Tunda, dicen que es una mujer. Era una mujer que era... le gustaba hacer oficio. Era grosera con la mamá y se fue al monte. Y de allá ya vino echa Tunda. Es una mujer normal. Que enamora a los hombres. Después que los lleva, los mata. A los hombres les da de comer camarón. Los mata. Los niños se los lleva y los mata.

Paula: ¿Y cómo escoge a quien va a llevar?

Targelia: Los que son groseros. Cuando son los muchachos groseros, entonces ella se los lleva porque son groseros ${ }^{279}$.

As histórias sobre os seres que habitam a natureza contêm um aspecto disciplinar; ensinam a como se portar perante a natureza, perante os mais velhos, perante as mulheres.

O duende, a tunda, o riviel são muito próximos do povo afro-pacífico, têm forma humana, atitudes humanas, interagem com as pessoas, porém são capazes de fazer coisas que, de modo geral, elas não fazem. Por exemplo, a tunda pode se apresentar de diversas formas, assume afigura de pessoas conhecidas, como na história contada por Piedad Porozo, mãe de Yonny, na qual a Tunda apareceu sob a forma da irmã de Piedad:

Piedad Porozo: La tunda salía y gritaba: 'uhu' y los muchachos que eran groseros, los llevaban. La Tunda misma aparecía como mi hermana Margarita, que era la Negrita. Tenía un hijo que era solito. Y con una falda azul y un pañal blanco, con esa parte sin camisa, así desnuda. Andábamos nosotros con mi hermana Juana apañando aguacate, aquí era un aguacatal. $Y$ yo estaba encima de una lomita. Cuando yo la miré, estaba ella era así mirándome para allá, donde estaba mi papá, mi mami. Y entonces yo: "Magnifica en grandeza, mansión del verbo divino. Para que el señor del cielo nos guie por el buen camino" Y ahi: bum! Al suelo. La tumbé al piso. $Y$ salió: bum, bum, bum, bum, bum. ;Uh! La Tunda. Se fue arrastrada por el camino. Yo estaba como de unos tres años.

Paula: ¿Y por qué usted dijo eso?

Piedad: Le enseñaban a uno que eso se decía cuando se vía la tunda ${ }^{280}$.

Em suas aparições, esses seres parecem disciplinar principalmente os homens ou meninos, aqueles que são grosseiros e brigões.

\footnotetext{
${ }^{278}$ Entrevista concedida em 7 de dezembro de 2013.

${ }^{279}$ Entrevista concedida em 27 de janeiro de 2014.

${ }^{280}$ Entrevista concedida em 7 de dezembro de 2013.
} 
Amada Cortez: Se dice que el duende era un hombre que sabía tocar guitarra.

Piedad Porozo: Sí y él enseña. Después que mira que ya saben tocar la guitarra, la coge y jbum! La guitarra en la cabeza de uno. El duende peleaba con un cuñado mío: Hector Vernez. El otro día aparecía con el cuerpo todo dolido. Después empezó a estropearlo. Se lo llevaran a San Lorenzo, al hospital. Pero él se murió. Y a ese Juliano acá de San Francisco. Ellos peleaban mucho, pero cuando vino a matarlo jél se hizo un hombrísimo! Cuando él lo miró, que no podía ni abarcarlo, le metió un tiro. Le pegó el vuelo y: ¡bam bam bam! Ahí tuvieran que venir a rebajarlo. Se quedó loco, loco, ahora está normal ${ }^{281}$.

A tunda e o duende podem até matar certos homens, como mostram as histórias.

Ainda no domínio da verticalidade, aquele que conecta inframundo e supramundo, humanos e espíritos, encontramos dentro dos rios as pedras. Pedras misteriosas, pedras que curam, pedras que alumbram. Inés é uma mulher fascinada por pedras:

Con doce años encontré una esmeralda en el Río Esmeraldas. Había ido a visitar una tía. Siempre me bañaba en el Rio Bogotá, en Carondelet. Pero en ese río no. Y encontré allá una esmeralda. ¡Hermosa!!!

Ahora en ese trabajo de investigación, yo conocí una señora en Playa de Oro que me mostró una piedra, que ella tenía, que tomaba agua. Después, yo estaba en la playa mirando las piedras cuando una señora me dijo, ¿usted qué quiere con las piedras mija? Yo la dije que colecciono piedras y ella entonces me mostró. "Mire esta." "Hum... iBonita! ¿Me regala?" "Sí". Yo la traje a la casa y la vi parecida con la de la señora. Amadita me dijo: "¿ya la pusiste en agua? ¡Póngala!” Cuando lo he hecho, miré que el otro día se había bajado el nível del agua. En el siguiente día, aún más.

Yo fui a Carondelet para una reunión con Plan Ecuador. El compañero me llamó y me dijo: "tenemos que hablar duro con ellos, venga pa'cá". Busqué un chofer y me fui en la camioneta roja. Llegando allá, yo me encontré con una piedra negra que se volaba del carro. Había un montón de piedras, pero esa me llamaba la atención. Parecía que ella me estaba mirando. Yo dije a mis compañeros que quería verla. Después les dije que quería llevarla. Cuando ya tenía dos meses de estar acá en la casa, un día, un amigo que es clarividente, me dijo que yo tenía algo muy precioso en mi casa y que no tenía conciencia de eso. Me dijo que, cuando yo muriera, que mis hijos le regalaran la piedra negra. Y que, si Don Armengol todavía estuviera vivo, lo curaríamos con esa piedra. Al siguiente día, fui al Maestro Hugo y le pedí que viniera acá a la casa. Él consulto el Opelê y me dijo que la piedra no era común. Que ella tenía más de dos mil años viviendo en el agua y un indio la había trabajado. "Ahora mismo me estoy conectando con ese indio". Me dijo que los ojos de la piedra son esmeraldas y que se quedaron en el fondo del río. La piedra es trabajada, es como si fuera una cara. El maestro me dijo que ella necesita agua. Todos los días yo le echo agua. Y, cuando siento que debo, me dirijo a ella. Primero a Dios, después hablo con ella - Inés Morales.

${ }^{281}$ Entrevista concedida em 7 de dezembro de 2013. 
As pedras têm agência. Há uma relação entre as pessoas e as pedras. Enquanto sangara, piangua e guañas travavam um embate com as mulheres, nos casos narrados por Inés, trata-se de um encontro. Um relato de Ana Granja reitera a dimensão do encontro na relação entre mulheres afro-pacíficas e pedras. "Hay una piedra. La concha y la sangara la tienen. Es una piedra blanquita, como si fuera una perla, ahí está el secreto. Cuando uno la encuentra, uno se programa. Yo la encontré pero no supe. Y la cocinê”. Essa pedra é como um amuleto. Quem a encontrar, deve guardá-la e carregá-la consigo, sempre que sair a mariscar. Assim será capaz de encontrar todas as conchas e sangaras. É como se a pedra chamasse os mariscos. Ela é, portanto, um agente social.

Nos casos relatados por Inés, o encontro com as pedras, às vezes, é mediado por outras pessoas ou por outros seres. A rede de agência social, portanto, conecta coisas inanimadas, pessoas encarnadas e seres não encarnados. No segundo relato, a agência da pedra se expressa no atributo de tomar água. Analisando o terceiro relato, vejo novamente que a pedra é dotada de intencionalidade. Ela olhava para Inés. Era uma pedra negra, assim como Inés. O encontro se deu pela troca de olhares entre ambas, relação que posteriormente se tornou um diálogo. Saberes do Culto de Ifá, cuja raiz é nigeriana e que chegaram a Inés pela mediação do Babalaô Hugo ${ }^{282}$, trazem a referência da esmeralda, narrada no primeiro relato. As esmeraldas eram os olhos da pedra negra, que ficaram no fundo do rio. Ainda que não estivessem mais ali, sua intencionalidade dirigia o olhar à Inés. Ao mesmo tempo, a pedra negra, as esmeraldas e o Babalaô mediavam a conexão entre Inés e um índio, ser desencarnado, remetendo essa rede de agência social a um tempo de longuíssima duração ${ }^{283}$. O ambiente causal em que se dão as relações tecidas nessa rede é o rio, são as águas.

Enquanto Inés narra seu encontro com as pedras, a narrativa de Melania é centrada no ouro: outro importante elemento dos rios. Os afluentes do Rio Santiago conformam um cenário onde historicamente se desenvolve a mineração artesanal. "Las mujeres del Alto San Lorenzo tienen su historia, que merece ser contada. Son mujeres que playaron toda una vida, actividad dura, en los ríos"284. Quem fala sobre elas é Fausto Eliceo Lastra, presidente da Federación de Comunidades Negras del Alto San Lorenzo (FECONA), nascido e criado na

\footnotetext{
${ }^{282}$ Sacerdote do Culto de Ifá.

${ }^{283}$ Por sua vez, a conexão entre Inés e o Babalaô Hugo passa por mim. Na segunda viagem a San Lorenzo, fui identificada como adepta das religiões de matriz africana. A mesma pessoa que assim me identificou, que fazia parte do Culto celebrado pelo Maestro Hugo, levou-me ao encontro do Babalaô, que, em seguida, recebeu uma visita de Inés. Quando regressei a San Lorenzo, em 2013, Maestro Hugo vivia na mesma rua de Inés, o que aproximou os dois. Já ao final daquele ano, ele deixou a cidade, regressando à Colômbia, seu país de origem.

${ }^{284}$ Entrevista concedida em 19 de novembro de 2013.
} 
localidade de La Boca, que visitei a convite dele ${ }^{285}$. A atividade, realizada nas ribeiras dos rios, é uma prática muito antiga nessa região. Vilma Estácio de Sá conta que "nuestros ancestros con eso nos mantuvieran. Sacando el oro". É diretamente associada às mulheres.

Ellas menean así la batea bien bonito y botan todo lo que es el cascajo, la jagüilla y solo les queda en el fondo de la batea el oro. Es un arte y aquí hay personas que viven de eso hasta hoy, playando. Antes playaban en el río, pues, en las playas a la ribera del río. Y ahí iban buscando y donde les salía ahí se quedaban playando. Playan en el Tululbí, playan en el Bogotá o se van también a los riachuelos, a los esteros. Estero de La piedra, Limones, Las Perlas, una sabaletera que dicen Las Viejas. Donde haya oro usted en un día puede hacerse millonaria. Donde hay, porque si usted saca dos, tres libras de oro ya para qué va a molestar más. Pero donde no hay ahí sí tiene que echarse sus tres, cuatro días para reunirse un adarmecito de oro $^{286}$ - Melania Ortiz ${ }^{287}$.

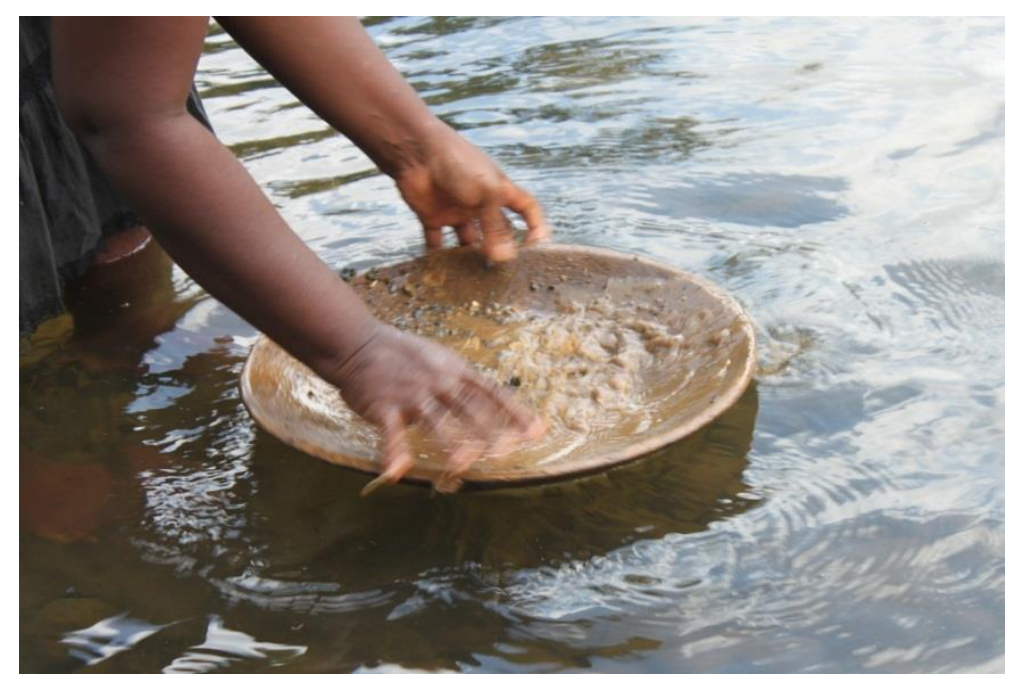

Figura 14 - Yonny Nazareno playando

Outras práticas produtivas eminentemente femininas, como a challada (ou pesca de guañas) e a pesca de camarões ou michillas, também se desenvolvem em ribeiras dos rios. Segundo Charvet (2010), enquanto as mulheres trabalham na ribeira, os homens navegam pelas profundezas dos rios, percorrendo grandes distâncias, na pesca embarcada. Nesse sentido, o rio é ambiente de ambos, mulheres e homens.

A avó paterna de Melania, Julia Ortiz, foi uma grande playadora.

\footnotetext{
${ }^{285}$ Eliceo é primo de Inés Morales e esteve envolvido na gestão da Comarca Afro-Equatoriana do Norte de Esmeraldas (CANE). Conhecemo-nos por meio de Inés.

${ }^{286}$ Um adarme equivale a um grama de ouro, como explica Melania.

${ }^{287}$ Entrevista concedida em 19 de dezembro de 2013. As demais falas citadas ao longo da tese são da mesma entrevista.
} 
Cuando yo era chiquita, en un baúl grande mi abuela manejaba un montón de joyas: cadenas, aretes, anillos, candonga, todo. Ella, cuando estaba de genio, abría en un manto negro y me decía: "mira mija, todas estas joyas me las hice hacer cuando yo playaba”. Entonces ella ¿qué hacía? Daba oro a cambio de que le hacían cadenas, pulseras, anillos, o sea, una parte pa' el que hacia y otra parte pa' que le hagan, por eso ella tenía bastantes alhajas. Pero aparte de esas alhajas, ella tenía dos botellas llenitas de oro, y un pomito de esos así del Colcafe. En el pomo tenía pedacitos y en la botella tenía lo que era más fino. Entonces mi abuela cuando falleció, nosotros no sabemos dónde ella dejó ese oro. Nadie habló con ella, pero antes de ella morir, la angustia que ella no quería morir era verlo a mi papi para decirle algo. Nosotros pensamos que seguro a él le iba a decir dónde es que estaba el oro. Pero mi papi tan necio, se fue de viaje. A la tarde él ya pasa pero ya mi abuela solo le alcanzó a decir "en..." y nada más. Murió . Ella tenía 105 años, pero estaba que todavía caminaba. Ella estaba criando un nieto que se llama Augusto, vive en Ibarra. Entonces ese muchacho, después que se murió mi abuela, decía que había llegado mi abuela en el sueño y le había dicho que acá atrás donde había una piedra que le diga al tío que alce esa piedra que ahí debajo tenía algo para él. Y ese Augusto no le dijo nada a mi papi, sino que vino a alzar esa piedra, sino que como había tres piedras, él no sabía en cuál de las piedras estaba. “¿Y qué cobas Augusto?” "Mi mamá - porque él le decía mi mamá-mi mamá que ayer se me reveló y me decía que le diga a mi tío German que debajo de una de estas piedras le había dejado algo, y yo vine a buscar y nada". Mi mami le dijo: "es que a tu no te va a aparecer porque eso es para tu tío, porque ella te dijo fue que le avisaras a tu tío, no que fueras tú mismo, por eso aunque estés ahí no te va a aparecer a tu", le decía mi mami. Y así fue, ese oro nunca apareció. Pero mi papi tampoco nunca lo bajó a buscar - Melania Ortiz.

O ouro de Dona Julia também é um agente social. Segundo a interpretação de Rosaura, mãe de Melania, o ouro era encantado, só apareceria para quem estava autorizado por Dona Júlia a manejá-lo, que no caso era German, pai de Melania. Porém, ele mesmo não o buscou, de modo que o ouro permaneceu no quintal do solar dessa família. A mineração artesanal permitia a mulheres como Dona Júlia o acúmulo de uma riqueza e de um esplendor que se materializam nas joias dessa centenária mulher.

Os encantos do rio estão também em sua gente. Yonny conta que, seja no Equador, seja na Colômbia, as práticas culturais do Pacífico Negro são as mesmas. "los cantos, cuando se cantan los arrullos, los alabaos, las canciones de cuna. Cuando se dicen las décimas, las poesías, los cuentos, en la misma época que celebran las fiestas patronales, las fiestas religiosas". Tais saberes são transmitidos pela tradição oral. Como vimos no depoimento de Eva Lucia Grueso, os contos fazem parte da socialização das crianças, são um elo entre mais novos e mais velhos. Trazem temas para a reflexão. Assim também são os vários tipos de canções e poesias.

Entre as poesias, chama atenção a décima cimarrona ou "décima afro", como a nomeia Amada Cortéz. Trata-se de uma poesia que se estrutura em 44 versos; são quatro 
primeiras glosas e dez versos subsequentes. Seus compositores não sabiam ler nem escrever, de modo que a oralidade fazia cargo da criação e disseminação das "décimas afro". Algumas delas são textos antigos, como a intitulada "Blanco y negro", composta por Manuel Saturio Valenzia, intelectual afro-colombiano. Tem cinco estrofes com 44 linhas ou versos. As décimas falam sobre fantasias, como, por exemplo, viajar em uma concha de almeja $^{288}$. Os decimeiros e decimeiras aprendem o texto clássico e o recitam em ocasiões especiais. Essas são as décimas tradicionais.

Conforme me explicou Amada Cortéz, que publicou um livro de poesias intitulado $M e$ llaman la Cimarrona (2009), também se pode compor décimas contemporâneas, ofício ao qual ela se dedica, escrevendo histórias sobre as vivências do povo negro. Amada ressalta que já não lhes interessa tanto a forma, mas o conteúdo dos poemas, que serve para a reflexão. Amada compõem décimas que falam sobre Illescas, seus companheiros e companheiras que fundaram um palenque: território de liberdade. Fala sobre a maternidade, fonte de empoderamento feminino e ícone de coesão da coletividade negra.

Entre as canções, os arrullos são cânticos de baile de marimba, instrumento tradicional do Pacífico Negro, feito de madeira. Podem ser dedicados a crianças e santos/as, chamados chigualos, como explica Edith, cantadora e bailadora de Marimba de Ricaute. "Se le canta el arrullo al homenaje del niño que se muere, se le compone ahí a la mamá, si se me muere un hijo a mí, ahí mismo me componen el arrullo". Ela conta como aprendeu a compor e cantar arrullos: "eso nace voluntario, uno aprendió de sus ancestros, de sus antepasados. A mi mamá le gustaba. La miraba a ella y eso me gustaba a mí también y eso yo también cuando ya fui joven, formé mi grupo de arrullo y chigualo. Se llama Grupo arrullo, chigualo Tululbi ${ }^{, 289}$.

Os arrulllos deixaram de ser uma expressão associada sempre à morte de crianças e rituais cristãos. Edith explica: “del arrullo nació la marimba, la música de la marimba es el arrullo. Entonces el arrullo ahorita es en todas ocasiones porque nosotros bailamos marimba, chigualo. El chigualo es uno y el arrullo es otro" ${ }^{290}$. Chigualo, arrullo, andarele, agua, bambuco, todos são modalidades do Baile de Marimba, a senhora da musicalidade afropacífica $^{291}$.

\footnotetext{
${ }^{288}$ Molusco bivalvo que vive enterrado na areia.

${ }^{289}$ Entrevista concedida em 20 de dezembro de 2013.

${ }^{290}$ Entrevista concedida em 20 de dezembro de 2013.

${ }^{291}$ Está em curso um processo binacional envolvendo governos e sociedade civil do Equador e da Colômbia para uma Declaração de Patrimônio Mundial dos cantos de Marimba. Em finais de 2013, houve uma Oficina
} 
A musicalidade é um ícone da expressividade afro-pacífica e guarda relação direta com o ritmo das águas. Como coloca Charvet, "del sonido del río, de su fluir permanente, nace, precisamente, el ritmo y sonido de su música" (Charvet, 2010: 116). A água é elemento da afinação da marimba, como nos explica Inés Morales: "recordemos que el río también sierve para la confección de los instrumentos musicales, por ejemplo, para la marimba". Reitero, pois, que o território-água expressa a imagem que o povo afro-pacífico construiu sobre si mesmo.

Os rituais fúnebres são protagonizados por mulheres e indicam que a morte é uma seara na qual prevalecem os saberes e as energias femininas. Os alabaos são cânticos tradicionais mortuários proferidos neste ritual. Conforme ensina Inés Morales, “El alabao es una conexión del dolor de la muerte con nuestro señor, Dios. Composiciones que ayer nos enseñaron nuestros mayores, así como la medicina ancestral que le salvó la vida a tantas personas". Vida e morte são duas facetas de um mesmo processo, como indica a fala de Inés.

Participamos do velório de uma tia-avó de Inés em Carondelet. A sentinela ocorreu na casa de uma das filhas da falecida. A sala da residência abrigava um altar em homenagem à tia, em torno do qual cerca de vinte mulheres, em sua maioria veteranas, cantavam e rezavam: el Credo, el Padrenuestro, el Avemaria. Algumas delas, na perspectiva de Inés, eram "boas cantadoras". Vieram de comunidades vizinhas para prestigiar a família condoída pela perda de um ente querido. Antes de entoarem suas potentes vozes, jovens mulheres de Carondelet rezavam o Rosário, rito que deu início à cerimônia. Ao longo da madrugada, as mulheres entoavam alabaos enquanto os homens permaneciam sentados no lado de fora da casa, debaixo de uma tenda, jogando cartas, tomando trago (cerveja e rum) e fumando. Mulheres também bebiam e fumavam, na parte exterior à sala. Mulheres mais jovens, familiares da falecida, serviam a todos e cuidavam de outras questões logísticas. Foram ofertadas várias comidas ao longo da noite/madrugada/manhã: pescado com banana-da-terra verde acompanhado de arroz no começo da noite, chocolate com pão em torno da meia-noite, balinhas e água em vários momentos, até cigarros eram distribuídos. Ao longo de toda a noite e madrugada, tivemos a companhia de uma chuva subliminar, interrompida pelos primeiros raios matinais.

Quando era em torno das duas horas da manhã, o repertório da cantoria mudou. As mulheres começaram a entoar antigas canções populares que remetiam à função social da falecida, que era acima de tudo, mãe. Nesse momento, um homem adentrou o recinto e passou

Binacional em Atacames, Esmeraldas, Equador, sobre o tema, da qual participaram Yonny Nazareno e Amada Cortez. 
a acompanhá-las no violão; mas era figura secundária, já que o repertório era ditado pelas mulheres. As filhas da falecida e outras parentes choravam bastante. Percebi esse como o momento de maior emotividade das mulheres. Depois dessa seção, retomaram-se os alabaos. Por volta das 4 da manhã, houve um momento de clímax. As luzes apagaram-se e entoou-se um canto de partida. Conforme explicado posteriormente, era o momento em que a alma da falecida deixava esse mundo, seguindo outra direção. Não poderia haver sequer uma rajada de luz que interferisse na passagem da alma.

Por meio de suas vozes, entoadas em cantos e rezas, são as mulheres que fazem essa passagem, do mundo ao supramundo. São matronas, especialmente as "boas cantadoras", como coloca Inés Morales. Como rezadeiras e cantadoras, atuam no plano simbólico; conectam mundo e supramundo. Mas também atuam na vida cotidiana da comunidade. Algumas delas são conselheiras, como é o caso de Inés, requisitada em Carondelet quando há um velório, um conflito, ou uma reunião política. Nesse sentido, transitam entre o plano simbólico e o material. Matronas como Inés são ainda lideranças políticas centrais. No campo da movimentação política, saberes ancestrais, como as décimas e os arrullos, são plataformas de articulação entre concepções de "território" e "cultura".

\section{ENCONTRO DE EXPRESSÕES NEGRAS}

No norte de Esmeraldas, a década de 1990 foi palco de várias mobilizações paralelas em torno da territorialidade e da identidade cultural. Nas narrativas de minhas interlocutoras, muitas delas professoras, a escola e o processo educativo foram o cenário do despertar político.

Yo me reconocía como una mujer cargada de raíces africanas. Pero me planteaba: ¿qué es África?, ¿por qué estoy aquí? Yo voy a plantear en mi universidad un tema que guarde relación de quiénes somos nosotros los negros y cómo los planteles educativos han influenciado en ese comportamiento, en ese ser nosotros. Eso porque yo pensaba: en la escuela no se enseña nada de lo que somos nosotros, yo soy profesora por tanto años y todavía no puedo enseñarles nada a mis alumnos - Inés Morales.

Os anseios por desvendar a história de africanos no Equador e de seus descendentes afro-equatorianos levou Inés Morales a Juan García Salazar, uma das peças-chave no diálogo contemporâneo entre Equador e Colômbia. Juan García, antropólogo e ativista afroequatoriano, que se reconhece como um "obreiro do processo", a essa época já dialogava com 
o movimento étnico-cultural colombiano, especialmente com o PCN. Ele foi um catalisador do debate em torno da identidade étnica no norte do Equador.

Entonces Andrés Valencia, el bibliotecario, me decía: - de pronto Juan García que él anda preocupado por hacer investigaciones. Entonces ahí es que salgo del colegio y escribo la carta para Juan García. El maestro Juan llegó acá en el 1992. En esos mismos noventa fueron de partida para muchas cosas, empezamos a reunirnos con Juan y Andrés era como el vocero. Nos encontrábamos en el parque, por el muelle, en el malecón - Inés Morales.

Esse foi o caminho pelo qual o Processo de Comunidades Negras rompeu fronteiras nacionais, conectando contemporaneamente Colômbia e Equador, em um território ancestral cuja gênese foi uma só, a República Zamba, um grande palenque liderado por Alonso de Illescas. Sanchéz (2010) ressalta a importância da leitura equatoriana sobre concepções que o PCN formulou a respeito do território ancestral.

Segundo Inés Morales, o que propiciou o encontro entre ativistas afro-esmeraldenhos e afro-colombianos foi, em grande medida, a relação binacional vivenciada ao longo das décadas de 1980 e 1990, no Festival Internacional del Currulao, realizado em Tumaco, Colômbia. Currulao é um ritmo musical afro-colombiano autóctone do Pacífico sul. O termo alude à palavra cununao ou cununos, que faz referência a tambores de ascendência africana, os quais desempenham um importante papel nas representações da espiritualidade afropacífica. É evocado como representação da pessoa afro-pacífica, a partir da água: "nosotros somos la etnia currulao. Currulao es agua. Todo es currulao. Nosotros somos hijos del agua de la luna. En la Gran Comarca, somos hijos de la cultura Currulao"292. Inés fala "la cultura Currulao pasó de la raya hace muchos siglos. En Ecuador la música es marimba, es lo mismo". Ou seja, currulao e marimba são sinônimos. A musicalidade expressa-se no fluir das águas, conectando corpo, pessoa e território. As concepções de "território" e de pessoa, por sua vez, articulam-se à "cultura".

O Festival Internacional do Currulao talvez tenha sido uma inspiração para o equatoriano Encontro de Expressões Negras, que, ao longo de dez anos, de 1995 a 2005, promovia constante intercâmbio entre afro-equatorianos e afro-colombianos. Nessa mesma época, fundou-se em San Lorenzo a Frente Cultural em Defesa do Território Ancestral, cuja primeira luta foi pela defesa dos manguezais, que estavam sob forte ameaça com a presença das camaroeiras. A Frente em seguida transformou-se na Federación de Organizaciones Culturales Afro (FEDOCA). Novamente, "território" e "cultura" formam um par.

${ }^{292}$ Frases proferidas em reunião binacional da Comissão de Apalencamiento, em dezembro de 2012. 
Ya empezamos a organizar los eventos de expresiones negras. Lo hacíamos a nivel local. Entre el 95, 96 ya empezamos a hacer cosas a nivel internacional, ahí es donde ya nos encontramos con los hermanos colombianos. Dueños de casa eran Ecuador, Colombia y Perú, los otros eran eventualmente, cuando había respuesta de la embajada, apoyo. Brasil participó dos años. Panamá participó. El proceso de revitalización cultural nace como una iniciativa nuestra, o sea mía, de Pablo de la Torre, de Andrés Valencia, de nosotros. Y a la luz de ese proceso de revitalización cultural que tenía como elemento fuerte la defensa del territorio entonces nacen los eventos de expresiones negras. Con los eventos de expresiones negras nosotros invitamos a la gente de Colombia, que allá manejaban el tema del currulao. Había un espacio que le llamaba coloquio. Carlos Rosero, Hernán Cortes, Juan García venían como expositores. Fue muy importante para la defensa del territorio. Logramos apoyo para la titulación colectiva de nuestras tierras, también para la gestión, control y protección de los manglares - Inés Morales.

É como se a "revitalização" da cultura passasse pela defesa do território. A expressividade musical, por exemplo, tem uma base material e simbólica que é territorializada. A marimba é feita com madeira nativa, as águas dão seu tom. A elaboração conceitual e política desse processo se deu no encontro com os "irmãos" colombianos. Notase que os nomes elencados por Inés Morales são masculinos. Mulheres que foram protagonistas na gênese do processo de comunidades negras como Eva Lucia Grueso, Ana Granja, Mailén Quiñones, entre outras, não viajavam para o Equador para participar do Encontro de Expressões Negras, o que reforça o problema da invisibilização das mulheres dentro dos movimentos mistos na Colômbia. Isso porque certo tipo de liderança foi privilegiado. Enquanto as mulheres faziam as mobilizações ao longo dos rios, nas salas de aula, dentro das casas, nas localidades ribeirinhas, fosse como parteira, rezadeira ou conselheira, os homens representavam a coletividade negra para um público externo. Em 1994, nasceu o Processo de Comunidade Negras do Equador, semente da Comarca Afroecuatoriana del Norte de Esmeraldas (CANE), institucionalizada em 1996.

\section{Comarca Afroecuatoriana del NORTE de Esmeraldas (CANE)}

Tu silencio duplicará el dolor de tus ancestros. Juan García Salazar.

O processo organizativo afro-equatoriano usa um léxico que tem lastro na ancestralidade. O termo "comarca", segundo Inés Morales, foi usado por Alonso de Illescas 
em carta escrita ao Rei da Espanha: "yo tengo que gobernar en mi comarca”, dizia Illescas. Nesse sentido, trata-se de uma proposta política territorial na qual a gestão do território é protagonizada pelo povo afro, conforme sua própria concepção de desenvolvimento. Segundo Inés Morales, conceitualmente, as Circunscrições Territoriais, abordadas anteriormente, seriam o mesmo que a comarca. A diferença é que comarca é um termo endógeno, como diz Inés, "un término nuestro, propuesto por nosotros", enquanto as circunscrições fazem parte do léxico legal.

Inicialmente, no norte de Esmeraldas, tratava-se da Gran Comarca de Indios Chachi y de Negros en la Provincia de Esmeraldas. Kumuinchi Tu Llukaju, uma proposta conjunta entre negros/as e indígenas:

Juntos para la administración del territorio. Porque teníamos cosas parecidas. Ambos pueblos con un legado cultural muy fuerte, con unas costumbre parecida', como también con unas diferencia' culturales bien marcadas. Entonces haciamos algunos ejercicios y deciamo': "la misma agua del río nos ha bañado a negros y a indios". Y entonces también decíamos el territorio es un derecho históricamente de estos pueblos, y ambos pueblos concebíamos el territorio como la madre para recrear el desarrollo de nuestra cultura y buscábamos también un desarrollo desde nuestras propias miradas, concepciones. Estábamos en ese proceso junto con los hermanos indígenas Chachi básicamente. En ese entonces no hablábamos con los hermanos Awá ni Epera, a pesar de que ya su presencia estaba aquí en el Ecuador en el norte. Empezamos en 95 por ahí, estuvimos tres años juntos, eso fue un trabajo fuertísimo, de talleres bajo la conducción de Juan García. Claro que entendíamos que el protagonista de la propuesta política territorial de la comarca, su lucha de resistencia, había sido Alonzo Illescas que había sido nuestra referencia - Inés Morales.

Mais uma vez, os principais tópicos evocados por Inés são "cultura" e "território", sendo que o primeiro parece expressar um sistema de costumes e o segundo é representado pela figura da mãe. A associação entre maternidade e território potencializa, no meu entendimento, o poder que ambas as categorias possuem no universo afro-pacífico. "Cultura" e "território" conectam-se, sendo o território plataforma de expressividade da cultura e de um modelo de desenvolvido endógeno. A concepção de território-água está também presente na narrativa de Inés. Enquanto a "cultura" simultaneamente aproxima e distancia indígenas e negros, as águas configuram um ponto de conexão direta entre ambos os povos.

Vale ressaltar ainda a dimensão do território como um direito histórico de Povos Negros e Indígenas, presente na narrativa. Ainda que as elites de origem europeia, ao longo da história, tenham cindido as relações entre ambos, naquele momento, negros/as e indígenas conseguiram construir uma aliança no tocante à concepção e à reivindicação de direitos. A 
linguagem do direito contextualiza-se no processo de reforma constitucional equatoriana que se consolidou na Constituição Política de 1998.

Éramos también unos apostadores que la constitución no nos recogía como tal, ni a los pueblos indígenas, y mucho menos a los pueblos negros. $Y$ entonces ya habian unas posibilidades que se hablaba de esas reformas y era ahi donde nosotros decíamos: "tenemos que apresurarnos, tener una propuesta clara, que esa reforma sea capaz de reconocer los espacios territoriales propios de las comunidades negras, de los pueblos indígenas”. $Y$ cuando ellos [os Chachi] nos dieran la sacada de que no iban con nosotros, ya en eso entre el 96, 97, bueno nosotros dijimos: "vamos solos". $Y$ seguimos trabajando solos. Así fue que en el 98 se dice que se va a reformar la Constitución, nosotros presentamos la propuesta solos. Una propuesta clara: qué era la comarca, para qué la queríamos, cómo funcionaría y todo lo demás, incluso donde se hablaba del respeto a la presencia de los otros pueblos. Pero igual no tuvo mayor acogida pese al esfuerzo que hicimos. Desgraciadamente, con este gobierno neoliberal en ese momento no fue posible - Inés Morales.

Povos indígenas e negros juntos reivindicavam o reconhecimento de sua territorialidade. Pouco antes da promulgação da nova Constituição Política, os indígenas abdicaram do processo conjunto, mas o povo negro seguiu em frente, apresentando a proposta da Comarca à constituinte. Na leitura de Inés, a matriz negra protagonizava aquela proposta política territorial, iconizada na figura de Alonso de Illescas, o fundador desse território. A circunscrição da Comarca do Norte da Província de Esmeraldas contemplava os três cantões com majoritária presença negra nesse setor: Rio Verde, Eloy Alfaro e San Lorenzo. Porém, a proposta não foi acolhida pela Constituinte.

Sem embargo, os indígenas foram contemplados no texto constitucional de 1998, como coloca Inés: "todos los artículos se los reconocían a los indígenas y en la parte final decía: "y todo será en lo que sea aplicable para los negros”. En un pequeño artículo nos recogía. Creo que es el artículo 54. Solamente esa parte”. Nesse sentido, a Constituição de 1998 reafirmou as diferenças estabelecidas ao longo dos períodos colonial e republicano entre negros e indígenas perante o Estado-nação, conforme ressaltam Rahier e Dougé-Prosper (2014).

Paralelamente a essa mobilização em nível regional, havia uma movimentação nacional que também incidia sobre a reforma da Constituição Política. No mesmo ano de 1998, em Quito, realizou-se o I Congresso do Povo Negro no Equador, com o lema "Nunca más en Ecuador sin nosotros los negros". O povo negro de todo o país estava mobilizado em busca da garantia de direitos na nova Constituição. Entretanto, na perspectiva de Inés Morales, a mais sólida proposta político-territorial provinha do norte de Esmeraldas. Como a 
Constituinte não acolheu essa proposta, os caminhos para a titulação de território coletivos negros no norte do Equador foram outros.

Vamos apostando a la titulación de tierras en comunas. Porque la reforma agraria que ya se había hecho en el 95 nos daba elemento del derecho a la titulación de la tierra colectiva como pueblos negros. Antes la ley agraria no nos recogía a nosotros, solamente a los indígenas - Inés Morales.

A Ley de Desarrollo Agrario, conhecida como Ley de Comunas ${ }^{293}$, reconhece o direito ao Povo Negro de legalização do território coletivo mediante adjudicação por posse ancestral. Estabelece ainda a comuna como forma de organização territorial. O que o povo afroesmeraldenho conceituava como Comarca teve de se encaixar na categoria legal "comuna".

As primeiras titulações sob o modelo de comuna se deram logo em seguida, a encargo do Ministério da Agricultura e do Instituto Nacional de Desarrollo Agrario (INDA). Em 1998, titulou-se a Comuna Afroecuatoriana de La Boca, com 914 hectares, e a Comuna Afroecuatoriana de Carondelet de Bogotá, com aproximadamente 800 hectares, que leva no próprio nome a referência ao rio que banha a localidade. Melania e sua mãe Rosaura relatam como o processo de titulação coletiva foi vivenciado em La Boca:

Hubo muchas charlas, porque en eso teníamos que estar todos unidos para luchar por la misma causa. Una lucha bien grande. Hubo seminarios en San Lorenzo con las otras comunas. Hubo procesos que se dieron a nivel nacional en Quito, entonces uno tenía que participar en las diferentes actividades que se hacían. Pero eso todo empezó muchos años atrás. Los protagonistas de esa lucha fueron Inés Morales, Fausto Chirán, Eliseo Lastra, Pablo de la Torre, todo' ellos. Sobre todo lo que más nos enfocaban era de los derechos colectivos, los derechos que nos corresponden a nosotros como afro. El territorio es un derecho colectivo que nos corresponde. Por ejemplo, las tierras comunales son indivisible', inajenable', invendible', inembargable'. La fundadora acá [da Comuna Afroequatoriana La Boca] es mi mamá - Melania Ortiz.

No caso do Equador, em contraposição à experiência colombiana, as mulheres têm alguma visibilidade desde o nascedouro dos processos organizativos, ainda que minoritária. Nesse sentido, Inés Morales é uma figura de destaque, nacionalmente reconhecida como uma das principais lideranças na luta pelos territórios negros ancestrais. A linguagem do direito, em especial, dos direitos coletivos é bem articulada por Melania, sendo que o direito ao território é mister.

\footnotetext{
${ }^{293}$ Ley de Organización y Régim en las Comunas, Decreto Supremo n. 142, de 30 de julho de 1937, revisado pela Ley de Reforma Agraria de 1973 e novamente revisado pela Constituição Política de 1998.
} 
Ya, entonces anduvo dándonos unas charlas, que han de venir personas a comprar las tierras y los que éramos débil íbamos a vender las tierras y nos íbamos a quedar en nada y después teníamos que estar trabajándoles a los mismo que compraran. Y que entonces los que teníamos nuestra tierra los metiéramos a comuna porque en la comuna ya no se podía despojarnos. $Y$ así sucedió - Rosaura Quiñones ${ }^{294}$.

A ameaça à integridade do território estimulou o povo de La Boca a mobilizar-se em torno do reconhecimento e da titulação coletiva do território. Inicialmente foram 23 sócios, que se organizaram e pagaram pelo título da terra comunal. É interessante observar que cada sócio/a tem título de sua porção. Rosaura, por exemplo, é proprietária de uma área de 30 hectares. Porém, as várias porções estão agregadas em um título coletivo. No caso da Comuna La Boca, ele corresponde a 914 ha.

Os procedimentos assemelham-se, portanto, ao do país vizinho, em que áreas residenciais e agrícolas, as chamadas fincas, são tituladas por família, enquanto manguezais, ribeiras de rios e praias, áreas de bosque de respaldo, áreas em que constam edificações e outras referências ao patrimônio cultural são tituladas coletivamente. Outra semelhança reside no caráter das terras tituladas coletivamente: indivisíveis, inalienáveis e não embargáveis ${ }^{295}$. Enquanto na Colômbia, a gestão do território coletivo cabe ao Conselho Comunitário, no Equador, é realizada pelo Cabildo, composto por cinco membros: presidente, vice-presidente, tesoureiro, secretário e síndico. O Ministerio de Agricultura, Ganadería, Acuacultura y Pesca tem de validar a lista de dirigentes eleitos por comunheiras e comunheiros para a formalização dos cabildos.

Apesar da mobilização com vistas a resguardar o território, quinze anos após a titulação de La Boca e Carondelet, o principal desafio contemporâneo é recuperar terras comunais que foram incorporadas por empresas de palma africana ${ }^{296}$, por meio de vendas ilegais. Há uma incoerência nesse ponto, uma vez que os títulos de terras comunais são invendáveis. Porém, a pressão econômica é grande. A maioria de comunheiros/as vendeu integralmente e alguns parcialmente suas terras, com a cumplicidade dos funcionários do Estado. Segundo informa Eliceo Lastra, presidente de FECONA, dos 914 ha titulados

\footnotetext{
${ }^{294}$ Entrevista concedida em 19 de dezembro de 2013.

295 Brasil soma-se ao Equador e à Colômbia nesse tocante, no que se refere ao estatuto dos territórios quilombolas.

${ }^{296}$ A pressão das empresas de palma africana sobre territórios coletivos negros também se faz presente em Tumaco. Rosalba assinala a luta do Conselho Comunitário União Rio Rosário com a empresa Astorga, que também impeliu a coletividade desse rio a se organizar em torno do reconhecimento e da titulação das terras ancestrais.
} 
coletivamente na Comuna La Boca, cerca de 600 estão em mãos de palmeras. Outras porções estão arrendadas para a mineração com retroescavadeira.

No caso do Equador, assim como no da Colômbia, há uma sobreposição de instâncias organizativas. Na divisão político-administrativa nacional, Carondelet é uma paróquia e, assim, tem sua junta paroquial, a qual abarca cinco recintos: San Juan de Carondelet, La Boca, Najurungo, El Sandé y El Encanto. A junta paroquial é encabeçada pelo "tenente político", autoridade da cabeceira paroquial ${ }^{297}$. Trata-se do governo autônomo em nível local, tendo como uma de suas atribuições a gestão de recursos. Ou seja, a junta paroquial recebe um orçamento mensal do Estado. Paralelamente, o cabildo faz a gestão da Comuna, configurando uma autoridade étnica, inscrita no âmbito da divisão político-administrativa nacional e, portanto, a ela submissa.

Nesse sentido, a Comuna não expressa o sentido ancestral da Comarca, a qual pressupõe uma gestão do território protagonizada pelo povo afro, de acordo com sua própria concepção de desenvolvimento, conforme define Inés Morales. Entendo, pois, que há uma perda para o povo afro-esmeraldenho no exercício forçoso de encaixar a Comarca na categoria legal "Comuna". Por outro lado, a proposta das circunscrições territoriais afroequatorianas, ainda que também não tenha incorporado a autodenominação, aproxima-se mais do conceito de Comarca, na medida em que seriam regimes especiais de governo autônomo descentralizado, estabelecidos por livre determinação, com gestão de recursos públicos.

Paralelamente às dinâmicas locais de titulação coletiva, está em curso um processo organizativo do povo afro-esmeraldenho do norte desta província em torno da Comarca AfroEquatoriana do Norte de Esmeraldas (CANE). Como explica Inés:

Nosotros hablábamos de dos comarcas. El proceso regional local que tenía la propuesta política territorial de construir la Comarca del norte de Esmeraldas. Entonces a nuestro proceso organizativo también le llamamos Comarca, la legalizamos como Comarca, no le pusimos otro nombre a nuestra organización. Al menos cuando vimos que en el 98 no logramos ganar en la figura política territorial, dijimos legalizamos nuestra organización con el nombre de Comarca - Inés Morales.

O formato dessa organização explicita as conexões entre família e política, o que reforça a tese de que não há cisão entre o âmbito doméstico e o público no Pacífico Negro colombo-equatoriano. Os cargos diretivos da organização são denominados a partir das

\footnotetext{
${ }^{297}$ É conformada por intermédio de eleições populares. Após eleita a junta, o presidente submete aos vocais, demais membros da junta, a sugestão de um nome para a Secretaria da Junta, cargo de confiança da presidência. Em caso de aprovação da maioria dos membros, nomeia-se a secretária.
} 
relações de parentesco. O cargo de maior hierarquia é designado como Palenquera ou Palenquero Mayor. O/a tesoureiro/a é Papá Grande ou Mamá Grande, que remete à posição da avó ou avô. Bambero é o assessor. Ñaño/a Grande, termo que se refere ao irmão/ã biológico ou social mais velho, designa o/a secretário/a. E os vocais são padrinos e madrinas de uña e de agua.

As posições de parentesco evocadas pertencem ao domínio da consanguinidade e da afinidade, ambos vistos como relações em construção. Retomamos a ideia de que as nutrizes de tais relações são as mulheres. Retomamos também a concepção política de família, que compreende a coletividade negra como um todo. Na concepção afro-pacífica, seja da família extensa, seja da família política, o aspecto primordial é a construção de vínculos. Nesse sentido, o processo organizativo negro do norte de Esmeraldas incorpora a ideia de que a política perpassa o âmbito doméstico e o público e de que as mulheres são peças-chave na construção de vínculos e relações nesses cenários.

Como pode ser visualizado no Anexo III, a Comarca é a instância agregadora das organizações afro-equatorianas do norte de Esmeraldas. A ela estão vinculados palenques, organizações gremiais que atuam em diferentes setores dos três cantões da região. A instância de governabilidade da Comarca é o Conselho Regional de Palenques, que agrega um representante de cada. Trata-se de um órgão diretivo, de dimensões menores. O grande espaço de concertação são os encontros realizados em Kosangana, "termo ancestral" que alude às tradicionais formas de organização e designa algo similar a assembleia. Nota-se que a estrutura da CANE em muito se assemelha a do PCN, com uma assembleia nacional e palenques regionais agregados em torno de um conselho. As Comunas Afro-Equatorianas Carondelet de Bogotá e La Boca estão vinculadas ao Palenque FECONA, que representa as Comunidades de Rio e Bosque Úmido Tropical do Alto San Lorenzo, congregando treze Comunas.

\section{O Processo BinACIONAL}

El proceso binacional pudo haber empezado entre 93-94, pero lo que es en términos de diálogo, acercamiento, conversaciones. Luego empezamos a planificar ya reuniones oficialmente que eran financiadas por el Comité Andino de Servicio. En Estados Unidos, hay un grupo que se llama el grupo de los Quaker, ellos nos daban el dinero. El proceso binacional es diferente a los eventos de expresiones negras, que son dos espacios distintos pero como que el uno se articulaba al otro. El evento de las expresiones negras es 
una propuesta nuestra. El proceso de construcción de la propuesta política de la Gran Comarca nace bajo la ideología de Juan - Inés Morales.

Conexões contemporâneas entre Colômbia e Equador desencadearam a construção de uma proposta política territorial que une territórios nacionais, cuja gênese organizativa se deve às articulações entre a Comarca Afro-Equatoriana do Norte de Esmeraldas (CANE) e o Processo de Comunidades Negras (PCN). A Comarca Afro-Pacífica Binacional, em sua primeira concepção, formulada no começo da década de 1990, nascia em Portete (Esmeraldas, Equador), subia por Tumaco, Buenaventura, Chocó, Antioquia (Colômbia) e chegava até Darién (Panamá). Como narra Inés, o processo binacional corria paralelo ao da Comarca do Norte da Província de Esmeraldas.

A palenqueira maior, Inés Morales, fala sobre as motivações do processo binacional protagonizado pelo povo afro-pacífico:

La razón de nuestra lucha, de juntarnos, reencontrarnos con los pueblos negros era más bien que nos veníamos sintiendo víctimas de una exclusión, de una marginación, de una discriminación, de una falta de oportunidades como pueblos negros. $Y$, más que todo, de saber que habíamos sido unos pueblos que habíamos aportado tanto a la construcción de estos Estados y hasta ahora estos Estados no nos daban lo que verdaderamente tenían que darnos, por lo menos empezando por educación - Inés Morales.

A narrativa de Inés Morales situa a exclusão, a marginalização, a discriminação e a falta de oportunidades como cerne da luta e como razão da unificação contemporânea de povos negros no Equador e na Colômbia. Ao mesmo tempo, a luta se expressa na reivindicação de uma territorialidade negra binacional, que está inscrita também pela chave da "cultura", o que se explicita nos nomes das organizações: Frente Cultural em Defesa do Território Ancestral, Festival Currulao, Encontro de Expressões Negras. O depoimento de Inés revela que a construção do discurso da etnicidade no Norte do Equador não se contrapõe a um discurso da negritude. Fato que, no Pacífico colombiano, parece decorrer de uma configuração local de disputa entre tendências do movimento social negro ou afro-colombiano situadas no Pacífico, no contexto da Constituinte, no final da década de 1990. Ainda que esse cenário tenha se configurado a partir de uma questão pontual, creio que deixou lastro na construção do discurso político sobre a afrodescendência nas décadas seguintes, especialmente em Tumaco.

Em que pese a diferença apontada, a concepção de territorialidade em torno da qual se constrói a Gran Comarca Pacífica é a mesma concepção proposta pelo PCN-Colômbia, o conceito de território-região. 
El Territorio Región del Pacífico es la tierra donde, contra nuestra voluntad, nos trajo la ambición de los otros. Pero también es la tierra nueva, la tierra donde nos ancló el amor por la tierra madre que se quedó al otro lado del mar. Estos cientos de años antes que nazcan los Estados que ahora nos ordenan ser lo que nosotros somos por nuestra propia voluntad, nunca quisimos ser. De la sabiduría del Abuelo Zenón.

Tive acesso à fala do ancião Zenón, compilada por Juan García e Guerrero, por meio de um documento da biblioteca de Inés Morales. Ela traz elementos ímpares para compreender as identificações em torno da raça/etnia como atualizações de relações. $\mathrm{O}$ passado ganha sentido em uma visão de futuro. A referência à África é trazida para se falar sobre uma "terra nova", que é o território-região. Ele antecede os Estados-nação. Essa raiz histórica comum é o que motiva o "processo binacional", que se materializou em diversos encontros binacionais, os quais se revezavam entre Equador e Colômbia.

O primeiro encontro binacional realizou-se em Tumaco, em 1995. Em 1997, foi a vez de San Lorenzo sediar a reunião. O terceiro foi em Buenaventura, em 1998, e o quarto Encontro foi sediado no Valle del Chota, la Concepción y Salinas, em 1999. Segundo a perspectiva de Inés Morales, a proposta política da Gran Comarca Afropacífica inspirou as discussões sobre territorialidade em outras partes do país, como no Valle do Chota. "Los compañeros del Chota como que lo deciden armar y mirar el tema territorio a partir de la motivación con nosotros. Entonces, como se habla muy fuertemente del territorio, ellos participaban".

A luta pela titulação coletiva da Comarca Afro-Pacífica poderia ser materializada na criação de uma "Reserva Binacional” entre Equador e Colômbia, como explica Inés Morales. Nesse sentido, confluíam movimentos sociais e uma negociação entre governos, emoldurada em preexistentes acordos de vizinhança. Segundo relatos locais, há treze anos existe um espaço de discussão binacional entre Equador e Colômbia, que agrega governo e sociedade civil organizada. Tive oportunidade de participar do quarto Fórum Binacional Fronteiriço "Del dicho al hecho", realizado em Tumaco, entre 27 e 29 de novembro de 2012, no qual a criação de uma Reserva de Bioesfera Binacional foi tema da mesa sobre meio ambiente. $\mathrm{O}$ foco da referida Reserva seria o manejo dos manguezais, pensando a questão da mariscagem e da pesca, bem como ações de reflorestamento.

A territorialidade binacional abre caminho para a reivindicação de uma dupla nacionalidade, articulando concepções ancestrais do território com a atualidade das relações entre nações. A dinâmica do Fórum Binacional Fronteiriço baseia-se em debates por mesas. A mesa "desplazados" e refugiados falou sobre o tema da dupla nacionalidade para Povos 
Indígenas e Afrodescendentes fronteiriços, com objetivo de que possam movimentar-se entre as nações sem maiores dificuldades, o que envolve revisão das legislações de ambos os países $^{298}$. Nessa discussão, estão envolvidos o Ministério do Interior e as chancelarias. Ao longo do trabalho de campo, notei em Tumaco a demanda pela implementação da cédula de identificação binacional, de modo que as mulheres, e a população em geral, possam acessar serviços básicos como saúde, moradia e proteção laboral no Equador. De certa forma, isso demonstra que há uma fragilidade maior do Estado colombiano em prover os serviços básicos à população, comparativamente ao Estado equatoriano ${ }^{299}$.

Se inicialmente o processo binacional foi protagonizado pela CANE e o PCN, a partir da primeira década do milênio passa a se dar em um diálogo entre CANE e RECOMPAS.

Perdimos la relación con el proceso binacional y pasaron dos, tres, cuatro años. También paramos los eventos de expresiones negras desde el 2005. Con RECOMPAS estamos desde el 2004. Alli nos enteramos de la existencia de este proceso de RECOMPAS. Había unos chicos que venían bastante aquí a conversar conmigo, que el uno ya está perfilándose a ser dirigente y, como había sido mi alumno, él me venía a contar cosas. "¿Te viniste de Colombia?", me dice: "Sí profe, va haber un evento con el tema de los manglares". Entonces yo le informo a Pablo y le digo: "porque no nos invitan, para nosotros ir porque tenemos años que hemos perdido la comunicación con ellos". Y él me dice: "ellos hablan de una red de Consejos Comunitarios, ellos ya no nacieron más como PCN". Entonces Pablo va y se encuentra con Jorge García que estaba acompañando el proceso de RECOMPAS, que tenía un año que había nacido, y nosotros acá no sabíamos nada. Ahí Pablo ya se conoce con Hilda, ahí nos encontramos al padrino Antonio Alegría. Eran los viejos del PCN pero estaban ahí en RECOMPAS - Inés Morales.

Nesse depoimento, vemos que o papel de Inés Morales como professora articula-se com seu papel como liderança política. Foi a relação com um ex-aluno, que se constituía à época como "dirigente" - ou seja, cabeça do processo organizativo -, que levou ao conhecimento de Inés e outros líderes da CANE a existência da RECOMPAS. Em outras narrativas, no entanto, Inés relata as dificuldades que enfrentou ao conciliar ativismo político

\footnotetext{
${ }^{298}$ Essa possibilidade parece respaldada por um acordo entre os países andinos que estabelece a "tarjeta social andina".

${ }^{299}$ Cada mesa deve fazer uma gestão para seguir trabalhando no intercurso entre as edições do Fórum. A mesa de "Pueblos y etnia", por falta de financiamento, não avançou muito, segundo relatos de dirigentes da RECOMPAS. A mesa de mulheres e equidade de gênero falou sobre a situação específica de mulheres na fronteira. Exigiram um plano de ação com disponibilidade orçamentária tendo em conta o enfoque etário, étnico, territorial e populacional. Além dessas, reuniram-se: Mesa de Juventude, de Governabilidade e Descentralização, de Infraestrutura e Desenvolvimento Econômico, de Cacau, de Coco (que foi tema de uma mesa pela primeira vez em 2012), de Palma Africana, o Comitê Técnico Binacional de Pesca Artesanal (que falou sobre o manejo e controle do recurso concha, enfocando a situação das mães cabeça de família), a Mesa de Turismo e a de Cultura e Esportes.
} 
e docência. Ela narra que a gestão da primeira instituição educativa em que trabalhou não foi capaz de compreender seu fazer político, o que a levou ao Colégio de Carondelet, sua "comunidade", onde foi possível construir um arranjo mais harmônico. Ou seja, a trajetória de construção como matrona é eivada de tensões. Assim como no caso da maternidade, o engajamento em processos educativos locais, ao passo em que abre o caminho para o reconhecimento coletivo, também se tenciona com o exercício político.

Em 2004, a Rede de Conselhos Comunitários recém havia sido criada; acolhia lideranças das veredas que estiveram na gênese do PCN, como Antonio Alegría, do Rio Mira. Trabalhava, naquele momento, temas que anteriormente estavam na agenda do processo binacional, como a defesa dos manguezais compartilhados pelo Equador e a Colômbia. Porém, o fazia com um tônus diferente. Pelo que pude apreender ao longo do trabalho de campo, os diálogos entre CANE e RECOMPAS deixam um pouco de lado a proposta política territorial e passam a focar questões como etno-educação, formação e capacitação de jovens líderes, entre outras. Isso reverbera nas críticas à RECOMPAS, analisadas no capítulo anterior. Tendo em vista o processo binacional, enquanto o PCN concebe a territorialidade a partir de um discurso político da etnicidade, a RECOMPAS tem dificuldades em externalizar uma visão de conjunto dos Conselhos Comunitários e em consolidar uma plataforma étnica.

Recentemente, o PCN retomou os diálogos com companheiras e companheiros afroequatorianos.

En el 2012, Carlito' Rosero vino aquí. Esa noche que discutimos muy fuerte con él. Él ya no hablaba de la construcción de una Comarca Afropacífica entre Colombia, Ecuador y decíamos tenerla hasta Panamá. Él hablaba de una Comarca que venía desde Brasil, involucraba un montón de países. Al menos en la conversación aquí fue así. Le decíamos ¿Cómo íbamos a lograr? Empezar a soñar una cosa tan grandísima que en términos legales para nosotros iba a ser una utopía, un mito... iAh! Él decía que no, que ya tenía hablado, que incluso iban hacer reuniones, dos en cada país durante ese año. Dos veces aquí en el Ecuador, dos veces en Colombia, dos veces en Panamá, él hablaba hasta de Brasil. Pero bueno ¿cómo vas a unir el Pacífico con el Atlántico? Le decíamos... - Inés Morales.

Tive a oportunidade de participar de uma oficina promovida pelo Proceso de Comunidades Negras - PCN, em Tumaco, entre 3 e 5 de dezembro de 2012, que se inscreve nesse momento de retomada do contato do PCN com a CANE. Configurava, ao mesmo tempo, uma reunião binacional da Comissão de Apalencamiento $^{300} \mathrm{e}$ uma oficina sobre a campanha encabeçada pelo PCN “Otro Pazífico es Posible”. Estavam presentes afro-

\footnotetext{
${ }^{300}$ A Comisión de Apalencamiento é um dos espaços em que se constrói a proposta territorial binacional. Além da CANE e do PCN, conta também com a participação da RECOMPAS.
} 
colombianos/as das seguintes regiões: Cauca, Buenaventura, Tumaco (Conselhos Comunitários Bajo Mira y Frontera, Alto Mira y Frontera, ACAPA), de Chocó (Chanco), das Cordilheiras Narinhenses (COPDICONC) e afro-equatorianos/as do Valle del Chota, La Concepción y Salinas, bem como de San Lorenzo.

Eram muitas vozes dissonantes. Não havia unidade sobre a circunscrição da Gran Comarca. Inés Morales, em posição compartilhada pelo tumaquenho Hernan Cortés, ativista do PCN-Colômbia, com base na luta de duas décadas em torno do processo binacional, defendia a proposta inicial do processo binacional. A Gran Comarca Afropacífica abarcaria desde Portete, na Província de Esmeraldas, Equador, até Darién, no Panamá, passando por toda a extensão da costa pacífica colombiana. Em contraposição, ativistas do PCN radicados em Bogotá ou no Norte do Cauca não viam sentido em engajar-se em uma proposta política territorial que não contemplasse seu "território".

A campanha "Otro Pazífico es Posible" também tinha seu conceito debatido: seria ela estendida ao povo afro, "a todos os irmãos e irmãs que sofrem as consequências da diáspora"? Ponderou-se, então, que são realidades muito complexas e que seria melhor concentrar na região colombo-equatoriana. Nesse escopo, lançava-se uma mirada ampliada sobre o Pacífico, para além do corredor litorâneo, agregando áreas como o colombiano Vale do Cauca e o equatoriano Vale do Chota. Por isso a ortografia "Pazífico", que alude a uma amplitude de sentido. Ademais, manifestava-se a expectativa de que a campanha contemplasse o urbano, partindo de uma avaliação de que no rural houve mais avanços do que no urbano. Por fim, o escopo da campanha foi assim formulado: "Campaña Otro Pazífico posible y la Perspectiva Territorial-Ambiental en la década de los Afrodescendientes". Suas principais metas: proteger os direitos coletivos e fortalecer os processos de gestão da territorialidade coletiva por dentro dos Conselhos Comunitários.

Na década de 1990, o Processo de Comunidades Negras inspirou as mobilizações do povo negro do norte de Esmeraldas em torno do conceito de território-região. Já nas duas décadas seguintes, Equador e Colômbia parecem seguir diferentes caminhos na formulação de discursos políticos em torno da etnicidade, da negritude, da afrodescendência e da territorialidade.

O diálogo contemporâneo entre afro-equatorianos e afro-colombianos inscreve-se numa disputa de conceitos que é atravessada pela questão da permeabilidade entre rural e urbano. Ao mesmo tempo em que a vivência da territorialidade se dá por dentro dessa permeabilidade, a fala de Inés Morales indica que há um limite para o prolongamento do 
território. Também relativiza o princípio da solidariedade na luta por direitos dos povos negros de todo o mundo, o quinto princípio de PCN-Colômbia. Inés argumenta que: "si ampliamos demasiado, no avanzamos. Primero luchamos por la Gran Comarca Pacífica, después por la Atlántica. Ningun excluído es excluyente". Ela faz um apelo para a legitimidade de uma luta histórica que se inscreve em um território circunscrito: o corredor Pacífico litorâneo e, dentro dele, mais especificamente, o extremo norte de Esmeraldas, Equador, e o extremo sul de Nariño, Colômbia. Há um debate sobre estratégias de luta: de um lado, uma proposta de unificação; de outro, uma proposta de concatenação de frentes de batalha.

Ao longo dos anos 1990, as formulações ideológicas e políticas colombianas do Processo de Comunidades Negras propuseram um conceito de etnicidade que partia da "lógica do rio" e propunha abarcar toda a coletividade negra. A Lei n. 70, de 1993, materializa em grande medida tais formulações, usando o vocabulário político da etnia. Porém, seu texto é restritivo, na medida em que circunscreve o sujeito de direitos às comunidades rurais das ribeiras dos rios do Pacífico. $\mathrm{Na}$ minha percepção, contemporaneamente, a voz negra urbana se alça e busca caminhos para se inserir cabalmente dentro do discurso da etnicidade/negritude. Deparei-me uma série de vezes com a avaliação de que houve mais avanços no rural do que no urbano. Essa leitura apareceu em Tumaco e em Bogotá; em falas públicas em eventos sobre afrodescendência e etnicidade, em diálogos intimistas.

No caso do norte de Esmeraldas, desde o fim da década de 1990, existe uma proposta política territorial bem definida, direcionada à organização e à luta do povo afro, válida para todo o território equatoriano, naqueles pontos onde há concentração negra.

Empezamos a motivar a nuestra gente en el tema de defender el territorio desde la posición donde estábamos, que si tú estás en Guayaquil ahí hay una comarca, ahi hay un territorio donde tienes derechos. Ahí es que todo el mundo decía: "somos la Comarca, somos el Palenque. Hablemos de un Palenque en Quito, de la Comarca en Guayaquil". El maestro Fabio decía: "donde hay la presencia del pueblo negro ahí está su Comarca, su Palenque” - Inés Morales.

Trata-se de uma concepção de território posicionada. Os direitos emergem do lugar de fala. Todos são palenques, todos são comarcas. Mas cada foco de presença negra constitui um palenque, uma comarca. Paralelamente, há um discurso que articula a linguagem de raça e a de etnia, cuja materialidade se visibiliza no Plan Plurinacional contra la Discriminación Racial y la Exclusión Étnica y Racial. 


\section{Movimento de MulHeres Negras do NORTE de ESMeraldas (MOMUNE)}

A criação de MOMUNE está inscrita em um cenário de mobilização em defesa do território ancestral, sobre o qual falei nas sessões anteriores, e um cenário de mobilização de mulheres negras ou afro-equatorianas. Em 1999, ocorreu o I Congresso Nacional de Mulheres Negras, realizado em Ambuqui, no Valle del Chota, La Concepción y Salinas, cujo lema era "Buscando voces de mujeres que rompan el silencio". Nessa ocasião, houve participação das "mulheres da Comarca". Aí estavam Inés Morales, Amada Cortez, entre outras. No ano seguinte, 2000, essas mulheres formaram a primeira organização de mulheres negras do extremo norte de Esmeraldas. Chamava-se Asociación de Mujeres Negras María Illescas, em referência à filha de Alonso de Illescas, uma mulher "mulata", em um esforço consciente de visibilizar nomes que a história nunca havia posto à luz. Quando havia muitas mulheres de San Lorenzo agregadas na Associação, elas se articularam com outras dos cantões de Eloy Alfaro e Río Verde, ambos da região norte da província de Esmeraldas.

Eso fue ya cuando entramos al tema de mujeres, cuando yo ya fui palenquera mayor, claro que habíamos mujeres participando, pero era poca la participación. Bueno, en la medida en que ya en el país se hablaba el tema de género, de mujer, entonces yo empecé a plantearlo al interior de la Comarca - Inés Morales.

Entre 2001 e 2005, Inés Morales foi Palenqueira Maior da Comarca Afro-Equatoriana do Norte de Esmeraldas (CANE), título pelo qual é conhecida ainda hoje no cenário do movimento afro-equatoriano. Segundo conta, naquele momento sentiu a necessidade de constituir espaços próprios de mulheres dentro da Comarca, espaços de debate e reflexão das mulheres palenqueiras. Isso foi possível tendo em vista a configuração de um cenário nacional em que o gênero passou a ser uma questão. Rememorando diálogos que teve à época com Pablo de Torre, mais um dos fundadores da Comarca, Inés relata que houve resistência dos companheiros homens. Ele dizia: "mucho cuidado. Ustedes van a volverse solamente mujeres, por ser mujeres y para las mujeres". Questão que Inés contestou: "en el proceso no queremos solamente pensar de nosotras para nosotras, pero pensar desde nosotras para el conjunto de la comunidad".

Sob a ótica masculina, o movimento das mulheres da Comarca era um tipo de separatismo; já sob a perspectiva delas, tratava-se de uma visão feminina sobre a coletividade negra, uma visão crítica ao sistema machista, a qual os homens não eram capazes de fazer. Como explica Amada: “no es ninguna pelea de la mujer con el hombre. Es una pelea del 
sistema". Vale ressaltar, mais uma vez, que a luta de mulheres negras é uma luta pela coletividade negra. A diferença de perspectivas novamente demonstra o contraste entre a pluralidade do eu feminino e o masculino unitário. Os homens da Comarca tiveram dificuldades para entender que a mobilização daquelas mulheres era uma mobilização pela coletividade.

O I Encontro do Movimento de Mulheres Negras da Comarca do Norte de Esmeraldas, realizado em 2002, foi um momento marcante nessa mobilização, imbuída de um sentido de pertencimento como "mulheres negras da Comarca"; "pertenencia que hasta ahora tenemos pero ya con una figura organizativa más institucionalizada", como explica Inés Morales. Foram dois anos agregando novos grupos de base de mulheres nos três cantões no norte da província: San Lorenzo, Río Verde e Eloy Alfaro. Paralelamente, formavam-se outros palenques, vinculados à Comarca, como FEDARPOM, FEPALHUM e UONNE.

Em 2004, no II Congresso, o movimento institucionalizou-se como Movimento de Mulheres Negras do Norte de Esmeraldas (MOMUNE), tendo como tônica a temática produtiva, agregando doze "grupos de interesses" de mulheres. Nesse ponto, noto uma semelhança entre o movimento das mulheres do norte de Esmeraldas e o das mulheres do Baixo Rio Mira, que também se organizaram em torno de atividades produtivas. O binômio território-produção expressa sua força, de modo análogo à força que tem a comida como elemento constitutivo da pessoa, em especial da mulher afro-pacífica. Em 2006, o MOMUNE passou a reunir 38 grupos de mulheres dos cantões de San Lorenzo, Eloy Alfaro e Rio Verde. Em 2008 e 2010, dada as dificuldades financeiras, foram realizadas assembleias com um menor número de mulheres.

Nos últimos anos, houve uma desarticulação dos grupos de interesse que compõem o MOMUNE, o que Inés relaciona ao engajamento feminino no trabalho com a palma africana, contextualizado no boom desse empreendimento na região. Segundo argumentam Escobar, Lozano (1996), entre outros autores, o cultivo da palma africana e do camarão representaram a proletarização de mulheres e homens afro-pacíficos. Lozano ressalta que, no caso das mulheres, a entrada na vida proletária incorporou cargas de subordinação anteriormente vivenciadas pelo pertencimento étnico-racial e de gênero. Nas palmeiras, assim como nas camaroeiras, as mulheres desempenham funções consideradas secundárias, de baixa qualificação e recebem remuneração inferior à dos homens. O engajamento nessas empresas desencadeou um arrefecimento das organizações próprias de mulheres ligadas ao MOMUNE. 
Yonny entende que a gestão do presidente Rafael Correa criou um cenário em que cessou o apoio aos processos organizativos, o que permite uma interpretação complementar.

MOMUNE no está activo porque no tiene plata. O mejor, estamos activas porque nos conocen y nos invitan, pero no hacemos encuentros nuestros. CONAMUNE no tiene apoyo. Antes apoyaban las ONG, ahora está correteándolas. El presidente está sacándolas del país. Está asumiendo todo supuestamente el presidente. A él le conviene desorganizar todas las organizaciones. Él quiere tener un solo partido político. Que pesque su canasto - Yonny Nazareno ${ }^{301}$.

Atualmente, continuam mobilizadas as mulheres-cabeça da organização, como Inés Morales, Amada Cortéz, Yonny Nazareno, todas professoras, Sulia Maribal Caicedo, que é funcionária pública, e Mercedez Cortez. O MOMUNE nestes últimos tempos está atuando principalmente casa afuera, como dizem elas.

Proponho, então, uma leitura comparativa entre os processos organizativos que envolvem mulheres negras no Equador e na Colômbia. Como visto nos capítulos anteriores, prevalece o alijamento das mulheres dos postos de liderança nos processos organizativos colombianos, o que se reflete na incipiente formalização de organizações de mulheres, a exemplo da jovem Comissão de Mulheres do Conselho Comunitário Baixo Mira e Fronteira e da ainda mais jovem instância organizativa das mulheres dos Conselhos Comunitários, formada dentro da Rede de Conselhos Comunitários do Pacífico Sul, chamada África Viva ${ }^{302}$.

Já no Equador, parece-me que a presença feminina nas mobilizações em torno da identidade étnica se converteu em ocupação de espaços de poder por mulheres negras, ainda que em minoria, o que se refletiu na consolidação de movimentos de mulheres negras palenqueiras no norte de Esmeraldas. O MOMUNE faz parte da Comarca Afroecuatoriana del Norte de Esmeraldas (CANE). Ou seja, o movimento de mulheres atua por dentro do movimento étnico. Charvet defende que "o discurso étnico tende a subsumir as particularidades de gênero" (Charvet, 2010: 413). Penso que a questão é mais complexa do que isso.

O MOMUNE também integra a Coordinadora Nacional de Mujeres Negras del Ecuador (CONAMUNE). A Coordenação Nacional de Mulheres Negras, por sua vez, foi criada a partir da realização do I Congreso de Mujeres Negras del Ecuador (1999) e realizou encontros em 2002, 2005, 2007 e 2009. Atualmente, tem uma sede em Quito (Casa de

\footnotetext{
${ }^{301}$ Entrevista concedida em 13 de dezembro de 2013.

${ }^{302}$ Essa instância foi criada no fim de 2014, a partir de um projeto desenvolvido pela RECOMPAS com mulheres dos Conselhos Comunitários integrados na Rede, o qual foi financiado pela Colombia Responde, uma agência que opera recursos da USAID em Tumaco. A informação me foi relatada pela representante legal da RECOMPAS, Hilda Nayibe Hurtado.
} 
Iemanjá), além de casas-abrigo e casas culturais, chamadas Casas das Mulheres Negras, em mais dez locais, entre as cidades e comunidades rurais: Pichincha, Esmeraldas, Guayas, El Oro, Imbabura, Carchi, Los Ríos, Sucumbíos, Orellana y Pastaza. Em Esmeraldas, a Casa das Mulheres Negras da CONAMUNE é a sede do MOMUNE, que fica no bairro Magdalena, próximo ao cemitério de San Lorenzo, e se chama Casa de Obatalá ${ }^{303}$.

Entre as frentes de atuação do MOMUNE, vale destacar a "construção de uma nova cultura de masculinidade e feminidade afro-esmeraldenha", ação que partiu, segundo Inés, de uma percepção de que as mulheres tinham uma responsabilidade demasiado forte no âmbito dos afazeres domésticos. Nesse contexto, julgou-se relevante estimular a corresponsabilidade: que os homens assumissem seu papel e que as mulheres compreendessem que os afazeres têm de ser compartilhados. O objetivo era uma mudança de perspectiva a partir das novas gerações, "enseñar a nuestro hijos". O financiamento do Fundo de Igualdade de Gênero da Agência Canadense de Desenvolvimento Internacional (FIG-ACDI), em 2006, viabilizou um projeto de pesquisa nessa temática ${ }^{304}$. Um dos resultados deste projeto é o livro Feminidad y Masculinidad en la Cultura Afroecuatoriana. El caso del norte de Esmeraldas, assinado por Erika Silva Charvet, que coordenou a referida pesquisa (Charvet, 2010). Nas duas atuações apontadas, estão presentes os componentes étnico e de gênero.

As relações entre etnicidade e gênero leva-nos de volta à crítica das afro-tumaquenhas de Conselhos Comunitários à Mesa Municipal de Mulheres de Tumaco e a outras organizações de mulheres tumaquenhas. A luta das mulheres dos Conselhos Comunitários e das mulheres da Comarca é indubitavelmente uma luta por equidade de gênero, em minha visão. Em várias narrativas, foi possível observar como essas mulheres têm uma perspectiva crítica sobre a opressão de gênero que vivenciam, seja nas relações afetivas, seja no processo organizativo. Porém, trata-se de uma luta por equidade de gênero protagonizada por mulheres que estão territorializadas. A perspectiva territorial é intrínseca à perspectiva de gênero.

É por se tratar de uma mirada territorializada sobre o gênero, que a Comissão de Mulheres do Conselho Comunitário do Baixo Rio Mira não pode ser uma pessoa jurídica, já que ela atua por dentro do Conselho Comunitário do Baixo Rio Mira, o qual já possui a sua junta diretiva. É também nesse sentido que compreendo a escolha das mulheres negras de San

\footnotetext{
${ }^{303}$ Em agosto de 2012, a Casa de Obatalá foi roubada e levaram todos os equipamentos. Inés conta que esse episódio desmotivou as mulheres, que anteriormente iam sempre à Casa e lá guardavam os materiais coletivos. Também recebiam nesse espaço mulheres afro-colombianas refugiadas. Atualmente, vivem três jovens colombianos para manter a casa ocupada.

304 “Construyendo una cultura de masculinidad y feminidad afro, con perspectiva de gênero y equidad en las relaciones de convivência y participación social, política, cultural y económica en la comarca y anexos”.
} 
Lorenzo por criar um movimento de mulheres no âmbito da Comarca Afroecuatoriana del Norte de Esmeraldas. Enquanto outras organizações de mulheres afro-equatorianas, espelhando-se na Coordenação Nacional de Mulheres Negras no Equador, fundaram a Coordenação de Mulheres Negras em Carchi (CONAMUNE-Carchi), a Coordenação de Mulheres Negras em Imbabura (CONAMUNE-Imbabura), aquelas do norte de Esmeraldas fundaram uma organização de mulheres negras "da Comarca”. Essa organização, que assumiu a identidade de MOMUNE, está vinculada à Coordenação Nacional de Mulheres Negras no Equador e com ela dialoga, mas nasce dentro da Comarca. O território do Norte Esmeraldas é o contexto do MOMUNE. São mulheres palenqueiras, são mulheres da Comarca.

Tal perspectiva de gênero não necessariamente conflui com a agenda de gênero da cooperação internacional, aliada com instituições governamentais equatorianas e colombianas, muito presentes no território fronteiriço em foco. Foi a agenda de gênero da cooperação internacional que informou a pesquisa coordenada por Erika Charvet. Na minha percepção, essa agenda agregou uma questão interessante, especialmente no contexto tumaquenho, qual seja, a exigência de mulheres nas juntas diretivas das organizações afro. Por outro lado, há uma crítica dura na narrativa de mulheres com quem dialoguei sobre a cooperação interacional, da qual compartilho. Elas denunciam que a atuação da cooperação internacional alija as mulheres afro-pacíficas da luta das "comunidades negras" e interfere no protagonismo delas dentro de seus territórios. Como coloca Inés Morales:

Cuando la cooperación internacional llega nosotras ya estábamos, ya habíamos nacido. Nos tenían como facilitadoras para acceder a las mujeres, para nos decir cosas que ya antes decíamos que era asi que queríamos hacer. O, por ejemplo, nosotras decíamos: San Lorenzo necesita eso. Y en la hora de ejecutar ya no éramos nosotras, buscaban el gobierno local - Inés Morales.

Nesse sentido, organizações de mulheres negras são instrumentalizadas por agências da cooperação internacional, servindo como porta de entrada para o Pacífico Negro, porém a execução e a gestão de recursos não passam por elas. Há queixas também quanto ao processo de visibilização dos resultados de ações feitas em parceria com a cooperação internacional. É o caso do livro Feminidad y masculinidad en la Cultura afroecuatoriana. El caso del norte de Esmeraldas, assinado pela pesquisadora serrana, contratada pela cooperação internacional. A obra menciona de forma secundária a participação das mulheres do MOMUNE na realização da pesquisa, enquanto essas mulheres veem sua participação como aspecto-chave na consolidação do projeto. 
Existem tensões entre a dimensão étnica e a de gênero, as quais, por vezes, estão em disputa dentro do movimento afro-equatoriano/afro-colombiano, o que fica explícito em depoimentos como o de Eva Lucia, apresentado no capítulo anterior, e outros apresentados ao longo deste capítulo. A questão é como a análise antropológica ou sociológica apresenta essas tensões. O que pude compreender etnograficamente é que as mulheres afro-colombianas e afroequatorianas que participam dos processos organizativos de cunho étnico não abrem mão da dimensão de gênero, disputando conceitos e rumos dentro desses processos a partir de seu lugar como mulheres.

Ao mesmo tempo em que essas mulheres encontraram um caminho na constituição de movimentos de mulheres negras territorializadas, elas não deixam de fazer parte do movimento afro/negro, tampouco do movimento de mulheres, concebido em sua amplitude. Trata-se de uma fluidez identitária. Elas estão em todos esses movimentos. Assim como a água, possuem uma capacidade de penetrar em muitos campos identitários e de atuação política. É a força das águas, que entra e ocupa o espaço. Ela é permeabilidade, mas também tensão. Pode ser leito liso, ou cascata; caudal ou abismo, loca, grota seca. Assim como os rios, as matronas manifestam o atributo do acolhimento, mas também da disputa, da contravenção e da incerteza. 


\section{CAPÍTUlo 5 - As ÁGUAS DeSCANSAM NO MAR}

No capítulo final desta parte, passearemos novamente pelo Rio Patía, porém o cenário principal é Palma Real, que, desde 1941, é a cabeceira da paróquia Ancón de Sardinas ${ }^{305}$, cantão de San Lorenzo, província de Esmeraldas, Equador. O Professor Humberto Perea conta que o surgimento de Palma Real se deu em torno das águas. Segundo ele, as mulheres que viviam em Casa Vieja, povoado colombiano, iam frequentemente à região de Palma Real para lavar roupas, em um poço de água doce que ali se situava. Nessa época, entre os anos de 1848 e 1857, em Casa Vieja, o mar avançava sobre a terra, encantoando a população e comprometendo a permanência no local, o que levou esse grupo à Palma Real, não só para lavar roupa, como também para viver. Assim, famílias colombianas e equatorianas, "de la costa arriba y de la costa abajo", foram se agregando na região. A família do professor e diretor da escola é colombiana, uma das primeiras a povoar o local. Ao lado do poço de água doce, havia uma imponente palmeira. Como conta o Professor, "dice que Palma Real nace porque habia acá una palma y era real"306.

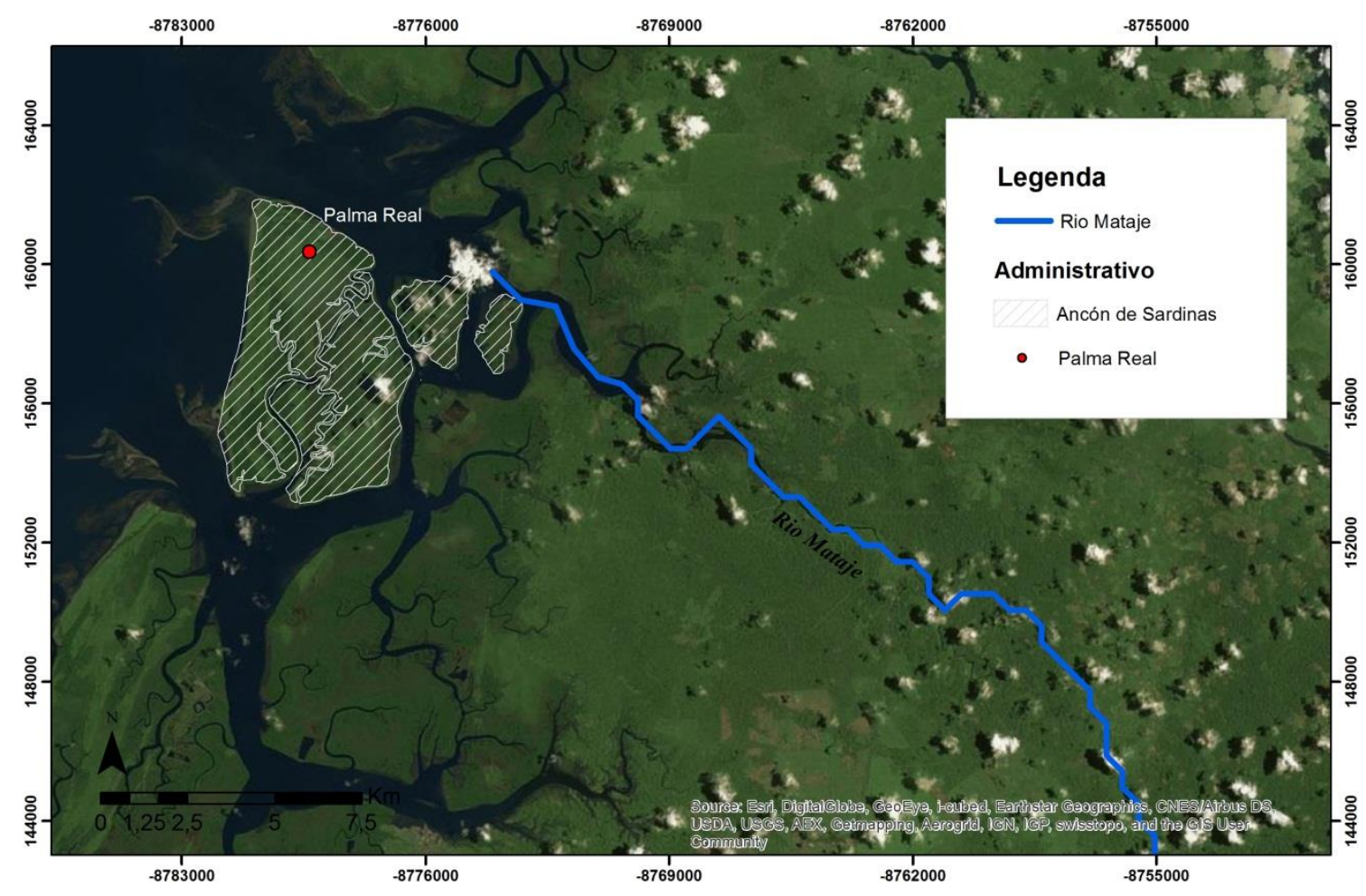

Figura 15 - Mapa do Rio Mataje

\footnotetext{
${ }^{305}$ A paróquia Ancón de Sardinas abriga os seguintes recintos: Pichangal, Changuaral, El Cauchal, San Pedro, El Viento, El Brujo e La Lagartera, La Punta e La Vuelta.

${ }^{306}$ Entrevista concedida em 06 de novembro de 2012.
} 
Situada no ponto de fronteira entre os países em foco, desde a sua fundação até a contemporaneidade, Palma Real é palco de fluxos constantes entre equatorianos e colombianos, seja na dimensão demográfica, afetiva, econômica, política. Vivem aí 1.735 pessoas, sendo 827 homens e 906 mulheres. 95\% da população é afro-equatoriana e 5\% "mestiça" 307 . Segundo informações locais, em Palma Real a população soma cerca de 800 famílias, residentes em aproximadamente 200 vivendas. A eletricidade permanente recentemente chegou ao povoado, no mês de outubro de 2012. Funcionam linhas de telefone fixo do Equador e linhas de celular e internet da Colômbia.

O acesso é por água, sendo a principal via de ingresso à Paróquia um cais de concreto, na desembocadura do Rio Mataje. As águas cobrem grande parte da superfície de Palma Real $^{308}$. Assim, as pessoas movem-se principalmente em embarcações ${ }^{309}$. Quando há ocorrência prolongada de chuvas intensas, pode haver inundações, em razão da dificuldade de drenagem da água, provocada principalmente pela ação local sem planejamento. Do cais, segue uma rua principal, da qual se desdobram nove ruas, a maioria de palafita. Os corredores de palafita dão acesso a casas de madeira, também palafíticas, com tetos de placas de zinco.

A narrativa local e os dados do município de San Lorenzo coincidem em apontar a coleta de conchas e a pesca como principais atividades laborais dos moradores de Palma Real. São também as principais fontes de renda na paróquia. As águas, pacíficas e fluviais, são o esteio desse povo. Nota-se que a maior parte do território, cerca de metade da área da paróquia, é composta pelos manguezais ${ }^{310}$.

A conchería configura atividade eminentemente feminina. Rosalba recorre à tradição para explicar a divisão do trabalho nas "comunidades de mar": "los hombres pescan, las conchas es mujer. Las conchadas es pura mujer. Sacar la concha, churros, eso son las mujeres. ¿Será la tradición o la costumbre? Tradición, es por la tradición”. Ou seja, o mar é masculino e o mangue, feminino. Nesse universo, homens e mulheres circulam, porém, por circuitos diferentes. Os homens seguem mar adentro para pescar, as mulheres se embrenham nos manguezais para conchar. Essa é a tradicional divisão sexual do trabalho. Contudo,

\footnotetext{
307 Dados do Município de San Lorenzo, 2010. Nesse levantamento, não foram contados os habitantes colombianos, porém, segundo estimativas de Targelia Micolta cerca de $40 \%$ da população de Palma Real provêm da Colômbia, sendo que muitos já adquiriram nacionalidade equatoriana.

${ }^{308}$ Os rios Mataje e Changuaral ocupam quase toda a área de Palma Real, ambos desaguando no mar. Além deles, banham essa paróquia os esteiros La Miguelo e La Corocera, bem como o canal La Caida.

${ }^{309}$ Além da zona fluvial, há uma via marítima com extensão de $16.5 \mathrm{~km}$, que une Cabeceira Paroquial e Recintos, bem como manguezais e outros locais.

${ }^{310}$ Ancón de Sardinas é uma zona rural com área total de 6.125,796 hectares, da qual 3.320,9604 hectares são manguezais.
} 
contemporaneamente, homens também concham. Charvet (2010), a partir de pesquisa recente na localidade de Palma Real, observou que há um manejo diferenciado dentro dos próprios manguezais: enquanto os homens mariscam nas margens, as mulheres o fazem no centro do mangue. Conversando com as mulheres concheiras, não pude confirmar etnograficamente essa observação.

\section{A RevoluÇão do Cemitério}

Ya. Nosotros íbamos a conchar agua de mañana. Cuando viene la gente, todos que con miedo. ¿Y qué les pasa? En el cementerio hay hombres armados y han puesto un letrero que dice "prohibido conchar". Entonces ahi ya cuando la gente se dio cuenta que iban a hacer la camaronera, vinimos, ya hablamos al pueblo, el pueblo ya fuimos. Igual estaban ahi que no podíamos pasar porque allí tenían las máquinas encima del cementerio para botar los muertos al agua. Entonces nos fuimos a San Lorenzo, a la capitanía del puerto y ninguno nos escuchó. Entonces ahí comenzamos a hacer grupo, ¿ya? Grupo de mujeres, de hombres, de todo, ya nos fuimos al cementerio. Ya nos paramos que ahí no podían hacer camaronera porque teníamos nuestros muertos. Eso aquí el pueblo se levantó contra ellos - Targelia Micolta ${ }^{311}$.

Targelia explicou-me que a família Carbache tinha terras ao pé da região do Cemitério, porém, não tinha título do terreno, como de costume à época. Isso porque, até a década de 1990, a propriedade se estabelecia pela ocupação da terra. "Si yo topaba un firme, yo me hacía una casita ahí, o sea que eso era mío". Não havia formalização legal do usufruto da terra, mas, sim, um acordo entre a coletividade local sobre sua gestão. Nesse momento, que ficou conhecido como a "Revolução do Cemitério", houve dissenso na coletividade.

Aquí nos dividimos, el bando de acá dentro opuesto a las camaroneras, y los de afuera, que nosotros le decimos, faltos de conocimiento. Nosotros acá en el centro éramos una sola voz. Aquí no hay otra fuente de trabajo. Toda la vida ha sido la pesca y la concha, es nuestra fuente de vida ¿por qué la vamos a dejar derrocar? Porque si derroca los manglares estamos acabando con todas las especies - Mérice Bengera ${ }^{312}$.

Nessa disputa, foram vitoriosos os defensores dos manguezais. Com base no acordo coletivo sobre a gestão da terra, os moradores de Palma Real contrapuseram-se à família que havia vendido sua parcela à empresa de criatório artificial de camarão, argumentando que se

\footnotetext{
${ }^{311}$ Entrevista concedida entre 5 e 6 de dezembro de 2012.

${ }^{312}$ Entrevista concedida em 18 de dezembro de 2013. As demais falas de Mérice Bengera citadas ao longo do capítulo são da mesma entrevista.
} 
tratava de um bem coletivo. Diziam que essa família havia vendido sua consciência e que os manguezais são a fonte de riqueza da coletividade negra. Novamente há uma leitura racial do quadro. Targelia explica que os investidores do cultivo do camarão, brancos, compram uma pequena porção da terra, porém, apropriam-se de áreas maiores. Aproveitam-se da mão de obra negra pouco valorizada e, quando o empreendimento gera lucros, quem ganha são os brancos, enquanto os negros ficam sem renda e sem os manguezais. E assim a peleja foi resolvida: "Ilegamos al cementerio. Ya se hablaron, ya llegamos a un consenso, ya ellos cedieron y ya se fueron. No hubo sangre, no hubo matanza. No hubo nada",313.

El manglar es la cuna de los moluscos, de los peces, de las especies. Por eso el manglar no debe de desaparecer. Porque en el manglar es donde los pescados, cuando van a tener su bebe, se van allá por las quebraditas. Allá desfogan, dice uno. Eso es parir. Entonces echan su semillita y la dejan allá, donde no las atropelle lo grande acá del mar. Cuando los pescaditos están más grandecitos salen de esos anegadales y empiezan bañando más afuerita, más afuerita, hasta que ellos también salen a bañar con los otros pescados. En el manglar: la concha, en el manglar; el cangrejo, en el manglar; los churros, todo eso se da en los manglares. Entonces por eso es una cosa muy importante en nuestro territorio. El manglar es importante $y$ necesario - Rosalba Quiñones.

Como se vê nos depoimentos, há uma atitude de cuidado com os manguezais, fonte de vida para todos no Pacífico colombo-equatoriano: peixes, camarões, pianguas, mulheres, homens e crianças que deles se alimentam, direta ou indiretamente. Isso porque a extração de concha é a atividade que gera circulação de mercadorias. Antigamente, a concha, ou outro molusco, funcionava como moeda. Ainda que não seja mais usada como moeda, é o recurso da venda da concha que fomenta o comércio local.

Hablemos de unos quince años atrás, por lo menos los días de lluvia yo me lo hartaba con mis hijos a canalete, y me iba aquí allá, al otro lado. A Casa Vieja. Todo ese barrial ya con mis hijos. Yo traía media canoa de ostión. Pero eran unos grandes, ¿sí o no, comadre? Yo llegaba aquí, le sacaba a mis vecindades. Cuando no tenía plata, mandaba a la tienda, aquí a donde el finado Samuel, y allá me mandaban mi arroz, mi azúcar, mi sal, todo me mandaban. O sea que había como un intercambio todavia - Targelia Micolta $^{314}$.

Os depoimentos mostram também uma consciência de que o bem-estar dos humanos, animais e vegetais está diretamente relacionado ao bem-estar dos manguezais. Eles são "os donos de toda a natureza", nas palavras de Merice. Reitero, portanto, que se trata de uma

\footnotetext{
${ }^{313}$ Targelia Micolta. Entrevista concedida entre 5 e 6 de novembro de 2012.

${ }^{314}$ Entrevista concedida em 29 de dezembro de 2013.
} 
interação particular entre natureza e humanidade; ambas são concebidas em relação. Tal concepção e vivência, ainda que possa ser atribuída à coletividade afro-pacífica como um todo, tem muito das mulheres afro-pacíficas. Enquanto os homens tomam o mangue como fonte de recursos, tais quais a madeira ou o pescado, as mulheres referem-se à importância dos manguezais como fonte geradora de alimentação e renda para suas famílias; como fonte de vida. Como bem observa Charvet (2010), há uma identificação pessoal das mulheres com o mangue.

O cultivo do camarão em cativeiro está em absoluta contrariedade com essa relação. Exige apropriação privada da costa, em contraposição à gestão coletiva do território, e provoca a devastação dos manguezais, impedindo a população concheira de trabalhar em áreas nas quais tradicionalmente mariscam. As camaroeiras, cujo boom expansivo se deu entre 1987-1991, foram centrais na degradação ambiental dos manguezais. Em 1969, foram registrados 32.039 hectares de mangue na província de Esmeraldas. Em 1995, o número se reduziu para 23.799 ha. Ao final dos anos 1990, 80\% dos manguezais esmeraldenhos estavam devastados (Charvet, 2010: 128).

A intervenção das indústrias camaroneiras e os consequentes impactos de tais intervenções sobre os manguezais motivaram a organização comunitária em Palma Real. O grupo composto para dialogar com a empresa no episódio narrado por Targelia, que tinha cerca de 50 mulheres, homens e crianças, transformou-se na Asociación de Recolectores de Productos Bioacuáticos del Manglar Palma Real, cuja pessoa jurídica se formalizou em 1992, inicialmente presidida por Humberto Perea; em seguida, por Mérice Banguera; e, posteriormente, por Targelia Micolta, que, em 2013, levava quatorze anos na presidência.

Foram paralelamente desencadeados processos organizativos locais e regionais. $\mathrm{O}$ cenário de luta das comunidades em defesa de seus ancestrais manguezais tem como marco a criação do Comité de Desarrollo de las Comunidades Fronterizas, também no fim dos anos 1980. Nesse contexto, Charvet (2010) ressalta o protagonismo de lideranças femininas, as quais, em Palma Real, de modo geral, participam das organizações comunitárias com mais intensidade que os homens ${ }^{315}$.

Aproximadamente em 1995, o Comitê desarticulou-se, dando passo à criação da Asociación de Grupos Organizados Comunitarios Recolectores del Manglar (AGROCREM). Nesse momento, formalizaram-se os grupos locais de concheiras e concheiros, como explica Humberto: "allí con AGOCREM se forman las Asociaciones de Productos Bioacuaticos del

\footnotetext{
315 Além de sua pesquisa etnográfica, a autora baseia-se em dois estudos de casos realizados em Palma Real em 1996 e 1998, os quais ressaltam a centralidade do papel econômico das mulheres na manutenção do lar.
} 
Manglar Palma Real, Pampanal, Tambillo y Changal y así, todas las organizaciones ya se forman con AGOCREM"316. A Associação de Palma Real, ou grupo de concheiras, como é mais conhecida, atualmente agrega 42 pessoas, sendo $70 \%$ mulheres e $30 \%$ homens, aproximadamente.

A AGOCREM transformou-se em seguida em Federación de Recolectores Artesanales de Productos del Manglar (FEDARPOM), em San Lorenzo, formalizada em 1998. Agregando atualmente 25 organizações de base do cantão de San Lorenzo, os principais obstáculos são os mesmos do momento inicial de mobilização comunitária em Palma Real: a presença de empresas multinacionais camaroeiras, bem como palmicultoras. Na mesma época, em Eloy Alfaro/Limones, surgiu a Federación de Asociaciones de Recolectores de Productos Bioacuáticos y Naturales (FEDARPROBIM). Ambas as federações são palenques da Comarca Afro-Equatoriana do Norte de Esmeraldas (CANE) ${ }^{317}$.

Targelia fala sobre esse amálgama de organizações usando o rótulo genérico de Organizações Não Governamentais e comenta também que instituições públicas paralelamente atuaram nesse contexto. As narrativas ressaltam, por exemplo, o Programa de Manejo de Recursos Costeiros (PMRC), organismo adscrito ao Ministério de Indústria, Integração e Pesca. Algumas instituições governamentais, por sua vez, contavam com apoio financeiro de organismos internacionais, especialmente voltados à proteção e à defesa do meio ambiente. É o caso da Proyectos de Apoyo al Pescador Artesanal (PRAPESCA), como resgata na memória Humberto Perea, uma organização voltada para apoiar pescadores $\operatorname{artesanais}^{318}$. Assim como no Pacífico colombiano, também houve no Pacífico equatoriano uma entrada massiva da cooperação técnica internacional, com o discurso de conservação da biodiversidade e do desenvolvimento sustentável.

Ainda que mencionem os apoios institucionais, as narrativas de Targelia, de Mérice e de Humberto ressaltam que a mobilização inicialmente se autofinanciava e se articulava com o processo organizativo nos rios, sobre o qual falei nos capítulos anteriores.

$Y$ nosotros llevábamos su cobija de su casa y su toldo. Ya ahí las comunidades llevaban la comida. Nosotros, como éramos acá de la mar, llevábamos las conchas, llevábamos el pescado. De San Lorenzo las otras compañeras llevaban también lo que era el azúcar, lo que era arroz, lo que era aceite. Eso así, le hacíamos grupos e íbamos de cada comunidad para poderle hacer grupo, llevar todo y hacer el nombre de CIDESA y

\footnotetext{
${ }^{316}$ Entrevista concedida em 18 de dezembro de 2013.

${ }^{317}$ Ver Anexo III - Organizações Negras no Norte de Esmeraldas.

${ }^{318}$ Tratava-se de um projeto de cooperação entre Equador e Alemanha, liderado por VBet, Peter Pehen.
} 


\section{AGOCREN. O sea que nosotros venimos luchando desde abajo, ¿ya? - Targelia Micolta ${ }^{319}$.}

Nessa época, chegavam a reunir-se em torno de cinquenta localidades. Do norte de Esmeraldas, a luta avançou para outras regiões do país. Mulheres como Targelia e Inés Morales, às vezes carregando seus filhos caçulas Elvia e Chunchi, foram a Muisne, a Costa Rica (fronteira do Equador com Peru), a Rocafuerte, em enfrentamentos diretos com as indústrias camaroneiras, em apoio aos povos marisqueiros de outras províncias equatorianas ao longo da costa pacífica.

A luta em defesa dos manguezais no extremo norte de Esmeraldas culminou com a criação da Reserva Ecologica Manglares Cayapas Mataje (REMACAM), correspondente a 51.300 hectares da Baía de Ancón de Sardinas ${ }^{320}$. Criada em 1996 como área pública, não é passível de titulação, mas, sim, de concessão de uso. Porém, a reserva foi apenas decretada; não foi acompanhada de uma política de sustentabilidade do território. Humberto Perea comenta que a reserva foi criada sem fundos para corrigir o corte indiscriminado de árvores dos manguezais, para a contratação de guarda-parques, assim como para barrar a construção de camaroeiras dentro da área. O Estado reconheceu concessões às indústrias camaroneiras que já vinham explorando certas áreas, permitindo sua permanência dentro da reserva. No caso da região de Palma Real, conforme indica a memória de Targelia, seguiram atuando as empresas Barrial Alto e Puerto Azul.

Três anos depois de criada a REMACAN, em 1999, o Decreto Executivo n. 1102 proibiu a ampliação das atividades de indústrias camaroneiras e possibilitou a concessão de áreas de mangue a "comunidades ancestrais". Foram concedidos 1.057 hectares de mangue para manejo por dez anos à Asociación de Artesanos Afroecuatorianos Recolectores de Productos Bioacuáticos del Manglar Palma Real ${ }^{321}$. Segundo Targelia, como "guardiã" da Reserva, a Associação tem como função fiscalizar e garantir a não derrubada das árvores dos manguezais, que não se vendam as terras, não se permita a exploração do mangue pelas indústrias camaroneiras, tampouco para se fazer carvão.

Nota-se que a categoria presente nas narrativas de Palma Real é a mesma usada por Pazmiño quando analisa o processo desencadeado pelo Estado colombiano com a Lei n. 70,

\footnotetext{
${ }^{319}$ Entrevista concedida entre 16 e 18 de dezembro de 2013.

${ }^{320}$ Com apoio de FEDARPOM visitei cinco comunidades ligadas à Federação onde estão presentes grupos de mulheres concheiras: Campanita, Palma Real, El Viento, Tambillo e San Antonio, todas elas localizadas na REMACAM.

${ }^{321} \mathrm{O}$ mesmo aconteceu com as demais associações abrangidas pela Reserva. Cada uma delas tem uma área da REMACAN sob custódia.
} 
de 1993, que, na visão do autor, converteu as organizações étnicas em "guardiãs da natureza" (Pazmiño, 2003: 21). A centralidade da dimensão ambiental permite estabelecer um paralelo entre os processos de reconhecimento e titulação de territórios coletivos pela colombiana Lei n. 70 e os processos de concessão de uso dos manguezais à associação de marisqueiras afroequatorianas. Creio que a ênfase na questão ambiental não necessariamente representa um problema, já que a coletividade afro-pacífica se reconhece como "guardiã" dos manguezais. O problema reside na contradição do Estado que, ao mesmo tempo institucionaliza essa peculiar relação entre coletividade negra e natureza e avaliza, dentro dos territórios negros ancestrais, a presença do grande capital, imbuído de uma lógica de intervenção à natureza diametralmente oposta à lógica ribeirinha afro-pacífica.

A cada dez anos, o Ministério do Meio Ambiente equatoriano faz nova medição dos manguezais e emite nova concessão de uso. Segundo conta Targelia, na avaliação realizada em 2009, a área da Asociación de Artesanos Afroecuatorianos Recolectores de Productos Bioacuáticos del Manglar Palma Real foi reduzida para 1.027ha. Isso porque, na medida em que cessou a atividade das camaroneiras e prevaleceu a lógica ribeirinha na interação entre humanos e natureza, o mangue recuperou-se e houve ampliação das áreas firmes, de bosque, e consequentemente redução das áreas inundáveis, dos manguezais.

\section{A MARISCAGEM}

Na vivência da territorialidade em Palma Real, assim como na Zona 4 do território da ACAPA, na desembocadura do Rio Patía, os manguezais desempenham um papel central. As práticas de gestão coletiva do território referem-se basicamente a eles e ao oceano. Áreas de moradia são familiares. Em ambas as localidades há uma lógica de manejo dos manguezais, que é seletivo e rotativo, como explica a família concheira de Salahonda, Puertocarrero.

Marien: uno concha por dos días, ahí no conchamos más. Al otro día vamos vuelta y ya no vamos ahí.

Gerson: para que el conchero reúna conchas.

Paula: o sea se va un día, al otro día se puede ir al mismo sitio, después ya se deja descansar. ¿Y cuánto tiempo toca dejar descansando hasta que se vuelva?

Segunda: cuando vuelva la puja 
Gerson: digamos si estamos sacando conchas en esta puja le damos una semana y la otra puja ya no vamos, esperamos que se reúna en el conchero $^{322}$.

No caso de Palma Real, segundo informações da concheira Ruth Aida, pode-se trabalhar no mesmo concheiro até três dias, em seguida, ele precisa de descanso. A gestão territorial assume um caráter de grande relevância, já que deve haver acordos entre a população concheira para que a rotatividade funcione, o que nem sempre ocorre.

Estudo realizado junto a concheiras de Santa Rosa (Veach apud Charvet, 2010) observa um sentido de territorialidade definido entre as concheiras de Santa Rosa, que promove o respeito pelos territórios de outras comunidades, bem como ações de proteção do mangue frente à ação ameaçadora das camaroeiras. Também na percepção de Charvet, há um respeito pelos territórios de outras comunidades (Charvet, 2010: 127). Em contraposição, etnograficamente, observei que a gestão territorial dos territórios ancestrais localizados na zona rural sofre intervenções em virtude da presença de marisqueiras, especialmente da zona urbana, tanto em San Lorenzo como em Salahonda e Tumaco. A concheira de Palma Real Mérice diz que a extensão dos manguezais de San Lorenzo não alcança a demanda, já que são muitas as concheiras e concheiros do casco urbano que estão arruinando os manguezais do povoado. Nesse sentido, a permeabilidade rural/urbano interfere na gestão produtiva e ambiental dos Conselhos Comunitários e da REMACAN. Por outro lado, há de se observar que as tensões decorrem do esgotamento do recurso concha, que, por sua vez, é consequência de um problema ambiental.

Por sua vez, a prática da mariscagem no contexto de Palma Real envolve a exploração de manguezais em terras colombianas. Targelia argumenta que: “cuando pasamos aquí del pueblo, pa'llá llegamos a Colombia. No tiene nada que ver con las comunidades. Allá son mangles libres" 323 . Aí entramos na seara das tensões entre os povos fronteiriços. A região a qual Targelia se refere como de "manguezais livres" pertence ao Conselho Comunitário Baixo Mira e Fronteira. E lideranças desse território denunciam, ainda, a exploração indevida de equatorianas/os e de gente da zona urbana de Tumaco de seu território marisqueiro.

Cada concheiro ou raizero, ou seja, cada porção de mangue em que se marisca, recebe um nome, dado pelos grupos de concheiras, o que pode seguir o critério das características

\footnotetext{
${ }^{322}$ Entrevista concedida em 25 de outubro de 2013. As demais falas dessa família citadas ao longo do capítulo são da mesma entrevista.

${ }^{323}$ Entrevista concedida em 29 de dezembro de 2013.
} 
físicas do local ou dos caminhos das águas. Em Palma Real, Mérice Benguera mapeia o território marisqueiro da REMACAN sob custódia da Associação:

Unos cogen para adentro de Changuaran, otros cogen para arriba para el Cementerio y ahí se van dispersando para los manglares. El Bajito. Son los nombres de los esteros: las Ollas, Estero Hondo, las Tablas. Nosotros llegamos por aquí por Changuaran. Hasta el Cauchal, hay un estero. De ahí para acá es Palma Real. Y por acá de Punta de Espada hasta salir a la Bocana, que se sale para El Viento, y para Pampanal. De ahí esa punta a mano derecha de aquí para acá todo eso es nuestro. Pues de aquí hasta Bajo Largo es Ecuador y Changal - Mérice Benguera.

A mariscagem é uma atividade ditada pelo ritmo das águas, especificamente das marés. Segundo West (2000), o mar sobe e desce a cada seis horas e meia. Há um período de oito dias durante o qual sobe mais água relativamente ao que baixa. Isso quer dizer que, a cada vez que a maré sobe, alcança um nível mais alto do alcançado doze horas antes. Esse fenômeno é chamado puja. Seu inverso simétrico é a quiebra, com a mesma duração ${ }^{324}$. Quando a lua está cheia, a maré é alta. Minguando a lua, é época de quebra ou vaciante. Além da lua, outros elementos da natureza são referência para conhecer o movimento das marés. Como diz Ana Granja, "piura es el pajarito que avisa cuando el agua va a subir"325.

Cuando es quiebra el agua sube muy tarde, entonces uno a veces se tiene que venir de noche de allá. Cuando es puja, como el agua amanece grande y va bajando, entonces uno en la mañana se levanta, tipo cinco se levanta, hace su desayuno y su medio día - uno no le dice almuerzo cuando se embarca sino medio día-, hace su medio día y se va temprano. Llega con el agua alta, entonces cuando baja el agua el potrillo queda arriba, cuando sube el agua uno no tiene necesidad de empujar sino que el potrillo está arriba, entonces uno se embarca. Allá el agua sube más rápido que acá, cuando acá está subiendo allá ya está honda. Entonces uno se viene, uno dice acá:- están buenas las aguas - Nidia Granja ${ }^{\mathbf{3 2 6}}$.

Nidia explica a mariscagem conforme a lógica do movimento das marés. Sua descrição refere-se à atividade que se realiza na desembocadura do Rio Patía ao Oceano Pacífico. A população de ACAPA e Salahonda pratica mariscagem em uma área que se estende da Caleta Vereda Viento Libre, pertencente ao município de Tumaco, a Llanaje, vereda pertencente à ACAPA. Uma das áreas mais comentadas quando se fala sobre a mariscagem é a vereda de Carcajal. Já o Cocal, que fica próximo a esse local, é área de concheo. Segundo Ana Granja, Llanaje é a única vereda que contemporaneamente controla o

\footnotetext{
324 "Después de la última llena (o subida de marea) de la puja viene la primera vaciante de la quiebra llamada también "cabeza de agua" por inaugurar el nuevo ciclo con esta primera vaciante" (West, 2000: 49).

${ }^{325}$ Entrevista concedida entre 20 e 28 de outubro de 2013.

${ }^{326}$ Entrevista concedida entre 28 de outubro e 03 de novembro de 2013.
} 
que se passa dentro de seu território. "Ellos dependen del camarón y del pescado. Tienen dinámica propia. Si pescaran esa puja, en la otra no pescan",327.

Há, pois, uma diferença entre o que chamo amplamente de mariscagem e o concheo. No primeiro caso, são vários os recursos hidrobiológicos (moluscos e crustáceos) artesanalmente extraídos: a sangara (Anadera grande), bulgao ${ }^{328}$, pata e' burro, almeja, cholga, cholguilla, rastro de nao, chirripiangua ${ }^{329}$, mejillones, ostión ${ }^{330}$, sarnabi ${ }^{331}$. Mexilhões e sangara são encontrados na praia, enterrados sob a areia. Já a cholga, no manguezal. A chirripiangua, por sua vez, é encontrada na praia e nos manguezais. E a pata'eburro é encontrada na praia, mas em dadas condições da maré, como explica a mãe de Targelia, María Magdalena: "Había una puja que era agua del pata'e burro. Entonces se iban y se fondiaban, zambuídos"332. Alguns desses mariscos podem ser comercializados, contudo, destinam-se principalmente para o autoconsumo. Todos eles são considerados saborosos ao paladar, preparados com sopa con fideos $^{333}$, seco, ceviche. Esse tipo de mariscagem é uma atividade praticada por mulheres. Como diz Ana Granja: “almeja es pura mujer"

O concheo, por sua vez, é a extração artesanal da piangua (Anadera similis), prima da sangara, que também pode ser escrita como changara e jangara, cujo tamanho é superior e cuja concha negra se assemelha à da piangua ou concha fêmea, que tem maior valor comercial. A piangua habita as raízes da Rhizophora mangle e o lamaçal dos manguezais. Desde a década de 1960 até a contemporaneidade, o grande foco da atividade marisqueira é a coleta de pianguas, que têm maior valor comercial que os demais mariscos. O concheo pode ser realizado na puja ou na quiebra. Porém, neste último caso, há algumas exceções, como nos explica Gerson, jovem concheiro de Salahonda: "porque hay quiebras que son muy pequeñas y no podemos nosotros llegar al conchero o de acá no podemos salir, porque, es muy pequeña, no nos da el agua para llegar al conchero".

\footnotetext{
${ }^{327}$ Entrevista concedida entre 20 e 28 de outubro de 2013.

${ }^{328}$ Caramujo.

329 "Hay dos tipos de chirripiangua: la que se asemeja mucho a la piangua y otra que es más larguita que está siempre pegada a la arena. Cuando no está pegada, es que se murió ya”, explica Nidia.

${ }^{330}$ Ostra.

${ }^{331}$ Sururu.

${ }^{332}$ Entrevista concedida entre 16 e 17 de dezembro de 2013.

${ }^{333}$ Feijão.

${ }^{334}$ Entrevista concedida entre 20 e 28 de outubro de 2013.
} 


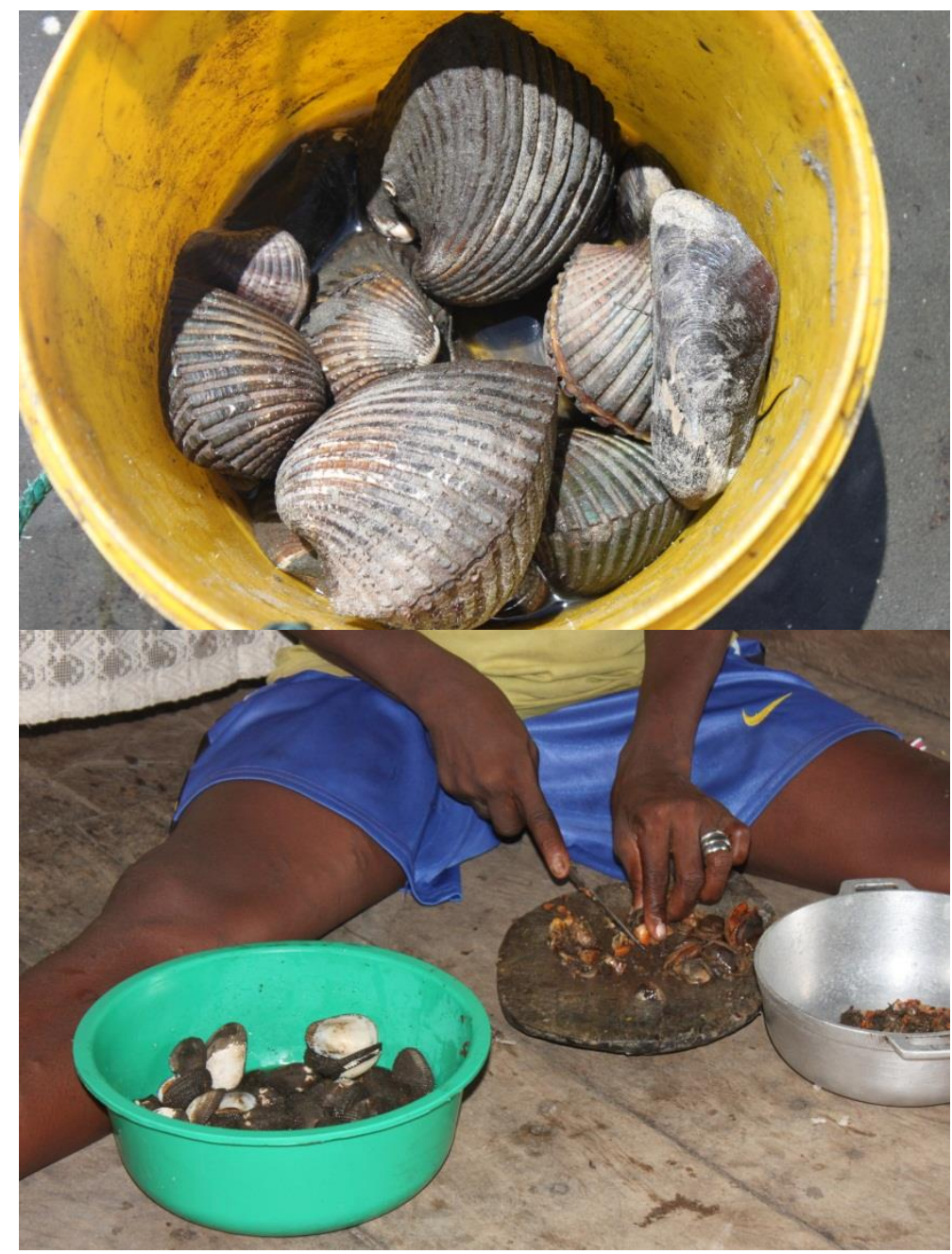

Figuras 16 - Sangara e piangua

Segundo Whitten (1997), a coleta de piangua começou a prosperar na região de San Lorenzo nos anos 1960, quando as viagens entre esse povoado e a capital Quito se tornaram regulares, depois da construção da ferrovia que conecta os dois locais. Antes disso, as conchas eram transportadas em barcos de carga a Limones, Esmeraldas, Manta, Salinas, Playas e Guayaquil (Whitten Jr, 1997[1965]: 88). Na década de 1980, Arocha trabalhou com um grupo de concheiras da zona urbana tumaquenha, do bairro Panamá. Encontrou uma organização social e produtiva muito parecida com a que Whitten descreve a partir de pesquisas realizadas na década de 1960 em San Lorenzo.

O depoimento da mãe de Targelia, María Magdalena, que começou a conchar nos anos 1950, na vereda Puerto Palma, no Baixo Mira, converge com as descrições de Arocha (1986) e Whitten (1997[1965]), ao mesmo tempo, indica as inovações das últimas décadas: “Antes nos íbamos a canalete, hoy día siempre motor. Antes nos íbamos en el potrillo con las 
compañeras, todas de la familia. No me gustaba llevar los niños. Cuando los llevaba no era para trabajar, solamente para acompañar" - María Magdalena ${ }^{335}$.

Antigamente, saía-se para a labuta em canoa a remo. O advento dos motores se deu em fins da década de 1980, segundo cálculos de memória da concheira de Palma Real Mérice Bengera. Se a composição do grupo concheiro mudou, contemporaneamente, o concheo segue sendo uma atividade eminentemente coletiva.

Marien: uno solo no puede conchar, no. Es haciéndole compañía.

Paula: ¿por qué Marien?

Marien: porque cualquier cosa les pase en el conchero

Segunda: un sapo

Gerson: un golpe que se pegue en la raíz, se resbale y se pegue, mal golpeado se quiebra algún hueso. Si hay gente, que ha ido en familia, lo puede ayudar.

Os perigos da atividade exigem companhia, o que vale não apenas para a conchería. Rojas Silva (1996) ressalta o Pacífico como um território no qual não se pode estar só.

El monte es tan espeso y hermoso, que aunque se conozca, caso nadie se arriesga a salir solo a cazar y menos a sacar madera, la tunda lo puede embolatar; el mar es tan inmenso y profundo, que aunque la persona distinga perfectamente la dirección de los vientos y las olas, navegar solitariamente lo hace vulnerable, incluso el riviel puede perderlo (Rojas Silva, 1996: 209).

Parte dos perigos está, portanto, relacionada aos demais seres que habitam o Pacífico junto com os humanos.

$\mathrm{Na}$ atualidade, a conformação do grupo concheiro varia de acordo com o tipo de embarcação. Nas embarcações de menor porte, como o potro, a média é de cinco pessoas, a maioria delas de um mesmo tronco familiar. Nas canoas a motor, saem entre quinze e vinte pessoas para uma labuta de concheo. Além de parentes, são vizinhos ou pessoas que vivem na mesma vereda ou "comunidade". Ainda que seja muito mais comum a conchada a motor, a família Puertocarrero, por exemplo, prefere conchar a remo.

Segunda: andando en potrillo, me pica ese sapo me voy pa'mi casa, andando en canoa...

Marien: hasta que no acaben todos no nos vamos. Mi potro, ya me marié, ya me voy para mi casa.

Gerson: en la canoa demoran más tiempo, hasta que no recogen a esa cantidad de gente no se pueden venir

Paula: ósea que el potro es lo mejor

${ }^{335}$ Entrevista concedida entre 16 e 17 de dezembro de 2013. 
Segunda: sí. Cuando se va en canoa pagan la gasolina, en cambio con el potro no pagan nada, y le sale más cara la conchada a los que la compran, vale más.

A maioria das mulheres com quem dialoguei prefere canoas motorizadas, porque reduz o esforço físico da atividade; não precisam remar até o conchero. As veteranas Martina Granja, María Magdalena, Mérice Benguera, Segunda Rosa Ángulo Cuero - contam que, na sua época, não se usavam botas ou luvas. Já hoje em dia, a maioria se protege do peixe-sapo e de outros riscos usando tais aparatos. Segunda Rosa, concheira de Salahonda, diz que não foi ensinada a conchar com luvas e que é incapaz de encontrar a concha quando não tem as mãos nuas. Conta também que concha com as duas mãos. Sua filha diz que usa sempre a mesma mão e apenas ela. Dona Segunda tampouco pode mover-se bem com as botas: "mamita, uno se enrieda, usted lleva bota y uno se enrieda". Martina conta que, mesmo sem botas, dado o sobrepeso, ela afundava-se no lamaçal e contava com a ajuda dos filhos para se levantar. Não conheci ninguém que usasse facão, mas ouvi dizer que esse é um novo apetrecho usado no concheo. Porém, muito criticado.

No, machete no, porque acaba con los concheros, la concha se aleja. Si la saca con la mano, ahí sí hay posibilidad de que la concha vuelva ahí. Quedan las pequeñas y otra vez crece y otra vez concha ahí mismo. Pero con machete uno le daña el lugar que ella tiene y se aleja la concha, lo mismo con el cangrejo, si le dañan la cueva no entra más ahí. Algunos llevan el machete para conchar, digamos que hay conchas que uno mete la mano y está atascada que uno no la puede sacar. Entonces cortan la raíz y arrancan eso. Si lo dejaran, otra concha podría meterse ahí, pero no se mete otra porque dañan el hogar de la concha - Gerson Puertocarrero.

É a maré quem indica a hora da labuta. Entre sete da manhã e uma da tarde, é a primeira maré, a primeira labuta. Do meio dia às cinco da tarde, é a segunda maré. Elas irão conchar em uma das duas. Porém, no ciclo de marés baixas, pode-se alcançar as duas labutas ou faenas, como se diz. Mérice Bengera explica:

Es que las aguas vacían rápido, pues temprano, y entonces alcanzan a hacer las dos faenas, de mañana y de tarde. Hoy, por ejemplo, salieron más o menos a las ocho, regresaron por ahí a las 10:30, 11. Si se fueron vuelta a la 1 más o menos, llegan a las 5:30, porque vienen recién la puja. Estamos terminando la quiebra. Porque se van y buscan los lugares más altos, donde seca más rápido el agua, en las partes altas entonces ahí se meten. Hacen hasta tres días de esas faenas - Mérice Benguera.

A saída acontece um pouco antes que baixe a maré. Ao chegarem, os manguezais já estarão relativamente secos, de modo que se pode movimentar dentro deles e escavar o lodo em busca das conchas. Quando a maré começa a subir, é hora de regressar. Sixta Tulia 
Londoña Ponce explica como a pessoa se posiciona para conchar: "uno se tiene que agachar y meter la mano a las raíces de los mangles, ahí hay partecitas que hay, otras que no hay, pero así uno va cobando, va cobando y va sacando",336. A família Puertocarrero explica que há pessoas que concham sentadas, outras agachadas. Arocha compara a posição da conchada com a da playada: "Quien haya visto la extracción artesanal del oro en ese litoral, se dará cuenta de que la posición empleada por las concheras para escarbar la tierra es prácticamente igual a la acostumbrada en la minería" (Arocha, 1986: 5). Essa não é a única semelhança entre ambas as atividades. Convergem também as enfermidades que acometem mulheres cuja vida foi dedicada ao concheo e à playada, em especial aquelas decorrentes da queda de temperatura do corpo.

Gerson Puertocarrero nos explica que a concha fica escondida em certos locais:

Gerson: la zanja, ese espacio pequeño que uno se mete allá a buscar la concha, zanja que se hace con la lluvia, nos metemos allá en los choritos que hay para buscar las conchas.

Paula: ¿en general hay más conchas donde hay un poco de agua, dónde hay una zanja o apenas en el barreal?

Gerson: a veces la concha se encuentra más en parte durita, las conchas, pero los machos en parte blanda, pero ahi es peligroso porque ese sapo a uno le pica, eso es peligroso. Cuando ese día se encuentra también el que es más tupidito, medio durito, uno la busca mejor, debajo de las raíces dónde hay unos huequitos. En las raíces uno las encuentra más. Las más grandecitas.

A dinâmica da mariscagem é semelhante, porém, tem suas especificidades. Com Ana Granja, no dia 22 de outubro de 2013, saímos a mariscar em uma região chamada El Bajo, ou Bajamar, situada na Zona 4 do território da ACAPA, a zona em que o Rio Patía desagua no mar. Saímos da casa de Ana Granja, na área urbana de Salahonda, em canoa de madeira, a remo, as 8:30 da manhã $\tilde{a}^{337}$. Levamos duas panelas: uma com peixe frito no dia anterior e banana da terra verde cozida; outra com arroz doce, feito com rapadura e canela. Levamos também frutas: maçã e zapote, além de um galão de água. Vestíamo-nos com short, camiseta e chapéu. Ana vestia uma camisa de manga comprida sobre a camiseta, que cumpria a função de protegê-la do sol. Cruzamos o Canal de Salahonda na direção do mar, bordeado por manguezais, no mesmo esteiro que passamos na travessia aquática de Tumaco a Salahonda. Quando o canal abriu seus braços, dobramos à direita, em direção à Ilha do Galo, e

\footnotetext{
${ }^{336}$ Entrevista concedida em 15 de dezembro de 2013. Outras falas de Sixta Tulia Londoña Ponce ora citadas são da mesma entrevista.

${ }^{337}$ A embarcação é localmente conhecida como potro, uma peça inteiriça de tamanho pequeno, artesanalmente confeccionada com madeira proveniente do bosque úmido tropical (cedro, maria, guarapiro, tangare). O potro difere do que se conhece por canoa nessa região.
} 
estacionamos a canoa à beira de uma ampla faixa de areia em frente ao manguezal. Quando chegamos, a água ainda estava alta. Escolhemos essa região porque aí vivem as sangaras, enterradas na areia rasa, em áreas cobertas por uma fina e morna camada de água do mar, já distante donde quebram as ondas. "Las sangaras tienen defensa debajo del agua, así que siempre se la busca en los esteritos, donde hay un poco de agua"338.

Minha anfitriã me regalou os instrumentos de trabalho: um facão e um balde amarelo feito de fibra de plástico, ao qual se acoplou uma alça feita de corda. Inicialmente, caminhei um pouco ao lado de Ana Granja, que me explicava como identificar onde possivelmente havia sangara. Os sinais são sutis: quando a cor da água está levemente amarelada; quando se observa um movimento de água soprando para fora, como se fosse o alento de uma respiração; nas proximidades de onde se identifica as fezes da sangara boiando, as quais se assemelham a dejetos pequeninos de galhos ou outro material vegetal que corre dos manguezais para a praia. "Donde está la mierda de la sangara, ahí usted no la encuentra nunca. Ella está un poco abajito o arribita. Lo único animal que vive con su mierda es el cochino del puerco". Como a sangara fica enterrada na areia rasa, "a veces uno la siente, pisa sobre la sangara" ${ }^{339}$. Ou sente seus vestígios, temperatura ou textura diferente da água.

No momento em que qualquer desses sinais é percebido, risca-se o facão sobre a areia. Quando ele soa em tom metálico, indicando que se topou com algum objeto, agacha-se para tocar o objeto. Muitas vezes não é sangara, pode ser outro tipo de marisco. Alfred Gell, em Art and Agency (1998), ressalta que relações sociais são relações entre diferentes participantes em sistemas sociais de vários tipos. Para compreender uma cultura, é necessário observar o comportamento cultural em um setting específico, ou seja, como os sujeitos se relacionam em cada interação social. Na atividade de mariscagem ora descrita, trata-se de uma relação entre a mulher e a sangara, ambas sujeitos. Não se trata de mera concatenação de eventos físicos, mas de uma sequência causal em que ambos os sujeitos agem.

Quando o sol está a pino, as sangaras dele se escondem, enterrando-se mais profundamente na areia. Sua movimentação é dotada de intenções. Nesse sentido, as sangaras têm agência, assim como a mulher. Todos os fatores do sistema são afetados pelo sol escaldante: a cor da água, sua temperatura, e até mesmo a textura, assim como a presença dos dejetos. Desde a perspectiva do sujeito mulher, a situação oposta, de chuva, tampouco é boa para sangariar, pois não se percebem bem os sinais que indicam o local onde está escondida a

\footnotetext{
${ }^{338}$ Ana Granja, 22 de outubro de 2013.

${ }^{339}$ Ana Granja, 22 de outubro de 2013.
} 
sangara. Nesse sentido, o sol e a chuva são fatores do ambiente causal no qual se dá a relação entre a mulher e a sangara. É como se, nesse ambiente, o estado climático servisse às intenções da sangara ou da mulher. Isso porque, como a agência é relacional e transitiva, a mulher também age na medida em que busca a sangara. Do ponto de vista da mulher, o cenário ideal para esse tipo de mariscagem é a estiagem com sol ameno.

Se, nas "comunidades de mangue", a mariscagem constitui uma atividade produtiva eminentemente feminina; nas "comunidades de rio", seria a challada.

En el río se challa, para coger lo que se llama la guaña. Va un grupo de mujeres dentro del río, de abajo para arriba, así dando golpes con unos palos hasta el fondo. ¿No ve que ellas están en las piedras? Y se va subiendo. Entonces, cuando ellas sienten el ruido en las piedras ellas se van subiendo y se van amontonando. Si quieren salir por acá no pueden por el ruido de acá, por acá tampoco por el ruido de acá, adelante está la cobija esperándolas. Ahí la encierra a esa cobija y luego la alza y ahí le salen las guañas en esa cobija. Es rico ese pescado. 12 personas ya se chaya, y, si hay más, mejor. Entonces, se va agarrando y se va haciendo un solo montón. Entonces cuando ya no se va a echar más ahí se va repartiendo, partes iguales, cada quien trae para su casa a comer. Uno se va de mañana y vuelve en la tarde, de golpe a las 4, 5 ya se viene. Y eso se hace en las partes más secas del río, donde uno alcance plan, porque en la parte que tú no alcanzas a pararte no puedes manipular el palo, es muy hondo. Pero ahora la guaña ya tú no la topas en las partes secas donde antes se la acostumbraba a chayar. Ahora está en el fondo, en los charcos hondos que nosotros no alcanzamos, pues - Melania Ortiz ${ }^{\mathbf{3 4 0}}$.

O relato de Melania permite pensar que a guaña, assim como a sangara e a piangua, tem agência. Suas movimentações são dotadas de intencionalidade. No caso da challada, trata-se de um embate que se estabelece entre o grupo de peixes e o grupo de mulheres. Como indica Gell (1998), a agência social não é definida em termos de atributos biológicos básicos, como coisa inanimada versus pessoa encarnada. Ela é relacional. O status de "agente social" não diz respeito a uma coisa ou pessoa em si mesma, mas ao seu lugar em uma rede de relações sociais ${ }^{341}$. A presença do grupo de mulheres pescadoras no rio torna as guañas agentes sociais.

Enquanto trabalhávamos com Ana Granja, a maré foi vazando, construindo novos cenários propícios para se encontrar a sangara, pequeninos esteiros sinuosos que partem do mangue em direção ao mar. No auge da maré seca, a água do esteiro por onde aportamos distava bastante de nossa canoa.

\footnotetext{
${ }^{340}$ Entrevista concedida em 19 de dezembro de 2013.

${ }^{341}$ Segundo Strathern (2006), há uma distinção entre pessoa, construída da perspectiva das relações que a constituem, e agente, construído como quem age em virtude dessas relações.
} 


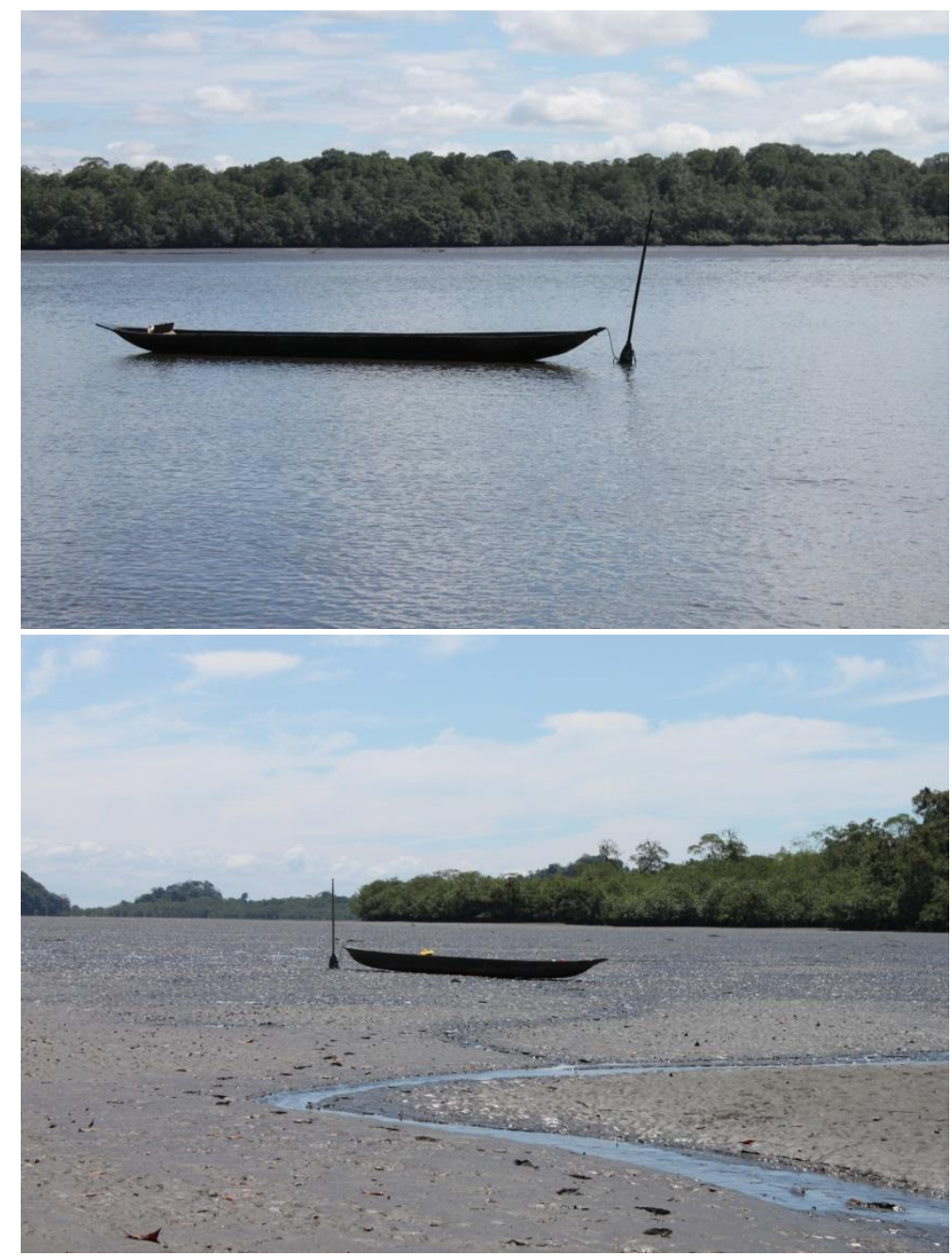

Figuras 17 - Sangariando: quando chegamos; quando a maré secou

Quanto mais nos aproximávamos dos manguezais, proliferavam-se as sangaras e chirripianguas. Mesmo assim, quase não fui capaz de ler os sinais que os mariscos emitem. Coletei pouquíssimas. Já Ana Granja encheu seu baldinho e em seguida o meu, totalizando 155 unidades, majoritariamente sangaras e chirripianguas. Permanecemos sangariando até por volta das três da tarde, quando a maré outra vez subiu, ou seja, quando a água novamente encontrou nossa canoa. Voltando, encontramos alguns grupos de concheiras, algumas ainda em plena labuta, outras já regressando. Paramos a canoa para conversar com uma mulher que estava dentro do mangue com algumas crianças, pianguando. Saindo do mangue, Ana comentava: “'Miraste como ese trabajo es duro? ¡Durísimo! Y pagan lo mismo que la Sangara. 10 mil [pesos colombianos] el kilo"342.

Por outro lado, Ana Granja ressaltava que "a la sangara casi no le ponen cuidado porque no tiene comercio. La captura que se hace a los productos es más cuando tiene

${ }^{342}$ Ana Granja, 22 de outubro de 2013. 
comercio ${ }^{343}$. Na comercialização da sangara, a prioridade é para as conchas pequenas, que se assemelham à piangua, das quais se a carne extraída da concha e embalada. Como explica Nidia:

antes no la compraban, antes uno la sacaba para la comida. Ahora tam bién se saca la más pequeña y se vende la sangara. La sangara no la compran en concha porque es muy pesada, la compran cocida sacada de la concha. A la sangara uno debe cocinarla, abrirla y luego la vende por kilo, el kilo vale como diez mil pesos. Pero un kilo es harta sangara. Ella es grande pero adentro la carne no es del tamaño de la concha, es más pequeña - Nidia Granja $^{344}$.

No caso da piangua, o comércio é garantido, sendo que o principal comprador é o Equador, para onde se destina $80 \%$ da produção de Salahonda; o resto vai para Tumaco.

Em que pese o grande interesse mercadológico pela piangua, o recurso está em extinção. Talvez esse seja um dos motivos pelos quais o mercado se abra para a sangara. A média de coleta da piangua nas décadas de 1970-1980 era de 350 pianguas/dia, conforme assinala Arocha (1986). No início dos anos 1990, conforme estudo realizado entre concheiras de Santa Rosa/Esmeraldas, Veach (apud Charvet, 2010) indicava que, das 1.000 conchas diárias que eram recolhidas há quarenta, cinquenta anos, havia uma diminuição para 100-200.

Na segunda década do milênio, o recurso concha é ainda mais escasso. María Magdalena conta que, nas décadas de 1950 e 1960, em um dia se podia coletar até duas mil conchas, enquanto hoje em dia o máximo não ultrapassa 200. No dia 28 de dezembro de 2013, a filha mais velha de Targelia, Eneida, regressou a Palma Real celebrando a boa faena que a havia regalado um cento de concha. Em Salahonda, segundo a família Puertocarrerro, em uma conchada a pessoa pode encontrar entre 50 e 200 conchas. Todas elas atribuem a extinção da piangua à degradação ambiental dos manguezais. Meu diálogo com María Magdalena explica o caso:

Paula: ¿Y por qué se acabó la concha?

María Magdalena: Se cortan los mangles, entonces la legía se va por todo el manglar. La leche del mangle, eso se pudre y se va contaminando la concha y eso mismo mata la concha, chica, grande, todo. De eso viene la muerte de la concha.

Paula: ¿Y por qué lo cortan?

María Magdalena: Es un negocio que tenían, que venían y cortaban los mangles. La gente también lo cortaba para quemar carbón. Ya quedaba el manglar desalejado. Se pudrían las raíces del mangle, entonces ¿dónde hacían larva las conchas? No podían pues ${ }^{345}$.

\footnotetext{
34322 de outubro de 2013.

${ }^{344}$ Entrevista concedida entre 28 de outubro e 03 de novembro de 2013.

${ }^{345}$ Entrevista concedida entre 16 e 17 de dezembro de 2013.
} 
Além do corte indiscriminado das árvores dos manguezais, outras atividades econômicas protagonizadas pelo grande capital têm um forte impacto na escassez do recurso concha. Lucrecia Borges, comerciante de concha sanlorenzenha, fala sobre o impacto das camaroeiras na degradação dos manguezais e sobre a falta de atenção do Estado equatoriano para o problema:

La concha se está escaseando porque hubo la tala de manglares para las piscinas. No hubo un gobierno que se empoderara de proteger los manglares, de proteger el medio ambiente. Entonces eso hizo pues que la falta de responsabilidad de las autoridades, prácticamente acabara con los manglares de esta zona fronteriza con esa camaronera - Lucrecia Borges $^{346}$.

Ademais, o tamanho do molusco está reduzindo. Segundo as normas da atividade pesqueira e marisqueira, atualmente, não se pode coletar conchas de tamanho inferior a $4,5 \mathrm{~cm}$. Trata-se de um veto permanente. Porém, muitos depoimentos informam que os intermediários compram a concha pequena.

Y nosotros con la lucha de los manglares, incentivando a la gente de sacar la concha grande y que dejemos la pequeña. Es una lucha incansable porque nuestra gente no entiende, pero ¿por qué no entiende? Porque ellos dicen que si sacan un ciento de concha grande se la van a pagar al mismo precio que les van a pagar las doscientas conchas. Los intermediarios ellos no hacen diferencia, compran la pequeña, la grande. Hay épocas que ellos agarran hasta las recién nacidas. Nosotros les decimos: miren, si sacamos solo las conchas grande va a durar más el producto y puede costar mejor, se saca un producto de mejor calidad y puede costar más - Mérice Benguera.

Os intermediários estão no meio da cadeia, que envolve vários módulos no circuito de comercialização. Quando tem capital inicial, a filha de Targelia, Eneida, ocupa esse posto. Ela espera as embarcações na beira da praia e compra a concha das mulheres que acabam de chegar da labuta. Porém, no mais das vezes, são os donos das embarcações que saem para o concheo que fazem as vezes de intermediários. Ao comprar a concha dentro da embarcação, o preço é um pouco inferior do que comprando na beira mar. Chegando a San Lorenzo, a concha passa às mãos de comerciantes da cidade. Segue, então, para Quito ou Guayaquil, os principais mercados consumidores.

Os intermediários ganham espaço construindo uma relação de dependência com as famílias que vivem da concha, especialmente aquelas em maiores condições de pauperização. A família salahondenha Puertocarrero explica que às vezes o "apoio" da intermediária María é fundamental para que se concretize a labuta:

\footnotetext{
${ }^{346}$ Entrevista concedida em 9 de janeiro de 2014. Outras falas de Lucrecia Borges a seguir apresentadas são da mesma entrevista.
} 
Marien: uno le vende a ella porque cuando uno no tiene, uno le dice Maria no tengo pa' llevar y ella ahí mismito le da mil pesos y no se los cobra.

Gerson: cuando no tiene para uno llevar la comida uno va donde ella y ella le presta y cuando saca poquita pues ella le dice que no le pague que otro día le puede pagar.

Em troca do empréstimo, a família concheira fica obrigada a vender a produção à María, que paga um preço inferior ao da venda da concha para "o barco equatoriano". Em Palma Real, existe a possibilidade de negociar com os donos das embarcações a forma de pagamento pelo transporte: em dinheiro, ou em conchas. Isso influencia diretamente os preços no comércio da produção obtida naquela labuta. Essa situação pode levar à escolha de sair para conchar com canoa a remo, de modo a garantir um maior lucro na labuta diária. $\mathrm{O}$ mesmo caso se passa em Salahonda.

Os valores relativos ao cento da concha variam a cada etapa do circuito comercial. Relatos de mulheres afro-equatorianas datados de fins de 2012 revelam que, na sede do município de San Lorenzo, o cento da concha fêmea valia \$7,5 dólares americanos, enquanto o cento do macho valia $\$ 5^{347}$. Nas localidades rurais, o preço informado pelo centro da concha fêmea é de $\$ 7,8$, ou $\$ 8$ dólares americanos a concha fêmea e $\$ 3,0$ a concha macho. Lucrecia Borges fala que o preço médio da concha comprada das marisqueiras é de sete dólares. Segundo Mérice, os intermediários, que também são afro, compram a concha por sete dólares e a revendem por quatorze ou quinze, a concha mediana, chegando a vinte dólares a concha grande. Ou seja, na revenda, o tamanho do marisco influencia no preço.

A relação entre Colômbia e Equador atravessa as transformações sobre as quais estamos tratando, cujo epicentro é a questão do comércio de concha. Lucrecia nos explica:

Con precisión le puedo decir que gracias a los manglares de Colombia se están cubriendo las necesidades que tenemos aquí en San Lorenzo. Porque si nosotros, los comerciantes de concha, comercializáramos solo la concha ecuatoriana, le juro que en San Lorenzo, en esta zona fronteriza, concha no hubiera - Lucrecia Borges

Segundo ela, a capacidade produtiva de San Lorenzo é em torno de 100 mil conchas, enquanto a colombiana são 500 mil conchas. Ou seja, em decorrência da situação de degradação dos manguezais, com o passar dos anos, estabeleceu-se uma relação de dependência comercial entre Equador, como comprador de concha, e Colômbia, como fornecedor. Isso porque o mercado consumidor da concha é o Equador. Na Colômbia, o

\footnotetext{
${ }^{347}$ No Equador, os relatos convergem com os dados da Colômbia. A concha macho tem pouco comércio e sua durabilidade é menor, vive cerca de dois dias, enquanto a fêmea vive entre cinco e sete dias.
} 
consumo é pequeno. Uma liderança do tumaquenho Rio Chagüí explica que, até a década de 1950, a concha colombiana era destinada ao consumo das famílias afro-colombianas. Entre 1953 e 1980, dado o interesse do mercado equatoriano sobre a concha, esse passou a ser a maior renda de tais famílias. Nesse momento, o Equador realizava um Plano de Manejo de seu território, quando a extração local de conchas foi submetida a um controle maior, o que desencadeou a entrada de extrativistas coletores de concha em território colombiano, com uma lógica de produção que visava o lucro, sem sustentabilidade.

Mais uma transformação sobre a qual dialogamos reside no perfil das pessoas extrativistas. Em que pese ser o concheo uma atividade feminina, na atualidade é muito praticada por homens. Novamente, o diálogo com María Magdalena ilustra o tema:

Paula: En la época suya de los quince años, ¿los hombres conchaban?

María Magdalena: No.

Paula: ¿Y hoy día?

María Magdalena: Sí, pero para acá. O sea por Candelilla y por allá todo por Tumaco, pero acá en Puerto Palma no les ha gustado conchar, los hombres. Cuando venían hombres de otras partes a conchar en Puerto Palma, les daba vergüenza. Cuando vean que los hombres de Puerto Palma no conchaban, salian, se venían vergonzosos. No conchaban.

Paula: ¿Porque uno tiene pena de conchar?

María Magdalena: Ellos trabajan en pie de monte, en la finca. Tirar su machete, tirar su pala.

Paula: ¿Hay una idea de que hombre que es hombre no concha?

María Magdalena: $\mathrm{Si}^{348}$.

Esse diálogo explicita a divisão sexual do trabalho, ou a ideia de que certos trabalhos são masculinos e outros femininos. Sendo um "trabalho de mulheres", conchar é algo que polui ou contamina a virilidade.

O concheo é uma atividade cuja valoração apresenta certa dubiedade. Ao tempo em que as narrativas apontam uma perspectiva de que se trata de uma tradição afro-pacífica, passada de geração em geração, e que as concheiras trabalham duro; é também a última alternativa laboral que uma mulher escolhe desempenhar. Em primeiro plano, é uma atividade associada à pobreza: "la gente pobre pues vive de eso, de la concha", como coloca Gerson.

Existe também uma associação entre a mariscagem e a sujeira. Lucrecia Borges é comerciante de concha em San Lorenzo, filha de mãe concheira, atividade que suas irmãs seguiram. Seu sonho desde criança era ser professora, o qual pôde realizar. Transcorrido um ano na experiência da docência, ela percebeu que não era sua vocação. Notou que tinha uma imagem

${ }^{348}$ Entrevista concedida entre 16 e 17 de novembro de 2013. 
idealizada da professora, um contraponto à realidade que ela vivenciava em um lar onde sempre havia muito marisco, mau cheiro, sujeira. Ela queria ser "limpinha", como eram as professoras.

A mariscagem é associada ainda à velhice, conforme diz novamente Gerson: "los que más conchan son veteranos". Segundo essas imagens, mulheres que vivem da concha têm baixa escolaridade, algumas são analfabetas; são mulheres chefes de família. María Orobio conta que em certo momento de sua vida ela conchava, mas sem que sua família soubesse, já que seu pai "não a havia criado para isso". Sixta Tulia Londoña Ponce diz que "me daba pena llevar a mis hijas, porque mi mamá a mí no me había criado en ese acto, mi mamá nunca me llevó a mí; entonces yo tampoco a mis hijas las llevaba a conchar".

As mulheres concheiras com quem dialoguei falam que prefeririam ter outro trabalho. Quase sempre a alternativa é no comércio, uma tenda, uma banca de comidas na rua, ou cozinhar em um restaurante. Entendo essa fala a partir do desejo de sair de uma situação de trabalho extenuante, mas também de sair de uma situação de discriminação social. A imagem sobre o concheo é também uma imagem sobre o Pacífico colombo-equatoriano: uma região pobre e perigosa. E o imaginário social cola essa imagem à mulher afro-pacífica: são mulheres guerreiras, mas também sujas. A matrona, centro de uma rede parental e política, investida de poder como a que nutre e cuida, é reduzida por uma representação discriminatória a uma mulher velha, solteira, cheias de filhos/as e inculta. Assim, a análise do concheo desvenda mais uma qualidade do feminino afro-pacífico. O imaginário social inverte a construção de um lugar de poder a um lugar de desprestígio. Nessa inversão, opera uma leitura sexista e racista, na medida em que a mariscagem é um ícone da presença afrodescendente, mais especificamente da presença de mulheres negras no Pacífico colombo-equatoriano.

Vale ressaltar que tal leitura se inscreve em uma realidade de desestruturação da socialidade afro-pacífica a partir da incidência do grande capital. Na medida em que indústrias camaroeiras e outros projetos desenvolvimentistas transformaram ecossistemas de manguezais locais, comprometeram um modo de vida que se constitui na relação com os manguezais. Esse modo de vida, baseado na mariscagem, é concebido e nutrido principalmente pelas mulheres, que reconhecem os manguezais como fonte de vida e constroem sua subjetividade na relação com o mangue. 
O percurso de matronas afro-pacíficas conduziu, ao longo desta parte da tese, a análise da organização territorial e política no Pacífico Negro colombo-equatoriano. Seus fluxos constantes desde as ribeiras dos rios aos centros urbanos - Tumaco, Cali, Guayaquil, chegando até outros países - revelam uma fluida concepção de território, em que se inscrevem a ancestralidade africana e um jeito de fazer política que perpassa os domínios doméstico e público. A participação de mulheres afro-pacíficas em movimentos sociais, seja em organizações étnicas, seja em organizações de mulheres, bem como naquelas que agregam ambas as pertenças, revela um ponto de vista situado, segundo o qual as perspectivas territorial e de gênero estão absolutamente imbrincadas. Nesse sentido, elas lutam pela desconstrução das iniquidades de gênero e de raça a partir de um lugar de fala territorialmente inscrito. A agenda de luta parte de questões que emanam do território a partir de uma perspectiva posicionada como mulher negra.

$\mathrm{Na}$ derradeira seção da tese, proponho uma análise na qual a violência nas relações interpessoais de gênero e no contexto sociopolítico atravessa a territorialidade e a construção da subjetividade feminina. 


\section{PARTE III \\ VIOLÊNCIAS ${ }^{349}$}

\footnotetext{
${ }^{349}$ Nesta seção, usarei as narrativas etnográficas sem recorrer a nomes, lugares ou datas, dada a dramaticidade dos eventos e vulnerabilidade das pessoas envolvidas. Conforme colocado na introdução, em um cenário de risco, esse passa a ser um cuidado vital, além de uma demanda explicitada pelas mulheres com quem dialoguei.
} 
Inicio a última parte do texto narrando meu trânsito nas áreas de pesquisa, o que ganha relevância na medida em que esse percurso levou ao encontro de questões presentes nas trajetórias de mulheres afro-pacíficas, relacionadas ao tema da violência. Meu encontro com a violência foi gradual e passou a fazer sentido conforme eu fui capaz de realizar certas associações às quais pretendo explicitar nas próximas páginas. Inicialmente, deparei-me com a categoria "violência" nas narrativas de minhas interlocutoras, a qual emergia sempre com uma intensa carga de negatividade.

Em posterior exercício analítico, percebi que, para compreender o cenário da violência, fosse no âmbito sociopolítico, fosse no domínio das relações interpessoais de gênero, não cabia usar o conceito apenas em sua negatividade. Há um sentido positivo da violência. Como coloca Todorov: "se toda e qualquer guerra fosse necessariamente má, as virtudes guerreiras nunca poderiam ser boas" (Todorov, 1995: 62). Machado (2010) ressalta a positividade da violência presente e constituinte de movimentos sociais e políticos que se querem revolucionários. É o caso dos grupos guerrilheiros colombianos.

Assim, a situação do Pacífico colombo-equatoriano envolve sujeitos sociais que invocam positivamente a ação bélica, dentro de determinados contextos. Nesse sentido, ao longo do texto, trarei a ideia de ethos guerreiro, compreendido como um "conjunto de disposições, valores e asserções sobre o mundo social que se associam ao comportamento violento, próximo à criminalidade" (Álvarez, 2013: 93) ${ }^{350}$. Em contraposição ao ethos guerreiro, ecoam vozes de mulheres afro-pacíficas que denunciam a violência à qual estão expostas, explicitando que a atribuição de sentidos à violência, positivos ou negativos, bem como suas subjetivações e representações, são múltiplas e dependem da posição diferencial e desigual dos sujeitos diante dos atos de violência, como ressalta Machado (2010 e 2014).

Arendt (2004), analisando sistemas políticos, distingue violência e poder, cuja essência é a efetividade do domínio. A autora refuta a tese expressa, por exemplo, na concepção weberiana do Estado, de que a violência é uma manifestação do poder. Em sua leitura, a violência caracteriza-se por seu caráter eminentemente instrumental, enquanto o poder é um fim em si mesmo. Por sua vez, a autoridade, na concepção de Arendt, caracterizase pelo atributo de ser reconhecida pelos outros, sem a mediação da coerção ou da persuasão. Sem embargo, ressalta a autora, poder, violência e autoridade comumente aparecem de forma combinada. Em especial, o poder e a violência apresentam-se juntos, mas são inversamente

\footnotetext{
${ }^{350}$ Vale ressaltar que Álvarez (2013) concebe o ethos guerreiro a partir das percepções de ex-combatentes e perpetradores das violências no contexto sócio-político. Já minha abordagem aprofunda a concepção do ethos guerreiro a partir da resistência de mulheres perante projetos masculinos que exaltam o comportamento violento.
} 
proporcionais. "O domínio através da violência pura vem à baila quando o poder está em vias de ser perdido" (Arendt, 2004: 33-34). Ao tempo em que a violência é dominante, desaparece o poder.

Convido, então, leitoras e leitores a percorrer comigo travessias etnográficas entre a Colômbia e o Equador e, assim, acercar-se dos múltiplos sentidos da violência no Pacífico colombo-equatoriano. Na primeira viagem por estes países, meus pontos de referência eram as capitais nacionais. De Bogotá, peguei um avião para Quito, onde me encontrei com Inés Morales. Juntas, voamos até Esmeraldas, cabeceira cantonal da província homônima. Lá os filhos de Inés nos esperavam; e com eles fomos de carro até San Lorenzo. Permaneci nesse povoado, hospedada na casa da Inés, por cerca de cinco dias.

No regresso à Colômbia, experimentei pela primeira vez a travessia por mar, encorajada pelo amigo tumaquenho Jhon Henry Arboleda, que me instigou a conhecer a extensão do território Zambo, al otro lado de la raya. Nesse momento, tinha alguns indicativos de que se tratava de uma região complexa, onde estava presente o "conflito político armado" colombiano. Acadêmicos colombianos com quem tive a oportunidade de dialogar, em Bogotá, assim como amigas e amigos colombianos, manifestavam preocupação quanto a minha inserção naquele ambiente para realizar a pesquisa de campo.

A travessia iniciou-se em uma embarcação de médio porte, movida a motor de polpa; pode ser um motor de 40 cavalos ou dois de 15 cada um. Em geral, a tripulação é composta por dois homens, um piloto e o outro que organiza os passageiros e maneja o barco, aproximando-o ou distanciando-o do cais e/ou de outros barcos. Cerca de trinta passageiros costumam atravessar em cada uma das embarcações.

Navegamos por esteiros em meio aos manguezais da costa equatoriana, o que exige habilidade e domínio por parte do piloto, que tem de conhecer bem os canais que dão passagem, pois nem todos eles o fazem. Há duas rotas: uma pela baía e outra por dentro dos manguezais, navegável apenas com maré alta. Nesse trajeto, passamos por alguns povoados negros, ou recintos, alguns dos quais posteriormente visitei, percorrendo localidades associadas à Federación de Artesanos Afroecuatorianos Recolectores de Productos Bioacuáticos del Manglar (FEDARPOM).

Em dado momento do percurso, adentramos a baía, cenário marítimo de amplitude. É onde passa a linha imaginária que divide Equador e Colômbia. Desse ponto, pode-se vislumbrar, do lado equatoriano, Palma Real, a oeste, e Campanita, a leste, ambas situadas na 
desembocadura do Rio Mataje. Do lado colombiano, a noroeste está localizada a comunidade de Candelilla del Mar, situada no Baixo Rio Mira.

Entrando no Pacífico colombiano, o barco navegou rumo ao norte, subindo até Puerto Palma, onde atracamos. Trata-se de uma vereda localizada no Consejo Comunitario Bajo Mira y Frontera, município de Tumaco. Finalizou-se, então, a primeira etapa da travessia. Ao aportar no cais de Puerto Palma, muitos jovens ofereciam insistentemente o serviço de transporte de carga. Na plataforma do cais bem próxima à água, uma senhora vendia almoço (peixe com arroz e plátano) ou lanches rápidos (empanadas e papa rellena) em uma banquinha.

Subindo as escadas, ao longo das quais há algumas casas em madeira, chega-se a uma estrada de chão em que comumente estão estacionados veículos que realizam a segunda parte da travessia. Podem ser pequenos caminhões onde são acomodadas malas e outras cargas na carroceria e, sobre elas, tábuas de madeira em cima das quais os passageiros se sentam. Nesses veículos, há dois postos mais confortáveis, que ficam na cabine, ao lado do motorista. Às vezes estão em estado de conservação relativamente bom, porém há outros bastantes desgastados. Alternativamente, podem ser ônibus escolares que oferecem maior conforto para todos. Creio tratar-se de veículos traçados, com capacidade de mobilidade na estrada de chão em más condições. E podem ainda ser motos, nas quais nunca viajei.

Nessa etapa, passamos por dentro de Puerto Palma, em verdes campos tropicais cheios de palmeiras. Chegamos até o Rio Mira, o qual se atravessa em uma canoa, barco de pequeno porte conduzido por um piloto que maneja o motor de polpa de quinze cavalos. As águas desse rio podem correr com força, de maneira que, dessa vez, atracamos ao outro lado em um ponto situado bem abaixo do qual saímos. Aí muitos homens trabalham trocando dólares por pesos colombianos ou vice-versa, dependendo da direção do/a cliente. Há também uma senhora com uma banca que vende comida. Um pouco mais distante da beira do rio, um pequeno comércio vende produtos industrializados e oferece serviço de banheiro. A única pessoa não negra que encontrei ao longo da travessia trabalhava nesse comércio, que seria localmente classificada como paisa ${ }^{351}$. As construções em todo o percurso são quase todas em madeira.

Inicia-se a terceira e última etapa da travessia, operada em caminhonetes brancas cabine dupla. Primeiro há um trecho em estrada de chão, por dentro da vereda de Imbilpí,

\footnotetext{
${ }^{351}$ Tal presunção deve-se não apenas ao seu fenótipo (brancos aos meus olhos, mestiço segundo classificação local), mas também a sua ocupação. Por onde transitam, os paisas são conhecidos por dominarem o comércio local.
} 
parte do Consejo Comunitario Imbilpí del Carmen. Neste trecho passamos por dentro do povoado; por casas, vendinhas e uma escola. Os motoristas podem parar aí para descarregar alguma coisa ou para que passageiros comprem artigos como plátano. Depois, a caminhonete entra em estrada asfaltada, é a via que conecta Tumaco à capital do departamento de Nariño, Pasto. Aí passamos por muitas veredas, ou pequenos povoados negros, dispostos ao largo da estrada, até chegar à cabeceira do município de Tumaco. Quando a travessia se direciona ao revés, é comum que passageiras, a maioria delas professoras, desçam em algum desses povoados, onde trabalham. Em nenhum momento ao longo da travessia, há postos migratórios, sejam colombianos ou equatorianos.

Permaneci em Tumaco cerca de cinco dias, depois viajei a Bogotá e, logo em seguida, tentei retornar ao Brasil, porém, fui detida no escritório de Migración Colombia, no aeroporto de Bogotá. Informaram-me que havia uma "irregularidade" em minha presença no país. Conforme se notava em meu passaporte, eu havia deixado a Colômbia em 6 de junho de 2012 e não havia retornado. Expliquei-lhes que sim, havia retornado: pelo mar Pacífico, na fronteira com Equador. Interrogaram-me por cerca de duas horas e cobraram-me uma multa pela “irregularidade". Ameaçaram deportar-me e prender-me quando questionei os procedimentos empregados. Em virtude da lentidão, perdi meu voo e tive de comprar outra passagem, pois a empresa área não foi capaz de compreender a situação. Ou seja, o episódio causou um transtorno financeiro e emocional.

Nesse momento, como apontei, tinha já indicativos de que se tratava de uma região onde estava presente o "conflito político armado". Pesquisando no google sobre Tumaco, soube, por exemplo, que, em fevereiro de 2012, explodiram uma bomba na unidade de polícia da zona urbana de Tumaco, levando dez civis à morte e deixando cerca de setenta pessoas feridas. Em contrapartida, minha curta estada entre San Lorenzo e Tumaco havia sido tranquila. Não pude perceber, então, qualquer indício de conflito, o que predizia meu acesso à complexidade do cenário da guerra ${ }^{352}$. Ao cruzar a fronteira entre Equador e Colômbia, sob intenso sol, que fazia tudo brilhar, embalada por rios e mares, encontrei uma paisagem belíssima, emoldurada pelos maiores manguezais do mundo. Enfim, meu primeiro olhar sobre a região foi de deslumbre.

Viajei pela segunda vez à Colômbia em outubro de 2012, permanecendo até dezembro de 2012, precisamente até o dia natalino. Ao longo desses dois meses, vivenciados majoritariamente entre Tumaco e San Lorenzo, percebi que o fluxo local na fronteira

\footnotetext{
${ }^{352}$ Uso o termo "guerra" enfatizando a dimensão guerreira e bélica do confronto político armado na região.
} 
marítima era intenso. Conheci, por exemplo, uma senhora que fazia compras em Tumaco e revendia produtos cosméticos em San Lorenzo. Pessoas que iam comprar gás, ou usar serviços de saúde pública em terras equatorianas. Gente que trabalhava sazonalmente em empresas de palma africana num lado da fronteira e vivia no outro. Influenciada por essa permeabilidade, experienciei muitas idas e vindas entre as duas cidades, sem desprender qualquer energia quanto aos trâmites burocráticos diplomáticos.

Em uma delas, quando estava junto de uma amiga, fomos interceptadas por homens armados e vestidos com fardas militares, no trecho terrestre de Puerto Palma ao Rio Mira, correspondente à segunda etapa da travessia anteriormente descrita. Eram cerca de sete homens, todos jovens, com distintos fenótipos: negros, indígenas e brancos. O rapaz que parecia comandar a operação, a meus olhos, seria branco; na classificação regional, penso que seria mestiço. Os oficiais pararam o caminhão em que estávamos e pediram a todos os passageiros que descessem, apresentassem seus documentos e disponibilizassem as bagagens para revista. Entendi que se tratava do Exército colombiano.

Ao olhar mis papeles, expressaram surpresa e simpatia pela minha procedência. Vale lembrar que era véspera do Mundial, ou Copa do Mundo de Futebol, o que gerava na população de modo geral amplo interesse e atração pelo Brasil. Questionaram-me sobre o trajeto e a motivação da viagem. Expliquei-lhes que estava realizando pesquisas com mulheres concheiras da região, que já havia investigado o tema em Tumaco e que então viajava para conhecer essa realidade no país vizinho. Tentaram insistentemente falar com " $e l$ comandante” por rádio, sem sucesso. Depois de alguns diálogos entre eles, liberaram-nos. Todo o episódio não ultrapassou trinta minutos.

Ao passar pelo mesmo trecho no retorno a Tumaco, dias depois, encontrei os mesmos homens que festivamente reconheceram-me como "la brasileira" (o rapaz que estava no comando da ação recordava meu nome), perguntando-me como havia sido a viagem e qual era afinal minha predileção; alegrando-se com a resposta que preferenciava a Colômbia ao Equador. Senti-me privilegiada por haver passado pelo Exército colombiano duas vezes sem qualquer tipo de repreensão em razão da falta de registro no passaporte referente ao trânsito entre países.

Nessa etapa do trabalho de campo, algumas vezes naveguei pelas águas pacíficas, no ponto de encontro entre os dois países, passando por lugares que visualizava ao atravessar a fronteira, situados em ambos os países. O intuito dessas visitas era definir uma localidade em 
cada um dos países, onde desenvolveria a etnografia no seguinte ano. Seria, portanto, um local no qual residiria por um período médio de cinco meses.

Um dos critérios para a seleção das localidades visitadas na Colômbia foi a relativa tranquilidade em sua cotidianidade. Segundo informações da Rede de Conselhos Comunitários do Pacífico Sul (RECOMPAS), que me apoiou nessa viagem, em algumas veredas não era possível ingressar, por conta do controle exercido por agentes ligados ao “conflito político armado". Em todas elas, segundo os relatos, recomendável seria mover-se conduzida por gente local. Assim sendo, no meu entendimento, o apoio da RECOMPAS era imprescindível, trazia uma sensação de segurança.

Nas três veredas colombianas visitadas, escutamos relatos associados ao "conflito político armado". Foram relatados roubos, especialmente de motores e, em uma delas, de um criatório de concha. Em certa localidade visitada, já eram sete motores roubados no intervalo de um mês. A magnitude dos roubos era tamanha que tivemos de desmarcar o compromisso de um dia para o outro, em uma vereda na qual estava agendada uma visita, pois haviam roubado o último motor de que dispunham. A reação aos roubos parecia ser o silêncio: "no enfrentan porque al que habla, lo dejan sólo". Ao perguntar sobre os agentes dos roubos, foram-me devolvidas respostas evasivas.

Depoimentos mencionavam a presença de atores armados: "el ejército está interveniendo en casi todos los Consejos". Ao mesmo tempo, dizia-se que "hay dos ejércitos, el nacional y el revolucionario". Em uma das localidades, chegou a haver um enfrentamento entre ambos, nas eleições presidenciais de 2010, nas quais obteve vitória o então presidente do país, Juan Manuel Santos. O exército oficial colombiano instalou-se naquela vereda, precisamente na escola onde estávamos então reunidos, e aí permaneceu por certo período. No dia 17 de junho de 2010, houve um enfrentamento entre as forças militares nacionais e as Forças Armadas Revolucionárias da Colômbia (FARC). Durante minha visita, não se falou sobre os impactos desse episódio. Houve aconselhamentos aos presentes para que não permitissem a permanência do exército na localidade, já que sua presença atraía os outros atores armados. "Si pasaran por acá, anoten el día, hora, comandante, la brigada. Ellos no pueden estar acá". Posteriormente compreendi que tais aconselhamentos configuram estratégias de resistência da coletividade negra à ação bélica organizada.

Em outra vereda visitada, foram-me narrados problemas decorrentes do cultivo de cocaína. As famílias afro-colombianas são impelidas a plantar coca, pela pressão exercida por atores armados. O cultivo incide diretamente sobre outros cultivos agrícolas. 
Tradicionalmente plantava-se mandioca, banana, coco, cacau, espécies frutíferas, entre outras. A cultura da coca, iniciada nessa localidade em 1986, trouxe com ela o uso de agroquímicos, anteriormente desconhecidos naquele território. As substâncias tóxicas, levadas pela chuva, chegam aos manguezais sendo esse um dos principais motivos para a degradação ambiental do ecossistema e a escassez da piangua, base da principal atividade produtiva das mulheres com quem pretendia trabalhar. Os demais cultivos agrícolas eram devastados pelas formigas provindas da plantação de coca.

Mais uma questão narrada, nas três localidades, está relacionada às ações de fumigação (ou pulverização área de glifosato), procedimento usado pelo governo colombiano para erradicar o cultivo da coca. Ocorre que, quando os aviões que emitem substâncias venenosas sobrevoam os territórios ancestrais negros, devastam não apenas a coca, mas todos os cultivos aí implementados, aniquilando-os. Assim, compromete os esforços produtivos locais e reforça a pressão econômica sobre essa população que vive em condições de pauperização. Fala-se ainda que a extinção da coca é um pretexto. O principal objetivo da fumigação seria preparar o solo para novas sementes, sementes transgênicas que estão sendo inseridas nos territórios negros, onde a produção ancestral é orgânica.

Escutei os relatos com muita atenção, começando a dimensionar o "conflito político armado" na vida das mulheres com quem me preparava para dialogar. Algumas impressões foram intensas, como, por exemplo, o silêncio das mulheres em uma das veredas visitadas, aquela onde dois anos antes havia ocorrido o enfrentamento entre exército e FARC. Ao mesmo tempo, vivenciei a segunda incursão a campo sem experimentar diretamente qualquer intercorrência relativa ao "conflito armado interno" colombiano, no meu entendimento.

Nessa ocasião, cruzar a fronteira marítima entre Colômbia e Equador tornou-se corriqueiro. Por vezes, a chuva tornava o caminho menos colorido e as águas mais bravas. Contudo, sentia-me muito à vontade nesse trajeto. Em uma das viagens, fui questionada por uma companheira de barco se eu era irmã da fulana, que vivia em Tumaco, o que me fazia sentir parte daquele contexto, como se fosse dali. Atravessavam os países mulheres com crianças de colo, homens jovens e velhos, gente transportando cama, gás e pacotes de chatarra (comida industrializada de baixo teor nutritivo). No vai e vem dessa gente, pouco presenciei ações de controle dos órgãos de migração colombiana ou equatoriana, nem pude perceber a presença da guerrilha ou de outros atores armados que atuam na região.

Ao finalizar a etapa de pesquisa, avaliei que viver em uma das localidades colombianas na seguinte jornada seria complexo. Por outro lado, essa vivência me parecia 
possível al otro lado de la raya. Estava, pois, decidida a acompanhar mulheres concheiras em sua labuta, em uma "comunidade de mar" na zona rural de San Lorenzo. Na casa de um amigo em Tumaco, deixei minhas luvas e botas, bem como roupas adequadas ao trabalho do concheo. Meus medos, naquele então, estavam relacionados aos perigos dos manguezais. Os relatos das mulheres com quem dialoguei sempre mencionavam o peixe-sapo e sua dolorosa picada, que condensavam meu maior temor.

$\mathrm{Na}$ terceira e última incursão a campo, a mais longa e densa, iniciada em abril de 2013, retornei à Colômbia em uma situação mais confortável. Como bolsista da CAPES na modalidade sanduíche, foi-me concedido visto temporário de estudante, com validade de um ano. A maior vantagem conferida por tal condição era uma cédula de identidade para pessoas estrangeiras, cuja portabilidade chamava bem menos atenção que o caderninho azul do passaporte brasileiro. Estava, pois, idealizando uma situação de maior inserção local. Quando não me expressava verbalmente, minha sensação era a de que passava por uma pessoa local. Acreditava, portanto, que fosse possível minimizar minha condição de estrangeira.

Conforme cronograma de trabalho, deveria descer ao Pacífico com a maior brevidade possível, para dar prosseguimento ao trabalho de campo. Passado um mês em Bogotá, viajei a Tumaco e, logo em seguida, a San Lorenzo, na travessia marítima fronteiriça. O objetivo era estabelecer residência em uma pequena localidade sanlorenzenha onde residem mulheres concheiras. Dessa vez, sabia que precisava buscar Migración Colombia em Tumaco e registrar em meu passaporte na saída do país, o que foi feito um dia antes de embarcar em direção ao país vizinho. O mesmo deveria fazer no Equador ${ }^{353}$. Por isso, apesar de meu destino estar localizado antes da sede de San Lorenzo, dirigi-me à cabeceira cantonal com vistas a obter visto de ingresso.

A travessia fronteiriça seguia com tranquilidade. Chegando em Puerto Palma, eu e quatro homens que também queriam cruzar a fronteira aguardamos cerca de uma hora para agregar o número suficiente de passageiros, de modo que saísse uma embarcação a San Lorenzo. Finalmente, dado que não havia mais interessados em viajar, fomos agregados a um grupo de professoras tumaquenhas que iam passar férias nas praias de Esmeraldas e saímos em duas embarcações que se acompanhavam.

Navegamos por manguezais colombianos, seguindo a rota das águas grandes. Em mar aberto, quando presumivelmente já estávamos do lado equatoriano do Pacífico, encontramos

\footnotetext{
${ }^{353}$ Em virtude dos trâmites requeridos para a implementação da bolsa, fui à Embaixada da Colômbia no Brasil, à Embaixada do Brasil na Colômbia e também à Embaixada do Equador na Colômbia. Assim, certifiquei-me dos procedimentos correntes nas dinâmicas de mobilidade internacional.
} 
um barco das forças armadas equatorianas, onde estavam cerca de sete oficiais, dois deles encapuçados. Pediram documentos a todos os passageiros. Ao olhar meu passaporte, a reação de surpresa não foi acompanhada pela bem-vinda simpatia do episódio anteriormente narrado.

Segundo o comandante da operação - que era branco aos meus olhos, mestiço segundo a classificação local -, eu não tinha direito de atravessar a fronteira por mar. Cruzada a imaginária linha fronteiriça, já figurava como "migrante ilegal" em território equatoriano, pois não tinha autorização para ingressar no país. Expliquei-lhe que estava indo exatamente providenciar a referida autorização. $\mathrm{O}$ chefe da operação contra-argumentou indicando-me que o caminho adequado seria a travessia terrestre, onde havia postos migratórios no exato ponto de fronteira.

Além da minha situação, havia um problema com o motorista de uma das embarcações, cuja licença para conduzir, segundo os policiais, não era adequada. A abordagem dos oficiais foi abusiva e a situação era tensa. Algumas professoras começaram a cantar; não pude compreender o que dizia a canção. Depois de aproximadamente trinta minutos, fomos liberarados. Chegando ao cais em San Lorenzo, esperavam-nos mais oficiais das forças armadas equatorianas, que revistavam as bagagens de todos os passageiros.

Consegui, portanto, chegar a San Lorenzo, contudo, não foi possível permanecer no país naquele momento. Novamente, pesaram os erros inicialmente cometidos quanto aos trâmites de mobilidade entre os países. Nesse momento, a "irregularidade" de minha situação devia-se ao fato de não estar registrado no sistema a minha saída do país no ano anterior. Minha infração, portanto, seria a de exceder o prazo legal de 180 dias de permanência no Equador. Ainda que tivesse apresentado cópia autenticada em cartório de meu passaporte, onde estão registradas todas as entradas e saídas, demonstrando que não estava no Equador há mais de 180 dias, não houve maneira de permanecer. Deixei o Equador sob a sanção de esperar seis meses para ingressar novamente no país e retornei a Bogotá. Esse episódio desencadeou uma mudança do planejamento de campo.

Acabei realizando trabalho de campo primeiramente em Tumaco, a partir de agosto de 2013, após um período de pesquisa bibliográfica na capital colombiana. Minha expectativa em Tumaco era de visitar as localidades conhecidas no ano anterior e quem sabe outras. Novamente, o apoio da RECOMPAS seria chave nesse empreendimento. Porém, o projeto da Rede que eu acompanharia - um projeto com mulheres dos Conselhos Comunitários - estava bastante atrasado e não havia previsão para as viagens às veredas. 
Ademais, estava vivendo um problema de saúde. Ao longo da pesquisa, reiteradas vezes, torci meu pé direito, sendo a primeira delas na inicial incursão a campo, em meados de 2012, em Esmeraldas, Equador, a caminho de San Lorenzo. Já no ano de 2013, fazia a quarta e quinta entorses do tornozelo direito, em Tumaco. $\mathrm{O}$ tratamento médico indicou imobilização total da perna, o que me levou ao uso de muletas por cerca de três meses e posterior trabalho de fisioterapia, bem como exercícios físicos para o fortalecimento muscular. Essa situação inviabilizou a meta de embrenhar-me nos manguezais junto com as mulheres concheiras. Segui trabalhando na área urbana de Tumaco, com mulheres da cidade, porém também da zona rural, que constantemente lá estavam para agendas externas.

No dia 19 de agosto de 2013, iniciou-se na Colômbia uma série de mobilizações que foram denominadas "Paro agrário", que assumiram projeção nacional, chegando também a Tumaco. Camponeses e caminhoneiros pararam de trabalhar, saíram às ruas, bloquearam estradas, em alguns casos queimaram veículos. Segundo pude apreender a partir dos noticiários nacionais, camponeses protestavam contra determinações vinculantes aos vários Tratados de Livre Comércio (TLC), subscritos pelo governo colombiano, que não foram acompanhados por medidas de proteção coerentes para os produtores rurais. Manifestavam em especial demandas contrárias à obrigatoriedade do uso de sementes certificadas, requisito exigido à Colômbia para assinar o TLC com EUA e que impactava especialmente pequenos agricultores, na medida em que proibia selecionar sementes para futuras plantações. Caminhoneiros, por sua parte, reivindicavam a redução dos preços de combustíveis, dos preços de fretes, bem como a proibição da entrada de veículos de carga de empresas transnacionais ${ }^{354}$. Os protestos abrangeram os colombianos departamentos de Boyacá, Cundinamarca, Nariño, Caquetá, Huila, Santander, Cauca, Putumayo. Outros setores sociais como pescadores, indígenas, "comunidades negras", estudantes e professores, segundo relatavam os noticiários, uniram-se às mobilizações de camponeses e caminhoneiros.

Ao longo deste mês de agosto, assistimos quase que diariamente notícias televisivas sobre as manifestações em Pasto, capital do departamento de Nariño. Sentimos os efeitos do Paro agrário ao encontrar vazias as prateleiras do setor de frutas e verduras do maior mercado da cidade. $\mathrm{O}$ protesto foi tema da tarefa de casa de uma adolescente da família que à

\footnotetext{
${ }^{354}$ Ver notícias: En el Congreso algunos consideran que el TLC no es causa de crisis agraria. Disponível em: http://www.elespectador.com/noticias/politica/el-congreso-algunos-consideran-el-tlc-no-causa-de-crisi-articulo445263; Campesinos colombianos gañan pelea contra polemica. Disponível em: http://www.telesurtv.net/articulos/2013/09/05/campesinos-colombianos-ganan-pelea-contra-polemica-norma9.70-8062.html; Camioneros de Norte de Santander se unen al paro nacional. Disponível em: http://www.vanguardia.com/actualidad/colombia/223455-camioneros-de-norte-de-santander-se-unen-al-paronacional. Acessados em: setembro de 2013
} 
época me abrigava, que me pediu ajuda para redigir um texto com suas opiniões em torno das características e motivações do protesto.

No dia 4 de setembro de 2013, manifestantes bloquearam a saída/entrada de Tumaco por via terrestre, que leva à capital do estado. O motim foi montado próximo à Puente del Pindo e protagonizado por gente dos Conselhos Comunitários tumaquenhos. Nesse dia, polícia e exército usaram demasiado gás lacrimogênio; crianças morreram asfixiadas, segundo relatos locais. Nos dias seguintes, as manifestações continuaram e mais gente morreu: um jovem de dezessete anos, de "família carente", que vivia no bairro de uma amiga, morreu vítima de bala perdida.

No contexto desses episódios, conversas com mulheres dirigentes dos processos de comunidades negras em Tumaco, algumas radicadas na cidade, outras em veredas, todas de origem rural, trouxeram dados que remetiam ao "conflito político armado". Foi nesse momento que elas começaram a falar sobre o assunto comigo, de forma muito contida. Ao tempo em que se distanciava a possibilidade de acompanhar as mulheres concheiras, meus vínculos com lideranças dos conselhos comunitários fortaleciam-se. O fato de estar impossibilitada de movimentar-me com destreza, por conta do uso das muletas, conduziu-nos a conversas em locais mais intimistas, como a casa delas (ou de parentes), ou ainda um quarto de hotel onde estive vivendo por um período. Em determinados momentos, quando narravam episódios relacionados ao "conflito político armado", o tom de voz das conversas diminuía.

Segundo elas, as FARC obrigaram o povo dos Conselhos Comunitários a protestar no contexto do "Paro agrário", o que acontecia também em outros tipos de mobilizações. Os "señores", termo utilizado pelas mulheres para se referir aos guerrilheiros, entraram nas casas das "comunidades negras", armados, exigindo que pelos menos uma ou duas pessoas seguisse com eles para as mobilizações. Eram voceros. Segundo as narrativas, quem fala em nome da guerrilha são voceros.

Conforme pude apreender etnograficamente, a expressão do "conflito armado interno" no Pacífico colombo-equatoriano envolve guerrilhas, paramilitares, exército, bandas criminais e outros "atores armados", legais e ilegais. Por meio da categoria "atores armados", são designados todos os grupos que ameaçam (ou de fato impedem) a autogestão dos territórios ancestrais. Na medida em que o tema se impunha densamente em minha pesquisa, busquei leituras e conversas que ajudassem a compreender sua complexidade. O que ora compartilho reflete uma leitura parcial do cenário de guerra, que pode embasar, contudo, um entendimento local da violência sociopolítica da maneira como se expressa em Tumaco, Salahonda e San 
Lorenzo, na segunda década do milênio. Vale destacar que a porta de entrada para essa leitura são as narrativas de mulheres desses locais, para as quais os impactos da guerra se fazem sentir contemporaneamente de modo intenso e dramático.

\section{GUERRILHAS, PARAMILITARES E VIOLÊNCIAS}

Conversando com uma mulher afro-colombiana que era do Partido Marxista-Leninista nos anos 1970, entendi que as FARC têm uma origem e uma trajetória diretamente conectada com a realidade camponesa. A partir de nossos diálogos, surgiram também reflexões sobre o Exército de Liberação Nacional (ELN), assim como o Exército Popular de Liberação (EPL), braço armado do partido em que ela militava ${ }^{355}$. As três guerrilhas surgiram em conexão com práticas político-partidárias de esquerda ${ }^{356}$.

Segundo Silvia Álvarez (2013), não se pode conceber as FARC exclusivamente como uma guerrilha marxista. Sua raiz vincula-se às guerrilhas liberais que se consolidaram durante o período conhecido na Colômbia como "La Violencia” (1946-1964), expressão resultante do embate entre Partido Liberal e Partido Conservador, durante o qual morreram em torno de duzentas mil pessoas. A vanguarda revolucionária das FARC, segundo ela, era camponesa ${ }^{357}$. Na década de 1980, as FARC fundamentavam-se no princípio de autodefensas campesinas, que consistia em armar a população civil camponesa.

O histórico das guerrilhas é parte de obra intitulada El presente permanente. Por una antropografia de la violencia a partir del caso de Urabá, Colombia - resultado de tese doutoral de Álvarez -, em que a autora propõe uma antropografia da violência, tendo como lócus de pesquisa Urabá, região localizada no extremo norte do país, na fronteira com o Panamá. Alvaréz ressalta a antropografia como uma maneira de falar sobre a condição humana e não sobre a natureza humana, premissa que permite observar como a violência

\footnotetext{
${ }^{355}$ Segundo Álvarez (2013), o EPL pode ser considerado o braço armado de uma dissidência do Partido Comunista Colombiano, denominada Partido Comunista Marxista-Leninista, que foi declarada durante o X Congresso do Partido Comunista em 1965 (Álvarez, 2013: 242).

${ }^{356}$ Segundo Sanchéz (2005), as guerrilhas são grupos armados insurgentes que se opõem ao Estado. As Fuerzas Armadas Revolucionarias de Colombia (FARC) são a força majoritária, com 16.492 membros; em seguida a Unión Camilista - Ejercito de Liberación Nacional (UC-ELN) com 4.533 membros; e o Ejército Popular de Liberación (EPL), que, segundo o autor opera em várias regiões do país, em especial nos limites dos departamentos de Chocó e Risaralda, no Catatumbo e Antioquia. $\mathrm{O}$ autor cita ainda guerrilhas que têm atuações regionais, como o Ejercito Revolucionario Guevarista (ERG), em Chocó; o Jorge Eliécer Gaitán (JEGA), no sul do Vale do Cauca e Cauca; e "Jaime BatemanCayón", no Cauca (Sanchéz, 2005: 221). Afirma ainda que, em 2001, segundo dados do Ministério da Defesa, as FARC estavam presentes em 50\% do território nacional.

357 Já a vanguarda revolucionária do EPL era trabalhadora, “obreira”, como indica Álvarez (2013: 247).
} 
surge e se reproduz no plano cosmológico (Alvaréz, 2013: 7). A região por ela enfocada configura extremo oposto ao meu contexto de pesquisa. Compartilhamos, então, o cenário de fronteira e do Pacífico colombiano, tendo em vista especialmente a porção chocoana da região pesquisada por Álvarez ${ }^{358}$. Compartilho com a autora também a concepção da violência como matriz das relações sociais e como fonte de signos.

Em uma sintética biografia da guerra na Colômbia, Álvarez mostra como a história é recheada de eventos de cunho político-partidário que levaram a manifestações bélicas de dimensões nacionais. Ao mesmo tempo, ela ressalta que as guerrilhas, ao longo de sua existência, situam-se em contextos de territórios específicos. Nesse sentido, dialogam com formas regionais de justiça, assim como estratégias políticas e militares ajustadas ao conteúdo de polarizações locais, imbrincando combatentes e população civil, que, por vezes, respaldam a atuação guerrilheira local (Idem, ibidem: 241-242).

Essa é uma das complexidades que possui o cenário interno de guerra nesse país. Trata-se simultaneamente de um fenômeno de proporções nacionais - qualquer colombiano/a tem alguma narrativa sobre a guerra - e uma realidade cuja compreensão exige uma imersão profunda nas tramas regionais e locais de cada território. Para mim, o tema ganha ainda maior complexidade pela pouca vivência com relação à expressão bélica dos conflitos. A história do Brasil também é eivada de episódios de tensionamentos político-partidários, porém raras vezes a resolução desses conflitos assume o caráter bélico. A exceção, no meu entender, seria o coronelismo do Nordeste brasileiro, bem como algumas revoluções populares que tiveram curso nessa região, como a Revolta de Canudos ${ }^{359}$. De modo geral, percebo que o discurso da nação brasileira sobre si mesma reitera o comportamento pacificista, democrático e harmônico do povo brasileiro, muito embora os conflitos de terra tenham sempre se revestido de um caráter de violência política (Almeida, 2004), e muito embora seja bastante comum o

\footnotetext{
${ }^{358}$ O Chocó é um departamento localizado às margens do Pacífico norte colombiano, cuja capital é Quibdó. Trata-se de uma região majoritariamente negra que compartilha certas práticas e valores, ao tempo em que também revela tensões com o Pacífico sul, no tocante, por exemplo, à consolidação do processo organizativo étnico, como abordei ao longo do texto.

${ }^{359}$ Trata-se de um movimento popular liderado por Antônio Conselheiro, que durou de 1896 a 1897 , em Canudos, no interior do estado da Bahia, no Nordeste do Brasil. A região, historicamente caracterizada por latifúndios improdutivos, secas cíclicas e desemprego crônico, passava por uma grave crise econômica e social. Milhares de sertanejos e ex-escravizados partiram para Canudos, fascinados pela figura do "peregrino" Antônio Conselheiro, revolucionário líder espiritual, cujas palavras criticamente se dirigiam aos flagelos do clima e da exclusão econômica e social do sertão. Foram combatidos pelo Exército brasileiro, mobilizado por grandes fazendeiros da região, articulados com a Igreja católica. O enfrentamento entre sertanejos e militares foi vitorioso para os sertanejos, em três diferentes expedições, até que o arraial de Canudos foi destruído e cerca de vinte mil sertanejos mortos (Arinos de Belém, 1940; Moniz, 2001).
} 
caráter da violência interpessoal na dinâmica de atualização de conflitos entre conhecidos e familiares (Machado, 1998 e 2010).

Donny Meertens, pesquisadora holandesa radicada na Colômbia, também apresenta um apanhado da história das guerrilhas colombianas. Ela realizou pesquisa de campo entre 1975 e 1994 na zona cafeteira, nos departamentos Tolima Quindío, Risaralda, Caldas y norte del Valle, bem como na zona de colonização camponesa de Guaviare, com foco inicial nas transformações agrárias e no papel das mulheres na economia camponesa de colonização. Já como docente da Universidad Nacional de Colombia, encabeçou proposta investigativa intitulada Mujer y violencia político-social. Dessas pesquisas todas, resultou a tese doutoral publicada em 1997. Assim como o trabalho de Álvarez, o apanhado realizado por Meertens me auxiliou a situar no tempo as várias movimentações revolucionárias armadas.

Meertens (1997) também situa o gérmen das FARC no contexto do período de " $L a$ violencia", na década de 1950. Segundo essa autora, em seguida, nasce o Ejército de Liberación Nacional (ELN), castrista, e o Ejército Popular de Liberación (EPL), maoísta. Para Álvarez (2013), a segunda metade da década de 1960 é o palco do surgimento oficial dos três grupos guerrilheiros. Tanto as FARC quanto o EPL, na concepção de Álvarez, originam-se de antigas guerrilhas liberais, posteriormente convertidas em guerrilhas comunistas.

A década de 1970, por sua vez, abriga o surgimento do M-19 e outros grupos menores cujos integrantes eram, em sua maioria, de contextos urbanos. Segundo Álvarez, o M-19 é recordado pela "sangrenta ocupação do Palácio da Justiça", em 1985, no coração político da capital colombiana, onde houve um massacre dos militantes do movimento, pelo qual é reconhecidamente corresponsável o Exército colombiano ${ }^{360}$ (Idem, ibidem: 240). Em 1989, como lembra Álvarez, o M-19 entregou as armas e surgiu o partido político Alianza Democrática. Em diálogos com colombianos/as e estrangeiros/as residentes na Colômbia, esse episódio parece central na configuração de um cenário propício à realização da Assembleia Nacional Constituinte no ano seguinte, em 1990, a partir da qual se emoldura o reconhecimento conquistado pelo povo afro-colombiano no tocante aos direitos territoriais.

Tema que interessa diretamente a esta pesquisa, a relação entre guerra e território é abordada por Álvarez (Ibidem). A autora afirma que é a partir da década de 1970 que as guerrilhas e os diferentes movimentos de esquerda deram início às invasões de terras, como estratégia de domínio territorial. Conforme ressalta Almario (2004), fazendo uma análise da

\footnotetext{
${ }^{360}$ Segundo Álvarez (2013), configura-se um massacre quando há assassinatos coletivos que superam quatro mortos.
} 
dinâmica implementada pelas FARC, nas décadas seguintes (1980 e 1990), amplia-se o escopo territorial considerado estratégico por esse grupo guerrilheiro.

En los últimos veinte años, la geoestrategia de las FARC consistió en superar su accionar constreñido a su núcleo vital e histórico, para extenderse y consolidarse hacia su núcleo de influencia o periférico y progresivamente llegar incluso hasta las zonas de frontera, donde su presencia era más débil o nula. En efecto, esta fuerza, una vez consideró que había consolidado su presencia en el núcleo vital en la Cordillera Oriental, incluido el objetivo de tender un cerco sobre Bogotá con la expectativa más o menos rápida de la 'toma del poder', decidió ampliar su capacidad operativa en el núcleo de influencia (Costa Atlántica, la Orinoquía y la Amazonia) y finalmente establecerse en las zonas de frontera (como el Pacífico), con la consiguiente dinámica de creación de los frentes y bloques respectivos. A partir de esta lógica, la guerra se ha convertido en nacional y, al parecer, estaría entrando ahora en una fase de urbanización (lucha por el control de los barrios y 'concentraciones subnormales' $y$ de sus corredores viales internos y externos), donde se presume que se resuelven o van a resolver los principales problemas de logística pura y dura (información, abastos diversos) y de respaldo político y reclutamiento (Almario, 2004: 84-85).

Considerando os atores da guerra de modo geral, o autor assinala que as movimentações espaciais buscam garantir a eficácia das tecnologias financeiras e logísticas da guerra, o que torna imprescindível o controle territorial.

Os diversos governos nacionais reagiram de forma variada às movimentações revolucionárias, segundo Meertens (1997). No período de 1978 a 1982, gestão do presidente Julio César Turbay, todas as formas de protesto social, em especial armados, foram duramente reprimidos. Entre 1982 e 1986, o então presidente Belisario Betancur deu início a um processo de desmilitarização do protesto social, abrindo pela primeira vez o caminho para soluções pacíficas ao "conflito armado interno". Reconhecia-se que havia problemas econômicos e sociais.

A partir daí, a política oficial frente aos grupos guerrilheiros tem sido de duplo sentido: repressão militar e negociação política. A maioria dos grupos mais recentes (com exceção de alguns setores do EPL) acordou com o governo um processo de reinserção na sociedade civil. Em contrapartida, as FARC e o ELN criaram a Coordinadora Nacional Guerrillera, ampliando suas frentes até cobrir grande parte do território nacional, e intensificaram suas ações. Depois de uma anistia geral e mesas redondas de negociações infrutíferas $^{361}$, as relações entre governo e guerrilhas voltaram a centrar-se na repressão militar, mediada, frente à ineficácia desta, por uma desenfreada dispersão do paramilitarismo.

${ }^{361}$ Ocorridas, em 1991, em Caracas, Venezuela, e em Tlaxcala, México. 
Adentramos, então, na caracterização de mais um ator armado no cenário da guerra, os grupos paramilitares. No território colombiano, de modo geral, junto com a chegada dos megaprojetos econômicos, chegaram os chamados paramilitares, um tipo de milícia armada que, de certo modo, conta com a conivência do poder público oficial. Álvarez (2013) situa o início dos grupos paramilitares entre 1983 e 1990. Segundo essa autora, houve uma mimetização dos grupos paramilitares em grupos de autodefesas, que culminou, em 1997, com a irrupção das Autodefensas de Colombia (AUC), organização confederada, de índole nacional, que realizava massacres, desaparições e "desplazamientos" da população em todas as regiões do país. Os traços característicos das AUC são assassinatos seletivos e massacres.

Analisando o contexto da zona cafeteira colombiana, Meertens (1997) também associa os grupos paramilitares à defesa de interesses econômicos e políticos no contexto do narcotráfico. Creio que tal associação é válida para a região de minha pesquisa. Em dimensões nacionais, segundo Álvarez, a associação com o narcotráfico possibilitou aos grupos de autodefesa a saída do isolamento e do localismo. Nas palavras da autora:

Las estructuras del tráfico, de producción, comercialización y exportación de cocaína, además de los vínculos con redes nacionales y globales de mercados ilegales y aliados políticos en todas las esferas, permitieron su letal consolidación e infiltración en la institucionalidad local, regional y nacional (Álvarez, 2013: 255).

Sanchéz também propõe uma retrospectiva dos grupos paramilitares, do final da década de 1960 até a primeira década do milênio:

Estos actores armados inicialmente se ampararon en una ley de 1968, la cual le otorgaba a civiles, la facultad de "colaborar" en acciones militares en contra de la guerrilla, en la forma de "Autodefensas", en este sentido los grupos paramilitares surgieron en el centro del país, en el valle medio del río Magdalena. Pero en 1989, con el asesinato del entonces candidato liberal a la presidencia, Luis Carlos Galán, el gobierno los declaró ilegales. Posteriormente, reaparecerían y se fortalecerían a través de las Cooperativas de Seguridad Rural, "Convivir", que luego tomarían la forma de las llamadas Autodefensas Campesinas de Córdoba y Urabá (ACCU) y otras, que después lograrían un consenso nacional con otros grupos ilegales de extrema derecha, conformando las Autodefensas Unidas de Colombia (AUC) o "paramilitares" [...] Actualmente en el 2004, las AUC superarían los 20.000 hombres armados, y se organizan en 20 frentes a lo largo y ancho del país. (Sanchéz, 2005: 222).

O autor, assim como Álvarez (2013) e Meertens (1997), associa o contexto de guerra com o perfil produtivo nacional que, a partir da década de 1980, passa a focar um novo 
modelo de desenvolvimento associado ao narcotráfico e à exploração em grande escala de recursos naturais, como o ouro e a madeira.

Ao longo dos dois mandatos presidenciais de Uribe (2002-2006 / 2006-2010), houve uma ação nomeada "desmobilização" dos grupos paramilitares ou autodefesas (AUC), a partir da Lei n. 975, de 2005, a Lei de Justiça e Paz ${ }^{362}$. Ressalto, nesse processo, o envolvimento dos Estados Unidos da América. Até o início de 2010, eram quase quarenta estruturas armadas de grupos paramilitares e autodefesas registradas. Ao final daquele ano, segundo Álvarez (2013), dos 25 comandantes paramilitares julgados, catorze haviam sido extraditados para os EUA, o que intervinha na consecução dos processos de verdade, justiça e reparação, que deveriam ser assegurados segundo a referida lei. Outro tema que merece destaque consiste nos escândalos de infiltração do paramilitarismo em altas esferas de governo, durante ambas as gestões de Uribe, como ressalta Álvarez (Ibidem).

O governo colombiano afirmava, então, ter extinguido tal expressão da ação bélica organizada. Porém, não foi bem assim. Segundo Álvarez (Ibidem), extinguiu-se o nome "paramilitar", porém as estruturas armadas e as redes políticas permaneceram. Conforme pude apreender nos relatos ouvidos em campo, a população afro-pacífica na região de fronteira entre a Colômbia e o Equador fica encurralada entre grupos guerrilheiros e grupos paramilitares. Os voceros assediam as comunidades, enquanto os paramilitares recrutam pessoas para compor o grupo. A comunicação dos paramilitares é feita pelos chamados "informantes".

Há relatos de diversos casos de violência contra a mulher e recrutamentos forçados protagonizados pelos paramilitares. Após a desmobilização, passaram a ser praticados por bandas criminais ${ }^{363}$. Ou seja, segundo a percepção de minhas amigas, não houve desmobilização de fato, mas um reordenamento e uma renomeação dos grupos à margem da lei. Eles estão presentes em territórios ancestrais negros, disputando o controle territorial com as guerrilhas. Em locais onde estavam instalados grupos guerrilheiros, punem famílias negras. Tomam as mulheres como troféus, principalmente quando seus companheiros, irmãos, filhos ou pai são ou eram guerrilheiros. Também atuam contra as organizações locais por enxergarem tais grupos como cúmplices ou "colaboradores" das guerrilhas. Assim sendo,

\footnotetext{
${ }^{362}$ Desmobilização seria o "ato individual ou coletivo de deixar as armas e abandonar o grupo armado perante a autoridade competente" (texto da Lei n. 975, de 2005).

${ }^{363}$ Segundo Álvarez, os dados nacionais de balanço da guerra até a "desmobilização" mencionam três milhões e meio de desplazados/as e 300 mil vítimas registradas perante a Unidad de Justicia y Paz de la Fiscalía. Desde 2005, foram exumadas 2.694 fossas comuns, nas quais estavam depositados 3.369 corpos não identificados. Até dezembro de 2009, os "desmobilizados" haviam confessado mais de 8 mil homicídios, 1.095 desaparições forçadas e 6 mil delitos de diferentes tipos (Álvarez, 2013: 259).
} 
findado os governos de Uribe, a despeito da "desmobilização", as barbáries associadas ao paramilitarismo seguiram assolando o povo afro-pacífico na região em foco.

Na primeira gestão do presidente Juan Manoel Santos (2010-2014), deu-se início a um novo processo de negociação entre guerrilha e governo, ou mais especificamente, entre as FARC e a gestão de Santos. O marco geral desse processo é o Acuerdo general para la terminación del conflicto y la construcción de una paz estable y duradera. Um dos princípios que guiam as conversações em curso é que: "nada está acordado até que tudo esteja acordado". Enfatiza-se, portanto, que os acordos construídos ao longo do processo de conversação estão condicionados ao Acordo Final e que ajustes e complementos em cada um deles podem ser feitos na medida em que avancem as discussões, já que estão interrelacionados. No dia 26 de maio de 2013, a mesa de negociação de paz em Havana firmou o atendimento à reivindicação número um das FARC: reforma agrária.

A primeira resolução da mesa de negociação é denominada "Hacia un nuevo campo colombiano: Reforma rural integral" ${ }^{364}$. O acordo reconhece as Zonas de Reserva Campesina como uma das figuras que o Estado possui para promover a economia camponesa. Mencionase ainda subsídios integrais para a compra e a criação de linhas especiais de crédito como mecanismos de acesso à terra. A perspectiva é do acesso integral à terra, ou seja, provisão de meios e capacidades para fazer uso delas (capital, sementes, irrigação quando for necessário, assistência técnica, crédito e moradia); além de estradas, saúde, educação, água potável e apoio a diferentes formas de associatividade solidária, cooperativismo e comercialização de produtos. Há um recorte de gênero na proposta. $\mathrm{O}$ acesso à terra priorizaria mulheres chefes de família e população desplazada.

Durante a Semana da Afro-Colombianidade de 2013, em um evento que visava à construção de uma agenda afro de paz (Encuentro Agenda legislativa y población afrocolombiana), pude acessar uma visão da coletividade negra sobre os acordos de paz ora em curso, em Havana, Cuba. Diego Angulo, assessor de Piedad Córdoba, ex-senadora afrocolombiana, chamou atenção para o fato de que se tratava do primeiro acordo no tema fundiário entre o governo e as FARC. Nos marcos do direito territorial étnico, lembrou o Artigo Transitório n. 55, da Constituição Política de 1991, e a Lei n. 70, de 1993.

Diego Angulo ressaltou a ausência de representantes afro-colombianos e indígenas na mesa de negociações. A isso se deve o fato de que temas concernentes a essas populações

\footnotetext{
${ }^{364}$ Documento divulgado no dia 21 de junho, ver: Gobierno y FARC dan detalles sobre el acuerdo agrario. Disponível em: http://www.semana.com/nacion/articulo/gobierno-farc-dan-detalles-sobre-acuerdoagrario/348359-3. Acessado em: 1 de julho de 2013.
} 
fossem apenas transversalmente tocados. As FARC falavam sobre Zonas de Reserva Campesina, porém não mencionavam os Conselhos Comunitários. Menos ainda falavam na possibilidade de reconhecer tais territórios como entidades territoriais, garantindo-lhes recursos próprios e autonomia ${ }^{365}$. Como pano de fundo desse processo de negociações, destacou as diligências dos Estados Unidos da América, que identificam e se interessam pelo potencial da Colômbia no tocante aos recursos naturais.

Por fim, fez um apelo quanto à necessidade de organização do povo afro-colombiano para o processo de paz, que, segundo informou, consiste em $27 \%$ da população colombiana. Nas etapas seguintes a Havana, sugere que as ações de pacificação levem em conta a proporcionalidade da representação do povo afro-colombiano em cada departamento. Angulo sustenta seu argumento no fato de que as regiões que mais sofrem com o narcotráfico são negras, ainda que os grandes produtores não o sejam.

Nas intervenções que sucederam a de Diego Angulo, esse ponto foi novamente tocado, quando se chamou atenção para as debilidades que decorrem da ausência de representantes afro na mesa de negociações. As intervenções revelaram que $98 \%$ das pessoas desplazadas, a maioria delas afro-colombianos/as e 12\% de mulheres, estão abaixo da linha da pobreza. Carolina Nevero, da AFRODES, chamou atenção para a relação entre o "desplazamiento" e os interesses econômicos. Foi trazida à tona a questão do retorno das pessoas ao território. A representante de AFRODES falou sobre a necessidade de que do processo em Havana decorram resultados práticos e falou sobre o pós-conflito como um momento no qual se deve gerar um espaço social participativo. Foi sugerido um mandato público convocado pelo movimento afro-colombiano nesse sentido ${ }^{366}$.

Durante o referido evento, a ênfase de lideranças afro-colombianas na necessidade de garantir sua participação dentro da construção de uma agenda de paz está relacionada a uma perspectiva mais geral que não legitima a Lei de Justiça e Paz, por considerar que ela não

\footnotetext{
${ }^{365}$ Diego Angulo lembrou que a reforma constitucional criou uma sexta modalidade de entidade territorial: "las entidades territoriales son personas jurídicas de derecho público que gozan de autonomía para la gestión de sus intereses dentro de los límites de la Constitución y la Ley". A Constituição Política de 1991, em seu artigo 286, assinala que "las entidades territoriales son los departamentos, los distritos, los municipios y los territorios indígenas". De acordo com a Ley Orgánica de Ordenamiento Territorial (LOOT, Ley 1454 de 2011), estabelecem-se associações de Departamentos, Municípios, Distritos Especiais e Áreas Metropolitanas. Criam-se ademais Provincias administrativas y de planificación y Regiones de planeación y gestión. Ver: Cartilha "Descentralización y Entidades Territoriales", da "Procuraduría delegada para la descentralización y las Entidades Territoriales" (em especial páginas 21 e 33). Disponível em: http://www.procuraduria.gov.co/portal/media/file/Cartilla\%20descentralizaci\%C3\%B3n.pdf. Acessado em: 2 de agosto de 2013.

${ }^{366}$ Desde o início da década do milênio, Rosero (2002) chamava atenção para a importância do pós-conflito, prevendo uma intensificação das pressões sobre os territórios étnicos, com vistas ao acesso a recursos naturais, o que poderá implicar retrocesso no campo dos direitos conquistados.
} 
assegura os direitos a verdade, justiça e reparação ao povo afro-colombiano. Para o historiador palenquero Luis Gerardo Martínez Miranda, o critério que norteia tal avaliação reside no entendimento de que a violação dos direitos humanos implica repará-los, ou seja, devolver a "vítima" ao estado anterior em que se encontrava antes do ato violento. No caso do povo afro-colombiano, trata-se de "un pueblo entero que ha sufrido daños casi imposibles de reparar" (Martínez, 2007).

Vimos, portanto, como surgem os movimentos insurgentes armados, os grupos paramilitares/autodefesas, bem como as interfaces entre ações dos atores armados e do governo colombiano, buscando enfatizar um olhar desde a coletividade negra sobre essa realidade. Para complementar a reflexão sobre o cenário da guerra na Colômbia, faz-se necessário agora lançar luz sobre a região do Pacífico colombiano.

Nesse contexto, segundo Sanchéz (2005), a marginalização da região chegava até os impactos da guerra, que a poupavam. Durante muito tempo, falava-se sobre o Pacífico como um "pacífico remanso de paz", o que durou até a década de 1980. A partir daí, a incorporação da região ao cenário da guerra foi maquiada por uma perspectiva desenvolvimentista, que concebia o Pacífico como "terra promissora", "geoestratégica", chave no contexto de modernização da nação (Sanchéz, 2005: 228). Assim, o final dos anos 1980 marca a chegada da guerra à região, primeiramente no departamento de Chocó.

Isso significa que, no Pacífico, a guerra chegou junto com o grande capital materializado em iniciativas desenvolvimentistas estatais e privadas. Oslender (2004) ressalta, então, a entrada dos grupos paramilitares na região.

Grupos paramilitares vacían los terrenos y los preparan así para la intervención del capital. Es esta la lógica de la 'gran pesadilla neoliberal': la destrucción y limpieza de futuras zonas de intervención para el capital sediento de nuevas esferas de explotación y apropiación, a cargo de agentes estatales y extra-estatales (Oslender, 2004: 37).

Essa dinâmica incidiu sobre territórios ancestrais negros que foram reconhecidos mediante processos de titulação coletiva, cuja inauguração no cenário nacional foi nas ribeiras de rios do Pacífico, como apresetado na seção anterior ${ }^{367}$. "A partir del 2000 ya tenemos compañía en el Consejo Comunitario. Hace 15 o 16 años. Así que ganamos la Ley 70, poquitos años después, empezó". Trata-se, portanto, de um processo sistemático: chega o

\footnotetext{
${ }^{367}$ Vários autores assinalam isso, entre eles: Rosero, que ressalta a existência de uma lógica de reconhecimento e uma contralógica de "desplazamiento forzado interno" (2002: 552).
} 
título coletivo, chegam os atores da violência, aliados com grandes empreendimentos econômicos, principalmente as empresas de palma africana.

Nesse sentido, o cenário contemporâneo da guerra, aliada aos interesses do grande capital, exige uma reavaliação do contexto de garantia legal de direitos que teve cabo na década de 1990. Como ressalta Rua (2002), no processo da Constituinte e da Lei n. 70, o Pacífico não se revestia da relevância estratégica geopolítica e econômica que passa a representar nas primeiras décadas do milênio. Interesses contemporâneos e os megaprojetos que deles derivam levam ao desconhecimento dos direitos adquiridos pela população afrocolombiana.

\section{NARRATIVAS FEMININAS E OS IMPACTOS CONTEMPORÂNEOS DA VIOLÊNCIA SOCIOPOLÍTICA}

A perspectiva de mulheres afro-pacíficas enfatiza que a violência sociopolítica inscreve-se em um contexto de disputas pelos territórios ancestrais negros, protagonizada por diversos atores.

Narradora A: En ese proceso de las FARC, los palmeros vinieron y arrebataron tanta tierra. De las tierras que antes INCORA no se las titulaba porque eran tierras baldías. Si usted tenía la finca aquí, no más le daban otro pedazo de respaldo. Y hasta ahí la titulaban. Y el resto de las tierras eran baldías. Entonces el gobierno, desde satelitalmente, vendía. O no sé que negociación hacia con esas tierras, que cuando la gente miraba, eran los blancos de allá de otros departamentos, de Huila, que vinieron a sembrar palma. Y cuando llegaban ellos, le prohibian a uno el paso porque a veces eran caminos que uno caminaba por ahí a su finca. Cuando llegaban, lo primero que hacian era prohibir el paso. Lo otro que hacían era: mataban a campesinos que estaban al lado de ellos. Decián que les vendieran, cuando les decían que no, los mataban. O otros tenían que irse, dejar las tierras ahí. Eso era. Yo creo que esa gente llego desde el 90, o antes del 90.

A narradora mostra que o grande capital, o Estado, o paramilitarismo e a guerrilha são questões associadas à disputa pelos territórios ancestrais. A coletividade negra sente-se perdendo poder perante tais atores. As mulheres percebem que a chegada dos espoliadores bloqueou a gestão dos territórios, impediu a mobilidade, ameaçou e tirou a vida das pessoas. Há mais um fator associado, o narcotráfico, que ganha preponderância nas narrativas das mulheres com quem dialoguei. Ele mimetiza-se com outros projetos econômicos, como apontam Grueso, Rosero e Escobar. Ao final da década de 1990, “los carteles de la droga también están entrando a la región bajo la apariencia de proyectos de minería a gran escala, 
agro/industriales y turísticos" (Grueso, Rosero e Escobar, 1999: 254). Vale ressaltar que se trata de uma região estratégia, na medida em que permite o controle de portos, ou seja, a entrada e saída de mercadorias.

Segundo Pazmiño (2003), na região dos Rios Satinga e Saquianga, os cultivos de coca surgem como uma alternativa ao decaimento da atividade industrial madeireira e com eles aparecem grupos armados ilegais que controlam o negócio e exercem domínio territorial. Trata-se de um processo de início imperceptível, mas que começa a modificar as condições sociopolíticas das localidades ribeirinhas da região. Anúncios de dinheiro começam a circular em grandes quantidades e atraem "paisas", que se instalam nas cabeceiras dos rios para abrir diferentes negócios. Outros se deslocam ao interior da floresta, onde estavam instalados os cultivos, estabelecidos sobre o desmatamento da floresta. Os habitantes das veredas ribeirinhas participam da atividade como guias para a localização de boas áreas para o cultivo, como intermediários das pessoas interessadas na venda de suas terras, ou como diaristas nas tarefas de desmonte e limpeza dos terrenos (Pazmiño, 2003: 137).

É interessante notar que as narrativas trazem uma leitura étnico-racial dos atores envolvidos nesse cenário de disputa. Os habitantes ancestrais das ribeiras do Pacífico são negros, enquanto quem chega com a palma africana, com a cocaína e a violência são brancos.

Narradora A: Porque allá en las comunidades se han introducido paisa' por el cultivo ese que persiguen tanto, la coca. Y ellos por ende viven de otro, son otras culturas muy diferentes de la de nosotros. Es que ellos empezaron con el cultivo de la coca, los paisa'. Entonces, a raíz de eso, los negros copiaron. Porque los negros somos copiones. Por lo menos en algunos ríos, ellos vinieron, hicieron sus cultivos grandes. El negro a veces es pedacito, pedacito. Los paisa' que están en el casco urbano, están ocupando todo lo que hay de negocio. Y los negros los van desagando. Ahorita no hay casi negro en el comercio, apenas aquí en lo que dicen San Andrecito, que mantienen su negocito. Pero los paisa' tienen los grandes graneros, Mercazeta.

Os paisas são não negros, representam a alteridade do povo afro-pacífico. A eles está associada a introdução do cultivo de cocaína na zona rural, assim como do cultivo de palma africana, como mostra o depoimento anterior. Na zona urbana, os impactos da ação bélica organizada estão se fazendo sentir sobre os empreendimentos negros.

Paradoxalmente, uma parte da população local, majoritariamente negra, engajou-se no contexto do narcotráfico e da ação bélica organizada. $\mathrm{O}$ depoimento a seguir mostra o quanto as matronas lamentam o fato de que a própria população negra tenha se engajado nas tramas da violência sociopolítica, seja como paramilitar, guerrilheiro, cocaleiro. A narrativa relata 
ainda como esse engajamento reflete uma dinâmica perversa para a população negra, instituída desde a escravização de povos africanos nas Américas.

Paula: $Y$ entre ellos, ¿hay también gente negra?

Narradora A: ;Son negros! iSon negros! Son de los índios de acá. Y los blancos que traen son pocos. Los blancos vienen a meterse acá. Negro, indígena, que se van metiendo y se van metiendo y se van metiendo. Inclusive eso es peligroso, porque es la gente que conoce a uno y es más fácil descifrarlo. Es gente de los mismos ríos. Si no es mi río es del otro río, es del otro río, del otro río. Porque yo estoy más que segura que si fuera gente de otro la'o, de pronto no pensaban de esa manera. No habían llevado algo que conseguimos, que era para ayudar a la familia. Yo estoy más que segura. Pero como somos los mismos y no sé por qué historicamente el negro le tiene rabia al mismo negro y el negro mata al negro. Porque eso nos lo dejaran reflejado en la memoria desde la historia de nuestros ancestros. Y eso ha quedado, eso no ha salido de la memoria de uno negro. No ve que cuando trajeron a nuestros ancestros, para castigarlos, ¿hacían castigar el mismo negro? Y eso ha sido como... en toda la historia ha sido la trayectoria.

O depoimento traz uma interpretação histórica, conectando o empreendimento da escravização de povos africanos nas Américas com o contexto contemporâneo da guerra, o que revela a dimensão da dor e da indignação que a guerra exerce sobre a coletividade negra. $\mathrm{Na}$ perspectiva da narradora, a escravização jogou os negros/as uns contra os outros/as e, contemporaneamente, a cocaína, a palma africana, o paramilitarismo e as guerrilhas fazem o mesmo. Rosero (2002) chama atenção para o fato de que a guerra na atualidade faz retornar à memória coletiva negra a experiência da escravização, com a dor da fragmentação familiar, a impossibilidade de possuir e conservar bens, o maltrato sofrido pelas mulheres, a vinculação dos homens a uma guerra alheia, o desconhecimento das autoridades próprias e a expropriação territorial.

Em Tumaco, a irrupção da guerra data de meados dos anos 1990 e está associada à chegada de "sicários" e "grupos à margem da lei”, junto com a cocaína.

Narradora B: Y es que sin temor a equivocarme hablo de 1996. En 1996, entran los Rastrojos aquí en Tumaco. Es un grupo al margen de la ley. En este tema cultural, en nuestro territorio, sembraba tabaco, sembraba cacao, sembraba café, sembraba todo. Y cuando entra esa gente, ya la gente cambió sus cultivos tradicionales por la coca y la palma africana. Y entonces, en esa época la gente empieza el cultivo. La gente empieza a radicar el cacao por sembrar eso. Entonces ahí como entra... es lo que yo llamo la epidemia. Toda esa gente que vino al Pacífico, la gente del interior de Colombia. Los mestizos que llegaron aquí, llegaron y sembraron esa semilla. Y esa semilla era, como mirar el mejor postor, quienes se quedaron con el manejo de eso aquí en Tumaco. ¿Por qué?, porque esa semilla, tenía una salida internacional que era Ecuador, tenían el Pacífico, tenía de todo. Luego... las Águilas Negras. O sea, a Tumaco le empezó a llegar de todo, de 
todos los virus, que pudieron haber existido o que existen aún. Y luego de eso, esa gente se fue, esa gente ya no está aquí en el territorio. Pero tal fue el daño tan grande que dejaron hecho que hoy son nuestros hijos. Ya la violencia, no la está dando el de afuera. Son nuestros hijos, los que se están matando entre ellos. Digo nuestros hijos, porque yo considero que Tumaco es una sola familia. Entonces es la misma sangre, la que se está derramando. Esto no es gratis, esta guerra que sembraron, Paula, no es gratis. Yo la tengo clara, que detrás de todo eso hay unos intereses. Y los intereses es, o por acabarnos, erradicar a nosotros los negros, sacarnos y ellos adueñarse de este territorio, ¿o qué piensan hacer con el Pacífico?

Da perspectiva da narradora, a década de 1990 marca a chegada de grupos que são considerados vírus: invadem a coletividade negra, infeccionam os territórios e provocam fissuras nas tramas da socialidade afro-pacífica.

Narradora C: Mira, el conflicto en Tumaco empieza en el 98. O sea, antes de eso ya estaba la guerrilla, pero no teníamos problemas con la guerrilla. Pero a partir del 98, empiezan a entrar en Tumaco los paramilitares. Y es cuando empieza el problema para nosotros. Bueno, es una hipótesis mía, no sé hasta qué punto sea real. Yo creo que los paramilitares vinieron en contra del Palenque Regional Nariño porque no quisimos hacer parte de esta estructura. Ellos, cuando recién llegaron, intentaran utilizarnos como informantes. ¡Nadie conocía mejor el territorio que nosotros! Y frente a la negativa es que empieza la arremetida contra nosotros. Entonces, cuando llega el 2000, el Palenque Regional Nariño ${ }^{368}$ ya no existía. A todos nos había tocado salir. Todos habíamos sido amenazados, a otros se habían hecho atentados y otros estaban muertos. ¿Si? (...) Yo salgo de Tumaco porque me dan de las nueve de la noche hasta el mediodía. Y cuando salgo de Bogotá igual no hay tiempo de nada. De hecho hasta hoy mis papás no saben por qué yo salí de Tumaco. Nunca encontré manera de contarles eso. No hay forma de contarles, por lo menos yo no la encontré. Mis hermanos lo saben muy por encima. Mis hijos se enteraron ahora, igual muy por encima, sin mayores detalles.

A narradora C enfatiza que a presença da guerrilha, anteriormente aos anos 1990, não interferia nas dinâmicas de gestão local do território. Seu depoimento abre as portas para a percepção das formas de subjetivação do medo e da violência. A pressão dos paramilitares foi tão dramática na trajetória dessa mulher, tamanho foi o poder por eles imposto, que a alternativa para ela foi sair do território. Uma saída acompanhada pelo silêncio.

Narradora D: Mire que yo nunca había escuchado de violencia. Yo tuve mi primer hijo en el 77 y uno iba a cualquier lado y nunca nada. Después el segundo que fue en el 79 y nada todo sano, uno del campo se venía al pueblo y dejaba a su hijo en la casa solo en el campo y no pasaba nada. Del 99 para acá fue que uno empezó a escuchar cosas que los paramilitares, porque primero fueron las Autodefensas Unidas de Colombia, las AUC. O

\footnotetext{
${ }^{368}$ O Palenque Regional Nariño, como explicado na segunda parte da tese, configurava à época a instância organizativa do PCN no departamento de Nariño.
} 
sea, los primeros que aquí yo miré fueron los sicarios, cuando los paisas trajeron sicarios. Sicarios son esos mismos de la mafia. Sí, ellos fue que empezaron, de pronto sí había su coca, sus mafiosos y todo eso, pero los paisas fueron los primeros que trajeron sicarios aquí. Los paisas son los dueños de los negocios. En el 99, en eso mataron a un paisa poderoso de negocios. Ahí fue que se unieron todos los paisas y trajeron sicarios para, según ellos, hacer limpieza.

A narradora D mais uma vez indica que os paramilitares são o nódulo da violência sociopolítica. Ela enfatiza que os atores da violência são racializados. São os brancos que trouxeram os sicários, com vistas a defender seus interesses, que são interesses econômicos.

Em todos os relatos, os não negros chegaram a Tumaco semeando o monocultivo, os cultivos ilícitos, a guerra e a violência. Os interesses que orientam tais ações são interesses econômicos associados a atividades produtivas, o que coloca a territorialidade no centro da questão. A guerra, portanto, vincula-se ao controle territorial, que tem como meta esvaziar o Pacífico, expulsando a população negra ribeirinha que ancestralmente ocupa esse território, dominando as áreas rural e urbana e desarticulando o processo organizativo negro em torno da territorialidade ancestral. Deixaram instaurada a guerra e uma lógica produtiva contrária à polivalência da gestão territorial ancestralmente exercida nas ribeiras de rios do Pacífico. Parte da coletividade negra incorporou isso e hoje, em certa medida, contribui para perpetuar a violência, o monocultivo e os demais fatores mencionados. De outro lado, as organizações negras, as lideranças e as matronas seguem resistindo.

É interessante notar que, nas narrativas locais, a presença guerrilheira na região, anteriormente à década de 1990, não representava problemas. Os conflitos parecem derivar, portanto, de uma lógica não negra que se apodera do Pacífico, a qual se materializa na figura dos "paisas", dos "paramilitares", "sicários", "Los Rastrojos", "Águilas Negras". Los Rastrojos e Águilas Negras são mencionados por Álvarez (2013) como protagonistas da guerra em Urabá, especialmente a partir de 2009. Os primeiros configuram, segundo a autora, braço armado de um cartel de traficantes do norte do departamento do Vale do Cauca. Já Águilas Negras, ela ressalta, seria uma denominação usada por diversos grupos, para atemorizar e aterrorizar a população. Não se trata, portanto, de um único grupo ou organização nacional $^{369}$.

\footnotetext{
369 Álvarez (2013) informa que os Rastrojo foram classificados pelo governo no segundo mandato de Álvaro Uribe Veléz (2009-2010) como organização criminal. Nesse sentido, não se encaixam no escopo da Lei de Justiça e Paz, que é direcionada à desmobilização de "grupos organizados à margem da lei", ressalvando-se que tais grupos não tenham iniciado suas atividades em consequência de envolvimento com o narcotráfico.
} 
Então, na primeira década do milênio, a guerra já estava instaurada em Tumaco. Em maio de 2003, como uma ação do Plan Colombia ${ }^{370}$, foi construída, próxima ao aeroporto da cidade, uma base policial antinarcotráfico, de onde partem os aviões para fumigação dos cultivos de $\operatorname{coca}^{371}$. Como a base ocupa quase metade da cidade, trata-se de uma materialização das dimensões que o conflito assume na região. Para a região de Tumaco, os rios da enseada e o corredor fronteiriço Colômbia-Equador, Plan Colombia determinava a ampliação do cultivo de palma africana em cerca de 20 mil hectares, como assinala Rosero (2002). Nas palavras do autor:

Con esto, además de los impactos ambientales, las políticas gubernamentales legalizan el asesinato de más decien personas en los últimos años, realizados por las empresas palmicultoras,y la expropiación que vienen sufriendo las comunidades afrodescendientesen ambos lados de dicha frontera (Rosero, 2002: 554).

Desde meados da década de 2000, Tumaco é o município com maior área cultivada de cocaína na Colômbia, conforme dados da Política Pública para Equidade de Gênero, para a Equidade das Mulheres Narinhenses desde sua diversidade étnica, social e cultural, em um território em construção de paz. Eram 7.128 hectares em 2006, com indicativos de um alto potencial de aumento da produção de cocaína. Segundo informes do governo de Nariño durante o Fórum Binacional Fronteiriço de 2012, 26\% é a porcentagem de participação do departamento no cultivo de coca na Colômbia.

Sanchéz (2005) ressalta o boom dos cultivos ilícitos em Nariño como o principal fator instaurador da guerra na região. Associado ao narcocultivo, os grupos armados assumiram o controle territorial e o controle social sobre a população afro-pacífica que habita a região. Esse é o gérmen dos processos de "desplazamiento" ou "destierro", uma das expressões contemporâneos em que "guerra y racismo se encuentran para convertir determinadas minorias - entendidas como grupos poblacionales con rasgos distintivos y posiciones no dominantes - en mayorías en el horror", como ressalta Rosero (2002).

\footnotetext{
${ }^{370}$ Trata-se da ação levada a cabo pelo governo colombiano no combate às drogas, com intenso apoio financeiro dos Estados Unidos da América, um dos principais destinos da droga colombiana, embarcada principalmente por Tumaco e Buenaventura. Foi iniciado no ano de 2000, o governo do presidente Andrés Pastrana, e fortalecido nos mandatos de Álvaro Úribe Velez. Rosero define o referido plano como "una discutida estrategia antidrogas que, lejos de erradicar los cultivos de uso ilícito, ha logrado que estos lleguen a otras zonas, entre ellas los departamentos de Nariño, Cauca, Valle, Chocó, Antioquia y otras áreas de la Amazonia" (Rosero, 2002: 554).

${ }^{371}$ Só para as ações de fumigação em Putumayo, Caquetá e Nariño, no primeiro ano do governo de Úribe (2002), os Estados Unidos destinaram 147 milhões de dólares, do montante total de 427 milhões de dólares enviados para assuntos militares (Sanchéz, 2005: 231). Em 2005, os EUA injetaram 577 milhões de dólares estadunidenses para "combater" o "conflito armado interno" colombiano (Sanchéz, 2005: 231).
} 
Narradora D: Y así fue la manera que la gente se ha desplazado, todo no es por la guerrilla, todo no es por Los Rastrojos, sino que también por aquellas personas que se adueñaron de tierras para hacer camaroneras, para ocultar su narcotráfico.

O depoimento reforça a atribuição do "desplazamiento" à atuação dos atores armados e à invasão dos territórios ancestrais pelo grande capital, ora representados pelas empresas camaroeiras e pelo narcocultivo.

Cabe aqui um parêntese para problematizar a noção de "desplazamiento", que, como ressalta Arboleda (2007), foi forjada na linguagem jurídica dos Direitos Humanos. O autor observa criticamente que o uso dessa categoria nas ciências sociais cumpre uma função homogeneizadora, a qual oculta a diferença colonial. Destaca, ademais, seu uso assistencialista. A migração no contexto da violência sociopolítica no Pacífico colomboequatoriano está inserida na dinâmica capitalista, implica, portanto, empobrecimento de uma ampla parcela da população, que é afrodescendente, legalizando sua expulsão de territórios ancestrais, como bem mostra o depoimento anterior.

Oslender também tem uma posição crítica ao conceito de "desplazamiento". O autor destaca a normalização e estandardização que se criou em torno do fenômeno na Colômbia, que "coisifica a pessoa desplazada por meio de estatísticas, discursos de expertos e políticas específicas" (Oslender, 2004: 39). O termo desterritorialização é usado por Oslender para enfatizar que, no Pacífico, a guerra instaura uma "geografia do terror", na medida em que embates entre paramilitares e guerrilha fragmentam o território, contrapondo-se aos processos coletivos de territorialização de povos afro-colombianos e indígenas. Trata-se, portanto, da perda do controle territorial.

Identifico-me com a preocupação de Oslender em observar o que está se passando antes que a pessoa seja expulsa do território, no contexto rural; como se transforma o cotidiano da coletividade negra ribeirinha mediante o regime de terror instaurado pela guerra. Já Arboleda (2007) propõe o conceito de "desterro", traçando um fio que conecta a experiência contemporânea da violência com a condição histórica de longa duração da diáspora africana, o que me parece fundamental para compreender as dimensões coletivas da violência que atualmente povos afrodescendentes padecem na fronteira Pacífica entre a Colômbia e o Equador.

De modo geral, as narrativas das mulheres e alguns homens com quem dialoguei reiteram a percepção de que a violência em torno da ação bélica organizada vem se acirrando nesse território nos últimos dez anos e parece acompanhar o ritmo da mobilização política do 
povo afro-pacífico. Assim, nos rios onde se iniciou a luta pelo reconhecimento e a titulação dos territórios coletivos negros, a ação bélica organizada chegou mais cedo.

A presença de grupos paramilitares/autodefesas na região em foco transformou a atuação dos grupos guerrilheiros, já que ambos se enfrentam militarmente. Sanchéz (2005) relata que, no ano de 2002, havia enfrentamentos constantes entre a Frente 29, das FARC, que domina a parte costeira de Nariño, onde estão situados Tumaco e Salahonda ${ }^{372}$, e o Bloque Libertadores del Sur, das AUC, levando Tumaco ao posto de segunda cidade mais perigosa do Pacífico, depois de Buenaventura. Houve, então, um deslocamento do foco da guerra no contexto pacífico, do norte para o sul. Segundo a imprensa, conforme assinala Sanchéz, o corredor de Buenaventura a Tumaco passou a ser considerado uma espécie de "Urabá", dada a relevância dessa costa para fins militares e econômicos.

O autor, citando texto de 2002 do Programa Atención Comunidades Negras, explica que:

las autodefensas rivalizan con la guerrilla al desplegar su presencia sobre la zona productora de coca en el suroccidente del departamento, desde Tumaco hasta El Diviso en jurisdicción de Ricaurte y desde alli hasta Barbacoas para tener el control del Río Patía hacia el Pacífico pasando por los municipios de Roberto Payan y Francisco Pizarro (Sanchéz, 2005: 264).

Segundo as narrativas que até mim chegaram, a presença das FARC em Tumaco é generalizada. O território parece dominado por essa guerrilha. Alguma menção foi feita ao ELN, em Salahonda, mas com pouca expressividade. Segundo informa Sanchéz (Ibidem), onde as FARC dominam territorialmente, não há presença do ELN e vice-versa, sendo as FARC mais significativas no Pacífico. Os guerrilheiros são mototaxistas, circulam pela cidade e pelas veredas. No tocante aos grupos paramilitares, na espacialidade rural, parecem não ter sido capazes de desbancar a guerrilha. Porém, sua presença é expressiva no ambiente urbano, onde aparecem também as bandas criminais, ou BACRIN, grupos armados territorializados que rivalizam entre si.

Esse é um ponto nebuloso nos relatos ouvidos e nas experiências vividas. Por um lado, entendo que existe uma divisão rural/urbana que é estrutural, segundo a qual a presença da guerrilha é expressiva na zona rural e a dos paramilitares e BACRIN na zona urbana. Por outro lado, os grupos armados não têm atuações estanques. Pelo contrário, parecem aliar-se

\footnotetext{
${ }^{372}$ Sobre a presença de outras guerrilhas, Sanchéz (2005) informa que a Frente Comunero del Sur, do ELN, também influencia Tumaco. Haveria ainda poucos redutos da Frente Aldemar Londoño, do Exército Popular de Liberación (EPL), que foi duramente golpeada pelos paramilitares.
} 
em determinados momentos e contextos. Há relatos, por exemplo, de crimes cuja ordem partiu de grupos guerrilheiros e cuja execução coube às bandas criminais.

$\mathrm{Na}$ atualidade, é difícil distinguir os vários atores no contexto da ação bélica organizada em Tumaco, já que eles parecem se imiscuir:

Narradora A: Acá a nivel de casco urbano operaban los paraco', o Los Rastrojo', o las Águilas. Pero a nivel de las comunidades allá en los ríos, opera es la guerrilla. Ellos eran enemigos antes, que no se podían ver unos a los otros porque luchaban por ese negocio [cocaína] y por el territorio. Ahora después ya se mira que, hasta se unieron. Unos cuidan acá y otros allá.

Narradora E: Según el Estado los paramilitares se desmovilizaron en el 2000. El último fue el Bloque Pacífico. Su columna estaba en Buenaventura. Para el Estado, los para' no existen. Apenas las BACRIM, que son grupos pequeños. Pero todavía tenemos Águilas y Los Rastrojos. Los paramilitares fueron creados por el mismo gobierno para proteger los terratenientes, las AUC [Autodefensas Unidas de Colombia]. Las FARC y EPL le estaban dando duro. Y ahora el propio gobierno quiere hacer eso. Hacerse ciego.

Na paisagem de Tumaco, a cidade é setorizada segundo a presença de atores armados. $\mathrm{Na}$ vivência etnográfica, com o passar do tempo, percebi que o senso comum valorava determinados bairros como "perigosos", onde estão "los chicos malos". É ilustrativo o diálogo com um policial de 22 anos, nascido no departamento de Manizales, região de paisas, que trabalhava na corporação havia três anos. Esse jovem inicialmente trabalhava na capital narinhense e foi mandado a Tumaco um dia depois do atentado ocorrido em fevereiro de 2012. Em suas palavras:

Tumaco es duro. Hay barrios que son de guerrilleros, como La Ciudadela. Otros son de paramilitares, como Panamá. La gente piensa que uno como policía puede andar en cualquier parte, pero allá no. Tengo dos compañeros que son de Tumaco, de estos barrios, y trabajaban en Pasto. Cuando tenían la semana de descanso, se iban a otra parte. Como policías, ellos no pueden entrar en sus barrios. Es peligroso. Aunque uno no esté uniformado, ellos lo reconocen a uno. Tienen sus conocimientos. Yo no puedo pasar por la frontera entre Colombia y Ecuador por la mar, hay guerrilleros. Como policía uno no puede pasar.

$\mathrm{Na}$ medida em que começavam a surgir diálogos sobre o "conflito político armado", meus temores transformavam-se. Até então, as conversas com as mulheres, em especial com as concheiras, ressaltavam os perigos dos manguezais. Percebi que os mecanismos de construção do medo, para mim, estavam conectados com o discurso das mulheres com quem estava dialogando, com os fatos que elas me traziam como temerários ${ }^{373}$. Estava imersa em

\footnotetext{
${ }^{373}$ A antropologia tem uma discussão sobre o medo e as emoções no contexto etnográfico. Ver: Machado, Borges e Moura, 2014.
} 
um contexto de guerra local e, até aquele momento da vivência de campo, meu grande temor era o peixe-sapo. Aos poucos comecei a compreender que, em um país que vivencia a guerra há cinquenta anos, o medo, como efeito da submissão prolongada à violência, leva ao silenciamento das pessoas.

Narradora A: La gente en las comunidades no dice nada. La gente simplemente está sufriendo callada. Callada. Porque ya llevamos varios muertos que más de uno se ha atrevido a decir cualquier cosita y sin saber de adónde le sale la muerte: jtrán! Sin saber cómo. Estamos viviendo una vida bastante lamentable. Y la gente con miedo. Sabemos que la gente que no hace daño somos más que los que hacen daño. Pero miedo nos tienen que nadie escapa de nada. Porque sabemos que hay tanta corrupción que no confía en las autoridades, que las autoridades son las responsables de que el país esté como está. Entonces uno, ni a las autoridad, ni a las leyes porque ha habido persona' que han ido donde el comandante fulano de tal y han ido allá y tan tan tan tan y no alcanza a ir llegar a la calle y ya está muerto. ¿Entonces qué? Uno no confía ahorita en nadie de cómo está uno de asustado. Es así, la gente ahora no habla, seguimos así callados. Afortunadamente somos fuertes que seguimos todavía haciéndole pierna al territorio. Porque esas cosas es de salir corriendo y no regresar más. Pero también se pone a pensar uno adónde se va, a pasar trabajo. No hay trabajo que le den a uno pa' uno subsistir.

Um dos códigos em torno da ação bélica organizada é o silêncio. Trata-se de um caminho que as pessoas encontraram para conviver com a guerra. Não se fala sobre isso, na medida em que falar vulnerabiliza o sujeito, ao ponto de leva-lo à morte. Como me foi dito em uma vereda afro-colombiana, "al que habla, lo dejan sólo". Nesse sentido, as pessoas são ensinadas a não falar, o que de certa forma as resguarda no meio da guerra. O silêncio passou a ser lei. Como coloca Álvarez, o código da guerra é composto por convenções ocultas pelo sigilo, a desconfiança e o silêncio (2013: 140). Álvarez (2013) ajuda a compreender que, do ponto de vista da relação que estabelecia com minhas amigas, o silêncio tinha também uma função pedagógica, a qual obedece a uma regra tácita de sobrevivência: quanto menos souberes, melhor.

Ao mesmo tempo, há um sofrimento associado ao silêncio, código disciplinador. $\mathrm{O}$ silêncio é uma imposição, à qual as mulheres com quem dialoguei almejam transformar. Ele é feito com muita dor. Os depoimentos expressam a vontade de subverter o código do silêncio. Por outro lado, o clima de terror instalado parece furtar-lhes tal possibilidade. Partindo da definição proposta por Todorov, entendo por terror a condição imposta pela situação de violência sociopolítica, a partir da qual se busca eliminar a autonomia das pessoas, ou a "vontade como móbil da ação", nas palavras do autor (Todorov, 1995: 313). Os atores da violência sociopolítica - sejam eles paramilitares, bandas criminais, sicários, matones, 
exército ou grupos guerrilheiros -, impõem um modo de agir que causa nas mulheres dor e sofrimento. Para tal, usam a violência física, mas também as pressões sociais, como os códigos de silêncio, o medo e a desconfiança.

Na medida em que minhas interlocutoras não falavam sobre o conflito, ele não se materializava para mim. Sabia que estava ali, mas não o enxergava, não o sentia, não o percebia. Isso porque, até certo momento, não era algo evidente para quem não domina os códigos locais. Passou a se materializar no discurso delas, foi se concretizando dentro de mim e projetando-se especialmente. Nesse momento, comecei a perceber a cidade e as pessoas a partir dos códigos em torno da ação bélica organizada, aprendendo a reconhecer o que se passava conforme o local da cidade ou da zona em que estava inserida, por exemplo. Tratavase do mesmo cenário, porém, entre maio de 2012 e agosto de 2013, meus olhos enxergavam diferentes paisagens.

A situação de imobilização parcial em decorrência do uso das muletas, ao tempo em que me fragilizava emocionalmente, de alguma maneira parecia proteger-me de riscos que, aos poucos, começava a dimensionar. Isso porque, se na cidade estão presentes os "atores armados", na zona rural essa presença é imperativa. "Allá en el campo ha sido más intenso, hay mucha fosa ${ }^{374}$. Porque allá ha sido menos presente la de la ley”. Álvarez ressalta que, nas zonas rurais, há um controle visível por parte dos grupos armados que vigiam as rotas de cultivo, produção e vazão da cocaína (2013: 20). Segundo Sanchéz (2005), as ribeiras dos rios do Pacífico colombiano transformaram-se em corredores de trânsito e refúgio dos grupos à margem da lei. $\mathrm{O}$ autor afirma que, desde a primeira década do milênio, narcotraficantes estabeleceram cultivos de folha de coca e um conjunto de laboratórios para o processamento de alcaloides nos Rios Mira, Mataje e Patía.

Especialmente no Mira, há referências de atividades associadas ao narcocultivo e ao narcotráfico. Segundo Sanchéz:

En la región del río Mira, frontera con el Ecuador, motivados por la ejecución del proyecto binacional de la carretera Tumaco-Esmeraldas y la expansión de las áreas de cultivo de palma africana, nuevamente grupos ilegales armados financiados por los grupos económicos vienen ejecutando atropellos y amenazas contra la población afrocolombiana asentada en la región, por ejemplo en el Congal Alto Mira los paramilitares invitan a los Afrocolombianos a sembrar palma y coca por tal razón algunas personas se han desplazado para el Ecuador. En las comunidades del Congal, Sagumbita, Cacaotal, entre otras, los paramilitares tienen aproximadamente cinco laboratorios de coca, venden la semilla a los campesinos a dos mil

\footnotetext{
${ }^{374}$ Locais de desova de corpos assassinados por grupos armados, legais e ilegais.
} 
pesos por árbol, hacen prestamos millonarios a los campesinos para la siembra de coca con el compromiso de venderles la producción, enamoran a las jovencitas y las convierten en informantes, establecen retenes en las canoas de pasajeros que transitan por el río Mira y le sustraen parte de la remesa a los pobladores como cuota a la organización paramilitar (Sanchéz, 2005: 294-295).

Almario (2004), por sua vez, relata que, em agosto de 2002, a imprensa nacional informava a destruição de um centro de produção de cocaína no Alto Mira, na área onde operava a Frente 29, das FARC. O centro contava com quarenta hectares de cocaína cultivada, bem como equipamentos de processamento, armazenamento e distribuição de seis a dez toneladas de cocaína por mês.

Minha imobilidade parcial foi também um vetor de aproximação com mulheres tumaquenhas, que estavam se tornando minhas amigas. Compreendo que as entorses no tornozelo direito somatizavam a dificuldade de me estabilizar em um contexto que a princípio era encantador e aos poucos foi se tornando temerário, paradoxalmente, sem deixar seu encanto. Dificuldades de lidar com relatos de violência e sofrimento das mulheres com quem convivia e de sustentar o peso do medo e da dor. Paralelamente, minha permanência na cidade, pesadas as condições adversas, conferia maior credibilidade à minha pessoa, creio eu, o que adensava as relações e a possibilidade de realização da pesquisa. Isso porque outro código local em torno da ação bélica organizada é a desconfiança, também efeito da vivência prolongada da violência, como ressalta Álvarez (2013).

Mesmo que não fossem o principal e inicial foco da pesquisa, relatos de violência começaram a surgir. $\mathrm{O}$ caráter contido dos primeiros relatos foi cedendo a um discurso mais aberto e emotivo. Em alguns casos, elas pediam que eu desligasse o gravador. Com uma de minhas amigas, foram vários diálogos, sempre acompanhados da mesma pergunta: "o que você vai fazer com essas gravações?”. Em um de nossos últimos encontros, quando finalmente fui capaz de explicitar minha compreensão do risco que elas corriam ao me revelar certas coisas, ela expôs muitos relatos que escancaravam situações decorrentes da violência sociopolítica. Nesse tipo de narrativa, como ressalta Álvarez (2013), o relato irrompe e a quebra do silêncio tem uma força emocional arrebatadora.

Quando falávamos sobre o território, sobre viver no Pacífico, sobre a vida de liderança, sobre a família, na mesma medida em que nossas relações se estreitavam, o tema da ação bélica organizada aparecia.

Narradora B: Vivir en el Pacífico hoy es un reto. Es seguir en el Pacífico, haciendo resistencia. Hoy estamos aquí, las lideresas, en el Pacífico, 
haciendo resistencia. Porque, alli unas dicen, "No, esto está dificil, lo mejor que uno puede hacer es irse y olvidar". Coger sus hijos y olvidar, por la violencia ... por tantas cosas que hoy nos azotan. Pero, las mujeres lideresas, las mujeres que estamos aquí en el Pacífico, haciendo resistencia. Nos hemos quedado, porque tenemos la plena seguridad de que, Tumaco va a volver a ser lo que era antes. [...] Un remanso de paz.

As narrativas mostram que os protagonistas da violência contemporaneamente são muitos: os paramilitares, especialmente Rastrojos e Águilas, as BACRIN, o exército, a guerrilha.

Narradora A: Por eso murió este hombre, hace tres años. Era un buen líder, un líder Uno A, un tipo que trabajó por todas esas comunidades. Resulta que donde él vivía se metieron unos tipos, paraco' y hicieran una masacre allá. Fueron y mataron un señor y una señora que estaban dormidos, por matar a otro. Entonces la gente dijo que no iba sembrar más coca. La gobernación trajo un proyecto que se llamaba Seguridad alimentaria. A él le tocaba hacer socialización allá sobre la seguridad alimentaria. Y la gente empezó a trabajar con la seguridad alimentaria y a eliminar esa coca. Entonces, a los que no les convenía eso, dijeron que ese tipo tenían que matarlo porque él hubiera hecho que la comunidad cambiara de pensamiento. Entonces los dueños del negocio lo mandaron liquidar. Entonces fue que lo aguaitaran y buscaron el momento preciso. Eso acudieran a toda su cadena, organización de lo ilícito, hasta que lograron conseguir de Cali, desde Cali llegó la orden para matarlo. Acá no más se reunieran, lo esperaron allá en la carretera y lo mataron. Eran Rastrojos. No fueron los paracos, porque los paracos estuvieron y después se fueron muriendo, se fueron yendo y después llegaron otra organización que se llamaba Los Rastrojos y la otra es lo' Águila'. Yo creo que fue Rastrojo'.

Nesse caso, uma liderança comunitária foi assassinada em razão do seu trabalho em prol da coletividade contrário aos interesses da produção da cocaína. Essa é uma das questões que as narrativas trazem. Paralelamente, as rivalidades entre grupos armados desencadeiam assassinatos de pessoas, ou grupos de pessoas, supostamente pertencentes a outro grupo. O que também ocorre em Tumaco, segundo narrativas locais, é que, por vezes, pessoas são confundidas com outras e são assassinadas coletivamente.

Narradora F: Hubo una masacre en el 2004, por ahí, 2005. Antes de eso habían vivido ahí cinco muchachos que habían gustado andar robando, atrapando aquí en Tumaco. Ellos solían reunirse todas las tardes jugando dominó bajo la sombra de un árbol de almendra. Alguien le dijo a ellos: "nos vamos ahi a buscarles". Entonces ellos calladitamente se fueron. Entonces cuando de tres meses que estos jóvenes se habían desaparecido del pueblo, ese día, como a las siete de la noche, empezaron a jugar dominó mi hermano con mi sobrino, mi primo, mi tío. Entonces unos jugaran y otros se paraban a mirar. Entonces pasaba una camioneta blanca, cuatro puertas, despaaacio. Y después que otra vez baja la camioneta. A lo que ya llega ahí adonde están ellos, es que se baja un señor y en seguida fueran 
encendiendolos a plomo, disparándoles. Entonces a mi hermano le entra un tiro por aquí por las nalgas, y le sale por la birrilla. Entonces él saca la cartera del bolsillo y le dice a uno de estos señores: "mire, tome mi cartera, nosotros somos personas de bien. Nosotros no hacemos daño a nadie. Trabajamos en una palmera". Y el de la patata le bota la cartera de la mano. Entonces él cayó encima de los brazos de mi sobrino que ya estaba herido. $Y$ ahí encima lo volvieran a disparar. $Y$ entonces pasó la otra bala por aquí por la pierna y le salió al otro lado. Entonces ahí quedaba la casa de ese mi sobrino que estaba herido. Estaban la mujer y dos niñas. Ellas se quedaron asustadas. "Cierre la puerta, para que tus hijas no vean". Entonces un muchacho de dieciséis años que estaba en la casa, lo sacaron, lo pisaron la cabeza y ahí pinchado lo agarraran. Ellos no entendían ninguna clase de súplica que les hacían. Y a mi sobrino también pisaron la cabeza y los mataron. A un primo mío también que nunca salía, ese día le dio por salir, también lo mataron. O sea, por todo fueron seis los muertos y siete heridos. Porque ya cuando ellos dejan la gente disparada ahí, ellos nuevamente se van para arriba. Entonces la gente alarmada toda salió condoliente a ver: ah, mataran mi primo, mi tío, a mi hermano. $Y$ ellos vuelven otra vez y disparan contra la comunidad, todos los que están allí. Entonces unos corrían para adentro del monte. Mi hermana, la bala le dejó un quemado aquí en la cabeza. Y eso quedaron un sobrino y una sobrina con las piernas que no servían para nada, quebrada, con los tiros. Mi sobrina cuando ella cae, tiene una niña en los brazos. Entonces ella lo que hace es jalarse por el piso y jalar la niña también para que no se la mate. La niña se pegó todo eso, el cuerpito. $Y$ todas las personas eran personas inocentes, gente de bien, de trabajo. Entonces un carro los llevó a Tanga Real porque decían que en Tanga Real estaba el Ejército. El Ejército no hacía caso de traerlos acá al hospital rápido. Estaban tranquilos. Entonces un señor que andaba en una camioneta, decía: "pero ustedes cómo van a dejar a morir a esta gente, ¿!desangrándose?!” Entonces dijo: - “yo mismo voy a llamar al general no sé qué, que es amigo mío". Entonces se asustaran, ya ya ya. Eso fue duro, duro, duro. Entonces después ya se fue llegando la ley, a investigar, a ver si conocían a esa gente y no sé más que cosa. Después trajeron a mi hermano acá, a investigar. Pero mi hermano dice que quien hacia las preguntas y las investigaciones era gente diferente, que él no tenía como confiar, ni hablar. Ya después que se fueron al mismo pueblo, ya de casa en casa a averiguar. Entonces dijo: "ellos están buscando alguien para decir algo y acabar lo de ellos". Porque él dice que él sí lo miro la cara de quién lo disparó. Él dice que donde lo ve, lo saca. Porque él dijo que cuando le disparaba le decía, "no me mires la cara". Uhum. Entonces eso fue lo que pasó.

Segundo a narradora, há indícios de que o próprio exército colombiano seja o protagonista desse massacre, daí a falta de atitude em levar os feridos ao hospital no fatídico dia. Álvarez (2013) ressalta que, no contexto da guerra colombiana, pode haver uma transcendência da fronteira entre a legalidade e a ilegalidade. Os procedimentos investigativos buscavam, então, um bode expiatório, alguém que pudesse ser culpabilizado pelo ocorrido. Eis, pois, um caso protagonizado pelos Rastrojos e outro provavelmente pelo exército.

O próximo depoimento referencia uma violência perpetrada pela guerrilha: 
Narradora D: Desde que uno comenzó a escuchar que la guerrilla, que ya a entrarse allá al pueblo, uno no puede porque para ir y venir toca en canoa con motor. Lo paran, lo arriman a un manglar, allá lo matan, le roban, le quitan el motor. Si no lo quieren matar le quitan todo, eso sí, todo, todo, todo y lo dejan a la deriva. A un cuñado de mi marido, lo mataron en el agua, desde ahi yo dije "iDios, yo no voy!" Ellos iban ya subiendo, sería por ahí la una de la tarde, con la marea que sube en la mañana. Cuando a esa hora la veo a mi hermana que ya no llegó por el puente sino que llegó por la calle y llorando. Ya la miro llena de sangre "iDios mio! ¿Qué pasó?". Casi me muero. Nosotros íbamos cuando vemos otra canoa que nos llaman. Ella le dijo al cuñado que no arrimaran, por el miedo que fueran a ser atracadores. Ya después les alzaban una ropa roja y, cuando miraron, era la familia del cuñado de mi marido. Ya lo habían matado a él, dejaron a la señora con un poco de muchachitos, iban como siete muchachitos, iban para la finca. Ya ellos le dijeron lo habían atracado. Disque gritaban los niños, y un hombre dijo "Mato a todos estos perros pa'que no jodan". Dizque una niña de siete añitos dizque se agarró de uno de ellos y le decía "No me maten a mi papi". Y no. Y los iban a matar a todos pero la señora dice que ella se abrazó con sus muchachos y se tiró con la canoa de boca abajo y lo mataron. Y el señor ya estaba en la canoa, él disque decía "Ayúdenme". Mi hermana lo agarró, le alzó la cabeza porque ya botaba sangre por la boca. Ella que sufre de la presión, antes no se murió ella, tuvo ese valor. Y ya los pasaron a todos en esa lancha grande que iban y cuando llegaron acá ya estaba muerto. Se le llevaron el motor, todo el mercadito, platica, todo se les llevaron.

A mobilidade é tolhida pelo medo. Há uma imprevisibilidade do ataque. Ele pode acontecer nas atividades mais rotineiras, como ir à roça. Não se sabe em que momento o cotidiano pode ser interrompido; quando a vida lhe será roubada. Ao mesmo tempo em que há uma ameaça constante, não se pode interromper o fluxo da vida. Há, portanto, uma sensação intensa de medo - um medo paralisante -, que corre paralela ao imperativo de continuidade da vida. E, nesse ínterim, as pessoas são surpreendidas com ataques dos atores armados.

Nessa etapa do trabalho, mulheres com quem já dialogava me revelaram que estavam com a vida ameaçada, por atores armados.

Narradora F: Yo por lo menos lo he tenido y hasta hoy tengo una amenaza muy fuerte. Yo he entregado todo a Dios. Ya era pá haberme ido, no estar aqui en Colombia. Hubo momento en que lo pensé [...] Pero dije: - No, yo quiero mucho a mi gente. Si me matan, que me muera aquí mismo. No voy a correr. O sea, yo digo, nada malo he hecho a nadie. Siempre lo' he procurado ayudar, hacer cosas buenas. Entonces, Dios me está ayudando que aquí estoy. Pero tengo una amenaza, eso comenzó ya hace nueve meses. Sin embargo, yo camino, ando. Sí, esa ha sido la actitud también de la gente: - no hay ningún problema con usted, nada le va a pasar.

O depoimento revela que o sentido de pertencimento ao território leva essa mulher a enfrentar uma ameaça de morte, a conviver com ela e declinar da ideia de sair dali. Como coloca Álvarez (2013), pertencer ao território significa ter uma relação metonímica com ele. 
Vale mais viver uma vida de ameaça no território do que sair e deixar de sentir-se a si mesma. Essa foi a escolha da narradora, porém, não é um caminho único, e nem sempre ele é possível.

O desplazamiento é um fato. Percebo-o também como uma estratégia de resistência, porque sair da zona rural não significa deixar a ancestral "cultura" afro-pacífica. Afinal, o território é o lugar por onde caminham as mulheres, os homens, os animais e a vida. Ele é fluido, prolonga-se acompanhando os passos das mulheres. No ano de 2013, não pude mais encontrar mulheres com quem havia dialogado nos períodos iniciais da pesquisa. Haviam migrado de Tumaco porque a violência as assolava. Uma delas teve assassinado o filho da minha idade, no intercurso entre a segunda e a terceira etapa de pesquisa.

Narradora G: La compañera está desplazada por amenazas, le mataron el hijo, hace poco. Pobrecito, como que de treinta y un años. No tiene ni tres meses. Y todos nos quedamos ahí pasmados, como quietos, y no queríamos continuar, nos daba como ese temor, ese miedo también. Luego seguí a ella. Yo dije: - No, ella ha estado ahí en la resistencia. Sí, con ella, compañera: ¿cómo hago para que continuemos con la organización de mujeres? Ella hace parte de ello. Y habrá cosas que Dios tiene que protegernos a todas nosotras. Unos estarán a favor y otros en contra. Pero hay que seguir, para lograr algo que favorezca a todas nosotras las mujeres de los ríos.

O depoimento mostra que sair e ficar são estratégias complementares. A luta tem prosseguimento nesse duplo movimento. As mulheres que saem, deixam sua contribuição e o exemplo às que ficam, as quais, por sua vez, seguem no processo organizativo em reverência ao legado que as companheiras desplazadas deixaram.

O ativismo político exerce, então, um duplo movimento: ao tempo em que vulnerabiliza ainda mais certas mulheres, colocando-as em evidência, como explicita o depoimento que narra o assassinato de um "buen líder",375, também mantém essas mulheres territorializadas, em atitude de resistência. A ação bélica organizada implode a rede de socialidade, cuidado, afeto e ativismo político que as mulheres constroem ao redor de si mesmas. Os grupos armados cooptam seus filhos, matam seus maridos e irmãos, desterritorializam suas companheiras. Contudo, as matronas encontram força para permanecer no território ou redirecionar-se, e resistir, assim como os rios.

\footnotetext{
375 Álvarez (2013) apresenta dados de que 45 líderes, em âmbito nacional, foram assassinados entre 2005, quando começou o processo de reparação e restituição de terras, e 2010.
} 


\section{SOFRIMENTOS, PERDAS, CONSTRANGIMENTOS E RESISTÊNCIAS DAS MULHERES AFRO- PACÍFICAS NO CONTEXTO DA VIOLÊNCIA SOCIOPOLÍTICA}

Muitas narrativas falam da perda de um filho nesse contexto. Álvarez (2013) menciona o fenômeno do "luto antecipado", o qual é desencadeado quando há envolvimento dos filhos em qualquer grupo armado ou atividade ligada ao narcotráfico e à delinquência de modo geral. Tal envolvimento, antes do desfecho trágico, provoca dor e sofrimento nas mães.

Narradora H: Mi hijo, me lo mató la guerrilla. Él fue soldado, de ahí se puso soldado profesional. Yo lloraba para que no fuera al cuartel, como veía que los mataban y sin embargo en el cuartel no pasó nada. Como soldado profesional, estuvo dos años con contrato en el Meta, en Quindio. De allá se vino, me dijo: - mami voy a descansar un tiempo para ir vuelta. En eso llegaron unos amigos y lo invitaron que fueran a trabajar a otra parte, y como él era trabajador, le gustaba trabajar, se fue. Llegó allá, tenía un mes cuando hubo una requisa de esos señores y él, como llevó la tarjeta de soldado profesional, y en vez de sacar la cédula sacó la tarjeta de soldado profesional. Usted sabe que a la guerrilla no le gusta eso, y por eso, - como él era bastante blanco - le dijeron: - no, vos no sos ningún trabajador, vos sos un espía del ejército. Dijeron los amigos: - no, nosotros trabajamos en el monte. Dijeron: - jcojan esa gonorrea del ejército!. Y lo mandó a matar. Yo no lo pude traer, porque, cuando nosotros llegamos allá, nos dijeran que nos fuéramos si no queríamos morir también. No lo pude traer a mijo, no lo enterré, allá lo enterraron como a un animal. ;Me duele tanto esa muerte! Que uno, aunque pobre, darle la sepultura a su hijo y no pude [...] Un hijo muy buena persona, que vea, lo que trabajaba era para darme a mí.

Em primeiro plano, esse depoimento dimensiona os choques entre os atores armados. Estavam todos jogando futebol, quando o filho dessa mulher foi então associado ao exército. Nesse momento, a convivência tornou-se inexequível. Guerrilheiros e oficiais do exército são atores antagônicos, ou "inimigos extremos", contra os quais se justifica o extermínio, como coloca Todorov (1995: 144). No código da guerra, esse encontro conduzia à morte de algum deles.

A narrativa faz também uma leitura étnico-racial. Por ser "bastante branco", aquele jovem não poderia ser trabalhador. No imaginário local, seria um espião do exército. Há, portanto, uma associação entre branquitude e nobreza. A branquitude afasta o sujeito do lugar de trabalhador. Ele era filho de um homem branco com uma mulher negra, concheira, pobre. Como explicita a narrativa de sua mãe, era trabalhador e o fruto de seu trabalho a ela era destinado.

Há ainda alusão ao destino do corpo sem vida, que é um dos temas mais problematizados por mulheres colombianas no contexto da violência sociopolítica, conforme 
indicam Álvarez (2013), Mosquera, Serrano e Zúñiga (2012), Martínez (2007). Para os familiares - desde minha perspectiva, para as mães -, a reintegração do corpo é um aspecto fundamental. O resgate da integridade do corpo é parte do processo de reconhecimento da humanidade, como ressalta Álvarez (2013.). Seu reverso equipara o corpo sem vida a um animal.

Ademais, o corpo é a materialidade da morte. O povo afro-pacífico tem uma forma própria de lidar com a morte, expressa nos complexos ritos fúnebres. Como dito na segunda parte da tese, as mulheres parecem ser encomendadoras de almas. Cabe, então, trazer o questionamento que propõe Álvarez (Ibidem): o que acontece quando não se tem a materialidade da morte? Nos casos de desaparição forçada, que são inúmeros nesse contexto, quais são as maneiras de enfrentar o sofrimento, a dor e perda na ausência do corpo? O que acontece com a alma quando não há possibilidade de expressão das vozes de mulheres que fazem sua passagem do mundo para o supramundo?

$\mathrm{Na}$ cosmologia afro-pacífica, o ritual mortuário que celebra a partida de um ente querido de certo modo reintegra o corpo ao mundo dos vivos. Casos como o narrado indicam a privação da atribuição feminina de encaminhar a alma. Nesse sentido, a guerra tem efeitos dramáticos também no plano cosmológico. Ela instaura outro tipo de relação com a morte e, consequentemente, com a vida.

Borges (2014) discute a importância do espaço devido para o sepultamento dos corpos sem vida na África do Sul. Em um contexto de relações entre negros/as e brancos/as no pósApartheid, o qual remete ao passado de segregação racial e expropriação territorial, moradores de fazendas ("farm dwellers") lutam pelo direito a enterrar seus mortos em "burial sites", localizados no interior de propriedades de pessoas brancas (Borges, 2014: 154). São territórios nos quais famílias negras trabalharam ao longo da vida e onde estão enterrados outros parentes. Terras que, no passado, foram usurpadas "a partir de uma prerrogativa garantida pelo governo sul-africano ao longo de um século marcado por uma sequência de 'atos' de expropriação, voltados para o confinamento da população negra" (Idem, ibidem: 162). A autora narra o episódio da luta de uma família negra para enterrar um parente, o Senhor Khubeka, o que foi recusado pelo dono da fazenda, branco. O pleito, que foi judicializado, não foi favorável à família do Senhor Khubeka, que teve de enterrá-lo em outra fazenda.

O caso analisado por Borges também remete aos ritos fúnebres como caminho de conexão com a história e de comunicação com os ancestrais. A autora mostra como o 
território é o fio que conduz os corpos sem vida à ancestralidade, embalados por cânticos de louvor. Na África do Sul, assim como no Pacífico colombo-equatoriano, a negação do direito a enterrar seus mortos secam as lágrimas e calam as vozes da coletividade negra.

Narradora A: La gente se mata su hijo. Lo llora, cuando puede. Cuando lo dejan enterrar, lo entierran. Cuando no dejan, lo entierran por allá. Así estamos viviendo.

Ao longo do ano de 2013 e início de 2014, encontrei, na área urbana, mulheres que havia conhecido nas veredas e que migraram porque a situação na zona rural era insustentável.

Narradora I: Yo me vine desplazada para Tumaco. Era tesorera de la organización. Robaran todo: los mapas de la zona, cuando yo me tuve que salir del campo. Mataron a mi hijo. Le pegaron tiros, pero él murió bien después. Él supuestamente andaba en estos grupos. Mi casa se quedó con todo.

Creio que o código do silêncio é especialmente relevante em contextos nos quais as mulheres estão diretamente envolvidas nos meandros da ação bélica organizada, o que não raro acontece. Conforme expressado por essa mulher, seu filho supostamente fazia parte de um grupo armado. Esse fato a colocava em uma situação de vulnerabilidade ainda maior, pois toda a família passava a ser, então, associada a certo grupo e, nesse sentido, antagônica a outros. Conheci mulheres cujos filhos ou companheiros eram do exército, ou da guerrilha, de um grupo paramilitar ou de uma banda criminal. O Coletivo de Estudantes Universitári@s Afrocolombian@s (CEUNA) ressalta que as escassas oportunidades laborais e educacionais estão conduzindo a juventude afro-colombiana ao enredo da violência sociopolítica.

Nossa juventude e nossas crianças estão sendo usadas como carne de canhão, engrossando as filas dos grupos armados à margem da lei, assim como de um exército oficial profundamente racista. Participar de um grupo armado se converteu para muitos jovens afro em possibilidade única de emprego e ascensão social ${ }^{376}$.

E assim, as tramas da guerra na Colômbia enredam a coletividade negra, tornando-a assassina e, ao mesmo tempo, assassinada; desplazada e deplazadora, como coloca Rosero (2002).

\footnotetext{
376 "Notas sobre a Juventude Afrocolombiana", texto de Rossih Amira Martínez Sinisterra, Rocío Cabezas Rosero e Ana María Valencia, integrantes do CEUNA e publicado na quarta edição do Nosso Jornal, em 2013. Disponível em: https://docs.google.com/file/d/0B3puEVu37tB9OVA0Mzd4MFU5NEU/edit. Acessado em: $25 / 04 / 2015$
} 
Ao longo do ano de 2013, os meses em Tumaco foram difíceis. Vivi por certo período em um apartamento, ainda em construção, que não tinha janelas nem portas. Com a ajuda de uma amiga, improvisamos cortinas nos vãos destinados às portas, uma delas sob o ângulo de minha visão, quando recostada na cama. Dormia com um canivete embaixo do travesseiro e celular a postos para chamar apoio, caso fosse necessário. Em minha imaginação, muitas vezes visualizei pés masculinos por debaixo da cortina, aproximando-se. Entendo que essa imagem se configurou como uma espécie de "paisagem de medo", nas palavras de Oslender (2004), que se desencadeia quando há uso contínuo de terror em certo contexto ou região. O autor fala de paisagens que se configuram como rastros das atividades de atores armados, tais quais povoados abandonados, dadas as ameaças, ou casas marcadas pela passagem de um grupo armado. Em meu caso, era uma paisagem de medo mental. Minha situação era sabidamente temporária, o que causava certo alívio. Pensava, no entanto, na vida de minhas amigas, diariamente sob a ameaça da morte, à espreita do ataque materializado em figuras masculinas.

Entre outubro e novembro de 2013, passamos cerca de um mês sem eletricidade, em toda a cidade de Tumaco. Minhas amigas diziam: "se tumbaran torres y más torres". Falavase que a responsabilidade pela derrubada de torres era das FARC. Algumas pessoas afirmavam terem sido oito torres, outras dez, outras ainda mais. Os episódios foram quatro, subsequentes, em 2, 15, 18 e 20 de outubro. Relatos de pessoas ligadas ao governo local atribuíam o ocorrido ao fato de que comerciantes, um dos setores mais impactados com a falta de eletricidade, não pagavam "vacuna",377 à guerrilha. Outros relatos explicavam a derrubada de torres como uma represália pela morte de um líder guerrilheiro. A versão de um homem camponês destacava as discordâncias dos grupos guerrilheiros locais com a proposta de negociação que estava em curso em Havana, Cuba. Certa perspectiva responsabilizava o governo local pelo problema: o então prefeito de Tumaco, Engeniero Victor Gallo, afrodescendente, para chegar ao poder teria "vendido el alma al diablo". E naquele momento estaria descumprindo o diabólico pacto, deixando de pagar sua "vacuna" à guerrilha, o que corresponderia a cerca de um milhão de pesos colombianos.

Após um mês de atuação da guerrilha no Pacífico sul colombiano, a rede televisa RCN noticiou o caso: “dejaron a Tumaco y Barbacoas sin luz”. Informaram que Tumaco naquele momento estava há dezenove dias sem energia elétrica. Não havia água, tampouco gasolina, insumo dos geradores de energia que alguns estabelecimentos comerciais e residenciais

\footnotetext{
${ }^{377}$ Cobranças extorsivas compulsórias, protagonizadas por paramilitares ou guerrilheiros, geralmente orientadas a comerciantes e empresários na cidade, assim como a habitantes da zona rural.
} 
possuíam. Caracterizaram a situação como "crise humanitária", ressaltando que os estudantes já não podiam ir à escola e o comércio estava prejudicado. Sendo Tumaco uma cidade desconhecida por boa parte de colombianos e colombianas, o noticiário informava que se tratava do segundo maior porto do país no Pacífico, com cerca de 180 mil habitantes. Mais uma vez, na reportagem exibida pelo Canal RCN, nenhuma pessoa negra foi entrevistada, em um município onde $88 \%$ da população é afro-colombiana ${ }^{378}$.

O depoimento de uma liderança afro-pacífica expressa a crítica às estratégias adotadas pela guerrilha naquele momento.

Narradora A: ¿Usted no imagina lo que acabaron de hacer? Tumbando torres como locos, dejando a la gente en oscuro. ¿Quién paga eso? Somos nosotros los pobres. El rico tiene como manejar sus plantas los días que sea. $Y$ manejar sus negocios. ¿Uno pobre? La gente pobre que vende sus pescaditos no puede venderlo ' porque lo' compran barato, o no lo' compran porque en las pesqueras están amontonados estos pescaos y perdiendo su venta. La gente que vive de rebusque, diga usted, compran concha allá y la revenden a ellos aquí, compran el cangrejo, lo revenden aquí. El plátano, lo compran y lo revenden acá. Eso uno le dice rebusque, estos pequeños negocitos, a buscar su ganancia. En ese sistema, los perjudicados somos los que no tenemos plata. Ahora que lleguen los recibos nos llegan más caros. En los graneros, en los comercios, todo le sube cien pesos o más. Porque está escasa la situación. Entonces, ¿quién paga? ¿Quién paga si no somos nosotros? Porque ellos no han podido entender que no están haciendo daño al gobierno. Están haciendo daño a nosotros, los más bajos, de bajo recurso. Se nos altera todo. Imagine lo de la gasolina, ¿qué hace con la gasolina?, la esconden y después empiezan a revender a los poquitos para que nos vendan aquí a doce mil pesos jel galón! ¡GGasolina que cuesta siete mil pesos, llega hasta doce mil pesos!! Entonces ¿qué hacen los de la moto taxi que llevan a uno? Cobran tres mil o dos mil pesos. ¿Los de los carritos que transportan de aquí hasta la gran vía? Dos, tres mil pesos. ¿Quién paga eso? Sino nosotros los pobres que no tenemos una moto, que no tenemos un carro para desplazarnos. ¿Ellos se han puesto a dimensionar eso?! ¿Por qué no miran eso?

Estávamos, ela e eu, perplexas com a resposta do governo local ao problema: a compra de novas torres de energia para que fossem derrubadas. Perguntava-me quais itens do orçamento público deixariam de ser atendidos para que o governo investisse tanto na compra de novas torres, que, em seguida, seriam destruídas. Contudo, estava mais que tudo preocupada; questionando-me até quando se utilizaria a estratégia da privação de energia, ou quando se recorreria a outras estratégias, como, por exemplo, aquela utilizada em fevereiro de 2012, que matou dez pessoas e deixou outras setenta feridas. Finalmente, havia compreendido $\mathrm{o}$ atentado à unidade de polícia de Tumaco.

\footnotetext{
${ }^{378}$ O mesmo ocorria nos noticiários sobre o "Paro Agrário".
} 
Nesse momento, despedia-me da cidade, começando a compreender melhor o novo cenário que me saltava aos olhos. Refletindo sobre os eventos vivenciados ao longo do trabalho de campo, questões em torno da atuação de grupos guerrilheiros em Tumaco, mais que tudo, despertavam-me inquietudes. As guerrilhas efetivamente estão conectadas com mobilizações populares. O Paro Agrário expunha pleitos explicitamente ligados aos interesses camponeses, assim como os itens levados pelas FARC à mesa de negociações em Havana, Cuba. Há elementos que conectam guerrilha e lutas populares.

Por outro lado, o que a etnografia me trouxe foi uma crítica feroz à atuação das FARC, provinda especialmente dos rios da enseada de Tumaco, onde estão instalados grupos guerrilheiros, como, por exemplo, do rio onde vive a narradora A.

Narradora A: Nosotros no tenemos plata y si un proyecto llega ellos piden tantos millones y es que tiene que dárselo, tiene que dárselo. Me parece tan fuera del normal. Porque si uno no tiene y por fuera vienen y le traen un proyecto que es para que usted trabaje y de eso ellos piden y tiene que dárselo... La gente, por no morirse.... Esa es la historia que estamos viviendo y no sabemos hasta dónde vamos.

O depoimento novamente menciona a prática corrente das "vacunas", explicitando que referida "contribuição" também é cobrada das organizações étnico-territoriais (de primeiro e segundo nível).

O controle territorial exercido pelos grupos armados pode chegar a comprometer a atuação das organizações. Quando não se trata de um suborno, a guerrilha pratica roubos. O depoimento a seguir narra a usurpação de maquinários de grande porte, para o uso em atividades produtivas, obtidos por meio de um projeto com financiamento internacional, manejado por uma associação comunitária.

Narradora A: Cuando llegaron las maquinarias aquí nos tocó inaugurarlas, iqué bonito! ¡Inauguramos todas estas maquinarias grandotas! Y eso para llevar allá fueron camiones y para embarcar un aparato de eso' a las canoas para poder subir donde se hizo el campamento para hacer el montaje de esas maquinarias, fue todo un sacrificio. Teníamos que unir hasta tres canoas grandes, para que aguantara el peso de una máquina de eso. Totalmente que fue un sacrificio y llevamos la maquinaria allá y las instalaran. Ya la gente lista, ya organizada [...] Ay ipao! Y eses infelices, ise las robaran las maquinarias! ¿Sabe que hicieran? Trajeran unos técnicos de no sé qué. Por eso yo digo que eso está tan dañado que todo se le presta es a ellos. Nosotros pasamos trabajo para llevarlas a instalar allá. Ellos trajeron dos o tres técnico que todita la... las despatillaran y en pedazos. Pieza por pieza, metidas en costalilla, unas fundas. Y de la misma gente obligarles que tenían que ayudar a bajar eso a las canoas. Las echaron en las canoas y las trajeran por la carretera y ahí 
tenían el camión esperando y ise llevaron las maquinarias! Nos dejaron así, solo con los deseos.

Segundo perspectivas mais críticas, a atual situação sinaliza que algumas organizações étnico-territoriais acabaram rendidas à guerrilha, tendo em vista que não há um enfrentamento político conceitual com os grupos guerrilheiros: "ahorita en este momento la dirección de los Consejos Comunitarios ya se asociaran con los de la guerrilla". Por outro lado, trata-se de uma relação absolutamente assimétrica, mediada pelo uso extremo de violência por parte dos atores armados.

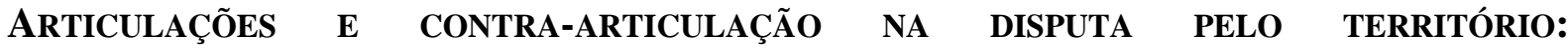 TEMPORALIDADES E PODERES ASSIMÉTRICOS}

Vale retomar então a perspectiva trazida anteriormente, que revela a existência de diferentes temporalidades quanto à atuação dos grupos guerrilheiros. Anteriormente à década de 1990, estava a guerrilha, porém, não estava a violência sociopolítica, desde a perspectiva dessas mulheres. Os depoimentos a seguir revelam que já houve um tempo em que a guerrilha atuava na promoção da justiça. A narradora B conta um episódio datado de 1980, aproximadamente.

Narradora B: Yo me acuerdo siendo muy niña, una vez entró la guerrilla acá a Tumaco. Y la guerrilla, toda la vida ha existido, porque eso me lo conto mi abuela, eso me lo ha contado mi papa, y la guerrilla siempre ha existido. Pero eran unas personas, con unas ideologías diferentes a las de hoy. Y lo puedo hablar muy de cerca porque tuve un tio que... o tuve familia que de alguna manera estuvo involucrada con el M-19. Y era como, según me contaban ellos, era como, si es que tú tienes un granero y entonces te va a llegar un camión de comida, entonces era coger ese camión, quitar esa comida y darle a la gente que no tenía que comer.

Paula: La guerrilla se llama Fuerzas Armadas Revolucionarias de Colombia. O sea, esa palabra como revolucionario me trae un sentido de que hay una otra propuesta de sociedad, hay una propuesta de revolución, ¿no?

Narradora A: Debía de ser. Y uno pensaba que era eso, porque uno antes escuchaba que la guerrilla, por lo menos cuando estuvo Pablo Escobar, ellos ayudaban era al pobre. Le quitaban al rico y ayudaban al pobre. Pero esto no. Esto ya es otros ideales que trae. Ya vienen con otro.

Como coloca Álvarez (2013), o discurso oficial das guerrilhas, sendo as FARC o caso emblemático, alega a busca pela sobrevivência social e a conquista do direito à inclusão política. Porém, esses "ideais", no depoimento anterior e na maioria dos relatos que encontrei 
no Pacífico sul colombiano, estão situados no passado. Ao que me parece, quando as guerrilhas fizeram uma aliança com o narcotráfico, motivadas pela necessidade de sustentação econômica, sucumbiram as ideologias fundantes dos grupos guerrilheiros.

Segundo Meertens, a luta guerrilheira perdeu seu conteúdo ideológico em função do somatório de alguns fatores: "los muchos años en el monte, la asociación con prácticas ilícitas de narcotráfico, el enriquecimiento fácil a través del secuestro y la dinámica cada vez más compleja de la retaliación". Assim, segundo a autora, as guerrilhas degeneraram em uma feroz contenda pelo domínio territorial (Meertens, 1997: 193). Ainda nas palavras de Meertens:

Ante los nuevos intereses económicos, la nueva dinámica de enfrentamientos y el rápido crecimiento de las organizaciones paramilitares, la motivación predominante de las acciones guerrilleras ha perdido su significado social. A pesar de los discursos que todavía conservan algunos planteamientos ideológicos sobre injusticia y lucha popular, el interés real de los grupos guerrilleros radica cada vez más en el dominio territorial, en una carrera de competencia con el ejército, los paramilitares e inclusive con guerrillas rivales (Idem, ibidem: 197).

Em meu entendimento, há duas dimensões na atuação dos grupos guerrilheiros. $\mathrm{Na}$ dimensão nacional, a gestão das FARC mantém um discurso em torno da luta camponesa e do direito à terra, que se vê refletida contemporaneamente nos diálogos de paz realizados em Havana. Na região pesquisada, esse discurso está muito distante das dinâmicas locais dos grupos guerrilheiros. De modo geral, na atualidade, a população enxerga tais grupos como mais um ator armado na disputa pelo controle territorial. $\mathrm{O}$ quadro de cisão e polarização entre a atuação da guerrilha em níveis local e nacional aponta para uma regionalização da guerrilha. Segundo relatos, nos departamentos de Nariño, Putumayo, Cauca, Vale do Cauca e Caquetá, há alianças e coincidências entre narcotraficantes e guerrilheiros ${ }^{379}$. Parece-me que essa aliança permite um trânsito ideológico e o estabelecimento de outros pactos entre a guerrilha e demais grupos armados, como os paramilitares ou bandas criminais.

Nesse sentido, a aliança entre guerrilha e o negócio da coca aponta para um ponto nodal do conflito que é a territorialidade. Alvarez (2013) ressalta que a medula da guerra na Colômbia é a terra. Na região foco da autora, a malha fundiária revela uma realidade de disputa, de fronteiras abertas, porosas e difusas. Urabá é considerada terra de ninguém, porém, sempre é território de alguém. Ela propõe uma diferenciação entre terra e território que reside no posicionamento dos atores como proprietários ou como pessoas com aspirações

${ }^{379}$ Segundo os relatos, parte principalmente dessas regiões o desinteresse nos processos de paz. 
de propriedade, por um lado, e pessoas sem essas aspirações, que atuam sob o comando de grandes proprietários ou "patrões". Nesse sentido, Álvarez concebe território como terra "pacificada", ou seja, reconquistada com base no princípio do extermínio ou do terror. Se a terra originalmente é considerada de ninguém, os grupos armados dela se apoderam, exercendo domínio e controle com base na instauração da violência e do medo.

$\mathrm{Na}$ região por mim pesquisada, a história da terra é outra. O povo negro secularmente ocupa esse território. Trata-se de uma espacialização de longuíssima duração, que remete à República Zamba, como vimos na introdução. Contemporaneamente, a partir da década de 1990, o povo afro-colombiano protagonizou um processo de incidência sobre o Estado que resultou vitorioso, o qual se materializa no Artigo Transitório n. 55, da Constituição Política de 1991; na Lei n. 70, de 1993; e no Decreto n 1745, de 1995. Finalmente, o Estado colombiano reconheceu a territorialidade ancestral desse povo negro ribeirinho. Essas terras, portanto, têm dono, e esses são os camponeses negros ribeirinhos.

Vislumbro uma disputa entre concepções e vivências do território experienciadas contemporaneamente pela guerrilha (e demais atores armados) e pelas "comunidades negras". Como visto na segunda parte da tese, do ponto de vista da coletividade negra, as dinâmicas territoriais nas ribeiras dos rios do Pacífico sul colombiano tradicionalmente se conformam em torno das organizações de rio, ou juntas de río. Nos dias recentes, tais dinâmicas passam pela estrutura dos Conselhos Comunitários. Cada Conselho possui sua junta diretiva, que também são nomeadas juntas de governo. Na visão de minhas amigas, trata-se de uma incoerência, já que a governabilidade sobre o território não está nas mãos da coletividade negra.

Narradora F: Bueno, el nombre era junta directiva, ahora que se cambió a junta de gobierno porque ejercemos gobernabilidad en el territorio. Aunque sean otros los que nos gobiernan, ¿no? Hablamos de una autonomía cuando tampoco nos la dan.

As veredas possuem juntas veredais, as quais se reúnem periodicamente com as juntas do Conselho. Paralelamente, em alguns territórios, há juntas de ação comunal.

Narradora H: las Juntas de Acción Comunal son a nivel nacional, o sea eso es lo que tiene la autonomía para vigencias de todas las cosas del pueblo, para la comunidad, es la líder que gestiona. Lo que uno no tiene autonomía es de obligar, pero sí tiene que velar por la comunidad. En todo barrio o en toda vereda hay Juntas de Acción Comunal. Eso es como una ley, es la responsabilidad del pueblo. Y la Junta Veredal no más es para organizar algunas cosas que lleven de parte de los Consejos, se une y entonces uno lleva las comunicaciones a los demás. 
Paula: ¿A veces puede pasar que una decisión que se tome por ejemplo en la Junta de Acción Comunal no se cuadre con una decisión de la Junta veredal?

Narradora H: sí, los Consejos Comunitarios están haciendo sus cosas con las Juntas veredales, pero no debe ser así, porque si todos somos de un solo territorio, todos somos las mismas personas. Mire, que en la Junta veredal también hay otras personas que son de la Junta de Acción Comunal. Entonces lo que falta es más diálogo entre los Consejos con la Junta de Acción Comunal, porque ellos no quieren tratar mucho con la Junta de Acción Comunal. Porque ellos quieren decir que las Juntas de Acción Comunal se terminaron, pero es muy mentira porque los que organizan son los presidentes de Juntas de Acción Comunal.

Teoricamente, quando se conformaram os Conselhos Comunitários, eliminaram-se as juntas comunais dentro desses territórios. Porém, elas estão sendo retomadas recentemente. A apropriação de alguns desses espaços configura uma das estratégias dos atores armados para fragilizar as dinâmicas territoriais afro-pacíficas. Nota-se, por conseguinte, que há uma sobreposição de formas organizativas: as tradicionais - como a junta de rio -; as governamentais universais - como as juntas de ação comunal -; as governamentais étnicas como as juntas veredais e juntas diretivas / juntas de governo dos Conselhos Comunitários. Todas atuam em nível local. Nem sempre há harmonia entre elas. E os atores armados aproveitam-se dessa multiplicidade de instâncias organizativas para se infiltrar nos territórios. Em alguns rios, segundo me relataram, as Juntas de Ação Comunal são retomadas por agentes da ação bélica organizada. Eles ingressam nas juntas, casam-se, por exemplo, com mulheres das "comunidades", e passam a intervir diretamente na gestão territorial.

\footnotetext{
Narradora A: Y van dejando resagado' a los Consejos Comunitarios, porque como eso cierra la puerta. [...] Entonces están haciendo reuniones en las comunidades y hay personas que le siguen el juego, o sea que están pa'l lado de ellos. Y con eso están formando unas asociaciones, aparte de lo que es el Consejo Comunitario, de la misma gente que es de las juntas veredales, están conformando otras asociaciones. Argumentan que la misma gente que está dentro de la asociación o que anda haciendo cosa' por la comunidad, por las veredas, se están robando la plata. Que están es robando. Entonces ellos creen que si llegan ahí a ese poder, a manejar ellos, es que la van a manejar bien. Eso es lo que andan haciendo ahí.
}

Associando-se a certas estruturas organizativas territoriais, obtêm informações sobre as dinâmicas em curso. Há quem colabore e quem não, devendo pagar uma multa de cerca de 200 mil pesos. Quando não há dinheiro, paga-se com mão de obra, trabalhando para eles, principalmente com a cocaína. "Siempre donde hay coca, ellos van a estar. Es la forma de fortalecerse ellos". 
Essa região do Pacífico constitui um ponto estratégico para o comércio mundial, já que tem ampla vazão da produção por rios e mares. Não apenas os grupos armados estão infiltrados nos territórios: os vários atores armados e institucionais estão conectados e grande parte deles é movida pelos interesses do grande capital. Nesse sentido, vale dedicar atenção às relações entre atores transnacionais, governamentais e organizações negras no Pacífico colombo-equatoriano, desde a perspectiva de que as políticas afrodescendentes são um terreno-chave para as políticas locais, nacionais, hemisféricas e globais, como sugere LaóMontes (2011). Ao mesmo tempo, conforme ressalta o autor, no "sistema-mundo capitalista moderno-colonial”, a relação entre o global e o regional é uma relação contraditória, na qual espaços regionais, como a costa Pacífica colombiana, tem autonomia relativa e suas próprias temporalidades e configurações espaciais (Idem, ibidem: 286).

A entrada dos organismos internacionais na região está relacionada ao tema antidrogas, ou seja, trata-se de cooperação internacional de combate ao narcotráfico. O país receptor tem de oferecer uma contrapartida, o que se expressa muitas vezes nos primeiros investimentos estruturais do Estado na região do Pacífico, historicamente abandonada. Nesse sentido, o Pacífico foi incluído à nação por meio do conflito, como ressaltam Escobar (2004) e outros autores.

Atenho-me à inserção da Agência Estadunidense para o Desenvolvimento Internacional (USAID), que foi amplamente comentada ao longo da etnografia. O programa voltado para afro-colombianos/as da USAID é o segundo maior investimento mundial da organização, perdendo apenas para o Haiti. Laó-Montes (2011) ressalta que a USAID atua em conjunto com o Departamento de Estado dos Estados Unidos, o qual adotou posturas neoconservadoras e imperialistas ao longo dos governos Clinton e Bush, postura que em grande medida o governo Obama tem mantido.

Ao tempo em que grande parte das ações de organizações étnico-territoriais de primeiro e segundo níveis se realiza com recursos da cooperação técnica internacional, algumas lideranças com quem dialoguei expressam uma leitura crítica radical à atuação da cooperação. Dizem que seu aporte financeiro quase não contempla efetivamente o tema organizativo, que levaria ao fortalecimento das instituições que representam o povo afropacífico. É sempre direcionado à dimensão produtiva, cujo contexto de crise é extremamente complexo, no qual uma perspectiva resolutiva transcende em muito o âmbito de projetos ou ações pontuais, já que dependeria de decisões e ações da alta cúpula de governo. Nesse âmbito, por meio de projetos financiados pela cooperação internacional Colômbia-EUA, 
ingressam em territórios ancestrais sementes transgênicas, produzidas por grandes corporações estadunidenses, entre outras, o que aponta para uma relação nefasta entre políticas negras e neoliberalismo, ressaltada também por Laó-Montes (2011).

Forma-se, assim, um ciclo vicioso centralizado no capital e expresso na violência. Ele manifesta-se, por exemplo, na injeção de recursos por parte dos EUA no sentido de militarizar a Colômbia ${ }^{380}$. O Exército colombiano provoca guerras no campo, em enfrentamento às guerrilhas, com envolvimento de paramilitares, bandas criminais e sicários. A coletividade negra e, especialmente, as mulheres negras são impactadas pelas intervenções armadas de todas as formas, com violência sexual, desterritorialização e diversas outras violências mecionadas nesta parte da tese. Em seguida, chega a cooperação internacional oferecendo apoio e aporte às lideranças. Com esse tipo de atuação, fornece estruturas como celulares e outros equipamentos. Assim, tem-se a possibilidade de acessar informações privilegiadas no contexto da guerra.

Por outro lado, estabelecer relações com atores transnacionais é um caminho para a visibilização e o combate à dramática situação que a coletividade negra vivencia na atualidade. Na visão de Oslender (2004), a "globalização da resistência" é uma estratégia imprescindível. Para Arboleda (2004), as "solidariedades transnacionais" jogam um papel importante nesse cenário. Rosero (2002), por sua vez, ressalta que o Parlamento europeu e missões humanitárias buscam interceder perante o governo colombiano com vistas a combater agressões de atores armados à população civil colombiana. De modo análogo, segundo esse mesmo autor, a Comissão das Nações Unidas para os Direitos Humanos, o Comitê para a Eliminação da Discriminação Racial e a Comissão Interamericana de Direitos Humanos, em diversos informes, chamaram atenção para a situação de violação de direitos humanos no tocante à coletividade negra na Colômbia.

Laó-Montes (2011) vislumbra duas tendências na cooperação estadunidense com movimentos afrodescendentes latino-americanos, as quais ilustra analisando o caso colombiano. Uma delas seria o "pan-africanismo conservador neoliberal", aliado a governos colombianos conservadores como o de Álvaro Uribe, que o autor associa ao colombiano Proyecto Color. O Proceso de Comunidade Negras (PCN), por seu turno, representa, na leitura do autor, um "pan-africanismo de base popular", que critica as políticas neoliberais e imperialistas estadunidenses, defendendo bandeiras como a oposição ao Tratado de Livre

\footnotetext{
${ }^{380}$ Laó-Montes (2011) destaca que a política imperial estadunidense se visibiliza em ações como a escalada militar no Oriente Médio e o estabelecimento de bases militares na Colômbia. Vale lembrar que a base militar instalada em Tumaco, em 2003, ocupa quase metade da cidade.
} 
Comércio, entre outras que se contextualizam em um modelo de desenvolvimento endógeno das "comunidades negras", assunto da segunda parte da tese, especialmente do primeiro capítulo.

O PCN estabeleceu uma aliança com setores afro-estadunidenses ${ }^{381}$. Lideranças afrocolombianas que vivem ou viveram nos EUA, ou que para lá viajam com frequência, fazem lobby no Parlamento estadunidense, especialmente com o Caucus Negro do Congresso dos Estados Unidos ${ }^{382}$. Essa articulação desencadeia uma pressão estadunidense sobre o governo colombiano, para que o tema étnico-racial avance no cenário interno do país, o que impacta o governo colombiano, pois os EUA financiam o combate ao narcotráfico no país ${ }^{383}$. Vale ressaltar que, segundo me narraram lideranças afro-colombianas ligadas ao PCN, a organização não aceita recursos da USAID. Já a Rede de Conselhos Comunitários do Pacífico Sul (RECOMPAS), organização étnico-territorial de segundo nível, sobrevive basicamente de recursos da USAID, e, nesse sentido, se aproxima do "pan-africanismo conservador neoliberal". Entendo, pois, que estamos lidando com uma ampla heterogeneidade ao considerar a relação entre organizações do Pacífico Negro colombo-equatoriano e atores transnacionais.

Como exposto em capítulos anteriores, as lideranças fundadoras do processo de comunidades negras em Tumaco e Salahonda estão afastadas da gestão do território. No meu entender, foi justamente nessa quebra de gestão que a lógica do capital, articulada aos atores institucionais (governamentais e transnacionais) e à ação bélica organizada, penetrou nos territórios coletivos afro-pacíficos, processo que tem curso nos últimos dez anos. Como coloca Laó-Montes (2011), trata-se de uma virada de uma política de mobilização de base popular a uma política de acomodação e integração em redes transnacionais de governabilidade neoliberal. Nesse processo, há gente do próprio território envolvida.

\footnotetext{
${ }^{381}$ Segundo Laó-Montes (2011), o PCN aliou-se com a AFRODES para organizar nos Estados Unidos uma rede de solidariedade com organizações de base e comunidades negras colombianas. Tal rede estabeleceu alianças como importantes grupos progressistas estadunidenses como o Foro Transáfrica e o Escritório de Washington para América Latina (WOLA). O autor ressalta que se trata de uma rede de afinidade e solidariedade transnacional entre organizações e movimentos que compartilham uma causa: contra a guerra e pela paz, contra as diversas opressões e pela redistribuição do poder e da riqueza, que ele denomina "pan-africanismo libertário".

382 Trata-se da bancada negra do Congresso dos EUA.

383 A pressão realizada nesse contexto se materializa, por exemplo, na criação, em 2008, pelo governo colombiano, da Comisión Intersectorial para el Avance de la Población Afrocolombiana, Palenquera y Raizal, composta por representantes governamentais e das organizações afro-colombianas, em face de uma solicitação de Gregory Meeks, parlamentar democrata membro do Caucus Negro. A missão da referida Comissão foi avaliar as condições de vida da população afro-colombiana, palenqueira e raizal e propor medidas ao governo com vistas à superação da inequidades (Mosquera Rosero-Labbé e León Díaz, 2009).
} 
Narradora A: Algunos están convencidos que ellos la van a organizar mejor y es donde están equivocados. Porque, de todas maneras, en esa forma como estamos mirando no es organizar, sino desorganizar. Porque lo que yo miro que la gente lo que va hacer es mucha presión, van empezar a salir del territorio, ¿no?

Essa dinâmica já aconteceu em alguns rios e está em processo em outros. Chegam os atores armados, chegam os projetos de monocultivo e cultivos ilícitos, provocando transformações profundas na gestão territorial e pressionando a coletividade negra a se desterritorializar. Ao mesmo tempo, há um entendimento de que o atual quadro se deve também às vulneráveis e débeis condições da vida da coletividade negra. "Por eso estamos con ese problema ahora en cima, que ya los del monte [guerrilheiros] han tomado parte en eso y están reclamando. Es que en realidad ya a la comunidad no ha llegado casi nada”.

Apesar da intensa luta pelo reconhecimento e a titulação dos territórios coletivos negros, as condições de vida ainda são muito precárias, o que diz respeito diretamente à ausência do Estado. "El gobierno colombiano se ha descuidado desde miles de años de la parte rural. Ha sido descuidado. Por ahorita se mira estos pañitos de agua tibia, por los proyecticos y eso que siempre llegan a las comunidades". Tal é o quadro de vulnerabilidade que abre espaço para a ofensiva dos grupos à margem da lei, os quais oferecem uma alternativa econômica rentável a quem se envolve com o narcotráfico.

A meu ver, um dos cernes da disputa em torno da territorialidade, entre a guerrilha (e demais atores armados) e a coletividade negra reside no fato de os atores armados entrarem nos territórios negros coletivos desrespeitando a territorialidade ancestral.

Narradora E: Antes uno subía y bajaba cuando se quería. Ellos no han llegado junto con la gente, pero a desplazar a la gente. El principal impacto sería el desplazamiento y muerte. Mataron un sobrino. Uno siente mucho, uno cree que a uno mismo le hace daño. Uno siente.

Vejamos ainda esse depoimento:

Narradora E: Cuando nosotros éramos de la junta llevábamos al conocimiento de todos los dueños del territorio. Ahora se trabaja apenas con la junta directiva cuando alguien venía a trabajar acá. Ellos son los dueños del territorio. Los que vienen pidiendo.

Conforme pude apreender etnograficamente, a expressão "donos do território" é uma maneira sarcástica de se referir aos grupos guerrilheiros. Álvarez (2013) encontra a mesma expressão em designação à comandantes de alto escalão de grupos armados ilegais, sejam autodefesas, paramilitares ou guerrilheiros. Na realidade etnográfica de Álvarez (2013), Urabá 
configurava um território controlado por atores armados, com normatividades e regulações por eles solidamente instaladas, de modo que, na narrativa de seus interlocutores (excombatentes e mulheres que sofretam diversas formas de vitimização), a expressão não era irônica. No caso em foco, o cenário é outro. O Pacífico é um território que secularmente pertence ao povo afrodescendente, que vive uma relação estreita com a natureza, de onde provém seu sustento material e simbólico. Contemporaneamente, ingressam no território grupos armados, que também são camponeses, com uma proposta revolucionária, seja do ponto de vista político, produtivo e ambiental. Ou seja, os grupos guerrilheiros.

Nessa linha de pensamento, poderia haver diálogo entre lideranças afro-pacíficas e a guerrilha; diálogo mediado pelo compartilhamento de uma visão crítica ao governo e ao grande capital, que costumam estar aliados na história colombiana. Setorialmente, até mesmo as práticas de gestão territorial dos grupos guerrilheiros e das "comunidades negras" poderiam convergir, marcada a exceção radical quanto ao narcocultivo.

Em algumas narrativas, pude identificar a valoração positiva da atuação de grupos guerrilheiros, no tocante, por exemplo, a ações de preservação do meio ambiente, reflorestação, conservação dos rios, temas correlatos ao primeiro ponto dos diálogos em Havana. Estimulam mutirões de limpeza das ribeiras dos rios; não permitem que se jogue dejetos na água dos rios e mar. Em certos povoados, o lixo sempre é recolhido e reservado dentro de uma muralha. Estão exigindo que toda casa tenha banheiros. Estimulam ainda a polivalência dos cultivos agrícolas. Vale ressaltar que isso acontece em determinado região que faz parte de certa frente guerrilheira das FARC. "El comandante trae un computador. Yo creo que él más que todo se está guiando por los diálogos en Habana”. Já em outras regiões, nas quais havia discordâncias entre a chefia local da guerrilha e as diretivas nacionais, as narrativas não apontam qualquer aspecto positivo sobre a guerrilha.

Nesse sentido, conforme me foi narrado, guerrilha e "comunidade negras" poderiam falar o mesmo idioma; com a diferença de que grupos guerrilheiros têm armas.

Narradora E: Sí, puede haber diálogo. El territorio es nuestro. Ustedes anden por ahí. Eso es diálogo. Porque nosotros también vamos a necesitarlos. A lo largo, todos tenemos que luchar por un bien común. Todo no lo entenderán. Se puede dialogar con ellos. Nos pueden hasta apoyar, pero sin violencia. Los malos también se hacen buenos y los buenos también se hacen malos. Hay momento en que se tiene que dialogar y ponerse en acuerdo, con los malos también. Ellos que creen que ellos son los dueños y ya dominan el territorio. 
A reflexão sobre o bem e o mal que esse relato propõe remete ao entendimento de que "o mundo se move em um estado de transformações sucessivas", como coloca Álvarez (2013: 192). A autora traz a mesma reflexão para pensar que, no contexto da guerra na Colômbia, os libertadores de ontem podem se converter em torturadores de hoje e assim sucessivamente.

A abertura para o diálogo entre a coletividade negra e a guerrilha, desde o ponto de vista citado, parte da premissa de que o território pertence à coletividade negra. $\mathrm{O}$ ponto de ruptura na possibilidade do diálogo, por sua vez, está centrado na disputa por reconhecimento em torno do território. Os grupos guerrilheiros e demais atores armados são invasores. Buscam mulheres para inserir-se no território e ter voz e voto nos processos organizativos locais. As lideranças que construíram o processo de comunidades negras, aquelas que trabalharam para erigir os marcos legais em torno da etnicidade, estão afastadas das juntas diretivas. Tudo isso configura o cenário que permite aos grupos à margem da lei se infiltrarem nas ribeiras dos rios do Pacífico.

Os territórios negros ancestrais não estão no vocabulário político da guerrilha, tampouco os territórios indígenas. Conforme ressalta Jaime Arocha (1992), a guerra na Colômbia não está referenciada desde a perspectiva étnica ${ }^{384}$. Mesmo quando há gente negra dentro dos grupos guerrilheiros, essa presença não está articulada com uma identificação em torno da etnicidade. Pelo contrário, como ressalta Álvarez (2013), há uma conexão entre guerra e mito da mestiçagem. A autora ressalta que, no período republicano, a diversidade étnica e racial foi ocultada na figura do/a mestiço/a, o qual, por sua vez, foi logo transformado em "cidadão armado". Ou seja, a construção da cidadania colombiana foi militarizada. A condição de vítima serviu como um eixo de aglomeração das pessoas, concebidas, então, como cidadãs. Nas palavras da autora:

La convocación “'Somos víctimas!” contribuyó eficazmente para crear una base para la identidad del proyecto de ciudadano creado en el "republicanismo mestizo" y llenó la ausencia de una comunidad originaria, que se convirtió en una comunidad de sufrimiento (Álvarez, 2013: 171).

Álvarez reproduz uma fala do então presidente da Colômbia, Álvaro Uribe, que bem sintetiza a ideia: "Todo ciudadano es soldado nato o defensor de la pátria en tanto sea capaz de llevar armas" (Idem, ibidem: 173).

\footnotetext{
${ }^{384}$ Por outro lado, conforme ressaltam Arboleda, Almario, Escobar e Oslender (2004), poder-se-ia pensar que a etnicidade estrutura a guerra, na medida em que a ação dos grupos armados configura uma "limpeza étnica", nas palavras de Almario. Nesse sentido, por meio do etnocídio e do genocídio de povos afro-colombianos e indígenas, a guerra objetiva eliminar a diferença cultural e desterritorializar o Pacífico. Vale ressaltar que os autores analisam o contexto específico da guerra no Pacífico na contemporaneidade.
} 
O discurso da guerrilha não articula categorias étnicas ${ }^{385}$. Nas negociações de Havana, por exemplo, as demandas das FARC no tocante à reforma agrária elencam uma série de ações no sentido de democratização da malha fundiária colombiana. Fala-se sobre a recuperação de "baldíos apropiados y ocupados contraviniendo la legislación vigente", sem prejuízo de camponeses beneficiários de programas de formalização, porém não se menciona os territórios coletivos negros. É como se eles não existissem. O discurso é articulado apenas em torno das Zonas de Reserva Campesina. O que se pode apontar como avanço na inclusão dessa pauta, no âmbito das negociações entre FARC e governo colombiano, é fruto de mobilização do povo negro que consolidava, então, uma proposta do povo afro-colombiano para os diálogos de paz, como dito anteriormente.

Ou seja, trata-se de um não reconhecimento por parte da guerrilha da autoridade territorial secular que dispõe o povo afro-colombiano sobre as ribeiras dos rios no Pacífico sul. Nesse sentido, retomo a distinção proposta por Arendt (2004) entre poder, violência e autoridade. Ao desconhecer a autoridade afro-pacífica, resta aos atores armados o uso da violência. É a forma de domínio possível. Sendo a violência e o poder inversamente proporcionais, como sugere Arendt (2004), mediante o quadro de violência pura exercida pelos atores armados, perde força o poder ancestral da coletividade negra sobre as ribeiras dos rios.

A perspectiva sobre o processo de negociação que estava em curso em Havana, enquanto realizava pesquisa, também demonstra uma descrença na capacidade de resolução dos conflitos pela via da negociação entre guerrilha e governo colombiano.

Narradora A: Yo soy una de las personas que no creo en esas negociaciones. A mí me da la impresión que se va dilatando el tiempo y dilatando el tiempo y hablando y hablando. Porque lo que se escucha es que cada vez que se avanza en ese punto, ellos plantean otras cosas que es imposible. Y que si el gobierno no les cede, pues para ellos no va. El uno es ese. El dos es que si ya están haciendo las negociaciones en Habana ellos por acá, ya por todos los territorios, deberían irse ya como modificando, cambiando. Así que uno no siente esa presencia, o ese agite con ellos acá.

A discussão sobre a permeabilidade entre rural e urbano deve ser matizada pela situação gerada em torno da ação bélica organizada. A presença majoritária do paramilitarismo/bandas criminais, na zona urbana, e da guerrilha, na zona rural, provocou uma ruptura entre a dinâmica pendular característica da socialidade afro-pacífica. Ademais, a

\footnotetext{
385 A exceção são algumas denominações de Frentes do Exército de Liberação Nacional (ELN). Segundo Sanchéz (2005), existiu uma frente chamada Benkos Biohó, já exterminada, e outra Frente Cimarrón, surgida em meados de 2002; ambas operavam no Chocó.
} 
violência sociopolítica é a grande protagonista da intensificação da migração afro-colombiana do campo para as cidades. Nesse sentido, parte dos descompassos que percebi entre organizações étnico-territoriais e organizações étnico-culturais pode estar relacionada com o processo de mudanças e rupturas que a violência sociopolítica instaurou.

A ação bélica organizada também interviu na proposta política territorial binacional. Inicialmente, não havia qualquer tipo de interferência da guerrilha no processo binacional.

Narradora J: Una cosa es esa lucha del conflicto armado en Colombia, al menos nuestro territorio acá, la Costa Pacífica, no existía y si existía no era una cosa que no estaba haciéndole daño a nadie. Entonces ese no era un tema de referencia para nosotros de ninguna manera, nunca lo consideramos, de decir vamos a juntarnos para luchar contra la guerrilla, contra los paras, contra diablos fuera.

A partir de fins da década de 1990, é que começam as ameaças, agressões, assassinatos e desplazamiento direcionados às lideranças afro-colombianas. A saída de tais lideranças comprometeu as dinâmicas do processo binacional. O problema passava ainda pela desestruturação do financiamento à mobilização negra binacional, como comentamos na segunda parte da tese. A majoritária injeção de recursos provinha de uma organização não governamental estadunidense. Conta-se que, em certo momento do processo binacional, houve interferências dessa organização no âmbito das dinâmicas da ação bélica organizada. "Dicen que ellos por el otro lado estaban recogiendo información del conflicto armado". Observa-se, então, como atores vinculados à cooperação internacional, ao aportar no processo organizativo da coletividade negra, têm a possibilidade de acessar informações privilegiadas no contexto da guerra.

\section{CONFLITOS NA REGIÃO FRONTEIRIÇA: EQUAdOR E COLÔMBIA}

Ponto nevrálgico nas relações entre a coletividade negra na região fronteiriça reside na intensificação do ingresso de afro-colombianos em terras equatorianas, consequência direta da desterritorialização. As narrativas que escutei no Equador, falam sobre uma "onda de colombianos refugiados", que ingressaram no país vizinho a partir de 2005.

Narradora K: Desde que se formaron los grupos subversivos en Colombia la gente empezó a migrar para acá para Ecuador. Hoy en día son más protegidos los colombianos que la gente nativa de acá del Ecuador, tienen más ayudas los colombianos que nosotros, que somos los nativos de aquí. ¡Ay! vea la cosa es seria, solo Dios con su divino poder ve lo que va a pasar. 
As queixas são muitas: migrantes colombianos estão tomando os poucos postos de trabalho disponíveis; recebem toda ajuda humanitária que chega ao território, enquanto famílias afro-equatorianas pauperizadas não são bonificadas; trazem práticas que afetam o coletivo, como a de não pagar pela água potável que, no caso do Equador, é gerida comunitariamente; entre outras questões. Nesse sentido, vemos que o "conflito político armado" atravessa as relações de irmandade ancestral entre os povos afro-colombiano e afroequatoriano. Simultaneamente, atividades ligadas ao narcotráfico e cultivos ilícitos são amplas na fronteira com o Equador, especialmente na bacia dos Rios Mira e Mataje.

A etnografia no Equador, assim como na Colômbia, também ganhou maior densidade na etapa final de pesquisa, entre os anos de 2013 e 2014. Em novembro de 2013, depois de cumprido o prazo estabelecido pela sanção diplomática, regressei ao Equador, dessa vez por Quito, sem atravessar a fronteira marítima, para evitar problemas. Chegando a San Lorenzo, logo escutei relatos sobre a violência do "conflito político armado" colombiano, que atravessava a fronteira. Uma pessoa conhecida narrava, a propósito, um episódio recém ocorrido, justamente na localidade para a qual me dirigia, onde ainda pretendia realizar a clássica etnografia.

Policiais dessa localidade haviam capturado três homens colombianos que circulavam em águas próximas, tendo identificado um deles como guerrilheiro e mantendo-o preso na unidade de polícia comunitária local. Ele carregava consigo uma pistola, apreendida pela polícia. Seu discurso, porém, enfatizava que a arma era para autodefesa: "ustedes saben cómo son las cosas por aquí...", dizia o rapaz, buscando desvincular-se da caracterização de guerrilheiro. O que os policiais não identificaram, contudo, foi a granada que ele levava, a qual foi acionada dentro da delegacia. O policial que estava trabalhando na ocasião, irmão do rapaz que narrava o episódio, conseguiu deter o homem com a granada. Naquele mesmo momento, os outros colombianos interceptados e que haviam sido liberados foram resgatar o companheiro, ação triunfadora. Os três saíram correndo e disparando pelas ruas da localidade, em direção ao mar, onde os estava esperando uma embarcação. E assim fugiram. O episódio da fuga acompanhada por tiros ocorreu por volta das sete da noite.

Passados alguns dias após o ocorrido, viajei a essa localidade. Novamente, houve mudança do planejamento metodológico de pesquisa, por precaução. Não mais residiria ali. Fixei-me na área urbana de San Lorenzo e viajava até o local para passar um par de dias, sempre acompanhada pelo sobrinho de uma amiga, sanlorenzenho. Foram quatro incursões curtas, entre 2013 e 2014. Em uma delas, presenciamos outro episódio que envolvia a 
guerrilha e a polícia equatoriana, no dia 28 de dezembro de 2013. Fomos até essa localidade para acompanhar uma reza, encabeçada por uma de minhas amigas. Chegamos pela manhã, bem cedinho. Ficamos na casa de minha anfitriã conversando ao longo da manhã. Na hora do almoço, observando as feições de outra amiga, notei que havia certa tensão no ar. Ela conversava com algumas pessoas em uma esquina e instruiu-nos a seguir, sem mais delongas, à casa onde iríamos almoçar.

Após o almoço, fomos até a igreja ajudar na limpeza do local para a reza, que seria realizada à noite. Ao lado da igreja, localiza-se a unidade policial, cenário do caso narrado. Por volta das três da tarde, observamos que saíam de lá quatro homens e duas mulheres, escoltados por cinco policiais. Um dos homens escoltados, ao centro do grupo, carregava ao alto um saco grande e repleto de coisas. No decurso da tarde, participando das conversas entre as mulheres, pude compreender que se tratava de uma deserção, ou "desmobilização", para usar o termo corrente na Colômbia. Eram guerrilheiros colombianos que estavam se entregando à polícia equatoriana. O saco estava cheio de armas. Por volta das sete da noite, começaram os rumores: voceros alertavam que a guerrilha entraria naquela noite e acabaria com tudo e com todos. Essa não era a primeira ameaça, como mostra o relato a seguir:

Narradora L: Eso la gente corría. Ya después, que ya se calmaron, yo me levanté. Escuchaba la gente que hablaba. ¿Qué pasa? Que la guerrilla, que se ha metido. ¡Ay, Dios mío! ¡Nos acabamos aquí! Estaba solita yo en mi casa. "Dios mío!”, decía yo, "Pues qué Dios haga lo que tenga que hacer con nosotros!”. Eran como las ocho, nueve de la noche. Temprano. Ellos como tienen una cámara arriba que ellos ven todo claro en la bocana. Habían mirado que venía una canoa llena de armas con guerrilleros a acabarnos a nosotros aquí. Venía para acá de Colombia. Aquí enseguida cogieron, salió el bote [do Exército equatoriano]. Aquí enseguida que aquí los corretearon, hasta que regresaron a su pueblo y no vinieron más pa'quí.

Na noite de 28 de dezembro de 2013 estávamos sob forte tensão. Ainda mais quando soubemos que os cinco policiais que trabalhavam na unidade policial haviam deixado a localidade. Escutava as mulheres dizerem: "por lo menos hubieran dejado las armas a nosotras, pá que nos defendíeramos". Ao longo da noite, da casa onde dormíamos, escutávamos ruídos, como os de um caminhar constante. Nada aconteceu. Na manhã seguinte, despertamos com cinco botes do Exército equatoriano no cais de entrada da localidade. Eles haviam chegado ao longo da madrugada. 


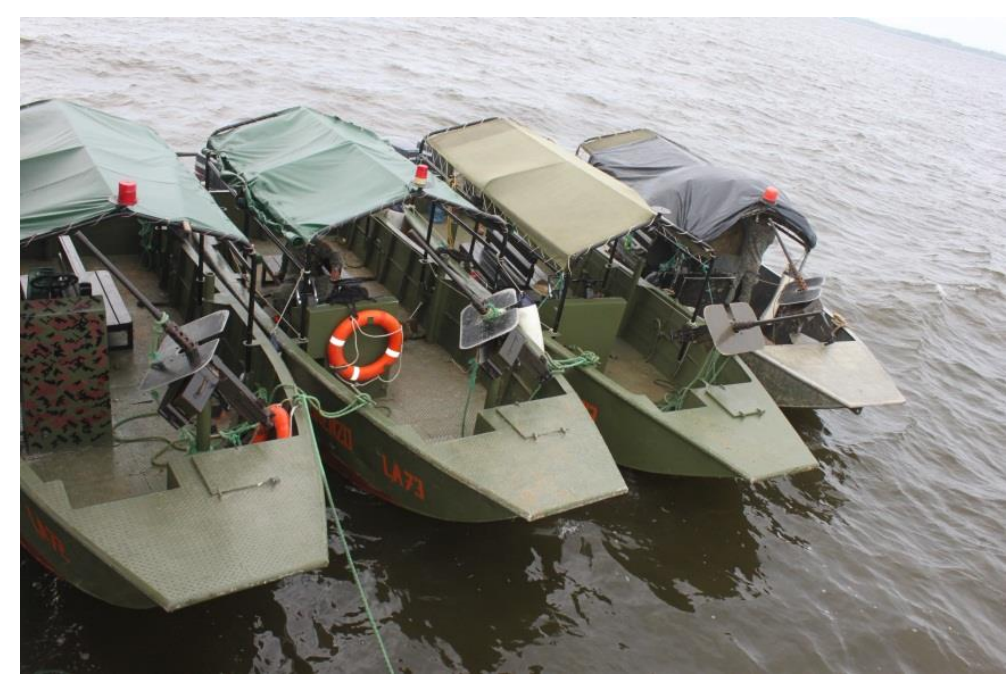

Figura 18 - Botes do exército equatoriano

Em outra ocasião, explicaram-me que o caso era ainda mais complexo. Os desertores já haviam sido paramilitares. Quando a guerrilha dominou a região, eles mudaram de banda, passando a atuar junto aos grupos guerrilheiros. Naquele momento, dava-se um processo de "limpeza interna" no âmbito da guerrilha e eles estavam à beira da morte, por isso foram “entregar-se” à polícia equatoriana.

Narradora K: Los venían siguiendo los otros de allá [a guerrilha] para matarlos. ¿No ve que los iban a matar? Entonces ellos para salvar la vida tuvieron que huir y entregarse a las autoridades para que los protejan. Ya ellos ahí tienen que llamar a la embajada de Colombia pa' que los rescaten. Ellos vienen volándose, ellos tienen que trasportarlos a Colombia a las autoridades, que los proteja su país.

Paula: ¿Eso a veces pasa aquí?

Narradora K: Sí, aquí en esta zona vivimos los valientes. Para estas fiestas tocó pedir refuerzos. El bote de la marina los lleva. Los lleva a la policía o a la marina. ¿No ve que tienen que transportarlos? Ellos se pasan por acá en el Ecuador, ellos son entregados en el Ecuador, entonces ellos tienen que transportarlo' a su país, pero con las autoridades, llamar allá y que sean entregados y que pasen a sus tierras. Ellos los sacan a Quito o a Guayaquil y se ponen en contacto allá con el otro presidente y, bueno, a retirarlos.

A ameaça das FARC de invadir a localidade naquela noite era uma represália e dirigiase especialmente à polícia, que havia recepcionado os desertores perseguidos pela guerrilha. Porém, como explicita o caso do ataque à unidade central da Polícia de Tumaco, tais ataques guerrilheiros "desconhecem os princípios de distinção e proporcionalidade, causando numerosas vítimas entre a população civil”, como ressalta Sanchéz (2005). A chegada em massa do exército equatoriano provavelmente coibiu a entrada dos grupos guerrilheiros naquela noite. Até o início do ano de 2014, permaneciam no cais os botes do exército equatoriano. 
Ambos os episódios, articulados com as narrativas locais, mostravam-me como o cenário nessa localidade havia se transformado no período de um ano, com o acirramento da violência.

Narradora L: En este pueblo matan a cualquiera. En ese entonces ya llegaron unos que les decían "paracos". Y después, otros más malos todavía. Aquí tenía de todo. Hay blancos, hay negros, hay jovencitos, muchachos de doce, trece años. En la guerrilla y en los paracos también. Es lo mismo. Gente que sólo tiene arma en el alma. Esos [os paramilitares] llegaron ahora poco. Esos llegaron ahora hace como unos cinco, siete años. $Y a$, pues es que los guerrilleros tienen más armas, tienen más poder que los paras. Ellos llegaron ... Yo sí creería un año. Que llegó la guerrilla por esta zona. Ya andaban, pero por otra parte. Por acá no. Cuando venían era apenas para tomar y comprar su comida. Hace año apenas que hayan venido a matar a la gente.

Narradora K: Y en el 2010 nos sucedió un problema aquí con la gente del frente, que mataron a un miembro de la Junta Parroquial y salimos a correr. Fue esa gente de allá, los paracos. Nos mandaban anónimos, nos mandaban chantajes. La Junta desmanteló y así muchas personas tuvimos que huir. Porque con esa gente no se puede estar jugando, salimos por precaución.

Essas falas reiteram explicitamente os fluxos em temporalidades diferentes e seus efeitos na percepção das mulheres afro-pacíficas sobre os atores da violência. Paramilitares e guerrilha movem-se permanentemente e desencadeiam novas necessidades de acomodação e resistência. O clima de terror instalado na região assolou a todos e todas. A perspectiva das mulheres com quem dialoguei é a de que contemporaneamente há uma perversidade geral. O sentimento que elas expressam é de que o espírito dos homens é essencialmente bélico, sua alma é constituída por armas.

Nessa região, primeiro chegaram os paramilitares, por volta de 2006. A guerrilha inicialmente frequentava o povoado de forma pacífica. A violência da guerrilha era bastante recente. Entre 2012 a 2014, grupos guerrilheiros começaram a promover assassinatos e ameaças nessa localidade. E então dinâmica muito semelhante a que se passava em Tumaco passou a ocorrer também em lugares da zona rural sanlorenzenha, o que envolvia morte e desplazamiento, as principais consequências da ação bélica organizada, conforme dito anteriormente.

No mesmo período, de 2012 a 2014, recorri cinco vezes a travessia por águas pacíficas entre Colômbia e Equador. Ademais, estive em localidades situadas nessas águas em cinco diferentes momentos, ao longo desses dois anos. A cada vez, enxerguei uma paisagem diferente, seja pelo movimento das forças da natureza, seja pela presença humana. Parece que 
a instabilidade política e ambiental (re)desenha permanentemente os contornos do território afro-pacífico no encontro entre a Colômbia e o Equador.

Minha leitura dessa paisagem era a de uma estrangeira, quase a leitura de uma criança que não compreende tudo o que vê pelo desconhecimento do léxico ali compartilhado. Inicialmente, sentia-me amañada à região, termo que significa acostumada ou habituada. Acreditava que podia compreender bem as dinâmicas locais, porém não era o que efetivamente se passava. Comecei a entender o cenário que vivenciava no Pacífico colomboequatoriano ao final do processo de pesquisa, a partir de agosto de 2013.

Apenas em dezembro de 2013, soube, por exemplo, que havia conhecido as Forças Armadas Revolucionárias da Colômbia, as FARC. Durante um ano pensei que fossem agentes do exército colombiano os homens que nos interceptaram em Puerto Palma, na travessia de Tumaco para San Lorenzo, vivida na segunda viagem de campo. Pela forma como se vestiam e como atuaram, bem como pela maneira que agíamos perante eles, não tive dúvidas de que fossem do exército colombiano. Posteriormente, finalmente compreendi a fala: "hay dos ejércitos: el nacional y el revolucionário". Meus olhos não sabiam diferenciar ambos ${ }^{386}$.

A partir de uma vivência mais densa na região, entendi que quem se encarrega do controle desse território - especialmente do trecho que percorríamos - é a guerrilha, ou melhor, as FARC. Trata-se de uma região de trânsito, via de entrada e saída de pessoas, mas também de drogas e armas. Nesse sentido, é monitorada pela guerrilha com muito zelo. Posteriormente, soube também que ainda existe a prática de sequestrar pessoas quando são interceptadas, principalmente estrangeiras, ainda que em menor escala do que em décadas anteriores. Nenhuma das pessoas que me acompanhavam na ocasião acreditava que eu seguiria com elas. Minha amiga me dizia: “mi Paulita, aquel momento yo pedí a Dios, a los santos y todos los orixás por ti”. O condutor do caminhão que nos levava a ela dizia: "uff, la pela'a tuve suerte". O sentimento inicial de temeridade e, posteriormente, o de fortuna das pessoas que me acompanhavam passaram-me despercebidos na ocasião.

A minha parcial ou equivocada leitura do episódio é coerente com a dimensão pedagógica do silêncio, ou a regra de que quanto menos souberes, melhor. De fato, se soubesse o que se passava, naquele momento, certamente teria demonstrado tensionamento que poderia dar outro rumo ao desfecho do episódio (ou não). Por outro lado, o desvendamento do ocorrido foi-me compartilhado como uma espécie de alerta. Quando estava novamente em situação de risco, minha amiga revelou-me o que efetivamente havia

\footnotetext{
${ }^{386}$ Segundo me informaram, há um brasão colado ao braço direito do uniforme que os distinguem como FARC. Não observei isso quando os encontrei.
} 
acontecido um ano atrás como uma maneira de me indicar como e por onde andar, em um território no qual tudo e todos estão mapeados. Também havia ali um sentido pedagógico da ação. Ao fazê-lo, de certa forma, ela se colocava em risco, rompendo o código do silêncio. Por isso, o diálogo que tivemos naquela tarde foi bem delimitado por cálculos que ela previamente deve ter elaborado.

Nesse cenário de guerra, é como se cada ator bem soubesse o papel que desempenha. O conflito é latente ou iminente. Ocorre enfrentamento quando os atores mudam de posição, percorrendo território alheiro. Ou quando, deliberadamente, se enfrentam, como aconteceu no ano de 2010, em uma das veredas colombianas que visitei. Assim, a materialização da guerra pode plasmar sobre a superfície por longos períodos, desde que esteja cada macaco no seu galho.

Em momentos de maior compreensão da situação, percebi que, como as FARC contemporaneamente constituem a principal força em Tumaco, especialmente na zona rural, muito provavelmente minha atuação ao longo da pesquisa havia sido mapeada, e consentida. Ao despedir-me da cidade, uma amiga revelou-me que o local de minha última residência ficava ao lado de um ponto de encontro da guerrilha. Segundo rumores, os fundos da boate que estava na esquina de meu apartamento foi o cenário de construção da bomba que havia detonado a delegacia de polícia de Tumaco em fevereiro de 2012.

Revendo mais um episódio de tensão que vivenciei ao longo da pesquisa, ocorrido em maio de 2013, concluí que possivelmente houvesse suspeita de carregamento de drogas e armas ou trânsito de pessoas procuradas pelas forças oficiais de ambos os países, mas especialmente equatorianas, naquela ocasião. Pelas reações de colombianos e equatorianos aos quais narrei o ocorrido, é incomum o tipo de abordagem que nos foi brindada. $\mathrm{O}$ fato de haver oficiais encapuzados era um ponto central para essa percepção. Aventando, por exemplo, a hipótese de que os oficiais houvessem detido algum de nós no momento em que nos abordaram no mar, os destinos possíveis são preocupantes, já que não há controle sobre o trânsito de pessoas nessa fronteira. Segundo relatos locais, uma jovem colombiana sumiu em situação similar. Os argumentos usados pelo comandante da operação apontam para a intolerância equatoriana quanto à migração direcionada ao país.

O itinerário entre os países se estende da fronteira em direção ao interior do Equador. Ou seja, San Lorenzo é a porta de entrada, mas a mobilidade extrapola o cantão e a província de Esmeraldas. Na província de Carchi, Imbabura e outras localizadas na região norte do país, a presença de colombianas e colombianos é intensa. Em suas movimentações, as pessoas são 
associadas aos atores armados ou algum agente no contexto da ação bélica organizada. $\mathrm{Na}$ Subjefatura Provincial de Migración em San Lorenzo, pela atitude do oficial que me atendeu, é possível que eu tenha sido associada à guerrilha. Enquanto estava viajando em ônibus de San Lorenzo (província de Esmeraldas) a Ibarra (província de Imbabura), dada a minha notória desestabilização emocional, questionaram-me se eu era refugiada. E assim pude experimentar diferentes emoções, as quais, embora ambivalentes, foram concomitantes - tais como coragem, medo, indignação, fragilidade e altivez -, emoções que vivenciei na posição de sujeito feminino, no interior de relações marcadas pela violência sociopolítica.

\section{A VIOLÊNCIA SOCIOPOLÍTICA E ALÉM DELA: VIOLÊNCIAS INTERPESSOAIS DE GÊNERO}

A irrupção da violência sociopolítica na região representou uma ruptura na socialidade afro-pacífica. Trata-se de uma ruptura de vínculos sociais, seara onde as matronas são as protagonistas. Esse momento estabelece um novo estado social, que se contrapõe à abundância de relações constantemente atualizadas pelas matronas. Nesse sentido, desrespeita um dos valores primordiais do universo ribeirinho, a solidariedade, como ressalta Álvarez (2013). O novo estado social instalou e disseminou o ethos guerreiro, o medo e o terror.

O depoimento a seguir mostra que, anteriormente à explosão da ação bélica organizada nos rios do Pacífico sul colombo-equatoriano, a expressão da violência se dava em outros termos.

Paula: Antes de todo eso, de los grupos, de la guerrilla, los paramilitares, el ejército, ¿había violencia, había guerra, había maltrato, cómo era?

Narradora A: Sí. Había violencia pero una cosa como más pausada. Uno miraba una noticia de que mató alguien a fulano, que mató a la mujer por celo', o que el compadre mató a otro compadre. Pero eso era esporádicamente. Cuando sucedía una cosa de esa en nuestras comunidades, eso era un dolor sentido en toda la comunidad. Todo el mundo se conmovía de mirar eso. Eso no se andaba dando, inclusive cuando empezaban a pelear entre linderos con linderos, por la tierra. As veces el vecino quería pasar p'allá. La gente en la misma comunidad otorgaba esas peleas. Empezaba hablar con el uno, empezaba hablar con el otro y se llegaba el punto que se les hacía dar las manos. Para que se respetaran y las peleas no seguían. Eso se hacía en las comunidades antes. Y cuando sucedían casos extremos, eso era de vez en cuando, años. Entonces la gente vivía como tranquilo, porque todo mundo era amigo. Todo mundo se colaboraba. Si la gente iba pescar, brindaba el pescado que se agarraba al vecino, al amigo, al compadre. Todos comían en la vecindad. Era muy bonito, divertido. Ahora da mucho miedo porque resulta que los del grupo son muchachos. Llegaron primero unos que no se sabe de dónde vinieron y 
se van metiendo la gente mismo de ahí porque a veces tienen problema. Que porque tiene un problema con uno, y para que no lo maten, y para que sea fuerte: zup, se mete en eso. O lo quieren matar: zup se mete en eso. Para sentirse fuerte y manejar las armas. Pero, cuando ya empiezan, ellos también no han tenido escrúpulos de que si yo voy y le digo: "vea Paola es de tal y de tal y de tal manera, viene y pluf. A veces sin investigar". Yo por mí, no investigan. Porque han matado mucha gente que no han sido lo que dicen de ellos. A veces porque gente no quiere, o no es su amigo, lo va y lo malinforma. Y los hacen matar. Ese es el miedo que a uno le da. Porque por lo demás, pues si ellos estuvieran atrás de su coca, o no más estuvieran haciendo negocio, no tenía problema. Uno sabía que uno no tenía coca, no peleaba con ellos. Ahorita se les ha metido de que quieren [...] La idea de ellos, que la organización que es el Consejo Comunitario, que se ha logrado ya hace veinte años a través de la Ley 70, quieren es que eso no exista y ellos tomar como ese poder.

O relato ressalta a temporalidade da violência. Anteriormente, era algo infrequente, já na atualidade faz parte do cotidiano. A qualidade das relações sociais de antes se expressa nesta última narrativa por meio de valores como a amizade, a colaboração mútua, o compartilhamento da comida. Havia conflitos, porém, eram geridos por códigos que não necessariamente passavam pela violência. Tratava-se de uma gestão comunitária de conflitos em torno do território e das relações interpessoais, essencialmente. Quando tais códigos não eram eficazes e o conflito resultava em um assassinato, por exemplo, o fato representava uma dor e um pesar coletivos. Contemporaneamente, ao contrário, há uma naturalização das mortes violentas. Os rios, fonte de vida e resistência, transformaram-se em fossas: seu leito abriga centenas ou milhares de corpos sem vida.

Os códigos tradicionais de resolução de conflitos já não mais funcionam, e o aparato da guerra - os grupos, a força bruta, as armas, os itinerários e a droga - é usado para a resolução de conflitos de outra ordem, que por vezes passam pelas relações interpessoais. Álvarez (2013) ressalta que, em Urabá, o imaginário social compreende o guerreiro camponês, geralmente associado à guerrilha, como guerreiro pleno, enquanto o urbano estaria mais próximo ao assassino ou delinquente ${ }^{387}$. Ele seria capaz, por exemplo, de matar, não em nome do grupo, mas por motivos pessoais. E de matar seu próprio povo.

No caso de Tumaco, nas narrativas que escutei, não percebo esse duplo imaginário social. Os atores armados mimetizam-se: paramilitares são bandas criminais, que, por sua vez, podem operar como braço armado da guerrilha na cidade. Ao final, todos são sicários, são matones, são assassinos. O aparato da guerra está dissolvendo o trabalho das matronas na consolidação e na manutenção de laços políticos e afetivos. As armas estão vencendo as

\footnotetext{
${ }^{387}$ Vale ressalta que, em Urabá, a chegada das autodefesas (ou grupos paramilitares) na década de 1990 logrou sobrepor-se aos grupos guerrilheiros e assumiu o controle e o domínio territorial.
} 
palavras e os atos de solidariedade. Uma parte da coletividade negra está de tal forma metida no contexto da guerra que são capazes de matar sua própria família, seja a família extensa, seja a irmandade política e afetiva.

São inúmeras as demonstrações de ressentimento perante o novo estado das relações sociais:

\begin{abstract}
Narradora M: Como dijo Dios, que el hombre tenía la sabiduría, la inteligencia. Tenía que ser hasta que él mismo hiciera para matarse. No ve que ahora las balas, el revólver, la escopeta, es la inteligencia del hombre ¿verdad?

Narradora B: Es difícil, porque imagínate, uno iba a la playa de noche, de día uno se iba a los muelles a nadar. Y uno se quedaba en la playa cogiendo icacos. Hoy ya no. Ya uno está con el temor, “¿quién viene?”. O sea, el susto, uno ya no tiene esa libertad de andar... Entonces llega el momento en que uno se siente extraño en su propia tierra. ;Claro!, se siente uno extraño porque, uno ya no puede caminar, ya no puede andar con la libertad que antes andaba, porque uno está pendiente con "jay! y al rato suena una bomba”, "¡ay!, irán a matar”. Entonces, la gente ya anda asustada. En la propia casa de uno, tener que andar asustado, jes terrible!.. Entonces uno no sabe si esta gente, es amiga o es enemiga. Uno no sabe, jen qué momento Tumaco cambió!... Es muy triste, Paula, hay muchos dolores. En toda esta situación hemos perdido familia, hemos perdido seres queridos. Algunos perdieron sus seres queridos, y dijeron "no, nosotros nos vamos de aqui". $Y$ se fueron para olvidar, se fueron para... hacer nueva vida en otro territorio, en otra ciudad. Y hábemos unos, que con el dolor aún estamos. Y estamos aquí... Es muy difícil todo esto, Paula.
\end{abstract}

Anteriormente, era uma socialidade por meio da qual se construía uma vida bonita e divertida, que foi substituída por uma vida guiada pelo medo, a desconfiança e o silêncio. A socialidade afro-pacífica antes da ação bélica organizada remete à economia da dádiva, conforme elaborado por Strathern (2006) na etnografia melanésia. Os laços de reciprocidade e expectativas de dádiva e contra-dádiva foram rompidos pela prevalência da lógica que a ação bélica organizada instituiu. Não há mais expectativa de que um ato gera outro, de que os fatos estão encadeados nas relações sociais. As pessoas estão vivendo diante da expectativa da ocorrência repentina de uma agressão. Como ressalta Arboleda, trata-se de um "confinamento do tecido social, dos sentidos de comunidade e de vida coletiva" (2004: 129).

Narradora E: Mi abuelo también dejó su finquita, los plátanos, en una vereda. Pero dejamos de ir porque se quedó muy peligroso. Por las FARC y por los paramilitares.

Não há mais o ir e vir com liberdade, a dinâmica pendular característica do Pacífico colombo-equatoriano. As pessoas movimentam-se com restrição e com medo, e muitas abandonam suas fincas. Ou seja, a mudança da socialidade reflete-se diretamente em 
concepções e vivências em torno do território. A territorialidade ribeirinha foi secularmente concebida ao redor da irmandade. Povos que depois foram declarados separados por fronteiras nacionais eram irmanados na República Zamba. Trata-se de um "só povo, um só território". A violência sociopolítica, em contraposição, instaurou um regime de medo e terror que se projeta territorialmente. Como o território é mapeado e controlado pelos grupos armados, fazer parte de certo território vincula o sujeito a determinado grupo. Estar em território inimigo, contemporaneamente, é motivo para ser morta ou morto.

Nesse sentido, a dinâmica estabelecida leva ao encerramento das pessoas em determinados locais, bem como à desterritorialização.

Narradora D: Yo le digo a mi marido, nosotros en la finca, criamos un cerdo, una gallina y tenemos todo allá, pero no podemos vivir allá, porque ¿Cómo vendemos los productos de nuestras tierras? Si no tenemos como sacarlas, no las podemos sacar. Entonces mejor será morirnos acá donde estamos. Pero sí que pienso que deberíamos estar en su finca ¿diga? Y estar tranquilos, no tenemos que comprar su plátano, usted supiera el dolor que a mí me da cuando me toca comprar un plátano, si a mí me duele mucho comprarlo y toca. Comprar un limón en doscientos pesos que lo venden en el barrio y uno teniéndolo. Un coco, si a uno le daban ganas de comer su pipa nomás era agarrarla y comérsela ... y ahora no. Que mango, todo eso tenemos allá. Nosotros sí somos unos prisioneros, porque allá yo no voy. No me han ultrajado, allá no me han hecho nada, pero eso a mí me da miedo, la violencia. La esperanza que yo tengo, porque Cristo es muy grande, porque algún día esto tiene que terminar. Y tiene que ser para bien de las personas, aunque los que estén vivos y de aquí a que suceda eso ya no, tenemos que tener buena fe.

Ou seja, quem fica no território tem sua mobilidade absolutamente tolhida, seja por restrições explícitas, impostas por atores armados, seja por restrições implícitas, impostas pelo medo. À luz da análise de Machado (2014), é possível identificar aqui duas emoções de medo: aquele que surge diante do perigo iminente, como o que enfrentou a irmã da narradora D quando encontrou no meio das águas Pacíficas um barco à deriva, que acabara de ser assaltado por um grupo guerrilheiro ${ }^{388}$; e aquele que se inscreve na memória sentimental e corporal como prevenção ao perigo. O segundo parece ser o que paralisa a narradora, impedindo-a de voltar a sua finca, gerando uma dor cotidiana que se expressa ao ir à venda comprar um limão ou uma banana. Ela semeou e cultivou esses mesmos alimentos em sua roça e agora se sente impedida de desfrutá-los. Ambas as emoções de medo estão diretamente conectadas. Foram as inúmeras histórias do perigo iminente vivenciadas por pessoas muito

\footnotetext{
${ }^{388}$ Caso narrado nas páginas 326/327.
} 
próximas que inscreveram na memória sentimental e corporal da narradora as medidas de prevenção ao perigo.

$\mathrm{Na}$ narrativa acima, a quebra da socialidade fica explícita. O encadeamento de fatos, tal como construída pela socialidade afro-pacífica, não existe mais. Strathern (2006) coloca que, em sistemas não capitalistas, o trabalho não se torna abstrato, mantém-se concreto, isto é, permanece indicativo de suas origens sociais e não pode ser medido ou quantificado por critérios comuns a todos os trabalhos. Tampouco pode o trabalho ser medido separadamente das relações sociais ${ }^{389}$. Certas relações, especialmente aquelas de âmbito doméstico - por exemplo, entre cônjuges -, são visibilizadas pelo trabalho. Nesse sentido, o trabalho é um dos domínios de genderização, na medida em que a distinção entre homens e mulheres toma forma nas relações sociais em cujos contextos eles são ativados. Entre os Hagen, na Melanésia, "o trabalho de homens e mulheres não é contrastado, o que é contrastado são os fins para os quais o trabalho é realizado" (Strathern, 2006: 229). Tampouco há um englobamento permanente ou estanque de esferas masculina e feminina, pois não se trata de esferas, nesse sentido. "Há posições a partir das quais as pessoas agem. E as mulheres, tanto quanto os homens, são capazes de construir-se como pontos de referência para seus próprios atos" (Idem, ibidem: 415).

A narrativa ora comentada indica que, ao romper-se o ciclo da socialidade no trabalho, rompe-se o encadeamento das relações sociais. Se existem posições de mulheres e homens que se constituem no mundo do trabalho, a partir das quais uma ação gera outra, a ruptura também se projeta sobre tais ações posicionadas. Ou seja, a ação bélica organizada implode configurações das relações de gênero no mundo afro-pacífico.

Esses são, pois, efeitos perversos da restrição da mobilidade territorial. Nesse contexto, uma opção é migrar para a sede do município, para outra cidade, ou até outro país, quando as ameaças são mais imperativas. Ou seja, desterritorializar-se, ser brutalmente expulsa de seu contexto rural e trasladada a um novo território, urbano. Em realidade, são estratégias complementares, de concentração e dispersão territorial, mecanismos conscientes de sobrevivência em meio à guerra, o que Arboleda (2004) corrobora.

As narrativas, especialmente da narradora A, trazem outra vez o ethos guerreiro, mais uma seara importante para se pensar as relações de gênero. Manejar armas, fazer parte do exército, de um grupo guerrilheiro ou paramilitar, ou ainda de uma banda criminal, faz o homem sentir-se forte. Ou seja, reforça a masculinidade do sujeito como função e lugar

\footnotetext{
${ }^{389}$ A troca de dádivas, por sua vez, é a produção de relações sociais. O jogo da dádiva revela relações entre os homens e oculta relações entre homens e mulheres, daí as hierarquias de gênero.
} 
legítimo de poder e controle, adjetivado positivamente como atributos de coragem e força. Adjetivos que perversamente aguçam e intensificam a valorização da violência e do controle sobre inimigos, e sobre, genericamente, as mulheres. Nesse sentido, a violência de gênero alimenta e estrutura as demais violências, como ressalta Machado (2014). O ethos guerreiro sobrevaloriza o comportamento violento, que de certa forma já está presente no ethos masculino.

Álvarez argumenta que guerrilheiros, paramilitares, desmobilizados, oficiais do exército, membros das bandas criminais, sicários e matones - para acrescentar categorias que emergem das narrativas de minhas amigas - todos compartilham esse ethos. É comum, como ressalta a autora, a troca de "uniforme". "El ethos guerrero es una constante ubicua e ineludible de las secuencias de las etapas de vida masculina, en la cual la adhesión al perfil guerrero de alguna organización inevitablemente es seguida por la adhesión a otro movimiento, grupo armado o bando" (Álvarez, 2013: 96-97). Nele, o controle territorial atua como se fosse uma extensão do narcisismo masculino, ou da virilidade. O ethos guerreiro visibiliza, portanto, uma associação entre guerra, masculinidade e virilidade, como ressalta Álvarez.

Segundo Mosquera, Serrano e Zúñiga:

As guerras legitimam valores, assim como universos simbólicos e estruturais nos quais se orientam as culturas patriarcais. Nos espaços públicos militarizados, as masculinidades guerreiras impõem formas hegemônicas de ser, sentir-se, mostrar-se e validar-se como homens, com normas coercitivas de convivência cotidianas e estratégias arbitrárias de controle social, que tomam forma na usurpação do direito à vida das mulheres (Comissão Nacional de Reparação e Conciliação, 2012: 53).

A violência instaurada pela guerra naturaliza o uso da força e das armas como forma de resolução de conflitos de outras ordens. Nesse sentido, extrapola os contornos da ação bélica organizada. $\mathrm{O}$ medo que está instalado na região em grande medida resulta desse extrapolamento; pessoas "de bem", que não mantêm, absolutamente, qualquer relação com o conflito, acabam morrendo, arbitrariamente envolvidas nas tramas da violência sociopolítica. Vale ressaltar ainda o nódulo do problema, em minha visão, qual seja, o não reconhecimento por parte dos atores armados quanto à autoridade ancestral das "comunidades negras" sobre as ribeiras dos rios do Pacífico sul colombo-equatoriano. Nesse contexto, quem permanece no território ancestral são guerreiras, são as pessoas "fortes", capazes de viver e sobreviver à guerra. 
Assim, há um deslizamento semântico; o ethos guerreiro dos grupos armados projeta para os grupos não armados o adjetivo positivado de guerreiras e guerreiros aos que resistem e se mantêm no território. Somente permanecem aqueles que se dispõem a enfrentar o medo e os perigos sempre presentes. Não assumem o ethos guerreiro que se expressa no uso da violência física; ao contrário, reprovam-no. Porém, assumem o ethos e a política da resistência de aí permanecer. Trata-se, portanto, de outro sentido do termo; guerreiros podem ser os atores da guerra, mas também aquelas pessoas que logram resistir à violência.

O primeiro depoimento trazido neste tópico, o da Narradora A, explica o que se entendia por violência antes da ação bélica organizada. "Uno miraba una noticia de que mató alguien a fulano, que mató a la mujer por celo, o que el compadre mató a otro compadre. Pero eso era esporádicamente". A narradora explicita o que contemporaneamente podemos denominar violência contra a mulher, ou violência baseada no gênero, e a violência interpessoal entre masculinidades. Segundo Machado, "violência contra as mulheres é um conceito para as movimentações feministas contemporâneas que supõem que sua ocorrência possa se dar com amplitude universal, mas de formas diversas" (Machado, 2010:71). A autora ressalta a pluralidade semântica do conceito. A violência baseada no gênero é o conceito que adota a Comissão Nacional de Reparação e Reconciliação, em especial a Área de Gênero e Populações Específicas, a partir de normativas internacionais ${ }^{390}$. É entendida como todo comportamento que causa violência a alguma pessoa em decorrência de seu gênero.

A narradora dá a entender que, antes da chegada dos atores armados, estava presente a violência contra a mulher, exemplificada na narrativa por meio de um feminicídio motivado por ciúmes. Presume-se que seja em uma relação conjugal. Nos espaços familiares, as agressões físicas, de modo geral, inscrevem-se em disputas em torno da consideração/desconsideração, da hierarquia e dos diferenciados graus de poderes dos gêneros, como ressalta Machado (2010: 80). Nas palavras da autora: “corrigir ou castigar tem um forte sentido moral e implica sempre efetivar uma forma de comunicação que visa limitar ou restringir a ação do outro, ou seja, que implica, ao mesmo tempo, formas de consideração e/ou desconsideração" (Idem, ibidem: 98).

\footnotetext{
${ }^{390}$ A referida Comissão surgiu junto com a Lei de Justiça e Paz (Lei n. 975, de 2005), responsável por materializá-la. Já a área de Gênero e Populações Específicas da Comissão foi criada em 2006, para atender mulheres, grupos étnico-culturais, grupos étnico-raciais, crianças, idosos/as e pessoas com deficiência. Nesse sentido, a Área de Gênero e Populações Específicas responsabiliza-se por aplicar o enfoque diferencial na execução da referida Lei. Entre os principais pontos da Lei, vale ressaltar o direito à verdade, à justiça e à reparação, bem como as medidas de restituição, indenização, reabilitação, satisfação e garantia de não repetição. A publicação da Comissão de Reparação e Reconciliação tem foco na reparação coletiva e nas mulheres na Colômbia e foi redigida por Claudia Mosquera Rosero-Labbé, Adriana Serrano e Natalia Zúñiga.
} 
Nesse sentido, a violência contra as mulheres assume um caráter normativo. A agressão física atua como ideia-valor da correção. Na seguinte narrativa, está presente esse sentido "corretivo" da violência. Se o sentido hegemônico e masculino é de correção, para as mulheres submetidas é de sofrimento e controle:

Narradora N: El papá de los otros dos niños, ahí tenía problemas con él, me separé de él.

Paula: ¿qué problemas?

Narradora N: me pegaba

Paula: ¿muchas veces?

Narradora N: sí, en ese tiempo no más me pegó una sola vez, la primera vez, ahí nos separamos. De ahí él se fue a vivir a Santo Domingo de los Tsáchilas, porque la familia de él es de allá, él también es negro. Yo me quedé viviendo en la casa de la tía de mi hija, de mi cuñada, la hermana del primer compromiso mío. Yo me separé del hermano de ella pero nosotras seguimos siendo amigas.

Paula: ¿y después que te separaste de él ya tenías los dos hijos?

Narradora N: cuando me separé del segundo compromiso tenía la niña de uno y el niño. Un año estuvimos separados, ahí otra vez nos juntamos, me vine a vivir a Santo Domingo. Yo también tuve otros problemas acá en Santo Domingo muchas veces.

Paula: ¿el siguió pegándote?

Narradora N: sí. Yo estaba en embarazo del otro niño.

Paula: ¿él te pegaba mientras estabas en embarazo?

Narradora N: sí.

Paula: ¿y por qué te pegaba, qué pasaba?

Narradora N: no sé

Paula: ¿él era borracho?

Narradora N: no, no era borracho. Él quería pegarle al niño mayor y yo no lo dejaba. Por bobadas, por todo le quería estar pegando. El niño tenía dos años. Que si el niño no lo saludaba, que aprenda a saludarme que soy tu papá.

Paula: ¿era muy agresivo?

Narradora N: sí, muy agresivo, me le pegaba a mi hijo por gusto, por eso me pegaba a mí. Así estuvimos hasta que definitivamente yo dije: - ¡No más!

Bater é então uma medida usada pelo homem-marido para controlar, em nome de um “corrigir" o comportamento de uma criança, mas também da mulher-esposa. Ao ser equiparada com a criança, a mulher é infantilizada, em um mecanismo que constrói e reforça assimetrias entre homens e mulheres. A agressividade como atributo masculino confere prestígio e honra a esse homem. Machado, ao explicar o problema de gênero para Strathern, a partir de sua configuração na socialidade melanésia, afirma que, "na área da socialidade conjugal, se estabelece uma relação onde o 'bater nas mulheres' é condição de mais prestígio para os homens no espaço comunitário masculino: dá-se aí a replicação da masculinidade, de tal forma, que se convertem nos 'grandes homens"” (Machado, 2010: 88). A atribuição de 
prestígio e de honra mostra a legitimidade hegemônica do poder e controle dos homens sobre as mulheres.

Quando tinha quatro meses de gravidez do segundo filho concebido com esse sujeito, a narradora viveu uma situação de agressão que quase a levou à morte. Quando retornou à casa materna, foi aconselhada pela avó a retomar a relação com o companheiro agressor, conselho que apenas se relativizou mediante novo intento de assassinato, feito perante a avó. Ressalto, portanto, a expectativa social de uma legitimidade hegemônica segundo a qual a mulher deve se manter nas relações conjugais, ainda que sob violência. Expectativa rompida pela maioria das mulheres com quem dialoguei, as quais tomaram iniciativas de desconstruir relações que não lhes satisfaziam. Ou seja, as mulheres estão dizendo que a agressão física não serve como ato corretivo e que não podem ser infantilizadas. Existe, portanto, uma voz feminina que rompe a expectativa social do suposto legítimo controle masculino sobre as mulheres, que, nesse depoimento, se expressa na contínua disputa de poder entre os cônjuges em relação aos filhos e culmina na atitude da separação.

As tentativas de controle masculino também se sustentam na imposição do medo. Vale ressaltar, então, as articulações entre o medo como núcleo da imposição relacional do poder de gênero, bem como forma de controle do homem sobre a mulher, e o código do medo na ação bélica organizada. Em ambos os contextos, a imposição do medo visa controlar e restringir a mobilidade feminina, seja no nível material ou no simbólico. Novamente, em ambos os contextos, as narrativas de mulheres afro-pacíficas expõem os esforços femininos em enfrentar a emoção do medo e desviar o controle masculino sobre elas.

Observo que a agressão física como ato corretivo constrói e ressalta de forma bastante sólida tanto as assimetrias de autoridade parental quanto as assimetrias de gênero. Como indica o depoimento: "mi madre era muy regia. Ella me latigaba (golpear con látigo) mucho". A mãe e o pai são investidos de uma autoridade que legitima o desempenho de atos corretivos por meio da violência física perante os filhos. Semelhante processo ocorre em relações conjugais heterossexuais assimétricas. "A autorização moral legítima, vindo prioritariamente no sentido de que cabe ao homem bater, seria o ponto nodal capaz de produzir posições assimétricas de gênero nas relações conjugais" (Machado, 2010: 100).

Machado ressalta que há uma diversidade e multiplicidade de sentidos e sentimentos agregados ao ato físico de bater ou impor a força de um sobre outro (Idem, ibidem: 102). Entendo que isso serve também para pensar o ato da violência sexual no contexto das relações familiares. O depoimento a seguir narra seguidos episódios de violência, que se perpetuam 
desde antes da instauração da ação bélica organizada até os tempos contemporâneos, direcionados a três mulheres de uma família - mãe e duas filhas. A mãe foi violada, tendo sido provavelmente sua primeira relação sexual, da qual resultou a primogênita. Esta, por sua vez, vivia uma relação conjugal precocemente celebrada, na qual era "humilhada" pelo marido, que tentava abusar da cunhada. A narradora, buscando sair da ameaça de estupro protagonizada pelo cunhado, acabou nas mãos de outro homem, que finalmente a violou.

Narradora F: Yo había ido a visitar mi hermana mayor. Ella es producto de una violación de mi mamá. Mi mamá tenía 15 años y el señor la engañó. Dijo que se iba a casar con ella, que iba a comprar un apartamento. La llevó a un apartamento y la violó. Después la dejó tirada y nunca más volvió a buscarla. El marido de mi hermana quería acostarse conmigo y yo no lo dejaba. Una noche él me dijo: - usted se va ya porque yo no voy a alimentar cuerpo pa' otro. Me dijo asi él. Él tenía a mi hermana muy humillada. Porque él la cogió muy niña, cuando ella tenía 13 años. Y él ya venía de experiencia con mujeres. Entonces mi hermana llamó a un muchacho, que ella creía que tenía en confianza, para que él me llevara a la casa de una señora, donde yo me iba a pasar la noche. Él me viola. Mi hermana se va a buscarme el otro día para darme el pasaje para que me viniera, donde mi mamá. Pero yo ya estaba violada. Entonces cuando yo la miro a ella, me boto a llorar encima de ella y ella me pregunta qué me pasa. Entonces yo le dije: - no ñaña, yo ya soy una mujer. Ella me dice: - ¿cómo así? Mira, le conté llorando y ella también empezó a llorar. Y me dice: - de todas maneras tú has perdido la virginidad, no has perdido la vida, te vas donde mi mamá. Pero ese tipo le dijo: - no, no la mande. Que yo voy hacerme responsable de ella. Entonces yo me puse a pensar, aquí la que se queda más sin honor soy yo. $Y$ de todas maneras mi mamá nos decía un dicho que: el que no espera, no goza. Pero entonces yo dije: - de pronto después él se gane el cariño mío, que yo lo perdone. $Y$ que se porte a la altura. Y de todas maneras también me daba miedo venir donde mi mamá ya así. Porque mi mamá era muy estricta. Que quedarme podría ser mejor que la paliza que me hubiera podido dar.

O diálogo entre as irmãs revela uma série de questões sobre a sexualidade nesse contexto. Tornar-se mulher passa pela iniciação sexual, a qual, no Pacífico Negro colomboequatoriano, não raro é uma violação. Primeiramente, a narradora refere-se a um senhor, um homem mais velho e não negro, que promete casamento, viola e abandona a sua mãe. Assim como a sociedade brasileira, trata-se de uma sociedade marcada pela herança colonial, patriarcal e racista, que enxerga essas mulheres como um corpo negro à disposição dos homens. Anos depois, a filha dessa mulher que foi violentada passa por uma situação semelhante. Ao visitar a irmã, por medo de ser estuprada pelo cunhado, ela é encaminhada a um rapaz, que deveria levá-la à casa da mãe. No entanto, ele a estupra. O diálogo entre irmãs manifesta a ideia-valor da perda. Após o ato do estupro, ela havia perdido algo muito valioso, que poderia equiparar-se a sua vida. A virgindade representa, pois, a honra da mulher. 
No depoimento, as sanções sociais decorrentes dessa perda se materializam na figura da mãe, já que a narradora expressa medo de encontrar a mãe na condição de "mulher", tendo sido violada. A situação levou-a a uma escolha dolorosa. A narradora permaneceu com o homem que a violou. Resignou-se a permanecer com aquele homem, vivendo uma relação de medo e desamor, ao longo da qual nunca tiveram uma relação sexual consensuada, tampouco qualquer troca de afeto. Ela viveu essa história até que a situação de violência doméstica agravou-se, chegando a ameaças de assassinato. Deixou definitivamente esse homem e partiu para a cidade. Mais uma perda: ela é levada pela situação de violência a que estava submetida a um deslocamento forçado, tendo de deixar o território.

Trata-se de uma história dolorosa porque mostra o imperativo das sanções sociais que reservam às mulheres um lugar desprivilegiado. A mãe da narradora também sofreu um estupro na inauguração de sua vida sexual. Porém, não havia ambiente para se desenvolver entre elas um sentimento de solidariedade. Ambas sofreram com as consequências do estupro, a mãe sendo abandonada pelo violador; a filha tentando viver com ele.

Outras mulheres também compartilharam relatos de estupros.

Narradora O: Yo estudié hasta el primer año de la escuela. Dejé de estudiar porque hubo un problema. Un señor me violó, un viejo. Fue un día de fiesta, un día domingo. La policía lo llevó preso. La gente empezó a comentar. El profesor me expulsó de la escuela. Yo tenía once años.

Narradora P: Tomacito me amenazó con un machete. Hizo lo que quizó. Él andaba con la hermana que me creó.

No primeiro caso, as sanções sociais direcionadas à menina estuprada levaram à expulsão da escola. Novamente, está presente a ideia-valor de que a "perda" da virgindade é uma desonra. Ainda que fosse uma relação não consensuada, violenta e assimétrica - neste caso, soma-se a abismal assimetria etária -, as consequências da sanção social recaem sobre a mulher, ou criança, nesse caso. No segundo depoimento, a mulher violada tinha dezesseis anos e estava vivendo com uma irmã, que a cuidava. $\mathrm{O}$ violador foi seu cunhado. $\mathrm{O}$ uso da força é explicitado nesse depoimento. Nos três casos relatados, a violação aconteceu no ambiente doméstico ou comunitário, tanto em "comunidades de rio" quanto em "comunidades de mar". Trata-se de uma violência intraétnica. Os homens violadores também eram afrodescendentes.

Contemporaneamente, o abuso e a violação sexual em Tumaco são generalizados. Dados apresentados em matéria da colombiana revista Semana revelam que, em outubro de 2013, já eram 74 casos de abusos sexuais registrados ao longo do ano, a maioria envolvendo mulheres menores de idade. Vale ressaltar que nem todos os casos são registrados. Tender- 
me-ia a crer que a maioria deles não o é. Os abusos acontecem no ambiente doméstico, mas também no público. No contexto da violência sociopolítica, as mulheres são recrutadas como objetos sexuais ou levadas a desterritorializar-se por se negarem a sê-lo. Dos 58 mil tumaquenhos desterritorializados na primeira metade do século XXI, mais da metade foi de mulheres.

A situação de pauperização extrema leva ainda à prostituição. Segundo depoimentos de lideranças comunitárias citados na reportagem, crianças de seis a dez anos oferecem sexo oral por fome. Segundo narrado, entre as bandas criminais, há um código interno que permite a cada integrante do grupo escolher uma adolescente como troféu. Eles escravizam sexualmente essas mulheres e posteriormente abandonam-nas, muitas vezes grávidas ${ }^{391}$. Daí resultam o que algumas de minhas interlocutoras chamam "hijos del Plan Colombia", crianças que são fruto de violações de mulheres afro-pacíficas no contexto da violência sociopolítica. Tanto do ponto de vista das relações que ocorrem entre conhecidos, no ambiente intraétnico, quanto em relações no contexto de disputas entre atores armados envolvendo o narcotráfico, a discriminação de gênero é potencializada pela disputa entre grupos armados.

Comigo ocorreu uma tentativa de abuso sexual no contexto da pesquisa de campo. Eram mais ou menos 7h30 da manhã, Praia do Morro, Tumaco, Colômbia, do dia 28 de novembro de 2012. Eu estava correndo, a única coisa que fazia sozinha na minha rotina de então. Havia uma restrição que aconselhava não mover-se em certos locais, especialmente no caso de uma mulher sozinha. Naquele dia, ultrapassei o limite recomendado por minhas companheiras mulheres, que outras vezes me acompanharam nesse afã matinal. Adentrei uma sessão da praia pela qual ninguém passava e que estava alijada dos olhos de qualquer pessoa que estivesse na praia nesse dia cinzento. Naquele dia não havia ninguém. Segui correndo, em uma pequena faixa de areia entre o mar e uma mata rasa e baixa.

Escutei um barulho vindo da mata e, em seguida, vi um jovem negro pulando por cima da mata e aterrissando na areia. Acercando-se de mim, que segui correndo no mesmo ritmo, ele perguntou se podia fazer-me uma pergunta, simultaneamente tocando meu corpo. Eu tirei a mão dele do meu corpo e disse: "passa". Ele novamente tocou-me e avançou alguns passos na minha dianteira. Agarrou meu braço, puxando-me para frente, na tentativa de levar-me ao chão. Com uma expressão de fúria, gritei novamente: "passa, passa", ameaçando golpeá-lo

\footnotetext{
${ }^{391}$ Ver: Mujeres en el peor de los mundos. Disponível em: http://www.semana.com//nacion/articulo/violenciamujeres-tumaco/361575-3. Acessado em: 10/05/2015.
} 
com a outra mão e desvencilhando meu braço. O rapaz ficou surpreendido e saí correndo velozmente.

Refleti posteriormente sobre como o corpo feminino, no imaginário social, está à disposição dos homens e sobre a naturalidade do uso da violência nas relações entre homens e mulheres, especialmente nesse contexto. Há um imaginário segundo o qual "mulheres decentes" ou "mulheres de família" não deveriam circular sozinhas em locais distantes de espaços familiares (Machado, 2014). Uma mulher "fora do lugar", nesse sentido, é imediatamente vista como uma mulher que pode ser tomada por qualquer um.

Chamou-me atenção ainda a maneira como me dirigi ao rapaz, ao ser abordada, como se ele fosse um cachorro bravo que me atacava. De certa forma, a expressão do desejo equiparava aquele rapaz a um animal. Os desejos masculinos estão referenciados em uma dimensão pela qual não se concebe, para as mulheres, a possibilidade de escolha, autonomia, menos ainda o prazer feminino. O estupro é o cúmulo desse arranjo sexual-afetivo, porém, as relações conjugais, de modo geral, passam por certo nível de expressão do desejo masculino e repressão do prazer feminino. Minhas amigas de San Lorenzo dizem que muitas mulheres envolvidas em atividades direcionadas ao empoderamento feminino, vivendo uniões livres heterossexuais, revelam que nunca sentiram prazer nas relações sexuais, por exemplo.

O diálogo com uma amiga tumaquenha, sobre a relação que ela mantinha com o marido, a qual envolvia desrespeito, descuidado e desamor da parte dele com ela, traz a reflexão sobre dicotomias entre amor, desejo e prazer versus a sexualidade feminina entendida como costume e dever:

Paula: ¿ustedes todavía hacen el amor, así?

Narradora D: ya por la costumbre o el deber, no sé

Paula: pero así, ¿cuándo usted lo mira, siente deseo?

Narradora D: sí pero uno ahí mismo se acuerda las cosas y ya no siente nada, uno únicamente por el deber de servirle al hombre pero ya no hay amor, por lo menos en mí ya no hay.

Paula: ¿usted no tiene placer en la relación?

Narradora D: no, ya no, ya no. Únicamente ya es costumbre pero ya no, ya eso se murió, uno mismo lo mata. Él por lo menos el orgullo de sentirse, qué sería, más hombre que cualquier hombre

Paula: Antes de que pasara todo eso con él, cuando usted se enamoró de él ¿a usted le gustaba hacer el amor? ¿Usted tenía placer con él?

Narradora D: pues al principio, al principio no, por eso siempre luchamos porque yo no quería. Yo no me fui de mi casa enamorada de él. Yo me enamoré de mi marido pero ya después, después de los dos meses de estar juntos. Pero ya cuando él comenzó así, ya no. Le tengo, como decir, un cariño, le tengo, no sé, mucha comprensión, pero como decir el amor que había al principio no, eso ya se murió. Yo ya estoy vieja, ya me acabé. 
Reiteradas vezes as narradoras, que se tornaram minhas amigas, referiam-se ao ato sexual no contexto conjugal como uma obrigação feminina de serventia ao homem. Também é comum nas narrativas a história de casamentos que se celebram por conveniência e não por enamoramento.

Retomando o tema dos abusos sexuais, outras narrativas trazem episódios de abuso em contextos citadinos. Mulheres afro-pacíficas migrantes, sofreram tentativas de abuso sexual por homens não negros.

Narradora F: Cuando yo tenía 14 años, en esa época yo vivía en la casa de una familia que me adoptó. Mi hermano, el hijo de esa señora, empezó a molestarme. Y mi mamá no me creía cuando yo me quejaba. Yo pensaba que ella me iba a entender, porque somos mujeres, pero ella no me creía. Cuando fue la cuarta vez, mi hermano ya me tenía acostada, pero yo no me dejaba. Él me rasgó mis ropas, yo le golpeó la nariz, que sangró mucho y huí de la habitación. Llegando con las ropas rasgadas a hablar con la mamá, aun así ella no me creía [...] Quisiera salir de la casa casada, para mostrar a mi mamá de crianza que no era como ellos pensaban. Porque ellos pensaban: - esa negrita que quiera meter mi hijo en la cama. Yo quería mostrarles que no era como ellos pensaban.

Outra amiga narrou-me episódio muito semelhante:

Narradora N: A los trece años yo trabajaba en una casa de una señora. Allá yo estudiaba, ella me puso a estudiar, estudiaba de noche, nocturno. La señora me compraba mis útiles, era buena persona. El esposo era mayor de edad ya. Entonces el esposo, cuando llegaba, me enseñaba los deberes, me enseñaba a escribir mi nombre, mis apellidos, la fecha de mi nacimiento, todo. Eran blancos. Me querían bastante. La señora, ella tenía un hijo que era vicioso. Entonces él, una noche, se metió a mi cuarto, yo iba a cumplir los quince años. Entonces se subió a mi cuarto y quiso abusar de mí, porque los cuartos de la empleada quedaban arriba en la terraza. Ese día no logró nada porque ya pues, la pelea. Él tenía un perro, el perro era de él pero el perro era amañado conmigo. Entonces yo gritaba y él me tapaba la boca. Entonces el perro se le boto a él. Entonces él me dijo que no le vaya a decir nada a la mamá, que, si yo le decía, me pegaba. Y al siguiente día la mamá mira los aruñones que le había hecho el perro en la espalda, porque cuando el perro se le boto lo aruñó. - ¿Y eso Ricardo qué es? Le dijo. Él dijo: nada, nada, nada. Entonces yo cogí y le dije a la mamá. Y a los días, me dijo que no me podían tener ellos ahi porque podía pasar otra cosa y salía perjudicada yo y no podían tenerme más allá porque corría peligro. Así fue.

A naturalização da agressão sexual às mulheres negras é um legado do projeto colonialista. Retomamos os ensinamentos de Sueli Carneiro (2001), que ressalta a intrínseca marca de gênero na fisiologia desse projeto, que tinha a violência sexual como modalidade estruturante. Ou seja, no processo de escravização, o padrão das relações entre senhores 
brancos e mulheres negras escravizadas era a violação sexual. Esse padrão se atualiza nos casos relatados, nos quais meninas/mulheres negras viviam em casas de famílias brancas ${ }^{392}$.

No primeiro caso, tratava-se de uma relação de adoção, portanto, familiar. No segundo, uma relação de trabalho, que envolvia afetos, como sugere a narradora. A primeira narradora explicita a expectativa de que houvesse uma solidariedade feminina entre mãe e filha, porém, não foi o que aconteceu. Ela permaneceu desacreditada perante a mãe, que não foi capaz de enxergar o filho biológico como um violador. A narradora manifesta ainda o desejo de responder à leitura implícita na atitude da mãe, que a caracterizava como responsável pelo problema, ou seja, como quem seduzia o irmão. O segundo caso, talvez pelo fato de que o filho dos empregadores manifestava comportamento socialmente reprovável pelo uso de drogas, não houve dificuldades na compreensão do ato abusivo. De todo modo, a mulher negra sofreu a sanção social de perder o emprego e o local de moradia, além do afeto dos empregadores que ela parecia estimar.

Nos diversos relatos, sejam os violadores negros ou não negros, o lastro histórico do processo de escravização faz-se presente. Viveros reflete sobre o grau em que a escravização e suas exigências repercutiram sobre a estrutura social colombiana. Nas palavras da autora:

Es preciso recordar que la esclavitud no solo fue un sistema de trabajo forzado, sino también una organización social y un dispositivo disciplinario de clase y raza. Las mujeres negras han sido víctimas del doble aspecto, sexual y conyugal, del estereotipo que existe sobre ellas, con base en una supuesta disponibilidad y desenfreno sexual y como mujeres cuya sexualidad no involucra consecuencias conyugales, ya que según el sentido común, las mujeres negras no se casan sino que se unen (Viveros, 2008: 253).

A autora ressalta que mulheres negras são percebidas não apenas como disponíveis sexualmente, mas como "naturalmente predispostas a serem disponíveis" (Idem, ibidem: 271272).

\footnotetext{
${ }^{392}$ Em abril de 2015, reportagens do Correio Braziliense e outros meios de comunicação denunciaram casos de escravização sexual de meninas entre 10 e 14 anos da comunidade quilombola Kalunga, em Cavalcante, Goiás, Brasil. Segundo as denúncias, saindo da zona rural para a sede do município, em um quadro de ausência de educação básica, trabalho e pauperização extrema da população quilombola, elas atuam como domésticas em casas de famílias brancas, muitas das quais de políticos locais. Não são remuneradas, ganham apenas comida, um lugar para dormir e horário livre para frequentar as aulas na rede pública. Nesse contexto, são sexualmente abusadas e estupradas, geralmente pelos patrões, homens brancos e com poder econômico e político. A Comissão de Direitos Humanos e Minorias (CDHM) da Câmara dos Deputados, junto com autoridades federais do Poder Executivo e do Ministério Público Federal, no dia 20 de abril de 2015, estiveram em Cavalcante (GO), em diligências para ouvir autoridades locais e familiares de crianças e adolescentes da comunidade Kalunga vítimas de exploração sexual. Ver: Audiência pública discute denúncias de abusos contra meninas em Cavalcante. Disponível em: http://www.correiobraziliense.com.br/app/noticia/cidades/2015/04/20/ interna cidadesdf,480028/audiencia-publica-discute-denuncias-de-abusos-contra-meninas-em-cavalcante.shtml. Acesso em: 20 de abril de 2015. Sobre a atuação da CDHM, ver: http://www2.camara.leg.br/atividadelegislativa/comissoes/comissoes-permanentes/cdhm/noticias.
} 
Fernández-Rasines (2001) aponta que a racialização das mulheres gera uma hierarquização na estrutura social contemporânea, que mantém mulheres afrodescendentes em condições laborais muito próximas à da escravização, especialmente no âmbito do trabalho doméstico. Nesse sentido, a autora argumenta que a discriminação racial é genderizada, já que mulheres e homens são objeto de diferentes atribuições estereotipadas. Em suas palavras:

Pienso que la nocturnidad, la maldad, el crimen y la holgazanería, son atributos más propios de la conceptualización de los hombres negros. Las mujeres, por su parte, y dentro del contexto de la servidumbre doméstica, son categorizadas principalmente como lascivas (...) Un atributo que se les asigna es el de provocadoras (Fernández-Rasines, 2001: 87).

Os últimos depoimentos explicitam o imaginário social que associa mulheres negras à lascividade e que as enxerga como corpos negros à disponibilidade dos homens. Nesse tocante, parece-me que, seja no caso dos violadores negros ou não negros, prevalece o mesmo imaginário social.

Por outro lado, talvez haja uma diferença de interpretação das mulheres em ambas as situações. No ambiente intraétnico, o ato de violência se dá no interior de vínculos sociais que previamente existiam entre mulheres e homens afro-pacíficos. Nesse caso, os episódios de violência estão contextualizados em formas coletivas hegemônicas de resolução de conflitos. Tais formas se expressam de modos muito variados, às vezes, limitando a violência dos homens, e às vezes mantendo a mulher em um lugar social desprivilegiado. Por exemplo, como indica a narradora do início da sessão, o ato de violência extrema contra a mulher, que ela entende como feminicídio, era esporádico. Se, anteriormente à ação bélica organizada, a gestão de conflitos interétnicos tendia a limitar a violência extrema, atos contínuos e intensos de violências contra as mulheres faziam parte da rotina. As narrativas registram simultâneas e frequentes ações masculinas em um longo ciclo de violência contra a mulher. Vale ressaltar que essa violência contextualiza-se em relações que envolvem também laços de afeto e irmandade.

A relação sexual intraétnica, ou no âmbito comunitário, projeta-se no plano cosmológico. No capítulo 4 da parte II, vimos que os seres que habitam a natureza, como o Duende e a Tunda, em sua relação com o povo afro-pacífico, disciplinam os comportamentos humanos. Piedad Porozo, mãe de Yonny Nazareno, explica que o Duende estabelece relações com meninas virgens, na puberdade: "Él se enamora de las que no han sido tocadas por ninguno, que están saliendo los senitos. Entonces cuando él se las llevaba, no les hacía nada, sino que les cogía el seno y las sobaba. Entonces cuando ya se le salía el mes, las dejaba". A 
história conta que o Duende tocava os seios das meninas. Na fala de Piedad, esse ato parece não representar uma violação. Segundo ela, o Duende não lhes fazia nada, apenas lhes tocava os seios. Sem pretender fazer uma análise antropológica do mito, essa história parece indicar que o Duende é o agente de um ritual de passagem, de menina para mulher. Ao mesmo tempo, o mito confere a iniciativa sexual aos homens. Elas não se tocam, mas são tocadas.

Trago essa reflexão também para apresentar um contraste entre as interpretações da violência sexual no âmbito comunitário e no contexto da ação bélica organizada. A imposição de força da figura masculina sobre a mulher no ato sexual, no contexto intraétnico, contextualiza-se em um ambiente de vínculos e relações amplas. As relações não estão constituídas apenas pela violência. Nesse contexto, a violência é uma ideia-valor que opera nas relações interpessoais marcadas pela assimetria de gênero, que causa dor e ressentimento nas mulheres. Elas, então, oscilam entre disputar o controle dentro da relação, buscar novos arranjos possíveis ou cortar os vínculos com o sujeito masculino. Já no contexto da violência sociopolítica, a interpretação é outra. É um ato de violência pura. Não há nada mais além da violência nessas interações. Como colocado por Mosquera, Serrano e Zúñiga: "las mujeres son violadas por sus compañeros o esposos, o familiares cercanos, pero consideran inconcebible sufrir actos de abuso sexual el día en el cual ocurre una masacre" (Mosquera, Serrano e Zúñiga, 2012: 56).

Nesse sentido, a violência sexual no contexto da ação bélica organizada não pode ser vista como um recrudescimento da violência sexual que sofrem as mulheres na socialidade cotidiana. A violência sociopolítica fragiliza toda a coletividade e potencializa a violência de gênero contra as mulheres. Violando as mulheres do grupo inimigo, o objetivo é humilhar toda a coletividade, especialmente os homens. Por vezes, conforme relatam Mosquera, Serrano e Zúñiga (Ibidem), as mulheres são violadas perante todos, mediante a impotência de seus companheiros, esposos ou filhos, e mediante a conivência de outros homens pertencentes à coletividade, que podem estar em aliança com atores armados perpetradores do ato violento. Trata-se de uma estratégia para desprestigiar a honra e a respeitabilidade dos homens do grupo dominado; desacreditar sua masculinidade e mostrar sua incapacidade em defender e proteger "suas" mulheres e crianças. A violência sexual contra as mulheres converte-se, portanto, em arma de guerra, destinada a humilhar, dominar, atemorizar e dispersar a coletividade (Idem, ibidem: 76). Nesse sentido, costuma ser intensa em etapas de consolidação do controle territorial por parte de certo grupo armado. 
Relatos de violência no contexto da ação de grupos armados fizeram-se presentes em seminários, fóruns e outros encontros que tive oportunidade de participar. As interfaces entre a violência interpessoal e a ação bélica organizada partem da ideia do corpo como primeiro território de paz. A experiência do projeto Planeta Paz, comentado por Viveros e Zambrano (2011), traz à luz essa ideia. O enfoque da paz concebe a superação das desigualdades econômicas, sociais, culturais e políticas do país como uma condição indispensável para a desativação do "conflito armado".

No Fórum Binacional Fronteiriço de 2012, mulheres afro-pacíficas alçaram sua voz na pessoa de Ecilda Castillo ${ }^{393}$ : "Las mujeres hacemos una manifestación pública del rechazo tangente de la violencia contra las mujeres haciendo énfasis para que nuestros cuerpos no sean botín de guerra". Ou seja, as mulheres começam a discutir a violência a partir de seus corpos, lugar onde a violência se expressa, seja no âmbito das relações em torno da ação bélica organizada, seja no âmbito das relações interpessoais.

Segundo o Auto n. 0092, de $2008^{394}$, mulheres estão expostas a certos fatores de vulnerabilidade específicos no contexto da violência sociopolítica. Complementarmente, o Auto n. 005, de 2009, evidencia que as mulheres afrodescendentes são duramente impactadas pelo desplazamiento e a desterritorialização ${ }^{395} .50 \%$ da população afrodescendente expulsa do território são mulheres, quase metade delas são cabeça de família ${ }^{396}$. Mulheres são afetadas em âmbito individual e coletivo, direta e indiretamente. A violência sexual é uma das afetações mais intensas e dolorosas. Segundo Mosquera Rosero-Labbé, Serrano e Zúñiga, $52 \%$ das mulheres desplazadas sofreram algum tipo de maltrato físico e $36 \%$ delas foram forçadas por desconhecidos a ter relações sexuais (2012: 76).

A atuação da Corte Constitucional, bem como da Área de Gênero e Populações Específicas da Comissão Nacional de Reparação e Reconciliação, indicam que há uma institucionalidade no reconhecimento da complexa afetação das mulheres no contexto da violência sociopolítica. Os Poderes Judiciário e Executivo reconhecem as vulnerabilidades

\footnotetext{
${ }^{393}$ Mulher afro-sanlorenzenha, vereadora em San Lorenzo, que disputou a prefeitura da cidade pelo Partido Movimiento Popular Democrático (MPD) em 2013.

${ }^{394}$ Trata-se de um documento judicial da Corte Constitucional Colombiana (Magistrado: Manuel José Cepeda Espinoza) que relata a situação de mulheres "vítimas" de desplazamiento no país.

${ }^{395}$ Segundo Sanchéz, "Colombia, Sudán y el Congo son los primeros tres países del mundo que encabezan la lista de ser responsables de desplazar a millones de personas, victimas que abandonan a la fuerza sus tierras producto de la violencia" (Sanchéz, 2005: 283).

${ }^{396}$ Por sua vez, das mais de dois milhões de pessoas desplazadas na Colômbia, 50\% são afrodescendentes (Oslender, 2004:45).
} 
que acometem as mulheres, em especial mulheres afro-colombianas, no contexto do "conflito armado interno".

A partir dos vários fatores que Mosquera Rosero-Labbé, Serrano e Zúñiga (2012) elencam no âmbito das afetações às mulheres, reelaboro e ressalto alguns que se destacavam nas narrativas das mulheres com quem dialoguei. Uma parte deles impacta diretamente a subjetividade feminina, como a discriminação racial por parte dos atores armados; a perda de entes familiares por assassinato, desaparição forçada ou recrutamento forçado; a perda das redes de socialidade políticas e afetivas habilmente tecidas pelas matronas; a privação do exercício dos ritos mortuários e de outros saberes ancestrais (como o das parteiras e rezadeiras); a desqualificação da autoridade ancestral; os ressentimentos em acompanhar filhos apreendendo a simbologia e as práticas do ethos guerreiro; intimidações constantes, seja por cartas e bilhetes, seja por visitas domésticas intempestivas dos atores armados; o assinalamento como "colaboradoras" da guerrilha, de paramilitares ou do exército; ser objeto de "vacunas".

Outras afetações estão vinculadas à vivência da territorialidade, quais sejam, o temor e a indignação ante a presença de atores armados intervindo nas práticas coletivas de gestão territorial; a exploração desenfreada dos recursos ambientais de território ancestrais por atores armados; a obrigação de calar-se perante o cultivo, a produção e o embarque da cocaína em territórios ancestrais; a privação de práticas produtivas territorializadas como a mariscagem e a challada, em razão do controle e do monitoramento territorial por atores armados; a degradação ambiental dos territórios mediante o cultivo extensivo e químico da cocaína; o desplazamiento pela ameaça, o temor ou o terror; o desterramento de paisagens geográficas e culturais de referência existencial para essas mulheres. Para além de todas essas afetações, os massacres e enfrentamentos armados em territórios ancestrais são atos de violência extrema que afetam as mulheres afro-pacíficas. Como diz Amada Cortez, "a todas nosotras nos ha pasado. Ninguna mujer en la vida puede decir que no ha sufrido violencia"397.

\section{MATRONAS AFRo-PACÍfICAS: RESISTÊNCIA À VIOLÊNCIA E DEFESA POLÍtica DA TERRITORIALIDADE}

\footnotetext{
${ }^{397}$ Fala proferida em oficina realizada por MOMUNE na sede do movimento, entre 21 e 22 de dezembro de 2013.
} 
Uma das dimensões mais proeminentes de organizações de mulheres com quem trabalhei é o estímulo para que as mulheres reajam à violência. A própria motivação da mobilização política para muitas mulheres é a transformação do quadro de violência a que estão submetidas. O MOMUNE acessa e profunde um repertório criativo de ditos combativos à violência contra as mulheres e empoderadores do feminino:

Si tu marido te pega, dale tú también. Si no puede con la mano, dale con el sartén.

Si el hombre tiene tres mujeres, la mujer va a buscar tres maridos.

Uno decide lo que va a ser en la vida. Si voy a ser una mujer maltratada, violentada, o si voy a ser una mujer echada pa'delante.

Las mujeres tenemos que decidir cuántos hijos vamos a tener. Con quién vamos a tener relación sexual.

A letra de uma canção muito apreciada em Tumaco e San Lorenzo, "Muerto Malo", também problematiza a violência contra as mulheres no contexto doméstico, desde uma perspectiva de empoderamento feminino.

\author{
Dicen que no hay muerto malo \\ $Y$ eso es una gran mentira, \\ El mari'o que tenía, \\ Estaba acabando con la vida mía \\ Tanto como yo lo amé \\ Pero el me hizo sufri' \\ Me pegaba y me golpeaba \\ No lo puedo perdonar \\ $\mathrm{Pa}^{\prime}$ que me muera yo \\ Que se muera él \\ Él era un mari'o malo, \\ Era un mari'o malo
}

O "mari'o malo" é uma constante na vida de algumas mulheres com quem dialoguei.

Uma de minhas amigas teve quatro relações conjugais nas quais vivenciou a violência.

Narradora O: Mucho problema. Él tenía otras mujeres. Era violento. Ellos llegaban. Eran solos y ahi buscaban. Después que los dejé, se fueron con otra mujer. Uno de ellos vive aquí. Cuando lo encuentro, no lo saludo. No tuve suerte con ninguno de ellos. Todos han sido malos. Eran jodidos. El primero me daba duro, mira mi ojo. Se emborrachaba. Me dejó parida y se fue. No aguanté más. Decidí dejarlo.

A presença do tema em letras de músicas e em ditos populares, bem como o depoimento citado ao início dessa sessão, que remete à violência conjugal do homem contra a mulher como uma das modalidades "antigas" da violência me levam a crer que se trata de 
uma prática de longa duração. Como argumentado na primeira parte desta tese, o mundo afropacífico é um mundo machista. Assim, é uma tradição assimétrica, do ponto de vista do gênero, na qual as mulheres estão em posição de agredidas e os homens de agressores.

Porém, isso não significa que as mulheres estejam confortáveis nesse lugar. Como coloca Machado (2010), a manifestação de prestígio e honra dos sujeitos que agridem é acompanhada pelo ressentimento das mulheres agredidas. Ressalto que há um esforço de mulheres sanlorenzenhas, tumaquenhas e salahondenhas no sentido de reconstruir esse caminho nas relações interpessoais entre mulheres e homens afro-pacíficos.

As reações das mulheres à violência são intensas. Não sofrem a violência passivamente. No âmbito das relações interpessoais, elas acionam recursos diversos: também agridem fisicamente os companheiros agressores, defendem-se espiritualmente, separam-se dos agressores, coletivizam-se e fortalecem-se entre si.

\begin{abstract}
Narradora F: Mi padrastro obligaba mi madre a beber, hasta que mi mamá se volvió alcohólica también. Y la bebida lo mató. Mi mamá murió antes. Él la pegaba. Cuando estaba borracho, se la echó una botellada en la vista y ella perdió un ojo. La obligó a regalar los hijos que no eran de él. Yo me sentí triste, pero entendí a mi madre. Ella también estaba buscando protegernos. Porque, cuando él la pegaba, nosotros nos metíamos, queríamos protegerla. Mi mamá también lo apuñaló a él. Fue a la cárcel por eso. Varias veces la mandaron a la cárcel, que era en el pueblo mismo, un calabozo. La agarraban como a un animal, la amarraban las manos y la arrastraban por la calle. El jefe de los policías del pueblo era 'amigo de la bebida' de mi padrastro. Por eso él lo protegía a él y agarraba a mi mamá. Pero ella se salió de la cárcel. Ella era ayudada. Es cuando uno sabe alguna oración para ayuda personal. La pusieron una multa que era limpiar un patio de una escuela. Ese día ella llevó a mí y a mi hermana. Llegamos allá y hacía un sol muy muy fuerte. Nosotras la decimos, mamá nos vamos de aquí... ella me dijo: hija, recoja dos piedras. Yo fui y volvi con dos piedras. Ella me dijo: no, estas están muy pequeñas, recoja las más grandes que puedas. Yo fui y volví. Mi mamá juntó las piedras, las puso así [a uma distância de mais ou menos 60 centímetros entre elas] y puso el machete sobre ellas. Ahí recogió otra piedra y lo golpeó así, con fuerza. Él machete se rompió. Ella dijo: vamos hijas, el machete se rompió. No hay como trabajar. [risas]. Mi mamá era sabida.
\end{abstract}

As sanções novamente recaem sobre a mulher. A mãe da narradora era constantemente agredida pelo companheiro. Ao revidar a agressão, era encarcerada. Nesse caso, há uma solidariedade entre os homens da história, que vulnerabiliza ainda mais a mulher. Ela responde a essa aliança masculina recorrendo aos saberes e ajuda ancestrais. Como diz a narradora, era uma mulher "sabida" e "ajudada", tinha suas maneiras de escapar das sanções sociais que lhe eram impostas. 
O seguinte depoimento mostra como a organização política das mulheres se apresenta como uma resposta, tanto no sentido coletivo quanto no individual. A narradora se diz motivada a lutar, dada a realidade de desrespeito aos direitos das mulheres. A filha dela, por sua vez, encontrou motivação na coletivização das mulheres em busca de seus direitos para enfrentar a situação de violência conjugal que vivenciava.

\begin{abstract}
Narradora G: Por ejemplo, mi hija tiene un maltrato familiar horrible que casi me la mata. Y son cosas que ya no podemos aceptar, vengase de allá, desnuda, ya, que lo sea. A veces no podemos, pero es el miedo que nos da que suceda algo a nosotras. ¿Sí? Pero eso hay que irlo manejando. Hay que mirar que hacer en estos problemas que suceden a diario. Por eso estamos en esa lucha por los derechos hacia la mujer. ;Estos derechos son violados! Entonces, ¿qué es que se lo va a sacar pa' que estos derechos no se lo olviden a nosotras como mujeres? A los niños. Y los procesos son demasiado lentos, muy deteriorados. A veces a ti te sucede algo, no te atienden hasta que la vean ya casi muerta. Hay problemas que tiene a veces con el marido: te voy a matar, incluso le mandan que haga una nueva conciliación y sigue uno peleando con el marido. i¿Va haber una conciliación y él dándole a uno?! Hay que proteger a esa mujer, a esa joven o a ese niño. No, a mí eso no me parece. En el caso de mi hija, ella tiene 21 años. Ella dijo: no mami, yo voy y voy a meterme en el proceso de las mujeres. Estaba en San Andrés, allá sola, sin familia, sin nadie que la defienda. Ya viene mañana. Pero ya viene muy golpeada, fue una experiencia muy horrible. Ella lo deja. Igual no tiene hijo, no tienen nada. Yo creo que de esa experiencia que usted viene, no creo que la vuelva a cometer. Entonces vamos a ver qué pasa con ella.
\end{abstract}

Outra amiga, que também viveu agressões no âmbito conjugal, conta as maneiras que encontrou para lidar com isso.

Narradora B: Yo lo perdoné... no quiero que otras mujeres pasen por lo que yo pasé. Yo lo perdoné. Pero, eso no es motivo para uno ser tolerante con esa situación. O sea yo por lo menos logré... decir basta y salirme. Volver a la casa de mis padres. Miré la casa de mis padres, como una muralla donde él no podía entrar. ¿Sí? Porque, pues, por el respeto que hay a los mayores. Entonces yo logré salir, pero también es como hacerles la invitación a mujeres que, en este momento, pueden estar pasando por esta situación. Decir que uno puede también salir de esa vida. Que uno no puede estar recibiendo violaciones, maltratos, ofensas, sólo porque, digan que uno tiene un hombre en la casa. O sólo porque digan, "no es que yo tengo a mi marido, yo soy una mujer de hogar". Porque muchas mujeres viven una vida de infierno. Y sólo la sostienen pa' que digan que son casadas, de que tienen marido, de que no son madres solteras. Decirles a esas mujeres que están en el silencio, aguantando maltratos, golpes, que están siendo violadas por sus propios esposos, decirles también que solas, también pueden. Que pueden hacer una vida sola y que pueden estar en los diferentes campos, como laboral, político, social; sin necesidad de tener ese hombre allí. O sea para mí, es importante tener un esposo, tener una relación, tener algo bonito. Es importante, no lo voy a decir que no. Pero también es importante la salud mental. Que goce una mujer de salud mental, que una mujer goce de tranquilidad, de armonía, de aprender a conocerse uno mismo; porque hay 
mujeres que no conocen su cuerpo, hay mujeres que no han explorado su cuerpo, conocen su cuerpo por lo que el hombre les puede brindar a conocer, mas no porque ellas se conozcan. Yo le digo así, mi cuerpo es un templo, está solo para recibir y dar amor. Entonces es como la invitación a todas esas mujeres que están allá sufriendo, encerradas, ino! La vida se ha hecho para cosas grandes.

As narradoras A e B novamente trazem o código do medo e do silêncio como veículos de opressão às mulheres. Há, portanto, uma dupla situação de opressão que mulheres afropacíficas estão vivendo: são pressionadas pela violência, assoladas pelo medo, impelidas a silenciar, tanto no âmbito das relações interpessoais como no contexto sociopolítico. Contudo, não cedem às pressões e opressões. Elas reagem, seja dentro das relações conjugais, ou fora delas. As narrativas indicam que a coletivização é uma estratégia de reação feminina. As mulheres reconhecem a violação de seus direitos, percebendo que a situação de violência transcende trajetórias individuais. Irmanadas na dor, unem-se no exercício político de luta por direitos.

A perspectiva da narradora $\mathrm{B}$, desde seu ponto de vista, baseia-se em uma ideologia política construída desde os processos organizativos de mulheres. A base de sua reflexão, portanto, são pensamentos de mulheres, de diferentes mulheres. Ela define-se como feminista e traz uma concepção do feminismo que vale citar: "Las feministas somos así, porque, el feminismo no quiere decir que no nos gusten los hombres. Sino que el feminismo es también, uno colocarse en la fuerza del hombre y poder mirar como él mira, y ocupar para que uno también pueda entender, y para que pueda accionar dentro de lo político".

Entendo que a resistência à violência (física, psicológica e moral) configura um aspecto fundamental para seu processamento subjetivo. Sempre há uma resposta à violência, que assume formas e conteúdos diversos. Assim, o registro que prevalece é o da resistência e não o da violência em si. Isso permite virar a chave, permite reescrever subjetivamente o episódio. É uma das maneiras de ressignificar a violência. Nesse sentido, a vergonha que sente a mulher agredida, violada, violentada - reduzida à impotência, à alienação total de sua vontade - pode ser reinscrita pela chave da resistência, a qual devolve o sentimento ao agressor, quem efetivamente deveria sentir vergonha. O episódio violento inscreve-se, então, no âmbito da "memória exemplar", usando conceito proposto por Todorov (1995). Configurase como um exemplo, entre outros, de uma categoria mais geral, ou um esquema, que serve para significar situações novas com agentes diferentes. Como memória exemplar, o episódio transforma-se em ensinamento. É assim também que trajetórias individuais são coletivizadas. 
Ao longo deste texto, busquei refletir sobre a violência nas relações interpessoais, bem como sobre a violência sociopolítica. Entendo que ambas as modalidades de violência podem ser inscritas no âmbito da "memória exemplar". Retomo, então, o viés da violência sociopolítica para pensar na gama de resistências que as mulheres afro-pacíficas exercitam.

Entendo que as mulheres respondem a essa violência escapando à tipologia bipolar que o contexto sociopolítico instaura. O ethos guerreiro constrói um tipo de masculinidade baseado no autoritarismo, na força e no manejo de armas, o qual, conforme ressaltam Mosquera Rosero-Labbé, Serrano e Zúñiga (2012), faz par com um tipo de mulher que lhe serve de confirmação. Nesse sentido, é construída também uma imagem da mulher, que estaria disposta a aceitar a suposta seguridade, proteção e status que os homens guerreiros oferecem. Há uma sedução no ethos guerreiro. Ao mesmo tempo, esse ethos instaura um estado de relações em que as mulheres estão subordinadas, suas vidas estão em risco, bem como a de suas famílias e da coletividade afro-pacífica de modo geral. A maioria das mulheres com quem dialoguei tem posturas que desafiam a tipologia bipolar instaurada pela ação bélica organizada.

As mulheres respondem à ação bélica organizada saindo em busca de uma nova vida em outra localidade, mas também se mantendo firmes no território, mantendo sua atuação como lideranças de base, como parteiras, rezadeiras, cantaoras, enfim, como matronas. Quando declaram uma posição neutra no âmbito da guerra, desvinculando-se de qualquer grupo armado, também estão estrategicamente se posicionando perante a guerra. Isso não significa, porém, isolar-se. Interlocutar com os atores armados, buscando negociar questões importantes para a coletividade, não cedendo ao controle territorial almejado pelos grupos armados, é uma resposta, uma atitude de resistência. Tudo isso implica adotar posições de autonomia com relação aos atores armados.

No livro Em Face do Extremo, Tzvetan Todorov (1995) reflete sobre a moral na situação extrema dos campos de concentração nazistas. Enfocando trajetórias individuais e relações intersubjetivas, o autor complexifica as reflexões sobre bem e mal ${ }^{398}$, assim como as análises sobre a condição de vítimas e algozes ${ }^{399}$. Ele conclui que, ainda em situações extremas - marcadas por regras de sociabilidade específicas, porém não inexistentes -, há possibilidade de escolha e, portanto, de vida moral. $\mathrm{O}$ autor ressalva que existe possibilidade

\footnotetext{
398 “O mal não é acidental, está sempre lá, disponível, pronto a manifestar-se; basta não fazer nada, para que ele emerja. O bem não é uma ilusão, preserva-se até nas mais desesperadoras circunstâncias" (Todorov, 1995: 176).

399 “deve-se recusar a tentação de estabelecer uma descontinuidade radical entre 'eles' e 'nós', de diabolizar os culpados, de considerar os indivíduos ou os grupos como completamente homogêneos e coerentes" (Idem, ibidem: 275).
} 
de escolha até certo limite. Além dele, os atos de uma pessoa transformam-se em reações mecânicas ao sofrimento causado, por exemplo, por uma sequência de fome prolongada ou pela ameaça iminente de morte. Sem querer comparar a situação dos campos de concentração nazistas com a da violência sociopolítica no Pacífico colombo-equatoriano, entendo que o autor traz à luz questões que ajudam a refletir sobre a realidade ora analisada.

Para mim, é valioso nas reflexões de Todorov o entendimento de que, em contextos extremos, sob determinado ponto de vista, "continuar humano é mais precioso do que continuar vivo" (Todorov, 1995: 49). Nesse sentido, a humanidade ganha sentido na dignidade, que, por sua vez, está inscrita pela chave da autonomia.

$\mathrm{O}$ autor inspira-me também a refletir sobre a resistência. Há diversas maneiras de resistir à violência. Uma delas consiste em respondê-la com violência. As matronas afropacíficas não o fazem, em minha percepção. Elas resistem à violência sociopolítica insistindo em manter as redes de reciprocidade, os vínculos afetivos e políticos, a solidariedade intraétnica. Ou seja, resistem na medida em que se dedicam e se esforçam em atualizar a socialidade afro-pacífica, da qual são protagonistas. Elas evocam a esperança de fazer do Pacífico novamente "remanso de paz". Entendo que instaurar a paz significa restaurar a socialidade afro-pacífica, restaurar os vínculos sociais comunitários. Participando das organizações políticas, a defesa da territorialidade é a defesa dos vínculos sociais.

Trata-se de uma resposta até mesmo àqueles com os quais as matronas compartilham o pertencimento étnico-racial. E essa resposta tem dupla orientação, direcionando-se tanto ao contexto sociopolítico quanto àquele das relações interpessoais. A despeito de uma parte da coletividade negra ter se envolvido, das mais variadas formas, nas tramas da violência sociopolítica, as matronas a ela resistem, desviando o curso das águas. Ao exercer a capacidade do desvio, elas exercem a autonomia. A não resignação à realidade da ação bélica organizada é resistência. Ao mesmo tempo, as mulheres denunciam a violência da qual são alvo por seus companheiros, no afeto e na política. Não fazer-se cega à violência, mesmo quando isso implica uma crítica interétnica, é resistência.

A resposta das matronas à violência perpetrada por "irmãos" é a de que a dignidade delas pressupõe o reconhecimento do outro, até mesmo deles. Elas conclamam toda a coletividade negra que siga se reconhecendo como família. Nesse tipo de resistência, as matronas afro-pacíficas sustentam subjetivamente a sua própria humanidade, que se constrói no coletivo. A preocupação com o outro dá a elas uma razão para seguir resistindo e, assim, seguir existindo. As matronas logram reelaborar a emoção do medo; são capazes de 
reconhecê-lo como paralisante e depois fazer dele um ponto de partida para seguir lutando pela coletividade negra. Nesse sentido, trata-se de defender um modo de viver primordialmente constituído por elas, que se contrapõe à violência sociopolítica e à violência de gênero nas relações interpessoais. 


\section{À GUISA DE CONCLUSÃo}

Ao final do processo de composição do texto, a releitura do livro de Silvia Álvarez levou-me a perceber que a escrita da tese, assim como no caso de Álvarez, reflete o ritmo da vivência de campo. Em meu caso, o primeiro tema trabalhado diz respeito às categorias de classificação, a saber, raça e gênero. Compreendo que essas foram portas de entrada ao universo afro-pacífico. Especialmente as maneiras como fui classificada me traziam inquietudes e me levavam à busca de uma compreensão mais profunda sobre como atuavam tais categorias no contexto de pesquisa. Ademais, a centralidade da etnicidade no discurso afro-pacífico matizou as percepções sobre os sentidos de pertencimento em torno dessas categorias, conduzindo-me a elaborações específicas de temas que, no Brasil, são articulados por vocabulários um pouco diferentes.

Em seguida, ganha espaço o território. Ainda que não tenha sido possível vivenciar a territorialidade dos Conselhos Comunitários como havia idealizado, o encontro com o território-água - essa concepção de território que se expressa pela metáfora das águas aconteceu por meio das narrativas de mulheres para as quais ele muito representa. Os trânsitos entre o Equador e a Colômbia por via Pacífica e algumas visitas pontuais às veredas, recintos e paróquias me permitiram sentir o balanço das águas e apreender a paisagem que era narrada nas conversas com minhas amigas. Ainda assim, levou tempo para que eu compreendesse a densidade do rio na vida do povo afro-pacífico. Focada como estava na labuta das mulheres concheras, meu olhar voltava-se aos manguezais e subsidiariamente ao mar. Mesmo com as leituras prévias sobre a socialidade ribeirinha, foi apenas na etapa final de pesquisa que consegui apreender o significado dos rios como fonte de vida e de resistência.

Por sua vez, o encontro com a violência foi um processo gradual. Recorro a uma tríade elaborada por Charles Pierce (apud Álvarez, 2013), segundo a qual existem três modos de ser: firstness/secondness/thirdness. O primeiro corresponde à possibilidade qualitativa, é algo peculiar e idiossincrático, em que predomina o sentimento, ou seja, um estado do ser. $\mathrm{O}$ segundo é um evento ou fato concreto, inscrito no aqui e agora; enquanto o terceiro se refere à convenção, modalidade que rege os eventos do futuro. Recupero também os trios elaborados por Valentine Daniel (1996) que inspiram Álvarez ao longo da obra, que, por sua vez, foram inspirados por Pierce. Valentine (apud Álvarez, 2013) compreende que quem pesquisa a violência vivencia as tríades: violência/escritura/tempo; momento/disposição/opinião; e objeto/representação/intérprete. 
Entendo que o tempo associado ao exercício da escrita cumpriu uma função central na minha forma de perceber e elaborar os eventos vividos no contexto da violência sociopolítica no Pacífico colombo-equatoriano. Certos estados e eventos vivenciados etnograficamente foram processados no momento da escritura do texto. Ou seja, a interpretação dos estados e eventos foi um processo gradual, que se deu posteriormente a sua vivência e ao desvelamento dessa mesma vivência. Em alguns episódios etnográficos, o primeiro modo de ser correspondeu a um estado de ausência de compreensão, como se tivesse uma venda nos olhos; o segundo modo foi um descortinamento da realidade; e o terceiro, uma interpretação, uma argumentação analítica sobre os eventos. Percebo, nesse sentido, que a escritura da tese, ademais de um exercício intelectual, foi também um processo de resolução afetiva.

Ao longo do texto, algumas ideias configuraram-se como eixos estruturantes de meus argumentos. Ainda que não fosse objetivo da tese tecer uma análise comparativa da realidade pesquisada com o Brasil, o olhar situado conduziu-me a analogias entre o Pacífico Negro colombo-equatoriano e as construções afro-brasileiras da raça, da etnia e do território. Nesse sentido, argumentei que, na concepção colombo-equatoriana de etnia, critérios geográficos territoriais são um dos elementos importantes. No Brasil há uma realidade múltipla; somos uma população negra amplamente distribuída por todo o território nacional, zona rural e urbana, sendo uma parte dela conformada por coletividades negras dotadas de uma existência territorialmente marcada, quais sejam, os quilombos e povos tradicionais de matriz africana. É como se no Brasil a negritude prescindisse da geografia, ainda que esteja inscrita também nesse registro. Assim sendo, as identificações em processo estão fundamentadas em torno da raça mais do que em torno da etnia. Já na Colômbia e no Equador, a etnicidade parece estar fundamentalmente territorializada.

Um contraste que ganhou peso reside no binômio raça/etnia. Se no Brasil a autodefinição foi construída em torno da raça, enquanto na Colômbia e no Equador é a etnia quem nomeia o sentido de pertencimento, em ambos os casos, foram escolhas feitas na contingência. Ao mesmo tempo em que manifestam um movimento consciente e calculado, a agência dos sujeitos acontece dentro dos limites do racismo e do neoliberalismo. Nesse sentido, ambas as escolhas são problemáticas. Meu intuito, ao longo da tese, foi lançar algumas interpretações sobre consequências de tais escolhas.

Na primeira parte da tese, minha ênfase é sobre os sistemas de classificação étnicoraciais. Intrigou-me o encontro no Pacífico Negro colombo-equatoriano com o discurso da inexistência da branquitude. Fazendo uma análise histórica, desde a colônia ao período da 
multi e interculturalidade, percebi que houve uma transmutação da categoria "mestiça". Inicialmente, tratava-se de uma construção contra-hegemônica, que partia do lugar de enunciação da população africana, afrodescendente e indígena. A partir do encontro entre negros/as e indígenas, a República Zamba instaurou um território de liberdade no Pacífico colombo-equatoriano, em pleno regime de escravização de ambos os povos. No período republicano, a categoria "mestiça" foi apropriada pelas elites nacionais e transformada em instrumento de opressão de afrodescendentes e indígenas, na medida em que a mistura era um processo de embranquecimento.

Na contemporaneidade, há várias maneiras de fazer sinônimas as categorias "mestiça" e "branca", cujos sentidos variam conforme o lugar de enunciação. Quando o lócus de fala é o de mulheres afro-pacíficas, trata-se, mais uma vez, de uma leitura contra-hegemônica, que questiona o lugar privilegiado da branquitude. Seria, pois, um questionamento à suposta superioridade (auto)atribuída a descendentes de europeus. Analisando, por outro lado, as pesquisas censitárias, interpretei que a fusão das categorias "branca" e "mestiça" representa um apoderamento da mestiçagem pela ordem hegemônica. De todo modo, a alteridade não negra contemporaneamente passa a ser a população mestiça.

Compreendo que as identificações em processo são exercícios de alteridade. Eu me reconheço a partir da negação de "outro". Nesse sentido, a fusão entre as categorias "branco" e "mestiço" pode desencadear um processo no qual uma parte da população mestiça que poderia, a partir de um exercício político, identificar-se como afrodescendente passa a identificar-se eminentemente como não negra. Vale ressaltar que a Colômbia vive um momento no qual o movimento social afro-colombiano almeja reconhecer e valorizar a diversidade de fenótipos negros (ou afro) presentes no país, considerando as gradações de mestiçagem. Isso se explicita na Campanha organizada por uma miríade de organizações afrocolombianas, mobilizando a autoidentificação para o Censo de 2005, comentada na segunda parte da tese.

A vivência das construções afro-brasileiras da raça leva-me a pensar sobre os efeitos políticos do processo em curso, na região pesquisada. No Brasil, o vocabulário da raça está imerso em uma leitura sobre as desigualdades, segundo a qual raça e classe se articulam, compondo uma ordem hierárquica de relações de dominação social. O movimento social negro brasileiro, desde a década de 1970, empreende o exercício político de estimular a autoidentificação "negro/a" entre pessoas de variadas cores, com ascendência africana e fenótipo negro, cujo lugar na ordem hierárquica sociorracial é o da subalternidade. Nas 
últimas décadas, o Brasil vive o aumento do percentual de pessoas mescladas que se consideram pardas e/ou pretas, ou seja, negras.

Retomo, então, o pensamento dos intelectuais negros colombiano e brasileiro Manuel Zapata Olivella e Abdias do Nascimento. A perspectiva da mestiçagem radical de Zapata Olivella compreende que a mistura é inerente a qualquer grupo humano. $\mathrm{O}$ autor rechaça a representação da mestiçagem colombiana como uma mescla orgânica, homogênea e desprovida de conflito, como ressalta Viveros (2013). Ao contrário, para Zapata Olivella, a herança colonial imbui de desigualdades sociais a hibridez latino-americana. Por outro lado, o autor deixa uma ambiguidade em suas interpretações, quando atribui à mestiçagem nas Américas um caráter ontológico e positivo, como se fosse uma condição necessária da existência e do destino da população americana. Viveros destaca que, a despeito do conceito de trietnicidade de Zapata Olivella aludir ao caráter forçado dos intercâmbios entre indígenas, africanos e europeus, parece ignorar a persistência das hierarquias dentro do resultado sincrético dessa trietnicidade (Viveros, 2013: 92). Trata-se, portanto, de um ponto em que os pensamentos de Manuel Zapata Olivella e Abdias do Nascimento se distanciam. Nascimento reitera o caráter ideológico da mestiçagem, que se constitui como um projeto de apagamento do componente africano na mistura e uma proposta de embranquecimento, segundo a qual as relações sexual-afetivas inter-raciais seriam preferíveis às uniões intrarraciais.

Compreendo que a mestiçagem definitivamente não traz consigo o atributo de constituir sociedades desprovidas de desigualdades inscritas sob a insígnia da raça. Mestiçagem e racialização podem coexistir. Ainda que mestiças, em sociedades racializadas, as pessoas são hierarquizadas. Quanto mais próximas do fenótipo branco-europeu, mais próximas estarão do topo da hierarquia sociorracial. Por sua vez, a proximidade com o fenótipo negro-africano conduz a um lugar de subalternidade dentro dessa mesma hierarquia. Em minha percepção, Colômbia, Equador e Brasil são sociedades racializadas, porém encontraram diferentes caminhos para falar sobre as desigualdades sociorraciais.

Na segunda parte, o território foi o foco da análise. A etnografia levou-me ao conceito de território-água, por meio do qual apreendi as dimensões geográficas e simbólicas da territorialidade. Ao enfatizar a construção política da territorialidade, o discurso da etnicidade no Pacífico colombo-equatoriano é articulado a uma ideia de permeabilidade entre rural e urbano, que situo como uma elaboração protagonizada principalmente pelo Proceso de Comunidades Negras (PCN), a qual informa a concepção de "comunidades negras" da Lei n. 70, de 1993. Trata-se de um arranjo conceitual que se projeta no campo político-acadêmico e 
jurídico; um campo em construção, no qual os vários discursos se interpelam e se (re)constroem permanentemente. Tal arranjo opera uma mudança de ênfase da raça para a etnia, da igualdade para a diferença, da integração das "comunidades negras" à sociedade englobante para o reconhecimento de sua diversidade. Esse discurso nasce no Pacífico colombiano, porém, em seguida, atravessa as fronteiras geográficas, chegando ao Pacífico equatoriano, ao norte de Esmeraldas.

Na Colômbia, o PCN encabeçou um processo de politização da etnia como uma aposta de gerar um sentimento de unidade entre o povo negro/afro-colombiano, estruturado em torno de um "território" e de uma "cultura". Nesse sentido, para o PCN, o étnico engloba o racial. A raça está suposta, porém o que nomeia, classifica, organiza e agrega seria a etnia ${ }^{400}$. O Pacífico Negro que conheci etnograficamente entre 2012 e 2014, nas cidades ao sul da região - Tumaco e Salahonda -, experiencia uma série de tensões entre a vivência da etnicidade/raça nas veredas e nas cidades.

As tensões explicitam-se, desde uma perspectiva relacional, nos processos organizativos de mulheres e nos processos organizativos negros/afro. Visualizo uma disputa entre discursos políticos estruturados em torno do gênero e outros estruturados em torno da etnicidade. Os Conselhos Comunitários, dos quais participam homens e mulheres, reivindicam um lugar de fala soberano, já que pressupõem autonomia na gestão territorial. Porém, são imbuídos de uma lógica masculina de exercício do poder, com a qual as mulheres ribeirinhas não se identificam. Ao longo dos rios que percorri, são recorrentes as críticas femininas sobre a gestão masculina das juntas diretivas de Conselhos Comunitários. Por sua vez, organizações femininas, como, por exemplo, a Mesa Municipal de Mulheres de Tumaco fala em nome de todas as mulheres desse município, sejam elas negras, não negras, das veredas, da cidade, indígenas. As mulheres das ribeiras dos rios, no meio desse jogo em torno da (não) representatividade, encontram uma saída construindo movimentos de mulheres negras territorializadas. É o caso do equatoriano Movimento de Mulheres Negras do Norte do Esmeraldas e da colombiana Comissão de Mulheres do Conselho Comunitário Baixo Rio Mira e Fronteira.

Tais tensões também se visibilizam em disputas intraorganizações negras/afrocolombianas. No cenário nacional colombiano, as vozes que emanam do contexto citadino,

\footnotetext{
${ }^{400}$ No campo político-acadêmico, muitas são as críticas a essa concepção, as quais emanam principalmente do contexto urbano. Lozano (2010), por exemplo, entende que a heterogeneidade da população negra forçosamente trazida da África para a Colômbia e, em seguida, da população afrodescendente que se constitui no país, não permite que o conjunto de negras e negros se comporte como um coletivo étnico que compartilha as mesmas referências socioculturais.
} 
desde a década de 1970, problematizam a questão do antirracismo, enquanto a linguagem da etnicidade provinda dos rios do Pacífico colombiano, a partir da década de 1990, problematiza a questão dos direitos territoriais. Desde certa ótica, são dois diferentes problemas, os quais não estão, porém, apartados na vivência da negritude/etnicidade.

Em dado momento histórico, foi estratégico enfatizar a etnicidade e sua relação com a biodiversidade, o que deu fôlego ao movimento negro nas negociações com o Estado colombiano, com vistas à aprovação do Artigo Transitório n. 55, da Constituição Política de 1991, e da Lei n. 70, de 1993, como bem ressalta Paschel (2010 e 2013). Setores do movimento negro, naquele momento, lograram formular demandas de autonomia territorial na linguagem que o Estado compreendia, que era a linguagem da etnicidade, cujo sujeito ideal são os povos indígenas. Ao mesmo tempo, era a linguagem que expressava o sentido de pertencimento negro enraizado territorialmente. Vale ressaltar que a maior defesa do povo afro-pacífico era em torno de seu território ancestral. Com essa estratégia, lograram-se avanços, especialmente na regularização territorial. Colômbia avançou muito mais nas políticas de reconhecimento e garantia de direitos às comunidades negras territorializadas do que o Brasil, no tocante ao povo quilombola.

Sem embargo, ainda que se tensionem ao longo da história colombiana, as tendências políticas em torno do antirracismo e em defesa dos direitos territoriais não se constituíram de maneira unívoca. O movimento Cimarrón, historicamente uma das principais vozes antirracistas na Colômbia, traz em seus pleitos políticos demandas relacionadas à territorialidade. O Proceso de Comunidades Negras (PCN), por sua vez, que protagonizou a luta étnica em torno dos direitos territoriais, nos últimos dez anos, engaja-se mais intensamente nas lutas antirracistas e em defesa dos direitos humanos de negros/as ou afrocolombianos/as. Houve momentos em que as tendências convergiram, como, por exemplo, quando da realização da Campanha "Las Caras Lindas de Mi Gente Negra", que antecedeu ao Censo de 2005. Estabelecer uma antinomia entre elas implicaria, portanto, prejuízo para análise da questão, do mesmo modo que o faria uma análise do rural e do urbano como domínios estanques. Ruralidade e urbanidade, ao tempo em que se tensionam, articulam-se e estabelecem entre si fronteiras fluidas.

Feita a reflexão quanto ao cenário nacional, proponho uma análise das tensões intraorganizações étnicas no Pacífico sul colombiano. Há, então, outro nível de tensionamentos entre organizações étnico-territoriais, como é o caso dos Conselhos Comunitários e da Rede de Conselhos Comunitários do Pacífico Sul (RECOMPAS), e 
organizações étnico-culturais, como o PCN. A pertença em ambas as organizações é construída em torno da etnia. Contudo, ambas disputam o lugar de fala das ribeiras dos rios do Pacífico Negro.

Na medida em que se consolidaram vários Conselhos Comunitários no Pacífico sul colombiano, ao longo da década de 1990 e das décadas subsequentes, o PCN perdeu fôlego. O perfil dos ativistas do PCN foi se transformando ao longo das décadas, agregando cada vez mais pessoas citadinas. No início do milênio, a RECOMPAS surge como instância agregadora das vozes que emanam das ribeiras dos rios da enseada. Paralelamente, os impactos da violência sociopolítica transformaram a dinâmica pendular campo-poblado, o que incide diretamente sobre as organizações, desencadeando um quadro de instabilidade e desestruturação. A RECOMPAS também perde fôlego nos últimos anos, na medida em que suas ações se vinculam ao capital externo e aos interesses mercadológicos, como criticam as vozes das mulheres com quem dialoguei.

Haja vista essa teia complexa de discursos e práticas dos movimentos sociais, no campo e na cidade, talvez esteja em curso um momento na história das organizações negras ou afro-colombianas marcado pela luta antirracista como elemento aglutinador da coletividade negra ${ }^{401}$. E, então, lutas e desafios dos movimentos negros na Colômbia e no Brasil aproximam-se. Desde minha vivência intelectual e política no Brasil, cheguei ao Pacífico colombo-equatoriano imersa na luta antirracista, portanto, em um discurso no qual as diferenças entre grupos sociais são nomeadas pela "raça", a partir de uma leitura na qual raça e classe são critérios articulados de classificação e hierarquização social. Deparei-me, pois, com construções nas quais a etnia tem centralidade na nomeação das diferenças, que são eminentemente territorializadas. E acabei, por fim, voltando à raça e ao antirracismo, sem deixar de compreender a relevância da defesa da etnicidade e da territorialidade no contexto colombiano e equatoriano, em especial na região fronteiriça do Pacífico.

No extremo norte do Equador, a base da construção da territorialidade foi a concepção de território-região elaborada pelo PCN. Ou seja, a territorialidade teve a mesma matriz conceitual embasada na etnicidade. Todavia, atualmente, o povo da Comarca AfroEquatoriana do Norte de Esmeraldas (CANE), em especial as mulheres da Comarca, formulou uma concepção de território que depende do lugar de fala. Enquanto o PCN propõe uma extensão da lógica territorial ribeirinha para o conjunto da coletividade negra, o Movimento

\footnotetext{
${ }^{401}$ Em que pese a convergência do movimento afro-colombiano em torno do antirracismo nas últimas décadas, Viveros (2015) chama atenção para o fato de que as demandas em torno da população negra vulnerabilizada ainda são privilegiadas no movimento social, pospondo demandas relacionadas à redistribuição econômica.
} 
de Mulheres Negras do Norte de Esmeraldas (MOMUNE) pressupõe que a territorialidade emerge do lugar de fala. Nesse sentido, cada foco de presença negra no Equador constitui um palenque ou uma comarca. Nas interações entre movimento social e Estado, construiu-se um discurso que articula a linguagem da raça e a linguagem da etnia, cuja materialidade visibiliza-se no Plan Plurinacional contra la Discriminación Racial y la Exclusión Étnica y Racial $^{402}$.

Enfim, seja na Colômbia, no Equador, no Brasil e de modo geral, entendo que a superação das iniquidades étnico-raciais pressupõe uma conexão entre o reconhecimento das diferenças e a demanda por igualdade de oportunidades. Percebo que tais iniquidades se manifestam e se projetam de variadas maneiras sobre os também variados grupos que compõem a população negra ou afrodescendente. Convergindo com Viveros (2013), compreendo que a produção intelectual e a mobilização política em torno da superação das desigualdades e da garantia de direitos não precisa obliterar, mas pode, ao contrário, acompanhar a heterogeneidade da negritude/afrodescendência.

Assim sendo, pode incluir as vivências heterogêneas da negritude/afrodescendência, com interesses que são múltiplos. A retomada da linguagem da raça, nesse sentido, não implica, portanto, a substituição da etnia pela raça. Contemporaneamente, a territorialidade segue sendo tema cabal na Colômbia e no Equador. Em que pese o avanço na regularização dos territórios coletivos ancestrais, especialmente na Colômbia, muito há ainda por fazer nos dois países. Mesmo no Pacífico sul colombiano, a regularização não garantiu a autonomia territorial, o autogoverno da coletividade sobre seu território, onde se inscreve a ancestralidade. A incidência do grande capital e a violência sociopolítica representam constantes ameaças à integridade da gestão dos territórios ancestrais.

No quadro que encontrei no Pacífico sul colombiano, a inscrição de demandas citadinas é um tema pungente, porém, ainda não reverberou intensamente nos discursos das organizações. Por outro lado, ressalto que a territorialidade segue sendo um tema caro à coletividade afro-pacífica e que deve ser continuamente defendido. Nesse sentido, compreendo que a luta deve incluir a capacidade de autonomia territorial das "comunidades negras". Seja no caso dos colombianos Conselhos Comunitários, ou nas Comunas equatorianas, a regularização dos territórios ancestrais é demasiadamente frágil. Em ambos os países, a coletividade negra depara-se com obstáculos impostos pelos interesses do grande capital, muitas vezes aliado ao Estado, e pela violência sociopolítica.

${ }^{402}$ Decreto n. 60, de 2009. 
A percepção das mulheres afro-pacíficas como matronas configura o eixo que estruturou a argumentação ao longo da tese. Por meio da escuta atenta a essas mulheres, conheci o universo afro-pacífico. Foi um diálogo com Marlene que me atentou para a categoria "matrona":

Marlene: Nosotras ya nacemos matronas.

Paula: ¿Matrona?, ¿es un sinónimo para lideresa, Marlene?

Marlene: Pues las matronas son las sabedoras, las pújapas, las mayores, que de alguna manera se les pide consejo. $Y$ las lideresas es un papel casi igual. Sino que la matrona, es más como de casa. Y la lideresa es de comunidad y de la calle.

As matronas são, portanto, um tipo de liderança feminina negra que carrega uma dimensão simbólica importante. São mulheres sábias, são xamãs. Atuando como parteiras, curandeiras, rezadeiras e cantaoras, elas indicam caminhos da existência. A cosmologia afropacífica é elaborada e praticada em torno delas. Suas mãos trazem ao mundo as pessoas; suas palavras rezam e curam as enfermidades do corpo, da mente e do coração; seus cantos encomendam as almas. Ou seja, ao redor delas, delineia-se o ciclo nascimento-vida-morte.

Na narrativa de Marlene, nota-se certa separação entre o doméstico e o público. Sem embargo, a etnografia leva-me à interpretação de que, em suas práticas, não há separação. A política perpassa ambos os domínios. Marlene faz política em sua casa, na comunidade e na calle. Nesse sentido, terminei de elaborar o conceito de matrona ao identificar a linha de continuidade entre "casa", "comunidad", "calle", no processo de construção da liderança feminina afro-pacífica. Em meu entendimento, ao construírem redes de irmandade política e afetiva, as matronas afro-pacíficas conectam doméstico e público. Trata-se de uma construção de longa duração, cujo gérmen se encontra na organização social das quadrilhas mineiras, quando da escravização da população africana e de seus descendentes na região em foco. As matronas, nesse sentido, agregam um sentido de poder cosmológico e uma atuação políticoorganizativa do povo afro-pacífico.

Como artesãs da tessitura social, elas fazem resistência à violência de uma forma muito particular. Um dos episódios etnográficos bem ilustra a questão. Quando estávamos em meio ao Oceano Pacífico sob intensa pressão, em uma ação abusiva do exército equatoriano, mulheres tumaquenhas começaram a cantar. Em um ambiente de ameaça, excesso e iminente violência das autoridades policiais, ao entoarem um cântico, aquelas professoras evocaram e inseriram no evento em tela outro registro, um registro afetivo. Elas foram capazes de responder à violência com uma ação de resgate das relações, dos vínculos sociais e dos afetos. 
E o fizeram em uma atitude de cuidado com todos nós que ali estávamos, até mesmo com os policiais.

No contexto contemporâneo de violências sociopolíticas e interpessoais, considero importante trazer à luz a especificidade da ação feminina afro-pacífica, bem como sublinhar as iniquidades que envolvem a coletividade negra e não negra, sob a insígnia da raça. Tendo em vista a relevância das conquistas negras em torno do multiculturalismo, assim como Wade (2012), compreendo que a exclusão da população negra persiste, expressando-se de forma dramática na contemporaneidade sob a faceta da violência sociopolítica. É como coloca o autor, "parece que tornar pública a diferença, e inscreve-la na lei, trouxe consigo formas mais drásticas e violentas de disciplinar a diferença" (Wade, 2012: 24). Na era do "multiculturalismo neoliberal", usando a expressão proposta por Viveros (2015), as formas de disciplinar diferenças sociais estão diretamente vinculadas aos interesses do grande capital. Nesse sentido, a guerra é um instrumento de dominação econômica racializada, que representa um retrocesso ao movimento de garantia de direitos das "comunidades negras" do Pacífico colombo-equatoriano.

Por sua vez, as iniquidades de gênero nas relações interpessoais, potencializadas pelas implicações da ação bélica organizada, colocam as mulheres afro-pacíficas em um lugar estrutural de desvantagem extrema. Seja no ambiente doméstico, como no comunitário, essas mulheres cotidianamente enfrentam violências perpetradas por seus companheiros no afeto e na política. Não obstante, elas e eles se aliam em diferentes frentes de luta, como a luta em defesa do território, a luta antirracista, a busca pelo reconhecimento e a valorização do legado cultural afrodescendente.

As matronas afro-pacíficas oferecem uma generosa resposta às violências. Ouvidos atentos e sensíveis são capazes de perceber o vigor e a potência da resistência dessas mulheres. 


\section{REFERÊNCIAS BIBLIOGRÁFICAS}

ALMARIO, Oscar. Dinámica y consecuencias del conflicto armado colombiano en el Pacífico: limpieza étnica y desterritorialización de afrocolombianos e indígenas y "multiculturalismo" de Estado e indolencia nacional. In: RESTREPO, Eduardo e ROJAS, Axel (orgs.). Conflicto e (in)visibilidad. Retos en los estudios de la gente negra en Colombia. Popayán: Editorial Universidad del Cauca, 2004, pp. 73-120.

ALMARIO, Oscar y CASTILLO, Ricardo. Territorio, poblamiento y sociedades negras en el Pacífico sur colombiano. In: VALLE, José Ignacio del e RESTREPO, Eduardo (eds.). Renacientes del Guandal: Grupos negros de los ríos Satinga y Sanquianga. Bogotá: Proyecto BioPacifico, Ministerio del Medio Ambiente, GEF-PNUD-Universidad Nacional, 1996, pp. 57-117.

ALMEIDA, Alfredo Wagner Berno de. Terras tradicionalmente ocupadas: processos de territorialização e movimentos sociais. Rio de Janeiro: ANPUR, 2004, pp. 1-30.

ALMEIDA, Alfredo Wagner Berno de. Os quilombolas e a base de lançamento de foguetes de Alcântara: laudo antropológico. Brasília: MMA, 2006.

ARBOLEDA, Santiago. Negándose a ser desplazados: afrocolombianosen Buenaventura. In: RESTREPO, Eduardo e ROJAS, Axel (orgs.). Conflicto e (in)visibilidad. Retos en los estudios de la gente negra en Colombia. Popayán: Editorial Universidad del Cauca, 2004, pp. 121-138.

ARBOLEDA, Santiago. Conocimientos ancestrales amenazados y destierro prorrogado: la encrucijada de los afrocolombianos. In: MOSQUERA Rosero-Labbé, Claudia e BARCELOS, Luiz Claudio (eds.) Afro-reparaciones: memorias de la esclavitud y justicia reparativa para negros, afrocolombianos, raizales. Bogotá: Universidad Nacional de Colombia, 2007, pp. 467-486.

ARBOLEDA, Santiago. El mestizaje radical de Manuel Zapata Olivella: raza, etnia y ciudadanía. In: MOSQUERA, Claudia Rosero-Labbé; LÁO-MONTES, Agustín; GARAVITO, César Rodríguez (eds.). Debates sobre ciudadanía y políticas raciales en las Américas Negras. Bogotá: Universidad Nacional de Colombia. Facultad de Ciencias Humanas, Centro de Estudios Sociales, Universidad del Valle, 2010, pp. 441-461.

ARBOLEDA, Jhon Henry Quiñones. Buscando Mejora. Migraciones, territorialidades y construcción de identidades afrocolombianas en Cali. 2.ed. Quito: Universidad Politécnica Salesiana, 2012[2011].

ARENDT, Hannah. Da Violência. Tradução: Maria Claudia Drummond. 2004 [1969/1970]. Disponível: www.sabotagem.revolt.org, acessado em 03/04/2015.

AROCHA Rodríguez, Jaime. Concheras, manglares y organización familiar en Tumaco. Cuadernos de Antropología, n. 7, Bogotá, Universidad Nacional, julio de 1986, pp 1-20.

AROCHA Rodríguez, Jaime. Los negros y la Nueva Constitución de 1991. En Bogotá: America Negra, n. 3, Pontificia Universidad Javeriana, 1992, pp. 39-54. 
ASHER, Kiran. Black and Green. Afro-Colombians, Development, and Nature in the Pacific Lowlands. Durham e London: DukeUniversityPress, 2009.

AZOPARDO, Ildefonso Gutierrez. Historia del Negro en Colombia Sumision o Rebeldia?. 4.ed. Bogotá: Editorial Nueva America, 1994 [1980].

BAIOCCHI, Mari. Kalunga: Povo da Terra. Goiânia: UFG, 2006 [1999].

BARBARY, Olivier e URREA, Fernando. Gente negra en Colombia: Dinámicas Sociopolíticas en Cali y en el Pacífico. Cali: Editora Lealon, CIDSE/Univalle, IRD, COLCIENCIAS, 2004.

BASS, Nelson Estupiñan. Memorias de una ciudad 1920-1930. In: SAVOIA, Rafael (org). El negro en la historia. Raíces Africanas en la Nacionalidad Ecuatoriana. 2.ed. Quito: Centro de Cultura Afroecuatoriana, 2002 [1992].

BEAUVOIR, Simone de. O Segundo Sexo. Rio de Janeiro: Nova Fronteira, 1980[1949].

BEJARANO, Juan Pablo Estupiñan. Qual a sua raça? - Censos, classificações raciais e multiculturalismo na Colômbia e no Brasil. Dissertação (Mestrado em Estudos Étnicos e Africanos) - Programa de Pós-Graduação em Estudos Étnicos e Africanos, Faculdade de Filosofia e Ciências Humanas, Universidade Federal da Bahia, Salvador, 2010.

BEJARANO, María del Pilar López. Aportes a una antropología con perspectiva de género en Colombia. Santafé de Bogotá: Universidad de los Andes, Facultad de Humanidades, Departamento de Antropología, 1995.

BELÉM, Arinos de. História de Antônio Conselheiro - Campanha de Canudos. Belém: Casa Editora de Francisco Lopes, 1940.

BHABHA, Homi. O local da cultura. Tradução: Myriam Ávila. Eliana Lourenço de Lima Reis. Gláucia Renate Gonçalves. Belo Horizonte: Editora da UFMG, 1998.

BORGES, Antonádia Monteiro. Funerais, Política e medo na África do Sul contemporânea. In: MACHADO, Lia Zanotta; BORGES, Antonádia Monteiro; MOURA, Cristina Patriota de (orgs.). A cidade e o medo. Brasília: Verbena/Francis, 2014, pp. 151-166.

CAICEDO, Amada Cortez. Me llaman la Cimarrona. Quito: CODAE, novembro de 2009.

CAMACHO, Juana. "Todos tenemos derecho a su parte": derechos de herencia, acceso y control de bienes en comunidades negras de la costa Pacífica chocoana. In: CAMACHO, Juana e RESTREPO, Eduardo (eds). De montes, ríos y ciudades. Territorios e identidades de la gente negra en Colombia. Bogotá: Fundación Natura, Instituto Colombiano de Antropologia e Ecofondo, 1999, pp. 108-126.

CAMACHO, Juana e TAPIA, Carlos. Mujeres negras, recursos naturales y territorio. Revista Esteros, n. 9, Santafé de Bogotá, fevereiro de 1997, pp. 27-31.

CAMACHO, Juana. Silencios elocuentes, voces emergentes: reseña bibliográfica de los estudios sobre la mujer afrocolombiana. In: ROJAS, Mauricio Pardo; MOSQUERA, Claudia; RAMÍREZ, María 
Clemencia (eds). Panorámica afrocolombiana. Estudios sociales en el Pacífico, Bogotá: Instituto Colombiano de Antropología e Historia e Universidad Nacional de Colombia, 2004, pp. 167-210.

CARDOSO, Ciro Flamarion S. Escravo ou camponês? O protocampesinato negro nas Américas. São Paulo: Editora Brasiliense: 1987.

CARNEIRO, Sueli Aparecida. Enegrecer o feminismo: a situação da mulher negra na América Latina a partir de uma perspectiva de gênero. 2001. Disponível em: http://grioproducoes.blogspot.com/2009/06/enegrecer-o-feminismo-situacao-da.html. Acessado em: 8 de agosto de 2012.

CARNEIRO, Sueli Aparecida. A construção do outro como não-ser como fundamento do ser. Tese (Doutorado em Educação) - Programa de Pós-Graduação em Educação, Universidade de São Paulo, São Paulo, 2005.

CASTAÑEDA, Digna. The Female Slave in Cuba during the first half of the Nineteenth Century. In: SHEPHERD, V.; BRERETON, B.; BAILEY B. (org.). Engendering History: Caribbean Women in Historical Perspective. Kingston 6, Jamaica: Randle Publishers, 1995, pp: 141-155.

CHARVET, Erika Sylva. Feminidad y Masculinidad en la Cultura Afroecuatoriana. El caso del norte de Esmeraldas. Quito: Abya-Yala, 2010.

CHAVÉS, María Eugenia. Color, inferioridad y Esclavización: la invención de la diferencia en los discursos de la colonialidad temprana. In: MOSQUERA ROSERO-LABBÉ, Claudia e BARCELOS, Luís Claudio (eds.). Afro-reparaciones: memorias de la esclavitud y justicia reparativa para negros, afrocolombianos y raizales. Bogotá: Universidad Nacional de Colombia, Observatorio del Caribe colombiano, 2007, pp. 73-92.

COLLINS, Patricia Hill. Black Feminist thought: knowledge, consciousness, and the politics of empowerment. 2.ed. Nova York e Londres: Routledge, 2000 [1990].

CUESTA, Ángela Edith González. Concheras negras de la ensenada de Tumaco: innovación cultural como respuesta a la modernización. Monografia (Gradução em Atropologia) - Universidad Nacional de Colombia, Santafé de Bogotá, 1997.

Reconfiguración identitária: el caso de la Asociación de Concheros de Nariño, ASCONAR. Dissertação (Mestrado em Antropologia) - Departamento de Antropología, Universidad Nacional de Colombia, Bogotá, 2004.

DAVIS, Angela. Women, Race and Class. Grã Bretanha: The Women's Press, Ltda, 1982.

ESCOBAR, Arturo. Viejas y nuevas formas de capital y los dilemas de la biodiversidad. In: ESCOBAR, Arturo e PEDROSA, Alvaro (eds.). Pacífico: ¿Desarrollo o diversidad? Estado, capital y movimientos sociales en el Pacífico colombiano. Santafé de Bogotá: CEREC, Ecofondo, 1996, pp. $109-131$ 
Desplazamientos, desarrollo y modernidad en el Pacífico Colombiano. In: RESTREPO, Eduardo e ROJAS, Axel (eds.). Conflicto e (in)visibilidad. Retos enlosestudios de la gente negra en Colombia. Popayán: Editorial Universidad del Cauca, 2004, pp. 53-72.

ESCOBAR, Arturo e PEDROSA, Alvaro. Introducción. Modernidad y desarrollo en el Pacífico Colombiano. In: ESCOBAR, Arturo e PEDROSA, Alvaro (eds.). Pacífico: ¿Desarrollo o diversidad? Estado, capital y movimientos sociales en el Pacífico colombiano. Santafé de Bogotá: CEREC, Ecofondo, 1996, pp. 13-26.

ESCUELA DE FORMACIÓN “Equidad de género en el desarrollo local y regional”. MÓDULO 9 Mujeres Afrocolombianas. Ministerio de Asuntos Exteriores y de Cooperación; Agencia Española de Cooperación Internacional al Desarrollo - AECID; Nariño Gobernación; Global Humanitaria, Noviembre de 2011.

ESPINOSA, Monica y FRIEDEMANN, Nina de. La Familia Minera. In: LEYVA, Pablo (ed.). Colombia Pacífico Tomo II. Santafé de Bogotá: Fondo FEN, 1993a, pp. 550-557.

Colombia: La mujer negra enlafamilia y ensuconceptualización. In: ULLOA, Astrid (ed.). Contribución Africana a la Cultura de las Américas: Memorias del Coloquio Contribución Africana a la Cultura de las Américas. Bogotá: Instituto Colombiano de Antropología. ProyectoBiopacífico. INDERENA-DNP, GEF, PNUD, 1993b. pp. 97-109.

FERNANDÉZ-RASINES, Paloma. Afrodescendencia en el Ecuador, raza y género desde los tiempos de la colonia. Quito: Abya Yala, 2001.

FRIEDEMANN, Nina S. de. La saga del negro: presencia africana en Colombia. Santa Fe de Bogotá: Instituto de Genética Humana. Pontificia Universidad Javeriana. Facultad de Medicina. 1993. Disponível em: http://www.banrepcultural.org/blaavirtual/antropologia/la-saga-del-negro/losafricanos-cifras-y-origen-diaspora, acessado em 11/05/2014.

FRIEDMANN, Nina de e WHITTEN, Norman Jr. La Cultura Negras del Litoral Ecuatoriano y Colombiano un Modelo de Adaptación Étnica. Revista Colombiana de Antropología, v. XVII, Santafé de Bogotá, 1974, pp.75-115. Disponível em: http://biblioteca.icanh.gov.co/DOCS/MARC/texto/REV0915V17a-4.PDF.

FRIEDEMANN, Nina de e AROCHA, Jaime. De sol a sol. Génesis, transformación y presencia de los negros en Colombia. Santafé de Bogotá: Planeta Colombiana Editorial, 1986.

FRIEDEMANN, Nina de e ESPINOSA, Mónica. Las mujeres negras en la historia de Colombia. In: Las Mujeres en la Historia de Colombia, Tomo II: Mujeres y Sociedad. Bogotá: Consejería Presidencial para la Política Social, Grupo Editorial Norma, 1995, pp. 32-71.

FRIEDEMANN, Nina S. e NIÑO, Hugo (eds.). Etnopoesía del Agua. Amazonía y Litoral Pacífico. Santafé de Bogotá: Instituto de Genética Humana. Facultad de Medicina. Pontificia Universidad Javeriana, 1997. 
FRIEDAN, Betty. Mística Feminina. Petrópolis: Editora Vozes, 1971 [1963].

FREITAS, Décio. Escravos e Senhores de Escravos. Porto Alegre: Mercado Aberto, 1983.

GONZÁLEZ, Nancy Motta. Enfoque de género en el litoral pacífico colombiano: nueva estrategia para el desarrolo. Santiado de Cali: Universidad del Valle, Editorial Facultad de Humanidades, 1995.

Por el Monte y los Esteros: Relaciones de género y familia en el territorio afropacífico.

Cali: Pontificia Universidad Javeriana, 2002.

GRUESO, Libia; ROSERO, Carlos e ESCOBAR, Arturo. El proceso de organización de comunidades negras en la región sureña de la costa pacífica de Colombia. In: ARTURO Escobar, ÁLVAREZ, Sonia e DAGNINO, Evelina (eds). Política cultural y cultura política: una nueva mirada sobre los movimientos sociales latinoamericanos. Bogotá: Taurus-ICANH, 1999, pp. 235-260.

GRUESO, Jesús Alberto e ESCOBAR, Arturo. Las Cooperativas Agrarias y la Modernización de los Agricultores. In: ESCOBAR, Arturo e PEDROSA, Alvaro. Pacífico: ¿Desarrollo o diversidad? Estado, capital y movimientos sociales en el Pacífico colombiano. Santafé de Bogotá: CEREC, Ecofondo, 1996, pp. 90-108.

GUIMARÃES, Antônio Sérgio Alfredo. Racismo e anti-racismo no Brasil. Novos Estudos CEBRAP, n. 43, São Paulo, novembro de 1995, pp. 26-44.

. Apresentação. In: GUIMARÃES, Antônio Sérgio Alfredo e HUNTLEY, Lynn. Tirando a máscara: Ensaios sobre o racismo no Brasil. São Paulo: Paz e Terra, 2000, pp.17-30.

Preconceito de cor e racismo no Brasil. Texto com base na aula preparada como requisito parcial para o concurso público de Professor Titular em Sociologia das Relações Raciais, no Departamento de Sociologia da USP, em 13 de maio de 2004.

HALL, Stuart. Da Diáspora: Identidades e Mediações Culturais. Organização de Liv Sovik. Belo Horizonte: Editora UFMG, 2003.

HARDING, Sandra. Whose Science/ Whose Knowledge?. Milton Keynes: Open University Press, 1991.

HARDING, Sandra. The Feminist Standpoint Theory Reader. Nova York e Londres: Routledge. 2004.

HERRERA, Gioconda (ed.). Antología Género. FLACSO: Sede Ecuador, 2001.

HERRERA, Gioconda e PRIETO, Mercedez. Género y nación en América Latina. Presentación. Iconos - Revista de Ciencias Sociales, n. 28, Quito, maio de 2007, pp. 31-34.

HOOKS, bell. Ain't a Woman: Black Women and Feminism. Boston, South End Press, 1981. . Feminism Theory: From Margin to Center. Boston, South End Press, 1984. . Talking Back: Thinking Feminist, Thinking Black. Boston: South End Press, 1989.

HULL, Gloria T, SCOTT, Patricia Bell e SMITH, Barbara. All the Women are White, All the Men are Black, But Some of Us Are Brave. Nova York: Feminist Press at CUNY, 1982. 
KOFES, Suely. Experiencias sociales, interpretaciones individuales: posibilidades y límites de las historias de vida en las ciencias sociales. In: LULLE, Thierry; VARGAS, Pillar e ZAMUDIO, Lucero (cords). Los Usos de la historia de vida en las Ciencias Sociales. Colombia: Anthropos, Série II, 1998, pp. 82-101.

LABRECQUE, Marie France. Metodología feminista e historias de vida: mujeres, investigación y Estado. In: LULLE, Thierry; VARGAS, Pillar e ZAMUDIO, Lucero (cords). Los Usos de la historia de vida en las Ciencias Sociales. Colombia: Anthropos, Série II, 1998, pp. 27-52.

LÁO-MONTES, Agustín. Cartografías del campo afrodescendiente en América Latina. In: MOSQUERA, Claudia Rosero-Labbé; LÁO-MONTES, Agustín e GARAVITO, César Rodríguez (eds). Debates sobre ciudadanía y políticas raciales en las Américas Negras. Bogotá: Universidad Nacional de Colombia, Facultad de Ciencias Humanas, Centro de Estudios Sociales, Universidad del Valle, 2010, pp. 281-328.

LEITE, Ilka Boaventura. O legado do Testamento: a Comunidade de Casca em perícia. Florianópolis: NUER/UFSC, 2002.

LEÓN, Claudia Leal. Usos del concepto "raza" en Colombia. In: MOSQUERA, Claudia RoseroLabbé; LÁO-MONTES, Agustín e GARAVITO, César Rodríguez (eds.). Debates sobre ciudadanía y políticas raciales en las Américas Negras. Bogotá: Universidad Nacional de Colombia, Facultad de Ciencias Humanas, Centro de Estudios Sociales, Universidad del Valle, 2010, pp. 389-438.

LOPEZ, Clara Ines Mazo. Mirando el Mundo con Ojos de Mujer. Revista Esteros, n. 9, Santafé de Bogotá, fevereiro de 1997, pp.54-63.

LOZANO LERMA, Betty Ruth. Mujer y Desarrollo. In: ESCOBAR, Arturo e PEDROSA, Alvaro. Pacífico: ¿Desarrollo o diversidad? Estado, capital y movimientos sociales en el Pacífico colombiano. Santafé de Bogotá: CEREC, Ecofondo, 1996, pp. 176-204.

La población negra de Colombia: grupos étnicos, sectores de continuidad cultural y sectores no étnicamente diferencias. In: GRUESO, DELFÍN e CASTELLANOS, Gabriela (eds.). Identidades colectivas y reconocimiento. Razas, etnias, géneros y sexualidades. Santiago de Cali: Programa Editorial, Universidad del Valle, 2010, pp. 145-167.

Negros, afros, afrocolombianos, afrodescendientes? Una discusión de nunca acabar. Intentando "casa adentro". Disponível em: http://www.pacificocolombia.org/novedades/negros-afros-afrocolombianos-o-afrodescendientes/889. Acessado em: 14 de agosto de 2013.

LOZANO LERMA, Betty Ruth e PEÑARANDA, Bibiana. Memoria y Reparación: ¿y de ser mujeres negras qué? In: MOSQUERA ROSERO-LABBÉ, Claudia e BARCELOS, Luís Claudio (eds.). Afroreparaciones: memorias de la esclavitud y justicia reparativa para negros, afrocolombianos y raizales. Bogotá: Universidad Nacional de Colombia, Observatorio del Caribe Colombiano, 2007, pp. 715-724. 
MACHADO, Lia Zanotta. Feminismo, Academia e Interdisciplinaridade. In: BRUSCHINI, Cristina e COSTA, Albertina (org.). Questão de Gênero. São Paulo: Ed. Rosa dos Tempos e Fundação Carlos Chagas, 1992, pp 24-38.

Matar e Morrer No Feminino e No Masculino. Série Antropologia, n. 239, v. 1, Brasília, 1998, pp. 1-19.

. Feminismo em Movimento. São Paulo: Editora Francis, 2010.

O medo urbano e a violência de gênero. In: MACHADO, Lia Zanotta; BORGES, Antonádia Monteiro e MOURA, Cristina Patriota de (orgs.). A cidade e o medo. Brasília: Verbena/Francis, 2014, pp. 103-125.

MACHADO, Lia Zanotta; BORGES, Antonádia Monteiro e MOURA, Cristina Patriota de (orgs.). A cidade e o medo. Brasília: Verbena/Francis, 2014.

MASSOLO, Alejandra. Testimonio autobiográfico femenino: un camino de conocimiento de las mujeres y los movimientos urbanos en México. In: LULLE, Thierry; VARGAS, Pillar e ZAMUDIO, Lucero (cords). Los Usos de la historia de vida en las Ciencias Sociales. Colombia: Anthropos, Serie II, 1998, pp. 9-26.

MALINOWSKI, Bronislaw. Os Argonautas do Pacifico Ocidental. São Paulo: Abril, 1984 [1913].

MEAD, Margaret. Sexo e temperamento em três sociedades primitivas. São Paulo: Perspectiva, 1979 [1935].

MEERTENS, Donny. Tierra, violencia y género: hombres y mujeres en la historia rural de Colombia 1930-1990. Nijmegen: Katholieke Universiteit, 1997.

MELO, Paula Balduino de. "Se a gente sentar pra contar dá um livro": história da Família dos Amaros de Paracatu/MG. Monografia (Bacharelado em Ciências Sociais/ Antropologia) - Departamento de Antropologia, Universidade de Brasília, Brasília, 2005.

MELO, Paula Balduino de; PARDO, Priscila; SANTOS DE PAULO, Carlos Alberto. Quilombos das Américas. Articulação de Comunidades Afrorrurais. Documento Síntese. Brasília: SEPPIR, IPEA, 2012.

MENA GARCÍA, Zulia. La mujer negra del Pacífico de reproductora de esclavos a... Matrona. In: ULLOA, Astrid (ed.). Contribución Africana a la Cultura de las Américas: Memorias del Coloquio Contribución Africana a la Cultura de las Américas. Bogotá: Instituto Colombiano de Antropología, Proyecto Biopacífico, INDERENA-DNP, GEF, PNUD, 1993, pp. 87-91.

MENA, Verónica. Género, manglar y subsistencia. Quito: Abya-Yala, 1999.

MENDOZA, Breny. La epistemología del sur, la colonialidad del género y el feminismo latinoamericano. In: MIÑOSO, Yuderkys Espinosa (coord). Aproximaciones críticas a las prácticas teórico-políticas del feminismo latinoamericano. Buenos Aires: En la Frontera, 2010, pp. 19-36. 
MIRANDA, Luis Gerardo Martínez. Desde adentro: una aproximación al tema de Verdad, Justicia y Reparación a partir de las víctimas afrocolombianas. In: MOSQUERA ROSERO-LABBÉ, Claudia. Afro-reparaciones: Memorias de la Esclavitud y Justicia Reparativa para negros, afrocolombianos y raizales. Bogotá: Colección Ces, Facultad de Ciencias Humanas departamento de Trabajo Social, Universidad Nacional de Colombia sede Bogotá; Facultad de Ciencias Humanas y Económicas, Universidad Nacional de Colombia sede Medellín; Instituto de Estudios Caribeños, Universidad Nacional de Colombia sede Caribe, 2007, pp. 425-441.

MOLANO, Alfredo. Mi historia de vida con las historias de vida. In: LULLE, Thierry; VARGAS, Pillar e ZAMUDIO, Lucero (cords). Los Usos de la historia de vida en las Ciencias Sociales. Colombia: Anthropos, Serie II, 1998, pp. 102-111.

MOLINA, Jennie Carrasco (org). Antología. Poesía de mujeres afroecuatorianas. Quito: Letras Memoria Patrimonio, Ministerio Coordinador de Patrimonio del Ecuador, novembro de 2012.

MONIZ, Edmundo. Canudos A Luta Pela Terra. [S.1.]: Gaia/Global, 2001.

MOORE, Henrietta L. Antropología y Feminismo. Madrid: Ediciones Cátedra, 1991.

. The Subject of Anthropology: Gender, Symbolism and Psychoanalysis. Cambridge: PolityPress, 2007.

MOSQUERA Rosero-Labbé, Claudia. Reparaciones para negros, afrocolombianos y raizales como rescatados de la Trata Negrera Trasatlántica y desterrados por la guerra en Colombia. In: MOSQUERA Rosero-Labbé, Claudia e BARCELOS, Luiz Claudio (eds.) Afro-reparaciones: memorias de la esclavitud y justicia reparativa para negros, afrocolombianos, raizales. Bogotá: Universidad Nacional de Colombia, 2007, pp. 213-278.

MOSQUERA Rosero-Labbé, Claudia e BARCELOS, Luiz Claudio (eds.) Afro-reparaciones: memorias de la esclavitud y justicia reparativa para negros, afrocolombianos, raizales. Bogotá: Universidad Nacional de Colombia, 2007.

MOSQUERA Rosero-Labbé, Claudia e LEÓN DÍAZ, Ruby. Acciones Afirmativas y ciudadanía diferenciada étnico-racial negra, afrocolombiana, palenquera y raizal: entre Bicentenarios de las Independencias y Constitución de 1991. Bogotá: Colección CES, Facultad de Ciencias Humanas Universidad Nacional de Colombia, 2009.

MOSQUERA, Claudia Rosero-Labbé; LÁO-MONTES, Agustín e GARAVITO, César Rodríguez (eds.). Debates sobre ciudadanía y políticas raciales en las Américas Negras. Bogotá: Universidad Nacional de Colombia. Facultad de Ciencias Humanas, Centro de Estudios Sociales, Universidad del Valle, 2010.

MOSQUERA Rosero-Labbé, Claudia; SERRANO, Adriana e ZÚÑIGA, Natalia. Las mujeres y la reparación colectiva en Colombia. Aprendizajes de las experiencias de la Comisión Nacional de 
Reparación y Reconciliación - CNRR. Bogotá: Comissão Nacional de Reparação e Reconciliação, Área de Gênero e Populações Específicas, 2012.

MOURA, Clóvis. Quilombos. Resistência ao escravismo. São Paulo: Editora Nova Ática, 1993 [1989]. NASCIMENTO, Abdias. O Quilombismo. 2.ed. Brasília: Fundação Palmares, 2002.

NOBOA, Fernando Jurado. Esclavitud en la Costa Pacífica: Iscuandé, Tumaco, Barbacos y Esmeraldas Siglos XVI a XIX. Quito: Ediciones Abya-Yala, Centro Afro-Ecuatoriano, Corporación Ecuatoriana de "Amigos de la Genealogía”, 1990. Esmeraldas en los siglos XVI, XVII y XVIII, sus tres afluentes negros colonialies. In: SAVOIA, Rafael (org.). El negro en la historia. Raíces Africanas en la Nacionalidad Ecuatoriana. 2.ed. Quito: Centro de Cultura Afroecuatoriana, 2002 [1992], pp. 31-40.

NOVOA, Rocío Rueda. De esclavizados a comuneros en la cuenca aurífera del río Santiaga-río Cayapas (Esmeraldas). Etnicidad negra en construcción en Ecuador Siglos XVIII-XIX. Tese (Docutorado em História) - Universidad Andina Simón Bolívar - Sede Ecuador, Quito; Universidad Pablo de Olavide, Sevilla, 2010.

ORTNER, Sherry B. Making Gender: The Politics and Erotics of Culture. BeaconPress: Boston, Massachusetts, 1996[1972].

OSLENDER, Ulrich. Espacio e identidad en el Pacífico colombiano. In: CAMACHO, Juana e RESTREPO, Eduardo (eds.). De montes, ríos y ciudades. Territorios e identidades de la gente negra en Colombia. Bogotá: Fundación Natura, Instituto Colombiano de Antropologia e Ecofondo, 1999, pp $25-48$.

OSLENDER, Ulrich. "La lógica del río": Estructuras espaciales del proceso organizativo de los movimientos sociales de comunidades negras en el Pacífico colombiano. In: PARDO, Mauricio (ed.). Acción Colectiva, Estado y Etnicidad en el Pacífico Colombiano. Bogotá: Colciencias e Instituto Colombiano de Antropología e Historia, 2001, pp 123-148.

- Geografías de terror y desplazamiento forzado en el Pacífico colombiano: conceptualizando el problema ybuscando respuestas. In: RESTREPO, Eduardo e ROJAS, Axel (eds). Conflicto e (in)visibilidad. Retos en los estudios de la gente negra en Colombia. Popayán: Editorial Universidad del Cauca, 2004, pp. 35-52.

PASCHEL, Tianna. The Right to Difference: Explaining Colombia's Shift from Color Blindness to the Law of Black Communities. The American Journal of Sociology, v. 116, n. 3, Chicago, novembro de 2010, pp. 729-769. Disponível em: http://www.jstor.org/stable/10.1086/655752, acesso em $18 / 05 / 2015$.

. "The Beautiful Faces of my Black People": race, ethnicity and the politics of Colombia's 2005 census. Ethnic and Racial Studies, 2013, pp. 1-20. Disponível em: http://dx.doi.org/10.1080/01419870.2013.791398, acesso em 18/05/2015. 
PAZMIÑO, Hernando Eugenio Bravo. Organizaciones étnico territoriales de los ríos Satinga y Sanquianga: los retos de su lucha por el reconocimiento de la identidad en el Litoral Pacífico de Nariño. Dissertação (Mestrado em Antropologia) - Universidad Nacional de Colombia, Bogotá, 2003. PETRUCCELLI, José Luis. A cor denominada. Estudos sobre a classificação étnico-racial. Coleção Políticas da Cor. Rio de Janeiro: DP\&A, 2007.

QUIJANO, Aníbal. Colonialidade do poder, eurocentrismo y América Latina. In: LANDER, Edgardo (comp.). A colonialidade do saber: eurocentrismo e ciências sociais. Perspectivas latino-americanas. Buenos Aires: Colección Sur Sur, CLACSO, Ciudad Autónoma de Buenos Aires, 2005 [2000], pp. 227-278.

¡Qué tal raza! In: MOSQUERA, Claudia Rosero-Labbé; LÁO-MONTES, Agustín e GARAVITO, César Rodríguez (eds.). Debates sobre ciudadanía y políticas raciales en las Américas Negras. Bogotá: Universidad Nacional de Colombia, Facultad de Ciencias Humanas, Centro de Estudios Sociales, Universidad del Valle, 2010, pp. 183-194.

RAHIER, Jean Muteba e DOUGÉ-PROSPER Mamyrah. Los afrodescendentes y el girro hacia el mculticulturalismoem las "nuevas" Constituciones y otras legislaciones especiales latino-americanas: particularidades de la región andina. Revista de Estudos e Pesquisas sobre as Américas, v. 8, n. 1, Dossiê Especial - Afrodescendentes na América Latina e Caribe: novos caminhos, novas perspectivas em um contexto global multicultural, Brasília, CEPPAC, 2014, pp. 220-235.

RATTS, Alex. Apresentação; "Quatro mulheres que eram mais”. In: ADÚN, Guellwarr; ADÚN, Mel e RATTS, Alex. Ogum's Toques Negros. Coletânea Poética. Salvador: Editora Ogum's Toques Negros, 2014.

RED DE MUJERES NEGRAS DEL PACÍFICO. Tejiendo Procesos Organizativos Autónomos. Revista Esteros, n. 9, Santafé de Bogotá, fevereiro de 1997, pp. 36-42.

REIS, João José e GOMES, Flávio dos Santos. Introdução - uma história da liberdade. In: REIS, João José e GOMES, Flávio dos Santos (orgs). Liberdade por um fio: História dos Quilombos no Brasil. São Paulo: Companhia das Letras, 2000 [1996].

RESTREPO, Eduardo. Hacia la periodización de la Historia de Tumaco. In: AGIER, Michel; ÁLVAREZ, Manuela; HOFFMANN, Odile; RESTREPO, Eduardo (eds.). Tumaco: haciendo ciudad. Historia, identidad y cultura. Bogotá: Instituto Colombiano de Antropologia e Universidad del Valle, 1999, pp. 55-81.

RESTREPO, Eduardo. Etnización de la negritud. La invención de las comunidades negras como grupo étnico en Colombia. Serie: Genealogías de la negridad. Popayán: Editorial Universidad del Cauca, 2013. 
REYES, Oscar Olarte. Pescadores negros de Tumaco, un puerto colombiano de la costa del Pacífico. Bogotá: Universidad Nacional de Colombia, Facultad de Ciencias Humanas, Departamento de Antropología, 1978.

RINCÓN, Lina María Cabezas. La organización de las mujeres en situación de desplazamiento como posibilidad de acción política: el caso de las mujeres de la Asociación Afrocolombiana de Desplazados - AFRODES. Bogotá: Universidad Nacional de Colombia, Facultad de Derecho, Ciencias Políticas y Sociales, Departamento de Ciencia Política, 2004.

RIVERA CUSICANQUI, Silvia. Ch'ixinakaxutxiwa: una reflexión sobre prácticas y discursos descolonizadores. Buenos Aires: Tinta Limón, 2010.

RIVAS, Nelly Yulissa. Ley 70, Medio Ambiente y Relaciones Intramunicipales: el Consejo Comunitario ACAPA, Pacífico Nariñense. Documento de Trabajo, n. 50, julho de 2000.

RODRIGUEZ, Betty. Vision y perspectiva político organizativa de la Red de Mujeres Negras. Revista Esteros, n. 9, Santafé de Bogotá, fevereiro de 1997, pp. 33-35.

ROJAS SILVA, Jeannette. Las Mujeres em Movimiento: crônica de otras miradas. In: ESCOBAR, Arturo e PEDROSA, Alvaro. Pacífico: ¿Desarrollo o diversidad? Estado, capital y movimientos sociales en el Pacífico colombiano. Santafé de Bogotá: CEREC, Ecofondo, 1996, pp. 205-219.

ROMERO, Mario Diego. Sociedades Negras: Esclavos y Libres en la Costa Pacífica Colombiana. América Negra, n. 2, Bogotá, Expedición Humana, Pontificia Universidad Javeriana, dezembro de 1991, pp. 137-151.

ROMERO, Mario Diego. Poblamiento y sociedad en el Pacífico colombiano siglos XVI al XVIII. Santiago de Cali: Editorial Facultad de Humanidades Historia y Sociedad. Universidad del Valle, 1995.

ROSALDO, Michelle Z. Mulher, cultura e sociedade: um panorama. In: ROSALDO, Michelle e LAMPHERE, Louise (orgs.). A mulher, a cultura e a sociedade. Rio de Janeiro: Paz e Terra, 1979 [1974].

ROSERO, Carlos. Los afrodescendientes y el conflicto armado en Colombia: la insistencia en lo propio como alternativa. In: MOSQUERA, Claudia; PARDO, Mauricio e HOFFMANN, Odile (eds.). Afrodescendientes en las Américas. Trayectorias sociales e identitarias (150 años de la abolición de la esclavitud en Colombia). Bogotá: Universidad Nacional de Colombia, ICANHIRD-ILAS, 2002, pp. 547-559.

RÚA, Carlos Angulo. Territorialidad ancestral y conflicto armado. In: MOSQUERA, Claudia; PARDO, Mauricio e HOFFMANN, Odile (eds.). Afrodescendientes en las Américas. Trayectorias sociales e identitarias (150 años de la abolición de la esclavitud en Colombia). Bogotá: Universidad Nacional de Colombia, ICANHIRD-ILAS, 2002, pp. 561-572. 
La situación territorial de los afrocolombianos: problemas y conflictos. In: ROJAS, Mauricio Pardo; MOSQUERA, Claudia; RAMÍREZ, María Clemencia (eds.). Panorámica afrocolombiana. Estudios sociales en el Pacífico. Bogotá: Instituto Colombiano de Antropología e Historia e Universidad Nacional de Colombia, 2004, pp. 343-368.

SAHLINS, Marshall. Ilhas de História. Rio de Janeiro: Zahar, 1990.

SANCHÉZ, Jhon H. Antón. Comunidades negras del Pacífico: Conflicto, Territorio y Región. Bogotá: Dissertação (Mestrado em Sociologia) - Departamento de Sociología, Facultad de Ciencias Humanas, Universidad Nacional de Colombia, 2005.

Territórios Ancestrais Afro-equatorianos: uma proposta para o exercício da autonomia territorial e dos direitos coletivos. Revista da Associação Brasileira de Pesquisadores Negros, v. 1, n. 3, novembro de 2010-fevereiro de 2011, pp. 15-52.

SANTOS, Julia Otero dos. Sobre Mulheres Brabas, Parentes Inconstantes e a Vida entre Outros. A Festa do Jacaré entre os Arara de Rondônia. Tese (Doutorado em Antropologia) - Programa de PósGraduação em Antropologia Social, Departamento de Antropologia, Instituto de Ciências Socias, Universidade de Brasília, Brasília, 2015.

SAVOIA, Rafael. Esmeraldas a mediados del siglo XVIII. In: SAVOIA, Rafael (org.). El negro en la historia. Raíces Africanas en la Nacionalidad Ecuatoriana. 2.ed. Quito: Centro de Cultura Afroecuatoriana, 2002 [1992], pp. 11-30.

El negro Alonso de Illescas y sus descendientes (entre 1553-1867). In: SAVOIA, Rafael (org.). El negro en la historia de Ecuador y del sur de Colombia. 2.ed. Quito: CCA, 2002 [1992], pp. 29-63.

SEGATO, Rita. Raça é Signo. Série Antropológica, n. 372, Brasília, Universidade de Brasília, 2005. La nación y sus otros. Raza, etnicidad y diversidad religiosa en tiempos de politicas de la identidad. Buenos Aires: Prometeo, 2007.

SILVA, Luiz Inácio Lula da. Prefácio. In: RIBEIRO, Matilde (org.). Políticas de igualdade racial: reflexões e perspectivas. São Paulo: Editora Fundação Perseu Abramo, 2012, pp. 7-9.

SOUZA, Bárbara Oliveira. Aquilombar-se: Um panorama histórico, identitário e político do Movimento Quilombola Brasileiro. Dissertação (Mestrado em Antropologia) - Departamento de Antropologia, Universidade de Brasília, Brasília, 2008.

STRATHERN, Marilyn. O Gênero da Dádiva: Problemas com as mulheres e problemas com a sociedade na Melanésia. Campinas: Editora da Unicamp, 2006 [1988].

TARDIEU, Jean-Pierre. El Negro en la Real Audiencia de Quito (Ecuador) SS. XVI-XVIII. Quito: Ediciones Abya-Yala, Instituto Francés de Estudios Andinos, Cooperazione Internazionales, 2006.

TENORIO, M. Cristina. Psicología Cultural en Bajo San Juan. Revista Universidad del Valle, n. 5 Santiago de Cali, agosto de 1993, pp. 61-73. 
TODOROV, Tzvetan. Em face do extremo. Campinas: Papirus Editora, 1995 [1994].

URREA-Giraldo, Fernando. La visibilidad estadística de la población afrodescendiente en Colombia (1993-2005). Entre lo étnico y lo racial. In: MOSQUERA, Claudia Rosero-Labbé; LÁO-MONTES, Agustín e GARAVITO, César Rodríguez (eds.). Debates sobre ciudadanía y políticas raciales en las Américas Negras. Bogotá: Universidad Nacional de Colombia, Facultad de Ciencias Humanas, Centro de Estudios Sociales, Universidad del Valle, 2010, pp. 757-806.

JABARDO, Mercedes (ed.). Feminismos negros. Una antología. Madrid: Traficantes de Sueños, 2012.

VIVEROS, Mara Vigoya. De diferencia y diferencias. Algunos debates desde las teorias feministas y de género. In: ARANGO, Luz Gabriele e PUYANA, Yolanda (orgs.). Género, Mujeres y Saberes en América Latina: entre el movimiento social, la academia y el Estado. Bogotá: Universidad Nacional de Colombia, 2007, pp. 175-190.

. Más que una cuestión de piel. Determinantes sociales y orientaciones subjetivas en los encuentros y desencuentros heterosexuales entre mujeres y hombres negros y no negros en Bogotá. In: VIVEROS, Mara Vigoya; WADE, Peter e URREA, Fernando (comp.). Raza, etnicidad y sexualidades. Ciudadanía y multiculturalismo en América Latina. Bogotá: Universidad Nacional de Colombia, Facultad de Ciencias Humanas, Centro de Estudios Sociales, Escuela de Estudios de Género, 2008, pp. 247-279.

Mestizaje, trietnicidad e identidad negra en la obra de Manuel Zapata Olivella. In: RESTREPO, Eduardo e ROJAS, Axel (eds.). Estudios afrocolombianos hoy: Aportes a un campo transdisciplinario. Popayán: Universidad del Cauca, 2013, pp. 87-103.

. Great Expectations: the ambiguity of social whitening in Colombia. No prelo. 2015.

VIVEROS, Mara Vigoya e ZAMBRANO, Marta."La diferencia: un concepto problemático para la antropologia y el feminismo. In: GAVIRIA, Luz Gabriela Arango e VIVEROS, Mara Vigoya (orgs.). El género: una categoria útil para las ciências sociales. Bogotá: Universidad Nacional de Colombia, Facultad de Ciencias Humans, Escuela de Estudios de Género, 2011, pp. 143-170.

WADE, Peter. Gente negra, nación mestiza, Dinámicas de las identidades raciales en Colombia. Bogotá: Siglo del Hombre Editores, 1997.

Liberalismo, raza y ciudadanía en Latinoamerica. In: MOSQUERA, Claudia RoseroLabbé; LÁO-MONTES, Agustín e GARAVITO, César Rodríguez (eds.). Debates sobre ciudadanía y políticas raciales en las Américas Negras. Bogotá: Universidad Nacional de Colombia, Facultad de Ciencias Humanas, Centro de Estudios Sociales, Universidad del Valle, 2010, pp. 467-486.

Afro-Colombian Social Movements .In: DIXON, Kwame e BURDICK, John (eds.). Comparative Perspectives on Afro-Latin America. Gainesville: University Press of Florida, 2012, pp. 135-155. 
WAGNER, Roy. Existem grupos sociais nas terras altas da Nova Guiné?. Cadernos de Campo, n. 19, São Paulo, 2010, pp. 237-257.

. A Invenção da Cultura. São Paulo: Cosac Naify, 2010 [1995].

WEISMANTEL, Mary. Alimentación, Género y pobreza en los Andes Ecuatorianos. Quito: AbyaYala, 1994.

WERNECK, Jurema. De Ialodês a feministas. Reflexões sobre a ação política das mulheres negras na América Latina e Caribe. Nouvelles Questions Féministes - Reveu Internationale Francophone, v. 24, n. 2, 2005 .

. Nossos passos vêm de longe! Movimentos de mulheres negras e estratégias políticas contra o sexismo e o racismo. Revista da Associação Brasileira de Pesquisadores Negros, v. 1, n. 1, marçojunho de 2010, pp. 8-17.

WEST, Robert. Las tierras bajas del Pacífico colombiano. Bogotá: Fundación para La Promoción de la Investigación y la Tecnología, 2000 [1957].

WHITTEN Jr., Norman E. Pioneros Negros: la Cultura Afro-latinoamericana del Ecuador y de Colombia. Quito: Centro Cultural Afro-Ecuatoriano, 1992 [1974].

Los Negros de San Lorenzo: Clase, Parentesco y Poder emum Pueblo Ecuatoriano. Quito: Centro Cultural Afroecuatoriano, Ediciones Afroamérica, 1997 [1965].

ZAPATA, Beatriz Elena Castaño. Papel económico de la mujer negra esclava durante el siglo XVIII en la Nueva Granada. Boletín de Historia, v. 4, n. 7-8, Bogotá, 1987, p. 28-30.

La esclavitud en la Nueva Granada y la situación de la mujer negra esclava durante el siglo XVIII. Bogotá: Pontificia Universidad Javeriana, Facultad de Ciencias Sociales, 1985.

A la búsqueda de las mujeres negras esclavas en la historia de Colombia. In: ULLOA, Astrid (ed.). Contribución africana a la cultura de las américas: memoria del Coloquio Contribución africana a la cultura de las américas. Bogotá: Instituto Colombiano de Antropología, Proyecto Biopacífico, INDERENA-DNP, GEF, PNUD, 1993, pp. 77-81.

ZULUZAGA RAMÍREZ, Francisco Uriel e ROMERO VERGARA, Mario Diego. Comunidades negras del Pacífico: territorialidad y economía. Revista Universidad del Valle, n. 5, Santiago de Cali, agosto de 1993, pp. 18-27.

ZULUZAGA RAMÍREZ, Francisco Uriel e ROMERO VERGARA, Mario Diego. (orgs.). Sociedad, cultura y resistencia negra en Colombia y Ecuador. Santiago de Cali: Universidad del Valle, 2007 [2011, reimp.]. 


\section{LEIS E DOCUMENTOS}

BRASIL, Constituição da República Federativa do $\quad$ Brasil, 1988. http://www.planalto.gov.br/ccivil 03/constituicao/constitui\%C3\%A7ao.htm\#adct.

CODAE. Boletim Informativo n. 2, ano 1, Quito, Sistema Nacional de Información Inter Étnica, setembro-outubro de 2010.

CECOMET. Las Parteras Afroecuatorianas del Norte de Esmeraldas toman la palabra: tradiciones, memoria, visiones y propuestas para un "buen nacer". Esmeraldas, Equador, 2011.

COLÔMBIA. Lei n. 2, de 1959, cria a Reserva da Costa Pacífica.

Constituição Política, 1991.

. Lei n. 121 de 1991, retifica o Convenio 169 da OIT.

. Lei n. 70, de 1993, Diario Oficial, n. 41.013, de 31 de agosto de 1993, desenvolve o artigo transitório n. 55, da Constituição Política.

. Lei n. 47, de 1993, cria os municípios étnicos de San Andrés, Providencia e Santa Catalina.

Decreto n. 1745, de 1995, regulamenta o Capítulo 3 da Lei n. 70, de 1993, e determina procedimentos para reconhecimento do direito à propriedade coletiva das "Terras de Comunidades Negras". Disponível em: http://www.alcaldiabogota.gov.co/sisjur/normas/Norma1.jsp?i=7389.

. Lei n. 975, de 2005, Lei de Justiça e Paz.

. Auto n. 92, de 2008. Corte Constitucional. Referencia: Protección de los derechos fundamentales de las mujeres víctimas del desplazamiento forzado por causa del conflicto armado. Magistrado Ponente: Dr. Manuel José Cepeda Espinosa. Bogotá, 2008.

Auto n. 5, de 2009. Corte Constitucional. Referencia: Protección de derechos fundamentales de la población afrodescendiente víctima del desplazamiento forzado. Magistrado Ponente: Dr. Manuel José Cepeda Espinosa. Bogotá, 2009.

Política Pública para Equidade de Gênero, para a Equidade das Mulheres Narinhenses desde sua diversidade étnica, social e cultural, em um território em construção de paz, Ordenanza $n$. 15 , de 29 de julho de 2009.

. Lei n.1454, de 2011, Lei Orgânica de Ordenamento Territorial (LOOT).

EQUADOR. Lei de Organização e Regime de Comunas, Decreto Supremo n. 142, de 30 de julho de 1937, revisado pela Lei de Reforma Agrária de 1973 e pela Constituição Política de 1998.

. Constituição Política, 2008.

. Decreto n. 60 de 2009, institui o Plano Plurinacional para Eliminação de todas as formas de Racismo e Discriminação Racial.

Anteprojeto de Lei Orgânica de Direitos Coletivos do Povo Afroequatoriano, proposta de Corporación de Desarrollo Afroecuatoriano (CODAE), 2011. 
Gente de esteros, ríos y mar. Zonificación para protección del Territorio Colectivo de ACAPA. Bogotá: Agencia Presidencial para la Acción Social y la Cooperación Internacional - Acción Social; Proyecto Protección de Tierras y Patrimonio de la Población Desplazada, junho de 2005. Disponível em: https://pt.scribd.com/doc/38045208/Gente-de-esteros-rios-y-mar\#scribd. . Evolución de las variables investigadas en los Censos de Población y Vivienda del Ecuador 1950, 1962, 1974, 1982, 1990, 2001 y 2010. Disponível em: http://www.ecuadorencifras.gob.ec/documentos/web-

inec/Publicaciones/Evolucion_variables_1950_2010_24_04_2014.pdf. Acessado em: 4 de outubro de 2014.

CONAMUNE. Haciendo Visible y Enfrentado la Violencia contra las Mujeres Afroecuatorianas. Quito: Fundación Azúcar e CONAMUNE, 2012.

\section{FONTES ELETRÔNICAS CONSULTADAS}

BLOGUEIRAS NEGRAS. Disponível em: http://blogueirasnegras.org/. Acessado em: 13 de agosto de 2014.

CÂMARA LEGISLATIVA. Disponível em: http://www2.camara.leg.br/. Acessado em: 01 de maio de 2015.

CAMPANHA "Morena não, eu sou negra". Disponível em: http://www.paraiba.com.br/2012/03/29/92361-organizacao-lanca-campanha-de-promocao-daidentidade-negra-na-paraiba-nesta-quinta-feira. Acessado em: 8 de setembro de 2014.

CARTILHA Descentralización y Entidades Territoriales, da Procuraduría Delegada para la Descentralización y las Entidades Territoriales, Disponível em: http://www.procuraduria.gov.co/portal/media/file/Cartilla\%20descentralizaci\%C3\%B3n.pdf. Acessado em: 2 de agosto de 2013.

COMERCIAL TELEVISIVO da Campanha "Las Caras Lindas de mi Gente Negra...". Disponível em: http://www.youtube.com/watch?v=RSq5FuhS1SE. Acessado em: 24 de junho de 2015.

CORREIO BRAZILIENSE: Disponível em: http://www.correiobraziliense.com.br/. Acessado em:

DANE. Boletim Censo General $2005 . \quad$ Disponível em: http://www.dane.gov.co/files/censo2005/PERFIL_PDF_CG2005/00000T7T000.PDF. Acessado em: 24 de junho de 2015.

DEMOGRAFIA DE SALAHONDA. Disponível em: http://www.venio.info/pregunta/cuantoshabitantes-tiene-francisco-pizarro-narino-16452.html. Acessado em 9 de outubro de 2014. 
DICIONÁRIO ELETRÔNICO WordReference. Disponível em: http://www.wordreference.com/. Acessado em: 4 de outubro de 2014.

EL ESPECTADOR. Disponível em: http://www.elespectador.com. Acessado em: 9 de setembro de 2013.

FUNDAÇÃO CULTURAL PALMARES. Disponível em: http://www.palmares.gov.br/. Acessado em: 15 de junho de 2015 .

GELEDÉS. Disponível em: http://www.geledes.org.br/. Acessado em: 6 de setembro de 2014.

INCRA. Disponível em: http://www.incra.gov.br/. Acessado em: 7 de setembro de 2012.

Instituto Nacional de Estatísticas e Censo do Equador. Disponível em: http://www.ecuadorencifras.gob.ec/. Acessado em: 4 de outubro de 2014.

NOSSO JORNAL, ano 4, n. 1, Brasília 2013. Disponível em: https://docs.google.com/file/d/0B3puEVu37tB9OVA0Mzd4MFU5NEU/edit. Acessado em: 25 de abril de 2015.

SEMANA. Disponível em: http://www.semana.com/. Acessado em: 1 de julho de 2013.

TELESUR. Disponível em: http://www.telesurtv.net/. Acessado em: 9 de setembro de 2013.

VANGUARDIA: Disponível em: http://www.vanguardia.com/. Acessado em: 9 de setembro de 2013.

WWF. Disponível em: http://www.wwf.org.co/. Acessado em: 3 de dezembro de 2014. 
Anexos 


\section{ANEXo I - ROTEIRo DE ENTREVISTA}

\section{Actuación política}

- ¿Usted siente que pertenece a un proceso colectivo? ¿Cuál?

- En el caso de respuesta positiva, ¿cuál es su rol en ese proceso?

- ¿Cuándo empezó usted a hacer parte de él?

- ¿Qué fue que la motivó a eso?

- ¿Qué es ser mujer afro en el movimiento político (en Recompas, en Cane/Momune, en la Asociación de Concheras de Palma Real/Fedarpom)?

- ¿Hay otras mujeres afro en el movimiento? ¿Cómo es la relación con las ellas?

- Mirando lo que aparezca en la respuesta anterior, ¿cuáles son los eslabones que conectan a usted con las otras mujeres del proceso colectivo?

- ¿Y hay mujeres blancas involucradas en el activismo? ¿Usted tiene relación con ellas? ¿Cómo es?

- ¿Qué piensan las mujeres de su comunidad sobre su actuación política?

- Y las mujeres de su familia ¿Qué piensan sobre su actuación política?

- ¿Cómo es la relación con los hombres en el proceso colectivo?

- ¿Hay diferencias en la manera como los hombres se relacionan entre ellos y con usted, dentro de la organización?

- Y fuera de ella, ¿Qué piensan los hombres de su comunidad sobre su actuación política?

- Y los hombres de su familia ¿Qué piensan sobre su actuación política?

- Hoy día ¿usted sigue motivada por las mismas razones que la hicieran empezar en el proceso colectivo?

- ¿Usted se considera una lideresa? ¿Por qué?

- ¿Usted cree que es importante para una mujer actuar políticamente? ¿Por qué?

\section{Territorialidad}

- ¿Usted siente que su vida cotidiana es influenciada por el espacio donde vive? ¿De qué formas?

- ¿Y usted siente que su trabajo o su actuación política influencian el espacio en que usted vive? ¿De qué formas?

- ¿Qué quiere decir para usted vivir sobre la costa Pacífica?

$-i Y$ en medio del agua? 
- ¿El proceso colectivo a lo cual usted pertenece tiene relación con un territorio o con una territorialidad (la forma de vivir el territorio)?

- ¿Cómo usted comprende este territorio o esta territorialidad?

- ¿Hay maneras diferentes de las mujeres y los hombres percibir el territorio? ¿Y de manejarlo?

- ¿Usted percibe la presencia del estado o del gobierno colombiano/ecuatoriano en este territorio? ¿Y cómo la ves?

- ¿El manglar tiene un lugar relevante en el territorio relacionado al proceso colectivo en el que usted actúa?

- ¿Qué piensa usted de las mujeres concheras?

\section{Conchería}

$-¿$ Usted es conchera?

- ¿Cuándo empezaste a conchar?

- ¿Cómo lo aprendiste?

- ¿Con quién usted concha?

- ¿Dónde ustedes conchan?

- ¿Ustedes salen a conchar embarcadas? ¿En qué tipo de embarcación? ¿A quién pertenece el barco? ¿Quién lo conduce?

- ¿Cuántas conchas usted recoge en una faena?

- ¿Dónde y a como la vende?

- ¿Y también se come la concha en la ingesta del hogar?

- ¿Siempre fue así?

- ¿Cuál es la ayuda financiera que la conchería trae a su hogar?

- ¿Hay otra actividades en el territorio que hacen difícil la conchería? ¿Por qué?

- ¿La conchería es una actividad de mujeres? ¿Por qué?

- Y los hombres, ¿pueden conchar?

- ¿Hay diferencias entre la manera en que conchan las mujeres y los hombres?

- ¿Qué quiere decir para usted el manglar (en cada momento/ciclo de vida)?

- ¿Usted hace parte de alguna organización de mujeres concheras? ¿Y de otro tipo de proceso colectivo?

- ¿Hay cambios en la actividad de la conchería cuando una está involucrada en una organización de mujeres concheras? (ejemplo: se gane más, se hace menos esfuerzo...) 
- ¿Hay cambios en la vida de una cuando se hace parte de esto tipo de proceso colectivo?

- ¿Usted cree que es importante para una mujer participar en procesos colectivos? ¿Por qué?

- ¿Qué es ser mujer conchera?

- ¿Cómo usted cree que la comunidad ve las mujeres concheras?

\section{Violencia}

- ¿En qué piensa usted cuando escucha la palabra violencia?

- ¿Y cuándo escucha la palabra guerra?

- ¿Usted siente algún efecto del conflicto político armado sobre el proceso colectivo al cual pertenece?

- ¿Y sobre el territorio donde vives y/o actúa políticamente?

$-¿$ Y sobre su propia vida?

- ¿Antes de los paras, del ejército y das las guerrillas había violencia/guerra/maltratos? ¿Cómo eran?

\section{Maternidad}

- ¿Usted es madre? ¿Cuántos hijos tiene? ¿Con que edad los tuviste?

- ¿Algo cambió en su vida después de los hijos? En el caso de una respuesta positiva, ¿Qué cambió?

- ¿Cómo se desarrolló su actuación política antes y después de los hijos?

$-i Y$ su actividad laboral?

- ¿Usted vive o vivió con los padres de los hijos?

- ¿Cómo se desarrolló la relación entre ustedes antes y después de los hijos?

- ¿Cómo se desarrolló la relación suya con su comunidad antes y después de los hijos?

- ¿Usted cree que es importante para una mujer ser madre? ¿Por qué?

- Y una mujer que nunca sea madre, ¿conoce a alguien en esa situación? ¿Qué le parece?

\section{Conyugalidad}

- ¿Usted tiene pareja?

- ¿Hace cuanto tiempo vive con él (o con ella)?

- ¿Tiene hijos con esta pareja? ¿Cuántos?

- ¿Cómo es la vida con él?

- Y la vida de soltera, ¿Cómo es? 
- ¿Usted y una pareja suya ya se han dejado? ¿Cómo fue?

- ¿A usted ya le han pegado? ¿Un hombre? ¿Era su pareja?

- ¿Usted ha tenido más de un hombre a la vez?

- ¿Y alguna pareja suya, ya ha tenido más otras mujeres mientras estaba con usted?

¿Cómo usted comprende familia?

¿Quién es su familia?

\section{Etnia y género}

- ¿Qué es ser mujer negra? ¿Es lo mismo que ser mujer afro?

- ¿Usted ya se sintió discriminada?

- ¿Ya dejó de lograr algo por ser mujer?

$-i Y$ por ser negra?

- ¿Usted conoce la idea de género? ¿Trabaja con ella? ¿Cómo usted comprende género?

- ¿Usted conoce la idea de patriarcado? ¿Trabaja con ella? ¿Cómo usted comprende patriarcado?

- ¿Usted conoce la idea de feminismo? ¿Trabaja con ella? ¿Cómo usted comprende feminismo? 


\section{ANEXo II - Histórias DE VIDA}

Quatro mulheres que eram mais

De terra

De mar

De rio

De vento

E mais

Quatro mulheres que eram

De lama

De mangue

De algas

De fogo

E mais

(Alex Ratts)

Do árduo exercício de sintetizar narrativas das matronas Afropacíficas, mulheres com quem dialoguei ao longo da etnografia, resultou uma breve história de vida de cada uma delas, as quais ajudam a contextualizar seus relatos trazidos ao longo da tese. Trouxe eventos por elas destacados como relevantes, tais quais a maternidade, o engajamento comunitário e político, uniões conjugais, dentre outros. Narrei ainda como foi meu encontro com cada uma.

\section{MULHERES DO Rio MiRA}

\section{Mailen Aurora Quiñones Mosquera}

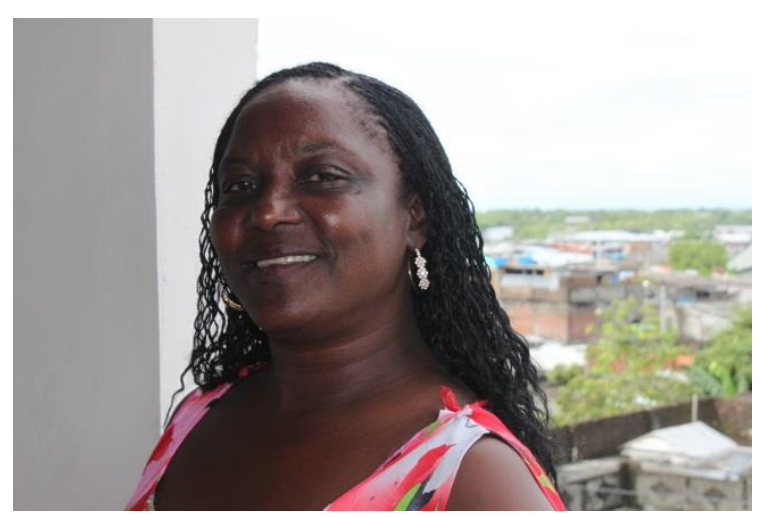

Nasceu em 1963, no centro de Tumaco. Com três anos, mudou-se para a vereda de sua mãe, quilômetro 28, localizada na estrada que liga Tumaco a Pasto. Mailen sofreu maus tratos quando criança, junto à família biológica. Foi dada pela mãe a umas monjas, ainda pequena. Foi quando seguiu para Ipiales, fronteira terrestre da Colômbia com o Equador. Depois de viver um período em Ipiales, migrou para Tulcán, Equador. Regressou à Colômbia, já com dezessete anos. 
Ao retornar, primeiro Mailen viveu na sede do município de Tumaco. Em seguida, conheceu o atual esposo, Tomás Mideros, com quem teve seis filhos: Jerson Tomáz, Diego Antonio, Deiton Esneider, Saidy Yanira, Cristian Yunior e Kevin Yoan. O primeiro nasceu em 1983 e o último em 1996. Passou então a viver na vereda do marido, Bocas de Guabal, no Baixo Rio Mira.

Desde pequena Mailen acompanhava a mãe parteando. E assim foi aprendendo os saberes do bem-nascer: a higiene, os usos de cada planta, as maneiras de cozinhás-la, a preparação das tomas e botellas curadas. Quando sua mãe estava à beira da morte, em 1995, Mailen realizou seu primeiro parto, embebida da confiança que nela depositava a irmã, ajudando a trazer ao mundo uma sobrinha. Em seguida, Mailen atendeu partos de outras parentes, comadres, vizinhas. Já trouxe ao mundo mais de trinta crianças em Bocas de Guabal. Constituiu-se uma das comadronas do povoado, seguindo o fio genealógico da tradição que começa em sua bisavó, passando por Estatilia Mosquera, sua avó, sua mãe, chegando nela e em seu irmão caçula, Juan Hernando, parteiro que vive na Suécia.

O engajamento de Mailen na docência partiu de sua angústia ao ver as crianças de Bocas de Guabal sem professores/as. Ela explica que os docentes iam duas vezes ao ano em sua vereda e davam duas ou três aulas ao mês. De forma voluntária, começou então a lecionar para as cerca de quarenta crianças do povoado. Certo dia, foi surpreendida pela equipe de uma fundação que atua em Tumaco, Fundación Plan, de Padrinos, cuja lancha aportou em Bocas de Guabal. Ao saber da situação, estimularam Mailen a formalizar sua atuação como docente. Da mesma forma, pais e mães das crianças sensibilizaram-se por sua dedicação e passaram a pagá-la uma pequena quantia, trinta mil pesos por mês. Assim foram os três primeiros anos de docência, até que ela conseguiu um contrato com o município, trabalhando institucionalmente por oito anos consecutivos na docência comunitária. Deixou o ofício em 1999, cansada das difíceis condições de trabalho e da baixa remuneração.

A parturia e a docência foram caminhos que levaram Mailen a uma atuação mais ampla junto à coletividade de Bocas de Guabal. Desde 1995, ela formula e propõe vários projetos a fundações públicas e privadas, bem como organizações não governamentais, na área de melhoramento de moradias, saneamento básico e aquisição de equipamentos comunitários de lazer infantil.

Esse mesmo caminho desembocou no engajamento de Mailen junto ao Processo de Comunidades Negras - PCN. Ela conta que, desde 1993, começou a participar de reuniões, conferências, encontros e outras agendas do movimento social afro-colombiano. Em seguida, 
foi eleita por sua "comunidade" para um comitê do "processo". Intensificou seu engajamento atuando como dinamizadora em projetos e atividades do "processo", momento que atualmente vivencia. Hoje em dia, ademais, Mailen está envolvida em uma mobilização de mulheres do Conselho Comunitário Baixo Mira e Fronteira e também desempenha a função de secretária na Junta Diretiva do Conselho Comunitário Baixo Rio Mira e Fronteira.

Não sei quando nos conhecemos precisamente. Ao longo do ano de 2013 muitas vezes encontrei Mailen em eventos de comunidades negras e eventos culturais na cidade de Tumaco. Nossa primeira conversa contou com a presença de María Cecilia, que também integra o grupo de mulheres do Conselho Comunitário Baixo Mira e Fronteira. Ocorreu no hotel em que estava hospedada quando aconteceu meu segundo incidente de saúde, que me impedia de caminhar. No dia seguinte, Mailen novamente me visitou no hotel, almoçamos juntas e ela começou a contar sua história de vida. Desse primeiro encontro, a narrativa de Mailen foi reconstruída logo após a conversa. Como o relato foi um movimento que partiu dela e chegou carregado de emoção, não houve espaço para usar gravador ou caderno de campo. Em seguida tivemos mais três encontros, que foram gravados e registrados no caderno de campo. Sempre aconteceram quando, por razão de algum trâmite ou evento, Mailen viajava de sua vereda ao centro de Tumaco. Os primeiros encontros foram no hotel e o último no apartamento onde passei a residir nos últimos dias da pesquisa de campo em Tumaco. Esta ocasião foi interessante, pois se encontraram no apartamento várias de minhas interlocutoras, algumas das quais já se conheciam anteriormente.

\section{Eva Lucia Grueso}

Eva Lucia Grueso nasceu em 1974, na vereda Bajo Jagua, no baixo Rio Mira, Tumaco, onde viveu até os oito anos de idade. Ela conta que viveu sua infância no rio. Mesmo depois de trasladar a Tumaco, motivada pela proximidade da escola, sempre estava na vereda Bajo Jagua. Filha de uma família que luta pelo território desde a década de 60, Eva Lucia se formou desde pequena na política. Na década de 90, foi uma das fundadoras do Proceso de Comunidades Negras - PCN, no qual segue atuando ainda hoje, precisamente no escritório da capital Bogotá, como parte da equipe de Coordenação Nacional do PCN, após viver dez anos em Toronto, Canadá.

Filha de Abel Grueso e Domingas Villareal, Eva Lucia reconhece sua ancestralidade na família paterna, cujas raízes estão profundamente fincadas nas ribeiras do Baixo Rio Mira. A tônica da criação impressa pelo pai formou Eva e Nela, sua irmã seis anos mais velha, 
mulheres diferentes do modelo tradicional Afropacífico. Eva Lucia conta que seu pai nunca permitiu que as filhas fossem ensinadas apenas a lavar, cozinhar, passar e cuidar da casa, expectativa social que sua mãe, Domingas, cria dever ser atendida. Ao contrário, estimulou-as a conviver com irmãos e primos homens e a enfrenta-los fisicamente. Estimulou-as também ao exercício crítico e engajamento político. Domingas e Abel amavam-se intensamente, os desacordos provinham das diferentes condutas na criação das meninas Eva e Nela. Eva Lucia caracteriza seu pai como um "homem a frente de seu tempo" e manifesta gratidão por sua insistência em educa-las para a vida, para o enfrentamento ao racismo, ao sexismo e para a luta étnico-territorial.

Eva Lucia teve a primeira filha, Kissy Liliana, aos dezoito anos, em 1992, um ano depois de que Nela havia parido sua primogênita. Ambas as descedentes chamam-se Kissy, em homenagem à personagem do seriado norte-americano Raíces, que representou para as irmãs o despertar para a negritude. No caso do segundo filho, Deivy, nascido sete anos depois, Eva Lucia também seguiu a irmã, obedecendo a mesma distância de um ano do nascimento da sobrinha. As irmãs acompanharam-se ao longo da vida, na conscientização sobre a negritude, na maternidade, no ativismo, na luta pelo território. Desde 2004, Eva Lucia vive uma relação inter-racial com Ruben Dario, a quem descreve como um homem perfeito para ela, dado seu apoio incondicional à luta negra.

Sabendo da centralidade do Proceso de Comunidades Negras - PCN na luta negra na Colômbia, queria conversar com as mulheres do Processo. O primeiro contato com a organização, intermediado por Inés Morales, foi feito com Carlos Rosero, cofundador e atual membro da equipe de Coordenação Nacional do PCN. Escrevi a Carlos Rosero, apresentandome e pedindo um encontro com representações femininas do Processo. Assim, conheci Eva Lucia Grueso, no escritório de PCN, dia 26 de junho de 2012. Tivemos duas longas conversas, com grande densidade narrativa. A primeira delas nessa data, cujos temas giraram em torno do engajamento político-institucional. A segunda, centrada na história familiar e afetiva de Eva Lucia, ocorreu um ano depois, dia 07 de fevereiro de 2014, data bem próxima ao meu regresso ao Brasil. 


\section{Martha García}

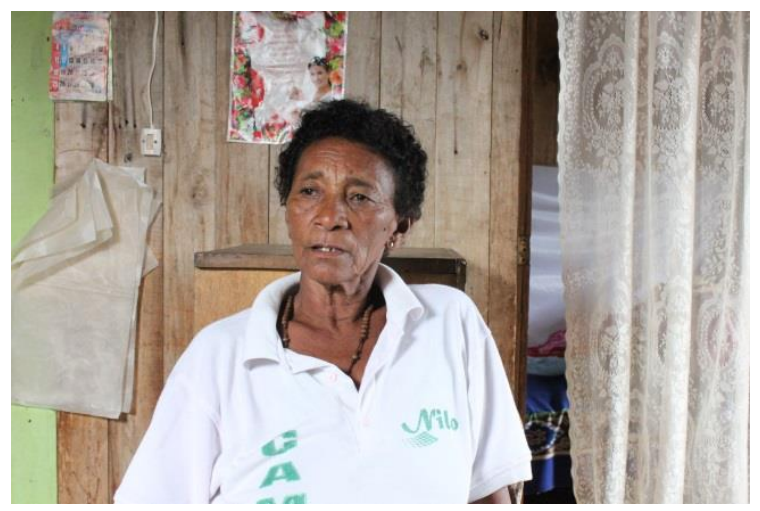

Martha García é liderança da vereda Bajito Vaquería, localizada na entrada/saída do Conselho Comunitário Bajo Mira y Frontera, quando as águas do Mira entregam-se ao mar. Ela preside duas organizações locais: El Raizal, que reúne 24 mulheres concheras, além de seus filhos e maridos; e La Corvina, associação de pescadores da referida vereda. Martha é também presidente da Junta da Ação Comunal em Bajito/Vaquería desde a década de 90. Como líder de seu povo, conta que viajou a Melgar - Tolima, próximo a Bogotá, a Buenaventura, a Pasto. Participou de conversatórios, reuniões, dentre outras atividades.

Ao longo da vida, a principal atividade desenvolvida por Martha foi o concheo ou coleta do marisco piangua. Por estar à frente das associações, atualmente pouco tem mariscado. Porém foi essa atividade que subsidiou o sustento dela e de seus sete filhos: Ana Cecilia, Milton Clelio, Jimy, Efrén, Maritza, Alexis, Jorge. Teve a primeira filha aos vinte e dois anos de idade. Martha teve duas famílias, como ela diz, Sevillano e Águila. Da primeira união, ficou viúva. Após a segunda, teve mais uma união conjugal, da qual resultou o caçula Jorge.

Conheci Martha em uma das primeiras viagens a Tumaco, no Restaurante Sabores del Manglar, por intermédio de Carmen Julia Palacios, que coordena uma associação de concheiras e concheiros em Tumaco. Em seguida nos reencontramos algumas vezes, em uma delas fui com o amigo Carlos Rua almoçar em sua casa, no Bajito/Vaquería. Quando estava vivendo e trabalhando em um apartamento em Tumaco, recebi uma visita de Martha. Apesar de termos tido vários encontros, o diálogo com Martha não se aprofundou muito. 


\section{Maria Barbarita Lara Calderón}

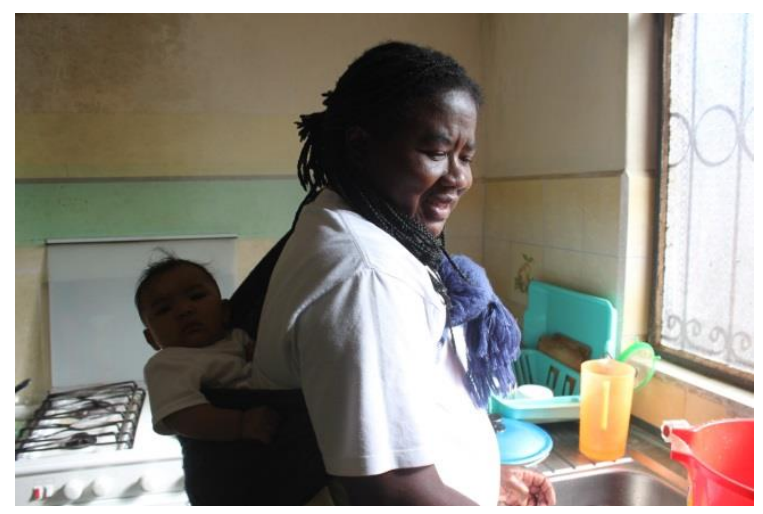

Nasceu em Mascarillas, recinto pertencente à Paróquia Mira, cantão homônimo, no dia 06 de fevereiro de 1956. É uma das cinco filhas de Luzmila Calderón e Vitoriano Lara: Heremita, Anita, Barbarita, Ofelita e Toíta. Sua mãe viveu de 1922 a 2002. Seu pai, de 1916 a 1992. Ele trabalhava dia e noite no trapiche de uma fazenda Jesuíta, produzindo rapadura. Não são bonitas as recordações de Barbarita sobre o ambiente de trabalho do pai. Ela caracteriza tais relações laborais como trabalho escravo, mesmo sendo no início dos anos sessenta. A "liberação" de seu pai, como conta, deu-se com a reforma agrária dessa década, que teve um impacto efetivo na redistribuição de terras nessa região do Equador.

Barbarita tem uma memória viva de seus antepassados, que remete ao período colonial e revela dados importantes sobre o sistema escravagista na serra equatoriana. Sua bisavó paterna, Dominga Arce, vivia no tempo da escravidão. Ela foi dada em troca de uma dívida que tinha o dono da fazenda Santa Anna com o dono da fazenda San Vicente. Nesse momento, era viúva de Pablo Lara. Ou seja, havia casamentos religiosos, porém as famílias eram parte das fazendas. Vale lembrar que os donos das fazendas, nessa época, eram jesuítas.

A ancestralidade materna remete a relações inter-raciais. Seu tataravô, Nicanor Viveros, "un hombre bien guapo, muy negro con ojos verdes y labios rojos", era casado com Joaquina Burbano, que era "branca-mestiça", de San Gabriel, hoje província de Carchi. Nicanor era colombiano; em meados de 1800, veio de Tumaco a San Lorenzo, para trabalhar nas minas. Em seguida foi trabalhar em uma fazenda agrícola chamada Parambas, que ficava próxima a La Concepción, onde atualmente Barbarita vive. Amalia Arellano, filha do casal, foi sua bisavó, e Ernestina Plaza Arellano, sua avó.

Passaram-se anos, porém, ainda na geração de Barbarita, a vida para a família Lara Calderón foi uma vida dura. Barbarita conta que não teve oportunidade de terminar a escola na época regular. Um dos motivos era a falta de recursos da família, que vivia na zona rural, em Mascarillas. As escolas rurais tinham apenas até o quarto grau primário. Foi na década de 
70 que o sistema educacional ruralizou-se, chegando ao campo a educação secundária, quando muita gente de idade madura retomou os estudos. Barbarita cursou o oitavo grau da educação básica com vinte e um anos. O bacharelado foi em ciências sociais. No Equador, o ensino médio é profissionalizante, oferecendo as seguintes opções: contabilidade, secretariado, física/biologia, química/matemática e sociais. Após o bacharelado, Barbarita cursou pedagogia e seguiu a carreira acadêmica. É diplomada em estudos culturais na linha de pesquisa sobre Diáspora Afro Andina, pela Universidad Andina Simón Bolívar e desenvolve atualmente um curso de mestrado à distância na Universidad Internacional del Atlantico, realizando pesquisa sobre experiências afroequatorianas de etnoeducação. Casou-se com Wilow Mendez em madura idade e foi viver na Paróquia La Concepción, situada no cantão Mira, dentro do território Chota, La Concepción, Salinas y Guallupe, cujo nome ancestral é Valle del Coangue.

Barbarita é professora há vinte e um anos. Entre 1999 e 2007, foi diretora da Escuela 29 de Noviembre da Paróquia onde vive. Barbarita está à frente da Coordinadora Nacional de Mujeres Negras - CONAMUNE na província de Carchi. Tem um percurso bonito no ativismo de mulheres negras/afroequatorianas, iniciado na década de 90. Barbarita participou de agendas nos EUA, África do Sul, Colômbia, Bolívia, Brasil, Honduras, Peru. Em 2014, elegeu-se pela primeira vez vereadora pela zona rural no cantão Mira, pelo partido político do presidente Rafael Correa, la Revolución Ciudadana.

Conheci Barbarita em Brasília, por ocasião da I Oficina para Intercâmbio de Experiências e Pacto de Ações, realizada no âmbito do Projeto "Quilombos das Américas: articulação de comunidades afrorrurais", no qual eu trabalhava. No início de 2014, estive em sua casa em La Concepción por cerca de dez dias, acompanhando a campanha para vereadora. Foi quando conversamos com mais profundidade.

\section{Elisa Isabela Folleco Lara}

Nascida em 1975, em Mascarillas, é uma das oito descendentes de Ana María Lara Calderón, conhecida como Toíta, e Raul Hernán Folleco Amangono. Isabelita é, portanto, sobrinha de Barbarita, mais uma na família de grande mulheres carinhosamente chamadas no diminutivo. Viveu a infância e adolescência em Mascarillas, trabalhando com a mãe na venda de produtos agrícolas produzidos, ou comprados e revendidos, em mercados situados em Mira, Loma e outras localidades. Ela conta que sua avó criava cabra, coelho e pato. Sua mãe, 
por sua vez, criava galinhas. O pai criava vacas e cultivava bastante tomate. Agora se dedica ao cultivo de cana-de-açúcar e abacate.

Ao terminar o sexto grau, em 1985, ela foi estudar em Ibarra, onde vivia uma irmã mais velha, na casa de uma tia. Estudava Secretariado e trabalhava no armazém de colombianos em Ibarra. Terminado o ensino médio em 1993, foi à universidade estudar Educação Física, entre 1997 e 2003. Empregou-se como professora de jardim de infância, em Ibarra. Em 2007, mudou-se para La Concepción, onde vive na casa de sua tia Barbarita, atuando como funcionária pública da prefeitura local.

Com 38 anos, Isabelita teve um filho, Aron Isaias, "mi compañerito", como ela diz. Aron é filho de um policial proveniente da Província de Bolívar, Guarando, que trabalha e vive em Mascarillas.

Conversei ainda com Manoela Salazar e María Cecilia, mulheres do Baixo Rio Mira; a primeira da vereda Puerto Palma e a segunda de Sagunbita, ambas pertencentes ao tumaquenho Conselho Comunitário Baixo Rio Mira e Fronteira. Manoela é uma das precursoras do processo organizativo na região. Mulher de fibra, primeira presidente do Conselho Comunitário e protagonista na criação da Comissão de Mulheres do Baixo Rio Mira. Com Manoela, conhecemo-nos por intermédio do amigo em comum, Carlos Rua, na minha primeira incursão a campo, em junho de 2012. Tivemos uma conversação rápida, que não pode se aprofundar nas demais viagens etnográficas. De todo modo, as referências a Manoela estão presentes em depoimentos de outras mulheres do Baixo Rio Mira. Uma delas é María Cecilia, que atualmente ocupa um cargo na equipe de gestão do Conselho Comunitário Baixo Mira e Fronteira e, junto com Mailen Quiñones e outras mulheres, está a frente da Comissão de Mulheres do Baixo Rio Mira. María Cecilia e eu tivemos um par de conversas, que também contaram com a presença de Mailen, entre agosto e setembro de 2013. 


\section{MULHERES do Rio RosÁRIO}

\section{Rosalba Quiñones}

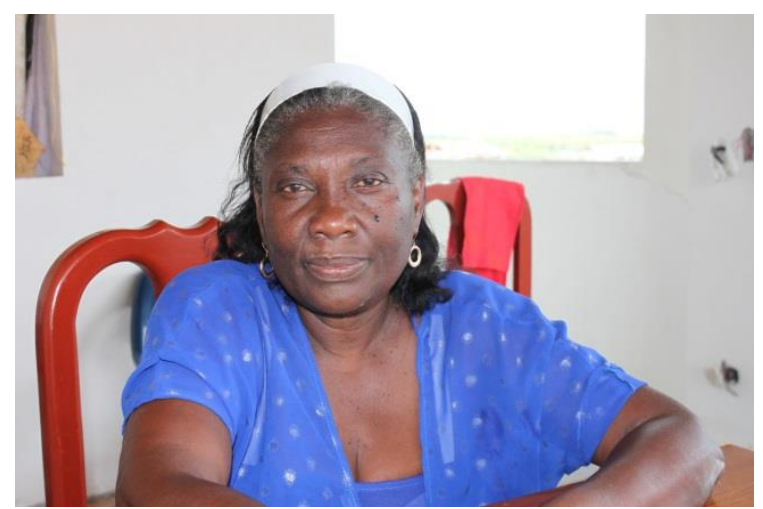

Nasceu em 1952 na Vereda San Luis Robles que hoje pertence ao Conselho Comunitário Rescate Las Varas. É filha de Maria Elina Marquinez, também nascida em Robles, e de Francisco Quiñones, que vive no Equador, a quem Rosalba desconhece. O pai de Rosalba deu banda-voa, ou passou voando, nas palavras de Vilma Estácio de Sá. Não a registrou. Ela chamava-se Rosalba Marquinez; seus primeiros filhos herdaram da avó materna o sobrenome. Aproximadamente no ano de 1980, Rosalba teve que trocar de nome. O órgão responsável pelo registro civil exigiu o sobrenome do pai. "El registrador me dijo que persona sin papá no había y que cuál era mi apellido del papá". Nesse momento, alguns tios a informaram que ela era filha de Francisco Quiñones.

É a primogênita de Maria Elina, que em seguida casou-se com Marcelino Castillo. Juntos, Maria Elina e Marcelino tiveram cinco filhos, dos quais três estão vivos, dois morando em Robles e a caçula em Bogotá. Rosalba foi criada pela avó materna, Juana Marquinez, boa parte do tempo na cidade de Tumaco, onde estudou.

Casou-se com Luis Antonio em 22 de janeiro de 1970, aos dezoito anos. Passou então viver com ele na vereda Isla Grande, no Rio Rosário. Rosalba conta que cursava o primeiro ano do bacharelado essa época, do qual abdicou para dedicar-se ao marido e aos filhos que começaram a chegar logo após o casório. A primogênita Cira Colorado Martinez nasceu em Robles, em 1971. Ao longo das décadas de 70 e 80, vieram mais sete filhos: Yaneth, Wilson Arnold, Rubi, Nilsa Marina, Dania Lorena, Luis Eber e Frank Arturo. Os primeiros também nasceram em Robles, perto da avó materna. Em seguida, com Rosalba seguiam para viver em Isla Grande. Os demais nasceram já em Isla Grande e uma delas em Tumaco. 
Na vereda em que viviam não havia opção de estudo, o que levou o casal a trasladar os filhos para Robles, Tumaco ou Pasto, de modo que dessem consecução à trajetória estudantil. Valiam-se do apoio de parentes e amigos próximos que eram anfitriões das crianças. Até que, em 1987, o casal logrou comprar uma casa no Bajito, bairro praieiro tumaquenho, onde passaram a viver os filhos do casal, cuidados por Cira.

No final da década de 80, Rosalba começou a engajar-se em atividades políticas em Isla Grande. Ela ressalta marcos importantes nesse processo, quais sejam, o trabalho nos rios da enseada de Tumaco com CVC-Holanda e a chegada de Jairo Rúben Quiñones com vistas a organizar o Conselho Comunitário União Rio Rosário, consolidado em 1998. Ela foi representante legal do Conselho ao longo de dez anos, desde sua fundação até 2008. Em 2012, passou a compor a junta diretiva da Rede de Conselhos Comunitários do Pacífico Sul Recompas.

Com Rosalba tive diversos encontros. Na Mesa de Gênero do Pre-Congresso Nacional de Nacional de Conselhos Comunitários e Organizações Étnica Afrocolombianas, Palenqueiras e Raizais, em agosto de 2013, aproximamo-nos. Em seguida, tivemos algumas conversas na casa de Cira, a filha mais velha de Rosalba, o que foi interessante pois tive a oportunidade de conhecer boa parte da família de Rosalba e com eles compartilhar momentos de descontração. Nosso último encontro foi no apartamento que vivi, em Tumaco.

\section{Maria Olinda Orobio}

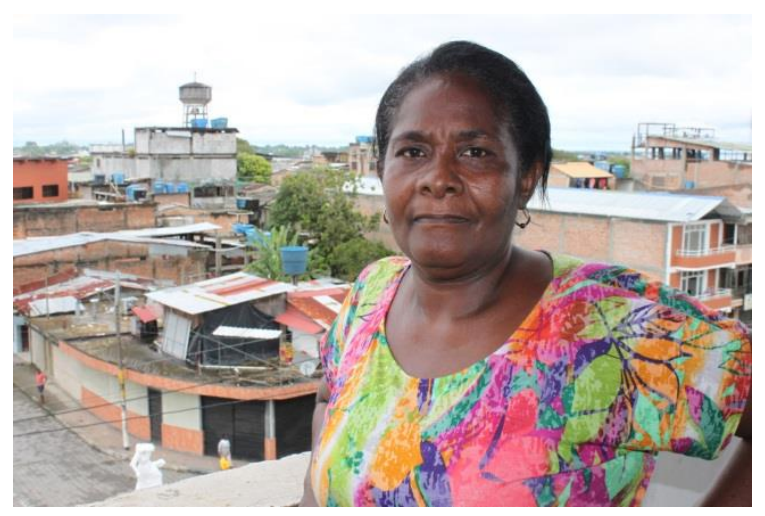

Nascida em 1957, na vereda Tambillo, que também pertence ao Conselho Comunitário Rescate las Varas, uma localidade entre mar e rio. É o Rio Rosario que desemboca em Tambillo. Uma "comunidade de mangue” ou "comunidade de mar", no dizer Afropacífico.

A mãe de Maria era costureira, seu pai, agricultor. Juntos, tiveram dezesseis filhos, dos quais sete não sobreviveram. Quando se casaram, a mãe de Maria era muito jovem. Teve vários filhos/as prematuros, que acabaram morrendo. Eles se separaram quando Maria era 
muchachita; tinha por aí nove anos. Uma parte dos filhos ficou com o pai, outra parte com a mãe. Ela conta que, mesmo querendo muito bem a sua mãe, resolveu viver com o pai. Sentia que ele necessitava ajuda: “lo sentía como más débil por ser hombre ¿verdad?”. Cresceu cuidando da casa e dos irmãos, ainda que fosse a mais nova entre eles. Vivia entre Tambillo, com o pai, e a vereda San Juan de la Costa, onde morava a mãe, que fica pouco acima de Salahonda, quando o ponto de referência é Tumaco. Viveu também certo período em Cali, com uma tia materna.

Casou-se com dezoito anos, em 5 de julho de 1975, com um homem de Tambillo chamado Brielo Wachinton. Maria tem sete filhos com este homem, dos quais dois faleceram. O primeiro nasceu em 1997, quando María tinha vinte anos, e a última em 1991. Recémcasada, Maria começou a conchar, em Tambillo. Trabalhava também com comida, fazendo arroz doce, pães, envueltos, tamales, empanadas. E ainda com o cultivo agrícola, na finca da família. Com o terremoto de 1979, a produtividade agrícola em Tambillo decaiu e o casal, que à época tinha três filhos, resolveu tentar a vida no Equador, em Limones e depois Montecristo, ambas localidades na província de Esmeraldas.

Ao retornar para Colômbia, construíram, em 1989, uma casinha no tumaquenho bairro Puente Fatima, bairro palafítico, à beira-mar. Nessa época, mantinham fincas em Tambillo, vivenciando a dinâmica pendular entre campo e cidade. Maria começou então a trabalhar em restaurantes na cidade de Tumaco, Hotel y Restaurante El Mirador, La Sultana, Los Corales. Ganhava salários miseráveis e trabalhava "duro, duro". Havia dias em que Maria não dormia, pois saía do restaurante e ia para casa lavar roupa alheia. Seu marido trabalhava em uma camaroeira. Ambos faziam milagre para a renda atender às despesas da família, que eram altas, pois os filhos estudavam em colégios particulares, já que as escolas públicas tinham greves sequenciais. Em Cali, Maria foi viver no ano de 2009, para trabalhar com seu primogênito em um restaurante próprio. De todas as atividades laborais que desempenhou, a predileção de Maria é a comida.

Maria e eu nos conhecemos na casa do amigo em comum, Carlos Rua, com quem ela trabalhou ao longo do ano de 2012. De início, não pensei que Maria pudesse ser uma interlocutora. Nossa aproximação deu-se em torno de uma questão pragmática. Quando retornei a Tumaco, em setembro de 2013, encontrei um apartamento que era ideal para os encontros e conversas com minhas amigas, porém não tinha segurança para viver. Maria seria então uma companhia. Na convivência cotidiana, na medida em que compartilhava com ela os 
interesses de pesquisa, Maria se autorreferenciava como interlocutora e aí começamos a gravar nossas conversas, que foram três longos papos.

\section{Marlene Tello}

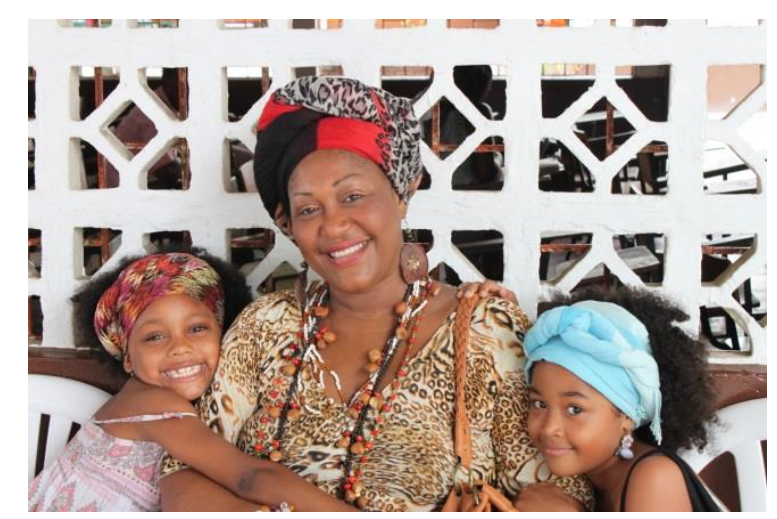

Marlene nasceu dia 08 de julho de 1968 na vereda Chilvi las Mareas, mais uma localidade pertencente ao Conselho Comunitário Rescate Las Varas. Ela é a antepenúltima dos nove filhos do casal María Fidela Granja e Juan Bautista Tello Cortés. Com três anos de idade, trasladou-se para a zona urbana de Tumaco, junto da família nuclear. Nesse ponto, a trajetória de Marlene distingue-se da de outras mulheres com quem dialoguei. Conforme pude apreender, a intensidade da conexão com a vereda onde nasceu acompanha a tenra idade da migração da família de Marlene. Ao lado do pai, da mãe e dos irmãos, Marlene viveu a maior parte da infância e adolescência no bairro tumaquenho Nueva Creación.

Quando tinha quatorze anos, apaixonou-se por um homem dez anos mais velho que ela. Ele tinha uma família, mulher e dois filhos. Aos dezessete anos a maternidade chegou para Marlene. Nasceu Carlos Alberto Sandoval, em 1985. Dois anos depois, nasceu Juan Enrique Calzada Silva. O pai das crianças não reconheceu a paternidade. Os avós María Fidela e Juan Bautista foram um grande apoio na criação de Carlos Alberto e Juan Enrique.

Em 1989, para terminar o bacharelado em comércio e também buscando sair daquela relação afetiva, Marlene trasladou-se para Cali, o que acabou levando-a a Buenaventura. Isso porque aproximou-se de colegas que eram da cidade portuária e então, nos finais de semana, estava costumeiramente em Buenaventura. Lá ela conheceu Nicolás Rodríguez Hoyos, pai de Zamir Rodriguez (1993) e Estiven Tello (1994), homem que Marlene caracteriza como seu “professor” na política. Nicolás era sindicalista, do Movimento Organizado Revolucionário MOIR e estava ligado à “ideologia de Mao Tsé-Tung”. Ela conta que essa relação despertou-a para a compreensão das problemáticas de seu território e de seu país. Aí começou sua 
militância. Ademais, em Buenaventura, Marlene realizou um curso técnico em "trabalho social e comunitário".

Nicólas não foi um bom companheiro, como conta Marlene. Logo após o nascimento de Estiven, ela regressou a Tumaco para viver junto dos pais e dos outros filhos. Aí encontrou Monica, pessoa que contratou para cuidar das crianças, apoiando os avós. E novamente viajou, dessa vez para o Panamá, onde estudou Náutica por dois anos, em uma escola em que era a única mulher. Regressando do Panamá, Marlene organizou novo traslado, para ainda mais longe. Viveu por cinco anos na Alemanha, motivada pela curiosidade de entender porque muitas mulheres Afropacíficas almejavam viver na Europa. Ela chegou à casa de uma prima, na cidade de Kelsterbach. Lá, trabalhava e mandava dinheiro para seus pais e filhos em Tumaco. Marlene cozinhava comidas latinas e vendia-as em casas de prostituição, onde encontrou suas conterrâneas. Em vistas do contato com muitos africanos migrantes, a Alemanha para Marlene representou uma aproximação maior com a África, fortalecendo suas raízes, em especial a espiritualidade.

A ancestralidade de Marlene provém da linhagem paterna. A bisavó, Julia Cortés, morreu com 117 anos. A avó chamava-se Digna Cortés. Com elas Marlene aprendeu práticas de cura por meio do manejo de ervas, tabaco, rezas e outros elementos. Ambas nasceram e viveram em Aguacate, vereda cerca de San Luis Robles. Patria Boya, filha de uma tia-avó de Marlene, é mais uma figura central na narrativa de Marlene no tocante aos "saberes ancestrais".

Em 2002, Marlene deixou a Alemanha e regressou definitivamente a Tumaco. Então, o ativismo político enraizou-se em seu território-natal. Em 2007, ela fundou uma organização chamada Tejiendo Esperanza (Asoeartes), que realiza trabalhos culturais com mulheres e jovens de periferia e zona rural tumaquenha. Um dos temas que trabalham são os penteados afro, uma das tônicas de atuação de Marlene, que concorreu como produtora em muitos desfiles da beleza negra em Buenaventura. Trata-se de uma organização mista; dentro da associação há mulheres "mestiças" trabalhando artesanato, como ela conta.

Em 2008, Marlene ingressou na Rede Kambirí, espaço de conexão com o espiritual e de reencontro pessoal, como ela define. A porta de entrada foi a escola de formação para mulheres líderes, que começou a cursar neste mesmo ano. Rede Kambiri é muito especial para Marlene, também por ter sido o caminho do encontro com Aura Dalia Caicedo, mulher afropacífica que vive em Cali, liderança no cenário nacional do movimento de mulheres negras. Marlene descreve esse encontro como um reconhecimento de mãe e filha. 
Também em 2008, pela primeira vez, lançou-se candidata à vereadora em Tumaco. Em 2010, Marlene foi uma das protagonistas na composição da Mesa Municipal de Mulheres de Tumaco, outro espaço de militância que lhe é muito caro, sobre o qual comento ao longo da tese. Quando a conheci, em novembro de 2012, Marlene trabalhava na Casa de Cultura do município de Tumaco.

Quando regressou a Tumaco, no ano de 2002, Marlene ficou solteira por um período, durante o qual teve muitos amores, coisas passageiras, como ela diz. Em 2004, conheceu Carlos Alberto Mendoza Ramos, um homem de Cartagena, e com ele passou a viver. Nesse então, Steven, o caçula de Marlene, tinha nove anos de idade. E ela havia feito laqueadura depois dessa gestação.

Conta, porém, que sempre havia sonhado em ter uma filha. A relação com os orixás, para Marlene, é envolvida por revelações ou profecias, como diz. Uma delas lhe dizia que ela, sim, teria uma filha. Com Carlos Alberto, a vivência conjugal ia mal; ela resolveu separar-se. Nessa mesma época, começou a sentir-se mal fisicamente e a engordar muito. Chegando ao médico, os testes indicavam gravidez, porém ninguém era capaz de crer na gestação, nem o pai da criatura, nem a avó, já que Marlene era ligada e tinha idade avançada (36 anos). Ademais, as ecografias nada mostravam. Quando já estava internada no hospital e lhe fizeram uma ecografia transvaginal, "la niña se dejó ver". Marlene carregava no ventre uma menina, antes escondida pela placenta. Nisso, já avançava para o oitavo mês de gestação. No dia 28 de outubro de 2005, quando fazia aniversário a mãe de Marlene, nasceu Génesis Madeleine. No começo do seguinte ano, 2006, a avó de Génesis faleceu.

Além dos cinco filhos biológicos, vivem com Marlene outras crianças, filhas de mães drogadictas ou alcoólicas. Crianças que, como diz Marlene, são carentes do calor de um lar e do calor de uma mãe. Ela cuida-os até que possam seguir a vida, retornar as suas famílias ou caminhar por conta própria. Conta que já passaram por sua casa em torno de vinte crianças. Quando convivi com a família, com ela viviam a pequena Valentina, o pré-adolescente Leandro e o jovem Chucho.

Marlene foi a primeira mulher tumaquenha com quem comecei a dialogar com mais profundidade. O diálogo começou com a pergunta: "Si usted fuera contar la historia de su vida, ¿cómo la empezaría?”. Queria saber qual seria a escolha narrativa para falar sobre si, caminho que me parecia mais interessante do que propor as perguntas por eixos temáticos. Previ que seria uma dinâmica fluida, já que, em conversas anteriores, Marlene havia 
manifestado o desejo de compartilhar comigo sua trajetória. Em seguida, o roteiro de pesquisa entrou em ação e mostrou como poderia ser exaustivo! Marlene comigo teve muita paciência.

Tivemos diversos encontros nos quais usei o gravador, de modo que a transcrição da narrativa de Marlene é a mais longa. Contudo, também vivemos juntas outros momentos. Marlene inseriu-me no seio de sua família, de seu trabalho e de sua militância. Foi, ademais, uma companheira espiritual, com quem pude compartilhar momentos sublimes. E ainda me cuidou quando tive os problemas de saúde relacionados à entorse do tornozelo. Enfim, construímos aí uma bonita amizade, celebrada também em Brasília, quando Marlene veio participar do Festival da Mulher Afrolatino Americana e Caribenha, em 2014.

\section{MulHeRes do Rio Patía}

\section{Familia Granja}

Ana Granja Castillo nasceu em 1954 na vereda Los Brazos. É uma das caçulas dos quinze filhos que tiveram Leona Castillo Iturra e Venancio Granja Castillo. Sua mãe, à época da etnografia, tinha 101 anos e vivia em Salahonda. O pai, falecido. Ana Granja conta que sua avó materna teve vinte e quatro filhos, dos quais apenas seis ficaram vivos.

Ela aprendeu a nadar quando tinha quatro anos, com quatro cocos. No canal que banha as ribeiras do povoado onde nasceu, uma das "comunidades de rio" que compõem o Conselho Comunitário ACAPA. Quando criança, não havia escola em sua vereda. Aos onze anos de idade, junto com um de seus irmãos, saía às segundas feiras de madrugada remando em direção a Salahonda. Passava a semana por lá, estudando. Aos sábados, às quatro da manhã, regressavam a Los Brazos. O trajeto a remo durava em torno de quatro horas. E assim cursou até o quinto grau, etapa do ensino fundamental colombiano. Já o bacharelado, ela cursou adulta: dos 42 aos 50 anos, estimulada pela necessidade de se capacitar dentro do processo de comunidades negras.

Com vinte e cinco anos, Ana Granja teve seu primeiro filho, Janer, que hoje vive com o pai. No ano seguinte, nasceu Lorith, que, segundo conta, era muito astuto e trouxe-lhe grande alegria. Quando jovem, Lorith desapareceu em Cali. Ana Granja fala que não sabe se esse filho estaria vivo ou morto. Em 1982, nasceu Alex. O pai deles faleceu, mas Ana Granja já o havia deixado oito anos antes disso. 
Ela viveu vinte anos em Cali, entre 1968 a 1988. Conta que foi estudar e acabou vendendo chontaduro (pupunha) em frente à Câmara de Comércio e fazendo filhos. Quanto tinha trinta e cinco anos, vendia pupunha no aeroporto de Cali, equilibrando uma bacia cheia do fruto na cabeça. $\mathrm{O}$ cotidiano em Cali era duro, despertava às três da manhã e retornava à casa às nove da noite. Deixava comida pronta para os filhos. Ana Granja regressou a Salahonda e, lá, segue vendendo pupunha na porta de sua casa.

Em 1990, juntou-se ao atual companheiro, com quem teve Ana Karina, no ano seguinte, e Yulisa Isabel, em 1998. Foi membro da primeira junta diretiva do Conselho Comunitário, em 1997. Foi representante legal do Conselho Comunitário Rio Patía Grande sus Brazos y Ensenada (ACAPA), entre 2003 e 2007. Fez parte da Consultiva de Alto Nivel entre 2004 e 2007. Nessa época, Ana Granja conta que vivia viajando. Quem mais se ocupava do cuidado das filhas era Chucho, o pai delas. Pelo trabalho realizado à frente de ACAPA, Ana Granja recebeu em 2005 o Prêmio Nacional pela Conservação e Uso Sustentável de Áreas Alagadas, concedido pelo Ministério de Meio Ambiente, Moradia e Desenvolvimento Territorial. Em 2004, ela viajou ao Peru, para o Congresso de Fauna Silvestre.

Quando era representante legal do Conselho, passou a integrar a Mesa Departamental de Mulheres, na qual as mulheres ingressam por "notório saber". Em 2010, junto com a companheira Edna Padilla, de Satinga, criou a Mesa Municipal de Mulheres de Salahonda envolvendo em torno de 400 mulheres. Pela Mesa Departamental de Mulheres, ela está envolvida na Política Pública para Equidade de Gênero, para a Equidade das Mulheres Narinhenses desde sua diversidade étnica, social e cultural, em um território em construção de paz.

Suas filhas caçulas, Ana Karina e Yulisa, por ela nutrem grande admiração e tomamna como exemplo do feminino, caracterizando-a como uma "mujer que echa p'adelante". Ana Karina Granja, quando a conheci, em 2013, fazia parte do grupo de jovens do PCN a nível nacional e também participava de reuniões da Mesa Departamental de Mulheres.

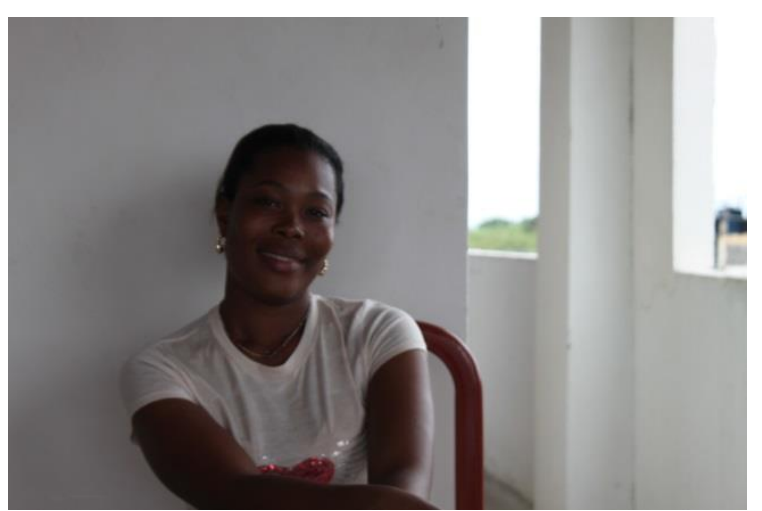


Ela nasceu dia 18 de setembro de 1991, na casa em que a família vivia, em Salahonda, amparada pelas mãos de uma parteira. Nasceu, portanto, no mesmo ano em que foi promulgada a constituição vigente na Colômbia. Conta que viveu a infância nesta casa, ao lado de sua avó materna Leona e de seu pai. Ainda que não tenha vivido na vereda, Karina conta que, ao longo de sua infância, sempre ia a Los Brazos acompanhando sua mãe. E que desenvolveu o sentido de pertencimento a partir da relação com o território ancestral.

Para estudar, Karina mudou-se para Cali, onde vivia no Bairro República de Israel, com o irmão Luís Carlos. Realizou curso técnico em Justiça e Investigação Judicial e um diplomado em Criminalística e Ciência Forense, no Instituto Politécnico Empresarial Colombiano. Estava preparando-se para ingressar na Polícia, o que logrou em meados de 2014.

Desde que estive em Tumaco pela primeira vez, em maio de 2012, ouvi falar de Ana Granja como uma dirigente de peso, bem como de sua filha, Ana Karina, como uma promissora liderança. Conheci Ana Granja na Mesa de Género no contexto do Pre-Congreso Departamental Nariño, Etapa preparatoria al Primer Congreso Nacional. Aí trocamos telefone e acordamos uma visita a Salahonda, que foi postergada pela minha condição de saúde. Ao final de outubro de 2013, cheguei junto com Ana Granja a sua casa, onde fiquei uma semana hospedada, convivendo também com seu companheiro Chucho e as filhas Ana Karina e Yulisa.

Martina Granja Castillo compartilha parte dessa história. Ela é a décima primeira filha de Leona Castillo Iturra e Venancio Granja Castillo. Nasceu em 1950, em Salahonda. É cantadora, toca cununo e bombo. Além de tocar, confecciona os instrumentos, ofício aprendido com o pai, que era músico e lavrava cununo, bombo, marimba. Martina conta que terminou de aprender a esculpir os instrumentos na madeira com o segundo marido, que também era lavrador. Em Salahonda, Martina iniciou sua militância. Junto com a irmã Ana Granja, protagonizou processos memoráveis na implementação da Lei 70 de 1993. Foi Martina quem levou Ana Granja para o processo de comunidades negras, segundo narram ambas.

Sua habilidade musical, casada com o ativismo político, levou-a a Espanha em 2003, para participar de um evento sobre o aquecimento global, viagem articulada pela WWF. Em suas palavras, ela diz que foi convidada para falar, cantar e tocar. Logo após regressar, Martina conta que participou de um Encontro Internacional de Cultura Afro em San Lorenzo, Equador. É onde sua história cruza-se com a de Inés Morales, uma das gestoras do tradicional 
Encuentro de Expressiones Negras Sanlorenzenho. Martina diz que está sempre à disposição da luta, mas em dado momento passou a participar com menos incidência no processo de comunidades negras, deixando o posto para sua irmã, que tinha mais estudo e vocabulário mais adequado à mobilização política, segundo avalia Martina.

Ela teve dez gestações; uma delas resultou em aborto. Outro filho faleceu com pouco mais de um ano, assim, foram oito filhos/as vivos/as. O primeiro filho resultou da relação com um sujeito que vivia em Salahonda, mudou-se para o Equador e posteriormente para Cali, levando consigo o filho deles. O pai de sua segunda filha, Filomena Quiñones Granja, era tumaquenho e faleceu em Buenaventura. Os demais descendentes são fruto da relação de dezenove anos com Segundo Noel Quiñones, quem conheceu quando vivia em Tumaco e trabalhava em um restaurante.

Quando estava vivendo com Segundo Noel, ela "quase não trabalhava". Fazia e vendia mazamorra, envueltos, majaja ${ }^{403}$; comprava concha em Salahonda e vendia em Tumaco. Regressando a Salahonda, após a separação, Martina ganhou a vida mariscando, até quando teve saúde para tal. Conchando conseguiu sustentar seus oito filhos. Posteriormente, juntou-se com outro homem, que era menor e mais novo que ela. Hoje em dia ganha alguma renda vendendo os instrumentos musicais que confecciona.

Encontrei Martina em sua casa, em Salahonda. Foi sua irmã, Ana Granja, quem nos relacionou. Ao longo de uma semana tivemos vários encontros. Além da narrativa em torno de sua trajetória de vida, os agradáveis momentos envolveram cantoria e música, embalados pela voz e o ritmo de uma das filhas de Martina.

Nidia Quiñones Granja herdou da mãe o dom da música. Junto com a prima, Ana Karina, desde pequenas estão envolvidas no processo de comunidades negras e nas mobilizações de ACAPA. Elas contam que "entraram no processo pela cozinha", alimentando as militantes do processo. Nidia e seus dois filhos pequenos vivem com Martina, no povoado de Salahonda. Ela já conchou em momentos de necessidade, mas não se identifica como conchera, e sim como manicure e pedicure.

\footnotetext{
${ }^{403}$ Mazamorra é como uma canjica de milho branco. Envuelto é feito de milho e envolvido em folha de bananeira, como a pamonha. Majaja também é de milho, um tipo de milho chamado chocló. É uma tortilha.
} 


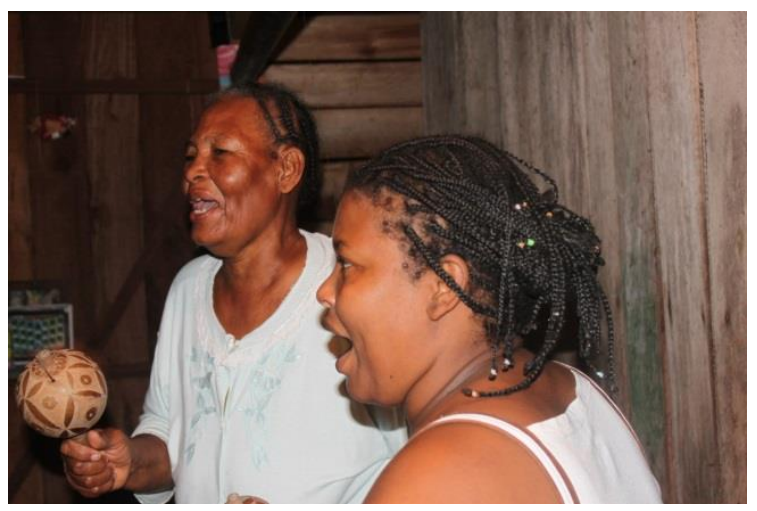

\section{Familia Puertocarrero}

Quando saímos a mariscar com Ana Granja, em El Bajo, Salahonda, conheci Segunda Rosa e Marién, mãe e filha. Ambas estavam conchando com um grupo composto por mais dois homens e voltaram no potro (ou canoa) com Ana Granja e eu. Essa família salaondenha vive em uma casa extremamente humilde, no povoado de Salahonda. Conforme me explicou o rapaz que me acompanhou até a casa delas, sobrinho de Ana Granja, é uma das residências mais pobres do povoado. Segunda Rosa, Marién, Jhon Jairo Montaño e José Antonio Quiñones Castillo - mãe, filha, filho mais novo e marido - receberam-me certa tarde para uma conversa sobre o concheo.

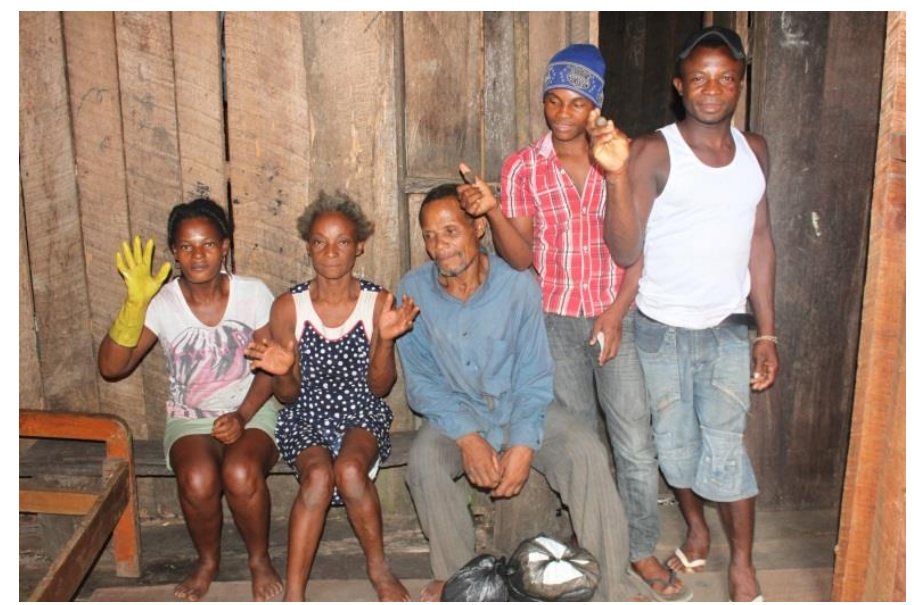

MULHERES DOS AFLUENTES DO RiO SANTIAGo 


\section{Inés Morales}

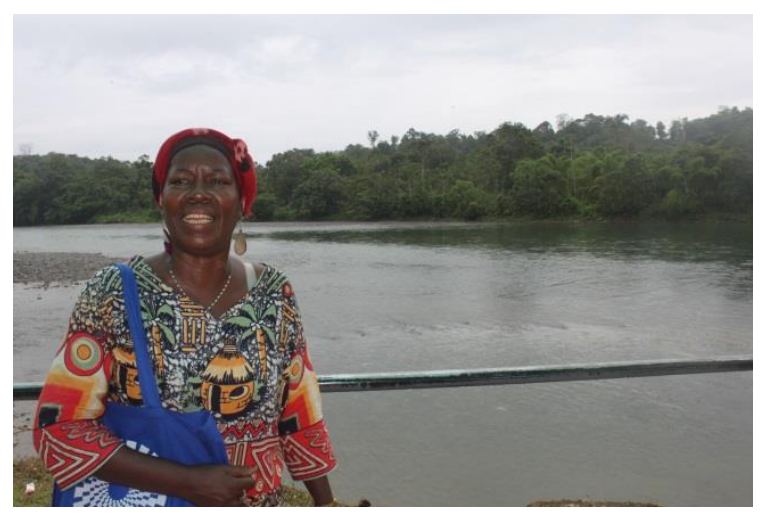

A palenqueira maior, Inés Morales, autoidentifica-se como mulher, negra, nascida e criada na "comunidade" de Carondelet. Diz-se afroequatoriana por haver nascido e crescido no Equador. É mãe de quatro filhos - Javier (1977), José Luiz (1981), Jairo (1983) e Yulisa (1985) -, avó e viúva de Don Armengol. É professora e dirigente nos processos de organização. Ao iniciar dinâmica por ela proposta em atividade do MOMUNE, no Projeto Ecoclube San Lorenzo 2012, na qual as participantes deveriam expressar "lo que llevamos adentro", Inés dizia: "hoy puedo me atrever a decir que soy una líder del pueblo afroecuatoriano. Soy una mujer que tengo algunas fortalezas y algunas debilidades".

Em 1956 nasceu essa líder do povo afroequatoriano, filha de Luis Morales, provindo de Cuajara, localidade do Valle del Chota, la Concepción y Salinas, e de Marcia Lastra, cujas raízes levam à localidade vizinha, La Boca. Da união entre Luis Morales e Marcia Lastra frutificaram três mulheres: Lucila, Inés e María. Em seguida, em 1958, Luis Morales faleceu em acidente na ferrovia, na qual trabalhava. Marcia contraiu outra relação após ficar viúva, na qual teve seis filhos. As filhas do primeiro relacionamente foram criadas pelos avós maternos Papá Lorenzo e Sinforosa.

O tio materno Abraham Lastra, que tinha uma boa condição econômica, foi um esteio para que Inés e suas irmãs pudessem estudar fora. Isso porque em San Lorenzo podia-se acompanhar apenas até o terceiro curso. Após completar esse ciclo, quando tinha em torno de dezesseis anos, Inés foi estudar em Ibarra, enquanto sua irmã seguiu para San Lorenzo. Inés perde o avô Lorenzo e o padastro na mesma época. Logo depois conhece Don Armengol, que seria seu companheiro por toda a vida. Quando começaram a namorar, Don Armengol apoiou financeiramente a Inés e sua família em Esmeraldas, de modo que ela pudesse finalizar os estudos. Ao casar-se, Inés regressa a San Lorenzo com Don Armengol. Primeiro vivem de aluguel, até que conseguem estabelecer residência própria no Bairro Nuevo Horizonte. 
Inés começou sua trajetória de militância no exercício da docência, em 1982. Foram as inquietudes quanto à ausência de conteúdos relacionados à negritude no Equador que levaram Inés ao cenário do ativismo político, concomitantemente ao engajamento cultural. Em 1988, ela compõe o Grupo de Marimba Patacoré, que presidiu até o ano de 1998. Paralelamente, movida por tais inquietudes, Inés dedicou-se à trajetória acadêmica. Entre 1985 e 1991, estudou Pedagogia na Universidad Nacional de Loja/Equador. Realizou mestrado em Etnoeducação para o Desenvolvimento na Universidad Técnica Estadual - UTE, finalizado em 2009. Em 2013, ela acumulava trinta e dois anos de docência, sendo quinze deles no Colégio Técnico, na sede de San Lorenzo, e dezessete no Colégio de Carondelet, a "comunidade" onde nasceu e se criou.

Ao longo de mais quatro décadas, Inés consolidou-se como uma referência em seu país para a luta negra e de mulheres negras. Em 1993, esteve à frente da fundação da Frente Cultural en Defensa del Territorio Ancestral e, no mesmo ano, da Comarca Afroequatoriana do Norte de Esmeraldas - CANE. Entre 2001 e 2005, Inés foi a dirigente principal, ou Palenquera Mayor, de CANE, título pelo qual é reconhecida até hoje. Foi nessa gestão que ela injetou energias para a formação do Movimento de Mulheres Negras do Norte de Esmeraldas - MOMUNE, no início dos anos 2000. Em reconhecimento à trajetória de luta, ganhou o Prêmio Illescas de Oro, uma iniciativa de reconhecimento e valorização entre Afroequatorianos, que nasceu na província de Pichincha.

Esteve nos EUA, Peru, Venezuela, Suiça, Bolívia, México, Brasil, quando nos conhecemos, durante Oficina do Projeto "Quilombos das Américas”, em Brasília, 2011. A relação com Inés representou, para mim, a porta de entrada ao Pacífico Colomboequatoriano. Ela foi minha anfitriã. Foi quem me relacionou a outras mulheres e organizações, no Equador, mas também na Colômbia, velhas conhecidas de Inés em vistas do processo binacional. A convivência com Inés, sempre muito agradável e enriquecedora, levou à construção de uma amizade que é um dos valiosos legados dessa experiência. Nosso último encontro foi em Brasília, durante o Festival da Mulher Afrolatino Americana e Caribenha, em 2014. 


\section{Melania Ester Quiñones}

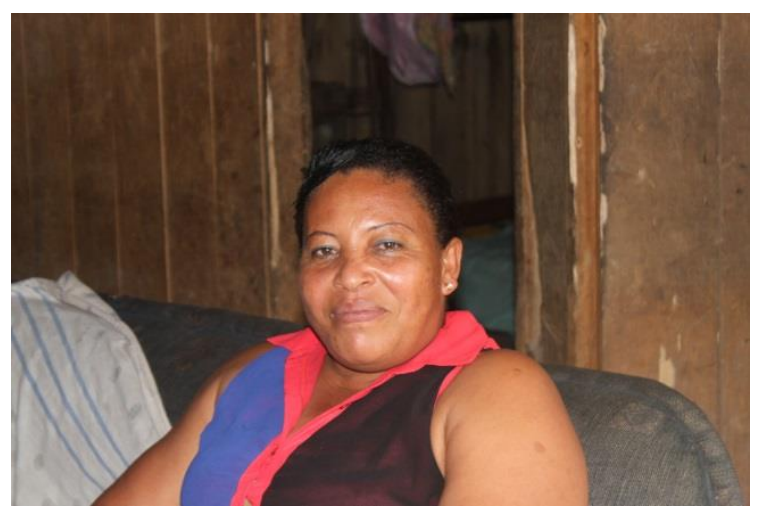

Nasceu no Recinto La Boca, San Lorenzo, em 14 de julho de 1976. Seus pais vieram da Colômbia, mãe, barbacoana e pai, tumaquenho. A família paterna de Melania migrou para a localidade de Minas Viejas, que fica na parte alta do Rio Tululbí. Em busca de estudos para os filhos, mudaram-se em seguida para a localidade de La Boca, onde desaguam os rios Palaví e Tululbí. Rosaura Quiñones, mãe de Melania, por sua vez, migrou em 1959 com o pai e a irmã, saindo de Barbacoas.

Em La Boca, Germán Ortiz e Rosaura Quiñones conheceram-se, estabeleceram-se e tiveram treze filhos. A primogénita, Melania, teve de cuidar dos irmãos menores enquanto os pais trabalhavam. Ainda assim, logrou estudar. Terminou o sexto grau e foi estudar em San Lorenzo, na escola 10 de agosto, onde vivia em casa alugada junto com um irmão. De lá seguiu para Ibarra, a fazer o bacharelado em mecanografia. Porém, não era essa sua vocação. A conclusão do bacharelado tardou algumas décadas. Em 2011, Melania graduou-se em Ciências Sociais pela extensión de Monseñor Leonidas Proaño, em Esmeraldas. E recentemente, quando já nos encontramos, em 2014, Melania fazia estágio para graduar-se em enfermaria, que foi sua aspiração desde que a família a mandou a Ibarra, estudar mecanografia.

Com dezessete anos, Melania arranjou "compromisso" com um conterrâneo, Bienvenido Arboleda. Dessa relação, brotou Ángela Yanela Arboleda Ortiz, que faleceu com dezenove anos, por parada cardíaca. A relação com Bienvenido foi curta, em seguida casou-se com Edson Castillo, com quem teve cinco filhos: Diego, Edif, Gaby, Vanesa y Harol. Desde a segunda filha, Melania começou a fazer planejamento familiar, de modo que os demais filhos chegaram em momentos esperados pelo casal. Segundo conta Melania, a relação com Edson foi tranquila até o nascimento do último filho do casal, quando ela descobriu que ele estava vivendo um processo de droga dicção. 
Ao longo de sua história de vida, acompanhando o marido que era ferroviário, ela viveu na zona urbana de San Lorenzo, em Quito e em Ibarra. Sempre trabalhou, porém, quando o orçamento familiar pesou para ela, o caminho resolutivo era o regresso ao território. Foi quando se separou do companheiro. Ao regressar a La Boca, em 1995, começou a trabalhar com a mãe em atividades agrícolas: cultivo de banana-da-terra, milho, mandioca, cana-deaçúcar e cacau.

Foi também quando brotou seu ativismo comunitário, começando na gestão escolar local. Em 2001, ela foi tesoureira da Comuna Afroequatoriana de La Boca. Regressou em 2011 como vice presidenta da Comuna. Entre 2005 e 2010, Melania foi secretária da Junta Paroquial de Carondelet. Em 2014, quando conversamos, Melania era suplente do Vereador Enrique Caicedo, vinculado ao partido MPD (Movimiento Popular Democrático)/San Lorenzo.

Conheci Melania por intermédio de Fausto Eliceo Lastra, liderança de La Boca e primo de Inés Morales. Tivemos apenas um encontro, em La Boca, na casa de Melania, quando conversamos toda a manhã e uma parte da tarde. Melania levou-me ao encontro de sua mãe, Rosaura Quiñones, com quem dialoguei, mais brevemente, principalmente sobre a fundação da Comuna Afroequatoriana La Boca.

\section{Yonny Nazareno}

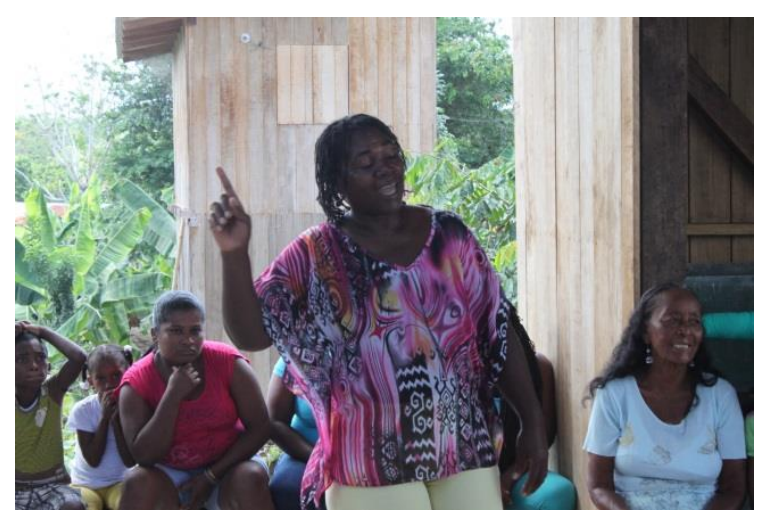

Em Ricaute, ou Paróqui Tululbí para usar o nome oficial, Yonny veio ao mundo no dia 25 de janeiro de 1964, uma das doze filhas de Piedad Porozo Mina e Ezequiel Nazareno Palas. Sua mãe é remedeira e curandeira, saberes que Yonny está aprendendo. Foi no território de Ricaute, base dos poderes curativos dessa família, que Yonny viveu a infância. Suas irmãs todas ainda vivem lá, assim como sua mãe e seu pai. Piedad desfez a união conjugal em virtude do alcoolismo de Ezequiel, segundo conta Yonny. 
A avó paterna de Yonny chamava-se Braulia Espalma Nazareno. Nascida aproximadamente em 1910 e falecida em 1989, foi uma das fundadoras da Paroquia Tululbí, cuja formalização como Paróquia ocorreu em 1956. Segundo conta Edith Rivas, que é filha de Braulia, tia paterna de Yonny, a mãe foi uma líder deste povo. Era negociante e cantadora. Yonny conta que Braulia era uma das mulheres mais ricas de Ricaute, porém, desagradava-lhe a relação do filho com Piedad, de modo que ela nunca apoiou a família de Yonny, que cresceu passando necessidade.

Quando tinha doze anos, Yonny deixou Ricaute em busca de continuidade dos estudos. Foi viver com uma tia, na província de Guaya, cuja capital é a conhecida Guayaquil. Viveu por lá até terminar o sexto ano, com quatorze anos. Aos dezesseis, começou os estudos em San Lorenzo, no colégio 22 de marzo. Piedad e Ezequiel sentiram então a necessidade de ter uma base na sede do município. Assim, começaram a construir uma casa no bairro Nueve de Octubre, onde Yonny vive atualmente. Pouco tempo depois, aos dezoito anos, conheceu o homem que seria seu primeiro e único homem, como ela diz. Após três anos de namoro, foram viver juntos. No mesmo ano de 1985, veio o primeiro filho, Darwin. A gravidez aconteceu quando ela cursava o terceiro ano do bacharelado. Afastou-se dos estudos, em seguida retomou-os. A filha do meio, Silvia, nasceu em 1988 e a caçula, Omayra, em 1996. A relação conjugal passou a ser problemática a partir de 2004/2005. Logo em seguida, Yonny separou-se.

Foi nessa mesma época que ela começou a fazer parte do Movimento de Mulheres Negras do Norte de Esmeraldas - MOMUNE. Nosso encontro deu-se por aí. Acompanhei as mulheres de MOMUNE em algumas agendas do movimento. Também aproximei-me da família de Yonny. Algumas vezes estivemos em Ricaute com Silvia e sua filhinha, Omayra, Piedad e algumas das irmãs de Yonny. No rancho de Piedad, a beira do Rio Palaví, comemos saboroso: pescado com chileno.

\section{Vilma Estacio Abá}

Moradora de Ricaute, Vilma nasceu em 1939, registrada na Paróquia Concepción. Filha de Pancho Estacio Cabezas e Carlota Abá Mina. Como muitas das famílias de Ricaute, a ancestralidade de Vilma também é colombiana. Sua avó paterna, Luiza Cabezas, era barbacoana. Pancho nasceu lá. Os dois migraram primeiro para Ricaute, em seguida vieram outros membros da família. Sua mãe, Carlota, é de Ricaute. Filha de Rosalina Abá e um pai 
não identificado. Da relação com Pancho, Carlota teve treze gestações e dez filhos nascidos, dos quais cinco estão vivos.

Vilma não viveu a infância junto de seus pais e irmãos. Criou-se em Limones, com uma senhora que a explorava, um capítulo triste de sua história. Não teve a oportunidade de estudar, de modo que nunca aprendeu a ler. Trabalhava na finca. Retornou a Ricaute já mocinha, quando seus pais inteiraram-se da vida dura que vinha tendo a filha.

Carlota Mina era parteira titulada, como diz Vilma. A filha acompanhava-a, porém não se interessava muito pela arte de partear; nessa época sentia asco. Depois que a mãe morreu, no começo da década de 90, Vilma e sua irmã Leona, a qual todos chamam de Domingas, começaram a partear e consolidaram-se como parteiras ou comadronas do povoado.

De 1957 a 2004 Vilma viveu com Arturo Mina Lastra, onde se conecta a história de Vilma e Inés Morales. A família Lastra de Arturo é a mesma de Inés, em Carondelet. Juntos tiveram duas filhas, as duas falecidas. Com Arturo, Vilma compartilhava a música. Tinham um grupo de arrullo e marimba, com o qual viajavam, chegando até Paris, em 1997 aproximadamente. Dois anos depois de falecido Arturo, Vilma juntou-se com Agapito Andrade Escobar, colombiano de Cangarial, Tumaco, com quem atualmente vive.

Conheci Vilma em uma oficina realizada na sede de San Lorenzo cujo tema eram os saberes ancestrais da água. Naquela ocasião, Vilma começou a contar-me sobre a tradição afro sanlorenzenha do bem-nascer. Dias depois, quando fui a Ricaute com Yonny, Vilma esperava-me em sua casa, expondo sobre uma toalha parte do material que usa para curar as enfermidades do corpo e da alma. Nessa ocasião conversamos longamente.

\section{Edith Rivas Klinger Palma}

Mais uma mulher de Ricaute, nascida em 1957, Edith é filha de Antonio Klinger Lara e Braulia Palma Nazareno, avó de Yonny Nazareno. Aos dezenove anos foi mãe. Ao todo Edith gerou sete filhos, os cinco primeiros com Octavio Rodríguez e os dois últimos com San Luis Chiyambo, que fazia parte do Grupo arrullo, chigualo Tululbi. A primeira união conjugal foi fonte de muitos problemas, como diz Edith. Já com o segundo companheiro, Edith compartilha o engajamento musical.

Edith é cantadora e bailadora de Marimba. Aos vinte e seis anos, formou o Grupo arrullo, chigualo Tululbi, valendo-se dos contatos com mulheres do povoado em seu ofício de enfermeira. Edith é a diretora do grupo, Chiyambo é o coordenador e toca carraca: "un palo largo que se hace como de chontilla y eso suena como guitarra". Em 1995, o Grupo Arrullo e 
Chigualo Tululbí fez um tour pela Europa, apresentando-se durante um mês na França e Alemanha, a partir de uma articulação feita pela Casa de Cultura Equatoriana. Atualmente, como conta Edith, o grupo segue vivo, sem embargo, boa parte de seus membros eram idosos e faleceram. O desafio atual do grupo dirigido por Edith é seguir adiante, ensinando as tradições aos mais jovens, bem como dispor de recursos para subsidiar os instrumentos e uniformes.

Quem me apresentou Edith foi sua sobrinha Yonny. Em Ricaute, a sombra de uma amendoeira que fica à frente do posto de saúde onde Edith trabalha, conversamos sobre sua história, especialmente sobre o grupo de marimba que ela dirige.

\section{Ana Germania Loma Abá}

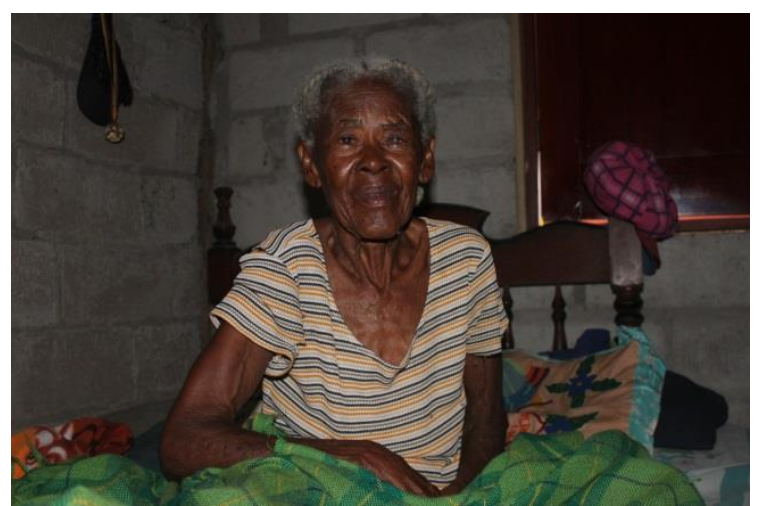

Filha de Juan Loma e Rosalina Abá, Ana Germania é uma das "parteiras tituladas" de Ricaute, para usar a expressão de Vilma. Seu pai Juan Loma é de Ibarra e a mãe dele era “de color", ou colorada, expressão que se usa nessa região para referir-se a pessoas de ascendência negra/afro, com pele clara. Quando a conheci era uma senhora de idade com a saúde bastante comprometida; estava de cama. Quem me levou até ela foi Yonny, minha anfitriã em Ricaute. Ana Germania explica sua enfermidade também em função da vida dedicada à mineração artesanal: "por eso es que tengo tanta frioridad. Playé bastante". Ainda assim, Ana Germania tinha disposição para conversar. Como sua fala para mim era de difícil entendimento, a filha de Ana Germania e Yonny ajudavam-me na compreensão.

Quando era criança, sua mãe biológica teve bronquite e faleceu. "Me decían que estaba dormida, pero ya estaba muerta". Foi criada por Carlota Abá Mina, por sua vez, mãe de Vilma Estácio. Ana Germania pariu dezesseis filhos, dos quais oito estavam vivos em 2013. Um de seus companheiros foi Eladio Preciado, que vinha do Rio Cachaví, cujo pai era colombiano, de modo que ele se criou às margens colombianas do Rio Mira, em uma vereda chamada La Balsa. 
O mundo do bem-nascer é central na vida de Ana Germania. Ela aprendeu a arte da parturia com uma senhora colombiana moradora de Ricaute chamada Ercillia, mais conhecida como Chilla, que era sua tia-avó paterna. Tinha entre dezesseis e dezessete anos quando acompanhava essa senhora no atendimento aos partos. A pedido dela, prepara infusões e bebidas que se deve dar a uma mulher gestante ou parida. Também aprendia a fazer as comidas devidas às mulheres nestas condições. "La mujer parida debe de comer la caperoleta del huevo de la gallina del campo". A narrativa de Ana Germania, e as de outras parteiras. enfatizam que se trata de um conhecimento apreendido pela observação e prática. Quando perguntei quantos partos já havia feito, indicou-me que não havia maneira de contabilizar. “!Uh!!!! Los hijos de todas mis hijas y mucho más ...”.

\section{Amada Cortéz}

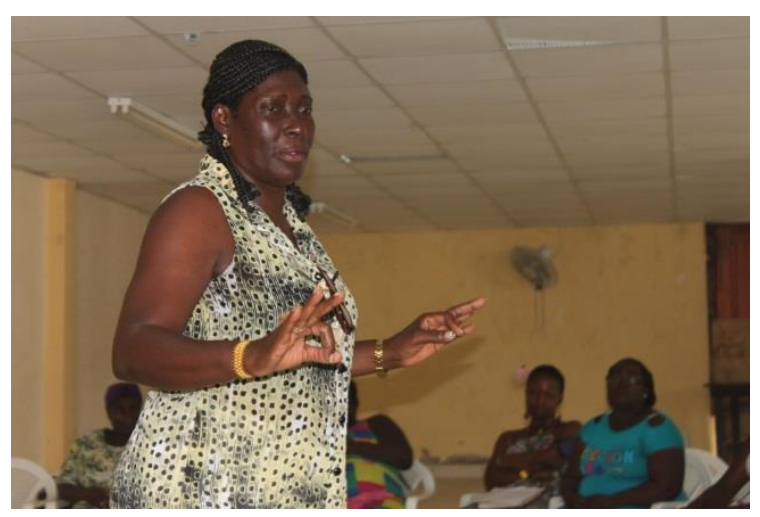

Caçula de uma família com doze filhos, Amada nasceu em 06 de dezembro de 1957, no recinto sanlorenzenho Los Ajos. Seus avós eram colombianos de Barbacoas. "Vinieron del mar para los ríos y se asentaran en el Río Cachaví, recinto Los Ajos. Eso fue en la época de la Guerra de los Mil Días". Quando tinha seis anos, mudou-se junto a família de Amada migrou de Los Ajos para a sede do município de San Lorenzo, o que possibilitou a ela uma trajetória escolar que as mulheres da zona rural de modo geral não têm acesso. Suas irmãs, por exemplo, dedicaram-se mais ao concheo. Tiveram de trabalhar desde idade tenra. Amadita ressalta esse como um fato definidor de sua história de vida.

Em San Lorenzo, Amada entrou para o Colégio 10 de agosto e realizou o ciclo básico. Quando ia para o quarto curso, teve de interromper o ciclo de estudos por um ano, durante o qual trabalhou e conseguiu poupar recursos para custear uma viagem a Esmeradas. Lá matriculou-se no Colégio Luis Vargas Torres, onde vivenciou uma fase de enfrentamento de dificuldades mas também de superação, vivendo em casas de familiares e amigos. Graduou-se 
com vinte e dois anos no Bacharelado em Humanidades Modernas e ingressou no esmeraldenho Instituto Dom Bosco para obter o título de professora da educação primária.

Os pais apoiavam-na financeiramente na medida das possibilidades. A trajetória acadêmica de Amada foi um investimento de sua família. Houve um momento em que sua mãe, junto de uma das irmãs de Amada, mudou-se para Esmeraldas de modo a apoiar a filha na lide diária com a casa, para que ela pudesse se dedicar com maior integridade aos estudos. Em 1982, Amada graduou-se como professora e foi trabalhar na Paróquia Carlos Concha em Esmeraldas, por um curto período. Desde 1983, Amada atua como docente em San Lorenzo.

O primeiro filho chegou aos 25 anos, fruto de uma curta relação da qual desvencilhouse e e voltou a viver com os pais, que estavam doentes, em San Lorenzo. Amada era o esteio da família, matinha a casa, alimentação e medicações necessárias. Foi sua retribuição à dedicação dos pais a sua trajetória acadêmica, avalia ela. O pai de Amada faleceu em 1987 e mãe, em 1988, com câncer no útero.

Logo antes da morte da mãe, ela resolveu casar-se com um homem mais velho, comerciante, que agradava muito sua mãe. Como diz Amada: "voy a darle el gusto de casarme a mi mami, y ella necesitaba que yo me junte con un hombre que me dé consejos, que me ayude a organizar, que piense diferente a los jóvenes”. A união conjugal com Pedro Jiménez Castillo ocorreu quando Amada tinha 30 anos e seu marido 50. Já no ano seguinte, chegou Cintia, que atualmente vive em Quito e trabalha na área de engenharia de empresa turística. E depois Emanuel.

Como docente, Amada Cortéz assumiu a direção da escola Quito Luz de América por décadas, entre 1987 e 2011. Tem também uma forte atuação no campo religioso. Desde 1983, ela é catequista e legionária, ligada à Legião de Maria. É vinculada ainda à Pastoral Afro, sua porta de entrada para a conscientização em torno da negritude e da cultura afro. Em 1984, junto com outras mulheres, Amada inaugurou a Guardería Amparo de Niños, para receber filhas/os de mulheres concheiras e outras mulheres de baixa renda. Creche que ainda hoje elas trabalham para manter. 1994 foi um ano marcante para Amada. Ela entrou para a política: foi vereadora em San Lorenzo pelo partido MPD (Movimiento Popular Democrático), época que ela define como "uno de los mejores días de mi vida". Ao longo da atuação como vereadora, Amada sensibilizou-se pelas desigualdades de gênero: "No sé porque todavía no entramos nosotras mujeres como primeras en la política. Aquí en San Lorenzo no he visto una mujer como primera en la lista". 
Foi também em 1994 que Amadita protagonizou a criação da Asociación de Mujeres 8 de Marzo, que atuava em San Lorenzo, zona urbana e rural; foi uma de suas fundadoras e presidente da Associação. Passou então a "dirigir grupos de mulheres". Também neste ano começou a declamar suas poesias, a primeira delas intitulada "La pregunta del negro". Atualmente, Amada tem três publicações: Las Voces de las Cimarronas, coletiva; Me llaman la Cimarrona, que assina sozinha, e La Voz de Nuestros Ancestros, coletiva. O reconhecido trabalho como poetisa concedeu-lhe o título de La Cimarrona.

A partir daí, foi crescente o engajamento de Amada com o movimento de mulheres e com o movimento negro ou afroequatoriano. Em 1999, ela participou do $1^{\circ}$ Congreso del Pueblo Negro em Quito e do I Congreso de Mujeres Negras em Ambuqui. Sua militância é motivada pelo anseio de descontruir a exclusão e opressão a que são submetidas mulheres negras: "hasta que todas las mujeres no seamos libres, no somos libres". Quando a Coordenação Nacional de Mulheres Negras - CONAMUNE foi criada, em 1999, no contexto do I Congresso de Mulheres Negras, Amada foi nomeada a primeira coordenadora provincial no cantão San Lorenzo, Esmeraldas. Foi a primeira presidenta da Associação de Mulheres Negras María Illescas e também a primeira Palenquera Maior (Coordenadora) de MOMUNE. Atualmente ela faz parte do Movimiento de Mujeres em Sectores Populares Luna Creciente. Como reconhecimento da trajetória no ativismo negro, Amada ganhou o Prêmio Illescas de Oro, assim como Inés Morales.

Inés apresentou-me Amada na minha primeira visita a San Lorenzo, em junho de 2012. Além das agendas de MOMUNE, compartilhei com Amada atividades em torno do projeto Guardianes del Conocimiento, da Secretaria Nacional de Educação Superior, Ciência, Tecnologia e Inovação - SENESCITY, no qual ela e Inés trabalhavam ao longo dos anos de 2013 e 2014. Elas visitaram "comunidades ancestrais" de San Lorenzo e Eloy Alfaro, assim como bairros de San Lorenzo onde vive muita "gente de comunidade" e entrevistaram anciões sobre conhecimentos e práticas tradicionais. Tive a oportunidade então de acompanhar e assessorar esse trabalho, especialmente no tocante à sistematização das informações. Foi muito interessante, já que nessa atividade Amada e Inés estabeleciam com os/as mais velhos/as relações semelhantes às que eu estabelecia com elas no contexto de minha pesquisa de doutorado.

A convivência em torno do trabalho revelou-me uma mulher muito generosa com outras mulheres, uma das virtudes de Amada. Amada, Inés, Yonny e outras mulheres de MOMUNE organizaram para mim uma festa de despedida de San Lorenzo, regada a 
sancocho de galinha caipira e ceviche de concha. Recitaram-me poesias, cantaram e bailaram ao meu redor, compartilhando-me a boa vibração dessas mulheres de luta.

\section{Mulheres do Mangue}

\section{Família Micolta}

Quando a conheci, Tarjélia Micolta estava em sua segunda gestão como presidenta da Asociación de Artesanos Afroecuatorianos Recolectores de Productos Bioacuáticos del Manglar Palma Real. Era também vice-presidenta da Federação de Concheros - FEDARPOM e presidenta do sistema comunitário de água potável. Cheguei a sua casa conduzida por uma equipe da mesma Federação. Targelia recebeu-nos com ânimo, apesar de não nos estar esperando, pois estava "incomunicável”; as linhas telefônicas estavam danificadas há um par de dias. Ela tinha então 49 anos, mãe de seis filhos - Liliana Eneida (1978), Jefferson Gabriel (1980), José Valentín (1982), Leonela Rocío (1984), Tania Valencia (1990-1992), Miguel Ángel (1992) e Elvia Eunice (1995) -, e vivia em Palma Real havia 30 anos.

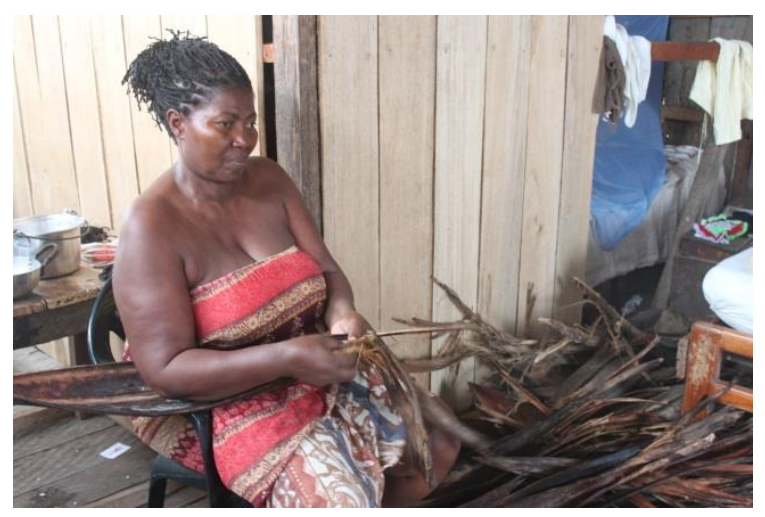

Nasceu em 1963, em El Triunfo, pequeno povoado na província de Guaya, cuja capital é Guayaquil. Seu pai, Leonardo Micolta, era esmeraldenho e a mãe, María Magdalena, colombiana de Puerto Palma, Baixo Rio Mira. Enamoraram-se na Colômbia e em seguida mudaram-se para San Lorenzo. Como María Magdalena tinha uma irmã vivendo em Guayaquil, o casal esteve na região; foi quando Targelia nasceu.

Desde pequena viveu na região fronteiriça entre Colômbia e Equador. Passava férias em Puerto Palma, onde aprendeu a conchar com a avó materna, María Luísa Nuñez, quando tinha em torno dos dez anos de idade. As mulheres dessa família, desde tenra idade, praticaram o concheo. María Magdalena começou a conchar quando tinha quinze anos. Seu pai faleceu, a família ficou "desamparada" e ela passou a acompanhar a mãe na labuta dos manguezais. Luísa Nuñez era barbacoana enquanto Candelario Branda, o avô materno de 
Targelia, era italiano. Ela era parteira, foi quem ajudou a trazer à luz a bisneta Elvia, caçula de Targelia. Nessa época estava em Palma Real, onde passou os derradeiros anos, vivendo até 2002, quando a bisneta fez sete anos.

Ao longo de sua vida, Targelia realizava movimentos pendulares rio-cidade. Como ela diz: "yo iba y venía". Viveu em Cali, Guayaquil, Esmeraldas, mas seu ponto de referência era o Baixo Rio Mira, raiz da família materna. No começo da década de 80 ela chegou à Palma Real e aí estabeleceu-se, dando início à trajetória como líder comunitária.

Durante quatorze anos, Targelia foi presidenta da Asociación de Recolectores de Productos Bioacuáticos del Manglar Palma Real. Saiu duas vezes candidata ao governo autônomo local, a primeira delas em uma chapa com Inés Morales, que era candidata a Prefeita enquanto Targelia pleiteava o cargo de Vereadora da zona rural. Na segunda candidatura, em 2013, era o segundo nome da lista presidida pelo Professor René, pleiteando a administração da Junta Paroquial de Palma Real. Em ambos os casos trata-se de eleições populares, as quais não foram vitoriosas para Targelia.

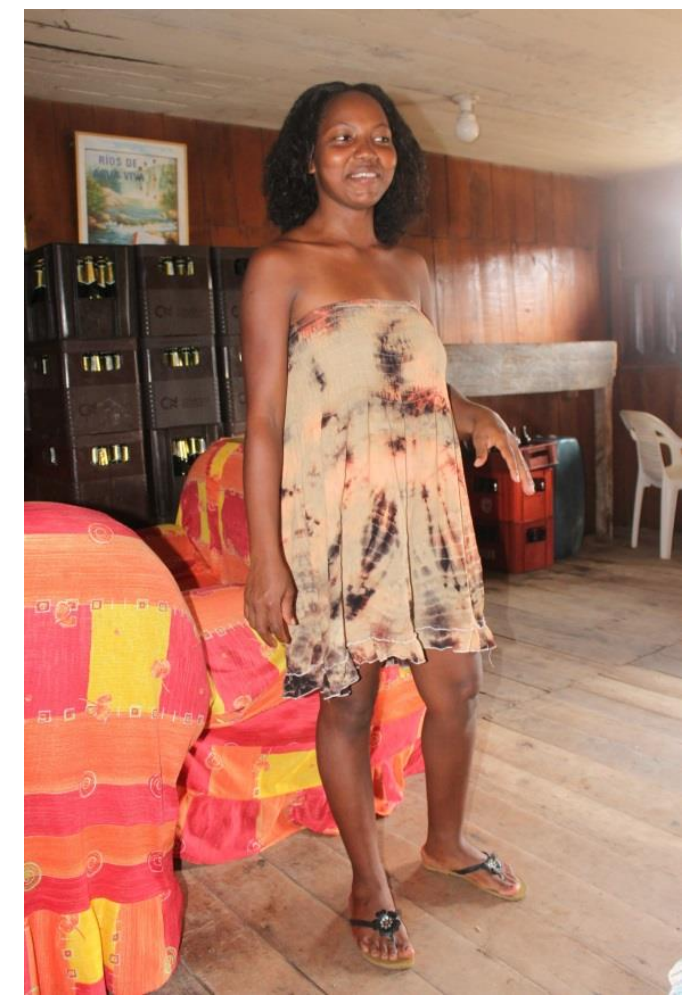

Depois de nosso primeiro encontro, em 2012, houve diversos outros ao longo dos anos de 2013 e 2014. Targelia era minha anfitriã em Palma Real. Passamos longas horas conversando em sua casa. Nessas ocasiões, dialoguei com a quarta filha de Targelia, Leonela Rocío Valencia Micolta, nascida em 1984, em Guayaquil. Leo, como é chamada, tem uma história de vida peculiar. Deixou a casa da família, em Palma Real, muito pequena, com sete 
anos, levada pela avó María Magdalena. Ela foi entregue a uma senhora que vivia em Guayaquil, para acompanhá-la. Porém, Leo foi explorada por essa senhora, da qual se desvencilhou em seguida. Viveu em diversos locais de Guayaquil, passando por situações de privação e dificuldades financeiras. Também viveu duas relações conjugais, na primeira teve uma filha, na segunda, dois filhos. Regressou a Palma Real em 2008. De uma nova relação conjugal com um rapaz de Palma Real frutificou mais um filho. Leo vive do concheo.

Conversei ainda com a caçula de Targelia, Elvia, que a família define como a seguidora de Targelia, uma jovem líder em formação. Elvia Eunice Valencia Micolta é filha de Targelia com Juan David Valencia Perlaza, um pescador da região de Barbacoas, que costumava trabalhar em Palma Real, onde ambos encontraram-se. Quando ela tinha cerca de nove meses de nascida, a união desfez-se e Elvia não teve mais contato com o pai biológico. Wellinton Castillo, conhecido como Tico, ex-companheiro de Targelia, foi quem a criou, dos sete aos quinze anos, aproximadamente.

Elvia nasceu e cresceu em Palma Real, na casa onde fui recebida por Targelia. De lá saiu por motivos de estudo, indo para Esmeraldas, onde viveu com uma prima de sua mãe. Ao regressar a Palma Real, Elvia engajou-se durante dois anos em uma atividade binacional, promovida por FEDARPOM/Equador e RECOMPAS/Colômbia. Trata-se de um curso de formação de jovens líderes no Centro Martin Luther King, na sede de San Lorenzo, desenvolvido em duas etapas, com intervalo de seis meses entre elas.

Em 2013, quando já tinha dezoito anos, Elvia foi viver na sede de San Lorenzo, zona urbana, para finalizar o bacharelado. Almejava seguir a carreira de agronomia. Quando estivemos juntos na etapa derradeira de campo, em 2014, Elvia acabava de ser eleita vocal suplente da junta diretiva de FEDARPOM.

Elvia conta que aprendeu muito acompanhando a mãe na luta em defesa dos manguezais, da qual participa desde que tem oito anos de idade. "Yo, como era la última en mi casa, mi mami no tenía con quien dejarme y mi mami me llevaba". A essa experiência, que a rodeou de conhecimentos, Elvia atribui a capacidade de expressar-se e desenvolver-se. O exemplo da mãe é central para ela: "con el espejo que tengo en mi casa me basta y me sobra". 


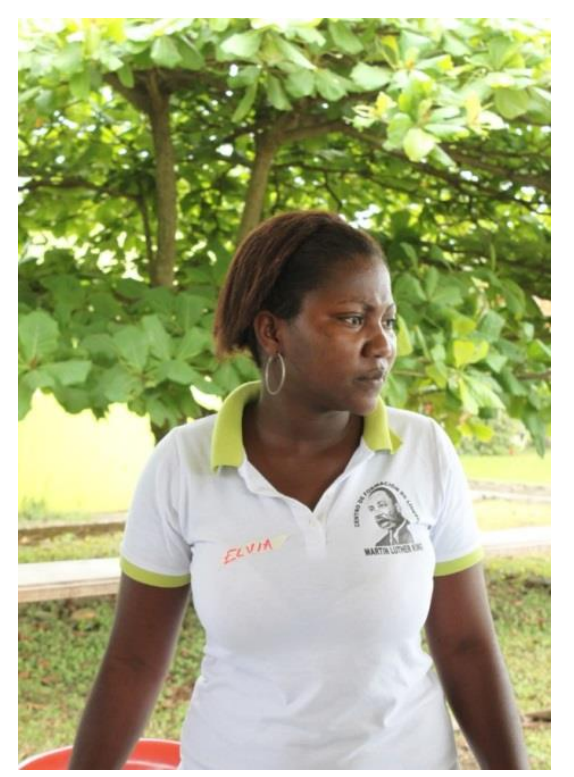

A caçula de Targelia conta que não sabe muito bem conchar e que sente medo. Ainda que não se identifique como uma mulher conchera, conta que se sente capacitada e preparava para dar continuidade à luta de sua mãe em defesa dos manguezais. "A pesar que yo no conche pero de ahí sale la comida de mis hermanas, de mis sobrinos, de muchas otras personas. Y quien quita que cualquier día que yo no tenga recursos, no tenga trabajo, también puedo ir".

\section{Mérice Benguera}

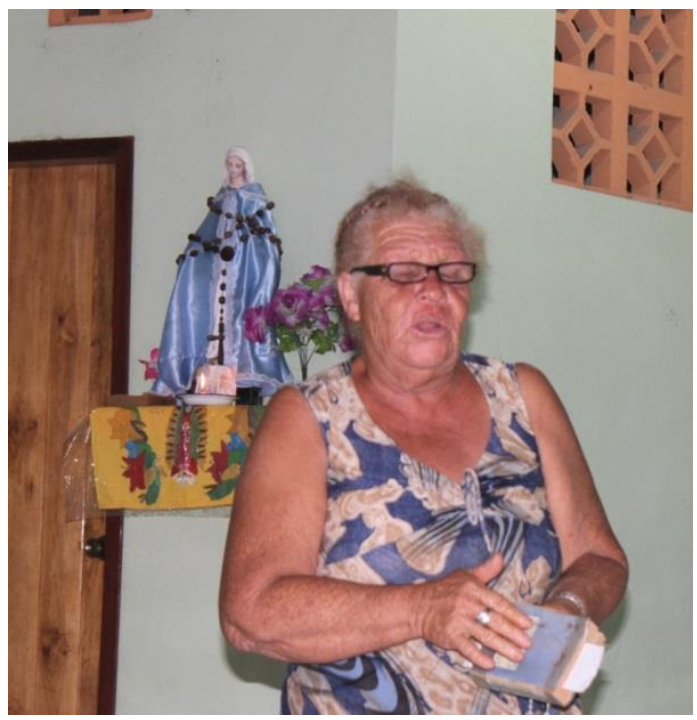

Nascida em 31 de maio de 1949, filha de María Segunda Ortiz e Arcelio Bangera, Mérice conta que foi "destetada aqui en la concha". A familia paterna descende da Colômbia, do rio Tapaje. Mérice é a primogênita de dez filhos, dos quais apenas dois se criaram, enquanto os outros oito morreram. Mérice se auto-identifica acima de tudo como 
uma mulher conchera. Ela conchou por quarenta e quatro anos de sua vida, até que as moléstias do corpo, especialmente das pernas e joelhos, apartaram-na dos manguezais.

Nem as inúmeras gestações afastavam-na do ofício no mangue. Parava apenas na semana em que dava a luz e nos dois primeiros meses do puerpério, durante os quais se mantinha financeiramente com a poupança realizada ao longo da gestação. Retomando a rotina, a criança recém-nascida e os demais filhos pequenos ficavam com a avó, tias ou outra parenta. Em caso de que não houvesse ninguém disponível, Mérice conta que pagava alguém para ficar com as crianças.

Poupando a renda obtida no concheo, Mérice logrou abrir um pequeno negócio no povoado de Palma Real, onde vendia açúcar, arroz, manteiga, biscoitos, dentre outros víveres. Porém, a má conduta do então companheiro, "la mala cabeza del hombre", como diz, levouos à falência.

Com dezesseis anos, casou-se com Germán Branda e teve os quatro primeiros filhos biológicos - Nixon (1971), Solanda (1973), Segunda (1975), Jacinta (1977) - e um filho adotivo, Nober Branda, que era o presidente da Junta Paroquial quando trabalhei em Palma Real. Deixou Germán Branda em 1978.

Em 1980 estabeleceu-se no rancho situado na praça de Palma Real, na região conhecida como firme. Em 1981, ela juntou-se com Juan Copete, que vinha da localidade de Limones, também no norte de Esmeraldas. Desta união, foram gerados três filhos, dois falecidos. A menina morreu de uma das "enfermidades ancestrais", como diz Mérice. "Fue el ojo que la mató".

A experiência da maternidade ativou em Mérice a sabedoria ancestral, no tocante ao poder curativo das plantas e ervas. Mérica é curandeira. Sabe curar "el mal aire, el espanto, el ojo, el bicho que nosotros decimos, que es la infección que dicen los médicos". Seus saberes entram em ação anteriormente ao tratamento da medicina ocidental. "Los mismos doctores le preguntan si ya lo hizo medir de ojo, de mal aire".

É também rezandeira. No culto católico, ela coordena cantos e rezas, as quais acontecem em ocasiões especiais - por exemplo, quando alguém da comunidade falece, que se reza a Novena; quando é Natal, reza-se o Rosário -, e cotidianamente aos domingos pela manhã, quando se reza o Rosário e difunde-se a palavra de Deus. Ademais, Mérice prepara crianças e jovens para o catecismo, comunhão e confirmação. Ainda que estejamos em terreno institucional, entendo essa prática como uma apropriação da liturgia católica pelas famílias Afropacíficas. Trata-se de um saber perpetuado ao longo de gerações: "yo aprendí de la 
mamá de Humberto, porque tengo descendencia, porque mis dos abuelos, de parte de mamá y de parte de papá, eran rezanderos. Eran los rezanderos de la comunidade". A mesma referência Mérice traz para explicar sua ascendência na curanderia. "mi abuelo por parte de padre era curandero, él era remediero".

Quando a conheci, Mérice trabalhava na creche de Palma Real. Ela é presidente do Seguro Campesino desde 1999 e também integra a junta diretiva da Asociación de Artesanos Afroecuatorianos Recolectores de Productos Bioacuáticos del Manglar Palma Real.

\section{Ruth Aida Cabezas Ortiz}

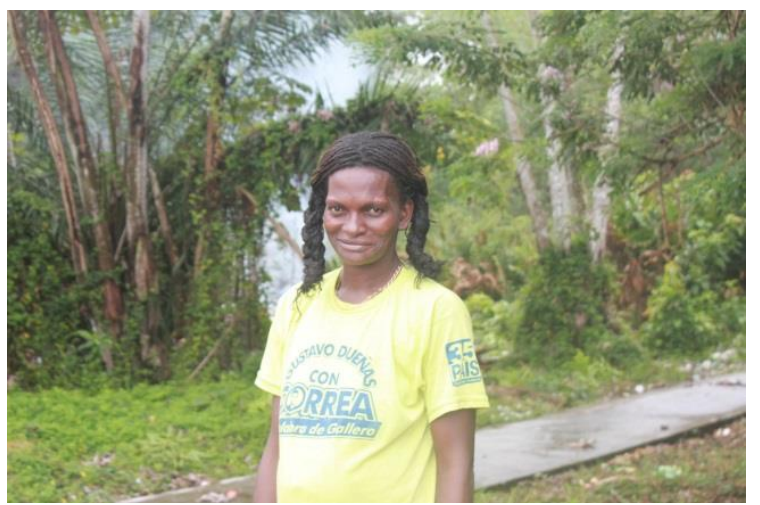

Nascida em 1969, em Palma Real, filha de pai e mãe tumaquenhos que se mudaram para o povoado trazendo oito filhos e Ruth Ainda no ventre. Estudou apenas até o primeiro ano do ciclo fundamental, em Palma Real mesmo.

Ruth Aida tinha dez filhos e estava esperando o décimo primeiro quando a conheci, em 2013. Todos haviam nascido com parteira; apenas o décimo havia sido no hospital, porém, de parto normal. Teve seu primeiro filho com dezoito anos. Em 2014, o primogênito tinha vinte e seis anos, enquanto o filho mais novo dela tinha cinco. Ela se identifica como uma mulher solteira, disse que já teve maridos, mas os deixou. $\mathrm{O}$ bebê que esperava era filho de um homem de Chontal, Baixo Mira. Ruth Aida possui três netos, filhos de duas de suas meninas.

Assim como Mérice, Ruth Ainda se auto-identifica como conchera, trabalho que empreende desde os doze anos de idade, aprendido com a mãe, que também era conchera. Diz que a atividade pode ser entediante, quando não se encontra concha alguma. Também pode ser perigoso: “una vez caí golpeé la pierna, fractura. Diez veces fue picada por el pez'sapo. ¡Duele duro!”. Como gosta muito de cozinhar, ela fala que gostaria de abrir um negócio de comida "vender coco, mazamorra". 


\section{Lucrecia Borges}

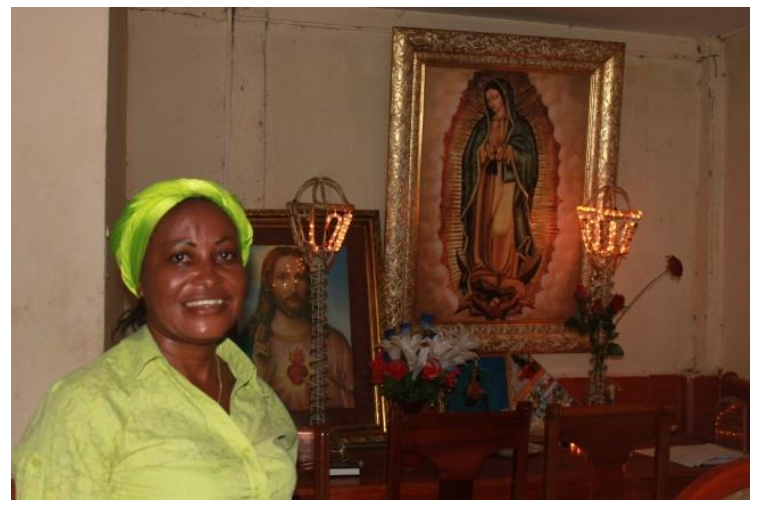

Lucrecia nasceu em 1965 e qualifica a história de sua vida como uma história bonita. É filha de mulher concheira, atividade que suas irmãs também assumiram. Em nossas duas conversas, ela começou me contando a história de sua mãe. Nascida em Esmeraldas, chegou a San Lorenzo com cinco anos de idade, junto da tia e madrinha, com quem foi criada. Aos dez anos começou a conchar, atividade que desenvolveu até os quarenta, quando se dedicou então a vender comida e fritar pescado. Com este trabalho, sustentava seus sete filhos, três homens e quatro mulheres, uma delas, Lucrecia. E assim conseguiu dar estudos a eles. Viveu em Candellila, uma vereda do Baixo Rio Mira, em Tumaco, em Palma Real e em Tambillo, ambos povoados da zona rural sanlorenzenha. Teve uma enfermidade no braço que se agravou, levando à amputação do membro. Ela deixou então de trabalhar com a venda de comida e começou sua carreira como comerciante de concha. Faleceu em 2005.

Lucrecia, por sua vez, ao terminar os estudos, fundou um colégio, em 1997, já sendo mãe de seus três filhos, experiência que vivenciou aos dezoito anos. Percebeu que não tinha vocação para a educação e, em 1999, ingressou no comércio de concha, "o início da etapa mais exitosa de sua vida”. Ela contou com o apoio da mãe, que tinha capital e todo o mapa do comércio da piangua. Lucrecia comprava concha em Pampanal e Tambillo, regressava a San Lorenzo e viaja para a Serra, com vistas a vender a mercadoria. O centro era Tambillo, onde chegava concha de várias localidade colombianas: Salahonda, Guapi, Guazá. Nessa época, não havia rodovias. O percurso era feito por mar, via Esmeraldas. Ela viajava em um barco chamado El Barbara, de um senhor esmeraldenho.

Lucrecia e sua mãe representam uma exceção dentro do grupo de comerciantes de concha, que é majoritariamente masculino. Começou comercializando 20mil conchas. Ao expandir o mercado de Esmeraldas para Guayaquil, Quito, Quevedo, Santo Domingo, Ambato e até Cuenca, no auge de seu trabalho, chegou a 300mil conchas entregues semanalmente e 
atualmente entrega 100mil conchas por semana. Atualmente, Lucrecia trabalha apenas com conchas colombianas, já que muitas das equatorianas têm tamanho pequeno, desvalorizadas no mercado. Junto com o companheiro, ela abriu um restaurante de comida do Pacífico em San Lorenzo.

Em 2010, elegeu-se vereadora pelo partido do presidente Rafael Correa, La Revolución Ciudadana, e em seguida foi eleita vice-Prefeita de San Lorenzo. Na carreira política, ela ressalta sua atuação em prol das mulheres concheiras de San Lorenzo, voltada para formalização jurídica do grupo de concheiras, aquisição de canoas e motores, construção de viveiros de conchas e um centro de comercialização.

Conheci Lucrecia por intermédio das mulheres de MOMUNE que com ela trabalham na organização do 8 de março do município. Estive no restaurante de Lucrecia um par de vezes, quando ela contou-me sua história de vida.

$* * *$

Acompanhando Amada Cortez e Inés Morales no projeto Guardianes del Conocimiento, visitei o Centro Gerontológico, onde conheci a senhora Sixta Tulia Londoña Ponce, nascida em 1927. Ela cresceu na cidade de Esmeraldas, capital da província homônima. Uniu-se a Eliseo Branda, com quem teve uma porção de filhos. Ao todo, Sixta Tulia teve onze filhos, dos quais seis estão vivos. Conta que o pai das crianças não se responsabilizou pelo cuidado delas. Quando a mãe de Sixta Tulia faleceu, ela migrou para San Lorenzo e começou a trabalhar no concheo, atividade com a qual sustentou seus filhos. Aprendeu a conchar com uma senhora tumaquenha que era amiga dela. Ela conchou por cinco ou seis anos, em seguida migrou pra Guayaquil e, ao regressar a San Lorenzo, não voltou a trabalhar na atividade. Ela trabalhou também com comidas ancestrais, champús, mazamorra, casabe. Conversamos sobre o concheo e também bastante sobre a culinária Afropacífica.

Por fim, dialoguei com Emilia Eneyda Valencia Murraín, que é criadora e diretora da Associação de Mulheres Afrocolombianas - AMAFROCOL, sediada em Cali. Emilia nasceu em uma área rural da colombiana região do Cauca. Migrou para Cali, com parte da família, e lá fez a vida. Ela está à frente de Amafrocol, que desenvolve ações afirmativas e projetos sociais comunitários com perspectiva étnico-cultural voltados especialmente a mulheres negras e ao povo negro, de modo geral. Uma tônica de sua organização é o trabalho em torno da valorização e promoção da estética negra. Ministrando uma oficina sobre penteados afro, Emilia participou do VI Festival da Mulher Afrolatino Americana e Caribenha, Latinidades, 
em 2013, em Brasília, Brasil-DF. Posteriormente, quando estava em Cali, ao final de 2013, para tratamento de saúde, encontrei-me com Emilia para um almoço. Foi nessa ocasião que conversamos sobre critérios de classificação étnico-racial na Colômbia e no Brasil, tema abordado na primeira parte da tese. 
Anexo III - Quadro de Organizações Afroequatorianas do Norte de Esmeraldas

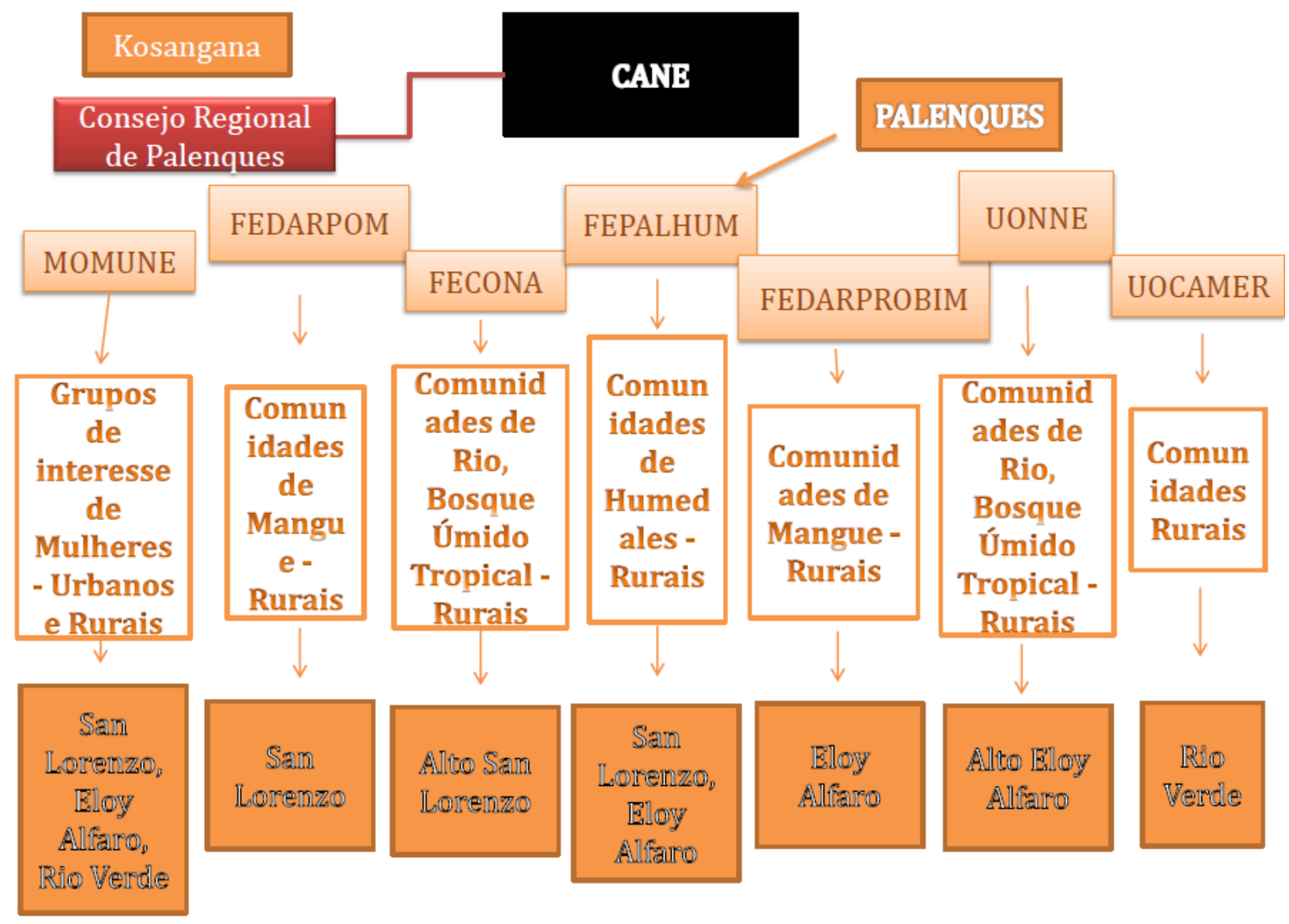




\section{Legenda}

- CANE: Comarca Afroecuatoriana del Norte de Esmeraldas

- MOMUNE: Movimiento de Mujeres Negras de la Frontera Norte de Esmeraldas

- FEDARPOM: Federación de Artesanos Afroecuatorianos Recolectores de Productos Bioacuáticos del Manglar

- FECONA: Federación de Comunidades Negras del Alto San Lorenzo

- FEPAlHUM: Federación Afro Palenque Los del Bajo Humedales Borbón

- FEDARPROBIN: Federación de Asociaciones de Recolectores de Productos Bioacuáticos y Naturales

- UONNE: Unión de Organizaciones Negras del Norte de Esmeraldas

- UOCAMER: Unión de Organizaciones Campesinas de Esmeraldas 